Universidade de São Paulo

Faculdade de Filosofia, Letras e Ciências Humanas

Departamento de Ciência Política

O PRocesso de ordenamento fiscal no Brasil na déCADA de 1990 e a Lei de Responsabilidade Fiscal

Cristiane Kerches da Silva Leite

Orientação: Profa. Dra. Maria Hermínia Tavares de Almeida

São Paulo

2005 
Universidade de São Paulo

Faculdade de Filosofia, Letras e Ciências Humanas

Departamento de Ciência Política

\title{
O processo de ordenamento fiscal no Brasil na década de 1990 e a LeI de Responsabilidade Fiscal
}

\author{
Cristiane Kerches da Silva Leite
}

Tese apresentada ao Departamento de Ciência Política da Faculdade de Filosofia, Letras e Ciências Humanas da Universidade de São Paulo, para a obtenção do título de Doutor em Ciência Política.

Orientação: Profa. Dra. Maria Hermínia Tavares de Almeida

São Paulo

2005 
Este trabalho foi realizado com o auxílio do Conselho Nacional de Desenvolvimento Científico e Tecnológico (CNPq), através de uma bolsa de doutorado. 
Ao Sérgio, à Marilena, à Mariana, ao Toy e ao

YURI, MINHA FAMILIA E MEU PORTO SEGURO, SEMPRE. 


\section{Agradecimentos}

Agradeço à minha orientadora Profa. Dra. Maria Hermínia Tavares de Almeida, por ter me aceito como orientanda no doutorado, pela seriedade e pelo comprometimento com o meu trabalho.

Agradeço aos meus colegas, professores e funcionários do Departamento de Ciência Política pelo apoio para tocar este trabalho adiante e pelas discussões sobre os caminhos a serem seguidos.

Agradeço especialmente à Profa. Celina Souza, que discutiu o meu projeto no seminário de pesquisa e aos meus queridos colegas do grupo de discussão da Profa. Maria Hermínia e do Prof. Leandro Piquet Carneiro, que me ajudaram a encontrar o foco deste trabalho.

Devo também um agradecimento especial à Rai, secretária do Departamento de Ciência Política, e todo o pessoal da secretaria, que sempre nos deu todo o suporte para tocarmos nossas pesquisas com tranqüilidade.

Agradeço às professoras Marta Teresa da Silva Arretche e Basília Maria Aguirre pela participação na minha banca de qualificação.

Agradeço a todos que me concederam generosamente entrevistas para esta pesquisa: Luiz Carlos Mendonça de Barros, Amir Khair, Yoshiaki Nakano, Arnaldo Madeira, José Roberto Rodrigues Afonso, Martus Tavares, Selma Pantel, Selene Peres Peres Nunes, Wéder de Oliveira, Dep. Sergio Miranda, Luiz Carlos Bresser Pereira.

Agradecimentos especiais a todos que me ajudaram a marcar as entrevistas: Profa. Maria Hermínia Tavares de Almeida, José Roberto Rodrigues Afonso, Silvia Lauandos, Neri Khair, Maria Rita Loureiro, Sergio Fausto, Deise Esteves (secretária Prof. Nakano), Suzete (secretária do Secretário Arnaldo Madeira), Selma Pantel, Raquel e Maria José (secretárias do Secretário Martus Tavares e de Selma Pantel), 
Paulo Kramer, Guilherme Canela, Flavio e Waldete (assessores do gabinete do dep. Pedro Novais), Gisela Mendonça (assessora do gabinete do dep. Sergio Miranda).

Agradeço com muito carinho aos amigos que me apoiaram nesses anos de doutorado: Kassia Caldeira, Bruno Raimundo Caetano, Moisés da Silva Marques, Franco de Matos, Iram Jácome Rodrigues, Ana Maria Bianchi, Maria Rita Loureiro, Gildo Marçal Brandão, Cícero Araújo, Eny Ceotto, Roberta Muramatsu, Cecília Olivieri, Tiago Cacique, Fernando Cosenza, Fernando Abrucio, Vanessa Elias de Oliveira, Simone Diniz, queridos amigos, agradeço pelos debates, pelas conversas, pelo interesse pelo meu trabalho e por mim, em vários momentos deste processo.

Dois agradecimentos especiais: à minha irmã, Mariana, que me ajudou no árduo trabalho de transcrição das fitas das entrevistas; ao meu pai, Prof. Sérgio Leite, que fez a revisão deste trabalho.

Agradeço, enfim, à minha família, Sérgio, Marilena e Mariana, que sempre estiveram ao meu lado, me dando apoio para continuar, força para buscar alternativas, carinho em momentos de desânimo, bronca em momentos de procrastinação, "reforço" em momentos produtivos (como bons psicólogos que são), enfim, tudo que eu precisei ouvir, nos momentos certos. Sem eles caminhando comigo, tudo teria sido mais difícil e sem graça. 


\section{Resumo}

Neste trabalho, analisamos o processo de ordenamento fiscal que ocorreu no Brasil, na década de 1990, abordando especificamente o processo de criação da Lei de Responsabilidade Fiscal (LRF). Alguns autores na Ciência Política argumentam que os projetos de lei votados no Congresso que afetam os interesses dos governadores não passam porque os governadores mobilizam suas respectivas bancadas estaduais para vetá-los. Assim, como podemos entender a aprovação da Lei de Responsabilidade Fiscal, lei complementar que afeta diretamente os interesses financeiros e fiscais dos entes federativos? Alguns autores argumentam que houve um consenso em torno da necessidade do ordenamento fiscal, na década de 1990, destacando o processo de incrementalismo das mudanças institucionais, o desenvolvimento de uma "cultura fiscalista" que vira consenso na opinião pública e na classe política e, as crises financeiras internacionais (México, 1995; Ásia, 1997 e Rússia, 1998) que colocaram em xeque a capacidade de reação do governo diante das ameaças à política econômica de estabilização. Este trabalho alinha-se com os que desenvolvem esses argumentos, mas enfatiza o processo de negociação, ou seja, a existência de um dissenso dentro do consenso, que caracterizou o processo de criação da LRF. Argumentamos que, a despeito da existência de um consenso em torno da idéia de promover um ordenamento fiscal, a criação e a aprovação da LRF caracterizaram-se por conflitos dentro do governo e por um processo de intensa negociação parlamentar.

\section{Palavras-Chave}

dívida pública; federalismo; lei de responsabilidade fiscal; ordenamento fiscal; negociação. 


\begin{abstract}
The aim of this work is to investigate the Brazilian process of fiscal ordering in the 1990s. More specifically, it focuses on the creation process of Fiscal Responsibility Law. Its point of departure is some political scientists' vision that legislative projects undermining the subnational governments' interests are not often approved due to State governors' efforts to veto them. The hypothesis is that this phenomenon happens because governors exert stronger influence on the behavior of legislators than the President and political parties. For this reason, they assume that governors are veto-players in the Brazilian political system. This is an important component of our research strategy that seeks to explain why Fiscal Responsibility Law was approved despite of the key players' financial and fiscal interests. The novelty of this work is to provide an approach that unveils a little explored explanatory element by previous works: the process of negotiation of the law project in the Federal Executive and in the Federal Legislative. In tune with some authors' claims that there was a consensus on the necessity of fiscal ordering, we scrutinize the incremental process of institutional change and the development of a 'fiscal culture' in the Brazilian society and its political class. We go on to suggest that international financial international crisis (México, 1995; Ásia, 1997 e Rússia, 1998) served as tests of the government's capacity to deal with the challenges posed to the economic stabilization policies. Furthermore, the current work gives special attention to addressing the process of negotiation that gave rise to the Fiscal Responsibility Law. We argue that the whole process was characterized by the existence of a dissension inside of consensus. Putting somewhat different, conflicts in the Federal Executive realm and complex negotiation schemes at the Federal Legislative level characterize the creation and the approbation stages of Fiscal Responsibility Law in Brazil.
\end{abstract}

\title{
Key Words
}

Public debts; federalism; Fiscal Responsibility Law; fiscal ordering; negotiation. 


\section{SUMÁRIO}

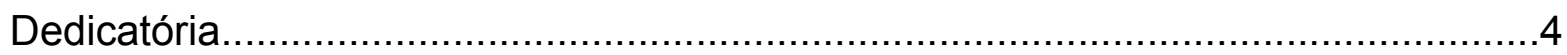

Agradecimentos

Resumo

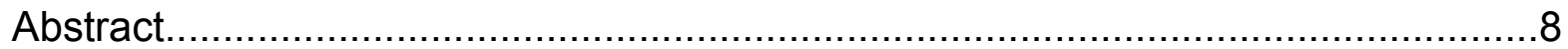

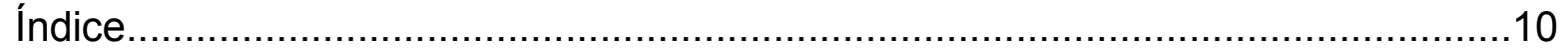

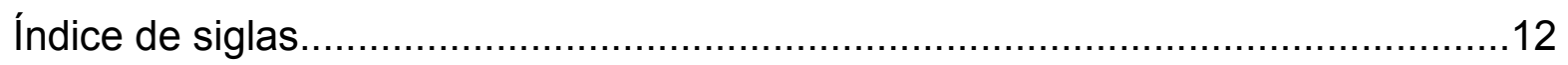

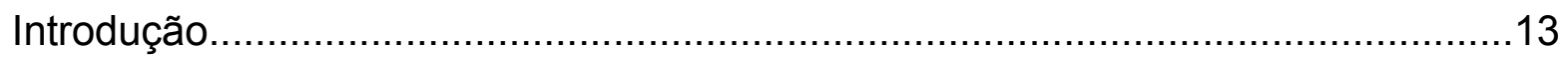

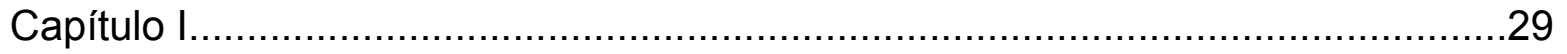

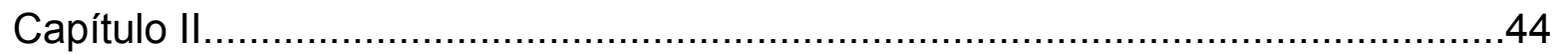

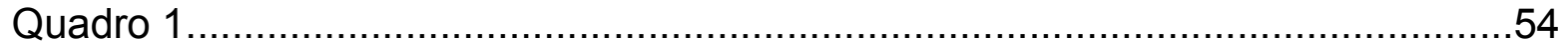

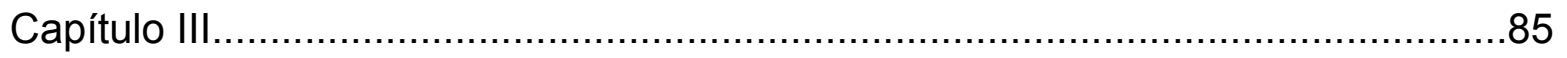

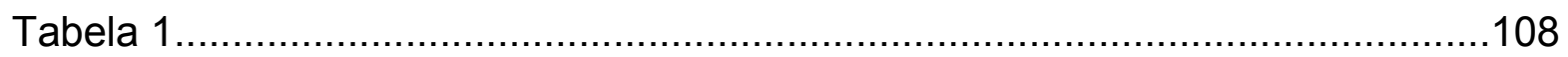

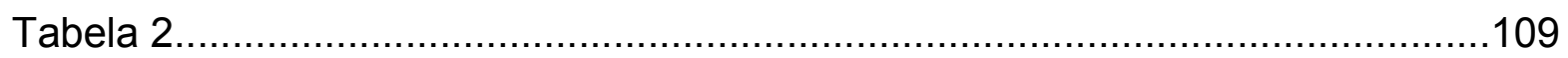

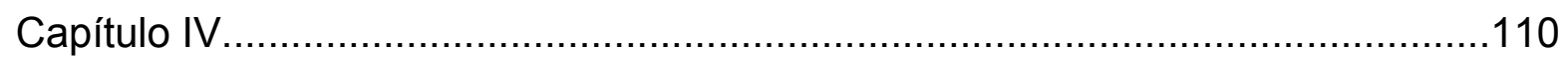

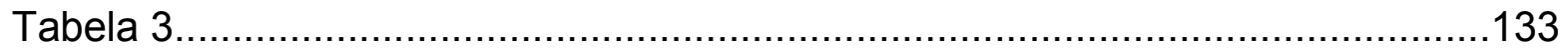

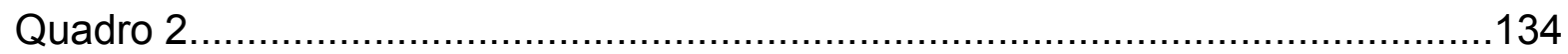

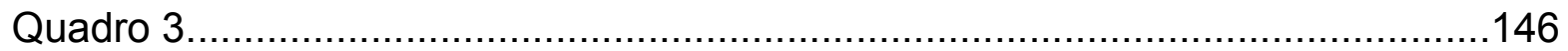

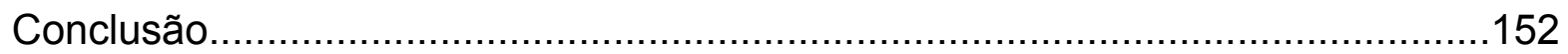

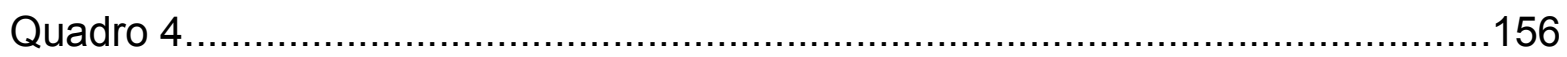

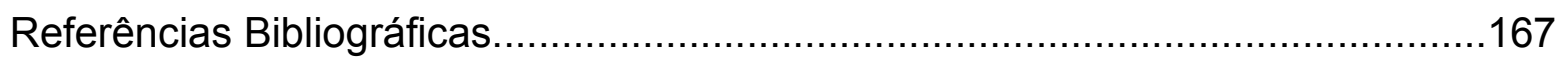

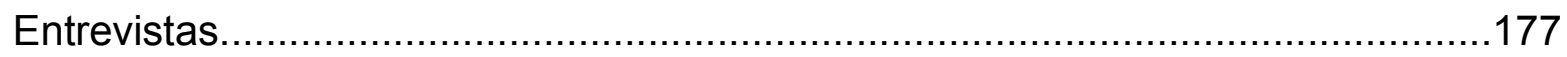

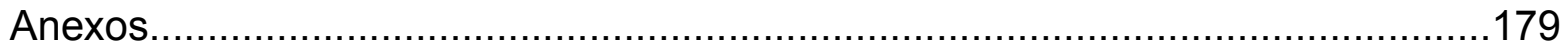




\section{ÍNDICE}

Introdução

I) Caracterização do problema e objetivos.................................................13

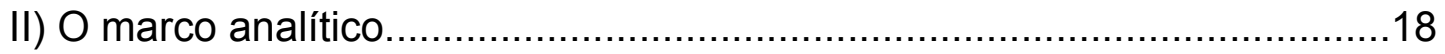

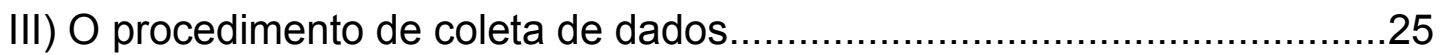

Capítulo I - Federalismo, problemas de governabilidade do sistema político

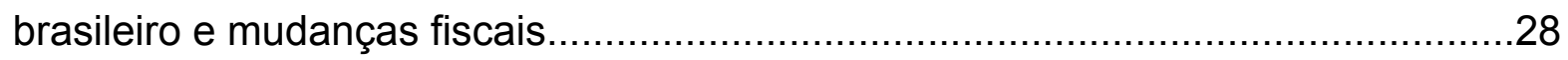

I.a) Os governadores na redemocratização..............................................29

I.b) O ultrapresidencialismo estadual e o federalismo estadualista................31

I.c) Federalismo, Constituição de 88 e descentralização fiscal......................33

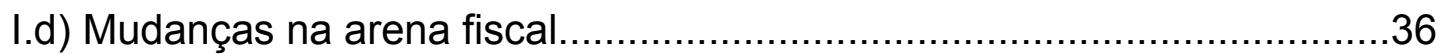

Capítulo II - O processo de ordenamento fiscal.................................................. 44

II.a) O início do processo de endividamento estadual na década de 1970...44

II.b) O padrão de financiamento e as mudanças no arranjo institucional-legal na década de 1980.

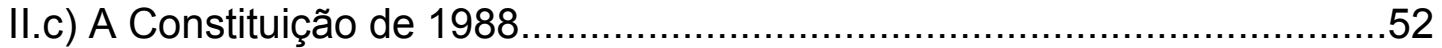

II.d) Década de 1990: o processo gradual de ordenamento fiscal.................56

II.d.1) Primeira metade da década de $1990 \ldots \ldots \ldots \ldots \ldots \ldots \ldots \ldots \ldots \ldots \ldots \ldots \ldots \ldots . . .56$

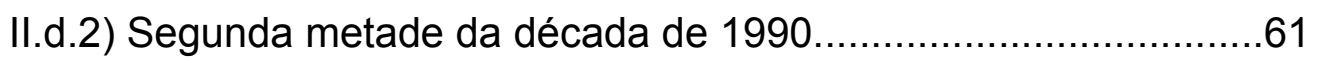

Capítulo III - Os caminhos da construção da Lei de Responsabilidade Fiscal no Governo Federal.

III.a) A criação do projeto de lei no Governo Federal...................................85

III.b) O papel dos governadores e dos prefeitos......................................102

Capítulo IV - Os caminhos da construção da Lei de Responsabilidade Fiscal na Câmara dos Deputados e no Senado Federal................................................110

IV.a) A tramitação na Câmara dos Deputados.........................................110 
IV.a.1) As discussões na Comissão Especial (CESP). 112

IV.a.2) As discussões no Plenário da Câmara dos Deputados.........122

IV.b) A tramitação no Senado Federal.

IV.c) O veto, as Adins, a implementação da lei e a situação dos prefeitos. 145

Conclusão. 152

Referências Bibliográficas. 167

Entrevistas. 177

Anexos. 179

Anexo 1 - Quadro 1. 179

Anexo 1 - Quadro 2 . 183

Anexo 1 - Quadro $3 .$. 190

Anexo 2 - Roteiro das Entrevistas. 196

Anexo 2 - Lei de Responsabilidade Fiscal. 201

Anexo 2 - Mensagem Presidencial $n^{\circ}$ 627, 04/05/00 ......................................224

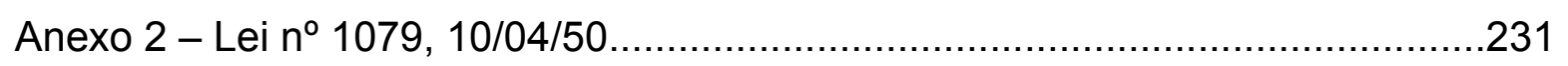

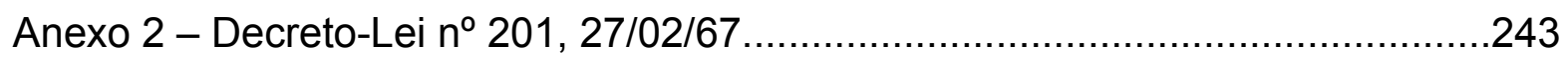

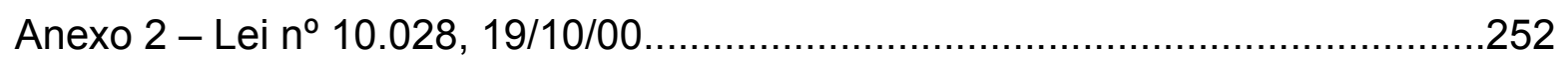

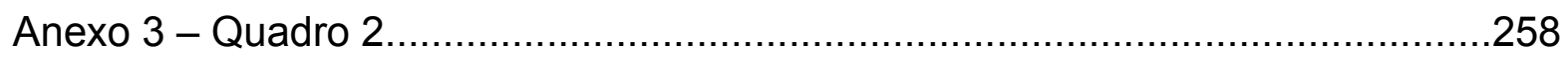

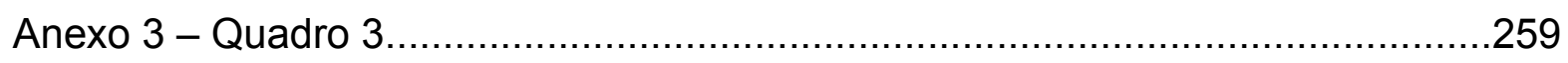

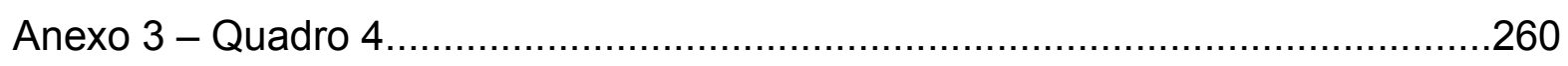

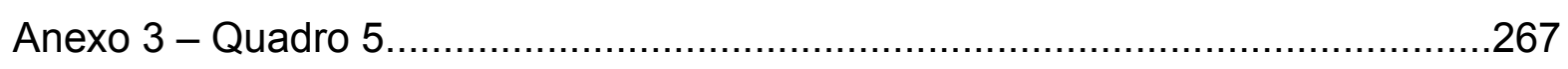

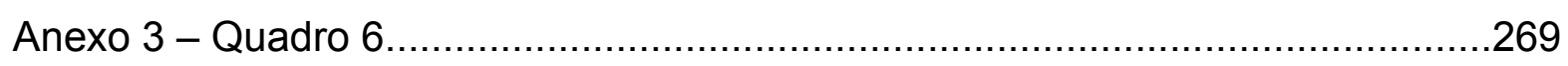

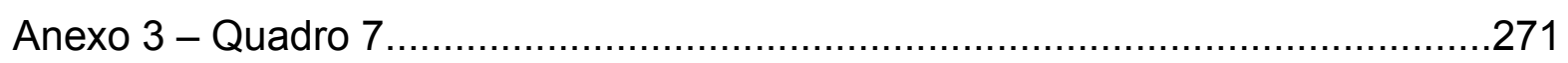

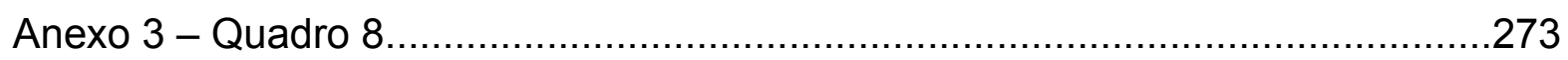

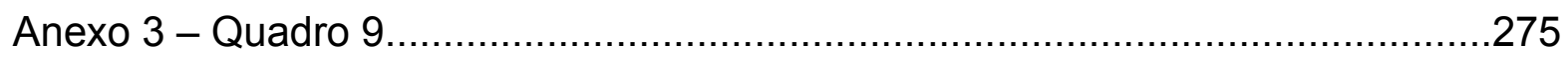

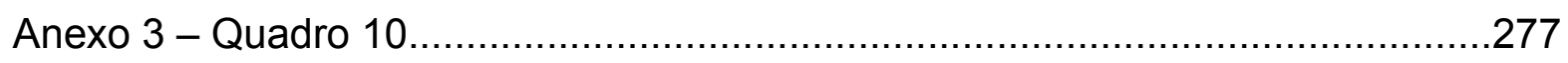

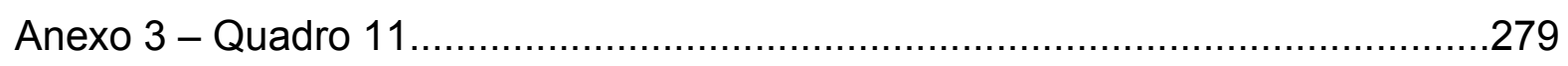




\section{Í ÍICE de SiglaS}

Adins: Ação Direta de Inconstitucionalidade

ARO: Antecipação de Receita Orçamentária.

ATRICON: Associação dos Membros dos Tribunais de Contas do Brasil

BB: Banco do Brasil

BNDES: Banco Nacional de Desenvolvimento Econômico e Social

BC: Banco Central

CAE: Comissão de Assuntos Econômicos

CCJ: Comissão de Constituição e Justiça

CESP: Comissão Especial

CMN: Conselho Monetário Nacional

CNM: Confederação Nacional dos Municípios

DCL: Dívida Consolidada Líquida

DVS: Destaque para votação em separado

FPE: Fundo de Participação dos Estados

FPM: Fundo de Participação dos Municípios

IBM: Instituto Brasileiro de Administração Municipal

LDO: Leis de Diretrizes Orçamentárias

PEF: Programa de Estabilidade Fiscal

PMAT: Programa de Modernização da Administração Tributária e Gestão dos Setores Sociais Básicos

PPA: Plano Plurianual

PROES: Programa de Incentivo à Redução da Presença do Estado na Atividade Bancária.

SIAFI: Sistema Integrado de Administração Financeira do Governo Federal

STN: Secretaria do Tesouro Nacional

RCL: Receita Corrente Líquida

UNALE: União Nacional dos Legislativos Estaduais 


\section{INTRODUÇÃO}

"O Brasil é um país singular. Você faz uma lei que, rigorosamente, não deveria existir. Você tem uma lei orçamentária. Se você a observa, os princípios gerais que estão na legislação, você tem que cumprir a lei, gastar o que está no orçamento. Não pode gastar mais do que está no orçamento...".

Arnaldo Madeira ${ }^{1}$.

I) Caracterização do problema e objetivos.

Nos últimos 10 anos, houve uma clara mudança no relacionamento financeiro e fiscal entre os entes federativos no Brasil. O Governo Federal implementou um arcabouço institucional-legal que constituiu um novo ordenamento fiscal. Entendemos por ordenamento fiscal um conjunto de medidas como: o planejamento e a transparência das contas públicas, a limitação à contratação de dívidas e aos gastos dos entes federativos ${ }^{2}$. Além de um processo de criação institucional, ocorreu um processo político, no qual a capacidade do Governo Federal em garantir o cumprimento das regras já existentes também melhorou, no sentido da construção de um ambiente institucional que dá incentivos consistentes para os governos dos Estados e dos Municípios realizarem uma boa administração das finanças públicas. Na medida em que a condução das finanças públicas pelos Estados e Municípios afeta a administração das contas públicas pelo Governo Federal, a questão do ordenamento fiscal federativo é um problema chave para a política macroeconômica do país.

$\mathrm{Na}$ década de 1980, houve grandes mudanças nas condições de financiamento dos Estados e dos Municípios. A crise econômica reduziu as receitas fiscais, os canais de financiamento internacional diminuíram drasticamente, no

${ }^{1}$ Entrevista com Arnaldo Madeira, 25/08/05.

${ }^{2}$ O texto do projeto de lei complementar $n^{\circ} 18-\mathrm{A}$, de 1999, que foi a versão do projeto da Lei de Responsabilidade Fiscal encaminhado pelo Executivo Federal à Câmara dos Deputados, define de forma clara os conceitos envolvidos na idéia de ordenamento fiscal. $O$ planejamento refere-se às práticas de atuação estatal no orçamento público, que envolvem "o fortalecimento do plano plurianual, das diretrizes orçamentárias e dos orçamentos anuais como instrumentos de gestão" (Art. $6^{\circ}, \mathrm{X}$ ). Entende-se por transparência o amplo acesso da sociedade às informações sobre as contas públicas e aos procedimentos de aplicação dos recursos públicos e a utilização de linguagem simples e objetiva na elaboração e divulgação dos documentos orçamentários e contábeis (Art. $6^{\circ}$, XI, XII). A limitação da dívida é entendida como o que seja "compatível com a receita tributária efetiva e o patrimônio líquido, de modo a propiciar margem de segurança para a absorção dos efeitos de eventos imprevistos" (Art. $6^{\circ}$, II). 
mesmo período em que o país passava por um processo de redemocratização, caracterizado pelo aumento das demandas sociais e por um processo de descentralização fiscal. Restava aos governantes financiarem-se através de emissão de títulos, Antecipações de Receitas Orçamentárias (AROs), precatórios, o uso dos bancos estaduais como mecanismo (ilegal) de "quase-emissão" de moeda - formas de financiamento que funcionavam num sistema caracterizado pela lógica do moral hazard, ou seja, a existência de canais de socorro financeiro das autoridades monetárias incentivava os governantes a realizarem essas práticas ad libitum $^{3}$. Assim, os governadores e os prefeitos financiavam-se sem a preocupação com a sustentabilidade temporal do endividamento (e muitas vezes, como no caso dos precatórios, sem levar em conta a legalidade do processo), incentivados por um sistema em que o socorro, ou a conivência, do Governo Federal era garantido, em caso de inadimplência ou investigação dos ilícitos. Havia regras de controle de gastos e de endividamento, assim como meios legais de punição para quem as infringissem, mas elas não eram respeitadas.

$\mathrm{Na}$ realidade, havia incentivos institucionais, mas também políticos, porque as regras que existiam e que podiam limitar os abusos dos governantes simplesmente não eram aplicadas. Um exemplo claro deste processo foram os pedidos de rolagem das dívidas dos Estados no Senado Federal. Até a Resolução $\mathrm{n}^{\circ} 78 / 98^{4}$, os governadores pressionavam os senadores das suas bancadas para autorizarem a rolagem da dívida do seu Estado, na medida em que é prerrogativa constitucional do Senado Federal legislar sobre esta matéria. Segundo Loureiro (2001), "na condição de representante de seu estado na arena política nacional e percorrendo uma carreira que passa na maioria das vezes por cargos executivos, 0 senador brasileiro sofre pressões dos governadores, que muitas vezes foram seus colegas no Senado, ao mesmo tempo em que está bastante envolvido com compromissos de governo. Assim, o endividamento, como uma das fontes importantes de geração de recursos para atender as demandas sociais inadiáveis, torna-se caminho praticamente irrecusável para um político, mesmo fazendo parte do Senado, órgão que tem como função constitucional garantir o equilíbrio

\footnotetext{
${ }^{3}$ Segundo Loureiro e Abrucio (2002), o relacionamento entre a União e os governos subnacionais se caracterizou pela lógica do moral hazard em função: das receitas extraordinárias geradas pelo chamado "imposto inflacionário"; do uso dos bancos centrais como mecanismo de "quase-emissão" de moeda e; a renegociação continuada do pagamento das dívidas com a União, que na prática representava sua postergação indefinida (Loureiro e Abrucio, 2002: 70/71).

${ }^{4}$ Ver detalhes sobre esta resolução no anexo 1 , quadro 2.
} 
financeiro dos entes federativos" (Loureiro, 2001: 57). Com a Resolução (RSF) $n^{\circ}$ 78/98, o Banco Central (BC) deveria emitir um parecer para autorizar o Estado a rolar a dívida ou não. Inseriu-se um veto técnico à negociação política, que ganhou peso de lei complementar com a promulgação da Lei de Responsabilidade Fiscal.

A partir de meados da década de 1990, a estabilização econômica fez uma grande diferença neste quadro, expondo as más administrações públicas dos entes federativos. Ao mesmo tempo, a política macroeconômica de juros altos do Governo Federal levou os Estados e Municípios que haviam contraído dívida a uma situação extremamente difícil. Entrou definitivamente na agenda política a necessidade de resolver o problema fiscal dos entes federativos, como pressuposto para a sustentabilidade do próprio processo de estabilização monetária. Não era suficiente que o ordenamento fiscal atingisse somente a União; era preciso que os governos subnacionais também trabalhassem sob condições mais transparentes e que permitissem o mínimo de previsibilidade e planejamento nas finanças públicas, em um novo regime inflacionário.

A cada crise financeira internacional, desde a crise do México, em 1995, esta consciência foi crescendo, na medida em que se gerava um impacto negativo na economia nacional, afetando a entrada de capital externo no país. Em 1998, entrou na agenda política do governo a idéia de se regulamentar o art. 163 da Constituição, que tratava de finanças públicas. Esta idéia foi levada adiante no Governo Federal, no âmbito de um programa de reação das autoridades brasileiras à crise da Rússia e, em abril de 1999, entrou na Câmara o projeto de lei complementar $n^{0} 18$, que daria origem à Lei de Responsabilidade Fiscal, logo após a crise de desvalorização cambial.

Pari passu ao crescimento da consciência, por parte da classe política e dos técnicos do governo, de que era preciso mudar o regime fiscal, a opinião pública começou a expressar o desejo de que os políticos eleitos tivessem um comprometimento com a austeridade fiscal. A reeleição do Governador Mário Covas $^{5}$, em 1994, e de outros governadores que se reelegeram com essa bandeira na época, além do ostracismo de políticos identificados com o mau uso do dinheiro

\footnotetext{
${ }^{5}$ Não estamos afirmando que o Governador Mario Covas se reelegeu somente em função do uso do tema da austeridade fiscal como bandeira eleitoral nas eleições de 1994. Estamos afirmando que o fato de o primeiro mandato ter sido marcado por práticas saneadoras concretas das finanças públicas estaduais, e não só por um discurso, como ficou evidente na entrevista com o prof. Yoshiaki Nakano, contribuiu para o sucesso eleitoral do Governador, na medida em que a opinião pública apoiava amplamente governos que praticavam a responsabilidade fiscal.
} 
público (envolvidos na crise do Banespa, por exemplo), foram somente alguns dos eventos que sugerem que uma mudança estava em curso na década de 1990. O papel da mídia neste processo foi fundamental, com extensas coberturas sobre os trabalhos da CPI dos precatórios, em 1996, e os inúmeros artigos e editoriais sobre a importância da responsabilidade fiscal, na época da discussão e da tramitação do projeto da Lei de Responsabilidade Fiscal no Congresso.

Asazu (2003) realizou um acompanhamento de seis jornais diários ${ }^{6}$, entre abril de 1999 e maio de 2000, e constatou que "foram publicadas 137 inserções que faziam expressamente referência à Lei de Responsabilidade Fiscal, entre reportagens acerca do trâmite, editoriais, colunas assinadas por colunistas fixos e por convidados, sem levar em consideração neste levantamento reportagens ou colunas iguais. A maior cobertura foi dada pelos jornais "O Estado de São Paulo" e pelo "Jornal do Brasil", que foi o primeiro a tratar em editorial do tema, após o início do trâmite na Câmara. (...) Dentre as 137 reportagens, editoriais e colunas contabilizados, apenas quatro traziam opiniões contrárias ao projeto proposto" (Asazu, 2003: 95).

A sanção desta lei não foi o último capítulo do processo de ordenamento fiscal. Este processo está longe de se consumar. Aliás, trata-se de um processo de contínua construção institucional, que envolve, entre outras coisas, o aprimoramento de uma rede de instâncias públicas para realizar efetivamente o controle dos gastos e do endividamento público, que inclui os Tribunais de Contas, encaminhando as punições legalmente cabíveis. Contudo, acreditamos que foi um capítulo relevante ao sistematizar e criar novas regras para ordenar o processo orçamentário, controlar gastos públicos e nível de endividamento dos entes federativos. Analiticamente, é também relevante, especialmente, se analisarmos este processo à luz dos trabalhos de autores da Ciência Política que argumentam que o sistema político brasileiro tende à ingovernabilidade em função da excessiva dispersão de poder, especialmente a partir da Constituição de 1988. Muitos autores produziram trabalhos chegando a esta conclusão olhando para a década de 1980 e início da década de 1990, especialmente o Governo Collor - Lamounier (1991) -. Recentemente, há trabalhos que sustentam esta tese, mesmo depois da

\footnotetext{
${ }^{6}$ Três de São Paulo (O Estado de São Paulo, Folha de São Paulo, Gazeta Mercantil); dois do Rio de Janeiro (O Globo e Jornal do Brasil); um de Brasília (Correio Braziliense).
} 
implementação do Plano Real, em 1994, e de todas as mudanças que ocorreram desde então, como Ames (2003).

Desta forma, como podemos entender que um sistema político que se caracteriza por ser repleto de atores com poder de veto, especialmente de natureza federativa, conseguiu produzir decisões que afetaram os interesses federativos, como a aprovação da Lei de Responsabilidade Fiscal? Se observarmos atentamente o conteúdo da lei, percebemos que ela implementa uma série de restrições fiscais e financeiras aos Estados e Municípios, reduzindo a autonomia federativa desses entes. Como este processo ocorreu? Qual foi o peso da lógica federativa no processo decisório dentro do Executivo Federal e dentro do Congresso?

Com base na análise dos dados, chegamos à conclusão que houve a formação de um consenso, entre os atores políticos relevantes, de que o ajuste fiscal seria necessário para um ordenamento fiscal, que gradualmente passou a ser desejado. O consenso foi criado a partir de um processo de aprendizado dos políticos e dos técnicos, como também por um processo de adesão à idéia de ajuste fiscal, a idéia de que "cada governo tem que caber dentro do seu mandato", na classe política e na opinião pública.

No entanto, argumentamos que o consenso e a força das idéias não explicam totalmente o processo de construção do ordenamento fiscal. A ocorrência das crises internacionais também foi importante, provocando a necessidade de uma ação governamental em direção à realização de mudanças estruturais na arena fiscal. Especificamente, os eventos do segundo semestre de 1998 suscitaram uma conjuntura de crise que criou uma demanda no Governo Federal por uma reação ao ataque à moeda, que se concretizou em janeiro de 1999. Alguns autores, como Sola, Garman e Marques (1998) e Loureiro e Abrucio (2002) analisam esses processos relacionados à criação de um consenso e a ocorrência da crise econômica como causadora da ocorrência de uma janela de oportunidade para a mudança fiscal. A presente pesquisa coaduna-se com os trabalhos desses autores, mas avança em outro ponto.

Houve a percepção, pelos atores políticos, de um processo de crescente valorização da estabilidade da moeda e de práticas fiscais responsáveis; houve crises internacionais que colocaram em xeque o poder de reação do governo, mas, mesmo assim, houve muita negociação política dentro do Executivo Federal e no 
Congresso Nacional para que a lei fosse promulgada. Estamos argumentando que, a despeito do consenso, da força das idéias e do imperativo da crise, o processo decisório que gerou o projeto da Lei de Responsabilidade Fiscal dentro do Executivo e dentro das duas casas legislativas foi marcado por um intenso processo de negociação, liderado pela equipe de técnicos do Ministério do Planejamento, que formulou o projeto de lei.

Alguns trabalhos, como Asazu (2003) e Asazu e Abrucio (2003), afirmam que o processo decisório da Lei de Responsabilidade Fiscal foi rápido e houve poucas mudanças no texto da lei no decorrer do processo. No presente trabalho, argumentamos que, a despeito da velocidade com que o projeto tramitou no legislativo, a aprovação do projeto da LRF caracterizou-se por um processo de intensa negociação e houve mudanças importantes no texto, especialmente durante a discussão na Comissão Especial da Câmara. Ou seja, esse processo foi marcado por dissensos dentro do Governo Federal, na Câmara e no Senado. Pretendemos mostrar, nos capítulos sobre os caminhos da criação da LRF, quais foram os atores políticos envolvidos nos dissensos e quais foram os termos dos dissensos. Desta forma, pretende-se explorar a construção do consenso da mudança na ordem fiscal e o dissenso dentro do consenso, no momento da criação do projeto da Lei de Responsabilidade Fiscal no Executivo Federal, até a sua saída do Congresso.

II) O marco analítico

O marco analítico que estrutura esta discussão é o neo-institucionalismo e, especificamente, os trabalhos institucionalistas históricos como Peter Hall, Ellen Immergut e Peter Gourevitch. A discussão sobre o processo decisório da negociação é baseada em Velasco Jr. (2005), que se inspira em autores da teoria da escolha racional. O trabalho de Hall (1992) fornece os subsídios analíticos para a elaboração do argumento da construção do consenso e do aprendizado. Immergut (1992) analisa a relação entre diferentes configurações institucionais e a formação de diferentes pontos de veto. Gourevitch (1986) discute, especificamente, a idéia de conjuntura de crise e mudança. Velasco Jr. (2005), baseado no trabalho 
de Bates, Greif, Levi Rosenthal e Weingast $(1998)^{7}$, propõe um modelo de coordenação de interesses para abordar o processo de negociação de políticas reformistas no contexto do presidencialismo de coalizão brasileiro.

Aqui vale um esclarecimento sobre as nossas escolhas analíticas. Sabemos que parte da teoria da escolha racional afirma que o processo de tomada de decisão política resulta estritamente de barganhas negociadas entre indivíduos que buscam satisfazer, ou maximizar, o seu auto-interesse. No entanto, ao trabalharmos com autores neo-institucionalistas históricos, consideramos uma concepção de cálculo estratégico dos tomadores de decisão bem mais ampla do que sugere a teoria da escolha racional. Segundo Souza (2003), "sem negar a existência do cálculo racional e auto-interessado dos atores (...), (os neoinstitucionalistas históricos) afirmam que este cálculo ocorre dentro de uma concepção mais ampla de regras, papéis, identidades e idéias. (...) Os interesses (ou preferências), são mobilizados não só pelo auto-interesse, mas também por processos institucionais de socialização, por novas idéias e por processos gerados pela história de cada país" (idem: 11/12). Na nossa concepção, as escolhas dos tomadores de decisão na elaboração do projeto de LRF devem ser entendidas dentro de um contexto específico, que se caracteriza, entre outros aspectos, pelo consenso em torno da idéia de responsabilidade fiscal entre os políticos e a opinião pública, e pela história profissional dos técnicos, que acumularam, em anos de trabalho em instituições públicas, como a Secretaria do Tesouro Nacional, um enorme aprendizado a respeito da policy a ser seguida (conteúdo da política) e da politics (processos políticos) a ser desenvolvida para que o projeto fosse aprovado.

Hall (1992) é um autor institucionalista que explora o relacionamento entre novas idéias políticas e a configuração institucional que faz a mediação entre as idéias e os resultados políticos específicos. O autor está interessado em discutir por que certas idéias (e não outras) tornam-se dominantes no discurso político. Como as idéias e os interesses interagem em contextos institucionais específicos para produzir mudanças políticas? Esta linha de análise é extremamente profícua no caso da presente pesquisa, na medida em que a trajetória da idéia de responsabilidade e ordem fiscal é importante para entender a construção institucional de um arcabouço de regras que geraram um novo ordenamento fiscal,

\footnotetext{
${ }^{7}$ BATES, Robert; GREIF, Avner; LEVI; Margaret; ROSENTHAL, Jean Laureant; WEINGAST, Barry.
} Analytical narratives. Princeton: Princeton University Press, 1998. 
entre elas, a Lei de Responsabilidade Fiscal. Na década de 1980, não havia interesse do governo e da classe política em promover uma reforma fiscal que afetasse os interesses federativos. A partir da década de 1990, este tema começa a entrar na agenda política e, a partir de meados da década, forma-se um panorama favorável para a proposta de uma reforma fiscal e o encaminhamento político desta na direção de uma mudança concreta. Desta forma, podemos perguntar: o que mudou entre as décadas de 1980 e 1990?

Ao enfatizar a relevância analítica da interação entre interesses, idéias e instituições, o autor propõe um confronto com as concepções de instituição caracterizadas por um viés de continuidade política ou de dificuldade para mudar. Hall (1992) explora a idéia de que algumas instituições podem facilitar, enquanto outras podem impedir a mudança política. Assim, algumas estruturas institucionais podem estabelecer uma tensão dinâmica que inspira a criatividade e encoraja a inovação (Steinmo and Thelen, 1992). No caso da mudança fiscal no Brasil, discutiremos a gradual mudança das idéias e dos interesses em torno da questão fiscal e o impacto da trajetória de interação desses elementos no processo de criação da Lei de Responsabilidade Fiscal. De fato, alguns autores, como Asazu (2003), já exploraram o referencial analítico desenvolvido por Peter Hall para explicar a gênese da LRF. Outros autores, como Loureiro e Abrucio (2002), enfatizaram o caráter incremental das reformas. Nas palavras destes autores, “(...) os pontos bem sucedidos de transformação das finanças públicas brasileiras, desde a redemocratização, obedeceram a uma lógica basicamente incrementalista, orientada por avanços e recuos nas propostas inicialmente estabelecidas e por negociações com diferentes atores políticos. A cada reformulação realizada, ademais, alterava-se o patamar das discussões posteriores, criando uma relação de path dependence (pp. 60). Ao invés de uma concepção exclusivamente totalizadora de reforma, que supõe a necessidade de uma alteração total do status quo e a um só tempo, (...) ocorre algo como uma sedimentação por "camadas geológicas" (pp. 59)". No nosso trabalho, vamos na mesma direção dessas linhas de pesquisa, a partir da análise dos dados apresentados nos capítulos que se seguem. A trajetória das idéias e dos interesses em torno do tema fiscal e o processo de mudança incremental explicam, em grande medida, o rumo e o resultado das mudanças, mas não totalmente. A análise do processo decisório da Lei de Responsabilidade Fiscal dentro do Executivo Federal, na Câmara e no 
Senado realizada neste trabalho, permite afirmar que houve uma dura negociação entre a equipe do Ministério do Planejamento, que elaborou a lei, e outros atores políticos, como os técnicos do Ministério da Fazenda e do Banco Central, os Secretários da Fazenda e Planejamento dos Estados, os deputados federais e senadores. Entre 1998 e 2000, período de discussão do projeto de lei da LRF, a despeito da existência de um amplo consenso em torno da responsabilidade fiscal e de regras que já vinham limitando o espaço da realização de gastos e dívida dos entes federativos, o processo decisório que gerou a LRF implicou em uma grande negociação, que envolveu a concessão de mudanças para a preservação da "alma" da lei e a deliberação constante com os atores envolvidos no processo.

Immergut (1996) analisa a política de saúde na França, Suíça e Suécia e demonstra a importância dos efeitos não intencionais da estrutura institucional e da mudança no processo de tomada de decisões políticas. As regras eleitorais de um país e sua estrutura constitucional constituem as regras do jogo, a partir das quais os conflitos políticos ocorrem. Segundo a autora, os sistemas de saúde desenvolveram-se de forma diferente naqueles países por ela analisados, devido ao fato que diferentes configurações institucionais possibilitam o surgimento de diferentes pontos de veto no sistema político decisório. "As instituições, ao tornarem alguns cursos de ação mais difíceis e outros mais fáceis, redefinem as alternativas políticas e mudam a ordem de atores relevantes. As instituições, em outras palavras, estabelecem um contexto estratégico para as ações desses atores políticos que muda o resultado de conflitos políticos específicos" (Steinmo and Thelen, 1992: 22). Immergut (1996) demonstra que a existência de certas estruturas institucionais modela subseqüentes conflitos políticos. Esta sugestão analítica da autora permite entender como agiram os atores políticos relevantes no processo de negociação da Lei de Responsabilidade Fiscal, especialmente os atores políticos federativos. Podemos entender porque os governadores não agiram como atores com poder de veto e porque os prefeitos tiveram uma ação mais contundente no processo decisório da Lei de Responsabilidade Fiscal do que os chefes dos Executivos Estaduais.

Um outro fator que influenciou o processo de criação da LRF foi a crise econômica, no segundo semestre de 1998. Naquele período, o Real sofreu ataques especulativos em função da crise da Rússia e das eleições presidenciais. Segundo Gourevitch (1986), os momentos de crise põem o sistema em situações de stress. 
As forças são expostas e as fraquezas são examinadas minuciosamente, permitindo aos observadores perceberem os relacionamentos que permanecem obscuros em momentos de prosperidade, quando bons tempos atenuam a propensão para contestar e desafiar. Em tempos de crise, novas instituições e novos padrões devem ser construídos, no lugar dos antigos, que sucumbem. Neste sentido, as crises econômicas criam um conjunto de pontos de escolha, nos quais formam-se alianças entre diferentes atores societais, que são decompostas e reformadas em cada período de crise. O que é interessante na presente pesquisa é a sugestão analítica do autor, ou seja, a análise da crise como um momento no qual se abre um leque de várias possibilidades de mudança de antigos padrões institucionais, dependendo da formação ou da dissolução de coalizões políticas no momento da crise. A crise russa, em agosto de 1998, e depois a crise de desvalorização cambial, em janeiro de 1999, sedimentaram o caminho para mudanças importantes na arena fiscal. Havia uma pressão internacional muito forte sobre o Governo Federal para a realização de programas de cortes orçamentários e o aprofundamento do ajuste fiscal ${ }^{8}$. Segundo Loureiro e Abrucio (2002), “(...), dizia-se que ou se fazia o ajuste, ou o Brasil entrava em bancarrota”. Em junho de 1998, foi promulgada a Emenda Constitucional $\mathrm{n}^{\circ} 19^{9}$, que previa, no Art. 30, a apresentação do projeto de lei infraconstitucional que regulamentaria o art. 163 da Constituição: "O projeto de lei complementar a que se refere o art. 163 da Constituição Federal será apresentado pelo Poder Executivo ao Congresso Nacional no prazo máximo de cento e oitenta dias da promulgação desta Emenda". Em um ambiente de crise e com uma "demanda para legislar", os técnicos do Ministério do Planejamento, que já vinham de experiências profissionais na área fiscal, formaram um grupo para elaborar o projeto de lei complementar da LRF.

Velasco Jr. (2005) desenvolveu um trabalho de análise do processo decisório que gerou duas reformas estruturais, durante o primeiro mandato do Governo Cardoso: a privatização da Companhia Vale do Rio Doce (CVRD) e a produção legislativa que permitiu a privatização do setor de telecomunicações. Nesses casos, o autor aplica um modelo analítico de coordenação de interesses, desenvolvido empiricamente a partir de uma narrativa analítica, ou

\footnotetext{
${ }^{8}$ Ocorreram mudanças importantes não só na área fiscal. Segundo Oliveira e Turolla (2003), em 1999, ocorreu uma tríplice mudança de regime, envolvendo os regimes cambiais, monetário e fiscal (pp. 197).

9 Ver quadro 2, anexo 1.
} 
seja, "um conceito que combina a história e a produção das políticas com a teoria da escolha racional. São identificados os agentes envolvidos - atores individuais ou coletivos -, suas preferências e os fundamentos de suas escolhas e decisões em seu nível micro, os caminhos evitados e os efetivamente adotados, bem como as formas pelas quais as escolhas resultam em fatos e se revertem em decisões políticas, buscando-se uma interação permanente entre o modelo analítico assumido e as pesquisa realizada, as idéias sendo confrontadas continuamente com a realidade" (Bates et al. 1998 apud Velasco Jr. 2005: 19/20).

Este modelo foi elaborado a partir de duas arenas de negociação: a partidária e a distributiva. Na primeira arena, os partidos são estruturas privilegiadas de organização institucional dos interesses dos parlamentares no Congresso. Na segunda, os partidos pesam pouco como estruturas aglutinadoras de interesses e as clivagens subnacionais e eleitorais de interesses são mais importantes. A interação entre essas duas arenas pode ocorrer ou não em um mesmo lócus de negociação (Velasco Jr, 2005: 19).

O autor indica alguns postulados do modelo de coordenação de interesses. Em primeiro lugar, as preferências dos atores são mediadas por instituições capazes de coordená-las, tornando críveis os benefícios para os cooperadores e os custos para os desertores (Tsebelis 1990 apud Velasco Jr., 2005: 20). Em segundo lugar, na condução das políticas econômicas de seu interesse, o presidente exerce um poder de superar os conflitos distributivos decorrentes dos interesses eleitorais dos parlamentares. Este poder se expressa na ação dos ministros e líderes partidários para garantir a aprovação da política, ao negociarem nas arenas partidária e distributiva (Velasco Jr., 2005: 20). Em terceiro lugar, na coordenação dos diferentes interesses, há um ator político governamental que age como líder de coalizão, ou seja, ele influencia e conduz a estrutura do processo decisório congressual, por ser capaz de antecipar as decisões de voto dos parlamentares, seja nas comissões, seja em plenário. Os líderes naturais são o presidente, o ministro diretamente ligado à área da política proposta e os líderes dos partidos da coalizão (idem).

Em quarto lugar, o autor destaca o papel das comissões congressuais e dos relatores das comissões. As comissões são um lócus natural da arena partidária, na medida em que elas são formadas a partir da escolha dos líderes partidários. Suas especificidades são a maior participação individual do parlamentar 
especialista no tema da comissão, que pode apresentar mais emendas do que em plenário (idem). O papel do relator é fundamental dentro da comissão. Além do enorme poder de influência sobre o projeto que sai da comissão na forma de um substitutivo, é através da ação do relator que determinados interesses relacionados à matéria em discussão podem ser expressos, mediados pela ação dos líderes partidários, que podem propor alterações ao status quo, em conjunto com o relator, além ou aquém das preferências dos grupos de interesse (idem). Do ponto de vista do processo decisório, o trabalho do relator na comissão é ampliar as bases de cooperação dos parlamentares da coalizão governamental em torno do projeto, antes do projeto seguir para o plenário, aonde "a maior pulverização dos interesses será em algum nível mediada pela arena distributiva” (Velasco Jr. 2005, 22).

Em quinto lugar, neste modelo, o Executivo tem recursos para garantir o apoio à proposta, baseado na ação dos líderes de coalizão, que mapeiam os interesses que podem obstruir a aprovação do projeto. O Executivo tem recursos de patronagem e as legislações pork-barrel, ou seja, ele pode conceder cargos e criar regras ou distribuição de emendas do orçamento federal para beneficiar os distritos eleitorais dos parlamentares que não necessitem de aprovação do Legislativo. Independente se a coalizão governista é maioria ou não, a proposta que deve ser gerada no processo decisório parlamentar deve aglutinar os interesses da base governista e, ao mesmo tempo, atrair parte da oposição até atingir o quorum necessário para a aprovação da matéria. Assim, no presidencialismo de coalizão, na medida em que a oposição tenha como estratégia dominante a preservação do status quo, a negociação será totalmente internalizada na base governista (idem).

Enfim, em sexto lugar, este modelo de análise deve valer para as duas casas legislativas, Câmara e Senado. No entanto, o centro da negociação pode ser uma das casas, dependendo das características da política em discussão. Ademais, o fato de o Senado Federal ser a casa legislativa de representação dos Estados permite inferir que esta casa é o lócus privilegiado para que os atores políticos estaduais atuem como sinalizadores dos interesses subnacionais.

É importante esclarecer porque o trabalho de Velasco Jr. (2005) tornou-se uma importante fonte de inspiração para tentarmos explicar o processo decisório que gerou a Lei de Responsabilidade Fiscal. Concordamos com o argumento do autor de que o modelo analítico baseado na coordenação de interesses demonstra- 
se adequado para a compreensão da produção de reformas conduzidas no presidencialismo de coalizão brasileiro, especialmente nos momentos de discussão do projeto de lei no interior do Executivo e nas casas legislativas. O autor justifica a sua escolha analítica discutindo as análises já amplamente conhecidas de Figueiredo e Limongi (1999) e Ames (2001), sobre o processo decisório brasileiro. Enquanto os primeiros autores afirmam que a configuração institucional, que surgiu a partir da Constituição de 1988, garante a existência de mecanismos de governabilidade no sistema político brasileiro, Ames desenvolve a tese de que o sistema tende à ingovernabilidade devido, entre outros fatores, à existência de um número excessivo de pontos de veto, conforme discutiremos no próximo capítulo.

Concordamos com Velasco Jr., que analisa as visões de Figueiredo e Limongi e Ames como "não necessariamente conflitantes, quando pensadas em termos das dificuldades associadas ao processo de negociação decisória" (Velasco Jr., 2005: 11). Conforme bem argumenta Palermo (2000), as certezas e as incertezas do processo decisório legislativo não devem ser avaliadas somente com base na votação na Câmara. As regras de funcionamento do processo legislativo não dão certeza ao Executivo Federal quanto à aprovação de uma proposição legislativa de sua autoria. Da mesma forma, a produção legislativa dos últimos anos demonstra que a existência de atores com poder de veto não paralisou a capacidade de criação legislativa do Executivo Federal. Desta forma, justificamos a opção pela realização das chamadas "narrativas analíticas", ou historiografia do processo decisório, na medida em que o intenso processo de negociação que caracteriza a produção de políticas públicas no Brasil não é captado somente pela análise da legislação aprovada e pelas respectivas votações parlamentares.

III) O procedimento de coleta de dados

Os dados primários desta pesquisa são relatos das entrevistas de técnicos e atores políticos envolvidos; legislação de controle de endividamento e gastos desde a década de 1970; atas de reuniões de técnicos no Executivo Federal, de reuniões das comissões parlamentares e transcrição dos debates em plenário na Câmara e no Senado, publicados nos Diários das respectivas casas legislativas. Todas as proposições legislativas citadas nos capítulos seguintes foram pesquisadas e analisadas em seus conteúdos. Os dados secundários sobre leis citados nos 
trabalhos de Mora (2002), Lopreato (2002) e Loureiro e Abrucio (2002) foram confirmados. A pesquisa sobre a criação da Lei de Responsabilidade Fiscal foi feita a partir dos documentos e dos arquivos publicados no site do Banco Federativo, do BNDES. A análise da tramitação do projeto de lei na Câmara e no Senado foi realizada através dos debates registrados nos Diários da Câmara dos Deputados e do Senado Federal, mapeando o caminho parlamentar que o projeto percorreu: por quais comissões passou, quem foram os relatores, qual foi o regime da tramitação, se houve muitas emendas incorporadas ao texto, como foram as votações nominais, quais foram os temas discutidos em plenário, quais eram os deputados que mais discutiram, etc.

Depois deste mapeamento, realizamos dez entrevistas abertas ${ }^{10}$ com pessoas envolvidas em várias etapas do processo: Luiz Carlos Mendonça de Barros, que participou do processo de renegociação das dívidas dos Estados, em 1997; Amir Khair, especialista em finanças públicas e, especificamente, na Lei de Responsabilidade Fiscal; Yoshiaki Nakano, Secretário da Fazenda do Governo do Estado de São Paulo, na época da renegociação das dívidas dos Estados; Arnaldo Madeira, Líder do Governo Cardoso na Câmara dos Deputados, em 1999; José Roberto Rodrigues Afonso, membro da equipe do Ministério do Planejamento e do BNDES que criou a lei; Martus Tavares, membro desta equipe, Secretário Executivo e Ministro do Planejamento; Selma Pantel, Assessora do Ministério do Planejamento; Selene Peres Peres Nunes, Assessora Técnica do Ministério do Planejamento; Wéder de Oliveira, Assessor do dep. Pedro Novais (PMDB/MA), relator do projeto na Comissão Especial (CESP) da Câmara dos Deputados; Dep. Sergio Miranda (PCdoB/MG), deputado de oposição atuante nas discussões em plenário e; Luiz Carlos Bresser Pereira, ex-Ministro da Fazenda no Governo Sarney e Ministro de Administração Federal e da Reforma do Estado, no primeiro Governo Cardoso. A análise das entrevistas foi feita a partir da transcrição das fitas.

Este trabalho é composto por quatro capítulos. No primeiro, abordamos um panorama dos principais argumentos da literatura que caracterizam o sistema político brasileiro como um sistema em que prevalece uma tendência à ingovernabilidade e à dispersão de poder, destacando o federalismo como um traço institucional importante neste quadro analítico. Abordamos também o processo de

\footnotetext{
${ }^{10}$ Ver anexo 2.
} 
descentralização fiscal e as mudanças nas condições de governabilidade na arena fiscal.

O segundo capítulo trata do processo de ordenamento fiscal, destacando o processo de mudança política e institucional que começou a ocorrer na década de 1980 e continuou na década de 1990, no que tange à construção do ordenamento fiscal, em um primeiro momento, no plano federal, e em um segundo momento, no plano subnacional. Constatamos que a Lei de Responsabilidade Fiscal foi um ponto de inflexão no processo de ordenamento fiscal, na medida em que deu organicidade para um arcabouço de regras que vieram anteriormente, no sentido do processo de ordenamento fiscal, ou seja, regras para limitar gastos com pessoal, endividamento, emissão de títulos, etc. Ademais, houve uma mudança do tipo de norma, especialmente no controle do endividamento público. Até a Lei de Responsabilidade Fiscal, esta área das finanças públicas era regulada basicamente por Resoluções do Senado Federal. Na medida em que se cria uma lei complementar para regular, entre vários pontos, o limite de endividamento dos Estados e Municípios, torna-se muito mais difícil, politicamente, promover um processo de mudança deste arcabouço de regras. Uma lei complementar exige quorum parlamentar qualificado para ser aprovada ${ }^{11}$.

No terceiro capítulo, tratamos da elaboração do projeto da Lei de Responsabilidade Fiscal no Executivo Federal e, no quarto capítulo, o processo de discussão o projeto de lei na Câmara e no Senado, observando também a impetração das Adins e a implementação da lei. Por último, desenvolvemos um capítulo de conclusão, procurando discutir os dados apresentados à luz do arcabouço analítico aqui apresentado.

\footnotetext{
${ }^{11}$ Conforme o Art. 183 do Regimento Interno da Câmara, "Art. 183. Salvo disposição constitucional em contrário, as deliberações da Câmara serão tomadas por maioria de votos, presente a maioria absoluta de seus membros. $\S 1^{\circ}$ Os projetos de leis complementares à Constituição somente serão aprovados se obtiverem maioria absoluta dos votos dos membros da Câmara, observadas, na sua tramitação, as demais normas regimentais para discussão e votação". O Regimento Interno do Senado, no Capítulo IV, Seção I, "Da Autorização para Operações Externas de Natureza Financeira", determina que, conforme o Art. 391, "qualquer modificação nos compromissos originariamente assumidos dependerá de nova autorização do Senado".
} 


\section{Capítulo I - Federalismo, problemas de governabilidade do sistema político BRASILEIRO E MUDANÇAS FISCAIS}

Neste capítulo, apresentamos um panorama dos principais argumentos da literatura que caracterizam o sistema político brasileiro como um sistema em que prevalece uma tendência à ingovernabilidade e à dispersão de poder, destacando o federalismo como um traço institucional importante neste quadro analítico. Pretendemos, também, abordar o processo de descentralização fiscal e as mudanças nas condições de governabilidade na arena fiscal. No final da discussão, esclareceremos a nossa posição diante do debate relacionado às questões financeira e fiscal.

Alguns autores, analisando o panorama político brasileiro da década de 1980 e primeira metade da década de 1990, assim como o período de 1946 a 1964 , argumentam que o país sofreu graves problemas de ingovernabilidade em função da existência de diversos fatores institucionais que se reforçavam para dispersar o poder, em um sistema político fragmentado. Segundo autores como Lamounier (1991), Mainwaring (1997), Kinzo (1999) e Ames (2001; 2003), o sistema político brasileiro caracteriza-se pela pior das combinações institucionais: sistema eleitoral com representação proporcional com lista aberta, multipartidarismo, uma combinação entre alta fragmentação partidária com baixa disciplina dos partidos na arena parlamentar, e formato federal, produzindo um sistema mais propenso ao veto do que às tomadas de decisões. Em recente trabalho, Ames (2001) argumenta que "o sistema eleitoral brasileiro, junto com o federalismo e a tradicional dependência do Executivo em apadrinhamento e concessões de recursos, produz um grande número de atores com poder de veto. (A premissa da minha análise é que) um excesso de atores com poder de veto, não apenas em termos partidários, mas também em termos de interesses estaduais, municipais e corporativos, leva à obstrução do Legislativo. Essa obstrução pode ter três causas: um número excessivo de partidos (fragmentação partidária), bloqueios regimentais e um excesso de membros com pouco interesse na legislação mais ampla" (p. 52).

O federalismo é um dos fatores que aparecem na literatura que reduziria a eficácia para a tomada de decisão e implementação de políticas públicas no plano federal. Além dos autores acima citados, Abrucio (1994; 1998), Abrucio e Samuels (1997) e Willis, Garman e Haggard (1999; 2001) discutem especificamente o 
federalismo, a partir da Constituição de 1988, como um fator institucional que gera problemas de ingovernabilidade. $O$ termo ingovernabilidade tem sido entendido, genericamente, como a dificuldade que o Governo Federal teria para fazer cumprir sua agenda, especialmente a de estabilização monetária, ajustamento do setor público e reformas econômicas de mercado. Mainwaring (1997) detalha algumas áreas de política relacionadas à estabilização, à reforma do Estado e à reforma tributária e fiscal que, entre 1985 e 1994, os presidentes foram incapazes de implementar: desindexação de salários e pensões, corte no funcionalismo público, privatização de empresas públicas, aumento de impostos, alteração nos repasses dos fundos de participação de Estados e Municípios, reforma no sistema de bancos públicos estaduais e privatização das empresas públicas estaduais, renegociação das dívidas dos Estados e reforma da previdência social (p. 99/100).

No Brasil, o processo de redemocratização trouxe uma forte pressão pela descentralização de poder no sistema político, inclusive no plano dos Municípios, que se consubstanciou na tendência à proliferação de centros de poder rivais na disputa pelos recursos do Estado e pela redistribuição de novos recursos políticos (Sola 1995: 35). A conseqüência desta transformação do sistema federativo centralizado do período autoritário numa federação mais descentralizada sob regime democrático é a enorme complicação do processo de decisão. Essa passagem efetivamente multiplica o número de participantes no jogo, como resultado tanto da democratização quanto da reforma federativa.

Para recuperarmos a lógica da argumentação desses autores abordaremos, a seguir, alguns tópicos que estruturam seus principais argumentos.

\section{I.a) Os governadores na redemocratização}

Segundo Abrucio (1998), o papel dos governadores na condução da redemocratização foi importante, na medida em que a negociação da transição foi articulada através de um pacto entre os governadores em ascensão na cena política nacional e as elites regionais, que sempre tiveram influência no jogo político federativo. Segundo o autor, na transição, a dinâmica federativa foi mais importante do que a dinâmica das negociações partidárias (idem: 101). Os governadores tiveram um papel atuante no movimento das Diretas-Já, especialmente nos Estados onde o governador era da oposição. Paralelo a isso, houve um processo 
de fortalecimento financeiro das unidades subnacionais. Segundo Abrucio, ao longo da década de 1980, as unidades subnacionais aumentaram sua participação nas receitas nacionais, ao passo que a União diminuiu gradualmente. A Constituição de 1988 fortaleceu o federalismo descentralizador, enfraquecendo a posição financeira e fiscal da União.

O argumento sobre a crise do poder central, desenvolvido pelo autor, relaciona a convergência temporal entre as crises do Estado desenvolvimentista, do regime militar e a perda de força política do presidente. O poder central enfraqueceu-se como condutor do desenvolvimento econômico, como centro político do país e como ordenador das relações federativas, perdendo força perante os outros núcleos de poder: o Executivo Federal e a Presidência da República perante o Congresso Nacional e a União perante os Estados. (Abrucio 1998).

Neste processo de enfraquecimento do poder central vis-à-vis o poder subnacional, a existência de partidos frágeis em termos nacionais e o papel central da eleição aos governos estaduais de 1982 geraram um sistema político que funciona mais a partir de uma lógica regional do que nacional (Abrucio, 1998: 103). Neste sentido, o caráter de fundação da eleição de $1982^{12}$ foi um fator determinante da proeminência dos governadores naquele contexto político, especialmente nas estratégias eleitorais dos deputados. As eleições para governadores, após anos de autoritarismo, envolveram real distribuição de poder e ajudaram a determinar a lógica da competição dos futuros pleitos. Segundo Abrucio \& Samuels (1997), como na transição houve duas eleições casadas, em que estavam em disputa apenas cargos cujos distritos eram estaduais (governadores, senadores, deputados estaduais e federais; em 1982 e 1986), constituiu-se um tipo de sistema partidário em que os nexos estaduais de campanha são mais importantes do que as diretrizes partidárias nacionais. Este fato ajudou no fortalecimento dos governadores frente às suas bancadas estaduais (idem: 154). Este ponto é importante para explicar os fundamentos da atuação dos governadores como veto players no Congresso, que será abordado logo adiante, como uma das formas de expressão da "nova política dos governadores", nos termos de Abrucio \& Samuels (1997).

\footnotetext{
${ }^{12}$ Segundo Abrucio, os autores que primeiramente utilizaram a noção de "eleições fundadoras" foram Linz \& Stepan (1992) Estados em via de integração e de desintegração. Revista de Estudos Avançados, $\mathrm{n}^{\circ}$ 14, São Paulo. O uso deste conceito para a análise do caso brasileiro foi originalmente feito em Almeida (1994) Federalismo e políticas sociais. Balanço e perspectivas do federalismo fiscal no Brasil. Fundap. Mimeo. São Paulo.
} 
O aumento do poder dos governadores no período da redemocratização ocorreu em dois planos: no âmbito interno dos Estados, ou seja, na existência de um sistema ultrapresidencialista estadual (Abrucio 1994, 1998), e no âmbito federal, denominado federalismo estadualista (idem).

I.b) O ultrapresidencialismo estadual e o federalismo estadualista

A hipertrofia dos Executivos Estaduais é explicada por quatro fatores. Em primeiro lugar, houve um desinteresse da opinião pública pela política estadual, o que levou a uma ausência de debates e fiscalização sobre as ações dos governadores (Abrucio 1994: 174). Um segundo fator é o grande poder que os governadores tinham sobre as bases municipais dos deputados estaduais (idem). Os outros dois fatores são a grande margem de manobra que os governadores possuíam para definir a distribuição dos cargos dentro da administração pública, e a capacidade que os governadores tinham de neutralizar as instituições incumbidas de fiscalizá-los - os Tribunais de Contas do Estado e o Ministério Público tornando-as pouco independentes com relação ao Executivo (idem: 176/177).

No âmbito federal, segundo Abrucio (1998), após a Constituição de 1988, mais especificamente no período de 1991 a 1994, os governadores conseguiram acomodar seus interesses em torno da nova ordem política e federativa, caracterizando o federalismo estadualista, ou seja, um processo de criação de um tipo de relação federativa que favorece os interesses estaduais, a partir de uma atuação conjunta, a fim de garantir o status quo adquirido. Para o autor, e para a maioria dos autores aqui citados, os governadores fortaleceram-se, no panorama político nacional naquele período, basicamente porque conseguiam influenciar as suas bancadas estaduais, especialmente na Câmara e, em menor grau, no Senado, nos debates parlamentares das questões que envolviam seus interesses federativos, em detrimento da bancada partidária no processo decisório parlamentar (idem).

O autor explica o processo de formação das bancadas estaduais elaborando uma argumentação que envolve a relação entre o federalismo e os outros fatores institucionais que dificultam a governabilidade. Segundo Abrucio \& Samuels (1997), Mainwaring (1997), Kinzo (1999), Garman, Haggard and Willis (2001) e Ames (2003), a existência de uma combinação institucional de partidos políticos com 
disciplina e lealdade fracas e de eleição proporcional com lista aberta gera incentivos para que os candidatos façam campanha individual (e não partidária). No plano parlamentar, a fraqueza dos partidos gera incentivos para que os deputados organizem suas ações mais pela via regional do que pela via partidária (Abrucio, 1998: 178/179). As conseqüências para as condições de governabilidade desta combinação institucional é que o Governo Federal não tem apoio garantido no Congresso e isto aumenta a imprevisibilidade do processo decisório. A combinação de presidencialismo com pluripartidarismo torna imperativa a formação de um governo de coalizão (Kinzo 1999: 26), no qual os presidentes devem construir coalizões não somente envolvendo um grande número de partidos, mas também coalizões que satisfaçam as demandas regionais (Mainwaring 1997: 84). Esses autores enfatizam, portanto, o quadro de alta fragmentação do poder, de um sistema com um número muito grande de atores com poder de veto, que dificultaria as possibilidades de policy change.

Os mesmos autores enfatizam as nuances desse processo, a partir das prerrogativas legais do presidente, garantidas pela Constituição de 1988. Se, por um lado, segundo Abrucio (1998), a partir de 1988, o presidente ficou politicamente mais fraco, com relação ao Congresso Nacional, ao Supremo Tribunal Federal e aos governadores, devido às mudanças constitucionais que aumentaram a eqüipotência entre os Poderes, por outro, segundo Mainwaring (1997), a Constituição garante ao presidente três tipos de poderes: poderes legislativos reativos, que capacitam o presidente a bloquear a legislação, os vetos totais e os vetos parciais; poderes legislativos proativos, que garantem a capacidade de criação legislativa do presidente através da edição de Medidas Provisórias (art. 62); a capacidade de influenciar a agenda legislativa, através da declaração de urgência de determinada matéria (art. 64) e da capacidade de convocação de sessões especiais do Congresso (art. 57) (idem: 60/64/65). Ademais, ao presidente é garantida a iniciativa exclusiva de legislar em algumas áreas importantes, como a área orçamentária (art. 61). Conforme Abrucio (1998) e Couto (1997), este quadro institucional permite que se afirme que o sistema político brasileiro tem características tanto do modelo majoritário, que favorece a concentração do poder no presidente, como do modelo consociativo, que favorece a dispersão do poder a partir do multipartidarismo, do sistema bicameral, do federalismo centrífugo e de um texto constitucional que toca em quase todos os temas nacionais relevantes, e que 
só é passível de mudança diante de uma maioria qualificada. A tensão entre o modelo majoritário e consociativo é resolvida dependendo dos recursos à disposição dos atores (p. 185).

I.c) Federalismo, Constituição de 88 e descentralização fiscal

A Constituição de 1988 gerou um impacto importante nas relações entre os entes federativos: traduziu um amplo apoio à descentralização e incluiu as forças políticas mais importantes, tivessem ou não relação com interesses subnacionais. Abrucio (1994; 1998), Kinzo (1997), Mainwaring (1997), Willis, Garman e Haggard (1999), Ames (2003) e, mais recentemente, Almeida (2005) argumentam que a Constituição de 1988 teve um papel fundamental na institucionalização de um quadro de autonomia político-administrativa dos Estados e Municípios. Segundo esta literatura, a Constituição de 1988 inseriu importantes mudanças nas regras de funcionamento do sistema tributário, coroando um processo que combinava redemocratização política com descentralização fiscal e federativa. A partir da Constituição de 1988, houve uma redistribuição de receitas públicas, por meio de uma considerável transferência de recursos fiscais do nível federal para o estadual e local (Kinzo, 1997: 21). Segundo Gomes e Mac Dowell (2000), um capítulo federativo importante do processo de descentralização política foi incremento de recursos transferidos aos Municípios, como também a sua elevação a membro da Federação, o que os autores denominam de federalismo municipal ${ }^{13}$.

O processo de descentralização fiscal, um capítulo do processo de descentralização política, amplamente abordado na literatura tanto de Economia como de Ciência Política ${ }^{14}$, é entendido como o processo de aumento relativo dos recursos financeiros postos à disposição dos Estados e Municípios, vis-à-vis à

\footnotetext{
${ }^{13}$ As evidências deste processo são o aumento dos recursos postos à disposição dos municípios, em termos absolutos e com relação ao PIB, de forma distorcida em favor dos municípios de menor população, e a proliferação de pequenas cidades, especialmente a partir de 1984 (idem). Segundo Serra \& Afonso (1999), entre 1984 e 1997, foram criados 1.405 novos municípios no país, a metade deles com menos de 5.000 habitantes, fenômeno induzido pelo critério de rateio do Fundo de Participação dos Municípios (FPM) - proporcional à população, mas com um piso de 10 mil e um teto de 150 mil habitantes. A conseqüência disso foi o surgimento de várias distorções, como a irrisória capacidade de autofinanciamento, disposição de receita per capita muito superior à das médias e até grandes cidades, além do gasto per capita com o Poder Legislativo muito acima das despesas sociais, como, por exemplo, na área da Saúde (idem: 08).

${ }^{14}$ Alguns autores que discutem a questão da descentralização fiscal: Abrucio (2002); Affonso (1995); Afonso (1994); Almeida (2005); Gomes e Mac Dowell (2000); Kugelmas (2001); Mora \& Varsano (2001); Piancastelli e Camilo (2003); Rangel (1999); Rezende e Afonso (2004); Samuels (2003); Serra e Afonso (1991); Serra e Afonso (1999).
} 
União. Segundo Serra e Afonso (1991, 1999), já nos anos de 1960, pode-se dizer que houve um processo de descentralização fiscal a favor dos Municípios, processo este que avançou na década seguinte (idem, 1991: 05). Ao longo da década de 1970, ocorreu uma forte elevação das transferências federais também ao nível estadual, as chamadas "não-tributárias" ou "negociadas" (idem: 06). Mas foi a partir da década de 1980 que o processo se intensificou, conforme gráfico a seguir (Serra e Afonso, 1999: 06). Segundo os autores, a fração dos dois principais impostos federais - sobre a renda (IR) e sobre o valor adicionado pela indústria (IPI) transferida aos fundos de participação dos Estados (FPE) e dos Municípios (FPM) aumentou de 18 para $44 \%$ entre 1980 e 1990. Considerando todas as transferências constitucionais, chega-se a uma parcela transferida de $47 \%$ do IR e $57 \%$ do IPI. Em 1980, este total era de $20 \%$ (idem).

Fundos de Participação: destinação constitucional da arrecadação dos IR e IPI - 19681993.

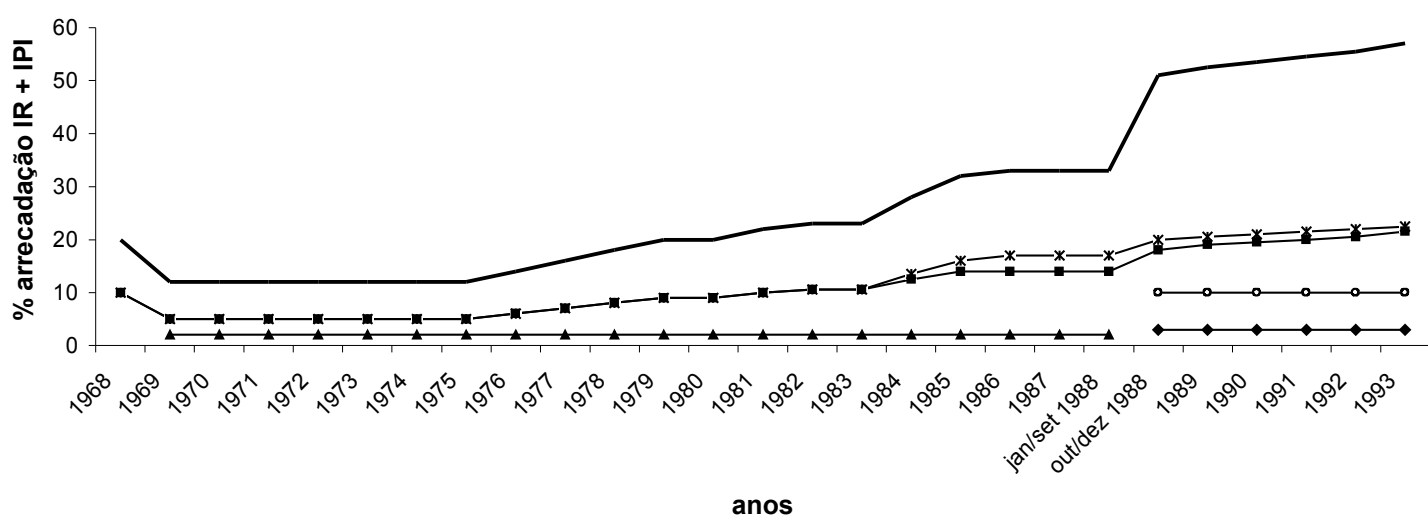

-*-FPM: Fundo de Participação dos Municípios.

$\rightarrow-$ FPE: Fundo de Participação dos Estados.

$\neg$ FE: Fundo Especial (para Estados das regiões pobres).

$\rightarrow-$ FFR: Fundo de Financiamento do Setor Produtivo das Regiões NE, N, e CO, aplicado pelos bancos federais regionais (para empresas). - - FPEx: Destinação para Estados (75\%) e respectivos Municípios (25\%); exportadores de produtos industrializados. 一 Total

Fonte: Serra e Afonso (1991).

Até setembro de 1988, o FPM representava $17 \%$ da arrecadação do Imposto de Renda (IR) e Imposto sobre produtos industrializados (IPI), e o FPE, 14\%. A partir da promulgação da Constituição, em outubro de 1988, esses valores passaram, respectivamente, para $20 \%$ e $18 \%$, e a partir de $1993,22,5 \%$ e $21,5 \%$ (Serra e Afonso, 1991: 05/06). Segundo Serra \& Afonso (1999), a partir da nova Constituição, foi fortalecida e consolidada a capacidade de tributação própria das 
esferas subnacionais de governo: no caso dos Estados, foi ampliada a base de incidência do imposto estadual sobre circulação para todas as mercadorias e os serviços (ICMS) de comunicações e transportes. Paralelamente, foram aumentadas em $25 \%$ as transferências desse imposto aos Municípios (Serra \& Afonso, 1999: 06/07).

Ao mesmo tempo em que a Constituição promoveu um processo de descentralização de recursos, beneficiando especialmente os Municípios, ela promoveu também novas distorções, na medida em que a redistribuição financeira não foi acompanhada de uma redefinição das atribuições alocadas a cada nível de governo. Segundo Kinzo (1997), as conseqüências dessas indefinições são graves. Governos e políticos locais e regionais têm seus próprios espaços de poder e suas ações podem afetar de forma considerável a eficácia governativa do poder central, na medida em que os governadores, ao readquirirem poder e influência, passam a ser atores com poder de veto no processo decisório nacional (idem: 22).

Segundo Almeida (2005) e Rezende e Afonso (2004), ao mesmo tempo em que a Constituição de 1988 ampliou a porção das receitas fiscais da União, compartilhadas com os governos subnacionais, também permitiu a expansão dos recursos do Governo Federal por meio das contribuições sociais, cujo objetivo deveria ser o financiamento das políticas sociais. Nos anos de 1990, os recursos não partilhados, à disposição da União, foram acrescidos com a criação da Contribuição Provisória sobre Movimentações Financeiras (CPMF), em julho de 1993, posteriormente tornada permanente ${ }^{15}$ (Almeida, 2005: 34). Segundo Rezende e Afonso (2004), apesar de seu ímpeto descentralizador, na prática, a Constituição de 1988 implantou um federalismo fiscal duplo. Por um lado, criou mecanismos de transferência de grande parte dos recursos arrecadados através dos principais tributos federais, IR e IPI, para Estados e Municípios. Por outro, criou contribuições sociais para financiar as responsabilidades sociais da União.

I.d) Mudanças na arena fiscal ${ }^{16}$

\footnotetext{
15 Em 13 de julho de 1993, foi instituído o Imposto Provisório sobre a Movimentação ou a Transmissão de Valores e de Créditos e Direitos de Natureza Financeira - IPMF (Lei Complementar $\mathrm{n}^{\circ}$ 77). Em 25 de outubro de 1996, foi instituída a Contribuição Provisória sobre Movimentação ou Transmissão de Valores ou de Créditos e Direitos de Natureza Financeira - CPMF (Lei Ordinária $n^{\circ}$ 9311).

${ }^{16}$ Neste momento, serão tratadas, de forma geral, as dificuldades do Governo Federal na administração da arena fiscal, advindas da atuação dos governadores, conforme a literatura que está sendo discutida. No próximo capítulo, será abordado mais especificamente a construção do
} 
Esta literatura que aborda as dificuldades de governabilidade no Brasil dialoga diretamente com alguns autores ${ }^{17}$ que relacionam as dificuldades enfrentadas pelo Governo Federal para avançar no processo de reforma fiscal, especialmente na década de 1980 e primeira metade da década de 1990, com a atuação dos governadores. O contexto a partir da implementação do Plano Real produziu algumas divergências. Há autores ${ }^{18}$ que argumentam que as dificuldades de governabilidade persistiram durante os mandatos do Presidente Fernando Henrique Cardoso e poucas mudanças significativas foram implementadas na direção de um ordenamento fiscal. Outros autores ${ }^{19}$ dão maior ênfase para o impacto do Plano Real nas relações financeiras intergovernamentais e no caráter incremental das mudanças que ocorreram na década de 1990 (Loureiro \& Abrucio, 2002).

No período da redemocratização, consubstanciou-se um problema político para o Governo Federal: ao mesmo tempo em que houve uma crescente demanda social pela estabilização econômica, houve uma enorme dificuldade para concentrar recursos fiscais ${ }^{20}$, inviabilizando uma estratégia de administração de perdas e ganhos, pelo Governo Federal. Para agravar o quadro, as idéias de equilíbrio fiscal e de restrição orçamentária constituíam-se em peças de ficção, como princípios administrativos totalmente ausentes do horizonte da classe política em geral.

Segundo Abrucio (1998), no campo financeiro e fiscal, os Estados atuaram de forma não cooperativa com relação à União e essa atuação se manifestou de três formas. A primeira, trata-se da recusa das unidades estaduais em participar de um esforço conjunto do Governo Federal para efetuar um ajuste fiscal. Os Estados lutavam na defesa da ordem federativa estabelecida a partir da Constituição de

processo de ordenamento fiscal, no tocante à construção de um arcabouço de controle do endividamento e do gasto dos entes federativos, pelo Governo Federal, com base em autores que trabalharam especificamente com o tema e com base nas entrevistas realizadas.

${ }^{17}$ Sola, 1993; Sola, 1995; Abrucio, 1998; Abrucio \& Samules, 1997; Bonfim \& Shah, 1994; Nogueira, 1995; Affonso, 1994; Dain, 1995; Lagemann, 1995.

${ }_{18}$ Ames, 2003; Samuels, 2003; Mainwaring, 1997; Montero, 2001.

${ }^{19}$ Abrucio \& Costa, 1998; Sola, Garman \& Marques, 1998; Garman, Leite \& Marques, 1998; Couto \& Abrucio, 1999; Loureiro, 2001b; Leite, 2001.

${ }^{20}$ Segundo Loureiro \& Abrucio (2002) e Sola (1995), esta dificuldade se verificava na existência da conta movimento do Banco do Brasil, na multiplicidade orçamentária (OGU, orçamento monetário, conta da dívida e orçamento das empresas estatais), a utilização das autoridades monetárias como bancos de fomento do desenvolvimento econômico e a utilização política dos bancos estaduais pelos seus controladores. Este assunto será abordado mais detalhadamente no próximo capítulo. 
1988 e postergavam constantemente o pagamento de suas dívidas com o Governo Federal. A segunda forma de manifestação do padrão não cooperativo refere-se ao fato de as unidades subnacionais, especialmente os Estados, adotarem medidas econômicas sem se preocupar com os efeitos na política macroeconômica do Governo Federal. Os Estados manejavam os incentivos do ICMS sem levar em conta os impactos para a concorrência no mercado interno.

A terceira forma refere-se ao caráter predatório da relação, como demonstra o caso dos bancos estaduais. Na década de 1980, havia uma multiplicidade de fontes de financiamento dos governos subnacionais que envolvia, além dos bancos estaduais, outros agentes e instituições financeiras, tais como os bancos oficiais federais, os bancos privados, o Banco Central, as instituições multilaterais de crédito, o Tesouro Nacional, as empresas estatais estaduais, entre outras. Esta multiplicidade de fontes de financiamento tornou-se um problema político e econômico, na medida em que os governadores lançavam mão, de forma intermitente, de recursos extra-orçamentários para atender às suas demandas políticas, cientes da disponibilidade incondicional do auxílio financeiro federal. ${ }^{21}$

Desta forma, consagrou-se um modelo de moral hazard nas finanças públicas, ao dar autonomia política e financeira aos Estados e Municípios e, ao mesmo tempo, não criar mecanismos de responsabilidade fiscal. Os entes federativos poderiam gastar além da arrecadação tributária, endividar-se e transferir o ônus da dívida para a União, que oferecia pleno socorro aos inadimplentes. A questão do endividamento progressivo dos Estados tornou-se um problema extremamente grave e de difícil solução.

Alguns autores argumentam que os obstáculos institucionais, que antes impediram a implementação de reformas econômicas nos governos Sarney, Collor e Franco, não bloquearam as ações reformistas capitaneadas pelo Governo Federal, a partir do primeiro mandato do Presidente Cardoso. A convergência de uma série de fatores, dentre eles a implementação do Plano Real, fez a diferença. A partir deste momento, os autores aqui abordados divergem: enquanto Ames (2003), Samuels (2003), Mainwaring (1997) e Montero (2001) enfatizam em suas análises que os obstáculos institucionais não deixaram de existir, que as reformas

\footnotetext{
${ }^{21}$ Assim como uma das funções clássicas do Banco Central é o de ser prestamista de última instância no mercado financeiro doméstico, minorando o risco de iliquidez no sistema, o Governo Federal brasileiro, por meio do Tesouro Nacional e do próprio Banco Central, agia como "prestamistas de última instância" dos governadores e municípios.
} 
foram realizadas com alto custo político e produziram ajustes ad hoc, Abrucio \& Costa (1998), Sola, Garman \& Marques (1998), Garman, Leite \& Marques (1998), Couto \& Abrucio (1999), Loureiro (2001b) e Leite (2001), enfatizam o impacto do Plano Real, o elemento da negociação política, o caráter incremental das mudanças que ocorreram na década de 1990 (Loureiro \& Abrucio, 2002).

Em linhas gerais, os autores citados convergem em um ponto: a partir de 1994, configurou-se um panorama político e econômico, no qual houve um processo de recentralização do poder no Governo Federal, que criaria condições para a realização das reformas econômicas. A profundidade da crise econômica conferiu um sentido de urgência para o esforço de aceitar novas medidas. Nessas condições, os legisladores e os governadores estavam dispostos a dar a Fernando Henrique Cardoso (primeiro como Ministro da Fazenda, depois como Presidente) maiores graus de liberdade para implementar políticas (Mainwaring, 1997: 104). O conteúdo dessas novas medidas refletia o crescente consenso em torno da idéia de estabilização monetária, ajustamento fiscal e reformas do Estado. Naquele momento, as opções ideológicas mais estatistas estavam deslegitimadas, em função do colapso do modelo soviético e da queda do Muro de Berlim (idem). Os novos governadores assumiram Estados falidos financeiramente, o que os fez depender fortemente dos recursos do Governo Federal e, por isso, tiveram que apoiar determinadas medidas propostas pelo presidente (Abrucio, 1998: 220).

O Presidente Fernando Henrique Cardoso foi eleito em 1994 com os louros de ser o criador do Plano Real, primeiro programa de estabilização bem sucedido desde as experiências da década de 1980. No período do primeiro mandato do Governo Cardoso, verificou-se um grande interesse governamental em sustentar o plano de estabilização. Usualmente, nas democracias representativas e federativas contemporâneas, o Executivo Federal é o poder governamental responsabilizável eleitoralmente pela manutenção da estabilidade monetária. No entanto, Sola, Garman e Marques (1998) argumentam que, no primeiro mandato do Presidente Fernando Henrique Cardoso, houve um interesse sem precedentes pela estabilidade monetária, em comparação a outros planos de estabilização já implementados no Brasil. O Presidente Fernando Henrique Cardoso foi o líder político que capitalizou o valor eleitoral da estabilidade, na medida em que gozou da prerrogativa funcional de ser o Ministro da Fazenda do governo Itamar Franco, no momento em que o Plano Real era arquitetado. 
Havia uma situação financeira internacional favorável à implementação do Plano Real na primeira metade da década de 1990, em função das baixas taxas de juros norte-americanas e pelo enorme fluxo internacional de capitais que imigravam para a América Latina, em função da adesão do país ao plano de reestruturação da dívida externa, o Plano Brady ${ }^{22}$. Ademais, as elites brasileiras organizaram-se em torno da candidatura de Fernando Henrique Cardoso (Abrucio, 1998). Cardoso era considerado, pela comunidade internacional e nacional, o candidato mais bem preparado para assumir o poder (Ames, 2003: 16), (Mainwaring, 1997: 104). As circunstâncias políticas das eleições de 1994 foram marcadas pelo "risco", percebido por parte de uma parcela da elite política, da vitória eleitoral do candidato Luís Inácio da Silva. Por outro lado, havia o trauma das eleições de 1989, o receio da vitória de um novo free rider.

O fato de a eleição presidencial de 1994 ter sido casada com os pleitos para deputado federal e governador fez com que o presidente eleito tivesse grande influência na formação da Câmara Federal e nos Executivos Estaduais (Abrucio, 1998: 220). Fernando Henrique Cardoso elegeu aliados nos cinco Estados mais importantes da federação ${ }^{23}$, apoiando decisivamente quatro dos cinco candidatos vencedores nestes Estados (Abrucio, 1998: 220). O evento da aprovação do Fundo Social de Emergência (FSE) no Congresso, em 1994, é um bom exemplo dos efeitos políticos das eleições casadas no processo decisório, que deram condições diferenciadas para o Governo Federal negociar com os governadores e deputados mudanças fiscais que atingiam interesses federativos ${ }^{24}$. A aprovação da emenda constitucional do $\mathrm{FSE}^{25}$ marcou a primeira reversão na tendência descentralizadora

\footnotetext{
${ }^{22}$ Em linhas gerais, o Plano Brady propôs: a extensão dos prazos de pagamento; a substituição dos juros flutuantes por taxas fixas; a redução no valor da dívida externa; a substituição de dívida velha, passível de suspensão, por nova, na forma de títulos de crédito negociados livremente no mercado internacional, os chamados Bradies. O Brasil foi o último país da América Latina a renegociar sua dívida externa com os bancos credores, convertendo-a em títulos.

${ }^{23}$ São Paulo, Minas Gerais, Rio de Janeiro, Rio Grande do Sul e Bahia.

${ }^{24}$ Conforme Abrucio (1998), além do efeito das eleições casadas, o fato de dois importantes líderes regionais, os governadores Antonio Carlos Magalhães (Bahia) e Hélio Garcia (Minas Gerais), terem sido articuladores da candidatura de Fernando Henrique Cardoso, lançando mão de suas ascendências políticas sobre outros governadores e sobre as bancadas de seus respectivos partidos (e/ou estados), ajudou a garantir a aprovação do FSE (idem: 215). Além disso, alguns governadores simplesmente não se articularam contra a aprovação do Fundo Social de Emergência. ${ }^{25}$ É importante considerar que a emenda constitucional que instituiu o FSE continha uma cláusula de vigência limitada, que precisava ser renovada. O Fundo Social de Emergência (FSE) foi instituído pela $1^{\text {a }}$ vez na Emenda Constitucional $n^{\circ} 1$, de 1.994, vigorando para os exercícios financeiros de 1.994 e 1.995. A Emenda Constitucional $n^{\circ} 10$, de 1996, prorrogou o FSE até junho de 1.997, já agora batizado de Fundo de Estabilização Fiscal (FEF). A Emenda Constitucional $n^{\circ} 449$, de 1997, prorrogou o FEF de $1^{\circ}$ de julho de 1.997 a 31 de dezembro de 1.999.
} 
que se iniciara no início dos anos de 1980 e, ao mesmo tempo, a primeira grande vitória fiscal da União desde a Constituição de $1988^{26}$.

Apesar de todos esses pontos positivos que marcaram o início do primeiro mandato do Presidente Cardoso, alguns autores afirmam que as dificuldades de governabilidade, que antes marcavam o sistema político brasileiro até então, persistiram pelo fato das restrições institucionais, representadas pela atuação dos governadores e pelo Congresso, continuarem atuando no processo político decisório. Houve êxitos, por exemplo, na área econômica, como a continuidade da abertura da economia e avanço no processo de privatização. No entanto, segundo Ames (2003), em outras áreas, o processo foi lento e desigual. Em fins de 1998, as reformas administrativa e previdenciária foram aprovadas depois de longa tramitação congressual e depois de substanciais concessões do governo (idem: 17). Contudo, a reforma tributária e as reformas fiscais, que deveriam consolidar a estabilização, não foram levadas a cabo em função do mau funcionamento das instituições políticas (idem).

Conforme Mainwaring (1997) e Samuels (2003), Cardoso, em seus dois mandatos, pagou um preço muito alto por seus êxitos e conseguiu menos do que buscava inicialmente. O presidente Cardoso conseguiu desvincular as administrações das finanças dos Estados e dos Municípios da estabilidade monetária. No entanto, para realizar este feito, o Governo Federal internalizou um custo enorme: no início de 2002, a União já tinha assumido R $\$ 297,7$ bilhões de dívidas estaduais, aproximadamente $25 \%$ do PIB nacional, sem contar os subsídios que a União forneceu aos Estados na renegociação das dívidas, através de taxas de juros abaixo do mercado e prazos longos de amortização ${ }^{27}$ (idem: 817). resultado deste processo de saneamento das finanças públicas, além da política de juros e câmbio da equipe econômica, foi o crescimento explosivo da relação dívida/PIB no Brasil durante o governo Cardoso.

\footnotetext{
${ }^{26}$ O FSE desvinculou $20 \%$ de uma grande parcela da receita da União constitucionalmente reservada a determinadas despesas, com a finalidade de proporcionar ao Governo Federal maior liberdade de ação na aplicação de recursos orçamentários (Samuels, 2003: 812). A percepção dos governadores sobre este fundo correspondia ao principal objetivo do Governo Federal: reter parte dos recursos anteriormente destinados às unidades subnacionais, visando à criação de um colchão de recursos públicos centralizados no plano federal. Ou seja, fazia-se mister alguma atuação de negociação do Executivo Federal no front federativo - seja na correção da descentralização fiscal e tributária cristalizada em 1988, seja na negociação da rolagem das dívidas dos estados e municípios, seja no enfrentamento do problema dos bancos estaduais - como pré-condição para o sucesso do processo de estabilização, que se iniciara naquele ano.

${ }^{27}$ Sobre a renegociação de 1997, no âmbito da Lei 9496/97, ver o próximo capítulo.
} 
A existência de obstáculos políticos impediu o governo de obter mais vitórias na direção de uma reforma fiscal mais consistente com os objetivos de crescimento econômico, como as ações provenientes dos governadores e dos prefeitos para limitar a centralização da receita pública. A dependência crescente do Governo Federal com relação às contribuições, levou-o a interessar-se menos pela Reforma Tributária (Samuels 2003: 826).

Outros autores fazem uma análise diferente, argumentando que a estabilização econômica provocou mudanças nas relações intergovernamentais e institucionais, com impactos consideráveis nas condições de governabilidade. $\mathrm{O}$ advento do Plano Real acarretou em um choque sobre as contas públicas dos entes federativos e sobre as suas instituições financeiras, através da queda brusca da inflação e das altas taxas de juros que incidem sobre as dívidas públicas.

Concomitantemente ao enfraquecimento financeiro dos Estados, a partir de 1994, a atuação do Governo Federal para a aprovação de medidas de sustentação do Plano Real, no front federativo, deu-se a partir de uma estratégia de barganha política com os parlamentares e os governadores, visando à aprovação de medidas de ajuste/saneamento das contas públicas estaduais e dos bancos estaduais, oferecendo, em contrapartida, o almejado socorro financeiro federal. Com o agravamento gradativo da crise fiscal dos Estados e da crise dos bancos estaduais, o espaço da barganha dos governadores foi se estreitando e o Governo Federal pôde propor medidas mais efetivas de ajuste, como a federalização ou privatização das instituições financeiras estaduais insolventes e um arcabouço de regras mais duras para o controle da administração das finanças públicas.

Conforme Garman, Leite \& Marques (1998), a despeito do fortalecimento do poder da União vis-à-vis o poder dos governadores, a partir da estabilização, o processo de redução do número de bancos estaduais, promovido pelo Governo Federal, demonstrou que os processos de ajuste fiscal e monetário ocorreram conforme as contingências do processo político federativo. A crescente despolitização da atividade bancária, que ocorreu especialmente após o PROES ${ }^{28}$, foi um processo que se deu invariavelmente pelo timing do processo político, mediante negociação com os atores envolvidos.

\footnotetext{
${ }^{28}$ O PROES (Programa de Incentivo à Redução do Setor Público Estadual na Atividade Bancária) foi criado em 07 de agosto de 1996, através de edição da Medida Provisória n 1.514 , estabelecendo mecanismos que objetivavam "incentivar a redução da presença do setor público estadual na atividade financeira bancária e, (...) a privatização das instituições financeiras." (Ver Leite, 2001: 128).
} 
Depois de 1994, a despeito da permanência do quadro institucional do processo político decisório, houve uma mudança no processo político. Concordamos com Palermo (2000), quando o autor afirma que, a partir deste período, o Governo Federal conseguiu realizar uma agenda política que, entre outros pontos, incluiu capítulos importantes da reforma econômica, que antes não tinham sido implementados. A forma como o Governo Federal lidou com as questões financeiras e fiscais dos entes federativos neste período e a eficácia das suas medidas demonstraram que houve uma mudança que não foi causada pelo incremento dos instrumentos à disposição do presidente para concentrar poder decisório, ou pelos incentivos institucionais das regras do jogo parlamentar. Outras variáveis devem explicar porque o sistema político produziu, especialmente a partir de 1997, avanços consideráveis na implementação da agenda da reforma fiscal, como o processo de renegociação das dívidas e o endurecimento das regras para endividamento público e gasto com funcionalismo público.

Como uma lei complementar, altamente complexa e com grande impacto na autonomia financeira e fiscal dos entes federativos, passou na Câmara, com votação de quorum qualificado (de Emenda Constitucional) e tramitação rápida? Neste trabalho, analisamos o processo de criação da Lei de Responsabilidade Fiscal, posicionando-nos previamente com relação a alguns pontos que foram abordados neste capítulo.

É inegável que, em grande medida, podemos explicar o panorama de crise da década de 1980 através das dificuldades de governabilidade advindas da tensão entre a lógica da redemocratização política e a lógica da estabilização econômica, e suas implicações no quadro de crise das finanças públicas. Contudo, por um lado, os argumentos da tese da ingovernabilidade e dos "barões da federação" não se sustentam empiricamente a partir de 1994, na medida em que o governo implementou vários pontos importantes da sua agenda econômica, como a própria LRF. O advento do Plano Real fez toda a diferença na mudança no quadro de correlação de forças entre os atores federativos. Ademais, a partir de 1988, houve um processo de concentração do poder decisório, em função, especialmente, dos mecanismos institucionais à disposição do chefe do Executivo Federal.

Contudo, por outro lado, como explicar a dificuldade na aprovação de alguns capítulos importantes da agenda política de reformas, como o da Reforma Tributária, tanto no Governo Cardoso, como no Governo Lula? A “caixa preta” do 
argumento da governabilidade e da concentração de poder deve ser aberta. $\mathrm{Na}$ análise das mudanças ocorridas na década de 1990, precisamos considerar o efeito do Plano Real como um ponto de inflexão importante no processo político de tomada de decisão na arena fiscal, a conjuntura da crise econômica de 1998 e o elemento da negociação entre vários atores implicados, inclusive os federativos, na questão do ordenamento fiscal. O que o estudo do caso da aprovação da Lei de Responsabilidade Fiscal permite-nos afirmar sobre o processo político decisório no Brasil?

Nos próximos capítulos, abordaremos a historiografia do controle do endividamento e dos gastos dos entes federativos, o processo de discussão dentro do Governo Federal da gestação do projeto de lei complementar da LRF, e o processo de discussão parlamentar do projeto na Câmara e no Senado. 


\section{Capítulo II - O processo de ordenamento Fiscal $^{29}$}

II.a) O início do processo de endividamento estadual na década de 1970

O endividamento estadual iniciou-se na década de 1970 como alternativa à gestão tributária centralizadora do governo militar que se configurou com as reformas financeira, de 1965, tributária, de 1966 e administrativa, de 1967. Em 1965, as reformas promovidas na área financeira, como a criação do Banco Central, do Conselho Monetário Nacional (CMN) e a manutenção do Banco do Brasil como autoridade monetária multiplicaram o espaço de poder do Governo Federal para realizar gasto e controlar os gastos das Unidades Federativas, à revelia do Congresso (Lopreato 2002: 50). A vinculação entre o Banco Central e o Banco do Brasil, via Conta Movimento, levou a um progressivo esvaziamento do orçamento fiscal como peça que deveria refletir as condições financeiras básicas do setor público e retirou do Congresso o poder de definição sobre os contornos gerais da política de gastos. Através da Lei Complementar $n^{\circ} 12$, de 1971, transferiu-se para o Banco Central e o Conselho Monetário Nacional o poder de autorizar a emissão de títulos públicos, circunscrevendo o controle do endividamento público ao raio de influência do Executivo, mais especialmente ao Ministério da Fazenda (Loureiro 2001).

A Reforma Tributária de 1966 caracterizou-se por medidas claramente centralizadoras. De uma forma geral, a União ficou com o maior número de impostos, com a capacidade de criar outros e com o direito de manipular livremente as alíquotas e os campos de incidência dos impostos de sua competência. A União deteve ainda o poder de determinar as alíquotas do ICM e de criar isenções nos impostos estaduais, sem a anuência dos envolvidos. Os Estados tiveram sua autonomia tributária limitada, na medida em que foram impedidos de criar novos impostos, de definir alíquotas ou de conceder favores ou isenções fiscais, sem acordo com os demais Estados interessados. Neste contexto, o objetivo da disciplina fiscal se deu no bojo de uma meta política mais ampla: o enquadramento dos Estados no movimento político centralizador do período $64 / 66^{30}$.

\footnotetext{
${ }^{29}$ Nos quadros 1 e 2 do anexo 1 encontram-se detalhadas todas as normas aqui citadas.

${ }^{30} \mathrm{Um}$ aspecto que vai "contra a corrente" deste movimento foi o estabelecimento de mecanismos de transferência baseado no Fundo de Participação dos Estados e Municípios (FPE e FPM) para as unidades da federação com menor renda, fortalecendo o poder político local das oligarquias
} 
O contexto político e institucional que se desenhava no início da década de 1970 marcou uma forte tendência de perda de autonomia dos governos subnacionais em matéria de política fiscal e tributária, que marcaria toda a década de 1970 e a primeira metade da década de 1980. Desta forma, restou aos Estados buscar alternativas de fontes de financiamento para alavancar os gastos estaduais, como a contratação de recursos externos e o acesso de recursos internos controlados pela esfera federal, vinculados a órgãos públicos (Lopreato 2002: 56).

Em 1976, a Resolução do Senado Federal $n^{\circ} 93$ marcou o início de um processo de regulamentação do endividamento estadual. Essa resolução estabeleceu limites às operações internas ${ }^{31}$ de crédito e definia aquelas classificadas como extralimites ${ }^{32}$, mas não tratava da dívida externa. 0 endividamento dos Estados cresceu significativamente após 1975 devido às peculiaridades da legislação que deveria teoricamente controlá-lo.

Segundo Lopreato (2002), a legislação de controle do endividamento deste período (Resolução do Senado Federal $n^{\circ}$ 62, de 28/10/1975; Resolução Bacen $n^{\circ}$ 345 , de 13/11/1975 e a Resolução do Senado Federal $n^{\circ}$ 93, de 11/10/1976) acabou criando normas que reforçaram as medidas em vigor no período anterior. $A$ legislação de controle do endividamento assegurava um elevado poder discricionário na concessão de crédito - a alocação desses recursos ao arbítrio da União (Mora 2002: 06). O nível de endividamento da cada Estado estava relacionado diretamente ao poder de barganha e aos interesses envolvidos no processo de negociação de cada novo pedido de operação de crédito.

II.b) O padrão de financiamento e as mudanças no arranjo institucional-legal das finanças públicas, na década de 1980 .

Além da crise econômica e da força política dos governadores, uma variável importante para compreender a desordem fiscal no período dos anos de 1980 é o arcabouço institucional das finanças públicas. Segundo Tavares (2005), até

\footnotetext{
regionais e garantindo uma base de apoio para o governo autoritário (Lopreato 2002: 52). Este sistema de transferências perdeu sua identidade a partir da promulgação do Al-5, em 1968, com o endurecimento das normas de transferências de recursos.

${ }^{31}$ As intralimites, as operações de crédito que poderiam ser efetivadas independente da autorização do Senado Federal.

32 Realizadas com recursos do Banco Nacional de Habitação, do Fundo de Apoio ao Desenvolvimento Urbano e do Fundo de Apoio ao Desenvolvimento Social, e só poderiam se concretizar após autorização do Bacen, da Sarem, do CMN e do Senado Federal.
} 
meados da década de 1980, havia no Brasil um arranjo institucional-legal de finanças públicas absolutamente insatisfatório, que prejudicava a boa conduta da política macroeconômica. Não havia uma definição clara das competências das autoridades fiscal e monetária. Segundo o autor, a autoridade fiscal, representada pelo Ministro da Fazenda, tomava decisões à revelia da autoridade monetária, representada pelo Presidente do Banco Central (BC). Este, por sua vez, administrava e representava interesses da primeira, sem qualquer tipo de prestação de contas (Tavares, 2005: 80). Os haveres e os passivos da Fazenda Pública Nacional eram administrados por diferentes órgãos ligados ao Ministério da Fazenda, como o Banco do Brasil e o próprio Banco Central (idem: 81).

Até 1984, havia, na prática, dois orçamentos fiscais no Brasil. Um orçamento era discutido e aprovado no Congresso Nacional, com atribuições amplas para modificar a proposta enviada pelo Poder Executivo, e um segundo, maior que o outro, que era decidido pelo Ministro da Fazenda, sem passar por qualquer tipo de controle do Congresso ou da sociedade. O Banco do Brasil realizava gastos financiados com emissão primária de moeda: concedia empréstimos agrícolas e de fomento às exportações e realizava gastos fiscais, utilizando recursos de suas reservas bancárias mantidas no Banco Central, com a autorização do Ministro da Fazenda, sem o conhecimento da autoridade monetária, que era subordinada ao próprio Ministro (idem: 81). Além das ações discricionárias do Ministro da Fazenda no Banco do Brasil, o Presidente do Banco Central também agia desta forma, fazendo emissões primárias de moeda para financiar gastos fiscais, atuando como agente de fomento de crédito agrícola e incluindo o impacto das emissões em sua programação monetária (idem: 81).

Outra dificuldade era a inexistência de um órgão que realizasse as funções do Tesouro Nacional. Até 1987, a dívida pública do Tesouro Nacional era emitida e administrada pelo Banco Central. A justificativa para este arranjo institucional era que o Banco Central emitia bônus em nome do Tesouro Nacional com o objetivo de controlar a liquidez da economia por meio de operações de mercado aberto (idem: 81).

Durante toda a década de 1980, o processo de elaboração e execução de medidas normativas, pelo Governo Federal, para ordenar as finanças públicas e para limitar o financiamento extra-orçamentário dos entes subnacionais refletiu a tensão entre a dinâmica concentradora de poder da estabilização versus a 
dinâmica descentralizadora da redemocratização. A escassez de recursos internacionais que caracterizou este período de crise da dívida externa agravava a situação. Começou a se discutir no país a necessidade da implementação de medidas que mudassem as instituições das finanças públicas.

O desequilíbrio financeiro dos Estados agravou-se enormemente no início da década, com a crise de dívida externa, em 1982, que causou uma ruptura do padrão de financiamento do setor público, inclusive o estadual. Foi assinado um Acordo com o FMI, no mesmo ano, estabelecendo a adoção do controle estrito do crédito interno líquido, com metas de expansão monetária e creditícia consistentes com os objetivos de reduzir a necessidade de financiamento do setor público, de conter a demanda agregada e de gerar um superávit comercial capaz de atender as obrigações externas não cobertas com dinheiro novo (Lopreato 2002). O resultado foi um aumento da restrição orçamentária federal, que levou a uma redução das transferências federais aos Estados e a conseqüente queda na receita fiscal estadual.

Os governos estaduais, no início da década de 1980, tornaram-se incapazes de ampliar os gastos com recursos estaduais próprios. A poupança fiscal e as receitas das empresas estavam reduzidas, devido ao panorama de recessão econômica. Ao mesmo tempo, não havia disponibilidade de fontes de financiamento responsáveis para reciclar a dívida pública. Segundo Lopreato (1992), este quadro de ruptura das condições de financiamento ainda agravou os problemas para assegurar a expansão dos empréstimos dos Estados em órgãos federais. Esta situação levou à maior demanda de operações com as instituições de crédito do próprio Estado. As restrições a operações externas e o controle sobre recursos internos deixaram os governadores com poucas alternativas, senão a de usarem os espaços disponíveis na articulação com os agentes estaduais de crédito para superar os momentos críticos de contração de financiamento.

O aumento da participação dos agentes financeiros estaduais no total dos empréstimos concedidos aos governos estaduais se deu às custas da captação de recursos de curto prazo a preços elevados no mercado, além da corrida intermitente dos bancos aos empréstimos do Banco Central com o objetivo de fechar o caixa. Conforme a análise de Lopreato (2002), o quadro de deterioração 
operacional crescente dos bancos estaduais ${ }^{33}$ - caracterizada, de modo geral, pelas alterações da composição do passivo e o aumento do custo médio da captação - foi reflexo direto dos compromissos criados para atender à demanda das operações dos governos estaduais e para apoiar a rolagem das dívidas não honradas. ${ }^{34}$

A escolha do controle do déficit público como elemento nuclear da política econômica, entre 1981 e 1982, inaugurou uma nova etapa no tratamento da dívida. As metas macroeconômicas de contenção do déficit público e as mudanças nas condições de financiamento do setor público fizeram o governo enfatizar o controle do endividamento e não apenas o uso dos recursos, como ocorreu no momento anterior (Lopreato 2002: 147).

As novas decisões do Governo Federal enfrentaram grande resistência dos governadores, que criaram obstáculos à definição de uma política de reciclagem das dívidas e de contratação de créditos suplementares. Estabeleceu-se uma arena de luta sem vencedores e o resultado, segundo Lopreato (2002), foi o maior ou menor grau de efetividade no controle do endividamento, dependendo do processo de negociação, da resistência dos governadores e do grau de autonomia com que as autoridades lograram conduzir as medidas de política econômica.

As primeiras medidas de ordenamento das finanças públicas foram reações ao Acordo assinado com o FMI, em 1982 (Loureiro \& Abrucio 2002; Lopreato 2002). Destacaram-se a criação do $\operatorname{COMOR}^{35}$ (Comitê de Acompanhamento da Execução dos Orçamentos Públicos), em 1983 e, posteriormente, na Comissão de Reordenamento das Finanças Públicas, instituída em 1984, e a Resolução do BC $n^{\circ}$ 831. A Resolução do $B C n^{\circ} 831$, de 09/06/1983, representou uma inovação

\footnotetext{
${ }_{33}^{33}$ Durante a década de 1980 e início de 1990, destacam-se basicamente três grandes esforços do Governo Federal para solucionar o problema dos bancos públicos estaduais: o PAC (Programa de Apoio Creditício), de julho de 1983; o PROREF (Programa de Recuperação Econômico-Financeira), de abril de 1984; e o RAET (Regime de Administração Especial Temporária), de fevereiro de 1987. Somente com o advento do PROES (Medida Provisória $n^{\circ} 1.514$, de 07 de agosto de 1996), o Governo Federal conseguiu estancar um processo no qual os bancos estaduais eram os protagonistas que produziam emissão de moeda - privando o BC do controle da base monetária - e federalização das dívidas dos seus respectivos Estados - através das operações com títulos. A MP 1.514 foi editada com um duplo objetivo: oferecer aos governadores opções de reestruturação para os seus respectivos bancos estaduais e para o equacionamento das suas dívidas. (Leite 2000: 129).

${ }^{34}$ Para mais detalhes, nesta linha de análise que relaciona a situação dos bancos estaduais como constitutiva do desenvolvimento das finanças públicas nos anos 80, ver Lopreato (1992), especialmente capítulos VI e VII.

${ }^{35}$ O COMOR era responsável pela supervisão do movimento dos gastos públicos e pela definição de novos cortes nas despesas correntes e de investimento do Governo Federal e das empresas estatais. Várias mudanças foram implantadas em decorrência dos trabalhos destas comissões.
} 
normativa no campo do controle do endividamento, ao criar um instrumento legal, sem concessões de ordem política: a fixação de tetos pelo Banco Central para as operações de crédito das instituições financeiras e das sociedades de arrendamento mercantil realizadas com o setor público, impondo sanções para quem desrespeitasse as normas legais (idem: 152).

A primeira equipe econômica do governo Sarney manteve o controle das políticas monetária e creditícia e as normas que regiam o endividamento do setor público, inclusive os limites de financiamento estadual. O fechamento da Conta Movimento do Banco do Brasil, em 1985, eliminou a capacidade do Banco do Brasil de sacar recursos de suas reservas bancárias no Banco Central para financiar despesas autorizadas pelo Ministério da Fazenda (Tavares, 2005: 82).

Um inegável avanço no processo de ordenamento fiscal realizado na época foi a redistribuição de competências entre o Banco Central e o Tesouro Nacional, de modo a garantir maior autonomia ao exercício da autoridade monetária e obrigar a uma maior transparência e accountability nos gastos dos Executivos Federal e Estaduais. Em 1986, foi criada a Secretaria do Tesouro Nacional (STN), segundo Tavares (2005), com a missão de administrar todos os haveres e todos os passivos da Fazenda Pública Nacional, de acompanhar as finanças dos Estados e Municípios, e de desenvolver e gerenciar um sistema único de contas e de administração financeira para o governo central (Siafi) ${ }^{36}$. A criação da Secretaria do Tesouro Nacional refletiu o esforço do Ministério da Fazenda de limitar a atuação financeira dos governos estaduais. Contudo, os governadores conseguiram ampliar as margens de gasto, flexibilizar as normas de rolagem e de contratação de novas dívidas e receberam autorização para contratar operações por antecipação de receita orçamentária - as ARO (idem: 158/159).

Mais três medidas foram tomadas envolvendo o Tesouro Nacional. Foi instituída a "conta única" do Tesouro Nacional, mantida no Banco Central, na qual deveriam ser depositados todos os recursos financeiros disponíveis das entidades do governo central. Em 1987, foi realizado um amplo encontro de contas entre o Tesouro Nacional e o Banco Central, além da transferência da administração da

\footnotetext{
${ }^{36}$ A partir de 1987, tornou-se obrigatório o registro on line no Siafi da execução orçamentária, financeira e contábil, permitindo o acompanhamento e controle por parte dos membros do Congresso Nacional. O Siafi se transformou, portanto, na base tecnológica sobre a qual se desenvolveram todos os sistemas de acompanhamento e controle das finanças do governo central" (idem: 82).
} 
dívida pública do Banco Central para a Secretaria do Tesouro Nacional (idem: 82/83).

Com a mudança de equipe econômica e a implementação do Plano Cruzado, a política de controle foi enrijecida, agora na direção do controle do crédito das instituições estaduais e das operações de curto prazo. A crise do Plano Cruzado, acompanhada pela retomada da inflação e pelo estouro da taxa de juros, levou a capacidade estadual de gestão do endividamento ao colapso. Segundo Lopreato (2002: 161), houve quatro grandes medidas de socorro financeiro aos governos estaduais neste período: a Resolução $n^{\circ} 1.309$, de 23/04/1987, a Resolução do Senado Federal $n^{\circ}$ 87, de 30/06/1987, Lei $n^{\circ} 7.614$, de 14/07/1987 e o RAET (Decreto-Lei n² 2.321, de 25/02/1987).

No governo Sarney, a concepção de que um processo de ajuste fiscal seria a pré-condição para a estabilização econômica não era aventada pelos técnicos e políticos, predominando uma prática de "frouxidão fiscal":

"Até 1987, o que domina a visão do problema fiscal no Brasil é um populismo fiscal desbravado. O próprio governo militar promoveu uma certa frouxidão fiscal, que era compatível com uma alta taxa de crescimento econômico. Só em 1981 que o Delfim muda a política econômica, no quadro da dívida externa, e faz um ajuste. Houve uma reação muito violenta dos democratas, inclusive eu, os economistas da oposição naquela época, estruturalistas, keynesianos, e essa coisa vai até o governo Sarney, o Ministério Funaro ${ }^{37}$. Este ministério marca uma posição de relaxamento fiscal (...) Toda a argumentação era baseada no Keynes, a idéia que você podia expandir a demanda agregada através do gasto fiscal, não compreendendo que o Keynes só era favorável ao déficit público a partir de uma situação de equilíbrio e por um período temporário, jamais como um sistema crônico e de crescente endividamento do Estado. (...) Quando eu saí do Banespa, eu fui para a Casa Civil do governo Montoro ${ }^{38}$ (Governo do Estado de São Paulo). E a política fiscal do governo Montoro, que foi exigida pelo Serra (Secretário de Planejamento do Estado de São Paulo na época), foi uma política muito rígida e muito boa, competente. Ele, pertencendo a um grupo de economistas estruturalistas latino-americanos keynesianos, naquele momento, fez uma política de ajuste fiscal, que eu participei dela muito ativamente no Banespa. Quando vem a crise do Cruzado, em agosto de 1986, eu disse ao Funaro que era dramático fazer um ajuste fiscal e um ajuste externo, e ele disse que eu não me preocupasse... Eu disse isso

\footnotetext{
${ }^{37}$ Dilson Domingos Funaro foi Ministro da Fazenda no Governo Sarney de 26/08/1985 a 29/04/1987.

${ }^{38}$ Luiz Carlos Bresser Pereira foi Presidente do Banespa de março de 1983 a março de 1985 e Secretário do Governo do Estado de São Paulo (Governo Montoro) de março de 1985 a março de 1987.
} 
também para o João Manuel (Cardoso de Melo) e ele disse: nem pensar!'39.

Durante o mandato do ministro Bresser Pereira e do ministro Maílson da Nóbrega ${ }^{40}$ no Ministério da Fazenda, ocorreu um fenômeno semelhante: em um primeiro momento, os ministros editavam novamente regras de controle de endividamento e bloqueavam operações com órgãos financeiros estaduais e federais. No momento seguinte, houve forte pressão dos governadores sobre o Governo Federal contra as medidas. As autoridades, então, relaxavam o alcance das medidas, ampliando as brechas de contratação de operações de crédito.

No mandato de Bresser Pereira no Ministério da Fazenda houve muita dificuldade para a implementação de mudanças na área fiscal ${ }^{41}$. Ao assumir o Ministério ${ }^{42}$, a primeira prioridade da equipe do ministro foi fazer o ajuste fiscal, em meio a uma grave crise econômica. Em 20 de fevereiro de 1986, o governo Sarney havia declarado moratória unilateral da dívida externa, as reservas internacionais estavam praticamente zeradas, o processo inflacionário estava descontrolado. Foi elaborado um plano de controle macroeconômico, uma espécie de carta de intenções com os critérios propostos pelo governo brasileiro. Este plano foi levado para Washington e foi a base do Plano Bresser. O Ministro Bresser Pereira era filiado ao PMDB naquela época e os deputados do partido fizeram uma moção para expulsá-lo, segundo ele, porque ele estava fazendo ajuste fiscal.

Segundo o ex-Ministro, a palavra de ordem no país em 1987 era: "quanto mais gasta, melhor, porque cria demanda agregada e permite que o Estado cumpra suas tarefas sociais". Não havia limitação fiscal real, que era vista como invenção de economistas ortodoxos "incompetentes e mal intencionados". Toda a classe política, inclusive os progressistas, era contra o ajuste fiscal.

No mandato do ministro Maílson, o Banco Central emitiu a Resolução $n^{\circ}$ 1.469, de 21 de março de 1988, estabelecendo limites rígidos de acesso ao crédito e de restrição à rolagem da dívida pública. Contudo, os governadores reagiram e conseguiram brechas para financiar as áreas de saneamento básico e habitação popular com recursos federais e deixaram de pagar as dívidas externas contraídas

\footnotetext{
${ }^{39}$ Entrevista com Luiz Carlos Bresser Pereira, em 07/10/05.

${ }^{40}$ Maílson da Nóbrega assumiu o Ministério da Fazenda de 06/01/1988 a 15/03/1990.

${ }^{41}$ Conforme relato do ex-Ministro Luiz Carlos Bresser Pereira, em 07/10/05.

42 Luiz Carlos Bresser Pereira foi Ministro da Fazenda no Governo Sarney, de 29/04/1987 a 18/12/1987.
} 
com o aval da União. O ministro Maílson decretou o congelamento dos repasses do FPE e de recursos de empresas estaduais.

Segundo Mora (2002: 07) e Lopreato (2002: 190), em 1989, o governo foi obrigado a federalizar parte das dívidas estaduais, a partir da primeira rodada de refinanciamento da dívida estadual, com base na Lei 7.976/89. A Lei 7.976 regulamentou os critérios de rolagem da dívida externa dos Estados, deixando o restante da dívida subnacional sem uma reestruturação financeira neste período. A esfera financeira dos Estados irrompeu a década de 1990 em aberto (Mora, 2002).

\section{II.c) A Constituição de 1988}

A Constituição de 1988 avançou mais ainda na direção do ordenamento fiscal, ao proibir o Banco Central de conceder, direta ou indiretamente, empréstimos ao Tesouro Nacional e a qualquer órgão ou entidade que não fosse instituição financeira. Diversos dispositivos constitucionais foram importantes neste processo, segundo Tavares (2005), como o que "previu legislação própria para regular as funções e o grau de autonomia do Banco Central, e unificou todos os orçamentos existentes, determinando que qualquer despesa pública só pode ser realizada com prévia autorização legislativa. Assim, nenhum centavo arrecadado pode ser gasto fora do orçamento unificado aprovado pelo Congresso Nacional" (idem: 83).

O autor também enfatiza a importância dos avanços na matéria orçamentária. A partir da Constituição, foram criados novos instrumentos para ampliar o papel do Congresso no processo de autorização, acompanhamento e controle do gasto público, mantida a iniciativa do Poder Executivo nessa matéria. "A nova constituição estabeleceu também que o Poder Executivo deve elaborar e encaminhar ao Congresso Nacional, na forma de projeto de lei, os planos plurianuais, estabelecendo os objetivos e as metas da administração pública para um período de quatro anos à frente. Também estabeleceu a necessidade de aprovar projetos de leis anuais de diretrizes orçamentárias, fixando os parâmetros e metas da política fiscal para cada exercício" (idem: 83). De uma forma geral, no campo das finanças públicas, a Constituição promoveu uma ampliação da competência do Congresso Nacional, que passou a exercer um controle prévio e efetivo sobre matérias de iniciativa do Poder Executivo, como a realização de gastos, subsídios, criação de tributos ou renúncia fiscal. 
Outra mudança importante foi que o Senado passou a exercer um papel fundamental no controle do endividamento público. $O$ artigo $\mathrm{n}^{\circ} 52$ da Constituição de 1988 fornece ao Senado a prerrogativa exclusiva de: autorizar operações de natureza financeira para a União, os Estados, os Municípios e as empresas estatais; estabelecer as condições de financiamento interno e externo e fixar os limites de endividamento de todos esses entes federativos. Desta forma, não só a União, mas todos os governos subnacionais precisam, para emitir títulos públicos e contratar outras dívidas, do consentimento do respectivo poder legislativo e também de autorização do Senado Federal (Loureiro, 2001: 54). O processo de autorização passou a funcionar da seguinte forma: os governos interessados em emitir títulos ou estabelecer contratos de créditos encaminham seus pleitos ao Banco Central que analisa cada caso e, em seguida, envia ao Senado parecer conclusivo, recomendando ou não a autorização. Uma vez no Senado, o parecer é recebido e discutido pela Comissão de Assuntos Econômicos (CAE), composta por 27 senadores, que aprova ou rejeita o pedido, enviando-o para a decisão final do plenário. Como todos os pareceres emitidos pela Comissão são sempre aprovados no plenário, a CAE acaba sendo o locus decisório central do processo de controle do endividamento público no Brasil (idem).

A Constituição de 1988 deixou importantes áreas do federalismo fiscal, como o controle do endividamento e dos gastos públicos, para posterior regulamentação complementar por legislação infraconstitucional (ver quadro 1). A Constituição já havia previsto, no Art. 163, a necessidade de uma lei complementar que disporia sobre finanças públicas, dívida pública externa e interna, garantias e fiscalização das instituições financeiras. Conforme Afonso (1992), as matérias relativas às finanças públicas e ao endividamento não constituíram matérias próprias do texto constitucional pois a subcomissão sobre Sistema Financeiro (na qual se localizavam as disposições sobre Finanças Públicas) havia determinado as definições dessa matéria para a legislação infraconstitucional, devido à complexidade dos temas e pela rigidez que causariam. Da mesma forma, as limitações ao endividamento aplicadas aos governos subnacionais seriam estabelecidas em lei complementar, nas palavras do relator, visando um controle efetivo exercido por todo o Poder Legislativo e sem envolver um "exame casuístico" de cada solicitação, o que seria imprescindível para fortalecer a autonomia dos 
governos subnacionais e entidades da administração indireta e para racionalizar os controles (Afonso: 1992).

Quadro 1: Os Artigos constitucionais referentes à matéria de ordenamento das finanças públicas e as respectivas regulamentações infraconstitucionais.

\begin{tabular}{|c|c|c|}
\hline $\begin{array}{c}\text { ARTIGO DA } \\
\text { CONSTITUIÇÃO }\end{array}$ & ASSUNTO & $\begin{array}{l}\text { REGULAMENTAÇÃO POR } \\
\text { LEI INFRACONST. }\end{array}$ \\
\hline Artigo $n^{\circ} 163$ & $\begin{array}{l}\text { Prevê lei complementar sobre finanças } \\
\text { públicas. }\end{array}$ & $\begin{array}{l}{\left[163, \text { caput, I] } \rightarrow \text { LC } \mathbf{n}^{\circ} \text { 101, }\right.} \\
\text { de } 04-05-00 \text { (LRF) } \\
{[163, V] \rightarrow \text { LC } n^{\circ} 105, \text { de }} \\
10-1-01 .\end{array}$ \\
\hline Artigo $n^{\circ} 165$ & $\begin{array}{l}\text { Prevê leis de iniciativa do Poder Executivo } \\
\text { que estabelecerão: o plano plurianual; as } \\
\text { diretrizes orçamentárias e os orçamentos } \\
\text { anuais. }\end{array}$ & $\frac{\left[165, \S 9^{\circ}, I, I I\right]}{D E ~ 07-01-94} \rightarrow$ LC no 79, \\
\hline Artigo $\mathrm{n}^{\circ} 167$ & $\begin{array}{l}\text { São vedadas operações de crédito que } \\
\text { excedam o montante das despesas de } \\
\text { capital }\end{array}$ & $\begin{array}{l}\text { ALTERAÇÃO ITEM IV; } \\
\text { ACRÉSCIMO \& } 4^{\circ} \rightarrow \text { EMC- } \\
\mathbf{0 3} 1993 \text { DOFC 18-03-93. } \\
\text { ALTERAÇÃO INC } 10 \rightarrow \\
\text { EMC-19 } 1998 \text { DOFC } \mathbf{0 5 - 0 6 -} \\
\mathbf{9 8 .}\end{array}$ \\
\hline Artigo $n^{\circ} 169$ & $\begin{array}{l}\text { Prevê que a despesa com pessoal não } \\
\text { poderá exceder os limites estabelecidos } \\
\text { em lei complementar. }\end{array}$ & 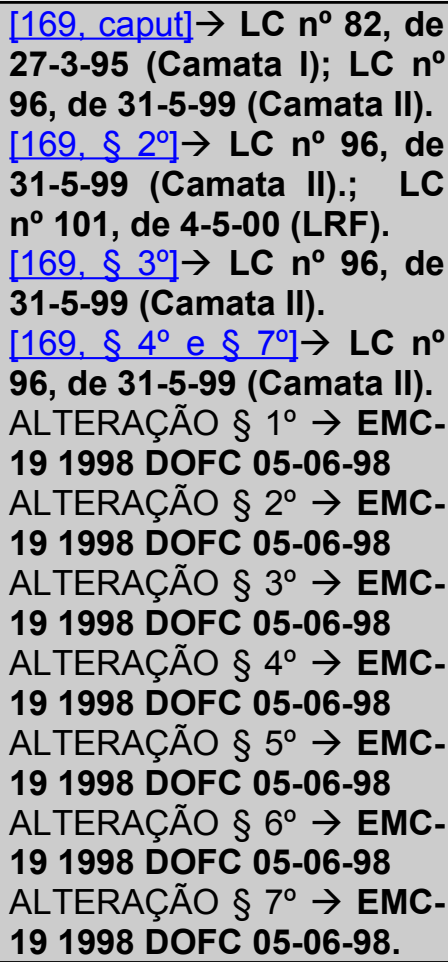 \\
\hline
\end{tabular}

Definiu-se na Constituinte que a implementação do "Código das Finanças Públicas" ${ }^{43}$, previsto com base nos dispositivos do art. 163, seria realizada mediante

43 Termo citado em Afonso (1992): "a proposta (que deu origem ao anteprojeto da Lei de Responsabilidade Fiscal) surgiu, pela primeira vez, no substitutivo da Comissão de Finanças e poucas alterações sofreu até a redação final, ressalvado o fato de que a definição original fazia referência explícita à elaboração de um "Código das Finanças Públicas"” (idem: 08). 
aprovação de legislação infraconstitucional. Há algumas hipóteses para isso. $\mathrm{Na}$ década de 1980, o tema fiscal não despertava interesse na classe política e na sociedade. Conforme relato de entrevista: "em 1988, se você falasse em déficit público, achavam que você era maluco. Não havia interesse! Não adiantava você apresentar (proposta de reforma fiscal)... Não tinha eco na classe política, aquilo não era matéria que interessava" 44 .

Outra hipótese é a falta de ação coordenada no Executivo Federal para promover a entrada desta agenda na pauta dos constituintes. Conforme relato ${ }^{45}$, não houve no Governo Federal uma organização por parte do Executivo em função de estarem tomando uma decisão importante. A Secretaria do Tesouro Nacional acompanhou os trabalhos constituintes, mas ela estava ainda se estruturando, pois tinha sido criada em 1987. Houve discussão no governo, mas não houve atuação política por parte do Executivo Federal. Faltou uma atitude pró-ativa, da parte do Governo Sarney, com relação a essa matéria.

O papel do redator da matéria na Constituinte, dep. José Serra, também foi citado pelos entrevistados. As hipóteses são complementares: não havia interesse político para promover o ajuste fiscal; não havia um diagnóstico técnico consensual entre os técnicos e políticos de que o ajuste fiscal era pré-condição para a estabilização monetária; não houve ação coordenada no Governo Federal para institucionalizar um arcabouço de ordenamento fiscal no corpo do texto da Constituição. Na presente pesquisa, não se pretende aprofundar essas hipóteses ${ }^{46}$. O intuito aqui é caracterizar as dificuldades que existiam para a implementação de uma reforma fiscal, na direção de um ordenamento, e como este quadro mudou a partir de década de 1990.

No final da década de 1980, ocorreu uma mudança importante em torno da idéia de ajuste fiscal. Conforme relato ${ }^{47}$, antes de virar a década, o clima no Brasil mudou substancialmente. Nas reuniões do Fórum Nacional ${ }^{48}$, em 1988 e 1989, começou-se a se falar em ajuste fiscal. $O$ conceito de que o ajuste fiscal era importante para se ter estabilização econômica não existia até o Governo Collor. Houve uma mudança de consenso: de um consenso populista, para um consenso a favor do ajuste fiscal.

\footnotetext{
${ }^{44}$ Entrevista com José Roberto Rodrigues Afonso, em 01/09/05.

${ }^{45}$ Entrevista com Martus Tavares, 06/09/05.

${ }^{46}$ Para uma análise dos trabalhos da Constituinte, ver: Afonso (1992) e Souza (2001).

${ }^{47}$ Entrevista com Luiz Carlos Bresser Pereira, em 07/10/05.

${ }^{48}$ Fórum Nacional do Instituto Nacional de Altos Estudos - Inae.
} 
II.d) Década de 1990: o processo gradual de ordenamento fiscal.

II.d.1) Primeira metade da década de 1990

Durante a década de 1980, não foram poucas as vezes em que se tentou equacionar de forma definitiva a questão do endividamento dos Estados e Municípios, seja por restrição da oferta de crédito, por meio de resoluções do Conselho Monetário Nacional, seja por restrição da demanda, limitando a capacidade de endividamento através de resoluções do Senado. Várias foram as tentativas de controlar de modo mais efetivo os bancos estaduais, fontes de desordens fiscais e monetárias (Tavares 2005). Muitas foram as oportunidades em que se tentou controlar as Antecipações de Receitas Orçamentárias (AROs), uma espécie de hot money, causa e conseqüência de sérios problemas financeiros dos Estados e dos Municípios" (idem: 84). Além dos problemas institucionais, havia um problema na aplicação das regras que regulavam as finanças públicas:

o "descontrole dos governadores só era possível porque o Governo Federal relaxava. Neste país é tudo tão centralizado, que eles tinham todos os mecanismos de controle, endividamento do estado sempre precisou de autorização (...). O Quércia jamais poderia ter feito aquilo que ele fez sem autorização. Ele indicava os diretores do Banespa. O Tribunal de Contas da União podia pedir o impedimento do governador. Legalmente possível, mas nunca se fez, ao contrário, autorizou-se, negociou-se (...) $)^{\text {s49. }}$.

Os Estados entraram na década de 1990 sem uma reestruturação financeira abrangente da dívida subnacional. $O$ desequilíbrio financeiro dos entes subnacionais agravou-se, em um contexto no qual, segundo Mora (2002: 07), o endividamento, uma forma de driblar a restrição orçamentária em tempos de centralização tributário-financeira, reforçou a dependência junto ao governo central, com implicações sobre a autonomia e sobre o processo de descentralização fiscal e tributária (idem: 04).

A análise da dívida líquida do setor público (DLSP) na década de 1990 indica que a dívida dos Estados e Municípios cresceu continuamente desde 1991,

\footnotetext{
${ }^{49}$ Entrevista com Yoshiaki Nakano, em 22/08/05.
} 
ganhando impulso a partir de 1994, até alcançar 13,5\% do PIB em 1998. esse crescimento deveu-se à expansão da dívida interna, liderada pela dívida mobiliária $^{50}$ e pela dívida bancária ${ }^{51}$, já que as dívidas renegociadas (Lei $\mathrm{n}^{\circ}$ 8.727/93 e Aviso MF-30) ficaram estáveis (Lopreato 2000: 135). Segundo a análise de Abrucio e Costa (1998), no período de 1990 a 1995, a dívida mobiliária dos Estados e Municípios cresceu aproximadamente 150\%, em grande medida devido ao impacto da elevação dos juros que incidem sobre a dívida, incorporados ao seu principal $^{52}$.

Segundo Lopreato (2002: 207), as propostas de renegociação das dívidas, nos primeiros anos da década de 1990, seguiram os padrões anteriores: a União não tinha como negar o apoio financeiro aos Estados, na medida em que havia a necessidade de se evitar o caos financeiro, assegurar a governabilidade e uma base parlamentar para a aprovação da agenda de reformas. Durante todo este período de gestação da crise financeira dos Estados, houve uma série de rodadas de negociação da dívida dos Estados. Segundo Werneck (1998) (apud Abrucio e Costa, 1998), entre 1988 e 1998, houve sete rodadas de negociação das dívidas, três delas somente em 1991. Em todas elas, o veto dos governadores às propostas de rolagem das dívidas foi patente, com exceção do acordo assinado em 1997, que será abordado adiante.

O governo Collor tentou restringir a rolagem das dívidas dos Estados e disciplinar o sistema de bancos estaduais, mas esbarrou na dificuldade de financiamento dos Estados e dos bancos estaduais e acabou flexibilizando a sua posição de força. A Resolução do Banco Central $n^{\circ} 1.718$, de 29 de maio de 1990,

\footnotetext{
${ }^{50}$ Para os Governos Estaduais e Municipais, a dívida pública mobiliária corresponde ao total dos títulos emitidos pelos respectivos tesouros menos os títulos em tesouraria. Incluem-se os títulos emitidos para pagamento de precatórios. ("Dívida Liquida e Necessidades de Financiamento do Setor Público", Banco Central, Agosto de 1999).

${ }^{51}$ A Dívida Bancária Líquida corresponde ao endividamento, líquido de aplicações, do setor público junto ao sistema financeiro. Estão incluídas as dívidas renegociadas com o Governo Federal relativas à Lei $n^{\circ} 8.727 / 93$. O endividamento do setor público junto ao FGTS também é incluído nessa rubrica. ("Dívida Liquida e Necessidades de Financiamento do Setor Público", Banco Central, Agosto de 1999).

${ }_{52}$ Segundo Rigolon e Giambiagi (1999), “(...) o estoque da dívida mobiliária estadual aumentou de $\mathrm{R} \$ 16,7$ bilhões em dezembro de 1990 para R\$55,9 bilhões em novembro de 1997 (a preços constantes de dezembro de 1998), com uma taxa de crescimento real média igual a $20 \%$ a. a.. A partir de dezembro de 1997, com a progressiva assunção das dívidas estaduais pela União, a dívida mobiliária estadual começou a cair, em contrapartida à elevação da dívida renegociada." (p. 118). Com relação à dívida contratual, em julho de 1996, o Banco Central estimou o saldo desta parcela da dívida dos Estados em $\mathrm{R} \$ 46,7$ bilhões. O endividamento total dos Estados, que inclui a dívida mobiliária, a contratual, a externa e as operações com ARO, registrou, no agregado, a marca de $\mathrm{R} \$$ 93,3 bilhões em setembro de 1996.
} 
limitou as operações de empréstimos e financiamentos, mas manteve de fora do contingenciamento de crédito, em resposta à pressão dos governadores, as operação de AROs e os empréstimos da CEF e do BNH (Lopreato 2002: 208). Por outro lado, o Senado alterou a legislação, aumentando as restrições ao dispêndio com encargos e amortizações, ao substituir a Resolução do Senado Federal $n^{\circ} 94$, de 15 de dezembro de 1989, pela Resolução do Senado Federal $n^{\circ} 58$, de 13 de dezembro de 1990.

Ainda no Governo Collor, o governo começou a negociar a federalização das dívidas estaduais. O primeiro passo foi o enfrentamento de uma situação de crise da rolagem da dívida mobiliária estadual. Segundo Lopreato (2000: 129), os Estados e os bancos estaduais estavam com problemas de colocação de títulos no mercado e o Banco Central efetuou a troca por outros de sua emissão, com o objetivo de reduzir os custos dos Estados e dos bancos estaduais com o carregamento dos títulos. Em contrapartida, os governadores comprometeram-se a não emitir novos títulos além da rolagem de $88 \%$ da dívida, conforme a Resolução do Senado Federal $n^{\circ}$ 1.813, de 05 de abril de 1991. A aprovação da Lei Ordinária $\mathrm{n}^{\circ}$ 8.388, de 30 de dezembro de 1991, foi o passo seguinte, estabelecendo o refinanciamento dos saldos devedores das dívidas estaduais contratadas com agentes financeiros federais (as dívidas extralimites), bem como das dívidas mobiliárias, fixando limites de comprometimento de receitas com o pagamento de encargos da dívida. Na vigência desta lei, não houve consenso quanto às condições do acordo e nenhum contrato foi assinado (idem).

Em suma, durante os governos Collor e Itamar, todas as rodadas de negociação das dívidas fracassaram pois os Estados descumpriam os acordos, normalmente realizados caso a caso, e o Governo Federal não tinha condições políticas para fazer valer de fato os contratos de negociação.

Segundo Tavares (2005), "a nossa cultura político-administrativa, até a aprovação da Lei de Responsabilidade Fiscal, era caracterizada pela falta de compromisso institucional em relação à dívida. Assim, quando um novo governador ou prefeito tomava posse, tomava também um avião para ir a Brasília queixar-se de que estava recebendo o Estado ou o Município em péssimas condições financeiras e dizer que a dívida encontrada não tinha sido feita por ele e que, portanto, não a pagaria, a menos que o governo central o ajudasse. Da mesma forma, mencionava 
os problemas relativos a seus bancos, prometia não utilizá-los como seus antecessores, jurava respeito ao Banco Central e, depois, nada cumpria" (idem: 85).

Com relação às dívidas contratuais dos Estados, as principais rodadas de negociação se deram em 1991 e 1993. Os acordos foram formalizados pelas Leis $n$ - 7.976/89 (já citada) e a n 8.727, a Lei do Acordo da Renegociação das Dívidas, de 05 de novembro de 1993, duas leis que marcaram o início do processo de federalização das dívidas estaduais. Segundo Rigolon e Giambiagi (1999), a Lei $n^{\circ}$ 8.727 foi um marco no relacionamento institucional entre o Governo Federal e os Estados. A grande inovação desta lei foi a criação de um mecanismo de enforcement que minora o risco de inadimplência: a possibilidade de bloquear as receitas tributárias próprias dos Estados - ou seja, o Imposto sobre Circulação de Mercadorias e Serviços (ICMS).

Entre 1991 e 1996, houve um crescimento contínuo e significativo da dívida líquida dos governos subnacionais. Esse movimento ocorreu a despeito da Lei $\mathrm{n}^{\circ}$ 8.727/93 e da Emenda Constitucional $n^{\circ}$ 3, de 17 de março de 1993, duas medidas que deveriam atenuar a velocidade de crescimento do passivo estadual, segundo Mora (2002: 07). O principal foco de aceleração da dívida líquida do setor público subnacional foi a dívida mobiliária que, entre janeiro de 1991 e dezembro de 1996, explicou R\$ 50 bilhões do aumento total de R\$ 60 bilhões. Em 1996, a dívida mobiliária representava $57 \%$ da dívida interna, contrastando com o moderado crescimento da dívida renegociada e o equacionamento do passivo externo (Banco Central apud Mora 2002: 08). Na Emenda Constitucional $n^{\circ} 3$, a área econômica do governo conseguiu regulamentar um dispositivo que estava sendo pensado desde 1988: o ICMS como garantia de dívida. O problema que se verificou é que, para o Estado mais rico e mais endividado na época - São Paulo - esta garantia era insuficiente, na medida em que o Fundo de Participação dos Estados (FPE) era 5\% da sua receita ${ }^{53}$.

Em meados de 1990, poucos Estados realizaram a captação de recursos por meio de títulos, em virtude da crescente dificuldade de colocá-los no mercado. Diante deste quadro, o Banco Central reiniciou, em 1994, a troca de títulos da dívida estadual por títulos federais, operação que só foi realizada anteriormente

\footnotetext{
${ }^{53}$ Entrevista com Martus Tavares e Selma Pantel, em 06/09/05.
} 
entre 1991 e 1992. Segundo Mora, este arranjo praticamente sancionou o endividamento dos governos estaduais e permitiu que a solução fosse postergada (Mora 2002: 09).

Diante desta nova norma de restrição da expansão da dívida e do agravamento da situação financeira, os Estados pressionaram o Senado Federal para alterar as regras e fixar inicialmente um percentual de rolagem da dívida equivalente a $90 \%$ da dívida total a vencer, viabilizando a rolagem parcial dos juros. Assim, a Resolução do Senado Federal $n^{\circ} 11$, de 31 de janeiro de 1994, bem como a sua sucessora, a Resolução do Senado Federal $n^{\circ} 69$, de 14 de dezembro de 1995, representaram um retrocesso à Emenda Constitucional $n^{\circ} 3 / 93$, permitindo a rolagem integral dos juros.

A despeito da rolagem integral dos juros, segundo Lopreato (2000: 139), o Banco Central fez prevalecer as regras da Emenda Constitucional $n^{\circ} 3$, não permitindo a colocação de títulos novos e forçando o pagamento de parte dos juros. As poucas exceções à regra ocorreram em razão dos precatórios, que foram usados, como ficou provado na CPI instalada no Senado, para fugir ao controle do Banco Central e ampliar o espaço de endividamento. Os casos mais notórios foram os de Santa Catarina e Pernambuco, que usaram os espaços dos precatórios para o pagamento de outros tipos de gastos. A CPI dos precatórios será abordada logo adiante.

A expansão da dívida mobiliária neste período não pode ser atribuída à captação de recursos novos. A dívida cresceu em função do elevado valor das taxas de juros impostas pela política monetária. O Governo Federal não foi capaz de obrigá-los a comprometerem recursos disponíveis no pagamento de encargos da dívida.

A falta de acerto e a expansão da dívida levaram, já no Governo Itamar, à outra onda de medidas contra o desequilíbrio financeiro dos Estados e de seus agentes financeiros e à retomada das negociações sobre as dívidas. Em 14 de junho de 1993, foi criado o Programa de Ação Imediata (PAI), preparando o terreno fiscal para a implementação do plano de estabilização. A principal mudança definida no PAI foi a restrição do crédito aos Estados ao incluir as AROs no contingenciamento de crédito, conforme a Resolução do Senado Federal $n^{\circ} 1.997$, de 30 de junho de 1993 (Lopreato 2002: 209). Contudo, esta resolução foi logo substituída por outra, a Resolução do Senado Federal $n^{\circ} 2.008$, de 28 de julho de 
1993, que estabeleceu limites ao financiamento estadual sem incluir as AROs no contingenciamento de crédito (idem). Segundo Tavares (2005), a implementação das medidas fiscais do PAI refletiu a formação de um consenso, depois dos vários programas de estabilização econômica fracassados, em torno da idéia de que somente haveria estabilidade econômica duradoura se houvesse um ajuste fiscal estrutural e a implementação de reformas de ordem econômica, administrativa, previdenciária e tributária (idem: 88).

Especialmente a partir de 1994, a dívida bancária também cresceu bastante. Um dos principais componentes da dívida bancária são as operações de Antecipações de Receita Orçamentária (ARO). Segundo Mora (2002: 10), existem indícios de que os Estados e Municípios estavam incorrendo sistematicamente em déficits primários e parte desses déficits, provavelmente, estava sendo financiada por meio de operações ARO. Segundo a autora, dados do Banco Central sobre as AROs, em 1994, demonstram que uma parte substancial delas foi "rolada", já que nos três primeiros meses de 1995, as autorizações para contratar novas dívidas atingiram $\mathrm{R} \$ 1,2$ bilhão, enquanto o acumulado de operações, em 1994, correspondeu a $\mathrm{R} \$ 940$ milhões. Em 1995, as operações em ARO atingiram R 2,3 bilhões.

No que tange especificamente à relação dos bancos estaduais com seus controladores, o Governo Federal reeditou, em 30 de junho de 1993, a Resolução 1.135 , de 15/05/1986, coibindo a prática de financiamento dos governos estaduais pelos seus respectivos bancos públicos.

\section{II.d.2) Segunda metade da década de 1990}

No período do primeiro mandato do governo Cardoso, importantes instrumentos de ordenamento fiscal da União já estavam criados e passaram a ser operacionais (ver quadro 3, anexo 1). Em 1995, passou-se a ter um controle administrativo, ainda não quantitativo, dos gastos federais. O Secretário do Tesouro Nacional na época, Murilo Portugal, começou a liberar recursos em função da existência de caixa e o Banco Central parou de dar crédito para os bancos. Neste momento, o Governo Federal 
"percebeu que tinha ficado de fora os Estados, porque eles podiam emitir dívida mobiliária que, no fundo, como era usado no overnight, era como se fosse moeda, dependendo apenas da aprovação da Comissão de Assuntos Econômicos (CAE) do Senado Federal. E, claramente, se percebeu que $60 \%$ dos senadores eram ex-governadores, que queriam voltar a ser governador. Então, aquilo era a "farra do boi", tanto que apareceu aquele escândalo dos precatórios, aquela confusão... Então, a leitura era a seguinte: nós estamos com controle dos gastos federais e sem controle dos gastos estaduais. Só que isso se dava na legislação, inclusive constitucional. Constitucionalmente é que se estabelece na CAE a responsabilidade de aprovação de rolagem da dívida mobiliária (...) A STN e o BC têm poderes para administrar racionalmente a questão fiscal e monetária. O que ficava fora eram os Estados. Por que? Como eles podiam emitir títulos, o título público estadual tinha dois impactos: primeiro, como ele era girado no overnight, era uma moeda, é como se estivesse emitindo moeda; e segundo, esses recursos eram usados fiscalmente para financiar os gastos do governo. Então isso foi desde cara identificado como sendo uma questão a ser resolvida. Já temos o controle sobre a dívida federal, e agora temos que ter o controle sobre os Estados. Então foi isso que foi feito" ${ }^{\text {"5 }}$.

A estabilização econômica advinda com o Plano Real agravou a situação fiscal dos Estados, seja pela via da redução da inflação, seja pela via dos juros altos. A redução drástica das taxas de inflação representou o fim da administração do orçamento pelo "tesoureiro de plantão" (Tavares 2005). Antes, "os controles fiscais estavam restritos à administração do caixa único do Tesouro. Como uma parte da arrecadação tributária estava indexada a índices de preços, o chamado Efeito Tanzi ${ }^{55}$ não se verificava em sua totalidade, sendo a arrecadação tributária afetada apenas parcialmente pela inflação. Por outro lado, como a quase totalidade dos gastos era fixada nominalmente, a inflação acabava corroendo os valores aprovados nas leis orçamentárias. Esses dois movimentos facilitavam a obtenção dos resultados fiscais desejados que eram criados a partir (...) de um simples truque da administração financeira do Tesouro Nacional. (idem: 88)". Depois do Plano Real, "um aumento nominal de gasto significava aumento real. Mas também é verdade que o fim da superinflação produziu efeitos razoáveis na arrecadação. Isso compensava, pelo menos parcialmente, os efeitos do lado dos gastos" (idem: $90)$.

\footnotetext{
${ }^{54}$ Entrevista Luiz Carlos Mendonça de Barros, em 05/08/05.

${ }^{55}$ Refere-se a uma redução no valor real dos impostos em função da inflação existente no espaço de tempo entre o fato gerador do imposto e o seu recolhimento.
} 
O regime de câmbio fixo valorizado e administrado por meio de bandas, pelo Banco Central, que vigorou desde o ano de 1995 até janeiro de 1999, produziu um importante impacto na dívida pública, quer pelo seu efeito direto sobre a dívida indexada em dólar, quer pelos efeitos indiretos resultantes das elevadas taxas de juros que tiveram de ser praticadas para manter uma atratividade mínima ao capital estrangeiro e evitar uma redução das reservas cambiais. Isso afetava diretamente a relação dívida/PIB (Tavares 2005).

Em 1995, houve o aprofundamento da crise fiscal dos Estados. A dívida dos Estados passou de $R \$ 20,6$ bilhões, em julho de 1994 , para $R \$ 37,1$ bilhões, em outubro de 1995. Houve novas pressões para renegociar as dívidas estaduais, inclusive as já incluídas em renegociações anteriores. As crescentes dificuldades financeiras foram enfrentadas com a antecipação de receitas tributárias futuras, mediante empréstimos bancários com altas taxas de juros e atrasos nos pagamentos de fornecedores e salários (Rezende \& Afonso 2004: 20). Neste período, constatou-se que os Estados que tinham dívidas atreladas à taxa de juros de mercado tornaram-se dependentes do poder central, na medida em que o financiamento do déficit operacional referente à dívida mobiliária foi viabilizado pela operação de troca de títulos estaduais por federais e pelo refinanciamento das AROs.

O Conselho Monetário Nacional (CMN), através do Voto $n^{\circ} 162$, de 05 de dezembro de 1995, instituiu o Programa de Ajuste Fiscal e Reestruturação Financeira dos Estados, conhecido como "FMI do Malan". Com o Voto CMN n ${ }^{162,}$ pela primeira vez, associou-se o auxílio financeiro federal à reforma do setor público estadual e ajuste patrimonial e incluiu-se a dívida mobiliária na renegociação global da dívida pública. Os Estados reagiram às condições restritivas estabelecidas pelo programa, levando o Governo Federal a estabelecer novas regras para o endividamento estadual que viabilizassem canais de financiamento. $\mathrm{O}$ acordo foi celebrado em um encontro do qual participaram, além do presidente Fernando Henrique Cardoso, o ministro da Fazenda, Pedro Malan, o presidente do Senado, José Sarney (PMDB-AP) e o senador Carlos Bezerra (PMDB-MT), relator da resolução que trata do endividamento dos Estados. Conforme as novas regras, os Estados poderiam tomar empréstimos externos para pagar seus gastos emergenciais. Com isso, os governadores contornariam a 
insuficiência de recursos oferecidos pelo Governo Federal por meio do Programa de Reestruturação e Ajuste Fiscal dos Estados. ${ }^{56}$

Em 27 de março de 1995, sete anos depois da promulgação da Constituição de 1988, foi promulgada uma lei complementar que regulamenta um importante artigo da Constituição (Art. 169), na área de finanças públicas: a Lei Complementar $\mathrm{n}^{\circ} 82$ (Lei Camata I). Esta lei, segundo Melo (2002), veio também a atender uma disposição transitória da Constituição de 1988, que estabelecia que, até a promulgação da lei complementar, não se poderia despender com pessoal mais do que $65 \%$ do valor das receitas correntes. O projeto entrou na ordem do dia do Senado $^{57}$ no mesmo momento em que o Governo Federal estava empenhado na promoção do ajuste fiscal dos entes federativos, em função da sobrevivência do Plano Real.

No mesmo ano de 1995, na esteira da promulgação da Lei Camata, em 25 de agosto, entrou em tramitação na Câmara o Projeto de Emenda Constitucional $n^{\circ}$ 173, da Reforma Administrativa. Naquele ano, mais três projetos de emenda à Constituição foram enviados ao Congresso pelo presidente Cardoso: reformas de ordem econômica (quebra de monopólios estatais nos serviços de utilidade pública e de exploração do petróleo e o fim das restrições ao capital estrangeiro nos setores de telecomunicações, energia e transportes), previdenciária e tributária. A emenda de reforma da ordem econômica foi aprovada em 1995, com poucas modificações. As emendas das reformas administrativa, que será abordada mais adiante, e a previdenciária foram parcialmente aprovadas em 1998, com relação à proposta original do Executivo ${ }^{58}$. A reforma tributária foi fatiada e alguns analistas apontam como exemplo de fracasso do esforço reformista do Governo Cardoso ${ }^{59}$.

\footnotetext{
${ }_{56}^{56}$ Estado de São Paulo, 09/12/1995.

${ }^{57}$ O projeto de lei complementar $n^{\circ} 60$, de autoria da Deputada Rita Camata (PMDB-ES), chegou na Câmara no dia 13 de março de 1989. O projeto tramitou por 5 meses na Comissão de Constituição e Justiça, 3 meses pela Comissão do Serviço Público e, o que é digno de nota, tramitou por 17 meses na Comissão de Finanças e Tributação da Câmara (tendo ficado um mês arquivado). Outro aspecto digno de nota foi o tempo em que o projeto tramitou no Senado: o projeto chegou no Senado em 09 de dezembro de 1991 e foi votado no plenário somente em 08 de março de 1995, ou seja, após um pouco mais de três anos.

${ }^{58}$ Ver Melo (2002) sobre o processo políticas das reformas constitucionais no Governo Cardoso.

${ }^{59}$ Campos (2002) e Melo (2002) analisaram a Reforma Tributária. Segundo Melo (2002), o fracasso do governo na tramitação da reforma tributária deveu-se à desistência do governo em investir politicamente para a aprovação do projeto. O governo desistiu da reforma tributária pois percebeu a resistência dos atores e optou por implementar parte de suas propostas pela via da legislação infraconstitucional (aprovando a Lei Kandir e a Lei de Responsabilidade Fiscal), por medidas provisórias e leis ordinárias (legislação do IR e criação do Simples). O governo fez a opção pelo menor esforço. Ademais, enquanto o projeto era discutido na CESP, houve uma mudança endógena de preferências no Executivo. Houve melhorias fiscais de 1995 a 1999 e para os setores do governo
} 
Segundo Tavares (2005), "paralelamente às discussões e aprovações das reformas no Congresso, a partir de 1995, foram adotadas sistematicamente medidas legais e administrativas para acelerar e garantir os resultados fixados para o Programa Nacional de Desestatização (PND) ${ }^{60},(\ldots)$ que produziu um importante impacto no estoque da dívida pública, porque os recursos arrecadados foram totalmente utilizados para o resgate da dívida" (idem: 89).

A situação das alternativas de crédito dos Estados, em 1996, reflete as escolhas dos governantes em períodos anteriores. Segundo Mora (2002: 14/15), ao longo da década de 1970, as escolhas de financiamento recaíram sobre as operações extralimites, junto ao Governo Federal, e operações de crédito junto ao exterior. Nos anos de 1980, os Estados de maior poder aquisitivo captaram recursos através de títulos. Nos anos de 1990, a Emenda Constitucional n 3/93 reduziu ainda mais as fontes de crédito, deixando como alternativas de financiamento as operações com instituições financeiras estaduais e as operações de ARO.

Em 1996, as operações com títulos desempenhavam um papel muito importante no financiamento dos governos subnacionais. Cerca de $43 \%$ da dívida interna da administração direta estavam sob a forma de títulos (idem: 15). No caso do Estado de São Paulo, além dos títulos, a dívida junto aos bancos estaduais representava $44 \%$ da dívida total ( $R \$ 33$ bilhões), o que indicava a importância do Banespa e da Nossa Caixa Nosso Banco na estratégia de financiamento do Estado. Em 07 de agosto de 1996, foi editada a Medida Provisória n 1.514, criando o PROES, o Programa de Incentivo à Redução do Setor Público Estadual na Atividade Bancária. Este programa estabeleceu mecanismos que objetivavam incentivar a redução da presença do setor público estadual na atividade financeira bancária e a privatização das instituições financeiras.

O PROES tornou-se viável politicamente em um momento de crescente agravamento das crises fiscal dos Estados e dos bancos estaduais, em 1995 e 1996. Ele não foi somente o produto do esforço isolado do Governo Federal em reestruturar o sistema bancário estadual em um momento de grave crise. Foi

que originaram a proposta, tornou-se mais desejável ou uma reforma mais ambiciosa ou manter o status quo. $\mathrm{O}$ único ator com poder de veto sobre a PEC 175 era o próprio Executivo. Por isso, o conflito entre a CESP e o Executivo adquiriu caráter de confronto institucional. A análise de Campos (2002) converge com a análise de Melo (2002), porém, enfatizando a posição dos diferentes atores e interesses sobre a Reforma Tributária - em especial, as posições do empresariado e do governo ${ }^{60}$ Ver Almeida (1999) sobre o processo de privatização nos anos 90. 
também a resposta política da União às pressões dos governadores, deputados e senadores para obterem condições tão favoráveis de ajuste, como obteve o governo paulista. Segundo Abrucio e Costa (1998), os deputados e senadores dos outros Estados da federação (em franca maioria no Congresso, no primeiro mandato do governo $\mathrm{FHC}$ ), sabendo que a negociação com São Paulo era fundamental para a União, barganharam melhores condições para os seus respectivos Estados, por meio da ameaça da obstrução às negociações com o governo paulista. De fato, o Estado de São Paulo apresentava o montante de débito que mais pesava sobre o déficit público global do Governo Federal. O risco de não resolver o problema do Banespa e não negociar a dívida do Estado era enorme para a própria União. (idem: 85).

Em março de 1996, o Senado Federal aprovou a Resolução n 19/96, em substituição à Resolução $n^{\circ} 69 / 95$, que flexibilizou o controle sobre a capacidade de endividamento dos Estados e Municípios. Isso permitiu que os pedidos estaduais e municipais para a emissão de títulos tramitassem mais rápido no Senado. Os Estados de Santa Catarina e Pernambuco, cujas emissões para pagar precatórios foram investigadas pela CPI dos Precatórios, valeram-se desta Resolução. $O$ autor da Resolução foi o Senador Carlos Bezerra (PMDB-MT). Segundo sua assessoria, a Resolução foi apresentada a pedido da Associação Nacional dos Municípios ${ }^{61}$.

Em novembro de 1996, foi instalada no Senado uma Comissão Parlamentar de Inquérito ( $\mathrm{CPI}$ ) para investigar irregularidades na aprovação de emissões de títulos públicos estaduais e municipais para pagamento de sentenças judiciais, ou precatórios. A CPI, conhecida como CPI dos Precatórios, foi requerida pelo líder do PMDB na época, senador Jader Barbalho (PMDB-PA), e teve o apoio de 35 senadores, incluindo lideranças governistas. A Constituição Federal de 1988 (artigo 33 das Disposições Transitórias) determinou que Estados e Municípios podem emitir títulos para pagar dívidas reconhecidas pela Justiça. O dispositivo constitucional restringe esse tipo de operação às dívidas contraídas até 1988 . Em 1995 e 1996, o Senado aprovou 11 operações de emissões de títulos, somando R \$ 2,2 bilhões, com base em documentos de Estados e Municípios solicitando recursos para precatórios. Todas as operações autorizadas nesse período (Municípios de São Paulo, Guarulhos, Osasco, Campinas, São Bernardo, Jundiaí e

\footnotetext{
${ }^{61}$ Folha de São Paulo, 05/12/1996.
} 
Goiânia e Estados de Alagoas, Pernambuco, Rio Grande do Sul e Santa Catarina) teriam de ser investigadas pela $\mathrm{CPI}^{62}$.

No decorrer dos oito meses de investigação, houve algumas dificuldades políticas para o encaminhamento das responsabilidades dos governadores, prefeitos e secretários nos escândalos dos precatórios. Em julho de 1997, havia uma disputa em torno da validade de dois relatórios. Um foi de autoria do Senador Roberto Requião (PMDB-PR), aprovado por unanimidade pela CPI, responsabilizando governadores, prefeitos e o Banco Bradesco. O outro, era o relatório do Senador Requião modificado por nove "votos em separado"63, no qual os principais beneficiados pelas mudanças foram o ex-prefeito Paulo Maluf (PPBSP), o prefeito de São Paulo na época, Celso Pitta (PPB), e os governadores na época Miguel Arraes (PSB-PE) e Paulo Afonso Vieira (PMDB-SC). Juntamente com o Bradesco, eles foram isentados de responsabilidade no escândalo ${ }^{64}$. Conforme editorial da imprensa na época, "antes de todo esse imbróglio, já tinha sido aprovado um relatório que, apesar de retirar algumas acusações e adjetivos, manteve o fundamental: a responsabilização dos governadores e prefeitos pelas violações cometidas. Após oito meses de investigação, o relatório do senador Requião traz conclusões que permitem processar Paulo Afonso (PMDB-SC), Miguel Arraes (PSB-PE), Divaldo Suruagy (PFL-AL) e o ex-prefeito Paulo Maluf. Políticos notórios procuram desfigurá-lo. É inaceitável" ${ }^{65}$.

A decisão da Comissão de Constituição e Justiça do Senado (CCJ) foi de retomar, como documento final da CPI dos Precatórios, relatório que apontava políticos e instituições financeiras como responsáveis por irregularidades e prejuízos aos cofres públicos na emissão e negociação de títulos para pagamento de precatórios. A decisão da CCJ foi uma reação do Senado à manifestação da opinião pública de que senadores, interessados em defender aliados políticos, estariam fazendo uma "pizza" com o relatório da CPI. O líder do PMDB, senador Jader Barbalho (PA), que liderou a reunião em que foram feitas alterações no relatório de Requião, nem sequer compareceu à reunião da CCJ. ${ }^{66}$.

\footnotetext{
${ }^{62}$ Folha de São Paulo, 27/11/1996.

${ }^{63}$ Os senadores que apresentaram voto em separado foram: Geraldo Melo (PMDB-RN), presidente interino, Ney Suassuna (PMDB-PB), relator "ad hoc", Gilberto Miranda (PFL-AM), Jader Barbalho (PMDB-PA), Carlos Wilson (PSDB-PE), Epitácio Cafeteira (PPB-MA), José Agripino (PFL-RN), Casildo Maldaner (PMDB-SC) e Onofre Quinan (PMDB-GO).

${ }^{64}$ Folha de São Paulo, 25/07/1997.

${ }_{65}^{65}$ Idem.

${ }^{66}$ Folha de São Paulo, 14/08/1997.
} 
A CPI dos Precatórios do Senado apontou várias irregularidades: o montante de títulos emitidos pela prefeitura de São Paulo superava em $\mathrm{R} \$ 1,3$ bilhão o valor gasto com o pagamento de precatórios, sendo que apenas $R \$ 495$ milhões teriam sido usados regularmente para o pagamento de dívidas judiciais. A CPI descobriu que uma equipe coordenada por Wagner Baptista Ramos (ex-coordenador da Dívida Pública da Prefeitura de São Paulo, assessor de Celso Pitta) montou um esquema que causou prejuízos ao erário, dando grandes lucros a empresas que operavam os títulos. Segundo a CPI, instituições financeiras formavam um esquema para auxiliar a emissão, recebendo comissões. O lucro obtido foi enviado ao exterior por meio de doleiros, empresas "fantasmas" e "laranjas"67. Bem antes da CPI, o Banco Central já vinha investigando irregularidades no mercado de títulos. Foi nesse rastro que chegou à emissão irregular, para pagamento de precatórios, aos desvios de finalidade e à chamada "cadeia da felicidade", que envolveu chefes e subordinados de governos e prefeituras, além de agentes financeiros. Apesar do pífio resultado político, houve desdobramentos de ordem prática. No próprio Congresso, durante a discussão do relatório final da $\mathrm{CPI}$, novas regras e leis para restringir o endividamento dos Estados foram discutidas, como a Resolução do Senado Federal $n^{\circ} 78 / 98$, que será abordada logo adiante ${ }^{68}$.

Em dezembro de 1996, no caso da dívida mobiliária, as vendas a termo atingiram $\mathrm{R} \$ 32,8$ bilhões, ou seja, $73 \%$ do montante total de títulos (Mora 2002: 30). Para evitar a inadimplência dos governos estaduais, em 19 de dezembro de 1996, o Governo Federal editou a Medida Provisória $n^{\circ}$ 1560. Com esta MP, responsável pela renegociação do conjunto das dívidas estaduais, o governo revelou o objetivo de fechar o espaço de financiamento alternativo (via ARO) e forçar o processo de ajuste fiscal dos Estados (Lopreato 2000: 144).

Uma mudança institucional importante ocorreu em 04 de junho de 1997, não tratando diretamente sobre as questões fiscais e financeiras que atingiam os Estados e os Municípios, mas gerando um impacto no sistema político e, conseqüentemente, no horizonte de cálculo dos atores políticos: a promulgação da emenda constitucional $\mathrm{n}^{\circ} 16$, a Emenda da Reeleição. O projeto de emenda constitucional foi apresentado pelo Dep. Mendonça Filho (PFL/PE) em fevereiro de

\footnotetext{
${ }^{67}$ Folha Online, 01/11/2001, http://www1.folha.uol.com.br/folha/brasil/ult96u26312.shl

${ }^{68}$ Folha de São Paulo, 27/07/97, "Para Loyola, a luta continua", Eliane Cantanhêde.
} 
1995. A reeleição já valeria para o pleito de 1998, para prefeitos, governadores e presidente.

Em julho de 1997, ocorreu a crise da Ásia e novos problemas surgiram no horizonte das autoridades econômicas. O país tinha que elevar a poupança doméstica, em especial a poupança do setor público, e isto teria que ser acompanhado pela mudança do regime fiscal vigente (idem: 91). Segundo Guardia (2004), até meados de 1997, a política fiscal adotada pelo Governo Federal pautava-se numa estratégia "gradualista", que se caracterizava pela expectativa de crescimento econômico aliada à percepção de uma tendência de redução das taxas de juros reais, que levaria a uma redução da relação dívida/PIB. Diante da crise asiática, o governo teve que abandonar esta estratégia e esboçar uma reação, que se manifestou "a partir de um conjunto de medidas de ajuste fiscal, conhecidas como o "Pacote 51", que visava promover um forte ajuste nas contas do Governo Federal. As 51 medidas não foram plenamente cumpridas e o resultado primário de 1997 foi o pior da década" (idem: 115/116). O aperto nas políticas monetária e fiscal, promovido pelas autoridades brasileiras a partir da crise asiática, em 1997, e da crise russa, em 1998, criou um quadro de maiores dificuldades para os Estados e Municípios enfrentarem a crise fiscal.

Em 1997, a situação financeira dos governos estaduais estava insustentável. Como eles cobriam o caixa utilizando as AROs, pagavam uma despesa de juros muito alta, que piorava ainda mais o quadro. Neste contexto de "desespero dos governadores", o Governo Federal resolveu negociar uma federalização das dívidas dos Estados, estabelecendo no contrato de federalização as limitações de endividamento, tanto ARO, como emissão de títulos públicos, por Estado. Esta renegociação das dívidas dos Estados seria feita através de um contrato de refinanciamento, dispensando a necessidade de uma reforma constitucional ou uma lei complementar.

A definição dos termos do contrato foi marcada por um conflito entre a equipe econômica do Governo Federal e os governadores. A Secretaria do Tesouro Nacional (STN) e o Ministério da Fazenda (MF) queriam que, neste contrato, os governadores assumissem um compromisso de uma redução brutal de despesas nos dois anos seguintes de mandato (1997 e 1998). Os governadores estavam pressionados pelo lado financeiro e não estavam dispostos a promover uma onda 
de demissões. O Ministério da Fazenda argumentava: "ou é isso ou não tem refinanciamento...".

Quando ficou configurado o conflito, os governadores procuraram outros membros do governo, tentando construir um canal para a negociação. O Ministro Sérgio Motta (na época, das Comunicações) foi procurado e solicitou que presidente do BNDES na época, Luiz Carlos Mendonça de Barros, encaminhasse junto ao Ministério da Fazenda uma negociação com os governadores, pautada na seguinte idéia: seria negociado um contrato de pagamento da dívida num prazo de 30 anos, com carência de 2 anos. Os governadores em exercício na época ficariam livres do encargo de ter que promover um ajuste nas suas contas e começar a pagar as parcelas de dívida, pois faltavam exatamente 2 anos para o término dos respectivos mandatos e havia a perspectiva da reeleição no horizonte político naquele momento ${ }^{69}$. O Governo Federal teria o apoio dos chefes dos executivos estaduais para resolver o problema da renegociação da dívida dos Estados e com menores custos, caso a renegociação não saísse naquele momento ${ }^{70}$. Ademais, seriam incluídas no contrato moedas de troca bem interessantes para o Governo Federal: limitações a futuros endividamentos e a privatização de empresas públicas estaduais.

O BNDES não tinha estritamente nada a ver com a questão da renegociação das dívidas dos Estados. No entanto, naquele momento, o presidente da instituição se legitimou para participar do processo de negociação por duas razões: em virtude da sua experiência pessoal na área financeira e devido ao fato do contrato prever a privatização das empresas estaduais para reduzir a dívida a ser renegociada por cada Estado. Desta forma, como o BNDES coordenava o processo de privatização, a instituição acabou se legitimando no processo de discussão da solução para a negociação da dívida dos Estados.

\footnotetext{
${ }^{69}$ A emenda da reeleição foi aprovada em junho de 1997 e a Lei 9496 foi aprovada em setembro de 1997. A aprovação da emenda da reeleição pode ser interpretada como um incentivo à realização de práticas de ajuste fiscal e especificamente, da renegociação da dívida, na medida em que, naquele momento, havia a percepção de que políticos identificados com as práticas de responsabilidade fiscal teriam sucesso eleitoral. Além do mais, caso se reelegessem, eles próprios receberiam o governo com graves problemas financeiros. Vale dizer que políticos de partidos diferentes utilizaram desta bandeira para se reelegerem nas eleições de 1998. Um estudo de economistas da UNb, Meneguin e Bugarin (2001) apresenta resultados teóricos que permitem afirmar que um governante com expectativa de ser reeleito apresenta comportamento fiscal mais responsável, sugerindo que a reeleição tem essa conseqüência positiva sobre as contas públicas.

${ }^{70}$ Entrevista Luiz Carlos Mendonça de Barros, em 05/08/05.
} 
Havia duas propostas em discussão no governo: a do Ministério da Fazenda, que propunha a renegociação mediante o compromisso dos governadores em promover uma grande redução das despesas nos dois anos que restavam de mandato, e a outra, com o apoio do Ministro Sérgio Motta e do presidente do BNDES, que propunha a flexibilização do esforço fiscal nos dois anos seguintes, para que o "governador não tivesse ônus algum nos seus últimos anos de mandato"71. "O Murilo Portugal (Secretario do Tesouro Nacional, até novembro de 1996) queria fazer um acordo de dívida mais dura e o Pedro Parente (então Secretário Executivo do Ministério da Fazenda) queria flexibilizar (..." $)^{m 2}$.

O impasse foi resolvido em uma reunião com o Presidente Cardoso, na qual a proposta favorável à flexibilização do esforço fiscal para os então governadores prevaleceu, jogando o ônus do ajuste para frente. A avaliação foi que

“(...) não se perdeu nenhuma qualidade técnica do contrato de refinanciamento. Ele é exatamente aquilo que se queria que fosse aprovado. Só que se deu um período de dois anos em que não houve nenhum esforço fiscal. "Mas esses caras vão ganhar...". Não interessa! Do ponto de vista objetivo do governo e da sociedade, o que interessa é que essa válvula de escape da emissão monetária pelos Estados seja fechada. Se para fechar isso, de uma forma tecnicamente correta, eu preciso conceder vantagens, eu tenho que fazer isso, porque a democracia é assim (...)" ${ }^{\text {"73 }}$.

A partir desse processo, em que ambas as partes cederam, estabeleceu-se uma proposta de acordo de renegociação das dívidas dos Estados, no âmbito do Programa de Apoio à Reestruturação Fiscal e Financeira, criado a partir da Lei ordinária $\mathrm{n}^{\circ} \mathbf{9 . 4 9 6 ^ { 7 4 }}$, de 11 de setembro de 1997. A promulgação da Lei 9.496/97 marcou o início da terceira rodada de refinanciamento da dívida, desta vez, em condições extremamente duras, comandada pela Secretaria do Tesouro Nacional. Segundo Mora (2002: 22), o empréstimo foi condicionado à realização de um abrangente ajuste fiscal e patrimonial e ao cumprimento de metas ou compromissos estabelecidos para cada Estado e presentes em todos os contratos.

No plano de execução do Programa de Apoio à Reestruturação Fiscal e Financeira foi previsto o envio de missões da Secretaria do Tesouro Nacional para

\footnotetext{
${ }^{71}$ Entrevista Luiz Carlos Mendonça de Barros, em 05/08/05.

${ }^{72}$ Entrevista com Martus Tavares e Selma Pantel, em 06/09/05.

${ }^{73}$ Entrevista Luiz Carlos Mendonça de Barros, em 05/08/05.

${ }^{74} \mathrm{Ver}$ todos os detalhes do programa no quadro 2, anexo 1.
} 
estabelecer metas e compromissos com base na situação fiscal e financeira de cada Estado. Vinte e cinco Estados assinaram o acordo, a maioria em 1998. A dívida assumida pelo Governo Federal, na maior parte mobiliária e junto a instituições financeiras estaduais, atingiu $\mathrm{R} \$ 132$ bilhões. O refinanciamento beneficiou particularmente os quatro Estados mais endividados - São Paulo, Minas Gerais, Rio de Janeiro e Rio Grande do Sul - que absorveram conjuntamente mais de 100 bilhões, aproximadamente $90 \%$ dos recursos totais (idem: 26 ).

Mora (2002) lista três pontos que foram as principais contrapartidas ao refinanciamento das dívidas que deveriam ser realizadas pelos Estados. O primeiro ponto foi um rigoroso programa de contenção de despesas e incremento de receita. O resultado desse esforço deveria ser repassado à União. De acordo com o segundo ponto, os bancos estaduais deveriam ser privatizados ou liquidados. $O$ último ponto de contrapartida refere-se à venda de ativos com a finalidade de obter os recursos necessários para pagar os "20\% à vista". Na maioria dos contratos, os Estados se comprometeram a privatizar suas empresas de energia elétrica (idem).

A despeito do rigor do acordo ao qual os Estados foram submetidos, caso os protocolos do contrato das negociações não fossem assinados, a situação dos Estados pioraria rapidamente. A assinatura do acordo de financiamento institucionalizou uma relação financeira entre os Estados e a União que já vinha se desenvolvendo há algum tempo, reduzindo a vulnerabilidade do Estados, na medida em que agora havia uma previsibilidade na manutenção desta política pelo Governo Federal. Contudo, o grande ônus financeiro dos acordos recaiu, novamente, sobre a União. Para refinanciar a dívida estadual, a União teve que: captar os recursos necessários ao refinanciamento e, como contrapartida, receber um crédito de baixa qualidade (dos Estados, que estavam próximos à insolvência); arcar com os custos de retroação da dívida; oferecer condições de financiamento de longo prazo; financiar a diferença entre a taxa de juros que remuneram os títulos colocados no mercado pela União e a dos contratos de refinanciamento (idem $)^{75}$.

\footnotetext{
${ }^{75}$ A prefixação da taxa de juros sobre as parcelas da dívida (de $6 \%$ ou de $7,5 \%$ ) protegeu os Estados das ingerências da política monetária e representou um subsídio concedido pela União aos governos estaduais. Mora (2002: 30) apresenta dados impressionantes. Se o Governo Federal capta no mercado recursos a uma taxa de juros de $8 \%$, e empresta aos Estados a $6 \%$, o subsídio concedido pelo governo em valor presente equivale a $27 \%$ do PIB. Caso a taxa de juros fosse de $10 \%$, o subsídio atingiria $88 \%$ do PIB... Como o subsídio concentra-se nos Estados de maior grau de endividamento, a socialização (ou federalização) das perdas foi inevitável.
} 
Em 1997, o efeito do Programa reverteu o quadro deficitário dos Estados; em 1998 houve novo crescimento do déficit primário e, a partir de 1999, uma reversão dessa trajetória. Pela trajetória do superávit primário, constata-se que os Estados estavam realizando um significativo esforço de ajuste fiscal mas, até 2000 , não se observava na grande maioria dos Estados um ajuste fiscal compatível com o comprometimento de receita previsto no acordo de financiamento (idem: 41).

No mesmo ano, a venda das empresas estatais estaduais se acelerou, motivada pela necessidade de pagar o equivalente a $20 \%$ da dívida à vista, pela Lei 9.496/97. Entre 1996 e 2000, as vendas representaram uma entrada de recursos cash para os governos estaduais na ordem de $\mathrm{R} \$ 38$ bilhões. Com este resultado de reestruturação patrimonial, os Estados conseguiram amortizar sua dívida e manter o equilíbrio fiscal. A maior parte dos Estados que privatizaram suas empresas conseguiu pagar os $20 \%$ à vista, conforme estipulado nos contratos de refinanciamento (idem: 44$)$.

Com relação à liquidação do sistema financeiro estadual, o Governo Federal instituiu uma linha de crédito através da Medida Provisória $n^{\circ} 1.590$, de 24 de setembro de 1997, que assegurava aos Estados financiamento em condições similares àquelas propostas na Lei 9.496/97 para sanear os respectivos bancos estaduais e, depois, encaminhá-los para a liquidação, privatização ou transformação em agência de fomento (idem: 46).

O Programa de Apoio à Reestruturação Fiscal e Financeira motivou uma profunda reforma de Estado no âmbito estadual e foi um passo importante na mudança nas relações financeiras entre os Estados e o Governo Federal. Os termos dos acordos de renegociação das dívidas circunscreveram uma situação na qual os espaços de financiamento dos governadores foram se reduzindo. Ademais, o caráter contratual deu consistência legal para o processo:

"o centro da racionalidade do equilíbrio fiscal dos Estados se chama esse contrato, (no qual) se colocou a vedação de qualquer tipo de endividamento. Quando o Itamar Franco assumiu, entrou na justiça (contra o contrato). Daí aconteceu o que a gente achava que iria acontecer. Como é um contrato entre duas partes, ele é julgado não pela justiça eleitoral ou política, mas pela justiça comercial. As duas partes legitimamente assinaram e, portanto, só pode mudar qualquer cláusula, se as partes concordarem (...). Nós achávamos na época, e estávamos certos, que a restrição comercial é mais forte que a restrição por lei. É mais difícil você mudar este contrato, principalmente se o governo 
federal for racional, porque mesmo que junte todos os estados, no Congresso, eles conseguem mudar a lei, mas não adianta, não é a lei, é o contrato que está em vigor" ${ }^{376}$.

Diante disto, pode-se dizer que a renegociação das dívidas ajudou a mudar as preferências dos governadores com relação às políticas de austeridade fiscal. Contudo, não foi somente a rolagem da dívida que contribuiu para a mudança no comportamento dos governadores. O governador Mario Covas havia feito um ajuste fiscal em São Paulo, a partir de 1995, assim como o governador Tasso Jereissati, no Ceará. O Maranhão e a Bahia também eram exemplos de boa gestão. Havia uma propensão de mudança de comportamento anterior à assinatura do contrato. Quando veio a crise financeira de 1998, o caminho para a aprovação da Lei de Responsabilidade Fiscal abriu-se mais ainda ${ }^{77}$.

Segundo Tavares (2005) e Guardia (2004), os resultados do programa de refinanciamento da dívida foram satisfatórios. "O Tesouro Nacional refinanciou as dívidas de 25 dos 27 Estados e de mais de 150 dos maiores Municípios, num montante total de mais de US $\$ 100$ bilhões" (Tavares, 2005: 87). "Passados mais de cinco anos do início do programa, todos os Estados estão em dia com os pagamentos junto ao Tesouro Nacional. (...) Em todos os episódios nos quais os governos estaduais tentaram não honrar os pagamentos estabelecidos nos contratos, como no caso do governo do Estado de Minas Gerais, durante a gestão Itamar Franco, a Secretaria do Tesouro Nacional executou as garantias contratuais, assegurando a regularidade dos pagamentos. Trata-se de uma profunda modificação no relacionamento entre a União e os governos estaduais e municipais, cujos efeitos são claramente apreendidos pela substancial melhora no desempenho fiscal das sub-esferas de governo, que passaram de um déficit de 0,74\% do PIB em 1997 para um superávit primário de 0,87\% em 2002" (Guardia, 2004: 115).

Em janeiro de 1998, o endividamento estadual alcançava $R$ \$ 205 bilhões, assim discriminados: $\mathrm{R} \$ 126$ bi em passivos com o Tesouro Nacional; $\mathrm{R} \$ 44$ bi de dívida mobiliária; $R \$ 25$ bi de dívida bancária; $R \$ 10$ bi de dívida externa. (Mora 2002: 49). Em 08 de julho de 1998, próximo à eclosão da crise financeira na Rússia, foi editada a Resolução do Senado Federal $n^{\circ} 78$, que substitui a

\footnotetext{
${ }^{76}$ Entrevista Luiz Carlos Mendonça de Barros, em 05/08/05.

${ }^{77}$ Entrevista Martus Tavares e Selma Pantel, em 06/09/05.
} 
Resolução $n^{\circ} 19$, de 1996, e as seguintes. Esta resolução reforçou o controle do endividamento, proibiu as operações em ARO no último ano de mandato e a emissão de novos títulos públicos por parte dos governos subnacionais que tiverem sua dívida mobiliária refinanciada pela União, assim como determinou que o Banco Central não mais encaminharia ao Senado Federal pedido de autorização de endividamento de governo que possuísse resultado primário negativo. Esta resolução foi considerada uma decorrência direta da $\mathrm{CPI}$ dos Precatórios. A despeito desta CPI não ter provocado a prisão de nenhum prefeito ou governador, ela "permitiu uma reforma institucional que prevenisse a repetição dos crimes"78.

Um dos pontos mais importantes desta resolução foi a mudança na atuação do Banco Central na autorização do endividamento. O Senado reiterou o seu comprometimento com o ajuste fiscal, ao transferir para o Banco Central porção considerável de seu poder decisório em matéria de endividamento. O artigo VII da Resolução 78/98 assim estabelece: "O Banco Central do Brasil não encaminhará ao Senado Federal pedido de autorização para a contratação de qualquer operação de crédito de tomador que apresente resultado primário negativo no período de apuração da Receita Líquida Real ou que esteja inadimplente junto a instituições integrantes do Sistema Financeiro Nacional" (Loureiro 2001: 57).

A CPI dos Precatórios permitiu que se observasse claramente o "jogo de empurra" entre o Senado e o Banco Central. Este dizia que seus pareceres sobre pedidos de autorização de endividamento não eram conclusivos, porque cabia ao Senado autorizar ou não. O Senado dizia que havia autorizado porque o BC não havia firmado posição contrária. Pela nova resolução, o parecer do BC deveria ser explicitamente favorável ou contrário. A análise da autoridade monetária não deverá ser apenas uma burocrática conferência de documentos, passando a opinar sobre as condições financeiras e o impacto macroeconômico da operação. No debate de cada pleito, no Senado, será obrigatória a presença do secretário da Fazenda do Estado interessado, que defenderá a operação pretendida, e de um representante do $\mathrm{BC}$, que defenderá o parecer da instituição. A CPI dos Precatórios também mostrou que a negociação política permitia que o Senado aprovasse pleitos em desacordo com a lei. Agora, os pleitos irregulares serão previamente reprovados pelo $\mathrm{BC}$ e nem sequer chegarão ao Senado. Haverá um veto técnico à negociação política. Os relatores dos pleitos eram, em geral, senadores do Estado

\footnotetext{
${ }^{78}$ Folha de São Paulo, 21/08/98, "E os precatórios?", Marcos Mendes.
} 
interessado, o que introduzia um viés favorável à aprovação. Pela nova lei, haverá uma lista preestabelecida de relatores, evitando-se tal coincidência"79.

O impacto positivo da Resolução 78/98 sobre o processo de ordenamento fiscal pode ser observado pelo número de operações ARO realizadas no período. Segundo Loureiro \& Abrucio (2002), "as restrições e limites impostos pela Resolução $n^{\circ} 78$ sobre as operações ARO fizeram com que o número delas caísse drasticamente. Conforme dados do Banco Central, foram autorizadas nos anos de 1996 e de 1997, respectivamente, 1.330 e 1682 operações ARO para Estados e Municípios. Só no primeiro semestre de 1998, antes da Resolução n 78 , o número chegou a 1.227. A partir do segundo semestre de 1998, sob a vigência da nova regra, tais operações despencaram para 46 e, durante todo o ano de 1999, elas não passaram de 128 (Loureiro, 2001). Mesmo sensível às pressões vindas dos governos estaduais, o Senado foi se comprometendo cada vez mais, ao longo do mandato de FHC, com medidas pró-ajuste fiscal" (idem: 77).

Em 04 de junho de 1998, foi promulgada a Emenda Constitucional $n^{\circ} 19$, da Reforma Administrativa. Segundo Melo (2002), o texto foi aprovado com razoável fidelidade ao texto original (idem: 153). Contudo, o processo político que gerou a Reforma Administrativa foi de intensa negociação política. A PEC $n^{\circ} 173$, antes de sua apresentação formal à Câmara, teve 58 versões do projeto, a partir de um debate conduzido pelo Ministro Bresser Pereira (idem: 155). Houve dois anos de intensa negociação na Comissão de Constituição e Justiça (56 dias) e na Comissão Especial (331 dias) (idem: 157). Com a promulgação da Emenda Constitucional $\mathrm{n}^{\circ}$ 19, os seguintes pontos da reforma administrativa foram aprovados: a criação das Agências Executivas e Organizações Sociais; o fim do Regime Jurídico Único; a generalização dos contratos regidos pela CLT no país; a aprovação da demissão de servidores por excesso de gastos e insuficiência de desempenho (embora os servidores de carreiras típicas tenham um tratamento diferenciado, que lhes faculta garantias de estabilidade de fato); o fim da isonomia salarial; a adoção de Contratos de Gestão no setor público.

Com exceção das questões da estabilidade dos servidores públicos e do teto de remuneração, que geraram grande controvérsia pública, os outros issues da reforma eram desconhecidos ou considerados irrelevantes. Com base na análise de Melo (2002), é interessante notar que justamente as questões mais controversas

\footnotetext{
${ }^{79}$ Folha de São Paulo, 21/08/98, "E os precatórios?", Marcos Mendes.
} 
foram aquelas que, gradativamente, foram se confundindo com o debate da agenda de reforma fiscal, não só pelo fato de serem controversas, mas pela natureza do tema, diretamente relacionado com o perfil do gasto público. O Art. 30 previa a apresentação do projeto de lei infraconstitucional que regulamentaria o art. 163 da Constituição: "O projeto de lei complementar a que se refere o art. 163 da Constituição Federal será apresentado pelo Poder Executivo ao Congresso Nacional no prazo máximo de cento e oitenta dias da promulgação desta Emenda". Conforme veremos no próximo capítulo, a inclusão desta matéria no texto da emenda da reforma Administrativa foi um fator institucional importante para a formulação do projeto da Lei de Responsabilidade Fiscal.

No processo de elaboração e tramitação do texto da Reforma Administrativa, os governadores foram atores políticos importantes, que apoiaram a reforma porque tinham interesse no ajuste fiscal dos seus respectivos Estados. Os chefes dos Executivos Estaduais

“(...) mudaram quando mudou a sociedade civil a respeito do ajuste fiscal, no final dos anos 80 . Nos anos 90 , os governadores estavam altamente interessados em ajuste fiscal. Para legitimar a Reforma da Administração Pública, um de seus objetivos era ajudar a fazer o ajuste fiscal. Embora não estivéssemos interessados em cortar despesas, o grande objetivo era melhorar a eficiência das políticas públicas. (...) $\mathrm{Na}$ Reforma Administrativa, nós queríamos fazer um teto, um subteto para pagamento de funcionários, nós queríamos ter flexibilidade para demitir por excesso de quadros e por insuficiência de desempenho. Quando começamos a falar, não tínhamos apoio nenhum. O Fernando Henrique não tinha incluído esta reforma na agenda de reformas. Quando ele viu a reação violenta que ocorreu sobre nós, inclusive da sociedade, ele se engajou mais na reforma. Os primeiros aliados que achamos foram os prefeitos. Os segundos aliados, que foram efetivos e presentes, foram os governadores, que estavam muito interessados no ajuste fiscal. Nós conseguimos apoio do Britto (Antonio Britto, RS), do Covas (Mario Covas, SP)... Daí os secretários de administração pública passaram a nos ajudar diretamente, inclusive na elaboração de emenda, e depois na aprovação da emenda. Aquela emenda permitia a eles fazer ajuste fiscal dentro dos seus estados, segurar o gasto com funcionários públicos. E isso era fundamental... Eles perceberam que a sociedade civil mudou e sinalizava que se eles queriam ter vitórias eleitorais, eles teriam que corresponder a esta agenda. O Collor foi o primeiro que correspondeu a esta agenda ${ }^{80 "}$.

\footnotetext{
${ }^{80}$ Entrevista com Luiz Carlos Bresser Pereira, em 07/10/05.
} 
Segundo Melo (2002), os governadores foram aliados ativos, mas esse apoio foi marcado por forte ambigüidade. Eles mostraram interesse na reforma administrativa por duas razões: 1) a flexibilização da estabilidade é instrumental para os jogos de patronagem, no âmbito local, no qual cumprem um papel decisivo; 2) a crise fiscal dos governos estaduais, sinalizada no crescimento vertiginoso do gasto com pessoal, que passou a absorver, em vários Estados, o total da receita líquida.

A crise do endividamento estadual, que se exacerbou no final de 1995, contribuiu para o realinhamento dos interesses na reforma, e também produziu uma nova estrutura de incentivos para os atores na burocracia executiva. Para os Ministérios da Fazenda, do Planejamento e a Casa Civil, a reforma passou a constituir-se em moeda de troca importante na renegociação das dívidas (Melo, 2002: 172). Conforme o autor, no meio do processo, a aprovação da emenda da reeleição (em junho de 1997) levou a uma mudança radical na estrutura de incentivo dos novos governadores. A perspectiva de reeleição estendeu o horizonte temporal do cálculo político desses atores. Deparando-se com a possibilidade de um novo mandato, os governadores passaram a considerar os ganhos fiscais resultantes da reforma, confrontando-os com os custos políticos das demissões. A razão para a mudança é que não interessava aos governadores patrocinar ondas de demissões nos seus Estados, o que poderia ser mal interpretado pelos eleitores, depois que a emenda da reeleição foi aprovada. Por outro lado, eles tinham interesse em fazer o ajuste fiscal, na medida em que a bandeira da responsabilidade fiscal poderia trazer bons dividendos eleitorais.

A solução de vincular as demissões à Lei Camata (que seria promulgada em dezembro de 1998) foi politicamente ótima porque dissimulava a responsabilidade de decisões impopulares que passavam a ser vistas como imperativos constitucionais (idem: 173).

Em setembro de 1998, o país enfrentava uma crise cambial que combinava alguns elementos: desequilíbrio fiscal, moeda valorizada, juros elevados e ambiente pré-eleitoral. Naquele mês, segundo Guardia (2004), o Governo Federal editou um decreto contingenciando $\mathrm{R} \$ 4$ bilhões do orçamento de custeio e investimento daquele ano. Este decreto representou um significativo esforço de controle dos gastos e, ao mesmo tempo, uma importante novidade que passou a permear a condução da política econômica até hoje: pela primeira vez, os objetivos da política 
fiscal foram definidos em função de uma meta clara e transparente de obtenção de resultados primários (idem: 117). Esta mudança foi institucionalizada a partir da edição da Medida Provisória $n^{\circ}$ 1.716, de 08/09/1998, que definiu a meta de superávit primário para aquele ano e o prazo de até 15/11/1998 para a formulação do Programa de Estabilização Fiscal (PEF).

O PEF, Programa de Estabilização Fiscal (PEF), foi anunciado em outubro de 1998, como uma resposta do governo à crise da Rússia. Segundo Guardia (2004), o programa foi "o embrião do sistema de metas fiscais que, posteriormente, viria a ser institucionalizado pela Lei de Responsabilidade Fiscal. Partindo de cenários econômicos claramente especificados, o PEF fixava o superávit primário mínimo consistente com a trajetória desejada da relação dívida/PIB. Permitiu-se assim, pela primeira vez em nossa história, que os objetivos e metas de política fiscal fossem claramente estabelecidos" (idem: 117).

A estratégia de ajuste gradual, que era a prática corriqueira dos técnicos do governo até a crise da Ásia, em 1997, já não era mais possível de ser levada adiante depois da crise da Rússia. O Brasil era, no jargão coloquial, "a bola da vez". A credibilidade externa do país precisava ser restaurada com uma sinalização clara que o governo estava disposto a realizar mudanças fiscais estruturais que atingissem o relacionamento financeiro das três esferas de governo e enfrentasse a questão previdenciária pública e privada. De acordo com Guardia (2004), o PEF foi arquitetado a partir de três pilares: em primeiro lugar, um ajuste dos fluxos de receitas e despesas da União, visando à elevação do superávit primário no exercício de 1999; em segundo lugar, a mudança nos procedimentos do processo orçamentário; em terceiro lugar, a implementação de reformas estruturais que permitissem assegurar o equilíbrio das contas públicas (idem: 118).

$\mathrm{Na}$ mesma época, o Governo Federal recorreu ao Fundo Monetário Internacional, utilizando o Programa de Estabilização Fiscal como base para a assinatura de um acordo. Segundo o Memorando de Política Econômica ${ }^{81}$, de 13 de novembro de 1998, o governo se comprometeu com uma meta de superávit primário do setor público consolidado equivalente a $2,6 \%$ do PIB em $1999^{82}$. O

\footnotetext{
${ }^{81}$ http://www.fazenda.gov.br/portugues/fmi/fmimpe01.asp

${ }_{82}$ Tal superávit deveria elevar-se até $2,8 \%$ do PIB em 2000 e a $3,0 \%$ em 2001. Um conjunto de medidas foi anunciado para poupar gastos e elevar receitas totalizando cerca de 3,5 pontos percentuais do PIB em 1999. As medidas de aumento das receitas incluem: uma elevação da CPMF de $0,2 \%$ para $0,3 \%$ com uma majoração temporária de $0,08 \%$ para 1999 ; um aumento da COFINS de 2 para $3 \%$ um terço do qual será compensado do imposto de renda da pessoa jurídica; uma
} 
Governo Federal também citou outras medidas no programa: as regulamentações das Reformas Administrativa e Previdenciária; a apresentação do projeto de Reforma Tributária antes do final daquele ano; a observância dos compromissos assumidos pelos Estados no contexto do acordo de reestruturação da sua dívida com o Governo Federal; a aprovação da Lei de Responsabilidade Fiscal até dezembro, que seria enviada ao Congresso. Esta decisão do Governo Federal possibilitou a disponibilização de empréstimos junto aos organismos internacionais e bancos privados para o país, além do aval da comunidade financeira internacional ao programa de ajuste fiscal brasileiro.

Em 09 de dezembro de 1998, chega à Câmara dos Deputados o Projeto de Lei Complementar $n^{\circ} 249$, da Lei Camata II. Esta lei, como a Lei Camata I, também disciplina os limites das despesas com funcionalismo público, na forma do art. 169 da Constituição. Contudo, comparada à Lei Camata I, ela reduziu o limite de gasto da União para $50 \%$ e manteve dos Estados e Municípios em $60 \%$, concedendo prazo de mais dois anos para enquadramento nos limites. Segundo Asazu e Abrucio (2003), "o mérito da lei, apesar de seu enforcement ter sido fraco, foi a de delimitar um parâmetro para que os Executivos pudessem realizar cortes por insuficiência de recursos, um parâmetro que não existia antes. Serviu também para trazer à tona 0 fato de que 0 ajuste fiscal não poderia concentrar-se apenas no esforço de um dos Poderes" (idem: 08).

O ano de 1999 começou com a crise de desvalorização do Real e a origem de um novo arcabouço institucional de política econômica, que se caracterizava num regime de câmbio flutuante, de metas de inflação e de regras fiscais. O contexto de juros altos e de moeda desvalorizada gerou um impacto negativo sobre a dívida pública. O governo reagiu aos efeitos negativos da desvalorização cambial com o Decreto $n^{\circ} 3.031$, de 20/04/99, elevando as metas de superávit primário do Governo Federal de 1,8\% do PIB para 2,5\%. Em 1999, o superávit primário alcançado foi de $3,2 \%$, superando a meta inicialmente estabelecida.

Em 15 de abril de 1999, é a vez do Projeto de Lei Complementar n 18, da Lei de Responsabilidade Fiscal, que chega com 6 meses de atraso à Câmara, a

elevação de 9 pontos percentuais na contribuição para o plano de aposentadoria do setor público pelos servidores que ganhem mais de R $\$ 1.200$ mensais; aplicação desta contribuição aos pensionistas do setor público (à taxa de 11 por cento para aqueles com pensões de $\mathrm{R} \$ 1.200$ por mês ou menos e de 20 por cento para os demais); além de uma série de outras medidas com vistas principalmente a ampliar as bases dos atuais impostos e contribuições bem como a eliminar distorções. 
contar de 05 de junho de 1998 (data da promulgação da EC n 19/98, que previa envio do projeto à Câmara até dezembro de 1998). A Lei de Responsabilidade Fiscal, promulgada em 04 de maio de 2000, estabelece três tipos de regras: metas gerais e limites para indicadores selecionados; mecanismos institucionais de correção para os casos de descumprimento temporário; sanções institucionais para o não-cumprimento definitivo. Tavares (2005) destaca catorze pontos da lei, relacionados à responsabilidade, disciplina e transparência:

"A Lei de Responsabilidade Fiscal:

1) estabelece que cada governo tem de fixar metas fiscais consistentes com os limites da dívida, relativas ao exercício seguinte e para dois exercícios à frente, a serem aprovadas nas respectivas leis de diretrizes orçamentárias anuais;

2) estabelece que desvios temporários com relação às metas fiscais aprovadas devem ser corrigidos no próprio exercício, assegura condições e instrumentos e determina o corte automático das despesas como forma de efetivar os ajustes necessários para cumprir as metas fixadas;

3) proíbe que um ente da Federação empreste, direta ou indiretamente, a outro, ainda que sob a forma de novação, refinanciamento ou postergação da dívida contraída anteriormente. Esse dispositivo reforça os princípios básicos dos acordos de dívida celebrados entre o governo central e os estados e municípios, em 1997/1998. Por esse dispositivo, o governo central fica proibido de conceder qualquer empréstimo aos governos subnacionais ainda que seja para refinanciar créditos existentes. (...) Com este dispositivo, a LRF transformou os acordos de 1997 e 1998 nos últimos acordos de dívida entre o governo central e os governos subnacionais da história do país;

4) estabelece que novos gastos de caráter permanente só podem ser aprovados se tiverem asseguradas as correspondentes fontes de financiamento de longo prazo. Assim, nenhum novo gasto permanente poderá ser criado sem ter seu custeio garantido;

5) determina que os benefícios tributários de qualquer natureza devem ser incluídos na proposta orçamentária anual e devem ser demonstrados os instrumentos de compensação dos novos benefícios nos orçamentos dos três anos subseqüentes à sua aprovação;

6) fixa o limite de $60 \%$ das receitas correntes líquidas como teto máximo para os gastos com pessoal dos governos estaduais e municipais. Para o governo central ficou estabelecido o limite de 50\%. Também ficam estabelecidas regras de conduta e de ajuste a serem observadas para cada governo e cada Poder. Pela primeira vez foi instituído limite de gastos com pessoal para os Poderes Judiciário e Legislativo; 
7) fixa limites prudenciais e finais de dívida e estabelece regras de conduta e de ajuste a serem seguidas por cada governo quando temporariamente esses limites sejam ultrapassados. A partir da sanção da $L R F$, o Senado Federal estabeleceu limites quantitativos de dívida no montante de 1,2 vez a receita líquida para os municípios, 2 vezes para os estados e 3,5 vezes para o governo central;

8) estabelece uma série de regras e limites para evitar transferências de dívidas de curto prazo de um exercício a outro, em particular em anos eleitorais, ficando vedada a contratação desse tipo de dívida nos últimos seis meses de mandato do governante;

9) veda a contratação de operações de crédito entre uma instituição financeira oficial e o ente da Federação que o controle. (...)

10) estabelece a obrigação do Banco Central prestar contas regularmente ao Congresso quanto às suas operações que tenham impacto quase-fiscal;

11) estabelece uma série de regras para a elaboração e execução dos orçamentos anuais, aumentando a transparência, facilitando o controle da gestão fiscal e da eficiência administrativa. (...);

12) determina a obrigação de cada governo enviar, ao respectivo Poder Legislativo, a cada quatro meses, relatório de gestão fiscal dando conta do cumprimento das metas aprovadas nas leis de diretrizes orçamentárias anuais. Havendo desvios em relação à meta aprovada na lei, o governante deve informar as providências que estão sendo implementadas para alcançar os resultados fixados;

13) estabelece, para ampliar a transparência e facilitar o controle social, a obrigação de cada governo divulgar, a cada dois meses, relatório resumido da execução orçamentária. Para tornar comparáveis os dados publicados por cada governo, foram definidos as principais contas e conceitos contábeis a serem observados por todos os governos;

14) fixa sanções institucionais e punições para governantes e administradores de recursos públicos que não cumprirem as determinações da lei. Essas sanções e punições são fixadas de acordo com a gravidade dos desvios cometidos, podendo um ente da Federação deixar de receber recursos federais e um governante ou um administrador ser preso, nos casos mais graves. Curioso é que a proposta original do Executivo era mais branda nas sanções e punições, que acabaram sendo mais severas por iniciativa do Congresso". (Tavares, 2005: 96/97)

Segundo Rezende \& Afonso (2004: 32), algumas normas citadas acima, que foram estabelecidas na lei, incorporaram princípios já presentes em regras 
anteriores: a) limites para gasto com pessoal - a remuneração dos servidores públicos não deve ultrapassar $60 \%$ das receitas líquidas correntes (Art. 18 ao 20; restabeleceu os conceitos e princípios básicos da Lei Camata II, em vigor na época, revogando-a); b) limites para o endividamento - o Senado pode aprovar uma revisão dos limites atuais da proposta pelo presidente da República e os precatórios judiciais não pagos durante a execução do orçamento que foram incluídos vão passar a integrar a dívida consolidada para fins de aplicação do limite (Art. 29 a 30; mantendo as exigências da Resolução do Senado Federal $n^{\circ}$ 78/98); c) exigências para a formalização do pleito de contratação de operações de crédito: prévia e expressa autorização no texto da lei orçamentária; inclusão dos recursos no orçamento, exceto ARO; observância dos limites e condições fixados pelo Senado; atendimento da "regra de ouro" (Greggianin \& Oliveira 2000: 19). (Art. 32; incorporando a exigências que já constam na Resolução do Senado Federal $\mathrm{n}^{\circ}$ 78/98, que passam, com a promulgação da LRF, a ter um caráter de permanência); d) as ARO (antecipação de receita orçamentária) estão proibidas no último ano de mandato e enquanto houver outra operação ainda não integralmente resgatada (Art. 38; está proibição já estava presente na Resolução do Senado Federal $n^{\circ}$ 78/98).

Dentre as inovações que a LRF implementou, está um sistema de planejamento, execução orçamentária e disciplina fiscal. Os Estados e Municípios deverão se preparar para fazer previsões de médio prazo (3 ou 4 anos) para suas receitas e despesas e acompanhá-las mensalmente, além de dispor de um bom sistema de controle de suas finanças, principalmente da dívida (Artigos 4 ao 10) (Greggianin \& Oliveira 2000). Os autores também enfatizam as novidades da Seção I da LRF, sobre geração de despesa. Os artigos 16 e 17 tratam da provisão para as despesas correntes. As autoridades públicas não podem tomar medidas que criem despesas futuras que durem mais de dois anos sem apontar para uma fonte de financiamento ou um corte compensatório em outros gastos. Os artigos 21 a 23 tratam da provisão especial para anos eleitorais. A lei proíbe que governadores e prefeitos em último ano de mandato antecipem receitas tributárias por meio de empréstimos de curto prazo, concedam aumentos de salários e contratem novos servidores.

A principal novidade trazida com a LRF, na opinião de muitos analistas (Greggianin \& Oliveira 2000; Sr. Eduardo Guardia - ex-Secretário do Tesouro 
Nacional, em argüição em uma banca da doutorado, em 2001, na FGV) está na Subseção II, Das Vedações, que insere uma regra importante no art. 35: a vedação da realização de operações de crédito entre os entes da Federação, ainda que por intermédio das entidades de administração indireta dos respectivos entes. Segundo Greggianin \& Oliveira (2000: 20), o art. 35 veda até mesmo as operações de refinanciamento, novação e postergação de dívidas contraídas anteriormente, ou seja, os Estados e Municípios não poderão mais recorrer aos outros Estados e à União para refinanciar suas dívidas, práticas comuns durante a década de 1980 e até 1997.

Em dezembro de 2001, foi sancionada a Resolução do Senado $n^{\circ} 43$. Esta resolução manteve as condições da RSF $n^{\circ}$ 78/98, mas transferiu do Banco Central para a Secretaria do Tesouro Nacional (STN) o poder de decidir sobre os pedidos de endividamento dos governos subnacionais. A Resolução do SF $n^{\circ} 78 / 98$ marcou a inserção da análise técnica do $B C$ no processo de pedido de autorização para contratação de qualquer operação de crédito dos Estados no Senado Federal. Ou seja, os pedidos dos Estados devem passar antes por análise técnica do BC. Em dezembro de 2001, a Resolução do SF n 43/01 estabeleceu a regulamentação parcial da LRF para Estados e Municípios, ao estabelecer, entre outros pontos, que a STN funcionaria como um filtro dos pedidos de endividamento dos Estados (caput dos art. 29 e 30). A STN funcionaria como assessor do Senado Federal na análise de pedidos de contratação de operação de crédito dos Estados. O órgão deve emitir um parecer. Se for favorável ao pedido, ele é encaminhado ao Senado. Se for desfavorável, não é encaminhado à Casa. Contudo, a Resolução n 43/01 regulamenta a LRF para Estados e Municípios, mas deixa de fora a União. O projeto que regulamentaria a LRF para a União não foi regulamentado até hoje ( $1^{\circ}$ semestre de 2006). Outra questão é a não regulamentação do Conselho de Gestão Fiscal, prevista no texto da LRF. Hoje, a STN edita as regras. "Provavelmente, a STN não quer compartilhar esta prerrogativa"”3.

\footnotetext{
${ }^{83}$ Entrevista com Selene Peres Peres Nunes, em 20/09/05.
} 


\title{
Capítulo III - Os caminhos da construção da Lel de Responsabilidade Fiscal no Governo Federal
}

III.a) A criação do projeto de lei no Governo Federal

\begin{abstract}
"O mercado é que nem um leão: vocês ficam dando bifinho, não vai matar a fome nunca. A gente tem que fazer alguma coisa que sustente mais. Ficar dando bifinho, para a gente, é um prejuízo enorme e do ponto de vista do resultado, pode ser inócuo".

Martus Tavares ${ }^{84}$.
\end{abstract}

O processo de aprovação da Lei de Responsabilidade Fiscal, como argumentamos neste trabalho, não se iniciou no momento da entrada do projeto de Lei Complementar na Câmara dos Deputados, em abril de 1999. Este processo iniciou-se anteriormente, a partir da conjugação de um conjunto de fatores históricos, institucionais e conjunturais. Historicamente, havia um

"processo de desordem fiscal muito grande. No caso do Congresso, isto ficou claro com as CPIs dos Anões e dos Precatórios. Então você tinha noção de que como estava não dava para ficar. Segundo, depois do Plano Real, você também tinha noção que não dava para ficar fazendo déficit público adoidado. Terceiro: você atravessou uma série de crises externas graves, que hoje você não tem. E a cada crise, você reagia com um pacote de emergência, baixava pacote no final do ano, sobretudo aumento tributário. Mesmo com a lei, você continuou fazendo ajustes pela via tributária. Mas você começava a chegar no Congresso e na sociedade e pedia sacrifício. E o pessoal do Congresso começou a falar: "poxa, mas vem cá, toda a hora precisa de sacrifício... Não dá"85.

Em 1997, após a crise da Ásia, o governo lançou o "Pacote 51", com medidas fiscais. Ao mesmo tempo, outras mudanças estavam sendo encaminhadas: tramitava no Congresso o Projeto de Emenda Constitucional $n^{\circ} 19$ da Reforma Administrativa e a revisão da Lei $4320^{86}$. A tramitação da Reforma Administrativa foi um fator institucional importante, na medida em que se inseriu um dispositivo no projeto de emenda constitucional (art. 30) que estabelecia que o

\footnotetext{
${ }^{84}$ Entrevista com Martus Tavares e Selma Pantel, 06/09/05.

${ }^{85}$ Entrevista com José Roberto Rodrigues Afonso, em 01/09/05.

${ }^{86}$ Lei que estatue normas gerais de direito financeiro para elaborarão e controles dos orçamentos e balanços da União, dos Estados, dos Municípios e do Distrito Federal.
} 
presidente da República teria seis meses para mandar um projeto de lei complementar para o Congresso, regulamentando o Art. 163 da Constituição. Alguns entrevistados afirmaram que foi sugestão do relator, dep. Moreira Franco (PMDB/RJ), a inclusão do art. 30 na Emenda Constitucional da Reforma Administrativa. A inclusão desse artigo ocorreu entre 1995 e 1996, na Câmara dos Deputados, antes das crises financeiras do Leste Asiático (1997), da Rússia (1998) e da assinatura do Acordo com o FMI, em outubro de 1998.

Naquele momento, a equipe do Ministério do Planejamento tinha também uma outra demanda de regulamentação constitucional: o art. 23, que trata da questão da divisão das competências entre os entes federativos. Era considerado um dispositivo basilar para os técnicos do governo, especialmente os da área de elaboração do orçamento:

"Eu fui o responsável pela elaboração dos oito orçamentos do Governo $F H C$, as oito $L D O^{87} s$ e os dois plurianuais. Cada $L D O$ que a gente escrevia tinha o eterno problema da divisão de responsabilidades nos serviços. Todo o ano, os parlamentares faziam emenda no orçamento e colocavam despesas que eram típicas de governos estaduais. E a gente tentava tirar isso e não tinha uma base legal. A base legal estaria na lei complementar que a gente nunca teve e não tem até hoje. Isso era uma demanda nossa, precisa regulamentar isso, como era demanda nossa a regulamentação do art. 163, do artigo do BC, só que por alguma razão, alguém chamou a atenção do art. 163 para o Moreira Franco. Como a gente tinha essas questões que precisava regulamentar a Constituição em vários dispositivos, nunca me chamou a atenção quem colocou isso na cabeça dele (Moreira Franco)..." ${ }^{\text {"88. }}$.

Conforme vimos de forma detalhada no capítulo anterior, em 04 de junho de 1998, foi sancionada a Emenda Constitucional $n^{\circ} 19$, de 1998 - a Reforma Administrativa. Em 19 de junho de 1998, foi aprovada no Senado a resolução "Kleinübing" ${ }^{29}$, que endureceu as condições de endividamento. O relator da resolução foi o senador Vilson Kleinübing (PFL-SC), mas o texto inicial do projeto foi apresentado pelo senador Esperidião Amin (PPB-SC), em maio de 1996. A ele, foram acrescentadas várias sugestões da Comissão Parlamentar de Inquérito, CPI dos Precatórios, já abordada anteriormente. ${ }^{90}$

\footnotetext{
${ }^{87}$ Lei de Diretrizes Orçamentárias.

${ }^{88}$ Entrevista com Martus Tavares e Selma Pantel, 06/09/05.

${ }^{89}$ O projeto de Resolução do Senado Federal n 49/1996, que deu origem à Resolução no 78/1998.

${ }^{90}$ País, Joinville, 19/06/1998, http://an.uol.com.br/1998/jun/19/0pai.htm
} 
Em agosto de 1998, ocorreu a crise russa e o Governo Federal precisava dar uma resposta para a crise. Era ano eleitoral e o caos estava instalado:

"Quando veio a crise russa, nós fomos para frente do pelotão e para a linha de tiro. A gente radicalizou na política fiscal. Vamos ter que fazer um programa plurianual, esta coisa de equilíbrio não dá mais... A poupança externa já vinha dando sinais desde a crise do México (95) que estava mudando... A coisa podia ir embora a qualquer momento. Tinha até uma brincadeira que chamavam o Martus e o Murilo Portugal de "dupla do mal", porque eles ficavam sacando as maldades, os cortes que iam fazer. Naquele momento, o Martus teve a idéia que a gente tinha que ter uma coisa mais sólida. Depois da segunda ou terceira reunião, o Martus resolveu colocar a primeira idéia no papel. Acho que eu tenho ele guardado até hoje. Ele botou a primeira idéia e foi conversar com o Ministro Clóvis Carvalho, na época Ministro da Casa Civil, que coordenava a Câmara de Política Econômica... "91.

Houve uma divisão de tarefas entre os técnicos da equipe econômica do governo: a equipe do Ministério da Fazenda ficou responsável pelas medidas de emergência e o acordo com o FMI. Eles acreditavam que o Governo Federal tinha que apresentar números e cumprir metas. "Eles tinham um viés de curto prazo, de ajuste numérico, a gente precisava de um ajuste qualitativo, de mais institucionalidade. Eles falavam de institucionalidade quando falavam de metas, mas não era o bastante....

Os técnicos do Ministério do Planejamento, então, dividiram-se em dois grupos: um tocaria medidas de emergência, como medidas de contingenciamento e um pacote fiscal, que incluiria mudança no percentual da COFINS (previsto no acordo com o FMI); outro grupo pequeno cuidaria da elaboração de medidas de longo prazo. Este grupo seria responsável por pensar em um ajuste fiscal permanente, em mudanças estruturais na gestão fiscal do país.

Neste período, após a crise russa, em setembro de 1998, formou-se uma equipe de trabalho liderada pelo Secretario Executivo do Ministério do Planejamento, Orçamento e Gestão, na época, Martus Tavares, e pelo Superintendente de Seguridade do Fundo de Previdência Complementar dos empregados do BNDES e da área fiscal e de emprego, na época, José Roberto Afonso. Esta equipe começou a trabalhar no projeto de lei complementar que regulamentaria o art. 163 da Constituição. É importante destacar que ambos

\footnotetext{
${ }^{91}$ Entrevista Martus Tavares e Selma Pantel, em 06/09/05.

${ }^{92}$ Entrevista Martus Tavares e Selma Pantel, em 06/09/05.
} 
traziam um histórico profissional relevante para a elaboração deste projeto de lei. Martus Tavares, antes de assumir o cargo de Secretario Executivo do Ministério do Planejamento, Orçamento e Gestão, trabalhou na Secretaria do Tesouro Nacional, na época da implementação das mudanças que ocorreram na década de 1980, foi diretor-adjunto do departamento de Orçamento da União, do Ministério da Economia, de 1989 a 1990 e Secretário-adjunto de Política Econômica da Secretaria Nacional de Planejamento, no período de 1990 a 1992. José Roberto Afonso foi assessor parlamentar do então deputado José Serra, que foi relator da Comissão do Sistema Tributário, Orçamento e Finanças na Constituinte. A inspiração das primeiras versões do anteprojeto de lei foi o resgate do que tinha sido pensado por este grupo em 1988, como a idéia do "Código de Finanças Públicas":

\begin{abstract}
"Nós propusemos fazer o Código de Finanças Públicas, para a gente dar uma resposta institucional, adicional à resposta quantitativa, que viria com o programa plurianual, com as metas. Num primeiro momento, a gente não tinha em mente a Lei de Responsabilidade Fiscal. A gente estava com o Art. 163 na cabeça. Quando eu e o Zé (José Roberto Afonso) sentamos para discutir a questão, ele procurou um material e veio com a coisa da Nova Zelândia. Estudamos os casos da Nova Zelândia, dos EUA e da União Européia. Juntamos isso com a nossa experiência: a minha no Governo e a do Zé, no Congresso, com o trabalho com o Serra... Juntamos isso com um grupo de pessoas para fazer a proposta. Três meses depois a gente tinha um projeto de lei... Havia uma necessidade de reação a um problema externo, mas não era só isso... A lei não surgiu só por causa da crise, a crise foi um catalisador, mas ela não foi a base... A gente vinha num progresso contínuo e permanente desde 1986... A gente vinha permanentemente fazendo progressos na área das finanças..."93.
\end{abstract}

Em outubro, foi assinado um acordo com o FMI e foi criado o Programa de Estabilidade Fiscal (PEF). As medidas de longo prazo, previstas pelo Governo Federal, foram inseridas no acordo com FMI por iniciativa do próprio governo brasileiro. O governo incluiu uma série de reformas no texto do acordo, mas foi o projeto da Lei de Responsabilidade Fiscal que acabou sendo aprovado no Congresso. É interessante notarmos a relação que existiu entre os técnicos do FMI e o projeto da Lei de Responsabilidade Fiscal. Ao contrário do discurso dos parlamentares da oposição, que argumentavam que a lei foi imposição do $\mathrm{FMI}$, o

\footnotetext{
${ }^{93}$ Entrevista Martus Tavares e Selma Pantel, em 06/09/05.
} 
projeto foi extremamente criticado pelos técnicos do Fundo. Segundo relatos dos entrevistados, o projeto da LRF ficou identificado pela oposição como um "projeto do FMI" porque o primeiro grupo de discussão do texto era formado pelo José Roberto Afonso, Álvaro Manoel e Ricardo Varsano: "O Álvaro Manoel tinha trabalhado no Fundo (FMI). Daí a oposição falou: mas isso é coisa do Fundo, é imposição do Fundo, o cara é interlocutor... "94. O FMI não impôs o projeto da LRF ao governo brasileiro:

"Na carta de intenções, de outubro de 1998, está a LRF e as reformas. Na verdade, a LRF estava lá por último, que era o que o pessoal menos acreditava. Essas reformas foram colocadas porque já estavam no Congresso. A tributária tinha mais ibope porque o Pedro Parente resolveu investir, apresentando um novo projeto, e a Previdenciária, começa a andar com o negócio de cobrança de inativos, que vai entrar neste pacotão como medida emergencial, que vai perder mais para frente. Mas a motivação é toda nossa, interna. (...) Aliás, no meio desse processo, entre apresentar o anteprojeto, mandar o projeto e ir para o Congresso, eu recebo uma carta do FMI, de um técnico, o George Kopitz, um cara que trabalhou num negócio chamado manual de transparência e responsabilidade fiscal. Tinha 3 páginas dizendo que o nosso projeto era um lixo, em grande parte porque primeiro a gente tinha que chegar ao paraíso para depois dizer que aquilo lá era o paraíso. 0 Brasil tinha que fazer primeiro as reformas Tributária e Previdenciária, tinha que acabar com a zona da federação, fazer o BC independente e depois se faz isso... Ele dizia que o projeto misturava regras e medidas; tem que decidir: não pode ser Nova Zelândia e EUA ao mesmo tempo."95

Entre outubro e novembro de 1998, a equipe formada por técnicos ${ }^{96}$ do Ministério do Planejamento e do BNDES trabalhou em ritmo de força tarefa. O prazo para apresentar o projeto no Congresso se esgotaria em dezembro. Nessa etapa, dois grupos do Ministério da Fazenda entraram no processo: a Secretaria Federal de Controle (hoje Controladoria Geral da União), que vinha trabalhando com a Lei 4.320, e o próprio Presidente do Banco Central, na época, Gustavo Franco, que apoiou o projeto da LRF:

"Ele entendia que precisava mudar o regime... Não adiantava ficar dando tiro, tiro, e não ir para lugar nenhum... E o BC tinha dois ou três

\footnotetext{
${ }^{94}$ Entrevista com Martus Tavares e Selma Pantel, em 06/09/05.

${ }^{95}$ Entrevista com José Roberto Rodrigues Afonso, em 01/09/05.

${ }^{96}$ Dentre os vários técnicos que fizeram parte do grupo, foram destacadas: Heloiza Camargo e Laira Vanessa, que trabalharam mais no início do processo, e Selene Peres Peres Nunes, que trabalhou no início, mas mais intensivamente no período da tramitação no Congresso.
} 
advogados que vinham trabalhando. Um grupo vinha trabalhando na Kleinübing no Senado, e o outro, trabalhando na revisão da Lei 4.320. E ele quis participar disso. A Fazenda, a Secretaria de Política Econômica, mesmo a Secretaria do Tesouro Nacional, no início, estavam fora. Daí vem o Gustavo com o peso dele, como presidente do BC. Quando a gente conseguiu rascunhar um projeto, ele sentou e ficou revisando para a gente dois dias inteiros, lá no BNDES"97.

Além do Gustavo Franco, várias instâncias técnicas do Executivo Federal foram consultadas: pelo menos dez coordenações da Secretaria do Tesouro Nacional, técnicos do Ministério da Previdência, da Receita Federal, e no Banco Central, pelo menos técnicos de três diretorias.

\begin{abstract}
"Foi, na verdade, um projeto escrito a várias mãos, quando a gente percebeu que havia uma oportunidade de fazer uma mudança estrutural e esse era o espírito da lei realmente, então as pessoas foram lembrando "puxa então isso aqui nós poderíamos impedir... Aqui também...". Então todo mundo lembrava de algum caso que não era desejável e que poderia ser convertido num inciso da lei, e isso foi se somando. E é interessante porque tem determinados dispositivos da lei que remetem a casos muitos específicos. Como, por exemplo, aquele que impede a antecipação de tributos cujo fato gerador não tenha ocorrido, foi um caso que aconteceu no Rio Grande do Sul. Então alguém lembrou que isso aconteceu e que poderia haver um dispositivo legal que impedisse essa aberração. $E$ assim como esse, vários outros casos. Então o número de técnicos que foram consultados dentro do governo, que eram especialistas nas respectivas áreas, foi muito grande. Isso foi se somando e nós ficamos como um grupo de referência, que recebia sugestões e ia acomodando, ia incorporando, enfim, algumas coisas não davam para incorporar porque eram incompatíveis, mas a gente foi construindo esse projeto"98.
\end{abstract}

Uma pessoa importante nesse período de formatação inicial do texto foi o Dr. Cid Heráclito de Queiroz, Procurador da Fazenda Nacional, aposentado, que prestou consultoria jurídica ao grupo que formulou a lei no Governo Federal. Uma preocupação grande desse grupo era com a constitucionalidade da lei:

“(...) Como fazer uma lei que se aplicasse à federação mas que, ao mesmo tempo, não ferisse o princípio federativo? $E$ havia algumas discussões muito polêmicas, por exemplo: eram os estados e os municípios obrigados a enviar as suas contas para a União? Até então isso não acontecia, veja que não havia estatísticas consolidadas porque

\footnotetext{
${ }^{97}$ Entrevista com José Roberto Rodrigues Afonso, em 01/09/05.

${ }^{98}$ Entrevista com Selene Peres Peres Nunes, em 20/09/05.
} 
havia um entendimento nos Estados e Municípios de que eles não eram obrigados a enviar contas pra União. Então apenas aqueles que refinanciavam as suas dívidas com a União aceitavam que se incluíssem nos contratos essa exigência, mas todos os outros não enviavam informação nenhuma... Até para construir um diagnóstico fiscal consolidado era difícil porque não havia números"99.

Em novembro de 1998, saiu um primeiro esboço do texto, baseado em dispositivos da LDO e na experiência em outros países. O texto era muito grande, com 110 artigos, e muita coisa ainda precisava ser decidida. Não havia a possibilidade de mandar um projeto extenso e complexo para o Congresso sem passar pela Assessoria Jurídica da Casa Civil (Gilmar Ferreira Mendes). Nesse momento, surgiu a idéia, bancada pelo Ministro Gilmar, de divulgar não o projeto, mas o anteprojeto. A diferença entre o projeto de lei e o anteprojeto de lei é que este não pode ser encaminhado ao Congresso. Então, foi elaborado um anteprojeto que foi aberto para a consultoria pública:

"Em dezembro (1998), o Clovis Carvalho manda um ofício, um aviso para o Congresso dizendo: de acordo com a emenda constitucional que me mandou fazer isso, nós resolvemos fazer um anteprojeto, abrindo para o debate público. O jogo era assim: tome ciência e me mande sugestões também... Vamos colocar em debate público, e este debate pode ser seu e dos parlamentares. Distribua na casa e me mandem sugestões. Mas aquilo, ao pé da letra, não era o que a Constituição mandava. Ela mandava enviar um projeto de lei e nenhum parlamentar iria mandar comentários para a gente. (...)"100.

Desde o início, os técnicos que formularam a lei fizeram uma mistura de três modelos de responsabilidade fiscal: o modelo neozelandês, o modelo norteamericano e o modelo europeu. A idéia de transparência fiscal foi inspirada nos textos do FMI, no caso neozelandês, e estava prevista no Art. 37 da Constituição (Emenda da Reforma Administrativa). Nos EUA, o Budget Enforcement Act regula o controle do Congresso sobre o processo orçamentário federal. O Congresso fixa, ex-ante, metas de superávit e mecanismos de controle de gastos, cuja autorização legislativa é mandatória. Em cada unidade federada há regras próprias. O caso dos Estados Unidos, apesar de ser mais conhecido pelo enfoque restrito ao governo central e pelo Congresso ser o grande motor que impulsiona e comanda o processo

\footnotetext{
${ }^{99}$ Entrevista com Selene Peres Peres Nunes, em 20/09/05.

${ }^{100}$ Entrevista com José Roberto Rodrigues Afonso, em 01/09/05.
} 
orçamentário (ao contrário do caso brasileiro), é um caso exemplar de controle da expansão do gasto ${ }^{101}$.

O regime fiscal da União Européia é regulado pelo Tratado de Maastricht, de 1992. Segundo este tratado, foi acordado que a verificação da sustentação da posição financeira de cada governo se daria pelo seguinte princípio: Estados Membros devem evitar déficits governamentais excessivos. Ainda foi estabelecido que: a Comissão monitorará o desenvolvimento da situação orçamentária e o estoque de dívida governamental dos Estados Membros visando identificar grandes desvios. Segundo o Pacto de Estabilidade e Crescimento, de 1997, na terceira fase da União Monetária Européia, os Estados Membros permanecem responsáveis pelas respectivas políticas orçamentárias nacionais, subordinadas às disposições do Tratado. Desta forma, a tônica deste modelo é o estabelecimento de critérios de convergência fiscal, metas e punições em protocolos e admissão de desvios em tendência. ${ }^{102}$

O caso da Nova Zelândia foi a maior fonte de inspiração para os técnicos do governo. A Nova Zelândia é considerada pelos organismos internacionais como um benchmark em termos de disciplina e transparência fiscal. Em termos de distinção entre os modelos, o Ato neozelandês (Fiscal Responsibility Act, de 1994) distinguese como peça legislativa concernente a assuntos de política fiscal e orçamentária pelo fato de, ao contrário dos pressupostos de Maastricht e dos atos americanos, não prever mandatoriamente metas fiscais específicas e apenas referir-se a níveis predicais, além de admitir afastamentos temporários, desde que justificadamente e com previsão de meios e prazos de retorno a esses princípios. Os motivos dessa postura seriam: a dificuldade de se antecipar eventos futuros e a conseqüente necessidade de flexibilidade de atuação; o perigo de perda de credibilidade no caso de não cumprimento de metas específicas; e o medo de manipulação de informações para cumprir artificialmente metas fixadas. Embora 0 ato seja aparentemente permissivo, na avaliação da OECD, a história da aplicação de metas fiscais rígidas em outros países era insatisfatória ${ }^{103}$.

A consulta pública do projeto da LRF ocorreu de dezembro de 1998 a março de 1999. Havia uma clara percepção de que, por se tratar de um projeto complexo,

\footnotetext{
${ }^{101}$ Ver: Anteprojeto de Lei Complementar da Responsabilidade Fiscal (Consulta Pública), pg. 06, http://federativo.bndes.gov.br/Destaques/docs_Pagina_LRF/Aplcqcom.doc

${ }^{102}$ Idem.

${ }^{103}$ Ver: Anteprojeto de Lei Complementar da Responsabilidade Fiscal (Consulta Pública), pg. 07, http://federativo.bndes.gov.br/Destaques/docs_Pagina_LRF/Aplcqcom.doc
} 
de difícil entendimento e de impactos significativos nas relações intergovernamentais, seria preciso promover um processo de apresentação, discussão e convencimento junto aos atores políticos implicados. O grupo de técnicos não podia impor politicamente o projeto aos atores políticos e sociais,

"a gente tinha que convencer os governos estaduais e municipais, através das associações deles"104. "A gente percebeu que a transformação era tão grande, era tão profunda, tão estrutural, que ela não seria viabilizada se a gente não conseguisse reunir forças políticas e construir um consenso em torno disso. Inclusive a nossa estratégia de colocação de divulgação do projeto começou por formadores de opinião, que foram chamados ao Ministério para ouvirem uma explicação sobre o que era o projeto da LRF. O receio maior era que surgisse uma resistência que inviabilizasse a tramitação do projeto. Então, a gente começou a acolher sugestões, foram acolhidas muitas sugestões nesses fóruns, nessas reuniões. Nós fizemos reuniões com secretários de planejamento, de fazenda dos estados, com pessoal de associação de municípios, com gente de mercado, com colunistas e articulistas de jornais, e fomos colhendo subsídios e incorporando."105

O anteprojeto de lei foi colocado na Internet e foram enviadas mais de 5000 sugestões. Um ponto que apareceu com destaque na consulta pública da Internet foi a preocupação com crescimento do número de Municípios sem condições de sustentabilidade fiscal:

\begin{abstract}
"Este ponto apareceu na Comissão especial e apareceu na Internet. Mas essa é uma questão que nós não tínhamos como resolver na $L R F$ porque é uma questão eminentemente constitucional. Contudo, isso originou pelo menos um dos dispositivos da lei que diz que todos devem instituir e prever arrecadar os impostos de sua competência, que passam um pouco por aquela idéia de que o município não pode simplesmente ficar a espera das transferências que caem do céu. Se ele tem a competência de arrecadar impostos, faz parte da responsabilidade fiscal instituir, prever e arrecadar os impostos, e é essa origem desse dispositivo"
\end{abstract}

Foram realizadas cinco reuniões: com secretários municipais da Fazenda, com assessores dos Estados, com secretários de Estado da Administração, com

\footnotetext{
${ }^{104}$ Entrevista com Martus Tavares e Selma Pantel, em 06/09/05.

${ }^{105}$ Entrevista com Selene Peres Peres Nunes, em 20/09/05.

${ }^{106}$ Entrevista com Selene Peres Peres Nunes, em 20/09/05.
} 
secretários de Estado da Fazenda e do planejamento e representantes do mercado $^{107}$.

$\mathrm{Na}$ primeira reunião, realizada em 16/12/1998 com representantes do mercado financeiro, assim como na segunda (07/01/1999), com a Associação Brasileira das Secretarias de Fazenda dos Municípios das Capitais (ABRASF), a receptividade foi boa. Na segunda reunião, surgiram sugestões que agregaram pontos ao texto do anteprojeto. José Roberto Afonso afirmou, na ocasião que, de forma geral, os secretários, tanto em nível estadual quanto municipal, viam as regras e limites da nova lei como uma forma de defesa contra pressões políticas indevidas. "Haverá punições penais para quem não cumprir as regras"108. Os secretários municipais apresentaram uma sugestão interessante: que a lei regulasse os gastos com pessoal não só por nível de governo, mas por esferas de Poder. O Executivo não controla gastos do Judiciário e do Legislativo, mas tem que cumprir a regra geral da Lei Camata, que limita os gastos com pessoal a $60 \%$ da receita líquida. A sugestão foi que se diga, por exemplo, que dos $60 \%$, digamos que $10 \%$ caberiam ao Legislativo, e $5 \%$ ao Judiciário. Apenas o Poder, ou os Poderes, que se desviassem da meta teriam que se ajustar. O governo gostou da idéia (idem). Outra idéia dos secretários municipais foi transformar os Adiantamentos de Receita Orçamentária (AROs) numa espécie de cheque especial. Os AROs deveriam ser empréstimos de curtíssimo prazo para cobrir desequilíbrios temporários de caixa, mas muitos abusaram de seu uso. A sugestão foi permitir o uso de um cheque especial pelos Municípios, mais flexível do que um empréstimo, mas com limites estritos, que teriam que ser zerados 15 dias antes do fim de cada ano.

Basicamente, surgiram duas críticas nessa reunião com secretários da Fazenda dos Municípios das Capitais: foi criticada a medida que obriga a liquidação das AROs antes do final de cada exercício financeiro e pedida que a operação fosse contínua ou tivesse 90 dias para seu fechamento. A principal justificativa é o descontínuo fluxo financeiro típico das prefeituras, com entradas concentradas no início do exercício (IPTU, taxas e IPVA) e saídas no seu final (décimo-terceiro salário). Também recebeu críticas a proposta de que seja empenhado apenas volume igual ao montante de caixa e solicitada uma maior flexibilidade, inclusive

\footnotetext{
${ }^{107}$ Ver: http://federativo.bndes.gov.br/f_Irfiscal.htm

${ }^{108}$ Folha de São Paulo, 10/01/1999.
} 
por conta do tradicional carry over da folha salarial - pedido que, ao menos, a folha salarial de dezembro possa ser levada de um exercício financeiro para outro.

$\mathrm{Na}$ quarta reunião, realizada com Secretários de Estado da Administração em 19/01/1999, sugeriu-se que a responsabilização e as punições contidas na lei também incluísse os Tribunais de Contas e o Legislativo. $O$ anteprojeto foi considerado tímido no que se refere à guerra fiscal e foi sugerido que houvesse dispositivo limitando a renúncia de receitas. Com relação aos limites na razão gasto com pessoal/receita, propôs-se estimular a correção de desvios não só pela contenção de gastos e mais pelo movimento da receita.

$\mathrm{Na}$ quinta reunião, realizada em Fortaleza (CE) com Secretários de Estado da Fazenda e do Planejamento, em 02/03/1999, houve algumas manifestações favoráveis e várias manifestações críticas ao projeto de lei. As manifestações favoráveis dos Secretários registradas na Ata da reunião foram de quatro Estados e do Distrito Federal: Piauí, Bahia, Pernambuco e Paraná. Em linhas gerais, os secretários defenderam que a Lei de Responsabilidade Fiscal era uma lei bemvinda, mas deveria considerar alguns pontos, como: 1) a necessidade de correção das desigualdades regionais; 2) a maior participação dos Estados na elaboração do Orçamento Federal; 3) as renúncias fiscais como mecanismo de compensação; 4) a receita tributária como parâmetro de endividamento.

As manifestações críticas ao projeto partiram de nove Estados: Pará, Ceará, Espírito Santo, São Paulo, Rio de Janeiro, Minas Gerais, Santa Catarina, Rio Grande do Sul e Amapá. Em linhas gerais, as críticas que mais surgiram no discurso dos secretários desses Estados foram as seguintes: 1) instabilidade das receitas de transferências para Estados (Pará perdia 2 bilhões em 4 anos com Lei Kandir, FEF, ex-INSS, etc.); 2) necessidade de revisão do prazo de enquadramento à lei; 3) rigidez nas despesas e receitas, que eram pouco administráveis (ICMS); 4) sugeriram mais descentralização e menos controle burocrático, na medida em que a responsabilidade não viria de regras burocráticas, mas de controle social (segundo eles); 5) os precatórios de 1995 a 1998 precisavam ser refinanciados, pois dificultavam cumprir regra de restos a pagar. Todos os secretários citaram a necessidade da lei explicitar os limites de gastos dos outros poderes estaduais, criando mecanismos de comprometimento dos outros poderes com o controle de gastos e do endividamento. 
As críticas mais contundentes ao projeto foram formuladas pelos representantes de São Paulo, em especial o Secretário das Finanças do Estado, na época, Yoshiaki Nakano:

"Eu peguei uma dezena de índices e eu desafiei alguém a cumprir. Se algum secretário confirmasse que conseguiria cumprir na prática, eu não era mais secretário, e se eles, no Governo Federal, conseguissem cumprir, também. Eles queriam um volume de caixa que era uma coisa absurda. O mês de dezembro, por exemplo, você paga o salário, o $13^{\circ}$, no $5^{\circ}$ dia útil tinha que pagar mais uma folha. Você tinha basicamente 3 folhas no período de um mês, mais todos os restos a pagar para deixar em caixa. Isto era impossível. Ainda escapou e passou na lei algumas coisas que, logo de cara, enquanto eu estava lá, o Judiciário deu risada, isso é besteira, não vamos cumprir nada... Eles não atentaram para o fato do mandato dos presidentes dos Tribunais ser muito mais curto, não sei se dois anos. Em função de ser um mandato curto, como eles colocaram a restrição? Como o mandato deles é curto, ficou uma coisa inexeqüível. (...) E daí eu falei: façam uma lei para segurar vocês também! Responsabilidade fiscal... Não é só prefeito e governador que é bandido. Eles são a mesma coisa! Mas porque não estavam os outros poderes? Na versão original não estavam os outros poderes. No que eles mandaram para a Câmara já estava (...)"'109.

O Secretário Nakano afirmou ainda que os princípios da lei eram bons, porém o corpo da LRF era uma decepção. Segundo ele, os outros poderes eram o maior problema e as punições só foram previstas para o poder executivo. A lei instauraria um projeto de controle centralizador burocrático, que feriria o princípio da autonomia das unidades federativas (UFs). O texto, segundo ele, era muito detalhista, engessando as administrações das UFs. A regra de restos a pagar seria inaplicável. Segundo ele, não se deveria multiplicar normas e sanções, para não virar letra morta. Ademais, a lei é necessária, mas tem que ser discutida com mais profundidade e com participação da Federação. Ao fim, ele questiona: "como ser responsável se não se tem autonomia?"110

No fechamento da reunião com os secretários, o Secretário Executivo do Ministério de Orçamento e Gestão na época, Pedro Parente, rebateu as críticas afirmando que o Governo queria um projeto efetivo, visando ao longo prazo e não ao ajuste fiscal imediato. O texto precisava ser flexível para durar, superando as

\footnotetext{
${ }^{109}$ Entrevista com Yoshiaki Nakano, em 22/08/05.

110 Ver: Reunião sobre o Anteprojeto de Lei Complementar de Responsabilidade Fiscal realizada com os Secretários de Estado da Fazenda e do Planejamento, http://federativo.bndes.gov.br/f_Irfiscal.htm
} 
conjunturas; o projeto integraria a federação e chamaria a uma co-responsabilidade na administração de todos os recursos públicos. Do seu ponto de vista, não se trataria de jogo de soma zero: seria bom para todos ${ }^{111}$.

A percepção dos técnicos do governo, que formulavam o projeto da LRF, sobre a posição dos governadores era a seguinte: os Estados que estavam mal financeiramente estavam interessados, porque viam no projeto uma possibilidade de encaminhamento do seu problema. Quem estava bem, não estava interessado. E ainda havia Estados que já estavam em processo de ajuste fiscal, como o caso de São Paulo, e tinha posições próprias com relação ao projeto ${ }^{112}$. O Estado de São Paulo já vinha em processo de ajuste das contas públicas desde 1995, no Governo Mario Covas:

"O Covas (Governador de São Paulo, Mario Covas) fez o ajuste. Naquele primeiro momento, foi um desgaste danado... E o Covas foi para a reeleição e foi reeleito, em grande parte, porque nós fizemos o ajuste. Não só o ajuste viabilizou depois fazer as coisas, mas foi um governo de austeridade e controle, e a população percebeu. Naquele momento, já havia uma percepção de que era preciso ter compromissos (...).E os governadores que não tiveram, mesmo do PSDB, não foram reeleitos. Isso você tem que fazer no começo do governo, para valer. Então o Covas foi reeleito, fez muito mais obras do que os dois governadores anteriores, reduziu os impostos, e fizemos tudo em cima do controle do gasto corrente. $E$ ainda melhoramos os serviços, aumentamos muito. (...) Eu acho que a população mudou e para mim a mudança da população foi quando reelegeram o Covas. O governo ficou tendo a marca do controle, do ajuste. Durante 3 anos e tanto, só se falava nisso. E ele foi reeleito em cima disso. E não é a toa que o Geraldo (Alckmin) continua com o mesmo discurso, de redução dos impostos. De um modo geral, a população tem aprovado e a primeira grande prova para mim foi a aprovação do Covas. E daí, para a LRF, ficou uma coisa fácil de passar no Congresso. Os políticos são muito mais espertos que a gente, mais rápidos para entender essas coisas $(\ldots)^{m 13}$.

Havia divergências técnicas entre o grupo da Secretaria do Estado da Fazenda de São Paulo e o grupo que formulava a Lei de Responsabilidade Fiscal no Governo Federal. Segundo o primeiro grupo, já existia um arcabouço legal que permitia punir governador que não respeitasse limites de endividamento e gastos, através de sanções políticas ou penais. O problema seria fazer com que a restrição

\footnotetext{
111 Idem.

${ }^{112}$ Entrevista com José Roberto Rodrigues Afonso, em 01/09/05.

${ }^{113}$ Entrevista com Yoshiaki Nakano, em 22/08/05.
} 
orçamentária funcionasse para valer, através de uma reforma constitucional que proibisse a União de socorrer os Estados e Municípios, em qualquer hipótese. Uma outra medida que complementaria a proibição de empréstimos seria a criação da figura da concordata do Estado e do Município. Criar-se-ia um sistema de arbitragem que colocaria o risco nas mãos de quem financia. $O$ emprestador analisaria o histórico do Estado em termos de cumprimento dos contratos, o histórico da carreira do governante na administração das finanças públicas em governos anteriores, e avaliaria a viabilidade do empréstimo ao ente federativo em termos do risco embutido na transação. Este grupo criticou a estrutura de incentivos que a LRF cria: "esta LRF coloca todo o mundo na vala comum. Todo o mundo é bandido e tem que fazer isto aqui... E aí quem administra bem não tem nenhuma vantagem. Proibido de fazer empréstimo, proibido disso, daquilo... Então não é uma lei que estimula as pessoas a fazerem uma boa gestão (...)"114.

A posição dos técnicos do Governo Federal, com relação à posição do secretário da Fazenda de São Paulo na época, era que se tratava de uma opinião contrária ao projeto de um dos Estados mais importantes no contexto federativo do país, mas que não ameaçava o andamento do processo de elaboração e implementação da lei. "Ele não jogou contra... Na essência, ele não era contra. O processo, para ele, tinha que ser diferente... A última reunião que teve do Confaz, antes de mandar a lei para o Congresso, ele foi lá e registrou: discordo, por causa disso, disso, disso (...)"115.

Se, por um lado, o Governo do Estado de São Paulo marcou posição crítica com relação à lei, mas não agiu politicamente para obstruir a sua aprovação, por outro lado, os governadores de esquerda, do Partido dos Trabalhadores, eram uns dos que mais tinham interesse na aprovação da lei. Um dos maiores problemas dos Estados, naquele momento, era como o Executivo Estadual poderia controlar os gastos do Legislativo e do Judiciário Estaduais. Alguns governadores que tiveram participação ativa no processo de discussão da lei foram Olívio Dutra (RS), Zeca do PT $(\mathrm{MT})$ e o Ronaldo Lessa $(\mathrm{AL})$. É interessante notar que a posição favorável desses governadores de oposição na época contrastava com a posição desfavorável dos deputados e senadores de oposição em plenário, independentemente de serem das bancadas estaduais dos governadores.

\footnotetext{
${ }^{114}$ Entrevista com Yoshiaki Nakano, em 22/08/05.

${ }^{115}$ Entrevista com José Roberto Rodrigues Afonso, em 01/09/05.
} 
Conforme será abordado mais adiante, os partidos de oposição, especialmente PT e PC do B, votaram contra a aprovação da Lei de Responsabilidade Fiscal.

Os governadores demandavam que fossem incluídas no projeto de lei as seguintes medidas: o controle dos gastos de pessoal dos poderes nos Estados ${ }^{116}$; não considerar, na despesa com pessoal, pedido de demissão e indenização; e os sub-limites de pessoal. O controle dos poderes foi incluído a partir da sugestão de um técnico do Estado de Minas Gerais, de quebrar o limite entre os três poderes. $\mathrm{O}$ interesse dos governadores nessas medidas se dava a partir do argumento que os Estados estavam com sérias dificuldades financeiras. Quando eles cortavam despesa no Executivo, o Legislativo e o Judiciário aumentavam e, no final, o Executivo estava desenquadrado de novo. Era uma ciranda. Ademais, a demissão representava custos extras, o que aumentava as despesas. ${ }^{117}$

No período em que o projeto foi discutido no Executivo Federal, houve uma importante divergência relacionada ao Banco Central. A divergência, neste caso, envolveu membros da equipe do governo que formulou o projeto da LRF, técnicos do Ministério da Fazenda e do Banco Central. O projeto inicial da LRF tinha um dispositivo que incluía as contas do BC dentro do limite de endividamento da União. O assunto da tese de mestrado da Assessora Técnica do Ministério do Planejamento, Selene Peres Peres Nunes, sobre o relacionamento do Tesouro Nacional com o Banco Central, influenciou a equipe no momento das primeiras versões do texto. No entanto, no decorrer do processo de discussão dentro do governo, este dispositivo foi retirado. Gustavo Franco e Armínio Fraga eram favoráveis, mas a burocracia do BC era contra. A divergência foi parar nas mãos do Presidente Cardoso, que pediu para retirar o dispositivo. Na CESP da Câmara dos Deputados, houve um desdobramento deste episódio (ver no próximo capítulo).

"Foi preciso aparar várias arestas internas porque por exemplo, a inclusão do $B C$ na LRF não foi uma coisa muito fácil. A corporação sempre reage, embora o Gustavo Franco e o Armínio Fraga sempre tivessem sido francamente favoráveis. A questão da transparência do Tesouro também era complicada. Diziam que era inviável fazer a consolidação das contas de todos e divulgar na Internet, que

\footnotetext{
${ }^{116}$ Era uma antiga reivindicação dos governadores: "O projeto da Lei de Responsabilidade Fiscal, que o governo enviará ao Congresso na próxima semana, estabelece limites de gastos para os Poderes Legislativo e Judiciário uma antiga exigência dos governadores, que têm enfrentado desgaste ao cortar despesas apenas no Executivo." (Folha de São Paulo, 02/04/1999).

${ }^{117}$ Entrevista com José Roberto Rodrigues Afonso, em 01/09/05.
} 
operacionalmente seria impossível fazer, e foi também um processo de convencimento difícil'118.

A equipe do planejamento conseguiu deixar no projeto a proibição do $B C$ de comprar títulos estaduais e municipais no redesconto, para evitar que ocorresse novamente o episódio da prefeitura de São Paulo, no qual

"o papel do Pitta foi parar na mão do Banco do Brasil (BB) e depois foi parar no BC. Por que tinha que rolar a dívida do Pitta? Porque o mico estava na mão... não era nem na mão do $B B$, na mão do $B C$. $O B C$ não podia "micar"... Ele tinha que devolver para o BB e o BB quebrava. Por isso, o Pitta foi esticando a corda e só renegociou na véspera da lei. E aí impedir o BC de fazer isso, era uma coisa que a gente conseguiu.. Mas a gente queria colocar o BC dentro do limite de endividamento da União. Eles não queriam"119.

Os técnicos do $\mathrm{BC}$ e do Ministério da Fazenda divergiam dos técnicos do Planejamento basicamente em dois aspectos: a Fazenda achava que seria melhor uma lei mais simples, que vedasse o financiamento da dívida dos Estados e dos Municípios com a União. Achavam também que não se pode resolver todas as pendências do Tesouro Nacional e do Banco Central dentro de uma lei de finanças públicas, porque eles iriam competir com um possível projeto de lei do $\mathrm{BC}$ independente, que estava no horizonte dos técnicos do Ministério da Fazenda.

"Ao aprovar a $L R F$, enfraqueceu-se a questão do $B C$ independente. $O$ FHC sabia disso direitinho. Ele falou assim: não precisa, o que a gente está resolvendo, está resolvendo aqui... Sabe quem topou o negócio de proibir o BC de emitir papel? O pessoal do Tesouro dizia que a gente ia quebrar o mercado, vai parar o mercado, eu não vou poder emitir papel, como é que eu faço, eu tenho um limite... Aí o Sérgio Werlang ${ }^{120}$, bem ortodoxo, topou. Ganhou o Armínio que dizia que lá fora, o BC não emite papel, o Fed (Federal Reserve), o BC inglês, o alemão, o europeu, os grandes BCs independentes não emitem papel e eu quero um banco central independente, então eu não quero emitir. Mas isso era briga dentro do Executivo"121.

Entre fevereiro e março de 1999, houve uma reunião dos técnicos do Governo Federal com os técnicos dos Estados das áreas fazendária, de controle e

\footnotetext{
${ }^{118}$ Entrevista com Selene Peres Peres Nunes, em 20/09/05.

${ }^{119}$ Entrevista com José Roberto Rodrigues Afonso, em 01/09/05.

${ }^{120}$ Diretor de Política Econômica do Banco Central, na época.

${ }^{121}$ Entrevista com José Roberto Rodrigues Afonso, em 01/09/05.
} 
de orçamento, para decidir a versão do texto que seria encaminhada para o Congresso. Foi repassado artigo por artigo da lei:

“(...) Então saiu dali que a gente tinha apoio técnico e acolhemos boa parte das coisas que o pessoal propôs. Daí ficou aquela questão: mas os governadores apóiam isso? A maior parte mandou secretário... A maior parte dos secretários, na minha opinião, não sabia o que estava acontecendo ali, mandou o cara (...). Mais do que desconhecimento por parte dos técnicos e dos governadores dos Estados, a equipe do Governo Federal atribuiu o aparente apoio dos governadores ao projeto de lei à descrença de que a aprovação daquele texto complexo e extenso não passaria no Congresso. "Não acreditavam que a gente ia apresentar uma lei tão grande em tão pouco tempo. Depois não acreditavam que a gente ia incorporar as sugestões que eles davam, depois não acreditavam que o presidente mandaria a lei para o Congresso... E o principal que não acreditavam, é que seria aprovada. Nessa de que não acreditava, foi indo... A gente acreditava e foi trabalhando... O presidente, quando mandou, duvido que ele achasse que a gente ia conseguir aprovar isso. Ele entrou, ajudou, o Madeira (Arnaldo Madeira, líder do governo na Câmara) trabalhou, todo mundo trabalhou. É um trabalho de construção, de saber a hora... O que contou muito é que você chegou no Congresso com um projeto que não é só (do grupo do Planejamento e do BNDES). Se você pegar minha fala lá na Comissão, na $2^{a}$ audiência, o PT falou: este projeto é do Executivo? Eu disse: não é, o do Executivo saiu em dezembro, era o anteprojeto, esse aqui recebeu várias sugestões. Daí eu me lembro, o Carlito Merss, o pessoal do PT, começou a perturbar um pouco eu e o Martus, daí o Martus disse: engraçado, isso que está aqui, foi o seu governador Olívio Dutra que pediu para incluir. O governador de Alagoas disse que ele faz qualquer coisa em troca do limite. Os que mais queriam limite com pessoal eram os de esquerda. E como isso era forte $(\ldots)^{122}$.

Comparando o texto do projeto elaborado pelo governo, de setembro de 1998, com a versão pronta para ingressar na Câmara dos Deputados, o governo cedeu basicamente em três pontos, que foram negociados entre os líderes dos partidos governistas e os governos estaduais e municipais. O primeiro ponto referese ao tempo para a correção de descontroles fiscais provocados pela recessão e pelo aumento da taxa de juros. Quando a receita cair por causa da recessão ou quando as despesas com dívidas crescerem por causa de um aumento nas taxas de juros, os administradores terão um prazo extra de seis meses para retornar às metas programadas de arrecadação e de gastos com juros. Esse prazo não existia

\footnotetext{
${ }^{122}$ Entrevista com José Roberto Rodrigues Afonso, em 01/09/05.
} 
até então, e o ajuste tinha de ser imediato, com corte de despesas para compensar os gastos adicionais. Nesses casos, a lei já prevê seis meses para a retomada do nível de endividamento e 24 meses para os gastos com a folha de pagamento ${ }^{123}$.

Outro ponto negociado foi a extensão da Lei Camata para os Poderes Judiciário e Legislativo. A equipe do governo que elaborou a lei atendeu a reivindicação de prefeitos e governadores, aplicando o percentual sobre as receitas tributárias disponíveis (um conceito menos amplo do que o de receita líquida). Para compensar essa flexibilização, os percentuais adotados nos Estados e nos Municípios seriam maiores do que os $60 \%$ previstos pela Lei Camata. Outra concessão foi a aceitação de que os restos a pagar (despesas orçamentárias de um ano que são transferidas para o outro) seriam pagos no dia 30 de janeiro e não mais no dia 20 , como previa o texto anterior ${ }^{124}$.

III.b) O papel dos governadores e dos prefeitos

Naquele momento, os governadores agiram mais como atores que proferiam sugestões técnicas e ajudavam a aprimorar a lei, em função de seus interesses, do que como atores políticos com "poder de veto". A resistência à vinculação das privatizações no pagamento das dívidas, conforme demonstrou o caso da privatização do Banespa, por exemplo, foi diminuindo no tempo ${ }^{125}$. Esta questão já tinha sido encaminhada e amplamente discutida entre os atores políticos envolvidos na ocasião da renegociação das dívidas dos Estados, entre 1997 e 1998. A questão da determinação do limite do gasto estadual com os Poderes Legislativo e Judiciário foi ganhando mais importância na agenda de reivindicações dos governos estaduais. A Lei de Responsabilidade Fiscal era uma mudança institucional desejada pelos governadores por vários motivos, destacando-se o fato de ela fornecer instrumentos legais para eles realizarem cortes de despesas, especialmente de pessoal. A existência de instrumentos legais reduziria o ônus político dos cortes de despesa que os governadores tinham que realizar. Além do mais,

\footnotetext{
${ }^{123}$ Folha de São Paulo, 29/04/1999.

124 Idem

${ }^{125}$ Para a análise do caso da privatização do Banespa, ver Garman, Leite e Marques (1998).
} 
"havia governadores mais preocupados com a Tributária do que com a responsabilidade fiscal. Neste meio tempo, estava andando, a comissão da LRF e a Mussa Demes, da Reforma Tributária. Foi simultâneo. Quase todas as atenções das secretarias da fazenda estavam na tributária. $E$ na responsabilidade fiscal, você negociou, acolheu emenda, e quando não dá para acolher, você senta e diz que não dá para acolher por isso, isso, isso... E com isso você ganhou apoio. Na Lei Kandir, o processo foi o mesmo. Eu trabalhei na Lei Kandir e a gente aprovou. É uma lei que a complexidade política é pior que a $L R F$, porque é mais fácil você aprovar uma LRF do que um corte orçamentário. Quando você faz o corte, você está dizendo de quem você está tirando dinheiro. E na LRF você não tem um perdedor identificado. Não é que eu estou retaliando este ou aquele. A maior de todas as retaliações é que você iria cortar endividamento de Estados e Municípios, sendo que as dívidas tinham acabado de ser roladas (1997/1998) (...)"126.

Em abril de 1999, foi submetido ao Presidente da República o projeto de lei que altera e acresce dispositivos ao Decreto-Lei $\mathrm{n}^{0} 2.848$, de 7 de dezembro de 1940 - Código Penal, à Lei no 1.079, de 10 de abril de 1950 (ver anexo 2), que define os crimes de responsabilidade e regula o respectivo processo de julgamento, e ao Decreto-Lei $n^{\circ}$ 201, de 27 de fevereiro de 1967 (ver anexo 2), que dispõe sobre a responsabilidade dos Prefeitos e Vereadores. Este projeto, conforme exposição de motivos interministerial $n^{\circ}$ 99/99127, "objetiva dotar o ordenamento de preceitos necessários à efetiva e permanente observância dos princípios fundamentais que norteiam o regime de gestão fiscal. A gestão fiscal responsável constitui instrumento indispensável para a manutenção da estabilidade da moeda e para o desenvolvimento nacional, merecendo, portanto, em virtude de sua magnitude e relevância, tutela e salvaguarda por meio de modernas normas de natureza penal, voltadas para a repressão de condutas que atentam contra as finanças públicas e a lei orçamentária".

No início, a Lei de Crimes, Lei Ordinária $n^{\circ} 10.028$ de 19/10/2000 (ver anexo 2), estava tramitando conjuntamente com o projeto da LRF. Durante o processo de discussão, a equipe recebeu uma orientação jurídica de que uma parte das sanções era matéria de lei complementar e a outra era matéria de lei ordinária. Os projetos foram desmembrados, apesar de ter redação muito parecida, porque foram concebidos simultaneamente.

\footnotetext{
${ }^{126}$ Entrevista com José Roberto Rodrigues Afonso, em 01/09/05.

${ }^{127}$ Assinado pelos Ministros: Pedro Sampaio Malan (Ministro de Estado da Fazenda); Pedro Pullen Parente (Ministro de Estado do Orçamento e Gestão); Renan Calheiros (Ministro de Estado da Justiça); e Waldeck Ornélas (Ministro de Estado da Previdência e Assistência Social).
} 
Os atores federativos que mais manifestaram desconfiança e resistência com relação à aprovação da Lei de Responsabilidade Fiscal foram os prefeitos. A razão principal é a dependência da maioria dos Municípios de verbas federais e estaduais. A receita disponível dos Municípios chegou a R 45 bilhões em 1998, mas só R\$ 13,2 bilhões foram gerados por receita própria (ISS e IPTU). O restante, $R$ \$ 31,8 bilhões, veio de transferências federais ( $R$ \$ 13 bilhões) e estaduais ( $R$ \$ 18,8 bilhões). Os Municípios, em média, controlavam apenas $29 \%$ das receitas que gastavam. No caso dos Municípios com menos de 50 mil habitantes, $91 \%$ do total, essa proporção cai para $13 \%$. O receio de muitos prefeitos era assumir mais responsabilidades na gestão fiscal, controlando, na verdade, uma parcela muito pequena dos recursos que utilizavam. Se algum problema, político ou econômico, afetasse o volume ou o prazo das transferências de recursos para os Municípios, eles correriam o risco de pagar pelo não cumprimento da Lei de Responsabilidade Fiscal, sem ter controle sobre o grosso da receita ${ }^{128}$.

Em 2000, a situação financeira das prefeituras era péssima. Conforme dados do Ibam (Instituto Brasileiro de Administração Municipal), 55,53\% das 5.507 prefeituras municipais estavam deficitárias. Em termos de déficit nominal, estavam deficitárias $73 \%$ das prefeituras com população entre 500 mil e 5 milhões de habitantes.

Os prefeitos eram contra a entrada em vigor imediata da lei, após a sua promulgação, que estava prevista para janeiro de 2000, pela equipe do Planejamento. O governo queria que a lei atingisse exatamente o último ano de mandato dos prefeitos em exercício na época. Por meio da ABRASF, os prefeitos reivindicavam que a lei entrasse em vigor um ano após a sua promulgação, para não serem atingidos pelas seguintes restrições: 1) proibição de inaugurar obras que não fossem concluídas até 8 meses antes do fim do mandato; 2) proibição de realizar empréstimos bancários por meio de AROs no último ano de mandato; 3 ) proibição da contratação de pessoal nos seis meses anteriores às eleições.

O descumprimento dessas três restrições deixaria os prefeitos sujeitos a penas de prisão de até 4 anos de reclusão. Outro ponto de resistência dos prefeitos era a necessidade de estabelecer metas fiscais para o ano de 2000 , último ano de mandato, no qual os orçamentos já estavam sendo executados. Segundo dados do Ministério do Planejamento, os Municípios com menos de 50 mil habitantes $(90 \%$

\footnotetext{
${ }^{128}$ Folha de São Paulo, “Concessão aos Municípios”, Celso Pinto, 06/06/1999.
} 
dos Municípios) somente precisariam se adequar às novas regras orçamentárias previstas na LRF a partir de 2005. O ponto que entraria em vigor imediatamente é o controle das despesas em final de mandato, ou seja, as dívidas com fornecedores. Na realidade, o ponto mais polêmico para os prefeitos era a proibição de ARO em ano eleitoral, o que restringiria o nível de gasto público.

Os prefeitos organizaram marchas à Brasília, uma delas no período em que o texto tramitava na CESP da Câmara. Eles temiam também que os ajustes que teriam que ser feitos, a partir da promulgação da lei, da conta dos restos a pagar, recaíssem sobre eles. O governo queria que a inscrição de despesas em restos a pagar fosse vinculada à existência de disponibilidade de caixa. De fato, a lei começaria a valer já em 2000 e recairia no último ano do mandato dos prefeitos. Além de terem que fazer o ajuste no último ano de mandato, que é, normalmente, um momento de aumento de gastos e não de ajustes, eles temiam as sanções penais envolvidas no descumprimento deste dispositivo.

\begin{abstract}
"Desde sempre, os prefeitos chegaram a fazer marcha a Brasília contra a LRF. E eles inclusive juntaram com segmentos do PT e do PCdoB pra formar pressão contra a LRF... Havia uma resistência muito grande por parte dos prefeitos porque eles percebiam que os ajustes dos restos a pagar recairiam sobre eles. Eles tinham medo da criminalização, porque é crime a questão dos restos a pagar e acabou entrando depois, em outubro, na Lei de Crimes Fiscais (reclusão de 1 a 4 anos) ${ }^{129}$. Esse foi um ponto forte da oposição, mas de outro lado a opinião pública estava francamente favorável a LRF. Embora a lei fosse complexa no seu conjunto, na sua juridicidade, o espírito da lei era muito fácil de se compreender para o cidadão comum" "30.
\end{abstract}

\footnotetext{
${ }^{129}$ Seção VI Dos Restos a Pagar:

410: Vetado;

42: É vedado nos últimos 8 meses do mandato, contrair obrigação de despesa que não possa ser cumprida integralmente dentro dele, ou que tenha parcelas a serem pagas no exercício seguinte sem que haja suficiente disponibilidade de caixa para este efeito. Na determinação da disponibilidade de caixa serão considerados os encargos e despesas compromissadas a pagar até o final do exercício.

LCF acrescenta ao Código Penal - pena: reclusão de 1 a 4 anos. Art. 2o O Título XI do Decreto-Lei no 2.848, de 1940, passa a vigorar acrescido do seguinte capítulo e artigos: "Art. 359-C. Ordenar ou autorizar a assunção de obrigação, nos dois últimos quadrimestres do último ano do mandato ou legislatura, cuja despesa não possa ser paga no mesmo exercício financeiro ou, caso reste parcela aser paga no exercício seguinte, que não tenha contrapartida suficiente de disponibilidade de caixa:" (Ver sobre artigos da LRF e suas respectivas punições em: Khair, Amir (2001) Síntese da LRF e Punições Penais.

Disponível em: http://federativo.bndes.gov.br//rf_enfoque_municipal_lei_comentada.htm. Último acesso em: 08/12/05.

${ }^{130}$ Entrevista com Selene Peres Peres Nunes, 20/09/05.
} 
A Lei de Responsabilidade Fiscal, em si, não trata de matéria penal. É a Lei de Crimes que trata de matéria penal e prevê algumas condutas que são tipificadas como crime. Algumas delas só vão incidir como crime penal sobre os prefeitos, e não sobre os governadores. Os governadores são regidos pela Lei $n^{0} 1.079$, de 10 de abril de 1950, lei de crimes de responsabilidade, e os prefeitos, pelo Decreto-Lei $n^{\circ} 201$, de 27 de fevereiro de $1967^{131}$. Este fator institucional também é um componente que explica as diferentes reações de prefeitos e governadores diante do projeto da LRF: "Incluiu-se a mesma conduta numa lei, uma para prefeitos e outra para governadores. Só que na de prefeitos, aquela tipificação é considerada crime, e na outra, é crime de responsabilidade, que é sujeito a um julgamento político. $E$ isso acabou gerando reações diferentes entre os prefeitos e os governadores"132.

Em suma, a avaliação que alguns técnicos entrevistados nesta pesquisa fazem da LRF é que os governadores mais ganharam do que perderam com a lei, pelo fato de não se ter estabelecido a vigência imediata de metas fiscais e de ter havido repartição de despesas entre os poderes estaduais. Os prefeitos tiveram mais pontos de discordância com relação à LRF, em função da lei de criminalização e da questão dos restos a pagar. Os governadores já conviviam com restrições fortes ao endividamento e à emissão de AROs antes da promulgação da LRF, desde 1998, a partir da Resolução do Senado Federal n 78 . A LRF avançou no âmbito da Lei Camata e isso atendia os interesses dos governadores. Interessava aos Estados o aprimoramento da Lei Camata, na direção da ampliação do controle das despesas com pessoal entre os outros poderes estaduais, pois se minimizava o ônus político de tomar a iniciativa de implementar os cortes de pessoal. Os governadores não se mobilizaram, inclusive diante do art. 35 , que proíbe empréstimos entre os entes federativos, porque já estavam refinanciados no âmbito da Lei 9.496/97.

Nos últimos anos, o descumprimento da LRF tem sido formal, como o atraso de relatórios, que atingem mais os prefeitos. Os governadores ficaram "apertados" financeiramente, mas dentro dos limites de despesa com pessoal ${ }^{133}$. Um estudo

\footnotetext{
${ }^{131}$ Conforme Art. 73 da LRF: As infrações dos dispositivos desta Lei Complementar serão punidas segundo o Decreto-Lei no 2.848, de 7 de dezembro de 1940 (Código Penal); a Lei no 1.079, de 10 de abril de 1950; o Decreto-Lei no 201, de 27 de fevereiro de 1967; a Lei no 8.429, de 2 de junho de 1992; e demais normas da legislação pertinente.

${ }_{132}$ Entrevista com Weder de Oliveira, 21/09/05.

${ }^{133}$ Entrevista com Weder de Oliveira, 21/09/05.
} 
divulgado no site da Cives $^{134}$ (Associação Brasileira de Empresários pela Cidadania), na ocasião do aniversário de cinco anos da LRF, de autoria do economista Amir Khair, demonstra que, em dezembro de 2004, somente os Estados de Alagoas e Paraíba estavam acima do limite de despesa com pessoal (DP) do Executivo, que é de $49 \%$ da receita corrente líquida $(R C L)$. Com relação à dívida consolidada líquida (DCL), Rio de Janeiro, Goiás, São Paulo, Minas Gerais, Mato Grosso do Sul, Alagoas e Rio Grande do Sul estavam acima do limite (200\% da $\mathrm{RCL})^{135}$, conforme a Tabela 1 . Com relação à situação das capitais dos Estados, somente a Prefeitura de São Paulo ultrapassou o limite da dívida (120\% da RCL). Em dezembro de 2005, conforme a Tabela 2, todas as capitais estavam enquadradas no limite de $54 \%$ da RCL para despesas com pessoal do Executivo.

\footnotetext{
${ }^{134}$ http://www.abrasse.com.br/downloads/cives.html

${ }^{135}$ A LRF definiu um limite de despesa com pessoal no Executivo de $49 \%$ da RCL para Estados e $54 \%$ para Municípios. A Resolução do Senado Federal $n^{\circ}$ 40/01 definiu um limite para a dívida consolidada líquida de $200 \%$ da RCL para Estados e $120 \%$ para Municípios.
} 
Tabela 1: Despesa com Pessoal e Dívida Líquida Consolidada do Estados, em dezembro de 2004.

\begin{tabular}{|c|c|c|c|c|c|}
\hline & (em \% da RCL) & Dez/04 & & (em \% da RCL) & Dez/04 \\
\hline & Estado & DP/RCL & & Estado & DCL/RCL \\
\hline 1 & Roraima & 29,86 & 1 & Roraima & 4,24 \\
\hline 2 & Rio de Janeiro & 31,25 & 2 & Amapá & 13,20 \\
\hline 3 & Distrito Federal & 32,35 & 3 & Amazonas & 25,39 \\
\hline 4 & Espírito Santo & 33,09 & 4 & Distrito Federal & 27,28 \\
\hline 5 & Amapá & 36,18 & 5 & Tocantins & 34,84 \\
\hline 6 & Rondônia & 37,07 & 6 & Rio Grande do Norte & 37,91 \\
\hline 7 & Mato Grosso do Sul & 37,22 & 7 & Pará & 60,43 \\
\hline 8 & Mato Grosso & 37,25 & 8 & Acre & 62,09 \\
\hline 9 & Tocantins & 39,64 & 9 & Sergipe & 64,71 \\
\hline 10 & Ceará & 40,09 & 10 & Espírito Santo & 73,04 \\
\hline 11 & Amazonas & 40,32 & 11 & Ceará & 92,24 \\
\hline 12 & Bahia & 41,29 & 12 & Paraná & 96,22 \\
\hline 13 & Maranhão & 42,13 & 13 & Pernambuco & 103,77 \\
\hline 14 & Sergipe & 42,95 & 14 & Rondônia & 106,27 \\
\hline 15 & Goiás & 43,04 & 15 & Paraíba & 107,63 \\
\hline 16 & Rio Grande do Sul & 43,28 & 16 & Bahia & 141,90 \\
\hline 17 & Pará & 43,30 & 17 & Piauí & 143,15 \\
\hline 18 & Santa Catarina & 43,85 & 18 & Santa Catarina & 162,66 \\
\hline 19 & Pernambuco & 44,55 & 19 & Maranhão & 173,84 \\
\hline 20 & São Paulo & 44,60 & 20 & Mato Grosso & 175,56 \\
\hline 21 & Rio Grande do Norte & 46,57 & 21 & Rio de Janeiro & 204,33 \\
\hline 22 & Paraná & 46,89 & 22 & Goiás & 221,38 \\
\hline 23 & Minas Gerais & 48,33 & 23 & São Paulo & 222,98 \\
\hline 24 & Acre & 48,58 & 24 & Minas Gerais & 224,39 \\
\hline 25 & Piauí & 48,73 & 25 & Mato Grosso do Sul & 232,69 \\
\hline 26 & Alagoas & 49,64 & 26 & Alagoas & 265,26 \\
\hline \multirow[t]{2}{*}{27} & Paraíba & 50,98 & 27 & Rio Grande do Sul & 282,70 \\
\hline & Média & 41,59 & & Média & 124,45 \\
\hline
\end{tabular}

Fonte: Amir Khair, http://www.abrasse.com.br/downloads/cives.html

Tabela 2: Despesa com Pessoal e Dívida Líquida Consolidada das Capitais dos Estados, em dezembro de 2004. 


\begin{tabular}{|c|c|c|c|c|c|}
\hline & (em \% da RCL) & Dez/04 & & (em \% da RCL) & Dez/04 \\
\hline & Capital & DP/RCL & & Capital & DCL/RCL \\
\hline 1 & Curitiba & 24,60 & 1 & Porto Velho & $-12,39$ \\
\hline 2 & Brasília & 32,35 & 2 & João Pessoa & $-3,29$ \\
\hline 3 & Salvador & 33,74 & 3 & Palmas & $-2,58$ \\
\hline 4 & Campo Grande & 34,18 & 4 & Teresina & $-1,34$ \\
\hline 5 & São Luís & 36,33 & 5 & Belém & 3,10 \\
\hline 6 & Fortaleza & 36,60 & 6 & Vitória & 5,60 \\
\hline 7 & Recife & 37,99 & 7 & Manaus & 5,70 \\
\hline 8 & São Paulo & 39,17 & 8 & Fortaleza & 6,36 \\
\hline 9 & Maceió & 39,87 & 9 & São Luís & 6,98 \\
\hline 10 & Belo Horizonte & 40,47 & 10 & Aracajú & 10,09 \\
\hline 11 & Vitória & 40,74 & 11 & Natal & 14,69 \\
\hline 12 & Palmas & 41,00 & 12 & Campo Grande & 14,93 \\
\hline 13 & Rio de Janeiro & 43,08 & 13 & Recife & 20,09 \\
\hline 14 & Natal & 43,14 & 14 & Belo Horizonte & 20,63 \\
\hline 15 & Teresina & 43,31 & 15 & Curitiba & 21,42 \\
\hline 16 & Porto Velho & 44,32 & 16 & Macapá & 21,98 \\
\hline 17 & Belém & 45,93 & 17 & Rio Branco & 22,12 \\
\hline 18 & João Pessoa & 46,29 & 18 & Brasília & 27,28 \\
\hline 19 & Florianópolis & 48,93 & 19 & Porto Alegre & 31,82 \\
\hline 20 & Manaus & 49,63 & 20 & Florianópolis & 32,76 \\
\hline 21 & Cuiabá & 49,82 & 21 & Goiânia & 33,78 \\
\hline 22 & Rio Branco & 50,26 & 22 & Maceió & 74,98 \\
\hline 23 & Porto Alegre & 51,66 & 23 & Rio de Janeiro & 79,07 \\
\hline 24 & Macapá & 51,80 & 24 & Cuiabá & 84,21 \\
\hline 25 & Goiânia & 52,05 & 25 & Salvador & 103,22 \\
\hline 26 & Aracajú & 53,29 & 26 & São Paulo & 243,84 \\
\hline \multirow[t]{2}{*}{27} & Boa Vista & & 27 & Boa Vista & \\
\hline & Média & 42,71 & & Média & 33,27 \\
\hline
\end{tabular}

Fonte: Amir Khair, http://www.abrasse.com.br/downloads/cives.html 


\title{
Capítulo IV - Os caminhos da construção da Lei de Responsabilidade Fiscal na Câmara dos Deputados eno Senado Federal
}

\author{
IV.a) A tramitação na Câmara dos Deputados
}

\begin{abstract}
"Era preciso ter uma construção coletiva, era preciso ceder, era preciso incorporar sugestões do Congresso porque era melhor a gente ter um projeto bom, viável e legitimado do que um projeto ótimo que fosse inviabilizado, como acabou sendo inviabilizada a reforma tributária (no Governo Cardoso)"
\end{abstract}

Selene Peres Peres Nunes ${ }^{136}$.

O projeto de lei complementar ${ }^{137} \mathrm{n}^{\circ} 18^{138}$ deu entrada na mesa da Câmara dos Deputados em 15 de abril de 1999. O texto do projeto de lei apresentado à Câmara foi basicamente o mesmo do projeto original do Executivo Federal, de abril de 1998, como 110 artigos, salvo algumas modificações inseridas no processo de consulta pública (de dezembro de 1998 a março de 1999), como os controles dos gastos dos Poderes Legislativo e Judiciário nos Estados.

$\mathrm{Na}$ Exposição de Motivos $\mathrm{n}^{\circ} 106$, que acompanhou o projeto, assinada pelos Ministros Pedro Malan (Ministro de Estado da Fazenda), Pedro Parente (Ministro de Estado do Orçamento e Gestão) e Waldeck Ornélas (Ministro de Estado da Previdência e Assistência Social), são destacados alguns pontos que foram acrescidos ao texto:

\footnotetext{
${ }^{136}$ Entrevista concedida em 20/09/05.

${ }^{137}$ Segundo o regimento interno da Câmara, a tramitação de um projeto de lei complementar deve ser discutido e votado nas Comissões Permanentes relacionadas a matéria de sua competência, não dispensando a discussão e votação em plenário (Art. 24, inciso II, a). As proposições em tramitação na Câmara são subordinadas, na sua apreciação, a turno único, excetuadas, entre outros, os projetos de lei complementar (Art. 148). Quanto à natureza da sua tramitação, são urgentes as proposições de iniciativa do Presidente da República, com solicitação de urgência, e as reconhecidas, por deliberação do Plenário, de caráter urgente, nas hipóteses do art. 153 (Art. 151, inciso I, I, o). Ademais tem prioridade na tramitação os projetos de leis complementares e ordinárias que se destinem a regulamentar dispositivo constitucional, e suas alterações (Art. 151, inciso II, b). Com relação à regra de votação parlamentar, os projetos de leis complementares à Constituição somente serão aprovados se obtiverem maioria absoluta dos votos dos membros da Câmara, observadas, na sua tramitação, as demais normas regimentais para discussão e votação (Art. 183, parágrafo $\left.1^{\circ}\right)$.

${ }_{138}$ Regula o art. 163, incisos I, II, III e IV, e o art. 169 da Constituição Federal, dispõe sobre princípios fundamentais e normas gerais de finanças públicas e estabelece o regime de gestão fiscal responsável, bem assim altera a Lei Complementar nº 64, de 18 de maio de 1990.
} 
a) imposição dos limites de gastos com pessoal a cada um dos três Poderes da União, dos Estados e dos Municípios, definindo assim responsabilidade específica para o Legislativo e o Judiciário;

b) utilização do conceito de receita tributária disponível para servir de base aos limites relativos às despesas de pessoal e de dívida;

c) dilatação dos prazos para enquadramento aos limites definidos para as principais variáveis das finanças públicas, quando verificadas mudanças drásticas na política monetária e cambial e desde que sejam reconhecidas como tal pelo Senado;

d) ampliação do prazo para liquidação de Restos a Pagar, com o objetivo de melhor adaptá-lo às especificidades de Estados e Municípios, bem como limitar os restos a pagar para cada um dos Poderes;

e) introdução de regra de transição para os entes que não estejam enquadrados nos limites referentes à dívida quando da entrada em vigor da lei; e

f) definição de regra, antes restrita à União, em suas relações com os Governos estaduais, que impede os Estados de transferirem recursos aos Municípios para atendimento de ações e serviços públicos próprios desses entes.

$\mathrm{Na}$ referida Exposição de Motivos, os técnicos utilizaram uma série de argumentos para defender a aprovação pelo Congresso do projeto de lei complementar da LRF, na direção da convergência com uma agenda de reformas que já estava em curso. Foram destacados alguns pontos do projeto de lei que representavam novidades na administração das finanças públicas. Na fixação de limites para variáveis cruciais das finanças públicas, como o endividamento e o montante da dívida; no estabelecimento de condições para o aumento de gastos com as despesas de pessoal, de seguridade social; e outras relativas às ações continuadas, consagram-se os limites máximos existentes e introduzem-se os respectivos limites prudenciais.

Instituem-se os mecanismos de compensação compulsória para todo ato que implique em aumento permanente de despesa, seja pela criação de receita, seja pelo corte de gasto equivalente, sob pena daquele ato ser considerado nulo. São definidos os dispositivos de correção e as sanções e penalidades de natureza institucional. As penalidades de caráter individual, por sua vez, estão contempladas em projeto de lei ordinária, cujo encaminhamento ao Congresso estava sendo igualmente proposto naquela data. São definidas também limitações mais rígidas a serem observadas nos seis últimos meses que antecedem o final 
do mandato, relativamente às regras gerais definidas para as despesas de pessoal, para a contratação de operações de crédito por antecipação de receita orçamentária e para a inscrição de restos a pagar.

Dois pontos foram especialmente enfatizados pelos técnicos. O primeiro foi a proibição de concessão de qualquer empréstimo ou financiamento para pagamento de despesa de pessoal, bem como a realização de operações de crédito que tenham por objetivo renovar, refinanciar ou postergar dívida anteriormente contraída (art. 90). Este dispositivo, salienta os técnicos, é proposto após a reestruturação saneadora, por parte do Governo Federal, das dívidas de Estados e Municípios, no âmbito da Lei nº 9496/97.

O segundo ponto foi o tratamento dos gastos com pagamento de pessoal. Em um certo sentido, a LRF viria para promover a efetividade da norma já existente na forma da Lei Camata. O presente projeto de lei complementar, segundo os técnicos do governo, além de acolher e consolidar as normas permanentes da Lei Camata II, define limites máximos das despesas com folha de pagamento, como proporção da receita tributária disponível, para cada um dos Poderes nas três esferas de governo, no que representa um avanço em relação àquele Projeto de Lei Complementar, que não prevê responsabilidade individualizada dos poderes Judiciário e Legislativo quanto à observância dos limites.

\section{IV.a.1) As discussões na Comissão Especial ${ }^{139}$ (CESP)}

Em 05 de maio de 1999, a mesa diretora da Câmara dos Deputados decidiu $^{140}$ constituir uma Comissão Especial para proferir um parecer sobre o

\footnotetext{
${ }^{139}$ Segundo Melo (2002), como regra geral, podemos afirmar que interessa ao Executivo encerrar o mais rápido possível os trabalhos em uma Comissão Especial, por que no plenário as decisões são mais politizadas, e seu conteúdo substantivo pouco discutido devido: a) ao número de atores envolvidos ser maior; b) ao fato de que a Comissão (ao contrário do plenário), em geral, reúne parlamentares com conhecimento especializado, que podem divergir, por razões técnicas, de propostas do governo, como foi o caso da PEC 173 com os juristas (Reforma Administrativa); c) ao fato de que o tempo disponível para exame da matéria é menor. Embora o número máximo de sessões estipuladas para uma Comissão Especial seja de 40, o número mínimo é de apenas 10. A comissão criada para mudança do Regimento da Câmara quer reduzir esse número de 40 para 10, aumentando, portanto, o controle do Executivo sobre o processo (da tramitação da Reforma Administrativa).

${ }^{140}$ Decisão tomada com base no Art. 34, inciso II, do Regimento Interno da Câmara dos Deputados: Art. 34. As Comissões Especiais serão constituídas para dar parecer sobre: I - proposta de emenda à Constituição e projeto de código, casos em que sua organização e funcionamento obedecerão às normas fixadas nos Capítulos I e III, respectivamente, do Título Vl; II - proposições que versarem
} 
projeto, no prazo de quarenta sessões. Foi indicado para a relatoria da CESP o Deputado Pedro Novais (PMDB - MA). A Presidência da CESP era ocupada pelo Deputado Joaquim Francisco (PFL - PE). O projeto permaneceu 7 meses em discussão na Comissão Especial. Entre 12 de maio de 1999 e 14 de dezembro do mesmo ano, foram realizadas 27 reuniões.

A criação da Comissão Especial foi uma determinação regimental, mas que teve um efeito positivo do ponto de vista do interesse do Governo Federal na aprovação rápida da matéria: a CESP facilitou a tramitação. Pelo Regimento da Câmara, toda a vez que o projeto tem que passar por mais de 3 ou 4 Comissões, a CESP deve ser criada. Se o projeto tem que passar por várias comissões, deve haver negociações com cada um dos relatores, e o processo torna-se mais complexo. Se o projeto passa somente pela Comissão Especial, designa-se um relator, que prepara um parecer; o governo discute o texto basicamente com o relator.

A formação da comissão se deu a partir de um processo objetivo coordenado pelo Líder do Governo Cardoso na Câmara, o dep. Arnaldo Madeira, junto às lideranças partidárias. No entanto, havia uma dimensão subjetiva no processo político da escolha dos deputados entre as lideranças, que se referia à escolha de membros do partido que não criassem problemas na discussão da matéria:

"A formação da CESP era sempre uma distribuição proporcional aos partidos. Proporcional à bancada do plenário. O que a gente às vezes discutia na reunião com os líderes, do PSDB, do PFL, do PMDB, era se tinha deputados mais complicados, menos suscetíveis às orientações da liderança. Então eu, às vezes, falava com o líder... Vamos tentar botar este cara de relator neste projeto aqui... Não vai colocar o outro que vai atrapalhar... Então tem um processo político subjetivo da relação entre os líderes. Você tem um processo objetivo que é o seguinte: a quem cabe a relatoria, tendo em vista o tamanho da bancada, e a vez de cada partido. Às vezes você trocava a vez... Mas você tinha critério objetivo na distribuição da presidência e da relatoria. E na composição das comissões também. Quando era uma comissão mais importante, você procurava definir com os líderes do partido: olha, PMDB tem direito a 7 membros aqui... Vamos ver quem são os 7 ... Este aqui é ruim, vota

matéria de competência de mais de três Comissões que devam pronunciar-se quanto ao mérito, por iniciativa do Presidente da Câmara, ou a requerimento de Líder ou de Presidente de Comissão interessada. $\S 1^{\circ}$ Pelo menos metade dos membros titulares da Comissão Especial constituída para os fins do disposto no inciso II será composta por membros titulares das Comissões Permanentes que deveriam ser chamadas a opinar sobre a proposição em causa. $\S 2^{\circ}$ Caberá à Comissão Especial o exame de admissibilidade e do mérito da proposição principal e das emendas que lhe forem apresentadas, observado o disposto no art. 49 e no $\S 1^{\circ}$ do art. 24. 
contra... Então aí entra o processo subjetivo de avaliação de cada um dos membros..." "141.

A distribuição da presidência e da relatoria da CESP foi realizada a partir de um critério de rodízio entre os partidos da base de sustentação do governo na Câmara dos Deputados. Nos partidos, a indicação ocorria em função da experiência do deputado na matéria a ser discutida:

"Nas CESPs, nós tínhamos uma distribuição de presidência e relatoria entre os partidos da base de sustentação do governo. Você tinha o $P S D B$, o PFL, o PMDB, o PPB na época, tinha um critério que era proporcional. Isso era em rodízio. Digamos, tinha uma relatoria que era do PFL, aí a relatoria da CESP seguinte era do PMDB, a seguinte do $P S D B$, e assim sucessivamente... A presidência era, digamos, do PFL, a relatoria do $P S D B$, daí na seguinte a presidência era do PMDB e a relatoria era $P P B$, então tinha um critério acompanhado rigorosamente pela Mesa, porque foi um acordo das lideranças partidárias, que ficou lá com o Mozart, o assessor da mesa que fazia a distribuição. Então isso era automático. Agora, dentro de cada partido, os líderes tinham que ver na sua composição interna, como é que eles distribuíam as relatorias em função dos deputados que apoiavam o líder, da sua experiência específica... Por exemplo, neste negócio da energia elétrica, no PFL o especialista era o Aleluia (José Carlos Aleluia - PFL/BA). No caso da LRF, o Pedro (Novais) era o homem do orçamento do PMDB na Comissão de Orçamento, o cara mais presente, e era a vez do PMDB pegar a relatoria, então como líder, foi contemplado o Pedro..." ${ }^{\text {"14. }}$.

O membro da equipe que acompanhou diariamente as discussões da lei, desde a entrada na CESP até a última votação na Câmara foi a Assessora Técnica do Ministério do Planejamento, Selene Peres Peres Nunes. A equipe montou, com os assessores da Câmara, uma sistemática de discussão da lei por blocos. Foi explicado cada dispositivo e a sua respectiva sustentação técnica, inclusive por outros membros do governo, quando o tema era muito específico e complexo. "Não foram oito meses discutindo na Comissão como às vezes se vê em alguns projetos, que tem uma reunião uma semana, outra reunião na outra semana... Eu passava a semana inteira no Congresso, de manhã até de noite, era o dia inteiro negociando a LRF, todo dia"143. Martus Tavares e José Roberto Afonso compareceram (ver quadro 1, anexo 4) nas sessões iniciais da CESP para prestar esclarecimentos

\footnotetext{
${ }^{141}$ Entrevista com Arnaldo Madeira, 25/08/05.

${ }^{142}$ Entrevista com Arnaldo Madeira, 25/08/05.

${ }^{143}$ Entrevista com Selene Peres Peres Nunes, 20/09/05.
} 
técnicos sobre o texto junto aos deputados. No meio do processo de discussão na CESP, José Roberto Afonso retira-se e Martus Tavares e Guilherme Dias encarregam-se de coordenar as negociações:

"o BNDES, na época que a lei foi concebida, era subordinado ao Ministério do Planejamento. Depois ele se separou e passou a ser subordinado ao Ministério do Desenvolvimento, e aí a orientação do Ministério do Desenvolvimento foi de que o Zé Roberto trabalhasse mais na questão da reforma tributária, que aliás é outra especialidade dele. $O$ Álvaro Manoel saiu do Brasil, foi trabalhar nos Estados Unidos, o Martus se tornou ministro, e eu fiquei tocando o projeto na Câmara, então eu toquei a negociação, do ponto de vista técnico, toda na Câmara e no Senado"144.

Os oito meses de trabalho na CESP foram marcados por muito debate e negociação, como não poderia deixar de ser a discussão de um projeto de lei complementar, que regulamenta um artigo constitucional. Durante o processo de discussão do projeto na CESP, houve algumas divergências entre os membros da equipe do Governo Federal e a Assessoria Técnica do Orçamento da Câmara, envolvendo a estrutura do projeto e a técnica redacional. A consultoria de orçamentos da Câmara é a que normalmente recebe os projetos orçamentários, de LDO, de PPA, encaminhado pelo Executivo. Havia uma percepção dos técnicos da equipe do governo que era necessário que os técnicos que trabalhavam com o relator Pedro Novais entendessem o que estava sendo proposto. Era preciso também desconstruir alguns mitos e alguns preconceitos que existiam historicamente com relação às iniciativas legislativas do Executivo Federal, por parte dos técnicos do Legislativo:

"O pessoal (da Assessoria Técnica do Orçamento da Câmara) é da maior qualidade... Dava para brigar tecnicamente, a gente tinha discordância de mérito... Esse pessoal tem um peso monumental dentro do Congresso até hoje. O poder político deles é muito grande. São raros os parlamentares que se movem sem eles... Então, o que aconteceu: a gente ia nessa, daí o Martus cedia, e eu dizia não, o Martus cedia, eu dizia não... A gente foi esticando a corda. O que a assessoria fez, que eu não concedia, mas não tinha poder nenhum? Ela mudou toda a estrutura do projeto. A técnica redacional é completamente diferente. É uma técnica não apropriada para finanças públicas. Nós mandamos um projeto feito por advogados. O pessoal que estava envolvido nele nem

\footnotetext{
${ }^{144}$ Entrevista com Selene Peres Peres Nunes, 20/09/05.
} 
advogado era. A gente ia discutir com eles assim: olha, tudo bem, você quer mudar isso, mas você chame os advogados da casa para fazer sua redação, porque você entende de orçamento, mas não entende de redação, você não é advogado. Este grupo da assessoria da casa era de economistas, contadores, administradores, mas não tinha advogado.... O Martus me dizia: Zé, isto aqui é a forma. Em troca desta forma, eles aprovam o projeto. Daí era o inverso, o Martus pegava o pessoal da assessoria e dizia: está do jeito que você quer. Agora, você que tem uma influência brutal aqui dentro, vai pegar os seus deputados e por eles para votar a favor. E eles fizeram isso. ${ }^{1145}$

De um lado, a equipe do Governo Federal argumentava que tinha concebido uma estrutura do texto muito lógica, que fazia sentido com a Constituição. Por outro lado, os técnicos da Câmara contestaram o fato de o texto começar com princípios de finanças públicas. Além do mais, havia uma concepção, por parte dos técnicos da Câmara, de que o Executivo estaria impondo um projeto para o Congresso concebido pelo FMI. Muitas vezes, acontecia o oposto:

"O SIAF brasileiro não foi concebido pelo FMI, foi concebido no Brasil e é até hoje considerado um sistema tão bom que ele é recomendado para outros países, mas é porque o Brasil desenvolveu uma tecnologia e um conhecimento específico em finanças públicas que inspira outros países, inclusive a partir da nossa LRF outros países fizeram uma lei similar. Eu, por exemplo, ajudei na elaboração da LRF do Equador e do Paraguai, e há outros casos em que não necessariamente técnicos brasileiros foram contratados mas que você percebe claramente que o texto foi tomado como inspiração e naturalmente foram feitas as adaptações que cada um julgou necessário fazer... E para ser muito sincera, uma coisa que as pessoas não comentam muito, mas que é verdade, é que a maioria dos técnicos do fundo que nos visitavam não acreditava na $L R F^{\text {"146. }}$.

Depois da fase difícil de relacionamento com a consultoria de orçamento da Câmara, os consultores perceberam a importância do projeto e começaram a trabalhar mais alinhados à equipe do governo. A partir daquele momento, foi preciso ganhar o apoio dos políticos e os consultores passaram a atuar junto aos membros da CESP para convencê-los sobre a importância do projeto. $\mathrm{O}$ relator Pedro Novais discordava de vários pontos da lei e elaborou várias versões do substitutivo, que contrariavam a equipe do governo que tinha elaborado a lei. Foram três versões formais do substitutivo e inúmeras versões informais. Diante

\footnotetext{
${ }^{145}$ Entrevista com José Roberto Rodrigues Afonso, 01/09/05.

${ }^{146}$ Entrevista com Selene Peres Peres Nunes, 20/09/05.
} 
das discordâncias com o relator, a equipe optou pela seguinte estratégia da negociação:

"O Martus ouviu o Zé, ouviu a mim e acabou fazendo a opção: decidiu realmente que nós íamos negociar e que não ia ser uma coisa fácil, a gente sabia que o caminho da negociação é um caminho sempre difícil, mas que era preciso negociar politicamente o projeto. E então nós fomos... Primeiro foi uma série de substitutivos, alguns foram divulgados informalmente para nós, nem todos foram anunciados na Comissão, nem sei te dizer quantas versões de substitutivas. E nós analisávamos tudo aquilo e... Quando dava pra resolver com a Comissão da consultoria da Câmara muito bem, mas depois foi ficando crescentemente difícil. Houve vários debates, quando algumas das versões substitutivas chegaram realmente a momentos de impasse técnico, aí nós tínhamos reuniões com o Martus, no ministério do Planejamento, e eram reuniões longas, difíceis, às vezes tensas, em alguns pontos nós cedíamos, em alguns pontos o relator cedia, e em alguns pontos não houve acordo. E aí a gente decidiu que ia para o voto. Onde não tinha acordo, ia para o voto, mas nós esgotamos junto ao relator ao máximo as possibilidades de acordo e de negociação"147.

Houve 27 reuniões da CESP sendo que, em algumas, técnicos do governo foram convidados para fazer esclarecimentos de pontos mais específicos do texto aos congressistas (ver quadro 1, anexo 4). Nessas reuniões, houve alguns episódios de conflito entre membros da equipe que formulou a lei no governo e o relator dep. Pedro Novais. Apesar do controle do governo na escolha do relator, este demonstrou uma grande disposição para inserir mudanças no texto. Nos termos do dep. Arnaldo Madeira,

"o Pedro Novais é um sujeito muito meticuloso, que exigiu da equipe do governo muita conversa e paciência no decorrer dos trabalhos. O projeto deu entrada na mesa da Câmara no dia 13 de abril e no dia 5 de maio, 20 dias depois, estava criada a Comissão Especial. Aqui, a demora grande foi entre a entrada na CESP, até a emissão do parecer do relator. Ele é uma pessoa muito aplicada, muito detalhista, e ele começou a levantar uma série de objeções. Então teve que se construir um entendimento com ele, com não foi fácil, foi complexo, mas que também não foi demorado porque um período de oito meses para a tramitação de um projeto deste tipo é um período não muito longo"148. “(...) embora o PMDB fosse um partido da base aliada do governo, ele

\footnotetext{
${ }^{147}$ Entrevista com Selene Peres Peres Nunes, 20/09/05.

${ }^{148}$ Entrevista com Arnaldo Madeira, 25/08/05.
} 
não era $100 \%$ afinado com o projeto que tinha saído do Executivo, e tinha opiniões muito próprias sobre finanças públicas e tal "149.

$\mathrm{Na}$ CESP, a questão do dispositivo sobre a inclusão do Banco Central na Lei de Responsabilidade Fiscal, que foi retirado do texto na etapa de discussão no Governo Federal, reapareceu. Os deputados do PT que faziam parte da CESP entraram com emendas que propunham dispositivos muito semelhantes àqueles que a equipe do governo queria ter colocado anteriormente no texto e haviam sido retirados. Os dispositivos que acabaram entrando novamente no texto eram considerados rígidos demais até para os membros da equipe do governo. Além de proibirem o BC de emitir títulos, inseriram outros dispositivos, como a sujeição da instituição a todas as outras condições de dívida e a obrigação do presidente do BC de ir ao Congresso prestar contas sobre o cumprimento dos objetivos e metas das políticas monetária, creditícia e cambial ${ }^{150}$.

\footnotetext{
${ }^{149}$ Entrevista com Selene Peres Peres Nunes, 20/09/05.

${ }^{150}$ Artigos da LRF que se referem ao Banco Central:
}

Art. 7o O resultado do Banco Central do Brasil, apurado após a constituição ou reversão de reservas, constitui receita do Tesouro Nacional, e será transferido até o décimo dia útil subseqüente à aprovação dos balanços semestrais.

§ $10 \mathrm{O}$ resultado negativo constituirá obrigação do Tesouro para com o Banco Central do Brasil e será consignado em dotação específica no orçamento.

§ 20 O impacto e o custo fiscal das operações realizadas pelo Banco Central do Brasil serão demonstrados trimestralmente, nos termos em que dispuser a lei de diretrizes orçamentárias da União.

§ 30 Os balanços trimestrais do Banco Central do Brasil conterão notas explicativas sobre os custos da remuneração das disponibilidades do Tesouro Nacional e da manutenção das reservas cambiais e a rentabilidade de sua carteira de títulos, destacando os de emissão da União.

(Art. $9^{\circ}$.) § 50 No prazo de noventa dias após o encerramento de cada semestre, o Banco Central do Brasil apresentará, em reunião conjunta das comissões temáticas pertinentes do Congresso Nacional, avaliação do cumprimento dos objetivos e metas das políticas monetária, creditícia e cambial, evidenciando o impacto e o custo fiscal de suas operações e os resultados demonstrados nos balanços.

(Art. $29^{\circ}$.) § 20 Será incluída na dívida pública consolidada da União a relativa à emissão de títulos de responsabilidade do Banco Central do Brasil.

Art. 34. O Banco Central do Brasil não emitirá títulos da dívida pública a partir de dois anos após a publicação desta Lei Complementar.

Art. 39. Nas suas relações com ente da Federação, o Banco Central do Brasil está sujeito às vedações constantes do art. 35 e mais às seguintes:

I - compra de título da dívida, na data de sua colocação no mercado, ressalvado o disposto no § 20 deste artigo;

II - permuta, ainda que temporária, por intermédio de instituição financeira ou não, de título da dívida de ente da Federação por título da dívida pública federal, bem como a operação de compra e venda, a termo, daquele título, cujo efeito final seja semelhante à permuta;

III - concessão de garantia. § $10 \mathrm{O}$ disposto no inciso II, in fine, não se aplica ao estoque de Letras do Banco Central do Brasil, Série Especial, existente na carteira das instituições financeiras, que pode ser refinanciado mediante novas operações de venda a termo. § 20 O Banco Central do Brasil só poderá comprar diretamente títulos emitidos pela União para refinanciar a dívida mobiliária federal que estiver vencendo na sua carteira. § $30 \mathrm{~A}$ operação mencionada no § 20 deverá ser realizada à taxa média e condições alcançadas no dia, em leilão público. § 40 É vedado ao Tesouro Nacional adquirir títulos da dívida pública federal existentes na carteira do Banco Central do Brasil, 
Nas discussões da CESP, Martus Tavares ${ }^{151}$ foi o membro da equipe do planejamento que mais negociou com a oposição, especialmente com deputados do PT. Esses deputados foram os mais atuantes na CESP (ver quadro 1, anexo 4). Foram incluídos vários pontos sugeridos pelos deputados do partido. No entanto, a bancada do partido votou contra, de forma intermitente, em todas as votações ${ }^{152}$, e este padrão manteve-se nas votações nominais em plenário. A equipe do planejamento, por um lado, tentava agregar os votos dos partidos de oposição, acolhendo as suas sugestões; por outro, havia um conflito interno com os técnicos do Ministério da Fazenda, que eram contra muitas concessões aos políticos. Segundo os membros da equipe do planejamento, não havia pressão dos governadores para inserir dispositivos no texto, havia pressão do PT. O discurso básico dos deputados do PT, e dos outros partidos de oposição, era contra a limitação dos gastos com saúde e educação e a favor da limitação dos gastos com juros da dívida (ver quadro 5 , anexo 4). O Governo Federal reagia a esse discurso:

"Qual era o discurso? Tem que ter a responsabilidade social. Como é que eu vou limitar o gasto para pagar a dívida, se eu tenho um monte de problemas sociais. Teve uma vez uma discussão fora do plenário, eu falei para o pessoal do PT: vocês justificam o Maluf quando fez o PAS em São Paulo. Se gasto social não tem limite, você não paga nada e sai gastando dinheiro para construir posto de saúde, hospital, sem controle. Então o PT, na verdade, teve uma postura muito contra, nesta linha que o compromisso principal era com o social' ${ }^{153}$.

Segundo os membros da equipe do planejamento, havia duas contradições básicas que caracterizavam o comportamento dos deputados do PT nas negociações do projeto da LRF. A primeira era entre os governadores em exercício na época e os deputados federais do partido:

"Eu fui convidada a fazer uma apresentação para o Zeca do PT, no Mato Grosso do Sul. O atual ministro Paulo Bernardo era secretário dele, e eu fiz uma apresentação reservada para o governador e o secretariado, explicando a lei e a despeito de todas as piadinhas oposicionistas, eles

\footnotetext{
ainda que com cláusula de reversão, salvo para reduzir a dívida mobiliária.

${ }^{151}$ A CESP iniciou-se no dia 05 de maio de 1999 e terminou no dia 02 de dezembro do mesmo ano. Em 19 de julho, o Secretario Executivo do Ministério do Planejamento Martus Tavares assume o cargo de Ministro do Planejamento, Orçamento e Gestão.

${ }^{152}$ A exceção foi a votação da emenda $n^{\circ} 56$, do dep. Rodrigo Maia (PFL-RJ), sobre a inclusão da terceirização nos limites de gasto.

${ }^{153}$ Entrevista com Arnaldo Madeira, 25/08/05.
} 
estavam absolutamente convencidos da importância da LRF. E mesmo assim (o partido) votaram contra"154.

A segunda contradição referia-se à avaliação do mérito do projeto pelos deputados do partido e o seu comportamento nas votações:

"Eu ouvi de vários integrantes do $P T$, na época, que eles acreditavam que a LRF era um bom projeto e que, inclusive, se eles estivessem no governo, eles apoiariam o projeto, mas que nós compreendêssemos que não seria possível apoiar o projeto porque eles eram da bancada de oposição. Eu ouvi isso assim com essa clareza cristalina e que a partir daquele momento eu entendi que realmente não havia nenhum espaço pra negociação porque, do meu ponto de vista, que eu era técnica, que nem filiação partidária eu tinha, eu vi esgotados todos os meus argumentos... E é interessante que ao assumir o governo e até mesmo naquele documento que antecedeu a posse do Lula, a "Carta aos Brasileiros", eles assumem o compromisso de cumprir a LRF, quer dizer, isso pra mim demonstra uma completa contradição pelo menos com o discurso oficial que eles vinham sustentando até então. Como é que alguém que votou contra o projeto, depois muda e diz que o governo vai manter?"155.

No dia 02 de dezembro de 1999, saiu o parecer favorável do relator, pela constitucionalidade, juridicidade, boa técnica legislativa e adequação financeira e orçamentária. O projeto foi aprovado no mérito, com substitutivo. No dia 09 de dezembro, o parecer do relator foi aprovado entre os membros da Comissão, contra os votos dos Deputados: Carlito Merss (PT - SC), Fernando Marroni (PT - RS), Luiz Salomão (PT - RJ), Sérgio Miranda (PC do B - MG) e lara Bernardi (PT - SP), todos da bancada da oposição. Os destaques apresentados foram rejeitados.

O Substitutivo, de autoria do relator Deputado Pedro Novais, reduziu o número de artigos do texto: de 110 , passou para 76 , bem próximo do número de artigos do projeto aprovado em plenário posteriormente na Câmara - 75. Segundo o relator, o projeto apresentava alguns problemas que redundariam em questões jurídicas:

1)feria o princípio da repartição de competência legislativa do art. 24 da Constituição, que diz ser de competência comum aos entes legislar sobre o direito

\footnotetext{
${ }^{154}$ Entrevista com Selene Peres Peres Nunes, 20/09/05.

${ }^{155}$ Entrevista com Selene Peres Peres Nunes, 20/09/05.
} 
financeiro, orçamento e previdência social, devendo a União limitar-se a estabelecer normas gerais;

2)com 110 artigos e 500 dispositivos, era abundante em detalhes e abordaria áreas temáticas fora do seu escopo. O substitutivo, com 76 artigos, restringia as normas de finanças públicas voltadas para a responsabilidade fiscal;

3)deixava de disciplinar aspectos importantes de administração tributária (renúncia de receitas, patrimônio público, despesas com juros e desapropriação). O substitutivo inseria mecanismos mais eficazes de controle de endividamento.

Segundo o relatório, algumas mudanças propostas no substitutivo da CESP ao texto foram as seguintes:

1)mudou a referência para fixação de limites: de receita tributária disponível para receita corrente líquida;

2)o substitutivo previa sanções de ordem administrativa e econômica como o projeto (arts. 23,31,51). O substitutivo excluiu, no entanto, as mudanças na lei 64/90, de inelegibilidades, que devem ser objeto de proposição específica;

3)explicitou a regra para o controle dos pagamentos de precatórios (art. 10);

4)enquanto o projeto dava excessivo peso ao controle das despesas, o substitutivo preocupou-se também com a administração das receitas;

5)inseriu dois conceitos: despesas obrigatórias de caráter continuado e aquelas que correspondem a uma expansão da atividade estatal (arts. 16 e 17);

6)com relação aos limites para despesa com pessoal, o substitutivo suprimiu restrição que limitava despesas dos Poderes Legislativos e Judiciário a $30 \%$ da receita tributária própria do ente, pois entendeu-se que semelhante condição inviabilizaria o funcionamento das Câmaras Municipais, uma vez que as receitas próprias dos Municípios são ínfimas;

7)amenizou congelamento das despesas dos poderes legislativo e judiciário: mudou dos 5 anos para 3 anos, estendendo este tratamento para o poder executivo (art. 73);

8)corrigiu falha do projeto com relação às despesas com seguridade social, que exigia a compensação dos aumentos de benefícios mediante novas receitas ou redução de despesas da própria seguridade. Para o substitutivo, as despesas são obrigatórias; os acréscimos devem ser compensados com aumento da receita ou cancelamento de despesa (art. 24);

9)inseriu limite de despesa com juros, o que foi pouco tratado no projeto (art. $4^{\circ}$ ); 
10)exigiu lei específica para socorro de instituições financeiras pelo BC e constituição de fundos privados (art. 28);

11)com relação ao limites de endividamento dos Estados e dos Municípios, o substitutivo remeteu-se à experiência da Resolução $n^{\circ} 78 / 98$, claramente enunciadas nos art. 48 e 52 da Constituição, dando ao Poder Executivo Federal a prerrogativa de encaminhar proposta de limites ao Senado e ao Congresso (art. 30);

12)o art. 33 estendeu ao setor privado financeiro a responsabilidade pelo bom cumprimento da lei;

13)o substitutivo acatou ou acresceu a vedação de operações de crédito entre entes da Federação (art. 35), o que implica que a União não voltará a financiar dívidas de Estados e Municípios;

14)restos a pagar: o substitutivo atendeu à necessidade de honrar os principais empenhos e adequar os valores inscritos às disponibilidades financeiras apuradas no fim do exercício (art. 41). Aliás, o substitutivo manteve as principais limitações de gastos em final de mandato - restrições ao aumento de despesa com pessoal, inscrições em restos a pagar e operações de crédito por antecipação de receita (arts. 21, 38 e 42) -.

O substitutivo proposto pelo dep. Pedro Novais promoveu muitas alterações no texto da lei. Mudou essencialmente a forma, mas a avaliação da equipe do planejamento, que formulou originalmente a lei, e da liderança do governo na Câmara foi que o texto melhorou, foi aprimorado com os trabalhos na CESP, que preservou o "espírito da peça":

\section{IV.a.2) As discussões no Plenário da Câmara dos Deputados}

No dia 18 de janeiro de 2000, o projeto retorna ao Plenário da Câmara dos Deputados, entre os 19 itens da pauta da Convocação Extraordinária. Foi aprovado um requerimento solicitando urgência ${ }^{156}$ para este projeto, nos termos do Art. 155

\footnotetext{
${ }^{156}$ O Art. 157 esclarece o tratamento da matéria urgente: "Aprovado o requerimento de urgência, entrará a matéria em discussão na sessão imediata, ocupando o primeiro lugar na Ordem do Dia. § $1^{\circ}$ Se não houver parecer, e a Comissão ou Comissões que tiverem de opinar sobre a matéria não se julgarem habilitadas a emiti-lo na referida sessão, poderão solicitar, para isso, prazo conjunto não excedente de duas sessões, que lhes será concedido pelo Presidente e comunicado ao Plenário, observando-se o que prescreve o art. 49. $\S 2^{\circ}$ Findo o prazo concedido, a proposição será incluída na Ordem do Dia para imediata discussão e votação, com parecer ou sem ele. Anunciada a discussão, sem parecer de qualquer Comissão, o Presidente designará Relator que o dará
} 
do Regimento Interno ${ }^{157}$ da Câmara. Assinaram o requerimento os líderes: Dep. Arnaldo Madeira (PSDB-SP), líder do governo; Dep. Inocêncio Oliveira (PE), líder da bancada do PFL; Dep. Aécio Neves (MG), líder da bancada do PSDB, Dep. Walfrido Mares Guia (MG), líder da bancada do PTB; Dep. Odelmo Leão (MG), líder da bancada do PPB; e o Dep. Geddel Vieira Lima (BA), líder da bancada do PMDB. O requerimento foi aprovado com 296 votos a favor e 143 votos contrários (ver tabela 3 a seguir). Segundo o líder do Governo na Câmara, dep. Arnaldo Madeira, a inclusão do projeto entre os itens da Convocação Extraordinária e o seu pedido de urgência fizeram parte de uma estratégia para agilizar a tramitação, porque era de interesse do governo que o projeto fosse votado o mais rápido possível: "No começo do segundo mandato, nós tivemos a desvalorização cambial, convocação de sessão extraordinária do Congresso, votamos um monte de coisas que, sem aquela situação, o ambiente que se criou para enfrentar a crise que o país estava vivendo, a gente não teria votado"158.

verbalmente no decorrer da sessão, ou na sessão seguinte, a seu pedido. $\S 3^{\circ} \mathrm{Na}$ discussão e no encaminhamento de votação de proposição em regime de urgência, só o Autor, o Relator e Deputados inscritos poderão usar da palavra, e por metade do prazo previsto para matérias em tramitação normal, alternando-se, quanto possível, os oradores favoráveis e contrários. Após falarem seis Deputados, encerrar-se-ão, a requerimento da maioria absoluta da composição da Câmara, ou de Líderes que representem esse número, a discussão e o encaminhamento da votação. $\S 4^{\circ}$ Encerrada a discussão com emendas, serão elas imediatamente distribuídas às Comissões respectivas e mandadas a publicar. As Comissões têm prazo de uma sessão a contar do recebimento das emendas para emitir parecer, o qual pode ser dado verbalmente, por motivo justificado. $\S 5^{\circ} \mathrm{A}$ realização de diligência nos projetos em regime de urgência não implica dilação dos prazos para sua apreciação".

${ }^{157}$ Sobre o requerimento de urgência, o regimento interno estabelece:

Art. 153. A urgência poderá ser requerida quando: I - tratar-se de matéria que envolva a defesa da sociedade democrática e das liberdades fundamentais; II - tratar-se de providência para atender a calamidade pública; III - visar à prorrogação de prazos legais a se findarem, ou à adoção ou alteração de lei para aplicar-se em época certa e próxima; IV - pretender-se a apreciação da matéria na mesma sessão.

Art. 154. O requerimento de urgência somente poderá ser submetido à deliberação do Plenário se for apresentado por: I - dois terços dos membros da Mesa, quando se tratar de matéria da competência desta;

II - um terço dos membros da Câmara, ou Líderes que representem esse número; III - dois terços dos membros de Comissão competente para opinar sobre o mérito da proposição. $\S 1^{\circ} \mathrm{O}$ requerimento de urgência não tem discussão, mas a sua votação pode ser encaminhada pelo Autor e por um Líder, Relator ou Deputado que Ihe seja contrário, um e outro com o prazo improrrogável de cinco minutos. Nos casos dos incisos I e III, o orador favorável será o membro da Mesa ou de Comissão designado pelo respectivo Presidente. $\S 2^{\circ}$ Estando em tramitação duas matérias em regime de urgência, em razão de requerimento aprovado pelo Plenário, não se votará outro.

Art. 155. Poderá ser incluída automaticamente na Ordem do Dia para discussão e votação imediata, ainda que iniciada a sessão em que for apresentada, proposição que verse sobre matéria de relevante e inadiável interesse nacional, a requerimento da maioria absoluta da composição da Câmara, ou de Líderes que representem esse número, aprovado pela maioria absoluta dos Deputados, sem a restrição contida no $\S 2^{\circ}$ do artigo antecedente.

Art. 156. A retirada do requerimento de urgência, bem como a extinção do regime de urgência, atenderá às regras contidas no art. 104.

${ }^{158}$ Entrevista Arnaldo Madeira, 25/08/05. 
Durante os discursos de encaminhamento dos votos dos líderes, apareceram pela primeira vez, no âmbito da discussão em plenário, alguns argumentos contra e a favor do projeto, que foram, respectivamente, proferidos pela bancada da oposição, cujo núcleo duro eram os deputados do PT e do Bloco PSB/PCdoB, e da bancada do governo, os deputados do PSDB, PFL e PMDB $^{159}$ (ver quadro 5, anexo $3)$.

O Deputado Sérgio Miranda (Bloco/PCdoB - MG) recomendou o voto contra o pedido de urgência, pois esta significaria restringir o poder de apresentar emendas ao projeto, já que não houve a oportunidade de apresentação de emendas na Comissão, por se tratar de um projeto de lei complementar examinado por uma Comissão Especial, cujo poder de emendamento é só no âmbito de plenário. O regime de urgência impede que se apresentem em plenário emendas que não puderam ser apresentadas regimentalmente na Comissão. Ademais, o deputado desenvolveu dois pontos de argumentação que serão recorrentes no discurso de outros deputados de oposição: a idéia de que se trata de uma lei feita para dar garantia absoluta ao credor financeiro e a limitar gastos de duração continuada, especialmente os sociais. Ele critica também 0 art. 17, sobre aumento de salário de servidor somente mediante aumento de alíquota ou criando novo imposto. "Essa lei é draconiana. É a lei do capital financeiro. É a lei que acaba com qualquer programa de enfrentamento da pobreza. Essa lei mente. (vai restringir gasto com pessoal mas já aprovamos uma lei para isto, que regulamenta o art. 169, a lei Camata II)" (DCD, 19/01/2000, 2393). Segundo o deputado, utilizou-se do artifício de considerar que a lei é para discutir gasto de pessoal, mas, segundo ele, não é verdade, pois ela privilegia o sistema financeiro e o Banco Central.

Os Deputados Aécio Neves (PSDB-MG) e Inocêncio Oliveira (PFL-PE) rebateram as críticas dos deputados de oposição, argumentando que a matéria foi devidamente discutida na Comissão Especial, que é representativa da proporcionalidade dos partidos políticos com assento na Casa. Então, não haveria porque ser contra a aprovação da lei ou do requerimento de urgência.

No dia 19 de janeiro de 2000, foram apresentadas 124 emendas de plenário (ver quadro 4, anexo 3). No mesmo dia, o deputado Sérgio Miranda formulou uma questão de ordem, propondo que se rediscutisse a questão da constitucionalidade,

\footnotetext{
${ }^{159}$ Somente em uma votação nominal, a bancada do PMDB não votou com o Governo (DVS n 10).
} 
que foi atestada pelo parecer positivo da Comissão Especial. O deputado anotou 17 inconstitucionalidades. O presidente da Câmara, Deputado Michel Temer, indeferiu a questão de ordem. Foi rejeitado também o requerimento dos Deputados José Genoíno, líder do PT, e João Fassarela, solicitando a retirada da pauta, da ordem do dia, do projeto (ver tabela 3 a seguir). O Dep. José Genoino frisou que o PT não era contra a LRF, mas só teria uma postura favorável ao substitutivo se duas objeções fossem apreciadas: o aumento da arrecadação quando houver crescimento econômico (ao contrário do aumento da base da tributação) e o tratamento dos investimentos sociais.

No dia 20 de janeiro de 2000, começou a votação em turno único, ${ }^{160}$ no plenário. Das 124 emendas de plenário, 93 foram rejeitadas, 24 aprovadas integralmente e 7 aprovadas parcialmente, pelo relator, Dep. Pedro Novais, que proferiu parecer sobre as emendas de plenário, em substituição à CESP. Das 93 emendas rejeitadas, somente $9(9,7 \%)$ foram de autoria de deputados da base do governo (PSDB e PFL). Todas as demais 84 emendas de autoria de deputados da oposição foram rejeitadas. Por outro lado, das 24 emendas integralmente aprovadas, 9 (37,5\%) foram propostas por deputados da oposição (PT, PC do B e PDT). Das 7 aprovadas parcialmente, $5(71,4 \%)$ foram de autoria desses mesmos deputados.

Fazendo uma breve análise das emendas rejeitadas, com aprovação parcial e com aprovação integral, é possível localizar algumas questões importantes, recorrentes nos debates em plenário, que foram tema de várias emendas. Com relação às rejeitadas, as emendas $n^{\circ} 7$ (Dep. João Fassarella (PT-MG)), $\mathrm{n}^{\circ} 50$ (Dep. Luiz Salomão (PT-RJ) e outros) e nº 87 (Dep. Sérgio Miranda (Bloco/PCdoB - MG)) tratam do Art. 17, propondo a supressão do parágrafo que previa que as despesas destinadas ao serviço da dívida não fossem incluídas nos limites das demais despesas de caráter continuado. Da mesma forma, as emendas $n^{\circ} 20$ e 21 (ambas de autoria do Dep. João Fassarella (PT-MG)) e a emenda n 49 (Dep. Luiz Salomão (PT-RJ) e outros) propunham a mudança da redação do Art. $4^{\circ}$ para incluir um dispositivo que limita as despesas com juros dos entes federativos. Outra questão que foi tema de algumas emendas, como a $\mathrm{n}^{\circ} 26$ (Dep. João

\footnotetext{
${ }^{160}$ Art. 148. As proposições em tramitação na Câmara são subordinadas, na sua apreciação, a turno único, excetuadas as propostas de emenda à Constituição, os projetos de lei complementar e os demais casos expressos neste regimento. (No caso do projeto da Lei de Responsabilidade Fiscal, a tramitação em regime de urgência garante a ocorrência de turno único).
} 
Fassarella (PT-MG)), no 86 (Dep. Sérgio Miranda (Bloco/PCdoB - MG)) e $n^{\circ} 121$ (Dep. Manoel Castro (PFL-BA) e Inocêncio Oliveira (PFL-PE)), foi o conceito de receita permanente $\left(\S 2^{\circ}\right.$, Art. 17 do Substitutivo). Os deputados questionaram o fato de o texto considerar o conceito de receita permanente baseado na elevação de alíquotas, ampliação da base de cálculo, majoração ou criação de tributo ou contribuição e incremento da arrecadação nos últimos doze meses. Segundo eles, o fator crescimento econômico também deveria ser considerado.

Outros temas importantes, cujas emendas foram rejeitadas, foram:

1) a volta dos $60 \%$ de receita corrente líquida como limite para a despesa com pessoal, como na Lei Camata (emenda ${ }^{\circ} 5$ );

2) a supressão do termo "refinanciamento" do caput do art. 35 , pois, do ponto de vista dos deputados, não era aceitável que a União não pudesse refinanciar dívida de outros entes, extinguindo a solidariedade entre eles (emenda $n^{\circ} 9$ );

3) a supressão do art. 20 , que estabelecia a fixação de limites de gasto por poder (emenda $\mathrm{n}^{\circ} 27$ );

4) a vedação de taxas flutuantes em operações de crédito realizadas pelos entes da federação (emendas n ${ }^{\circ} 31$ e 72);

5) a inclusão da terceirização nas despesas com pessoal (emenda $n^{\circ} 56$ );

6) a supressão do $\S 1^{\circ}$ do art. $7^{\circ}$ sobre financiamento do déficit do Banco Central pelo Tesouro Nacional e sobre a quebra da prerrogativa do Congresso Nacional de discutir esses déficits (emenda $\mathrm{n}^{\circ} 80$ );

7) a supressão do inciso II do $\S 1^{\circ}$ do art. 31 , que tratava da dívida consolidada de um ente da Federação que ultrapassasse o respectivo limite, deveria obter resultado primário necessário à recondução da dívida ao limite (emenda $\left.{ }^{\circ} 94\right)$;

8) a supressão da expressão do caput do art. 33 que excetuava do limite das contratações de operação de crédito a dívida mobiliária ou à externa (emenda $n^{\circ}$ 95);

9) a supressão do inciso I do art. 37, que vedava as operações de antecipação de receita cujo fato gerador ainda não tenha ocorrido (emenda $\left.n^{\circ} 96\right)$;

10) a substituição do inciso I do art. 29 pelos incisos I e II, que incluíam a dívida pública federal constituída de títulos de curto prazo no controle do endividamento (a dívida mobiliária federal) (emenda $\mathrm{n}^{\circ} 101$ ); 
11) a revogação da Lei Camata II a partir da entrada em vigor da lei e que a LRF entrasse em vigor em $1^{\circ}$ de janeiro do exercício seguinte ao da sua publicação (emendas $\mathrm{n}^{\circ} 119$ e 122).

Dentre as emendas integral e parcialmente aprovadas, destacaram-se três: a emenda $n^{\circ} 16$, que acrescenta ao art. 14 o $\S 4^{\circ}$, que veda a captação de recursos a título de antecipação ou pagamento de tributo cujo fato gerador não tenha ocorrido; a emenda $n^{\circ} 65$, que muda a redação do art. 28 , deixando claro que não se proíbe o Banco Central de conceder às instituições financeiras operações de redesconto e empréstimos de prazo inferior a 360 dias; a emenda $\mathrm{n}^{\circ} 99$ (parcialmente aprovada), que altera o art. 64, mudando o limite de $n^{\circ}$ de habitantes por Municípios de 20 mil para 200 mil que devem elaborar relatórios de prestação de contas. As demais emendas aprovadas não alteravam substancialmente o texto, propondo mudanças pontuais ou de redação. Como podemos constatar, nenhuma emenda que tratava de mudanças relevantes no texto foi aprovada.

No dia 25 de janeiro de 2000, o requerimento do Dep. João Fassarella (líder do PT), solicitando a retirada da pauta, da ordem do dia, do projeto, foi rejeitado em votação em plenário. Em trecho do discurso do deputado, foi citado a existência de "pressões" sobre os deputados para a votação do projeto: “(...) Apesar de toda a pressão que se criou sobre a Casa para que a votemos, apesar do clima criado por aqueles que não chegaram a analisar e conhecer mais profundamente o seu teor, continuo pensando que seria - e trago a posição do nosso partido - inoportuno votarmos essa lei no dia de hoje (...)." (DCD 3659, 26/01/00).

Neste mesmo dia, o relator Dep. Pedro Novais encaminhou a votação da sua subemenda substitutiva, a qual foi aprovada com 385 votos favoráveis e 86 contrários (ver tabela 3 a seguir). Foram encaminhados 43 requerimentos de destaque e foi aprovado o requerimento do Dep. Arnaldo Madeira (PSDB-SP) ${ }^{161}$, líder do Governo, solicitando a votação em globo dos destaques simples (299 votos favoráveis e 119 contrários - ver tabela 3 a seguir). A solicitação de votação em globo dos destaques simples foi mais um instrumento regimental dentro da estratégia do governo de agilizar a votação:

\footnotetext{
${ }^{161}$ Assinaram também o requerimento o líder do PFL, Deputado Inocêncio Oliveira; o vice-líder do PPB, Deputado Gerson Peres; o vice-líder do PMDB, Deputado Mendes Ribeiro Filho; e o vice-líder do PSDB, Deputado Jutahi Júnior.
} 
"Nós tínhamos um acordo que era o seguinte: você tem um monte de destaques. Destaque de bancada, cada bancada tem direito a um certo número de destaques. Então o que a gente fez? Aquele número de destaques, você pode fazer votação nominal, votar um a um. Os outros destaques são simples, você bota em globo para poder tramitar a matéria mais rápido. Se você não botasse em globo os destaques, o que ia acontecer? Você apresenta 500 destaques e fica votando um por um... Para a oposição, a apresentação de destaque é uma forma de obstrução. Eu lembro que eu brincava com o Prof. Luizinho, que era líder do PT, eu falava assim: pede para o pessoal do velho PSB, quando a derrota é inevitável, perde rapidinho... Não fica fazendo cera aí. Vocês vão perder mesmo! A gente acertou isso no começo da legislatura, no ano anterior, um acordo sobre o número de emendas a serem apresentadas por bancada que teria que ser votada individualmente. $E$ as outras entrariam... Então, o partido apresenta 100 emendas mas, digamos, ele tem direito a apresentar 4 . Então aquelas 4 são emendas de partido. O resto entra no bolo..."162.

Antes das votações dos requerimentos, deputados das bancadas da oposição e do governo travaram uma longa discussão sobre alguns pontos polêmicos do projeto, encaminhando os votos de suas bancadas. Os deputados Sérgio Miranda (Bloco/PCdoB - MG), João Fassarella (PT/MG) e Carlito Merss (PT-SC) (que foi $2^{\circ}$ Vice-Presidente da Comissão Especial) listaram uma série de críticas ao projeto:

1) já existia lei para limitar gastos (Lei Complementar $n^{\circ}$. 69) e emissão de AROs (Resolução n 78/98);

2) é uma lei para dar garantia ao credor financeiro, em detrimento aos gastos sociais;

3) é o fim do pacto federativo, ela enquadra de forma autoritária e rígida governadores e prefeitos e impede a renegociação das dívidas;

4) essa lei criminaliza o gestor fiscal, não o corrupto. Vai preso o prefeito que não quiser demitir, que não quiser fechar um posto de saúde, que não pagar a dívida;

5) promoverá a maior onda de demissões da história (DCD, 26/01/2000, 3662/3663).

Também proferem discursos críticos os Deputados João Herrmann Neto (PPS-SP) e Luiza Erundina (Bloco PSB/PcdoB). Os dois concordam em um ponto: o verdadeiro motivo desta lei, segundo eles, é o cumprimento das metas e do

\footnotetext{
${ }^{162}$ Entrevista Arnaldo Madeira, 25/08/05.
} 
compromisso firmado com o FMI, sacrificando a autonomia dos Estados e dos Municípios e o esvaziamento do pacto federativo.

Os deputados Joaquim Francisco (PFL/PE), que foi presidente da Comissão Especial que proferiu parecer sobre o projeto, Luiz Carlos Hauly (PSDB/PR) e Pedro Novais (PMDB/MA) rebateram as críticas dos deputados de oposição:

1) a lei combate a corrupção ao exigir transparência do gestor público, ao publicar de 4 em 4 meses uma declaração de gestão fiscal responsável;

2) a lei dá a possibilidade concreta e real de o governante se reeleger;

3) a lei não é utopia; há necessidade de se estabelecer um teto para transferências e gastos (DCD, 26/01/2000, 3663).

Após a discussão, entraram em votação todos os requerimentos de destaque simples, que totalizaram 25, conforme requerimento de iniciativa dos líderes aprovado em Plenário. Em votação simbólica, foram rejeitados os requerimentos $\mathrm{n}^{\circ}$ 1 ao 25 . No dia 01 de fevereiro de 2000, começaram a ser votados os destaques para votação em separado ${ }^{163}$, os DVS. Segundo o Dep. Inocêncio Oliveira (PFL/PE), por se tratar de um projeto de lei complementar, exige-se um quorum qualificado de 257 votos para a manutenção do texto ou para a aprovação das emendas (DCD, 02/02/2000, 5661). Os DVS que passaram por votação nominal estão no quadro 3, anexo 3.

O DVS $n^{\circ} 1$ tratava de questão recorrente no debate em plenário: o pagamento dos juros. No caso, a lei estabelece, no art. $4^{\circ}$, que constará da LDO um limite de despesa com juros com base em percentual de receita corrente líquida. Se os Estados e os Municípios excedessem este limite, haveria a vedação da realização de novas operações de crédito, ressalvadas as realizadas com a finalidade de pagamento de juros, as operações por ARO e as relativas ao financiamento das dívidas. Ou seja, conforme discurso do Dep. Dr. Helio (PDT/SP), a lei abriria brechas para pagamento de juros acima dos limites estabelecidos pela

\footnotetext{
${ }^{163}$ Segundo Melo (2002), os destaques para votação em separado, surgidos na Constituinte, são um instrumento que permite que parte de uma matéria seja destacada automaticamente, com a simples apresentação de um requerimento assinado por líder partidário, para ser votado separadamente do texto maior de que faça parte. Assim, uma vez destacada uma parte de uma emenda constitucional, a parte destacada será submetida a uma votação isolada, específica, e só será considerada aprovada se obtiver 308 votos favoráveis. Depois da Reforma da Previdência do governo FHC, houve uma mudança regimental limitando os DVS. Antes, qualquer parlamentar poderia propor um DVS, bastando que conseguisse o apoio de $10 \%$ da Casa, mediante assinatura. Após o primeiro turno da reforma da previdência (1995) a regra mudou, criando-se um sistema de quota partidária para uso de DVS: a) partido com entre 5 e 24 deputados, tem direito a um; b) entre 25 e 49, tem direito a dois; c) entre 50 e 74, podem apresentar 3; d) mais de 74, tem direito a 4 . À oposição caberia, portanto, o ônus de derrubar o DVS.
} 
LDO. Outro ponto destacado pela oposição (Dep. Fernando Coruja, PDT/SC) foi o fato de a lei dar responsabilidades fundamentais aos administradores estaduais e municipais, tirando a União dessa tônica da responsabilidade (exclui o BC e o BNDES dos mecanismos de controle). Segundo o Dep. Luiz Carlos Hauly (PSDB/PR), o acatamento deste destaque significaria o estabelecimento da moratória, acarretando na perda de credibilidade dos compromissos do país (DCD, $5660,02 / 02 / 2000)$. Votaram não, ou seja, a favor do destaque e da retirada do trecho da lei, 124 deputados; votaram sim, pela manutenção das expressões, 306 (ver tabela 3 a seguir).

O DVS $\mathrm{n}^{\circ} 2$ tratava da mesma discussão da DVS $\mathrm{n}^{\circ} 1$ e obteve o mesmo placar de votação por partido. Foram retirados o destaque $n^{\circ} 3$, da bancada do PTB, e os destaques $n^{\circ} 7$ e 11, da Bancada do PFL. O DVS $n^{\circ} 4$ questionava o fato de o texto citado condicionar o aumento de receita somente a partir da criação de novo imposto, aumento de alíquota ou ampliação da base de arrecadação. Criticava a noção de despesa e receita continuada, contida no Art. 17, artigo este que foi tema de algumas emendas de plenário. O voto contrário é favorável à manutenção do parágrafo $3^{\circ}$ do Art. 17. Foram 300 votos favoráveis e 131 desfavoráveis (ver tabela 3 a seguir). O DVS $n^{\circ} 5$ tratava do mesmo tema da $n^{\circ} 4$, propondo a votação em separado da Emenda de Plenário $n^{\circ} 75$, e também foi rejeitada, por 273 votos contrários e 141 favoráveis (ver tabela 3 a seguir).

O DVS n ${ }^{\circ} 6$ propunha destaque para a votação do parágrafo $6^{\circ}$ do Art. 17 , o mesmo que foi discutido no DVS n 4. O Dep. Carlito Merss (PT/SC) fez discurso contundente pedindo para os formadores de opinião pública atentarem para os artigos $4^{\circ}$ e $17^{\circ}$ do projeto, que, segundo ele, demonstram que a lei foi feita por imposição do FMI, atendendo aos interesses dos grandes bancos, além de ser muito dura com os Estados e os Municípios e extremamente benevolente com a União e o Banco Central (DCD, 5720, 02/02/2000). Venceu em plenário a manutenção da expressão em votação, por 308 votos favoráveis e 128 contrários (ver tabela 3 a seguir).

O DVS no 8 requereu destaque para a votação da emenda $n^{\circ} 56$, de autoria do Dep. Rodrigo Maia (PFL-RJ), sobre a inclusão das terceirizações nos limites de despesa com pessoal. Dentre todas as DVS, obteve a maior taxa de aprovação, em votação nominal: foi aprovada a emenda $n^{\circ} 56$ por 410 votos, contra 31 contrários (ver tabela 3 a seguir). Sobre esta emenda: "quando a matéria chegou 
ao Plenário da Câmara, ela já estava bastante consensuada, mesmo assim ainda houve emendas, inclusive algumas emendas de última hora que deram bastante trabalho, como a da terceirização, que foi acolhida pelo mérito mas que é até hoje considerada uma das coisas mais difíceis de operacionalizar"164.

Talvez a DVS que trouxe a discussão do tema mais polêmico foi a $\mathbf{n}^{\circ} \mathbf{9}$, sobre as operações de crédito entre entes federativos. O DVS de iniciativa da bancada do PT foi uma tentativa de alterar o art. 35, que veda as operações de crédito entre entes federativos, subtraindo do texto os casos de crédito por novação e refinanciamento, como a mesma bancada já havia tentado através de emenda de plenário $n^{\circ}$ 9. O dep. Waldir Pires (PT/BA) fez discurso contundente contra a proibição de empréstimos entre entes federativos, afirmando que a aprovação desse artigo era uma ameaça à federação, era inconstitucional e feria a autonomia dos Estados (DCD, 5750, 02/02/2000). O dep. Roberto Jefferson (PTB/RJ) defendeu o artigo porque ele acaba com a socialização do prejuízo que historicamente as grandes cidades sofreram com administradores irresponsáveis. Segundo o dep. Aloizio Mercadante (PT/SP), a lei acaba com a possibilidade de renegociação da dívida, o que é perigoso, porque não se sabe como vai ser a taxa de juros internacional. A resolução $n^{\circ} 78$ já estabelecia a política e os parâmetros da renegociação. A lei privilegiava a visão da tecnocracia, que tem visão de tesoureiro, em detrimento da visão política, do Senado e do Congresso como instâncias de definição da política de negociação (DCD, 5752, 02/02/2000). A despeito dos argumentos dos deputados da bancada de oposição, um dos mais importantes artigos do projeto não foi alterado, em função da larga margem de votos: 304 favoráveis, pela manutenção da expressão, e 127 desfavoráveis (ver tabela 3 a seguir).

A DVS n 10 foi iniciativa da bancada do PSDB, pela supressão do Art. 58 da Subemenda Substantiva, sobre prestação de contas dos executivos dos entes federativos nos respectivos poderes legislativos. Segundo o Art. 58, as sessões legislativas não seriam encerradas enquanto o executivo não apresentasse as contas do exercício anterior. Segundo o Dep. Pedro Novais (PMDB-MA), colocar a União no meio disso, como fez o artigo, incorria em inconstitucionalidade, o que fez com que o PSDB propusesse este destaque. O placar da votação foi apertado para o Governo: 212 votos foram favoráveis à manutenção do artigo, contra 244 votos

\footnotetext{
${ }^{164}$ Entrevista Selene Peres Peres Nunes, 20/09/05.
} 
desfavoráveis, levando à supressão do dispositivo destacado (ver tabela 3 a seguir).

No dia 02 de fevereiro de 2000 ocorreu a discussão da redação final do projeto. Foram apresentadas 4 emendas de redação ${ }^{165}$, todas apreciadas e aprovadas pelo relator, Dep. Pedro Novais (PMDB-MA). No mesmo dia, a redação final do projeto, oferecida pelo relator Dep. Pedro Novais, foi aprovada e o projeto foi despachado para o Senado Federal.

A tabela a seguir, sobre as votações nominais na Câmara, demonstra o quorum expressivo que o projeto teve na Câmara. Em todas as votações nominais, o governo conseguiu mobilizar uma consistente maioria parlamentar a favor do projeto. Dentre as 12 votações nominais, em sete ocasiões, a base aliada do Governo Cardoso na Câmara dos Deputados votou unida (PSDB; PFL; PMDB; PPB; PTB). Em duas votações, parte da base da oposição votou com a base aliada do governo: na votação da emenda substitutiva e na votação da emenda de plenário do dep. Rodrigo Maia. Nesta última, até a bancada do PT votou junto com a base aliada do governo.

Fazendo um balanço do resultado processo decisório da lei na Câmara, podemos afirmar que o Governo Federal derrotou todas as tentativas da oposição de modificar o projeto. Foram modificados dois pontos durante a conclusão da votação da proposta na Câmara. Os gastos com serviços terceirizados foram incluídos no limite de despesas com pessoal da União, dos Estados e dos Municípios (emenda $\mathrm{n}^{\circ} 1$ do dep. Rodrigo Maia). Além disso, o governo retirou do texto a obrigatoriedade do Legislativo examinar as contas do Executivo antes de entrar em recesso parlamentar.

\footnotetext{
${ }^{165} \mathrm{~A}$ emenda $\mathrm{n}^{\circ} 1$, de autoria do Dep. Rodrigo Maia (PFL-RJ), transformava o artigo $21 \mathrm{em} \S 1^{\circ}$ do artigo 18, incorporando a terceirização de mão de obra nos limites de despesa com pessoal. A emenda $n^{\circ} 2$, de autoria do Dep. Miro Teixeira (PDT-RJ), mudava a redação do inciso $\mathrm{VI}$ do $\S 1^{\circ}$ do artigo 19 do substitutivo. As emendas $n^{\circ} 3$ e 4 foram propostas pelo Dep. Pedro Novais, a primeira alterava a redação do caput do artigo 60 substituindo-se "e o Ministério Público" por "e do Ministério Público". A segunda suprimia o inciso VI do artigo 60 , que se refere ao art. $4^{\circ}$, inciso IV, que foi suprimido pela Emenda $n^{\circ} 63$, acatada pelo relator.
} 
Tabela 3: Votações Nominais na Câmara dos Deputados

\begin{tabular}{|c|c|c|c|c|c|c|c|c|c|c|c|c|c|c|c|c|c|c|c|c|c|c|c|c|}
\hline \multirow{2}{*}{$\begin{array}{l}\text { Partidos/ } \\
\text { Votações } \\
\text { PSDB }\end{array}$} & \multicolumn{2}{|c|}{$\begin{array}{c}1^{a} \\
\operatorname{sim} / \text { não }\end{array}$} & \multicolumn{2}{|c|}{$\begin{array}{c}2^{a} \\
\operatorname{sim} / \text { não } \\
\end{array}$} & \multicolumn{2}{|c|}{$\begin{array}{c}3^{a} \\
\operatorname{sim} / \text { não }\end{array}$} & \multicolumn{2}{|c|}{$\begin{array}{c}4^{a} \\
\operatorname{sim} / \text { não }\end{array}$} & \multicolumn{2}{|c|}{$\begin{array}{c}5^{a} \\
\operatorname{sim} / \text { não } \\
\end{array}$} & \multicolumn{2}{|c|}{$\begin{array}{c}6^{a} \\
\operatorname{sim} / \text { não } \\
\end{array}$} & \multicolumn{2}{|c|}{$\begin{array}{c}7^{a} \\
\operatorname{sim} / \text { não } \\
\end{array}$} & \multicolumn{2}{|c|}{$\begin{array}{c}8^{a} \\
\operatorname{sim} / \text { não } \\
\end{array}$} & \multicolumn{2}{|c|}{$\begin{array}{c}9^{a} \\
\operatorname{sim} / \text { não } \\
\end{array}$} & \multicolumn{2}{|c|}{$\begin{array}{c}10^{a} \\
\operatorname{sim} / \text { não }\end{array}$} & \multicolumn{2}{|c|}{$\begin{array}{c}11^{a} \\
\operatorname{sim} / \text { não }\end{array}$} & \multicolumn{2}{|c|}{$\begin{array}{c}12^{a} \\
\operatorname{sim} / \text { não }\end{array}$} \\
\hline & $\mathrm{X}$ & & & $X$ & $\mathrm{X}$ & & $\mathrm{X}$ & & $\mathrm{X}$ & & $X$ & & $\mathrm{X}$ & & & $X$ & $X$ & & $X$ & & $X$ & & & $X$ \\
\hline PFL & $\mathrm{X}$ & & & $\mathrm{X}$ & $\mathrm{X}$ & & $\mathrm{X}$ & & $\mathrm{X}$ & & $\mathrm{X}$ & & $\mathrm{X}$ & & & $\mathrm{X}$ & $\mathrm{X}$ & & $\mathrm{X}$ & & $\mathrm{X}$ & & & $X$ \\
\hline PMDB & $\mathrm{X}$ & & & $\mathrm{X}$ & $\mathrm{X}$ & & $\mathrm{X}$ & & $\mathrm{X}$ & & $\mathrm{X}$ & & $X$ & & & $\mathrm{X}$ & $\mathrm{X}$ & & $\mathrm{X}$ & & $X$ & & $X$ & \\
\hline PPB & $X$ & & & $X$ & $X$ & & $X$ & & $\mathrm{X}$ & & $X$ & & $X$ & & & $X$ & $X$ & & $X$ & & $X$ & & & $X$ \\
\hline PTB & & $\mathrm{X}$ & & $\mathrm{X}$ & $\mathrm{X}$ & & $\mathrm{X}$ & & $\mathrm{X}$ & & $\mathrm{X}$ & & $\mathrm{X}$ & & & $\mathrm{X}$ & $\mathrm{X}$ & & $\mathrm{X}$ & & $\mathrm{X}$ & & & $\mathbf{X}$ \\
\hline PL/PST/PSL & & $X$ & & $\mathrm{X}$ & $X$ & & & $X$ & & $X$ & & $X$ & & $X$ & $X$ & & & $X$ & $X$ & & & $X$ & $X$ & \\
\hline $\mathrm{PV}$ & & $\mathrm{X}$ & & $\mathrm{X}$ & $X$ & & & $\mathrm{X}$ & & $\mathrm{X}$ & & $\mathrm{X}$ & & $X$ & $X$ & & & $\mathrm{X}$ & $\mathrm{X}$ & & & $\mathrm{X}$ & $X$ & \\
\hline PPS & & $\mathrm{X}$ & $X$ & & $\mathrm{X}$ & & & $\mathrm{X}$ & & $\mathrm{X}$ & & $\mathrm{X}$ & & $\mathrm{X}$ & $\mathrm{X}$ & & & $\mathrm{X}$ & & $\mathrm{X}$ & & $\mathrm{X}$ & $\mathrm{X}$ & \\
\hline PDT & & $X$ & $\mathrm{X}$ & & $\mathrm{X}$ & & & $\mathrm{X}$ & & $\mathrm{X}$ & & $X$ & & $\mathrm{X}$ & $X$ & & & $X$ & $\mathrm{X}$ & & & $\mathrm{X}$ & $X$ & \\
\hline $\mathrm{PT}$ & & $\mathrm{X}$ & $\mathrm{X}$ & & & $X$ & & $X$ & & $\mathrm{X}$ & & $\mathrm{X}$ & & $\mathrm{X}$ & $X$ & & & $\mathrm{X}$ & $\mathrm{X}$ & & & $\mathrm{X}$ & $\mathrm{X}$ & \\
\hline PSB/PCdoB & & $\mathrm{X}$ & $\mathrm{X}$ & & & $\mathrm{X}$ & & $\mathrm{X}$ & & $\mathrm{X}$ & & $\mathrm{X}$ & & $\mathrm{X}$ & $\mathrm{X}$ & & & $\mathrm{X}$ & & $\mathrm{X}$ & & $\mathrm{X}$ & $\mathrm{X}$ & \\
\hline Resultado Final & 296 & 143 & 128 & 335 & 385 & 86 & 299 & 119 & 306 & 124 & 304 & 124 & 300 & 131 & 141 & 273 & 308 & 128 & 410 & 31 & 304 & 127 & 212 & 244 \\
\hline Resultado em \% & 67,4 & 32,6 & 27,6 & 72,4 & 81 & 19 & 71,2 & 28,8 & 71,2 & 28,8 & 71 & 29 & 69,6 & 30,4 & 34 & 66 & 70,6 & 29,4 & 92,9 & 7,1 & 70,2 & 29,8 & 46,5 & 53,5 \\
\hline
\end{tabular}

1a) 18/01/2000 - Votação do requerimento de urgência.

$2^{a}$ ) 19/01/2000 - Votação do requerimento de adiamento da votação.

$3^{\text {a) }}$ 25/01/2000 - Votação da subemenda substitutiva.

$4^{a}$ ) 25/01/2000 - Votação do requerimento do dep. Arnaldo Madeira solicitando a votação em bloco dos destaques simples.

$5^{a}$ ) 01/02/2000 - PLP N ${ }^{0} 18 / 99$ - DVS No 1 DAS EXPRESSÕES "as real. com fin..." e "as relat. refinan. da dívida".

$6^{a}$ ) 01/02/2000 - PLP N 18/99 - DVS Nº 2 DA EXPRESSÃO "inclusive aquelas destinadas ao pag. do serv. da dívida".

$7^{\mathrm{a})}$ 01/02/2000 - PLP No 18/99 - DVS Nº 4 - § $3^{\circ}$ DO ARTIGO 17.

$8^{a}$ ) 01/02/2000 - PLP No 18/99 - DVS Nº 5 - EMENDA DE PLENÁRIO Nº 75.

9a) 01/02/2000 - PLP No 18/99 - DVS Nº 6 EXPRESSÃO "AO SERVIÇO DA DIVÍDA NEM".

$10^{\mathrm{a})}$ 01/02/2000 PLP N 18/99 - DVS N 8 - EMENDA DE PLENÁRIO "DEP. RODRIGO MAIA".

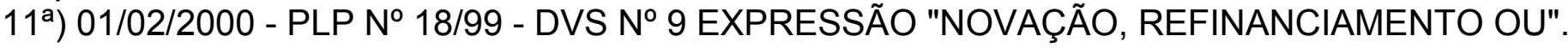

12a) 01/02/2000 - PLP No 18/99 - DVS No 10 - ARTIGO 58 DO SUBSTITUTIVO CE. 
O projeto da Lei de Responsabilidade, aprovado na Câmara dos Deputados, referendou a decisão dos líderes governistas que concordaram sobre a necessidade da vigência imediata da lei. Os prefeitos não conseguiram adiar a entrada em vigor da lei em 2000, especialmente em função da mudança que teriam que fazer com relação aos gastos públicos no último ano de mandato.

Em contrapartida, os governadores e prefeitos ganharam mais tempo para se adequarem aos limites de gastos com pessoal fixados na Lei Camata. A Lei de Responsabilidade Fiscal deu prazo de um ano para que a União, os Estados e os Municípios reduzissem o excesso de gastos com pessoal em 50\%. A Lei Camata determinava a redução desse excesso em dois terços até junho de 2000. Até junho de 2001, por essa lei, as três esferas governamentais teriam de estar plenamente enquadradas nos limites de gastos: $50 \%$ da receita líquida (descontadas as transferências entre governos) para a União, $60 \%$ para os Estados e $60 \%$ para os Municípios.

A restrição da Lei Camata deveria ter entrado em vigor em 1999, mas, por pressão dos governadores, esse dispositivo foi adiado para 2000. Pela Lei de Responsabilidade, os Estados e Municípios só teriam de estar enquadrados dois anos após a publicação do texto no "Diário Oficial" da União. Sendo a lei sancionada no primeiro semestre de 2000 , como previsto, o enquadramento ficaria para $2002^{166}$.

Quadro 2: Balanço das mudanças a partir do texto aprovado na Câmara dos Deputados $^{167}$

\begin{tabular}{|l|l|l|}
\hline \multicolumn{1}{|c|}{ Pontos } & \multicolumn{1}{|c|}{ Como era } & \multicolumn{1}{c|}{ O que mudou } \\
\hline Plano Plurianual & $\begin{array}{l}\text { Estados e Municípios não } \\
\text { eram obrigados a produzir } \\
\text { PPAs. }\end{array}$ & $\begin{array}{l}\text { O projeto do PPA, com o } \\
\text { detalhamento dos investimentos } \\
\text { dos governos (federal, estadual } \\
\text { ou municipal) nos quatro anos de } \\
\text { cada mandato, terá de ser } \\
\text { encaminhado ao Poder } \\
\text { Legislativo até o dia } 30 \text { de abril } \\
\text { do primeiro mandato. }\end{array}$ \\
\hline $\begin{array}{l}\text { Lei de Diretrizes } \\
\text { Orçamentárias }\end{array}$ & $\begin{array}{l}\text { Estados e Municípios não } \\
\text { eram obrigados a produzir } \\
\text { LDOs e nem a fixar metas } \\
\text { fiscais. }\end{array}$ & $\begin{array}{l}\text { Os governantes das três esferas } \\
\text { federais serão obrigados a } \\
\text { elaborar LDOs. Na lei, terão de } \\
\text { fixar metas fiscais déficit } \\
\text { (quando as despesas correntes } \\
\text { superam as receitas) ou }\end{array}$ \\
\hline
\end{tabular}

\footnotetext{
${ }^{166}$ Folha de São Paulo, 14/02/2000.
}

${ }^{167}$ Folha de São Paulo, 14/02/2000. 


\begin{tabular}{|c|c|c|}
\hline & & $\begin{array}{l}\text { superávit primário (economia de } \\
\text { receitas para pagamento de } \\
\text { juros)_para o ano em questão e } \\
\text { para os dois anos seguintes. }\end{array}$ \\
\hline Despesas com juros & $\begin{array}{l}\text { Não havia limites para as } \\
\text { despesas com juros. }\end{array}$ & $\begin{array}{l}\text { Apesar de determinar que os } \\
\text { governantes terão de fixar limites } \\
\text { para as despesas com juros na } \\
\text { LDO, a Lei de Responsabilidade } \\
\text { Fiscal assegura } \\
\text { refinanciamento da dívida pública } \\
\text { mesmo que esses limites tenham } \\
\text { de ser ultrapassados. }\end{array}$ \\
\hline Lei Orçamentária & $\begin{array}{l}\text { Esse tipo de planejamento } \\
\text { não era feito por todos os } \\
\text { administradores. }\end{array}$ & $\begin{array}{l}\text { O projeto do Orçamento, a enviar } \\
\text { ao Legislativo até o dia } 15 \text { de } \\
\text { agosto, terá uma reserva de } \\
\text { contingência para a cobertura de } \\
\text { "eventos fiscais imprevistos" e } \\
\text { dos "restos a pagar" (despesas } \\
\text { de um ano que são repassadas } \\
\text { para o ano seguinte). }\end{array}$ \\
\hline Banco Central & $\begin{array}{l}\text { Os resultados do } \text { BC eram } \\
\text { repassados anualmente ao } \\
\text { Tesouro e não havia } \\
\text { explicação sobre eles. }\end{array}$ & $\begin{array}{l}\text { Os resultados positivos ou } \\
\text { negativos da atuação do Banco } \\
\text { Central terão de ser somados ou } \\
\text { debitados na conta do Tesouro } \\
\text { Nacional dez dias úteis depois da } \\
\text { aprovação dos balanços } \\
\text { semestrais da instituição. O } \\
\text { impacto fiscal das operações do } \\
\text { BC, inclusive o custo de } \\
\text { manutenção das reservas em } \\
\text { dólares, terá de ser demonstrado } \\
\text { trimestralmente. }\end{array}$ \\
\hline Tesouro Nacional & $\begin{array}{l}\text { A transferência dos títulos da } \\
\text { dívida pública para o Tesouro } \\
\text { já estava ocorrendo, mas o } \\
\text { BC não era proibido de emitir } \\
\text { títulos. }\end{array}$ & $\begin{array}{l}\text { Dois anos após a publicação da } \\
\text { Lei, o BC terá de parar de emitir } \\
\text { títulos da dívida pública. Essa } \\
\text { atuação será exclusiva do } \\
\text { Tesouro. }\end{array}$ \\
\hline Execução Orçamentária & $\begin{array}{l}\text { Não existiam avaliações } \\
\text { formais sobre a execução } \\
\text { orçamentária e os Poderes } \\
\text { eram independentes nessa } \\
\text { execução. }\end{array}$ & $\begin{array}{l}\text { A cada dois meses, os Poderes } \\
\text { (Executivo, Legislativo e } \\
\text { Judiciário) deverão fazer uma } \\
\text { avaliação para verificar o } \\
\text { cumprimento das metas fiscais } \\
\text { do ano. Se a avaliação for } \\
\text { negativa, os Poderes terão a } \\
\text { oportunidade de limitarem suas } \\
\text { despesas por conta própria. Se } \\
\text { os Poderes Legislativo e } \\
\text { Judiciário não limitarem suas } \\
\text { despesas em um prazo de } 30 \\
\text { dias, o Poder Executivo ficará } \\
\text { autorizado a fazê-lo. }\end{array}$ \\
\hline Receita & $\begin{array}{lcr}\text { Não existiam } & \text { metas de } \\
\text { arrecadação } & \text { divulgadas } \\
\text { publicamente. } & \end{array}$ & $\begin{array}{l}\text { Trinta dias após a publicação do } \\
\text { orçamento, o Poder Executivo } \\
\text { terá de divulgar metas bimestrais } \\
\text { de arrecadação com detalhes } \\
\text { sobre as medidas de combate à }\end{array}$ \\
\hline
\end{tabular}




\begin{tabular}{|c|c|c|}
\hline & & $\begin{array}{l}\text { sonegação, ações ajuizadas para } \\
\text { cobrança de dívida ativa e a } \\
\text { evolução dessa dívida. }\end{array}$ \\
\hline Incentivos Fiscais & $\begin{array}{l}\text { Não havia uma obrigação } \\
\text { genérica para todos os } \\
\text { governantes. }\end{array}$ & $\begin{array}{l}\text { A concessão ou ampliação de } \\
\text { incentivo fiscal terá de ser } \\
\text { acompanhada do impacto } \\
\text { orçamentário no ano de início da } \\
\text { vigência do incentivo e nos dois } \\
\text { anos seguintes. }\end{array}$ \\
\hline Despesas com Pessoal & $\begin{array}{l}\text { A Lei Camata fixou os } \\
\text { mesmos percentuais } \\
\text { máximos, mas não repartia } \\
\text { os limites entre os Poderes. }\end{array}$ & $\begin{array}{l}\text { As despesas com pessoal } \\
\text { (ativos, inativos e pensionistas) } \\
\text { ficam limitadas a } 50 \% \text { da receita } \\
\text { líquida (descontadas as as as } \\
\text { transferências entre governos) } \\
\text { para a União, } 60 \% \text { para os } \\
\text { Estados, e } 60 \% \text { para os os } \\
\text { Municípios. A repartição desses } \\
\text { limites entre os Poderes será } \\
\text { feita pela LDO, mas o projeto fixa } \\
\text { percentuais máximos em caso de } \\
\text { omissão da LDO. }\end{array}$ \\
\hline $\begin{array}{l}\text { Excesso de despesas } \\
\text { com pessoal }\end{array}$ & $\begin{array}{l}\text { A Lei Camata estabelecia } \\
\text { medidas semelhantes. }\end{array}$ & $\begin{array}{lr}\text { As avaliações sobre as despesas } \\
\text { com pessoal serão } \\
\text { quadrimestrais. Se os limites } \\
\text { forem ultrapassados, os } \\
\text { governantes poderão extinguir } \\
\text { cargos ou diminuir os valores dos } \\
\text { salários com redução de jornada } \\
\text { de trabalho. Também ficarão } \\
\text { proibidos de deceber } \\
\text { transferências voluntárias ou } \\
\text { contratar operações de crédito. }\end{array}$ \\
\hline Bancos & $\begin{array}{l}\text { O BC já adotou lei específica } \\
\text { quando criou o Proer } \\
\text { (Programa de } \\
\text { Estímulo à } \\
\text { Reestruturação } \\
\text { Fortalecimento do } \\
\text { Financeiro). }\end{array}$ & $\begin{array}{l}\text { O projeto diz que será } \\
\text { necessária lei específica para } \\
\text { que os recursos públicos sejam } \\
\text { utilizados no socorro a bancos. } \\
\text { Também prevê a edição de uma } \\
\text { lei para a constituição de fundos } \\
\text { privados que cuidem dos } \\
\text { problemas de insolvência no } \\
\text { sistema financeiro. }\end{array}$ \\
\hline Dívida & $\begin{array}{l}\text { A determinação } r \text { era } \\
\text { constitucional, mas o } \\
\text { presidente nunca a cumpriu } \\
\text { por falta de uma lei } \\
\text { complementar. }\end{array}$ & $\begin{array}{l}\text { Noventa dias após a publicação } \\
\text { da lei, o presidente da República } \\
\text { terá de enviar ao Senado uma } \\
\text { proposta que indique limites para } \\
\text { a dívida de cada agente da } \\
\text { Federação, e um projeto ao } \\
\text { Congresso para o limite da dívida } \\
\text { mobiliária federal (em títulos). O } \\
\text { Ministério da Fazenda divulgará } \\
\text { mensalmente a relação de quem } \\
\text { ultrapassou os limites de suas } \\
\text { dívidas. }\end{array}$ \\
\hline Despesas continuadas & $\begin{array}{l}\text { Não existia uma regra única } \\
\text { para todos os governantes. }\end{array}$ & $\begin{array}{l}\text { As despesas continuadas (que } \\
\text { têm duração superior a dois } \\
\text { anos) só poderão ser elevadas } \\
\text { se forem promovidos cortes de }\end{array}$ \\
\hline
\end{tabular}




\begin{tabular}{|c|c|c|}
\hline & & $\begin{array}{l}\text { despesas ou aumento de } \\
\text { impostos. As despesas com } \\
\text { pessoal são uma exceção à } \\
\text { regra: poderão ser elevadas para } \\
\text { manutenção de seu valor real (de } \\
\text { acordo com a variação da } \\
\text { inflação) sem a necessidade das } \\
\text { medidas compensatórias. }\end{array}$ \\
\hline Refinanciamento & $\begin{array}{l}\text { Não havia restrições para o } \\
\text { refinanciamento de dívidas, } \\
\text { embora as operações } \\
\text { bancárias } \quad \text { estivessem } \\
\text { bastante restritas em função } \\
\text { da privatização dos bancos } \\
\text { estaduais. }\end{array}$ & $\begin{array}{l}\text { O projeto } \\
\text { refinanciamento de dívidas entre } \\
\text { União, Estados e Municípios. } \\
\text { Também serão proibidas as } \\
\text { operações de crédito entre } \\
\text { bancos oficiais e seus } \\
\text { controladores. }\end{array}$ \\
\hline Ano eleitoral & $\begin{array}{l}\text { As restrições à contratação } \\
\text { de pessoal já existiam na } \\
\text { legislação eleitoral, mas as } \\
\text { regras sobre início de obras } \\
\text { eram novidades e a } \\
\text { contratação de AROs era } \\
\text { proibida no prazo de seis } \\
\text { meses antes do final do } \\
\text { mandato. }\end{array}$ & $\begin{array}{l}\text { As AROs } \\
\text { Receitas } \\
\text { emprecipações de } \\
\text { emprimos } \\
\text { garantidos pontárias; } \\
\text { orçamentárias futuras) deverão } \\
\text { ser liquidadas até o dia } 10 \text { de } \\
\text { dezembro de cada ano e serão } \\
\text { proibidas no último ano do } \\
\text { mandato. No ano eleitoral, os } \\
\text { governantes também não } \\
\text { poderão começar obras que não } \\
\text { possam ser concluídas até o final } \\
\text { do mandato. As despesas com } \\
\text { pessoal não poderão ser } \\
\text { elevadas seis meses antes do } \\
\text { final do mandato. }\end{array}$ \\
\hline $\begin{array}{l}\text { Relatório de Gestão } \\
\text { Fiscal }\end{array}$ & $\begin{array}{l}\text { Não havia uma obrigação } \\
\text { genérica nesse sentido. }\end{array}$ & $\begin{array}{l}\text { A cada quatro meses, o chefe do } \\
\text { Poder Executivo e o chefe do } \\
\text { Poder Legislativo terão de } \\
\text { publicar o Relatório de Gestão } \\
\text { Fiscal, prestando contas sobre a } \\
\text { situação de tudo que estiver } \\
\text { sujeito a limites e condições } \\
\text { (despesas com pessoal, dívida, } \\
\text { operações de crédito). }\end{array}$ \\
\hline
\end{tabular}

IV.b) A tramitação no Senado Federal

No dia 03 de fevereiro de 2000, o Projeto de Lei Complementar n 18/1999 entrou na pauta do Senado Federal como o PLC n 4/2000. O projeto foi designado à Comissão de Constituição e Justiça (CCJ) no dia 04 de fevereiro, para ser relatado pelo Senador Álvaro Dias (PDT-PR), sob a Presidência do Senador José Agripino (PFL-RN).

No dia 24 de fevereiro, a CCJ aprovou o relatório do Senador Álvaro Dias, com voto pela aprovação da matéria com a emenda $n^{\circ} 01$ (de redação) que 
apresentou e pela rejeição das emendas de $\mathrm{n}^{\circ} 01$ a 07 , sem prejuízo das emendas destacadas para votação em separado, posteriormente rejeitadas. O Senador José Eduardo Dutra (PT-SE) votou favoravelmente, porém com restrição pela aprovação das emendas de sua autoria. No mesmo dia, a matéria foi apresentada à Comissão de Assuntos Econômicos (CAE).

$\mathrm{Na}$ CAE, a matéria foi relatada pelo Senador Jéfferson Peres (PDT-AM) e permaneceu durante 41 dias nesta Comissão. Foram realizadas 3 audiências públicas. A primeira contou com a participação de representantes de três entidades: Associação dos Membros dos Tribunais de Contas do Brasil (ATRICON); Confederação Nacional dos Municípios (CNM); União Nacional dos Legislativos Estaduais (UNALE). Três pontos foram discutidos centralmente:

1) a viabilidade dos limites a serem aplicados às despesas com pessoal, aspecto mais sensível para Tribunais de Contas e Assembléias Legislativas Estaduais;

2) a necessidade de saneamento financeiro dos Municípios, prévio à vigência da futura Lei de Responsabilidade Fiscal;

3) o processo de refinanciamento das dívidas dos Estados, esta uma reivindicação com origem na esfera municipal da administração pública.

A segunda audiência foi com os Governadores dos Estados, representados pelo Governador do Estado de Santa Catarina, Esperidião Amin. Segundo o relatório do Senador Jefferson Peres, esta audiência proporcionou o entendimento que também os Estados dariam sua cota de sacrifício para ajustar-se às restrições e limites propostos no projeto. Surgiram preocupações com relação: 1) à imperiosidade de que os limites relativos às despesas com pessoal sejam tão rigidamente aplicáveis quanto possível, assim como no tocante; 2) à metodologia de apuração da dívida e do endividamento especialmente, em função da pressão representada pelos precatórios, e a cobrança, por parte da União, pela concessão de garantias aos Estados e aos Municípios.

A última audiência, realizada com a participação do Ministro do Planejamento, Orçamento e Gestão e do Secretário-Executivo do Ministério da Fazenda, demonstrou, segundo o relator, o grau de importância atribuído pelo Poder Executivo ao PLC $n^{\circ} 4 / 2000$, muito especialmente em função dos impactos positivos que o novo regime fiscal poderá vir a produzir sobre a saúde das finanças públicas e, por conseqüência, sobre o restante da economia do País (DSF, 06/04/2000, 6465). 
Ao todo, foram apresentadas 10 emendas ao Projeto. As emendas de números 2, 5, 7 e 10 versavam, direta ou indiretamente, sobre a aplicação de limites às despesas com pessoal. As de números 3, 6 e 9, por sua vez, cuidavam dos impactos que as normas referentes à concessão de garantias (cobrança e contragarantias) poderão produzir, por um lado, sobre a prestação de aval oficial a mini e pequenos empreendedores, urbanos e rurais, em suas operações de crédito e, por outro, sobre os custos de captação de recursos, via empréstimos e financiamentos, a serem suportados por Estados e Municípios. Por fim, as emendas de números 1, 4 e 8 tratavam, respectivamente, de forma de participação popular no processo de elaboração das leis orçamentárias, das regras de inclusão dos precatórios judiciais não pagos na dívida consolidada e das transferências de recursos entre as administrações direta e indireta.

O parecer do relator foi aprovado na Comissão no dia 04 de abril, com as emendas 01 e 03 do relator e contrário às emendas 01 a 14. Foram votos vencidos os Senadores Eduardo Suplicy (PT-SP), José Eduardo Dutra (PT-SE) e Roberto Saturnino (PT-RJ). Foi rejeitada a emenda $n^{\circ} 11$ de autoria do Senador José Eduardo Dutra (PT-SE).

No dia 05 de abril de 2000, os pareceres dos relatores da CCJ e da CAE foram lidos em Plenário e foi aberto prazo de cinco dias úteis para recebimento de emendas perante a Mesa. No dia 06, foi lido e, posteriormente, aprovado o Requerimento $\mathrm{n}^{\circ} 167$, de 2000, subscrito por diversos líderes de bancada, de urgência para a matéria, nos ternos do inciso $2^{\circ}$ do art. $336^{168}$, do Regimento Interno de Senado Federal. Em função da aprovação do pedido do regime de urgência, a matéria entrou em discussão em turno único.

\footnotetext{
${ }^{168}$ Art. 336. A urgência poderá ser requerida: I - quando se trate de matéria que envolva perigo para a segurança nacional ou de providência para atender a calamidade pública; II - quando se pretenda a apreciação da matéria na segunda sessão deliberativa ordinária subseqüente à aprovação do requerimento; III - quando se pretenda incluir em Ordem do Dia matéria pendente de parecer. Parágrafo único. As proposições referidas no art. 91, I e II, reservadas à competência terminativa das comissões, não poderão ser apreciadas em regime de urgência, salvo se da decisão proferida houver recurso interposto por um décimo dos membros do Senado para discussão e votação da matéria pelo Plenário.

Art. 337. A urgência dispensa, durante toda a tramitação da matéria, interstícios, prazos e formalidades regimentais, salvo pareceres, quorum para deliberação e distribuição de cópias da proposição principal.

Art. 338. A urgência pode ser proposta: I - no caso do art. 336, I, pela Mesa, pela maioria dos membros do Senado ou líderes que representem esse número; II - no caso do art. 336, II, por dois terços da composição do Senado ou líderes que representem esse número; III - no caso do art. 336, III, por um quarto da composição do Senado ou líderes que representem esse número; IV - por comissão, nos casos do art. 336, II e III; V - pela Comissão de Assuntos Econômicos, quando se tratar de pedido de autorização para realizar operações de crédito.
} 
A equipe do planejamento que acompanhou a discussão na Câmara continuou acompanhando as discussões do texto nas Comissões do Senado Federal. Houve audiências públicas e várias questões de constitucionalidade foram levantadas, mas não houve mudança no conteúdo do texto. As negociações sobre as votações em plenário já saíram costuradas das comissões:

"no Senado só houve emendas de forma, até porque, feita toda a discussão com os senadores, eles se convenceram de que embora houvesse pontos que eles gostariam de modificar, o prejuízo de atrasar a aprovação da lei e, principalmente, o prejuízo do ponto de vista da aplicação do artigo $n^{\circ} 42$ (sobre restos a pagar) para os municípios era maior do que o benefício de fazer algum tipo de modificação. Eu diria que houve um consenso com relação a isso, houve um entendimento muito forte da parte dos senadores de que modificações de forma poderiam ser feitas porque não atrasariam o processo, mas com modificações de conteúdo não, que a matéria tinha sido exaustivamente discutida, os pontos que eram levantados no Senado não eram diferentes daqueles pontos que já tinham sido levantados na Câmara, e aí se avaliou assim: poderia ser melhor em tal aspecto.. Mas para que? Vai mudar uma palavra de "incentivo" pra "necessidade"? E aí? Volta todo o processo para que? Então houve de fato esse acordo no Senado mas não foi em nenhum momento alguma coisa truculenta, que é uma idéia que a oposição tentava vender, que a lei tinha passado rápido, que o governo tinha forçado a tramitação. De jeito nenhum... As discussões foram exaustivas" ${ }^{169}$.

$\mathrm{Na}$ CAE, houve uma discussão envolvendo o art. 42, sobre os restos a pagar. A regra do artigo $n^{\circ} 42$ impedia que se deixassem restos a pagar para o mandato seguinte, sem cobertura de caixa. Discutiu-se, então, se a lei deveria entrar em vigor imediatamente ou se a lei deveria entrar em vigor a partir da aprovação do PPA e da LDO. No Senado, apoiava-se que aquela regra do artigo $n^{\circ}$ 42 deveria valer imediatamente porque a situação financeira das prefeituras era muito ruim. Se a lei não fosse aprovada logo, os próximos prefeitos, quando assumissem, receberiam prefeituras quebradas por excesso de resto a pagar. Os senadores tinham interesse na manutenção daquela regra, na medida em que

"alguns senadores ou eram candidatos ou tinham aliados que eram candidatos. Eles não tinham interesse em receber a prefeitura quebrada no início do mandato. Então essa conjuntura política também ajudou a formar um consenso de que era preciso aprovar logo a lei pra segurar a

\footnotetext{
${ }^{169}$ Entrevista com Selene Peres Peres Nunes, 20/09/05.
} 
gastança das prefeituras... O nosso entendimento e a nossa defesa era de que essa não era simplesmente uma lei orçamentária, era uma lei de finanças públicas, e como uma lei de finanças públicas, ela incluía a matéria orçamentária, mas ela não se restringia a esta, tanto que havia disposições sobre dívidas, sobre pessoal, sobre execução orçamentária, como é o caso dos restos a pagar, que é uma questão eminentemente financeira, não é uma questão orçamentária"170.

Mais dois fatores que contaram a favor da rápida tramitação do projeto da LRF no Senado foram: o parecer favorável da Assessoria Técnica do Senado e o fato do texto do projeto, na parte de dívida, ser muito inspirado nas Resoluções do próprio Senado Federal, que controlavam limite de endividamento. "Muito da lei é uma Kleinübing turbinada, na parte de dívida, então a gente levou para uma lei complementar o que eles (os senadores) já tinham colocado na resolução do Senado Federal"171.

No dia 11 de abril, foram lidas 18 emendas de plenário (ver quadro 6, anexo 3). O relator da CCJ, Senador Álvaro Dias, proferiu parecer favorável à Emenda $\mathrm{n}^{\circ}$ 22 e contrário às Emendas $n^{\circ} 5$ a 21. Segundo o relator, "o acolhimento de qualquer dessas emendas implicaria retorno da matéria à Câmara dos Deputados e, seguramente, essa lei não vigoraria neste ano (2000) de eleições municipais. (...) Houve uma sugestão discutida já na CCJ e, posteriormente, na CAE no sentido de que as emendas de mérito que poderiam significar aprimoramento da LRF devessem ser apresentadas posteriormente como projetos de lei, a fim de que as duas Casas do Congresso pudessem discuti-las e, se possível, aprová-las". (DSF, 6936, 12/04/00).

Em plenário, não houve necessidade do Executivo negociar muitos pontos com os Senadores. O único evento lembrado por um dos entrevistados foi o envolvendo a votação da Lei Camata, que estava acontecendo no momento em que a LRF chegou ao plenário do Senado, o que demandou negociação com os Senadores interessados na aprovação da Lei Camata:

"Eu me lembro até hoje, quando nós chegamos em plenário para votar a $L R F$, estavam votando a Lei Camata (II). Os estados tinham feito uma variação da lei que não tinha quebra por sub-limite, mas tinha outras regras de demissão, que os Estados queriam. O Estado que mais queria

\footnotetext{
${ }^{170}$ Entrevista com Selene Peres Peres Nunes, 20/09/05.

${ }^{171}$ Entrevista com José Roberto Rodrigues Afonso, 01/09/05.
} 
isso era a Bahia (o Senado era o Paulo Souto). A gente teve que negociar com ele, a gente garantiu que isso estava dentro da LRF e com a lei, eu iria atendê-lo nisso. Daí ele não queria. Estava ele e o Paulo Hartung e eu fui falar com o Paulo Hartung, e o pessoal da Bahia foi com o Paulo Souto e ele aprovou... Mas assim, coisas pontuais... Sai a Lei Camata e em seguida, sai a LRF que revoga a Lei Camata..."172.

Em discurso em plenário, o Senador Eduardo Suplicy citou o art. 35 sobre a vedação da operação de crédito entre entes federativos e questionou como ficaria o caso da cidade de São Paulo que, na ocasião, havia assinado um contrato de refinanciamento da dívida que ainda não havia sido autorizado pelo Senado Federal. O Senador Álvaro Dias respondeu que a situação de SP estaria resolvida antes da sanção do projeto de lei da LRF.

Em seguida, o Sr. Jefferson Péres, relator da CAE, proferiu parecer, favorável às Emendas nos 5, 15 e 22 e contrário às de nos 6 a 14, 16 a 21. Alguns senadores usaram a palavra na mesma sessão, marcando posição crítica diante da matéria. O Senador José Eduardo Dutra (PT-SE) declarou que votou contra devido à rejeição das emendas e da falta de mais discussão sobre a matéria. Segundo o Senador Dutra, os problemas do projeto eram:

1) a vedação da renegociação da dívida dos Municípios;

2) o inciso I do art. 30; as subseções II e III da Seção IV, das Operações de Crédito; o art. 32 , $\S 1^{\circ}$; e o art. 40, que transferia aquilo que era de competência exclusiva do Senado Federal para o Presidente da República, ainda que o art. 52 da Constituição estabeleça as competências privativas do Senado;

3) o art. $9^{\circ}$ limitava o empenho para despesas de qualquer natureza, inclusive as sociais, e não se incluíam nesta limitação as despesas com juros da dívida;

4) o engessamento que viria com o aumento da receita associado à elevação de alíquota, ampliação da base de cálculo ou criação de tributo ou contribuição.

O Senador Jefferson Péres respondeu ao Senador José Eduardo Dutra sobre a alegação de que o Senado estaria aprovando um dispositivo que, além de inconstitucional, usurparia os poderes constitucionais do Senado. O art. 30 da lei estabelecia que o Presidente submeteria ao Congresso Nacional projeto de lei que estabelecia limites para a dívida mobiliária federal. Este artigo, segundo o Senador, convergia com o art. 48 da Constituição, que estabelece que cabe ao Congresso

\footnotetext{
${ }^{172}$ Entrevista com José Roberto Rodrigues Afonso, 01/09/05.
} 
Nacional, com a sanção do Presidente da República, dispor sobre todas as matérias de competência da União, incluindo endividamento. $\mathrm{O}$ art. 52, sobre as competências exclusivas do Senado, estabelece os limites de dívida dos Estados, Municípios e DF a serem definidos pelo Senado.

Os Senadores Sebastião Rocha (Bloco PDT-AP) e Roberto Saturnino (PSB/RJ) lamentaram o fato do Senado não poder emendá-la em virtude do acordo da bancada governista com o Palácio do Planalto, que fazia com que o Senado aprovasse o que vinha da Câmara (DSF, 6946, 12/04/00) e repetiram o discurso dos deputados de oposição: as casas legislativas estavam sendo pressionadas para discutir rapidamente a lei em virtude dos compromissos assumidos com o FMI.

Havia uma avaliação entre os senadores de oposição de que algumas áreas não foram bem abordadas na lei, com as questões ligadas aos Municípios, aos Tribunais de Contas, ao Legislativo Estadual e ao Judiciário. A despeito disso, a bancada governista argumentava que houve um acordo com o Executivo e as emendas do Senado seriam negociadas com o Executivo.

No processo de encaminhamento da votação da matéria, usaram a palavra para declarar voto favorável os Senadores: Arlindo Porto (PTB-MG), Paulo Hartung (PPS-ES), Edison Lobão (PFL-MA), José Roberto Arruda (PSDB-DF, líder do governo), Sérgio Machado (PSDB-CE) e Osmar Dias (PSDB-PR). Este último propôs a troca do IGP pelo IPCA para corrigir as dívidas dos Estados. Votou a favor, mas era contra a inviabilização do Fundo de Aval nas prefeituras, que fornecia crédito para pequenos empresários e pequenos proprietários rurais. 0 Ministro do Planejamento assumiu compromisso com o parlamentar de reconstituir o Fundo.

Os senadores que declararam voto contrário foram: Ademir Andrade (PSBPA), José Eduardo Dutra (PT-SE), Pedro Simon (PMDB-RS); Heloisa Helena (PT$A L)$ e o Roberto Requião (PMDB-PR). Houve um acordo entre o presidente do senado e os líderes para abrir a votação antes de encerrada a discussão. Logo em seguida, foi lido e prejudicado o Requerimento $n^{0}$ 175/2000, do Sr. Ney Suassuna, solicitando destaque para votação em separado do caput do art. 20 do projeto. A Senadora Heloisa Helena afirmou que houve um acordo dos governadores com o Presidente da República para vetar o artigo que seria alterado pelo requerimento do Senador Ney Suassuna. O Senado Pedro Simon (PMDB-RS) reclamou da pressa do governo no encaminhamento da tramitação da LRF. Se o projeto é importante, 
ele precisa ser mais discutido e até voltar a Câmara, se fosse o caso. "Estamos sendo uma casa de carimbagem oficial" (DSF, 6966-7, 12/04/00).

No mesmo dia, 11 de abril, foram realizadas 5 votações nominais. A primeira foi a votação do projeto, que aprovado, sem prejuízo das emendas (ver quadro 7 , anexo 3). Votaram contra os senadores do PT, do PSB e um do PMDB (Roberto Requião). Foi lido e aprovado o Requerimento $n^{\circ} 177 / 2000$, do Sr. José Eduardo Dutra, solicitando destaque para votação em separado da Emenda $n^{\circ} 7$, sobre aumento permanente da receita. Foi realizada a segunda votação nominal e a Emenda $\mathrm{n}^{\circ} 7$ foi rejeitada (ver quadro 8, anexo 3 ).

A seguir, foi lido e aprovado o Requerimento $n^{\circ}$ 179/2000, do Senador Romero Jucá, solicitando destaque para votação em separado da Emenda $\mathrm{n}^{\circ} 22$, do Senador Pedro Simon (ver quadro 6). Em terceira votação nominal do dia, a Emenda $n^{\circ} 22$ foi rejeitada (ver quadro 9, anexo 3). Na seqüência, foram lidos e aprovados os Requerimentos $\mathrm{n}^{\circ} \mathrm{s} 180$ a 182/2000, do Senador Edison Lobão, solicitando a retirada das Emendas $\mathrm{n}^{\circ} \mathrm{s}$ 18, 15 e 5, respectivamente. Em quarta votação, foram aprovadas, em globo, as emendas ns 1-CCJ e 2 a 4-CAE (ver quadro 10, anexo 3). Na última votação nominal, foram rejeitadas, em globo, as emendas $\mathrm{n}^{\circ} \mathrm{s} 8$ a 14, 16, 17, 19 a 21 (ver quadro 6), de parecer contrário (ver quadro 11, anexo 3).

Enquanto o projeto tramitou no Senado, a CNM entregou às lideranças do Senado uma proposta para suprimir os artigos que tratavam dos crimes contra as finanças públicas. Até a última votação da lei no Senado, os prefeitos pressionaram os senadores para mudanças no projeto, como a supressão do artigo 35 , que proíbe socorro financeiro entre entes federativos. O governo não abriu mão de manter este artigo, considerado um dos pontos mais fortes da lei, assim como não concedeu na flexibilização às restrições aos gastos públicos em ano eleitoral. No entanto, o Governo Federal fechou um acordo amenizando as punições para quem descumprisse a lei, alterando o projeto da Lei de Crimes. Em dois casos descumprimento do limite de gastos públicos com pessoal e o não cancelamento de despesas superiores ao teto previsto em lei - a prisão em regime de reclusão seria substituída por detenção, que permite penas alternativas, como prestação de serviços comunitários ${ }^{173}$.

\footnotetext{
${ }^{173}$ Folha de São Paulo, 12/04/2000.
} 
Ao final das votações nominais, o Senador Nabor Júnior proferiu parecer oferecendo a redação final da matéria (PMDB-AC). Em 04 de maio de 2000, a Lei Complementar $\mathbf{n}^{\circ}$ 101, de 2000, a Lei de Responsabilidade Fiscal (ver anexo 2), foi sancionada pela Presidência da República.

No período entre a aprovação da lei no Senado e a sanção do presidente, houve uma verdadeira corrida dos prefeitos ao Banco do Brasil para concluir as renegociações das dívidas que estavam pendentes. Como a LRF proibiria a renegociação das dívidas entre entes da federação, a rolagem da dívida de prefeituras, como a de São Paulo (R $\$ 10$ bilhões), teve que ser apressada antes da sanção da lei.

IV.c) O veto, as Adins, a implementação da lei e a situação dos prefeitos.

Em 12 de maio de 2000, a Mensagem Presidencial $n^{\circ} 627$ (ver anexo 2) comunicou o veto parcial ${ }^{174}$ aposto à matéria (VET 00012/00). O veto mais importante foi ao art. 41, sobre restos a pagar. Como vimos, este artigo foi discutido na CAE e teve o apoio dos Senadores, que argumentavam que a situação financeira das prefeituras seriam agravadas, se a regra dos restos a pagar não valesse.

O artigo $n^{\circ} 41$ sobre os restos a pagar foi elaborado pelo relator dep. Pedro Novais e acabou sendo vetado pelo presidente. Neste ponto, o veto do presidente deixou tudo como era antes. Do ponto de vista da equipe do governo que elaborou a lei, o texto do art. 42 abria uma brecha para os governos subnacionais deixarem encargos financeiros para o mandato subseqüente. Alguns técnicos discordaram desta posição do governo. Outros fizeram análises convergentes:

"Ele foi bem vetado... Dava um novo conceito de restos a pagar que permitia passar restos a pagar fortes. Se você leu as razões do veto, você viu que você aceita que as despesas liquidadas podem estar acima do limite. Ele só põe limite nas não liquidadas. Daí cria uma situação em que você poderia ter restos a pagar fortes passando de um exercício para o outro. E o art. 42, ele acaba ficando só no ultimo exercício, nos últimos oito meses de mandato"175.

\footnotetext{
${ }^{174}$ Foram vetos os seguintes dispositivos: Art. $3^{\circ}$; Alínea "c" do inciso I do art. $4^{\circ}$; Alínea "d" do inciso I do art. $4^{\circ}$; Inciso II do art. $4^{\circ}$; Inciso III do art. $4^{\circ}$; Alínea "a" do inciso III do art. $5^{\circ} ; \S 7^{\circ}$ do art. $5^{\circ}$; Art. $6^{\circ}$; $\S 6^{\circ}$ do art. 20; Inciso III do $\S 3^{\circ}$ do art. 32; § $3^{\circ}$ do art. 40; $\S 40$ do art. 40; Art. 41; Alínea "a" do inciso II do art. 63 e; Inciso II do $\S 10$ do art. 25.

${ }^{175}$ Entrevista com Amir Khair, 10/08/05.
} 
Outro ponto lembrado pelos entrevistados foi o dos relatórios de execução orçamentária das prefeituras (Alínea "a" do inciso II do art. 63). Os municípios poderiam encaminhar um relatório de execução orçamentária a casa seis meses:

"nós vetamos isso porque a Constituição estabelece prazo de dois meses, então se separou o que era efetivamente constitucional e o que não era. Naqueles demonstrativos que a LRF havia criado ficou a determinação dos seis meses, mas aquilo que era base constitucional nós não poderíamos interferir porque isso seria objeto de Adin, e com razão"176.

Em 08 de junho foi constituída uma Comissão Mista de Senadores e Deputados para relatar o veto, composta pelos: Senadores Jonas Pinheiro (PFLMT), Álvaro Dias (PSDB-PR) e Jefferson Peres (PDT-AM) e pelos Deputados Pedro Novais (PMDB-MA) e Jutahy Júnior (PSDB-BA).

A partir de agosto de 2000, foram impetradas algumas Adins (Ações Diretas de Inconstitucionalidade), contra dispositivos da Lei de Responsabilidade Fiscal, conforme quadro a seguir:

Quadro 3: As Adins contra dispositivos da LRF.

\begin{tabular}{|c|c|}
\hline \multicolumn{2}{|r|}{ Adin $n^{\circ} 2238$ (2000/2001) } \\
\hline Requerente & PT, PC do B e PSB \\
\hline Requerido & Presidente da República e Congresso Nacional \\
\hline $\begin{array}{l}\text { Dispositivo } \\
\text { questionado }\end{array}$ & $\begin{array}{l}\text { Lei Complementar } n^{\circ} 101 \text {, de } 04 \text { de maio de } 2000 \text { e } \\
\text { inciso Oll, do art. } 003^{\circ} \text { e do artigo } 004^{\circ} \text { da Medida } \\
\text { Provisória } n^{\circ} 1980-18 \text {, de } 04 \text { de maio de } 2000 \text {. }\end{array}$ \\
\hline $\begin{array}{l}\text { Decisão Plenária da } \\
\text { Liminar }\end{array}$ & $\begin{array}{l}\text { O Tribunal, por unanimidade, rejeitou a argüição de } \\
\text { inconstitucionalidade formal da lei, em sua totalidade, ao } \\
\text { argumento de que o projeto deveria ter voltado à Câmara } \\
\text { dos Deputados em razão de o Senado ter alterado certos } \\
\text { dispositivos da lei. }\end{array}$ \\
\hline \multicolumn{2}{|r|}{ Adin $n^{\circ} 2365$ (2000/2001) } \\
\hline Requerente & PC do B \\
\hline Requerido & Presidente da República e Congresso Nacional \\
\hline $\begin{array}{l}\text { Dispositivo } \\
\text { questionado }\end{array}$ & $\begin{array}{l}\text { Artigo } 020 \text {, inciso III, da Lei Complementar } n^{\circ} 101 \text {, de } 04 \\
\text { de maio de } 2000 \text {. Art. } 020-\text { A repartição dos limites } \\
\text { globais do art. } 019 \text { não poderá exceder os seguintes } \\
\text { percentuais : ( . . ) III - na esfera municipal : a) } 006 \% \\
\text { ( seis por cento ) para o Legislativo, incluído o Tribunal } \\
\text { de Contas do Município, quando houver ; b) } 054 \%\end{array}$ \\
\hline
\end{tabular}

\footnotetext{
${ }^{176}$ Entrevista com Selene Peres Peres Nunes, 20/09/05.
} 


\begin{tabular}{|c|c|}
\hline $\begin{array}{l}\text { Decisão } \\
\text { Liminar }\end{array}$ & $\begin{array}{l}\text { Trata-se de ação direta de inconstitucionalidade, com } \\
\text { pedido de liminar, ajuizada pelo Partido Comunista do } \\
\text { Brasil - PC do B, tendo por objeto o art. 020, III, da Lei } \\
\text { Complementar n }{ }^{\circ} 101 \text {, de 04/05/2000 ( Lei de } \\
\text { Responsabilidade Fiscal ). O Plenário do Supremo } \\
\text { Tribunal Federal, na assentada de } 11 / 10 / 2000 \text {, ao } \\
\text { apreciar a medida cautelar na ADI } 2238 \text {, igualmente } \\
\text { interposta pelo PC do B, juntamente com o Partido dos } \\
\text { Trabalhadores - PT e o Partido Socialista Brasileiro - } \\
\text { PSB, indeferiu o pedido de suspensão da eficácia do } \\
\text { mencionado art. 020 da Lei de Responsabilidade Fiscal } \\
\text { formulado pelos requerentes. Dessa forma, resta } \\
\text { prejudicado o pedido de medida cautelar deduzido nesta } \\
\text { ADI 2365, a qual determino seja apensada à ADI } 2238 \text {. }\end{array}$ \\
\hline \multicolumn{2}{|r|}{ Adin $n^{\circ} 2241(2000 / 2001)$} \\
\hline Requerente & $\begin{array}{l}\text { Mesa da Assembléia Legislativa do Estado de Minas } \\
\text { Gerais }\end{array}$ \\
\hline Requerido & Presidente da República e Congresso Nacional \\
\hline $\begin{array}{ll}\text { Dispositivo } & \text { legal } \\
\text { questionado } & \end{array}$ & $\begin{array}{l}\text { Art. } 020, \text { inciso 0ll, alíneas "a", "b", "c" e "d" da Lei } \\
\text { Complementar no } 101 \text {, de } 04 \text { de maio de } 2000 \text {. Art. } 020 \text { - } \\
\text { A repartição dos limites globais do art. } 019 \text { não poderá } \\
\text { exceder os seguintes percentuais : ( . . . ) } 0 \text { ll - na esfera } \\
\text { estadual : a) } 003 \% \text { ( três por cento ) para o Legislativo, } \\
\text { incluído o Tribunal de Contas do Estado ; b) } 006 \% \text { ( seis } \\
\text { por cento ) para o Judiciário ; c) } 049 \% \text { ( quarenta e nove } \\
\text { por cento) para o Executivo ; d) } 002 \% \text { ( dois por cento ) } \\
\text { para o Ministério Público dos Estados. }\end{array}$ \\
\hline $\begin{array}{lll}\text { Decisão } & \text { Plenária } & \text { da } \\
\text { Liminar } & & \\
\end{array}$ & Aguardando Julgamento \\
\hline \multicolumn{2}{|r|}{ Adin $n^{\circ} 2324(2000 / 2003)$} \\
\hline Requerente & $\begin{array}{l}\text { Associação dos Membros dos Tribunais de Contas do } \\
\text { Brasil (ATRICON) }\end{array}$ \\
\hline Requerido & Presidente da República \\
\hline $\begin{array}{ll}\text { Dispositivo legal } \\
\text { questionado }\end{array}$ & $\begin{array}{l}\text { Art. 056, caput e } \S 002^{\circ} \text {; e art. 059, da Lei Complementar } \\
n^{\circ} 101 \text {, de } 04 \text { de maio de } 2000 \text {. }\end{array}$ \\
\hline $\begin{array}{l}\text { Decisão } \\
\text { Liminar }\end{array}$ & Aguardando Julgamento \\
\hline \multicolumn{2}{|r|}{ Adin $n^{\circ} 2256(2000)$} \\
\hline Requerente & $\begin{array}{l}\text { Associação dos Membros dos Tribunais de Contas do } \\
\text { Brasil (ATRICON) }\end{array}$ \\
\hline Requerido & Presidente da República e Congresso Nacional \\
\hline $\begin{array}{l}\text { Dispositivo } \\
\text { questionado }\end{array}$ & $\begin{array}{l}\text { Artigo 020, incisos 0ll , "a", "b" , "c" e "d", III , "a" e "b", } \\
\S \S 001^{\circ}, 004^{\circ} \text { e } 005^{\circ} \text { da Lei Complementar no 101, de } \\
04 \text { de maio de } 2000 .\end{array}$ \\
\hline $\begin{array}{lll}\text { Decisão } & \text { Plenária da } \\
\text { Liminar } & & \\
\end{array}$ & Aguardando Julgamento \\
\hline \multicolumn{2}{|r|}{ Adin $n^{\circ} 2261$ (2000/2003) } \\
\hline Requerente & $\begin{array}{l}\text { Associação Nacional dos Membros do Ministério Público } \\
\text { (CONAMP) }\end{array}$ \\
\hline
\end{tabular}




\begin{tabular}{|c|c|}
\hline Requerido & Presidente da República e Congresso Nacional \\
\hline $\begin{array}{l}\text { Dispositivo } \\
\text { questionado }\end{array}$ & $\begin{array}{l}\text { Art. 020, da Lei Complementar } n^{\circ} 101 \text {, de } 04 \text { de maio de } \\
2000 \text {. }\end{array}$ \\
\hline $\begin{array}{l}\text { Decisão Plenária da } \\
\text { Liminar }\end{array}$ & Aguardando Julgamento \\
\hline & Adin $n^{\circ} 2250(2003)$ \\
\hline Requerente & Governador do Estado de Minas Gerais (Itamar Franco) \\
\hline Requerido & Presidente da República e Congresso Nacional \\
\hline $\begin{array}{l}\text { Dispositivo } \\
\text { questionado }\end{array}$ & $\begin{array}{l}\text { Arts. } 035 \text { e 051, da Lei Complementar } n^{\circ} 101 \text {, de } 04 \text { de } \\
\text { maio de } 2000 \text {. (Lei de Responsabilidade Fiscal) }\end{array}$ \\
\hline $\begin{array}{l}\text { Decisão } \\
\text { Liminar }\end{array}$ & $\begin{array}{l}\text { O Tribunal, por unanimidade, indeferiu o pedido de } \\
\text { liminar, relativamente ao artigo } 35 \text { da Lei Complementar } \\
n^{\circ} 101 \text {, de } 04 \text { de maio de } 2000 \text {. Em seqüência ao } \\
\text { julgamento, o Tribunal, por unanimidade, indeferiu o } \\
\text { pedido de liminar quanto ao artigo } 051 \text { da Lei } \\
\text { Complementar } n^{\circ} 101 \text {, de } 04 \text { de maio de } 2000 \text {. Votou o } \\
\text { Presidente, o Senhor Ministro Marco Aurélio. Impedido o } \\
\text { Senhor Ministro Gilmar Mendes. Ausente, } \\
\text { justificadamente, neste julgamento, o Senhor Ministro } \\
\text { Nelson Jobim. - Plenário, 02.04.2003 }\end{array}$ \\
\hline
\end{tabular}

As principais Adins foram impetradas pelos partidos de oposição, pelos Tribunais de Contas e pelo Governador do Estado de Minas Gerais, Itamar Franco. A mais abrangente era a Adin $n^{\circ} 2238$, dos partidos de oposição. As demais questionavam basicamente os limites de gastos de pessoal por poder.

"Depois de votar contra, os partidos de oposição iniciaram uma guerra no judiciário. (O trabalho de acompanhamento da equipe do planejamento) foi importante porque havia um risco de que alguns pontos pudessem ser considerados inconstitucionais, embora nós tivéssemos trabalhado intensamente na questão da constitucionalidade. Daí, todo o nosso trabalho iria por água abaixo. E o PT e o PC do $B$ entraram de fato com as Adins questionando toda a lei e um número grande de dispositivos, um a um, tentando se não derrubá-la por completo, derrubar o maior número de dispositivos possíveis. Eles tentavam principalmente atingir a questão das relações federativas... $O$ governador do Estado de Minas Gerais que, desde sempre, fez oposição ao governo $F H C$ e que, até por razões dessa natureza, queria derrubar a LRF. Mas você percebe que não houve nas Adins um risco efetivo à LRF. Alguns dispositivos que tiveram a sua eficácia suspensa, foram dispositivos que nós, inclusive, na negociação no Congresso, nós já tínhamos percebido que havia algum risco mas que até por uma questão de negociação se optou por deixar passar e que depois foram derrubadas pela Adin mas não eram coisas significativas que nós nem tínhamos colocado no projeto executivo original"m77.

\footnotetext{
${ }^{177}$ Entrevista com Selene Peres Peres Nunes, 20/09/05.
} 
No caso da Adin $n^{\circ}$ 2256, a ATRICON, na época em que a Adin foi impetrada, era dirigida por técnicos do Estado de Minas Gerais. O advogado da associação era o filho do presidente do Supremo Tribunal Federal. $\mathrm{Na}$ época do julgamento, ao invés de ser julgada a Adin impetrada pela ATRICON, foi julgada a $\mathrm{n}^{\circ} 2238$, do PT, PC do B e PSB, que atingia mais pontos da lei. O Governo Federal se mobilizou, tentando convencer os juízes de que os dispositivos, especialmente o do limite de pessoal, não era inconstitucional. O Governo acabou ganhando e o dispositivo foi mantido na lei.

Depois do processo legislativo e da "briga" no judiciário, começou um trabalho de implementação da lei. A maior demanda por investimento do Governo Federal na capacitação de pessoal para implementar a lei era das prefeituras. Foi feito um acordo com os deputados federais na época da tramitação na Câmara, no qual o governo se comprometia a dar apoio financeiro para os municípios. O papel do BNDES foi muito importante neste processo:

"Naquela época, a gente estava criando no BNDES o PMAT (Programa de Modernização da Administração Tributária e Gestão dos Setores Sociais Básicos). Aí os deputados disseram: "vocês vão financiar as prefeituras?". Vamos financiar as prefeituras... Entre outras, financiamos Ribeirão Preto. Eu negociei com o Palocci. Aliás, eu acho que as prefeituras do $P T$, teve a Marta aqui, o Sayad, eram as que mais recebiam financiamento do PMAT do BNDES"178.

O Ministério do Planejamento, juntamente com o BNDES, criaram cursos de capacitação e fizeram palestras por todo o Brasil, inclusive nos Tribunais de Contas, que até aquele momento tinham ficado apartados do processo e seriam instituições essenciais para o cumprimento da lei.

"Nós jogamos pesado na Internet. Fizemos 220 mil exemplares de livros, 13 coleções diferentes. O Amir (Khair) me escreveu um manual, ele apoiava a lei, conhecia a coisa da prefeitura como ninguém até hoje, e ainda era do PT, defendia a lei dentro do PT... Tribunal de contas: pegava os técnicos e dizia: me escreve um livro sobre algum aspecto. Tribunal de Contas do Rio Grande do Sul, um dos melhores: posso publicar e distribuir para o país inteiro? Municípios: você vai e contrata o IBM (Instituto Brasileiro de Administração Municipal). Vamos fazer um curso de ensino à distância, manual... Banco do Brasil: vídeo conferência. A gente trabalhou para caramba!! Isto não caiu do céu. O

\footnotetext{
${ }^{178}$ Entrevista José Roberto Rodrigues Afonso, 01/09/05.
} 
que é política? É trabalhar!! E os parlamentares estão vendo isso... Lógico que isso daí não conta... Já estava aprovada a lei, mas isso conta para o cara ver que era um compromisso que a gente assumiu e cumpriu. Nós vamos dar treinamento. Vídeo conferência do Banco do Brasil. A Selma (Pantel) pegava o ofício que a gente mandava para os prefeitos convocando, convidando para a vídeo-conferência e mandava para todos os deputados e senadores. O cara via. Sempre que a gente ia fazer alguma coisa em Brasília, a gente fazia no Congresso... A reunião dos estados, a gente sempre procurava fazer. Chamava parlamentar, a imprensa, jogo aberto... Eu acho que isso foi uma construção. Você não fez do nada. E você honrou e conseguiu manter porque foi combinado e foi honrado" ${ }^{\text {"179. }}$.

Depois das eleições municipais de 2000, os prefeitos eleitos começaram a pressionar o governo para que houvesse flexibilização em alguns pontos da LRF, como a reabertura da renegociação das dívidas e o perdão dos restos a pagar que os prefeitos anteriores deixaram para quem estava começando o mandato em 2001. Os prefeitos também reivindicaram, junto aos Ministros Pedro Malan (Fazenda) e Martus Tavares (Planejamento), um empréstimo de R\$ 5 bilhões do Tesouro Nacional para que eles conseguissem ajustar as contas municipais e se adequar aos limites estabelecidos em lei. Os técnicos do governo estavam irredutíveis: não estavam dispostos a negociar aqueles termos.

Naquele momento, a maior parte dos prefeitos conseguiria entregar a prefeitura em $1^{\circ}$ de janeiro de 2001 com um montante de dívidas menor do que recebeu em janeiro de 1997. Porém, a redução não foi suficiente para terminar o ano sem restos a pagar e se enquadrar à Lei de Responsabilidade Fiscal. Dos prefeitos que tomaram posse em 2001, 40\% foram reeleitos e sujeitos às multas, sanções e prisão previstas na Lei de Crimes, de outubro de 2000. Em novembro de 2000, 500 prefeitos organizaram um movimento em Brasília para pleitear, junto ao Congresso Nacional, uma anistia geral para todos os crimes relativos à Lei de Responsabilidade Fiscal cometidos nos quatro anos de suas administrações. Eles reivindicavam a aprovação de uma lei que adiasse a aplicação das penalidades para janeiro, o que, na prática, impediria qualquer punição aos prefeitos que deixariam o cargo em janeiro de 2001.

A maior preocupação dos prefeitos era em relação ao artigo $n^{\circ} 42$ da Lei de Responsabilidade Fiscal, que proíbe os administradores na época de deixarem restos a pagar para os políticos que assumem o cargo em $1^{\circ}$ de janeiro. Quem

\footnotetext{
${ }^{179}$ Entrevista José Roberto Rodrigues Afonso, 01/09/05.
} 
descumprisse a lei poderia ser condenado a penas que variavam de um a quatro anos de reclusão, além da proibição de disputar novos cargos eletivos por oito anos. Os prefeitos queriam o mesmo tratamento dado aos governadores, que puderam renegociar suas dívidas antes da aplicação das leis e somente estariam proibidos de deixar restos a pagar em 2002, quando eles deixariam os cargos. Além dos governadores, os prefeitos de 180 cidades, entre elas São Paulo, conseguiram renegociar suas dívidas com o Tesouro e não corriam o risco de prisão ao fim do mandato. Além da prisão, a principal pena que poderia ser aplicada é a proibição do repasse de transferências federais.

O impasse envolvendo a situação dos prefeitos foi resolvido a partir de uma decisão tomada em conjunto entre o Congresso Nacional e a Presidência da República, que concluíram que as penas previstas para os prefeitos que infringiram a Lei de Responsabilidade Fiscal, deixando dívidas para seus sucessores, só se aplicariam nos casos de débitos contraídos a partir do dia 20 de outubro de 2000, quando entrou em vigor a Lei dos Crimes contra as Finanças Públicas. Esse entendimento baseou-se em dois incisos do artigo $5^{\circ}$ da Constituição, segundo os quais uma lei penal não pode retroagir para prejudicar. Sendo assim, seria possível aos prefeitos deixar dívidas contraídas até aquela data ${ }^{180}$.

\footnotetext{
${ }^{180}$ Folha de São Paulo, 09/11/2000.
} 


\title{
Conclusão
}

\begin{abstract}
"Para compreender o impacto das instituições sobre os conflitos políticos contemporâneos, é preciso analisar os incentivos, as oportunidades $e$ as restrições que elas oferecem aos atores envolvidos nas disputas em curso. No âmbito dessas instituições, mais de um curso de ação era possível; o desenrolar dos fatos dependeu tanto do acaso histórico e da criatividade dos atores, quanto das restrições institucionais. Assim sendo, a lógica social da história não deve ser substituída por uma nova eficiência da história baseada nas instituições políticas".

Ellen Immergut ${ }^{181}$
\end{abstract}

A construção do consenso em torno da idéia do ordenamento fiscal iniciouse na década de 1980. A primeira manifestação da mudança institucional ocorreu no âmbito da União, com a criação da Secretaria do Tesouro Nacional e a extinção da Conta Movimento. A partir dos relatos das entrevistas realizadas, é possível afirmar que a idéia de ordenar as finanças dos Estados e dos Municípios surgiu no final da década de 1980, depois das várias experiências fracassadas de estabilização da economia. A interação entre essas idéias e os interesses em torno da construção do arcabouço institucional do ordenamento fiscal deu-se gradualmente durante a década de 1990. Da concepção da idéia de que era preciso mudar o regime fiscal à execução do projeto da Lei de Responsabilidade Fiscal, muitos fatores surgiram e criaram uma interação que caracterizou a trajetória desta mudança. Esta trajetória explica porque a idéia de responsabilidade fiscal tornou-se dominante no Brasil, na década de 1990, e não outra idéia alternativa. A partir de todo este extenso trabalho de pesquisa de dados primários (legislação, atas de reuniões de parlamentares e técnicos, tramitação parlamentar e entrevistas), pode-se destacar os fatores que determinaram a forma como as mudanças institucionais e políticas aconteceram.

São comuns na literatura análises sobre as reformas de mercado a partir de processos de natureza exógena ao sistema político ${ }^{182}$, através da predominância

\footnotetext{
${ }^{181}$ Immergut (1996).

182 Fiori (2001), O cosmopolitismo de cócoras. Educação e Sociedade, ano XXII, n 77, Dezembro de 200; Moraes (2001) Neoliberalismo: de onde vem, para onde vai. São Paulo: Senac e Fukuyama (1992) O fim da História e o último homem. Rio de Janeiro: Rocco, são exemplos desses trabalhos.
} 
das idéias neoliberais nos organismos financeiros internacionais. O receituário neoliberal que surgiu de forma sistematizada no horizonte da agenda de reformas dos países da América Latina, a partir do Consenso de Washington, em 1989, trouxe, como um de seus capítulos, o ajuste fiscal, financeiro e patrimonial dos países emergentes. No presente trabalho, refutamos a idéia de "triunfo do arcabouço neoliberal" e argumentamos, conforme Hall (1992), que as idéias têm poder político real na esfera política, mas elas não adquirem força política independentemente da constelação de instituições e de interesses anteriormente presentes nos contextos nacionais. Segundo bem argumenta Biersteker (1995), o processo de influência das idéias liberais na política econômica dos países em desenvolvimento é complexo. Existe uma grande variabilidade no processo de aderência às idéias liberais nos contextos nacionais particulares, ou seja, trata-se de um processo contingente, ao menos parcialmente, à configuração institucional do Estado, às experiências políticas anteriores e às recentes falhas, assim como à viabilidade política das novas idéias. Esta viabilidade depende da habilidade de mobilização de apoio entre as coalizões políticas existentes ou da formação de novas coalizões. Desta forma, examinamos a origem da Lei de Responsabilidade Fiscal levando em conta, como fator explicativo importante, a trajetória endógena de mudança na arena fiscal.

No que se refere ao que denominamos aqui como a construção de um consenso em torno da idéia de responsabilidade fiscal, constituiu-se como um dos fatores importantes o aprendizado dos técnicos do Governo Federal. Eles aprenderam: 1) que havia a necessidade do equacionamento do problema fiscal e financeiro dos entes federativos para sustentar a estabilização econômica; 2) que isto somente ocorreria se houvesse uma negociação na qual o Governo Federal cederia para os Estados poderem avançar, especialmente no caso da renegociação das dívidas dos Estados, em 1997; 3) e que medidas pontuais, que foram fartamente utilizadas pelas autoridades monetárias, não seriam mais eficientes no contexto da crise de 1998. Os técnicos perceberam, naquele momento, que era preciso acontecer uma mudança estrutural nas finanças públicas para o enfrentamento daquela crise. Na realidade, eles perceberam que a crise abriu uma oportunidade para a realização de uma mudança institucional nesta direção. Os técnicos tiveram um aprendizado "maquiaveliano": não era eficiente responder a cada crise com um pacote de medidas conjunturais; era preciso promover uma 
resposta estrutural, de uma só vez, que valesse a pena do ponto de vista dos custos políticos que eram crescentes, em momento de crise.

Neste sentido, podemos considerar os efeitos das crises financeiras internacionais sobre a conjuntura política e institucional da segunda metade da década de 1990. A cada crise financeira, o Governo Federal reagia para defender o plano de estabilização macroeconômica com um pacote de medidas - os tais "bifinhos para os leões"183. Quando ocorreu a crise russa, em agosto de 1998, formou-se uma conjuntura de mudança, como a desenhada analiticamente por Gourevitch (1986). Surgiu a possibilidade de se levar a cabo uma iniciativa governamental capaz de realizar uma mudança estrutural no regime fiscal brasileiro. A crise econômica criou um novo conjunto de escolhas para os policymakers, nos termos do autor, escolhas estas que já vinham se desenhando no horizonte institucional: a emenda da Reforma Administrativa já previa a regulamentação do art. 163, a partir do qual o projeto de lei complementar foi elaborado, para ocorrer em um prazo de 180 dias depois da promulgação da emenda (junho de 1998). A decisão de elaborar o projeto da LRF se deu neste momento de stress político e econômico, causando um efeito de criação institucional e um efeito de mobilização de determinados atores políticos para apoiar este projeto. Era preciso dar uma sinalização institucional, no contexto da crise econômica do segundo semestre de 1998, de que o governo brasileiro estava comprometido com a austeridade fiscal.

Foi afirmado em várias entrevistas que a elaboração da LRF não foi resultado da imposição do Fundo Monetário Internacional, como argumentavam os políticos de oposição, na época. O texto da lei já estava sendo desenvolvido pelos técnicos do governo na ocasião da assinatura do acordo, em outubro de 1998. Ademais, os técnicos do FMI criticaram duramente o projeto elaborado pelo governo brasileiro, em termos técnicos e em termos políticos.

É importante frisar que os dois técnicos que lideraram a elaboração do projeto da LRF tinham uma experiência profissional que foi importante para aproveitar as janelas de oportunidades da crise: José Roberto Afonso participou da equipe do Dep. José Serra, na Constituinte, e do processo de negociação da Lei Kandir; Martus Tavares trabalhou na Secretaria do Tesouro Nacional, na época da

\footnotetext{
${ }^{183}$ Citado na entrevista com Martus Tavares e Selma Pantel, 06/09/05.
} 
implementação das mudanças que ocorreram na década de 1980, foi diretoradjunto do departamento de Orçamento da União, do Ministério da Economia, de 1989 a 1990 e Secretário-adjunto de Política econômica da Secretaria Nacional de Planejamento, no período de 1990 a 1992. Ou seja, ambos tinham uma qualificação profissional técnica e politicamente importante para coordenar o processo de discussão do projeto de lei. Avaliamos que a forma como o processo foi conduzido, conforme abordado nos capítulos III e IV, contou significativamente para o resultado do processo decisório. Este grupo acabou elaborando um projeto que tinha como espírito o resgate do "Código de Finanças Públicas", discutido nos debates constituintes em 1987, mas não transformado em artigo da Constituição. Este é um fator importante para entendermos porque o projeto da Lei de Responsabilidade foi aquele apresentado à Câmara, um texto baseado em princípios e inspirado nos modelos da Nova Zelândia, dos Estados Unidos e da Comunidade Européia, e não outro, com outros pontos estruturantes e outra forma jurídica.

Outro ponto importante na formação gradual do consenso foi a mudança na classe política e na opinião pública sobre a responsabilidade fiscal. Gradualmente, os políticos que sustentaram a bandeira da austeridade fiscal e, especialmente, pautaram os seus mandatos com práticas saneadoras, foram premiados com a reeleição ou com a eleição dos seus candidatos. As entrevistas com os Srs. Arnaldo Madeira e Yoshiaki Nakano foram muitos indicativas deste fenômeno, ao citarem a experiência do governador Mario Covas, em São Paulo, em 1995, do governador Tasso Jereissati no Ceará e os casos dos Estados do Maranhão e Bahia. As entrevistas com os membros da equipe do Planejamento indicaram também o incisivo papel da mídia, especialmente durante o período da tramitação da LRF, entre os anos de 1999 e 2000, na difusão da idéia da importância da responsabilidade fiscal e de uma mudança institucional que refletisse esta idéia. Vários editoriais e reportagens, especialmente na mídia impressa, defendiam perante a opinião pública a importância da aprovação de uma lei como a LRF, não só como forma de nos recuperarmos da crise de desvalorização cambial, mas como prática política socialmente valorizada. O trabalho de Asazu (2003) já havia chamado a atenção para esta questão.

Um fator também importante que explica a construção do consenso é o caráter incremental do processo de ordenamento fiscal. A discussão sobre o controle do endividamento e do gasto público, realizada a partir dos trabalhos de 
Lopreato (1992; 1997; 2000; 2002) e Mora (2001; 2002), e dos dados coletados nas entrevistas, apresentados no capítulo II, demonstraram a idéia de que "mudanças importantes se dão gradualmente e que cada medida tomada e/ou aprovada influencia, em maior ou menor medida, o caminho posterior (...), a chamada path dependence (...)" (Loureiro e Abrucio, 2002: 59). Ou seja, as medidas tomadas pelo Governo Federal para controlar gastos e endividamento dos Estados e Municípios durante a década de 1990 ajudaram a abrir caminho para a aprovação da Lei de Responsabilidade Fiscal. Além de ter havido um crescente endurecimento nas regras, que foram criadas no decorrer da década de 1990, a lei incorporou muitas delas, conforme ilustra o quadro.

Quadro 4: O endurecimento da legislação sobre controle de gasto e de endividamento.

\begin{tabular}{|c|c|c|c|}
\hline Área & $\begin{array}{c}\text { Restrição mais } \\
\text { fraca }\end{array}$ & $\rightarrow$ & $\begin{array}{l}\text { Restrição mais } \\
\text { forte }\end{array}$ \\
\hline $\begin{array}{l}\text { Despesa com } \\
\text { pessoal }\end{array}$ & $\begin{array}{l}\text { D Lei Camata I } \\
\left(\text { LC n }{ }^{\circ} 82 / 95\right)\end{array}$ & $\begin{array}{l}\text { Dei Camata II } \\
(\text { LC n 96/99) }\end{array}$ & $\begin{array}{l}\text { Dei de } \\
\text { Responsabilidade } \\
\text { Fiscal (LC nº } \\
\text { 101/00) }\end{array}$ \\
\hline Despesas totais & & $>$ Lei 9496/97 & $\begin{array}{l}\text { Dei de } \\
\text { Responsabilidade } \\
\text { Fiscal (LC nº } \\
101 / 00)\end{array}$ \\
\hline Precatórios & $>E C n^{\circ} 3 / 93$ & $\begin{array}{l}\text { Resolução do } \\
\text { BC n² 2443/97 }\end{array}$ & $\begin{array}{l}\text { Lei de } \\
\text { Responsabilidade } \\
\text { Fiscal (LC no } \\
101 / 00)\end{array}$ \\
\hline $\begin{array}{l}\text { Bancos } \\
\text { Estaduais }\end{array}$ & $\begin{array}{l}\text { RAET } \\
\text { (Decreto-Lei } n^{\circ} \\
2.321 / 87)\end{array}$ & DPAI (93) & $\begin{array}{l}\text { DPROES (MP } n^{\circ} \\
1514 / 96) \\
>\text { Lei } 9496 / 97 \\
>\text { MP } n^{\circ} 1590 / 97 \\
\text { Lei de } \\
\text { Responsabilidade } \\
\text { Fiscal (LC n }{ }^{\circ} \\
\text { 101/00) }\end{array}$ \\
\hline ARO & $\begin{array}{l}\text { >Resolução do } \\
\text { SF n० } 1997 / 93\end{array}$ & $\begin{array}{l}>M P n^{\circ} \\
1560 / 96 \\
>E C n^{\circ} 19 / 98\end{array}$ & $\begin{array}{l}\text { > Resolução } n^{\circ} \\
78 / 98 \\
>\text { Lei de } \\
\text { Responsabilidade } \\
\text { Fiscal (LC } n^{\circ} \\
\text { 101/00) }\end{array}$ \\
\hline $\begin{array}{l}\text { Dívida } \\
\text { Mobiliária } \\
\text { (endividamento } \\
\text { através de } \\
\text { emissão de }\end{array}$ & & $>$ Lei 9496/97 & $\begin{array}{l}>\text { Resolução } n^{\circ} \\
78 / 98 \\
>\text { Lei de } \\
\text { Responsabilidade } \\
\text { Fiscal (LC n }\end{array}$ \\
\hline
\end{tabular}




\begin{tabular}{|c|c|c|c|}
\hline título) & & & 101/00) \\
\hline $\begin{array}{l}\text { Endividamento } \\
\text { (conceito mais } \\
\text { amplo) }\end{array}$ & & $>$ Lei 9496/97 & $\begin{array}{l}>\text { Resolução } n^{\circ} \\
78 / 98 \\
>\text { Lei de } \\
\text { Responsabilidade } \\
\text { Fiscal (LC } n^{\circ} \\
101 / 00) \text { - art. } 30 \\
\text { a } 33 .\end{array}$ \\
\hline $\begin{array}{l}\text { Negociação das } \\
\text { Dívidas } \\
\text { Estaduais }\end{array}$ & $\begin{array}{l}\Rightarrow \text { Lei } n^{\circ} \\
8727 / 93\end{array}$ & $\begin{array}{l}>\text { Voto CMN } \\
162 / 95\end{array}$ & $>$ Lei 9496/97 \\
\hline $\begin{array}{l}\text { Empréstimos } \\
\text { entre entes } \\
\text { federativos }\end{array}$ & & $>$ Lei 9496/97 & $\begin{array}{l}\text { Lei de } \\
\text { Responsabilidade } \\
\text { Fiscal (LC n } \\
101 / 00)- \text { art. } 35\end{array}$ \\
\hline $\begin{array}{l}\text { Empréstimos } \\
\text { para } \\
\text { financiamento } \\
\text { de despesas } \\
\text { com pessoal }\end{array}$ & & $>E C n^{\circ} 19 / 98$ & $\begin{array}{l}\text { L Lei de } \\
\text { Responsabilidade } \\
\text { Fiscal (LC } n^{\circ} \\
101 / 00)\end{array}$ \\
\hline
\end{tabular}

A Lei de Responsabilidade Fiscal deu uma melhor organicidade para o arcabouço que já existia, como também avançou em alguns pontos que ainda não existiam institucionalmente. Pode-se afirmar que, o fato dessas regras terem sido criadas de forma incremental, diluiu no tempo as resistências políticas ao projeto da LRF. A cada mudança institucional, abriu-se um espaço de avanço na direção de um maior ordenamento fiscal. É claro que os avanços foram mediados por alguns retrocessos pontuais ${ }^{184}$, mas a partir de 1998, com o agravamento da crise financeira internacional, os avanços superaram os possíveis obstáculos para a mudança.

O evento do refinanciamento das dívidas dos Estados foi um capítulo importante neste processo. Pode-se dizer que o fato de ter se iniciado um processo de refinanciamento das dívidas dos Estados, em 1997, e o modo como ocorreu, abriram um caminho de mudança pautado mais na negociação e em uma postura menos opositora, por parte dos governadores, do que se poderia imaginar a partir da concepção dos "barões da federação". Em todas as entrevistas em que se discutiu a questão federativa, foi afirmado categoricamente que os governadores não agiram politicamente para obstruir o processo decisório da Lei de Responsabilidade Fiscal. Houve reações críticas ao projeto no período das audiências públicas, mas a publicização da discordância não se converteu em

\footnotetext{
${ }^{184} \mathrm{O}$ argumento de que o processo incremental de ordenamento fiscal foi pontuado por avanços e retrocessos é muito bem trabalhado em Loureiro e Abrucio (2002).
} 
influência política dos governadores sobre as suas bancadas no Congresso, no sentido de obstruir a tramitação da matéria.

De fato, uma mudança institucional do sistema político que teve um impacto neste processo foi a aprovação da Emenda da Reeleição, em junho de 1997. Alguns estudos ${ }^{185}$ recentes permitem-nos afirmar que a perspectiva da reeleição gerou um incentivo para que o governante tivesse um comportamento fiscal mais responsável. Podemos dizer que esta mudança nas regras políticas afetou a disposição dos governadores em promover o ajuste fiscal, ou seja, assinar o acordo de renegociação das dívidas, que envolvia promover demissões e começar a pagar as parcelas da dívida. Contudo, o incentivo institucional para o ajuste fiscal foi mediado pelo ônus político que seria causado pelas demissões. A reeleição incentivou uma conduta fiscal mais responsável do governante, na medida em que este aspecto pesava significativamente no cálculo eleitoral da reeleição. Por outro lado, o ônus político da redução de gastos com pessoal através de demissões em massa não era desejável. Segundo Melo (2002), a solução deste impasse foi a aprovação da Lei Camata II, em junho de 1999. Os governadores puderam vincular as demissões a um imperativo constitucional, uma vez que se tratava de uma lei complementar. Se, na tramitação da Reforma Administrativa, os governadores foram aliados ativos, porem ambíguos, na tramitação da Lei de Responsabilidade fiscal esta ambigüidade foi pouco verificada. Este processo provocou uma mudança na disposição dos governadores com relação a LRF. Naquele momento, a lei acabou sendo encarada mais como uma maneira dos chefes dos executivos estaduais se desonerarem politicamente no processo de ajuste fiscal do que como uma restrição legal à autonomia fiscal e financeira dos governos estaduais.

Uma primeira leitura do texto do projeto da Lei de Responsabilidade Fiscal que entrou na Câmara pode sugerir que os interesses fiscais e financeiros dos atores federativos, especialmente Estados e Municípios, seriam afetados negativamente com a aprovação da lei, em função da redução do espaço de autonomia financeira e fiscal que a lei promoveria. A literatura abordada no primeiro capítulo sugere, entre outras coisas, que é difícil que um projeto de lei, que vá contra os interesses federativos, passe no Congresso, em virtude da ação das bancadas estaduais, mobilizadas pelos respectivos governadores dos Estados. Em função disso, o presente trabalho teve a seguinte pergunta de pesquisa: como a Lei

\footnotetext{
${ }^{185}$ Meneguin e Bugarin (2001).
} 
de Responsabilidade Fiscal foi construída em um sistema político caracterizado por diversos pontos de veto, entre eles os federativos?

\section{Com relação à ação dos atores políticos federativos no processo} decisório da LRF, a noção de Immergut sobre formação de pontos de veto no sistema político é bastante esclarecedora. O que observamos a partir da análise dos dados coletados? Os governadores e os prefeitos tiveram comportamento distinto no decorrer de todo o processo. Os governadores não agiram como atores com poder de veto no processo decisório da LRF. Eles agiram como facilitadores do processo, sugerindo idéias para o aperfeiçoamento da lei que convergiam com os seus interesses. Houve manifestações públicas de posições críticas, especialmente por parte de São Paulo, mas não houve uma mobilização política para pressionar as suas bancadas no Congresso, nem o Executivo Federal. Os entrevistados analisaram este fenômeno argumentando que os governadores ganhariam com a aprovação da lei, por duas razões básicas.

Primeiro, a possibilidade de financiamento por endividamento já havia sido encerrada com a renegociação das dívidas dos Estados, no âmbito da Lei 9496/97. Outras restrições severas - como a emissão de ARO no último ano de mandato e de novos títulos públicos por parte dos governos subnacionais que tiverem sua dívida mobiliária refinanciada pela União - também já estavam previstas na Resolução nº 78, de 1998.

Segundo, a LRF reduziria o ônus da realização do ajuste dos gastos com pessoal pelos Executivos Estaduais, especialmente ao estabelecer limites de gastos para os Poderes Legislativos e Judiciários estaduais. Os governadores argumentavam que tinham que respeitar os limites da lei diante das demandas dos seus eleitores e diante dos chefes dos outros poderes estaduais. O jogo político da LRF foi diferente do jogo da Reforma Tributária. Neste, os governadores disputam recursos entre si. Naquele, configurou-se um jogo de soma zero, no qual os principais problemas financeiros já estavam equacionados. Podemos afirmar que os governadores, naquele contexto político, econômico e institucional, deixaram-se amarrar ao "mastro", como Ulysses diante do "canto das sereias", mas temos que qualificar as razões para este comportamento. Enquanto o custo político das restrições ao endividamento e ao gasto diminuiu no tempo, em um quadro de grandes dificuldades financeiras, o custo da realização do ajuste nas despesas com pessoal aumentou, na medida em que os Legislativos e Judiciários estaduais não 
estavam enquadrados inicialmente nos limites que os Executivos estaduais estavam. A partir do momento que o Governo Federal incorporou o dispositivo da fixação de sublimites para despesa com pessoal de cada poder, a aprovação da LRF tornou-se interessante para os governadores.

A ação dos prefeitos foi diferente neste processo. Eles agiram de forma mais contundente, pressionando os deputados e senadores contra a aprovação da lei, através de marchas à Brasília, para fazer pressão sobre os parlamentares. Há algumas explicações para este comportamento diferenciado entre governadores e prefeitos. As condições de renegociação das dívidas dos Estados e dos Municípios foram diferentes. Os prefeitos tinham condições concretas de finanças públicas piores do que a dos governadores no momento da tramitação da LRF e agiram politicamente para defender seus interesses. Conforme relato, as condições do próprio endividamento dos governos estaduais e municipais eram bem distintas:

“(..) Boa parte dos estados já estavam muito amarrados pelos contratos de refinanciamento das dívidas. Os contratos de refinanciamento das dívidas seguravam muita coisa, exigiam metas esperadas primárias, enfim, tinha uma série de controles ali embutidos, e as prefeituras não. As prefeituras tinham menos possibilidade de formação de dívida no mercado, de dívida mobiliária. Na verdade, a dívida delas era de outra natureza, era dívida que consistia nos restos a pagar que eram deixados de um mandato para o outro. Então houve até um refinanciamento de dívidas dos municípios, mas foram poucos municípios, a grande maioria dos municípios do país tinha um problema com restos a pagar. E essa variável política ao meu ver pesou decisivamente pra acelerar a tramitação no Senado"186.

Havia incentivos institucionais diferentes com relação à possibilidade de punição: as regras de punição que estavam previstas na LRF referiam-se a sanções diferentes para governadores e prefeitos. Conforme foi abordado no capítulo III, os governadores são regidos pela Lei $\mathrm{n}^{\circ}$ 1.079, de 10 de abril de 1950, lei de crimes de responsabilidade, que prevê punição política, e os prefeitos, pelo Decreto-Lei $n^{\circ}$ 201, de 27 de fevereiro de 1967, que prevê punição penal. Esta diferença institucional gerou diferentes reações dos atores federativos diante do projeto da LRF. De acordo com a análise de Immergut (1996), a existência de diferentes configurações institucionais possibilitou subseqüentes conflitos políticos que envolveram prefeitos e governadores de forma totalmente diversa. As

\footnotetext{
${ }^{186}$ Entrevista com Selena Peres Peres Nunes, 08/09/05.
} 
alternativas políticas dos governadores e prefeitos foram desenhadas ex-ante, devido ao fato de que o arranjo institucional dos controles de gastos e de endividamento dos governos estaduais já vinham restringindo os espaços de atuação financeira dos chefes dos executivos estaduais, desde 1997 e 1998. No caso dos Municípios, durante a própria tramitação da LRF, alguns acordos de renegociação das dívidas tiveram que ser apressados, nas vésperas da sanção da lei no Senado, como foi o caso de São Paulo.

Da mesma forma, a reação dos governadores do PT foi totalmente diferente da reação dos parlamentares do mesmo partido: enquanto os últimos fizeram oposição ostensiva ao projeto de lei, os primeiros foram atores cooperativos e extremamente interessados na aprovação. Enquanto os governadores do PT, e outros em situação financeira delicada naquele período, apoiaram o projeto especialmente porque desejavam que fosse incorporado na lei o limite de gastos estaduais por poder, os deputados federais e senadores questionaram o tratamento dado às despesas com juros, em detrimento, segundo eles, das despesas com gastos sociais. Apesar de serem políticos do mesmo partido, a experiência na administração da máquina estatal estadual fez toda a diferença na posição que esses governantes assumiram diante do projeto da Lei de Responsabilidade Fiscal.

Os dados coletados sugerem que a construção da Lei de Responsabilidade Fiscal não pode ser entendida a partir da análise dos atores políticos federativos com poder de veto. Os governadores não tinham interesse em mobilizar suas bancadas parlamentares, a despeito de terem ou não canais de poder para tanto, o que não se constitui objeto de estudo do presente trabalho. O peso político desses atores foi levado em conta no processo de negociação, na medida em que o Governo Federal preocupou-se em criar canais de discussão e deliberação do projeto com os Secretários Estaduais da Fazenda, do Planejamento e do Orçamento. No entanto, ao contrário do que a literatura sugere, o fato de ter tramitado uma lei que provocaria mudanças institucionais importantes na autonomia financeira e fiscal dos Estados, não mobilizou politicamente os governadores para realizar o veto das bancadas estaduais ao projeto.

Apesar de todos esses processos convergirem para uma conjuntura que abria caminhos políticos para a implementação de mudanças estruturais, os dados demonstram que houve uma dura negociação política. A negociação se deu na arena do Executivo e do Legislativo, envolvendo os técnicos do Ministério da 
Fazenda e os do Banco Central de um lado, e os técnicos do Ministério do Planejamento e os do BNDES, de outro. Vários pontos foram objetos de conflito entre os técnicos, especialmente o que tratava da inclusão do Banco Central no limite do controle do endividamento da União e nos critérios de transparência que a lei estabelece. Um conflito que se destaca envolvia a competição dos grupos de técnicos pela iniciativa legislativa dentro do Executivo, no contexto da crise de 1998. De um lado, o grupo do Planejamento e do BNDES defendia a importância da elaboração de uma lei que equacionasse estruturalmente as finanças públicas e seus desdobramentos federativos. Esta lei trataria também da relação do Banco Central com os entes federativos. Por outro lado, os técnicos do Banco Central e do Ministério da Fazenda queriam que o projeto de lei do Banco Central independente fosse encaminhado para a Câmara e não admitiam que a instituição fosse incluída nos limites de endividamento da União, previstos na LRF. É interessante notar que os dois presidentes do Banco Central, Gustavo Franco e, posteriormente, Armínio Fraga, apoiaram o grupo do Planejamento e do BNDES no aprimoramento de vários pontos da lei.

Conforme o modelo de coordenação de interesses (Velasco Jr. 2005), no presidencialismo de coalizão brasileiro, o presidente de República age para superar os conflitos distributivos que envolvem matérias legislativas de seu interesse, através da ação dos ministros e dos líderes partidários, ao negociarem nas arenas partidárias e distributivas. No caso do processo decisório da LRF, isto se verificou na ação coordenada e intensiva da equipe do ministério do Planejamento. Primeiro, eles atuaram dentro do Executivo, discutindo com os técnicos do Banco Central e do Ministério da Fazenda. Depois, eles atuaram dentro da CESP da Câmara e acompanharam a tramitação no Senado e a impetração das Adins contra a lei. Durante todo o tempo, eles realizaram um trabalho de consultoria aos parlamentares in loco e também de convencimento, especialmente nas discussões na CESP. Segundo relato em entrevistas, na época da tramitação da Lei Kandir, esta forma de trabalho em equipe, visando promover o convencimento dos parlamentares sobre questões técnicas específicas, já tinha sido realizada por membros do grupo, que vieram com esta bagagem de aprendizagem de negociação para o processo decisório da LRF. Esse trabalho foi importante e fez a diferença no processo de produção da lei, na medida em que o nível de desconhecimento dos parlamentares sobre a área fiscal era muito grande. 
Inclusive, a equipe de técnicos do governo dedicou um tempo significativo com os trabalhos de discussão dos pontos da lei com a equipe de consultores da Câmara, sendo que estes exercem poder de convencimento sobre os parlamentares, na medida em que oferecem respaldo técnico para a atuação parlamentar dos deputados em áreas complexas.

As etapas do processo decisório que ocorreram no âmbito da Comissão Especial da Câmara foram fundamentais para definir o texto da Lei de Responsabilidade Fiscal. Ao contrário de alguns trabalhos que discutiram o processo decisório da Lei de Responsabilidade Fiscal, argumentando que se tratou de um processo de tramitação rápida, de pouco conflito e que o texto da lei foi pouco modificado, argumenta-se no presente trabalho que, a despeito da tramitação rápida e do "espírito" da lei ter sido imaculado, houve um amplo e duro processo de negociação. O texto da lei foi modificado substancialmente na forma e foi aprimorado, de um modo geral, na direção do interesse dos técnicos do Ministério do Planejamento, que agiram, nos termos de Velasco (2005), como líderes de coalizão, juntamente com o líder do governo na Câmara, dep. Arnaldo Madeira. Os líderes de coalizão são aqueles que influenciam e conduzem a estrutura do processo decisório. No início do processo, havia uma resistência por parte deste grupo para a concessão de mudanças no texto. No decorrer do processo legislativo, essa atitude mudou, em função das contingências do processo de negociação e da urgência que o Governo Federal tinha para a aprovação do projeto. No âmbito da CESP, ficou claro que o eixo do conflito parlamentar era partidário. Os atores políticos que estabeleceram uma postura opositora ao projeto, durante todo o processo, foram os partidos de oposição ao Governo Cardoso, especialmente o PT e o PCdoB. Conforme a interpretação dos membros do grupo do Executivo Federal que elaborou a lei, houve inúmeras conversas com os membros desses partidos, mas a postura opositora foi mantida em função de oposição política per se. O projeto da LRF era considerado um dos mais importantes do Governo Cardoso.

O papel do relator da Comissão Especial é importante no modelo de Velasco. Ele deve ampliar as bases de cooperação dos atores políticos. Conforme os relatos das entrevistas, no processo decisório da LRF, o relator da comissão agiu mais como catalisador de conflito dentro da comissão do que como agente de estratégicas cooperativas entre os atores. Segundo vários entrevistados, o relator 
tinha idéias próprias sobre alguns pontos da lei. Apesar do controle do governo na escolha do relator, este apresentou uma grande disposição para fazer mudanças no texto. Foi necessária uma grande mobilização da equipe do Planejamento e do BNDES para convencer os deputados sobre a relevância de cada ponto do projeto original. No final de sete meses de tramitação, o substitutivo do relator deu nova organicidade ao projeto, mas manteve os principais artigos defendidos pela equipe do governo. Inclusive o artigo que tinha saído do texto na discussão do projeto no Executivo, sobre a inclusão do Banco Central na lei, foi reincorporado no âmbito das discussões na CESP.

No modelo de coordenação de interesses de Velasco Jr. (2005), o Executivo, subsidiado pelos líderes de coalizão, no mapeamento dos interesses particulares, que poderiam colocar em risco a aprovação da política desejada, detém recursos para garantir apoio à proposta (p. 22). Nesse modelo, incluem-se recursos de patronagem. No caso da aprovação da LRF, segundo alguns relatos, esses recursos foram utilizados, com a distribuição de emendas do orçamento para beneficiar os distritos eleitorais dos parlamentares. Em algumas votações nominais, mesmo nas quais a coalizão do governo conseguiu maioria, alguns partidos da oposição também votaram a favor da posição do governo.

Enfim, a análise do processo decisório da Lei de Responsabilidade Fiscal nos permite demonstrar dois pontos. Primeiro, que a interação entre os entes federativos, os atores parlamentares e os técnicos do Executivo, nas arenas decisórias, é bem mais complexa do que nos sugere a análise dos atores com poder de veto. Segundo, que o Executivo Federal conseguiu implementar a principal lei da sua agenda fiscal, em pouco tempo e com pouca mudança no texto, utilizando mecanismos institucionais e políticos, tais como: a criação da Comissão Especial e a convocação extraordinária na Câmara, a tramitação em regime de urgência nas duas casas legislativas, a votação em globo dos destaques simples na Câmara, o trabalho de convencimento dos assessores parlamentares da Câmara, o acordo com os Senadores para que eles não realizassem mudanças no conteúdo dos dispositivos, o que provocaria o retorno do projeto à Câmara, a distribuição de emendas do orçamento aos parlamentares.

Contudo, ao abrirmos a "caixa preta" do processo decisório da LRF verificamos que, a despeito dos recursos à disposição do Governo Federal para aprovar a lei, o processo decisório que a gerou foi caracterizado por um amplo 
processo de negociação, que garantiu que os principais pontos da lei, como o art. 35, que proíbe o socorro financeiro entre os entes da federação, não fossem alterados no decorrer da tramitação da Câmara e do Senado. É importante destacar também que, ao abrir um amplo processo de negociação, o governo possibilitou que outros pontos importantes fossem incorporados, inclusive de interesse dos governadores. Ou seja, o governo incorporou os atores políticos que potencialmente poderiam obstruir o processo e criou, através de concessões concretas, uma dinâmica de co-produção e inclusão desses atores na elaboração da lei e no processo de responsabilidade fiscal das finanças públicas no país. Em todo este processo, o Governo Federal teve que ceder em alguns pontos, porém pouco relevantes, como a correção de descontroles fiscais provocados pela recessão e pelo aumento da taxa de juros.

A Lei de Responsabilidade Fiscal foi um marco não somente no processo de ordenamento fiscal e financeiro, mas nas relações políticas federativas. Acreditamos que foi um passo importante na direção de práticas de governo mais republicanas, concretizando no conteúdo desta lei complementar uma demanda política e social que foi historicamente construída.

A despeito da sua importância, a Lei de Responsabilidade Fiscal não pode ser considerada uma lei que garante a moralização permanente da administração pública. Esta lei faz parte de um processo de melhoria da gestão fiscal que começou na década de 1980, mas que ainda está inacabado. É preciso avançar no campo orçamentário e das finanças públicas, de um modo geral, corrigindo algumas falhas de normatização ${ }^{187}$. Podemos afirmar que a lei foi uma rígida resposta institucional diante do quadro de desordem fiscal e financeira nas contas públicas dos entes federativos na década de 1980 e na primeira metade da década de 1990.

No entanto, os incentivos às boas práticas de administração pública ainda dependem em grande medida de decisões políticas. A Lei de Responsabilidade Fiscal, ao ser uma lei complementar, representa um forte indicativo institucional para os agentes de mercado e para os atores sociais de que o Governo Federal está comprometido com a austeridade fiscal. Porém, ela não esvazia o espaço da política no controle do endividamento público. Desde a promulgação da LRF, ocorreram algumas pressões de governadores e, especialmente, de prefeitos pelo

\footnotetext{
${ }^{187}$ Sobre essas falhas, ver Oliveira (2004).
} 
refinanciamento das dívidas (caso da Prefeitura de São Paulo). Será no curso das próximas eleições e no encaminhamento jurídico dos processos contra os governantes que já incorreram em crimes previstos na lei que poderemos observar a consistência do ordenamento fiscal e financeiro que está ocorrendo no país há 20 anos. 


\section{Referências Bibliográficas}

ABRUCIO, Fernando Luiz (1994). Os Barões da Federação. Lua Nova, nº 33, pp. 165-183.

ABRUCIO, Fernando Luiz (1998). Os Barões da Federação: os governadores e a redemocratização brasileira. São Paulo: Hucitec, Departamento de Ciência Política, USP.

ABRUCIO, Fernando Luiz (2000). Os laços federativos brasileiros: avanços, obstáculos e dilemas no processo de coordenação intergovernamental. Tese de doutorado apresentada ao Departamento de Ciência Política da Universidade de São Paulo.

ABRUCIO, Fernando Luiz (2002). Descentralização e Coordenação Federativa no Brasil: Lições dos Anos FHC. In: LOUREIRO, Maria Rita e ABRUCIO, Fernando Luiz (orgs.). O Estado Numa Era de Reformas: Os Anos FHC (Parte II). Brasília: MP, SEGES, p: 143-245.

ABRUCIO, Fernando e COSTA, Valeriano Mendes Ferreira (1998) Reforma do Estado e o contexto federativo brasileiro. São Paulo: Fundação KonradAdenauer-Stiftung e. V. , Pesquisas, no. 12.

ABRUCIO, Fernando e SAMUELS, David. (1997). A Nova Política dos Governadores. Lua Nova, n 40/41, pp. 137-166.

AFFONSO, Rui (1994). A Crise da Federação no Brasil. Ensaios FEE, 15 (2), pp. 321-337.

AFFONSO, Rui. (1995) A Federação no Brasil: Impasses e Perspectivas. In: AFFONSO, Rui e SILVA, Pedro Luiz Barros (orgs.) A Federação em Perspectiva: Ensaios Selecionados. São Paulo: Fundap, 1995. 
AFONSO, José Roberto R. (1992). Memória da Assembléia Constituinte de 1987/88: As Finanças Públicas. Disponível em:

http://www.bndes.gov.br/conhecimento/revista/rev1102.pdf.

AFONSO, José Roberto R. (1994). Descentralização Fiscal na América Latina: Estudo de caso do Brasil. Santiago, Naciones Unidas/ Comisión Económica para América Latina y Caribe.

AFONSO, José Roberto R. (1996). Descentralizar e Depois Estabilizar: a Complexa Experiência Brasileira. Revista do BNDES, Rio de Janeiro, v. 3, n. 5, pp. 31-62, Junho de 1996.

ALMEIDA, Maria Hermínia Tavares. (1996) Pragmatismo por necessidade: os rumos da reforma econômica no Brasil. Dados - Revista de Ciências Sociais, Rio de Janeiro, vol. 39, nº 2, pp. 213-234.

ALMEIDA, Maria Hermínia Tavares. (1999) Negociando a Reforma: A Privatização de Empresas Públicas no Brasil. Dados - Revista de Ciências Sociais, Rio de Janeiro, vol. 42, $\mathrm{n}^{\circ} 3$.

ALMEIDA, Maria Hermínia Tavares. (2001) Federalismo, Democracia e Governo no Brasil: Idéias, Hipóteses e Evidências. BIB - Revista Brasileira de Informação Bibliográfica em Ciências Sociais, no. 51, pp. 13-34.

ALMEIDA, Maria Hermínia Tavares. (2005) Recentralizando a Federação? Revista de Sociologia e Política, Curitiba, Vol. 24, pp. 29-40, Junho de 2005.

AMES, Barry (2001) A democracia brasileira: uma democracia em xeque. In: ABREU, Alzira Alves (org.). Transição em Fragmentos. São Paulo: Editora FGV.

AMES, Barry (2003) Os entraves da democracia no Brasil. São Paulo: Editora FGV. 
ASAZU, Claudia Yukari (2003) Os caminhos da Lei de Responsabilidade Fiscal (LRF): instituições, idéias e incrementalismo. Dissertação de mestrado apresentada ao Curso de Pós-Graduação da EAESP/FGV.

ASAZU, Claudia e ABRUCIO, Fernando Luiz (2003). A Gênese da Lei de Responsabilidade Fiscal (LRF): a Construção de uma Agenda In: Anais do ENANPAD 2003, ENANPAD 2003, Atibaia.

BIERSTEKER, Thomas J. (1995). The "triumph" of liberal economic ideas in developing world. In Stallings, Barbara, eds., Global change, regional responses the new international context of development, Cambridge University Press, pp. 174198.

BONFIM, Antulio \& SHAH, Anwar (1994). Macroeconomic management and the division of powers in Brazil: perspectives for the 1990s. World Development, Volume 22, Issue 4, April 1994, 535-542.

CAMPOS, Iris Walquiria (2002). O impasse da Reforma Tributária na Era FHC: tecnocracia versus elite industrial: o triunfo da arrecadação sobre a produção. Tese de Doutorado apresentada ao Departamento de Ciência Política da USP.

COUTO, Claudio \& ABRUCIO, Fernando. (1999). Arenas políticas e agenda econômica: os caminhos institucionais do Real. Texto apresentado na Reunião Anual da ANPOCS, Caxambu.

DAIN, Sulamis (1995). Federalismo e Reforma Tributária. In: AFFONSO, Rui e SILVA, Pedro Luiz Barros (orgs.) A Federação em Perspectiva: Ensaios Selecionados. São Paulo: Fundap, 1995.

DIÁRIO DA CÂMARA DOS DEPUTADOS (abril de 1999 a fevereiro de 2000).

DIÁRIO DO SENADO FEDERAL (fevereiro a maio de 2000). 
EATON, Kent and DICKOVICK, J. Tyler (2004). The Politics of Recentralization in Argentina and Brazil. Latin American Research Review, vol. 39, $\mathrm{n}^{\circ}$ 1, February 2004.

FERNANDES, Antônio Sérgio Araújo (2002). Path Dependency e os Estudos Históricos Comparados. BIB - Revista Brasileira de Informação Bibliográfica em Ciências Sociais, no. 53, pp. 79-102.

FIGUEIREDO, Argelina \& LIMONGI, Fernando (2001). Executivo e Legislativo na nova ordem constitucional. Rio de Janeiro: Editora FGV, $2^{\text {a }}$. Edição.

GARMAN, Christopher da Cunha Bueno, HAGGARD, Stephan e WILLIS, Eliza. (2001) Fiscal Decentralization - A Political Theory with Latin American Cases. World Politics, 53, January 2001, 205-36.

GARMAN, Christopher da Cunha Bueno, LEITE, Cristiane Kerches da Silva e MARQUES, Moisés da Silva. (1998) Impactos das relações Banco Central x Bancos Estaduais no arranjo federativo pós-1994 - Análise à luz do caso Banespa. Revista de Economia Política, vol. 21, nº 1 (81), janeiro-março/2001, p. 40-61.

GOMES, Gustavo Maia e MAC DOWELL, Maria Cristina (2000). Descentralização Política, Federalismo Fiscal e Criação de Municípios: o que é mau para o econômico nem sempre é bom para o social. Texto para discussão $n^{\circ}$ 706, Brasília, IPEA, fevereiro de 2000.

GOUREVITCH, Peter (1986). Politics in Hard Times - Comparative Responses to International Economic Crises. Ithaca and London. Cornell University Press.

GREGGIANIN, Eugênio \& OLIVEIRA, Wéder (2000). Lei de Responsabilidade Fiscal: principais aspectos relativos aos Estados e Municípios (Estudo). Câmara dos Deputados; Consultoria de Orçamento e Fiscalização Financeira; Brasília, 27 de abril de 2000. 
GREENER, Ian (2002). Understanding NHS Reform: The Policy-Transfer, Social Learning and Path-Dependency Perspectives. Governance: An International Journal of Policy, Administration, and Institutions, Vol. 15, n 2, April 2002 (pp. 161183).

GUARDIA, Eduardo (2004). As Razões do Ajuste Fiscal. In: GIAMBIAGI, F.; REIS, J. G.; URANI, A. (orgs.) Reformas do Brasil: Balanço e Agenda. Editora Nova Fronteira.

HALL, Peter (1992). The movement from Keynesianism to monetarism: Institutional analysis and British economic policy in the 1970s. In: Steinmo, Sven; Thelen, Kathleen; Longstreth, Frank. Structuring politics: historical institutionalism in comparative analysis. New York: Cambridge University Press, pp. 90-109.

IMMERGUT, Ellen M. (1996). As Regras do Jogo: A lógica da política de saúde na França, na Suíça e na Suécia. Revista Brasileira de Ciências Sociais, $\mathrm{n}^{\circ}$ 30 , ano 11.

KINZO, Maria D'Alva Gil. (1997), Governabilidade, Estrutura Institucional e Processo Decisório no Brasil. Parcerias Estratégicas, vol.1, n 3, pp. 19-53.

KUGELMAS, Eduardo (2001). A Evolução Recente do Regime Federativo no Brasil. In: W. Hofmeister e J. M. B. Carneiro (eds.) Federalismo na Alemanha e no Brasil. São Paulo: Konrad-Adenauer Stiftung.

KUGELMAS, Eduardo \& SOLA, Lourdes. (1999) Recentralização/Descentralização: dinâmica do regime federativo no Brasil dos anos 90. Tempo Social - Revista de Sociologia Política da USP, São Paulo, 11(2): 63-81, out. 1999 (editado em fevereiro de 2000).

LAGEMANN, Eugênio (1995). O Federalismo Fiscal Brasileiro em Questão. In: AFFONSO, Rui e SILVA, Pedro Luiz Barros (orgs.) A Federação em Perspectiva: Ensaios Selecionados. São Paulo: Fundap, 1995. 
LAMOUNIER, Bolívar. (1991), Depois da Transição: Democracia e Eleições no Governo Collor. São Paulo, Edições Loyola.

LEITE, Cristiane Kerches da Silva. (2001) Autoridade Monetária e Federalismo no Brasil: uma reflexão sobre a reforma do sistema de bancos públicos estaduais. Dissertação de Mestrado apresentada ao Departamento de Ciência Política da FFLCH-USP, defendida em 06 de fevereiro de 2001.

LOPREATO, Francisco Luiz Cazeiro. (1992) Crise de Financiamento dos Governos Estaduais (1980/1988). Tese de Doutoramento em Economia apresentada ao Instituto de Economia da Unicamp, Campinas.

LOPREATO, Francisco Luiz Cazeiro. (1997) Um novo caminho do federalismo no Brasil? Economia e Sociedade, Campinas, (9): 95-114, Dezembro de 1997.

LOPREATO, Francisco Luiz Cazeiro. (2000) O endividamento dos governos estaduais nos anos 90. Economia e Sociedade, Campinas, (15): 117-158, Dezembro de 2000.

LOPREATO, Francisco Luiz Cazeiro. (2002) O colapso das finanças estaduais e a crise da federação. São Paulo: Editora UNESP, IE - Unicamp, 2002.

LOUREIRO, Maria Rita (2001a). O Senado no Brasil recente: política e ajuste fiscal. São Paulo Perspectiva, out./dez. 2001, vol.15, no.4, p.53-61. ISSN 0102-8839.

LOUREIRO, Maria Rita. (2001b) Instituições, Política e Ajuste Fiscal - O Brasil em perspectiva comparada. Revista Brasileira de Ciências Sociais, Vol. 16, $n^{\circ} 17$, outubro, pp. 75-96.

LOUREIRO, Maria Rita e ABRUCIO, Fernando Luiz (2002). Incrementalismo, Negociação e Accountability: Análise Preliminar das Reformas Fiscais no Brasil. In: LOUREIRO, Maria Rita e ABRUCIO, Fernando Luiz (orgs.). O Estado Numa Era de Reformas: Os Anos FHC (Parte II). Brasília: MP, SEGES, p: 57-102. 
MAINWARING, Scott (1997), Multipartism, Robust Federalism and Presidentialism in Brazil, in S. Mainwaring e M. S. Shugart (eds.), Presidentialism and Democracy in Latin America. Cambridge, Cambridge University Press.

MELO, Marcus André (2002). Reformas Constitucionais no Brasil instituições políticas e processo decisório. Rio de Janeiro: Ed. Revan.

MELO, Marcus André (2002b). As mudanças constitucionais na administração pública: a reforma "quase negociada". Apresentado no $3^{\circ}$ Encontro da ABCP, na Universidade Federal Fluminense, Niterói, Rio de Janeiro, 28 a 32 de julho de 2002.

MENEGUIN e BUGARIN (2001). Reeleição e Política Fiscal: um estudo dos efeitos da reeleição nos gastos públicos. Disponível em: http://www.unb.br/face/eco/mesp/professores/bugarin/HP-Feb2001/papers/RPF1101.pdf . Acesso em: 08 de março de 2006.

MONTERO, Alfred (2001) Elaboração de políticas econômicas em nível subnacional no Brasil: uma colcha de retalhos. In: ABREU, Alzira Alves (org.). Transição em Fragmentos. Editora FGV.

MORA, Mônica (2002). Federalismo e Dívida Estadual no Brasil. Texto para Discussão n 866. Rio de Janeiro, IPEA, Março de 2002.

MORA, Mônica e VARSANO, Ricardo (2001). Fiscal Decentralization and Subnational Fiscal Autonomy in Brazil: Some Facts of the Nineties. Texto para discussão nº 854, Rio de Janeiro, IPEA, dezembro de 2001.

NOGUEIRA, Julio Cesar de A. (1995). O Financiamento Público e Descentralização Fiscal no Brasil. Texto para Discussão $n^{\circ} 34$, Rio de Janeiro: CEPP. 
OLIVEIRA, Weder (2004). Lei de Responsabilidade Fiscal, Margem de Expansão e o Processo Legislativo Federal. Brasília: ESAF. Monografia premiada em $1^{\circ}$ lugar no IX Prêmio Tesouro Nacional - 2004, Lei de Responsabilidade Fiscal - Tema Especial.

PAES, Julieda Puig Pereira (1996). Bancos Estaduais, "Criação" de Moeda e Ciclo Político. Dissertação de Mestrado em Economia. São Paulo, Fundação Getúlio Vargas.

PALERMO, Vicente (2000). Como se governa o Brasil? O debate sobre as Instituições Políticas e Gestão de Governo. Dados - Revista de Ciências Sociais, v. $43, n^{\circ} 3$, Rio de Janeiro.

PIANCASTELLI, Marcelo e CAMILO, Ronaldo (2003). Redistribuição do Gasto Público em Democracias Federativas: Análise do Caso Brasileiro. Texto para discussão n 1001, Brasília, IPEA, novembro de 2003.

PIO, Carlos (2001). A Estabilização Heterodoxa no Brasil: idéias e redes políticas. Revista Brasileira de Ciências Sociais, Vol. 14, n 46, Junho/2001.

RAMOS, Ana Paula (2001). A Política Fiscal do Plano Real e o Ajuste Fiscal para 1999/2001. Revista de Economia Política, vol. 21, nº 4 (84), outubro/dezembro de 2001.

RANGEL, Marcos de Almeida (1999). Resgates Financeiros, Restrição Orçamentária Fraca e Postura Fiscal nos Estados Brasileiros. Dissertação de Mestrado apresentada no Departamento de Economia da PUC/Rio, em 02 de julho de 1999.

REZENDE, Fernando \& AFONSO, José Roberto R. (2004) A Federação Brasileira: Fatos, Desafios e Perspectivas. Capítulo da Parte III, pp. 301-362, do livro "Federalismo e Integração Econômica Regional - Desafios para o Mercosul", publicado pela Konrad Adenuaer, FGV e Fórum of Federations, em 2004. 
SAMUELS, David (2003) A Economia Política da Reforma Macroeconômica no Brasil (1995 - 2002). Dados - Revista de Ciências Sociais, v. 46, $n^{\circ} 4$, Rio de Janeiro, 805-835.

SANTOS, Maria Helena de Castro, RUA, Maria das Graças e MACHADO, Érica Mássimo (1994). Interesses Sociais e poderes constituídos na política fiscal e tributária dos Governos Collor e Itamar Franco: Padrões de Interação, Conflitos e Barganhas. Cadernos de Ciência Política, Fundação Universidade de Brasília, Departamento de Ciência Política e Relações Internacionais, Brasília, Setembro de 1994.

SERRA, José. (1989) A Constituição e o Gasto Público. Disponível em: http://federativo.bndes.gov.br/f_estudo.htm

SERRA, José \& AFONSO, José Roberto Rodrigues (1991). Finanças Públicas Municipais: Trajetórias e Mitos. Conjuntura Econômica, Vol. 45, n 10, pp. 44-50.

SERRA, José \& AFONSO, José Roberto Rodrigues (1999). Federalismo Fiscal à Brasileira: algumas reflexões. Revista do BNDES. Rio de Janeiro, v. 6, n. 12, p. 3-30, Dezembro de 1999.

SOLA L. Estado, Transformação Econômica e Democratização. In Sola, Lourdes (org.) (1993). Estado, Mercado e Democracia: Política e Economia Comparadas. Rio de Janeiro: Paz e Terra.

SOLA, Lourdes. (1995) Estado, Reforma Fiscal e Ordem Monetária: Qual Estado? In: SOLA, Lourdes e PAULANI Leda (org.). Lições da Década de 80 . São Paulo: EDUSP, p: 29-74.

SOLA, Lourdes, GARMAN, Christopher da Cunha Bueno e MARQUES, Moisés da Silva. (1998). Central banking, democratic governance and political authority: the case of Brazil in a comparative perspective. Revista de Economia Política, 18(2): 106-131. 
SOUZA, Celina (2001). Federalismo e Descentralização na Constituição de 1988: Processo Decisório, Conflitos e Alianças. Dados - Revista de Ciências Sociais, v. 44, $n^{\circ} 3$, Rio de Janeiro, p. 513-560.

SOUZA, Celina (2003). O Estado das Artes da área de políticas públicas: conceitos e principais tipologias. Trabalho apresentado no XXVI Encontro Anual da Anpocs, 2003.

STEINMO, Sven and THELEN, Kathleen. Historical institutionalism in comparative politics. In: STEINMO, Sven, THELEN, Kathleen and LONGSTRETH, Frank (1992). Structuring politics: Historical institutionalism in comparative analysis. New York, Cambridge University Press.

STEPAN, Alfred. (1999), Para uma Nova Análise Comparativa do Federalismo e da Democracia: Federações que Restringem ou Ampliam o Poder do Demos. Dados - Revista de Ciências Sociais, Vol. 42, nº 2, Rio de Janeiro, p. 197251.

TAVARES, Martus (2005). Vinte anos de política fiscal no Brasil: dos fundamentos do novo regime à Lei de Responsabilidade Fiscal. Revista de Economia \& Relações Internacionais, Vol. 4, nº 7, Julho de 2005, pp. 79-101.

VELASCO, Licínio Júnior (2005). Políticas Reformistas no presidencialismo de coalizão brasileiro. Textos para Discussão $n^{\circ} 105$, BNDES, Rio de Janeiro, outubro de 2005.

WILLIS, E. C., GARMAN, C. B. e HAGGARD, S. (1999). The Politics of Decentralization in Latin America. Latin American Research Review, vol. 34, $\mathrm{n}^{\circ} 1$, pp. 73-102. 


\section{Entrevistas}

Sr. Luiz Carlos Mendonça de Barros (Presidente do BNDES entre novembro de 1995 e abril de 1998; hoje, sócio-diretor da Quest Investimento e editor da revista Primeira Leitura), no dia 05 de agosto de 2005, em São Paulo.

Sr. Amir Khair (Consultor na área fiscal, orçamentária e tributária), no dia 10 de agosto de 2005, em São Paulo.

Sr. Yoshiaki Nakano (Secretário da Fazenda do Estado de São Paulo, de 1995 a 2001; hoje é professor de Economia, diretor da Escola de Economia e chefe do Departamento de Economia da Escola de Administração de Empresas de São Paulo, da Fundação Getúlio Vargas (FGV/EAESP)), no dia 22 de agosto de 2005, em São Paulo.

Sr. Arnaldo Madeira (Deputado Federal (PSDB-SP); líder do Governo Fernando Henrique Cardoso na Câmara entre 1998 e 2002; atual Secretário da Casa Civil do Estado de São Paulo), no dia 25 de agosto de 2005, em São Paulo.

Sr. José Roberto Rodrigues Afonso (Superintendente de Seguridade do Fundo de Previdência Complementar dos empregados do BNDES e da área fiscal e de emprego; atualmente é economista de carreira do BNDES e Consultor Técnico da Câmara dos Deputados), no dia $1^{\circ}$ de setembro de 2005, em São Paulo.

Sr. Martus Tavares (Secretário Executivo do Ministério do Planejamento, Orçamento e Gestão, entre 1996 e 1999; Ministro do Planejamento do Governo Fernando Henrique Cardoso, entre 1999 e 2002; atual Secretário do Planejamento do Estado de São Paulo) e com a Sra. Selma Pantel (Assessora do Ministério do Planejamento e atual Assessora da Secretaria do Planejamento do Estado de São Paulo), no dia 06 de setembro de 2005, em São Paulo.

Sra. Selene Peres Peres Nunes (Assessora Econômica do Ministério do Planejamento, Orçamento e Gestão; atualmente, Assessora de Política Fiscal e Orçamentária do INESC), no dia 20 de setembro de 2005, em Brasília. 
Sr. Wéder de Oliveira (Consultor de Orçamento da Câmara dos Deputados; atualmente, Consultor do Senado Federal), no dia 21 de setembro de 2005, em Brasília.

Sr. Dep. Sérgio Miranda (PCdoB-MG), no dia 22 de setembro de 2005, em Brasília.

Sr. Luiz Carlos Bresser-Pereira (Presidente do Banespa (Montoro), de março de 1983 a março de 1985; Secretário do Governo do Estado de São Paulo (Montoro), de março de 1985 a março de 1987; Secretário de Ciência e Tecnologia (Quércia), entre março-abril 1987; Ministro de Estado dos Negócios da Fazenda no Governo Sarney, de 29 de abril a 18 de dezembro de 1987; Ministro de Administração Federal e da Reforma do Estado, no primeiro governo FHC (95-98); Assessor do Presidente FHC para assuntos de governança e terceira via, de agosto de 1999 a dezembro de 2002), no dia 07 de outubro de 2005, em São Paulo. 


\section{Anexos}

Anexo 1:

Quadro 1: As principais normas fiscais da década de 70 à Constituição de 1988, em ordem cronológica.

\begin{tabular}{|c|c|}
\hline ETAPAS NORMATIVAS & OBSERVAÇÕES \\
\hline Lei Complementar nº 12, de 1971 & $\begin{array}{l}\text { Transferiu-se para o Banco Central e o Conselho Monetário Nacional o poder } \\
\text { de autorizar a emissão de títulos públicos, circunscrevendo o controle do } \\
\text { endividamento público ao raio de influência do Executivo, mais especialmente } \\
\text { ao Ministério da Fazenda (Loureiro 2001). Desta forma, o Banco Central } \\
\text { assumiu o comando da política de dívida pública e passou a ter autonomia } \\
\text { para ampliar o volume de títulos e responder pelos encargos decorrentes } \\
\text { (Lopreato 2002: } 51 \text { ). Nesta época, surgiu um mercado de títulos } \\
\text { governamentais que permitiu a expansão da dívida do setor público. Desta } \\
\text { forma, segundo Mora (2002), criaram-se as condições necessárias para o } \\
\text { financiamento subnacional por terceiros. (Mora 2002: } 05 \text { ). }\end{array}$ \\
\hline Resolução do Senado Federal n 93, de 1976. & $\begin{array}{l}\text { Marcou o início de um processo de regulamentação do endividamento } \\
\text { estadual. Essa resolução estabelecia limites às operações de crédito internas } \\
\text { (as intralimites, as operações de crédito que poderiam ser efetivadas } \\
\text { independente da autorização do Senado Federal) e definia aquelas } \\
\text { classificadas como extralimites (realizadas com recursos do Banco Nacional } \\
\text { de Habitação, do Fundo de Apoio ao Desenvolvimento Urbano e do Fundo de } \\
\text { Apoio ao Desenvolvimento Social, e só poderiam se concretizar após } \\
\text { autorização do Bacen, da Sarem, do CMN e do Senado Federal), mas não } \\
\text { tratava da dívida externa. Para a contratação de operações com credores } \\
\text { externos os governos subnacionais deveriam solicitar autorização ao Senado } \\
\text { Federal e consultar o Executivo Federal, que chancelava o pedido. Segundo } \\
\text { Lopreato (2002), ao definir as dívidas intralimite e extralimite, esta resolução } \\
\text { reforçou as oportunidades das unidades da federação não obedecerem aos } \\
\text { limites. }\end{array}$ \\
\hline $\begin{array}{l}\text { Resolução do Senado Federal } n^{\circ} 62 \text {, de 28/10/1975; } \\
\text { Resolução Bacen } n^{\circ} 345 \text {, de 13/11/1975; } \\
\text { Resolução do Senado Federal n 93, de 11/10/1976. }\end{array}$ & $\begin{array}{l}\text { A legislação de controle ao endividamento assegurava um elevado poder } \\
\text { discricionário na concessão de crédito, a alocação desses recursos ao arbítrio } \\
\text { da União (Mora 2002: 06). A possibilidade de as unidades se valerem das } \\
\text { operações externas, das dívidas extralimites do direito de requerer a elevação }\end{array}$ \\
\hline
\end{tabular}




\begin{tabular}{|c|c|}
\hline & $\begin{array}{l}\text { temporária dos limites de endividamento e de apelarem à descaracterização } \\
\text { das garantias oferecidas às autarquias e a outras entidades do governo, } \\
\text { provocou uma politização da questão da dívida. O nível de endividamento da } \\
\text { cada Estado passou a estar diretamente condicionado ao poder de barganha } \\
\text { e aos interesses envolvidos no processo de negociação de cada novo pedido } \\
\text { de operação de crédito, principalmente nas unidades com baixa capacidade } \\
\text { de expandir o endividamento intralimite (Lopreato } 2002: 73 \text { ). Assim, o controle } \\
\text { dos limites de endividamento apresentou poucos resultados técnicos e se } \\
\text { resumiu ao papel de instrumento de barganha política e anuência da União } \\
\text { sobre os governos estaduais. A aprovação de novas operações de crédito } \\
\text { estava sujeita a negociações e ao poder da área econômica de impor suas } \\
\text { decisões, que variavam de acordo com a força dos governadores e a } \\
\text { influência destes na configuração do momento político (Lopreato 2002: 74). }\end{array}$ \\
\hline Emenda Constitucional $n^{\circ} 17$, de 12/12/1980. & $\begin{array}{l}\text { Passo inicial do processo de descentralização fiscal, ao ampliar o valor do } \\
\text { repasse dos fundos de participação. }\end{array}$ \\
\hline Emenda Passos Porto ( $n^{\circ} 23$, de 01/12/1983). & $\begin{array}{l}\text { A partir de } 1982 \text {, em resposta à pressão dos governadores e prefeitos, o } \\
\text { Congresso aprovou a elevação da taxa do FPE para } 14 \% \text { e a taxa do FPM } \\
\text { para } 16 \% \text {. }\end{array}$ \\
\hline Resolução do BC n 831, de 09/06/1983 & $\begin{array}{l}\text { Impôs a fixação de limites mensais à expansão dos empréstimos do setor } \\
\text { público junto ao sistema financeiro nacional, buscando ampliar o controle do } \\
\text { endividamento e endurecendo as metas relativas ao setor público com } \\
\text { medidas de políticas monetária e fiscal agressivas, que visavam garantir um } \\
\text { orçamento operacional superavitário em } 1984 \text { (Lopreato 2002: 82). Esta } \\
\text { medida representou uma inovação normativa no campo do controle do } \\
\text { endividamento, ao criar um instrumento legal, sem concessões de ordem } \\
\text { política: a fixação de tetos pelo Banco Central para as operações de crédito } \\
\text { das instituições financeiras e das sociedades de arrendamento mercantil } \\
\text { realizadas com o setor público, impondo sanções para quem desrespeitasse } \\
\text { as normas legais (idem: 152). O rigor na limitação das operações de crédito }\end{array}$ \\
\hline
\end{tabular}




\begin{tabular}{|c|c|}
\hline & $\begin{array}{l}\text { refletiu no aumento das operações com os bancos comerciais estaduais e das } \\
\text { operações por antecipação de receitas. Para melhorar a situação de escassez } \\
\text { de recursos do setor público, o Governo Federal criou o Aviso MF } 30 \text {, que } \\
\text { consistia em empréstimos-ponte, com o objetivo de refinanciar o passivo } \\
\text { externo de órgãos públicos. No segundo semestre de } 1984 \text {, os governadores } \\
\text { começaram a pressionar o Governo Federal no sentido da flexibilização das } \\
\text { metas de expansão do financiamento, ocasionando o não cumprimento das } \\
\text { metas acordadas com o FMl. Apesar disso, o Governo Federal conseguiu } \\
\text { obter superávit primário e redução do déficit público, no conceito operacional, } \\
\text { no período de } 1983 / 1984 \text { (idem: } 83 \text { ). }\end{array}$ \\
\hline Resolução n 1.309, de 23/04/1987 & $\begin{array}{l}\text { Autorizou o Banco Central a criar uma linha especial de refinanciamento a } \\
\text { bancos comerciais, de investimentos e de desenvolvimento, destinada a } \\
\text { acolher as operações de ARO e outros empréstimos intralimites. }\end{array}$ \\
\hline Lei $n^{\circ} 7.614$, de 14/07/1987 & $\begin{array}{l}\text { Autorizou a realização de operações de crédito do Banco do Brasil, por conta } \\
\text { do Tesouro Nacional, com a finalidade de financiar o serviço da dívida vencida } \\
\text { e a vencer até dezembro de } 1987 \text { e cobrir o déficit decorrente de despesas } \\
\text { correntes de exercícios anteriores, condicionando as operações citadas à } \\
\text { aprovação, pelo Ministério da Fazenda, de planos de saneamento financeiro } \\
\text { apresentados pelas unidades. }\end{array}$ \\
\hline RAET (Decreto-Lei n² 2.321, de 25/02/1987) & $\begin{array}{l}\text { Regime de administração especial para os bancos estaduais, criado pelo } \\
\text { Banco Central, que representou uma intervenção direta do Governo Federal } \\
\text { nessas instituições. Esta intervenção permitiu que houvesse a assunção de } \\
\text { parcela da dívida estadual pela União, isto é, a federalização parcial da dívida. }\end{array}$ \\
\hline
\end{tabular}


Resolução n 1.469, de 21 de março de 1988.

Lei 7.976 , de 1989
Estabeleceu limites rígidos de acesso ao crédito e de restrição à rolagem da dívida pública. "Os governadores reagiram abertamente e conseguiram brechas para financiar as áreas de saneamento básico e habitação popular com recursos federais e deixaram de pagar as dívidas externas contraídas com o aval da União. Tal procedimento desencadeou enorme polêmica com o ministro Maílson e o levou a decretar (...) o congelamento dos repasses do FPE e de recursos de empresas estaduais. O confronto (...) foi solucionado em favor dos interesses estaduais depois da intervenção do governo Sarney. Entretanto, (ele) estava longe de ser resolvido (e deixou) novos desdobramentos" (Lopreato 2002: 189/190).

Esta lei regulamentou os critérios de rolagem da dívida externa dos governos subnacionais com prazo de vencimento até 01/01/1990, regularizando as operações que vinham transcorrendo por intermédio dos Avisos MF 30. A lei previa o refinanciamento do saldo devedor em 240 meses, com pagamento em parcelas semestrais; carência para o pagamento do principal até 1995; correção monetária e juros equivalentes aos desembolsados pelo governo federal nos respectivos contratos externos e o pagamento integral dos juros, inclusive no período de carência. A lei estipulava, ainda, a extensão das vantagens eventualmente obtidas pelo governo federal aos estados e municípios. Foram também incluídas no refinanciamento as operações de crédito internas realizadas sob o amparo dos Votos CMN 340 e CMN 548. 
Quadro 2: As etapas normativas do processo de ordenamento fiscal no período pós-Constituição de 1988, em ordem cronológica.

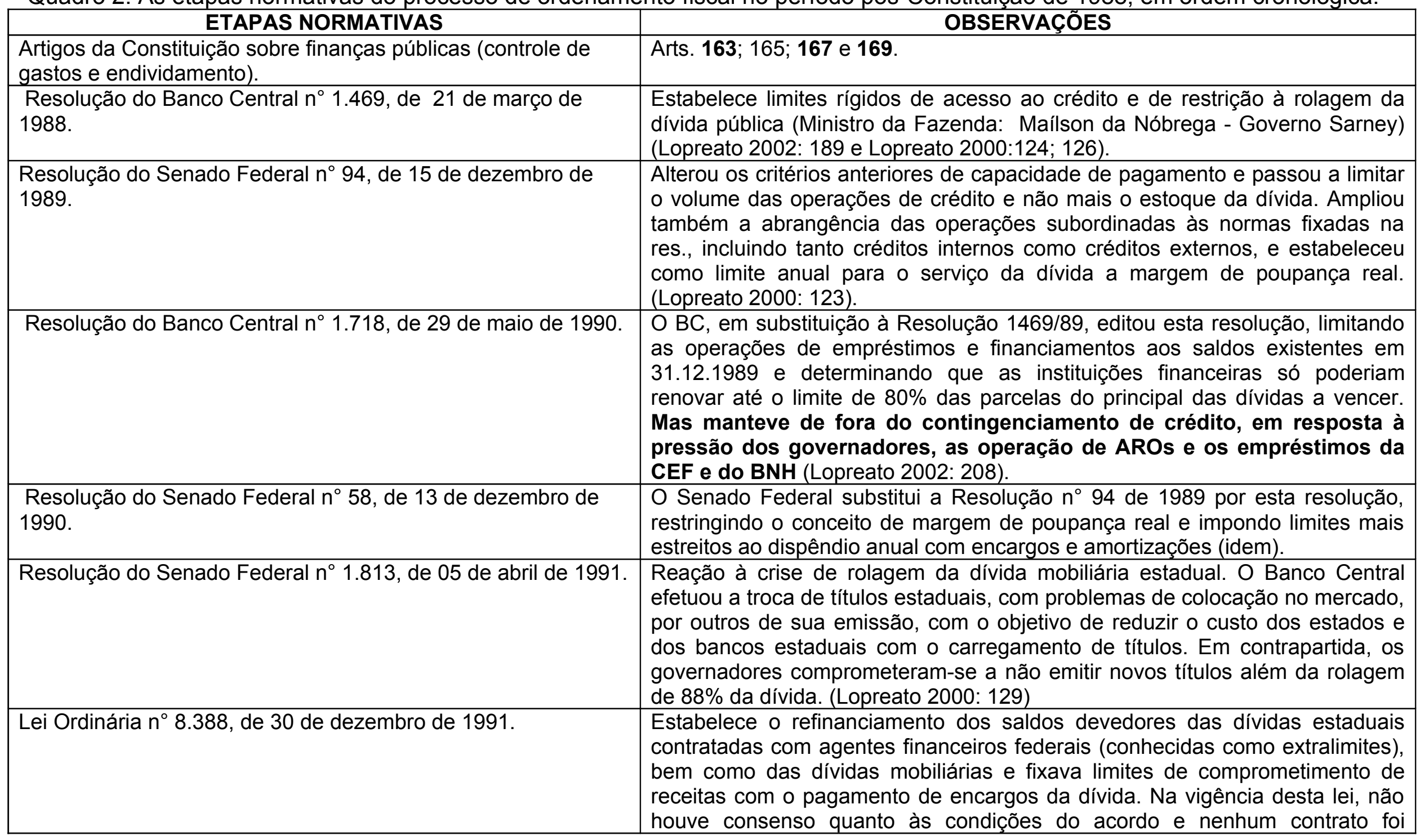




\begin{tabular}{|c|c|}
\hline & $\begin{array}{l}\text { assinado. A falta de acerto e a expansão da dívida levaram, já no Governo } \\
\text { Itamar, a outra onda de medidas contra o desequilíbrio financeiro dos estados } \\
\text { e de seus agentes financeiros e à retomada das negociações sobre as dívidas } \\
\text { (PAI). (Lopreato 2000: 130). }\end{array}$ \\
\hline $\begin{array}{l}\text { Emenda constitucional n 3, de } 17 \text { de março de } 1993 . \\
\text { Autor: Deputado Luiz Carlos Hauly (PSDB/PR) }\end{array}$ & $\begin{array}{l}\text { Alterou o quarto item do Art. } 167 \text { da Constituição ao estabelecer regras de } \\
\text { controle de expansão da dívida, limitando até } 31.12 .1999 \text { o lançamento de } \\
\text { novos títulos ao valor necessário à rolagem do principal e à correção } \\
\text { monetária, deixando de fora os juros, que deveriam ser pagos (Lopreato 2002: } \\
\text { 205). A exceção foi a emissão de títulos para pagar precatórios judiciais. Essa } \\
\text { foi na prática a única brecha deixada pela legislação para o financiamento dos } \\
\text { estados e municípios. Em novembro de 1996, foi instalada a CPI dos } \\
\text { precatórios. A lei } 9.496 / 97 \text { é considerada um efeito do escândalo dos } \\
\text { precatórios, no sentido de estabelecer critérios mais rígidos para a União } \\
\text { financiar a dívida pública mobiliária dos estados e do Distrito Federal (Loureiro } \\
\text { 2001: } 56 \text { ). }\end{array}$ \\
\hline Programa de Ação Imediata (PAI), de 14 de junho de 1993. & $\begin{array}{l}\text { Restringiu o crédito aos Estados; vedou a concessão de empréstimos dos } \\
\text { bancos estaduais aos controladores, ameaçando com a Lei do Colarinho } \\
\text { Branco os dirigentes bancários que não respeitassem a legislação; proibiu o } \\
\text { socorro financeiro aos bancos estaduais; coibiu as transferências voluntárias } \\
\text { aos governos subnacionais inadimplentes com a União e determinou a } \\
\text { execução das garantias oferecidas na concessão de avales a operações } \\
\text { externas das unidades inadimplentes (Lopreato 2002: 209). }\end{array}$ \\
\hline $\begin{array}{l}\text { Resolução do Senado Federal n 1997, de } 30 \text { de junho de } \\
1993 .\end{array}$ & $\begin{array}{l}\text { Estabelece a principal mudança definida pelo PAI, restringindo o crédito aos } \\
\text { Estados ao incluir as ARO no contingenciamento de crédito (idem). }\end{array}$ \\
\hline Resolução do Senado Federal n 2008, de 28 de julho de 1993. & $\begin{array}{l}\text { Recuo com relação à Resolução 1997, ao estabelecer limites ao } \\
\text { financiamento estadual com a não-inclusão das AROs no contingenciamento } \\
\text { de crédito (idem). }\end{array}$ \\
\hline Lei Ordinária n 8727, de 05 de novembro de 1993. & $\begin{array}{l}\text { Lei do Acordo da Renegociação das Dívidas: permitiu o refinanciamento, } \\
\text { por } 20 \text { anos, pelo Tesouro Nacional, dos saldos devedores existentes em } 30 \\
\text { de junho de } 1993 \text {, inclusive das parcelas vencidas, de todas as operações de } \\
\text { crédito interno contratadas, até } 30.09 .1991 \text {, junto a instituições financeiras } \\
\text { federais e estabeleceu limites de comprometimento das receitas com o } \\
\text { pagamento das prestações mensais do refinanciamento. O acordo de } \\
\text { renegociação significou o alongamento do perfil do endividamento e a }\end{array}$ \\
\hline
\end{tabular}




\begin{tabular}{|c|c|}
\hline & $\begin{array}{l}\text { possibilidade de retomada dos pagamentos das obrigações estaduais } \\
\text { suspensas desde o Governo Collor. Entretanto, a solução do problema da } \\
\text { dívida foi parcial e cobriu apenas as operações contratadas com as } \\
\text { instituições federais, deixando fora as dívidas com as instituições } \\
\text { financeiras privadas, bem como as operações de ARO e a dívida pública } \\
\text { mobiliária (idem). }\end{array}$ \\
\hline Resolução do Senado Federal n 11, de 31 de janeiro de 1994. & $\begin{array}{l}\text { Representou um retrocesso à EC } \mathrm{n}^{\circ} 3 / 93 \text {, permitindo a rolagem integral dos } \\
\text { juros quando definiu - atendendo ao disposto no artigo } 5^{\circ} \text {. da Emenda } \\
\text { Constitucional } n^{\circ} 3 / 93 \text { - o principal devidamente atualizado como o valor de } \\
\text { emissão devidamente corrigido pelo fator de atualização próprio da espécie de } \\
\text { título. Como a dívida era constituída de LFT-E e correção era dada pela taxa } \\
\text { overnight, sem distinguir juros e correção monetária, a legislação acabou } \\
\text { permitindo que toda a variação nominal do título fosse considerada correção } \\
\text { monetária e, conseqüentemente, a dívida fosse integralmente rolada, levando } \\
\text { à capitalização dos juros ao principal da dívida. Restaria ao Senado definir o } \\
\text { percentual de refinanciamento adequado dado a partir da análise das } \\
\text { condições próprias de cada solicitante. As regras definidas no Senado } \\
\text { Federal, ao contrário do espírito da EC, criaram espaço aos Estados de } \\
\text { negociarem caso a caso e viabilizarem a rolagem quase integral dos juros. } \\
\text { (Lopreato, 2002: } 205 / 206 \text { ). }\end{array}$ \\
\hline $\begin{array}{l}\text { Resolução do Senado Federal } n^{\circ} 69, \text { de } 14 \mathrm{de} \\
1995 .\end{array}$ & $\begin{array}{l}\text { Sucessora da Resolução do Senado Federal } n^{\circ} 11 \text {, de } 31 \text { de janeiro de 1994, } \\
\text { com pequenas alteraçoos. (Lopreato, 2002: 205/206). }\end{array}$ \\
\hline
\end{tabular}




\begin{tabular}{|c|c|}
\hline Voto $\mathrm{CMN} \mathrm{n}{ }^{\circ} 162$, de 05 de dezembro de 1995. "FMI do Malan" & $\begin{array}{l}\text { Programa de Ajuste Fiscal e Reestruturação Financeira dos Estados. Foi } \\
\text { criada uma linha de crédito emergencial, gerenciada pela Caixa Econômica } \\
\text { Federal, para o refinanciamento das AROs (fundando R\$ } 540 \text { milhões de um } \\
\text { total de R\$ } 1,6 \text { bilhão), com a finalidade de "equacionar insuficiência } \\
\text { conjuntural de caixa" (Mora 2002: 10). Pela primeira vez, associou-se o auxílio } \\
\text { financeiro federal à reforma do setor público estadual e ajuste patrimonial. } \\
\text { Condicionado a um ajuste fiscal dos estados, algumas linhas de financiamento } \\
\text { do programa tiveram seus prazos dilatados e o valor máximo dos empréstimos } \\
\text { foi elevado em } 25 \% \text {. O Governo Federal se comprometeu, ainda, a ajudar os } \\
\text { Estados a rolarem suas dívidas com os bancos oficiais e privados por mais } 36 \\
\text { meses e a negociar, caso a caso, os recursos adicionais de que algum Estado } \\
\text { necessitasse. Os Estados participantes teriam a obrigação de fixar, de forma } \\
\text { organizada e monitorada, compromissos com metas de ajuste fiscal e } \\
\text { saneamento financeiro, sendo forçados a adotar medidas de controle salarial e } \\
\text { corte de pessoal, privatização, concessão de serviços públicos e a obter a } \\
\text { aprovação da Assembléia Legislativa à implementação do programa, bem } \\
\text { como seriam monitorados pela STN. (Lopreato, } 2002: 211 / 212 \text { ). }\end{array}$ \\
\hline Medida Provisória n 1514, de 07 de agosto de 1996. & $\begin{array}{l}\text { Cria o PROES (Programa de Incentivo à Redução do Setor Público Estadual } \\
\text { na Atividade Bancária). "Art. } 3^{\circ} \text { Para os fins desta Medida Provisória, poderá a } \\
\text { União, a seu exclusivo critério: I - adquirir o controle da instituição financeira, } \\
\text { exclusivamente para privatizá-la ou extinguí-la; II - financiar a extinção ou a } \\
\text { transformação da instituição financeira em instituição não financeira ou } \\
\text { agência de fomento, quando realizada por seu respectivo controlador; III - } \\
\text { financiar os ajustes prévios imprescindíveis para a privatização da instituição } \\
\text { financeira, ou prestar garantia a financiamento concedido pelo Banco Central } \\
\text { do Brasil para o mesmo fim, segundo normas baixadas pelo Conselho } \\
\text { Monetário Nacional; IV - adquirir créditos contratuais que a instituição } \\
\text { financeira detenha contra seu controlador e entidades por este controladas, e } \\
\text { refinanciar os créditos assim adquiridos; ou } V-\text { em caráter excepcional e } \\
\text { atendidas as condições especificadas no art. } 5^{\circ} \text {, financiar parcialmente } \\
\text { programa de saneamento da instituição financeira, que necessariamente } \\
\text { contemplará sua capitalização e mudanças". no seu processo de gestão } \\
\text { capazes de assegurar sua profissionalização." }\end{array}$ \\
\hline Medida Provisória $\mathrm{n}^{\circ} 1560$, de $19 \mathrm{c}$ & Houve uma ampliação do âmbito das negociações das dívidas dos estados e \\
\hline
\end{tabular}




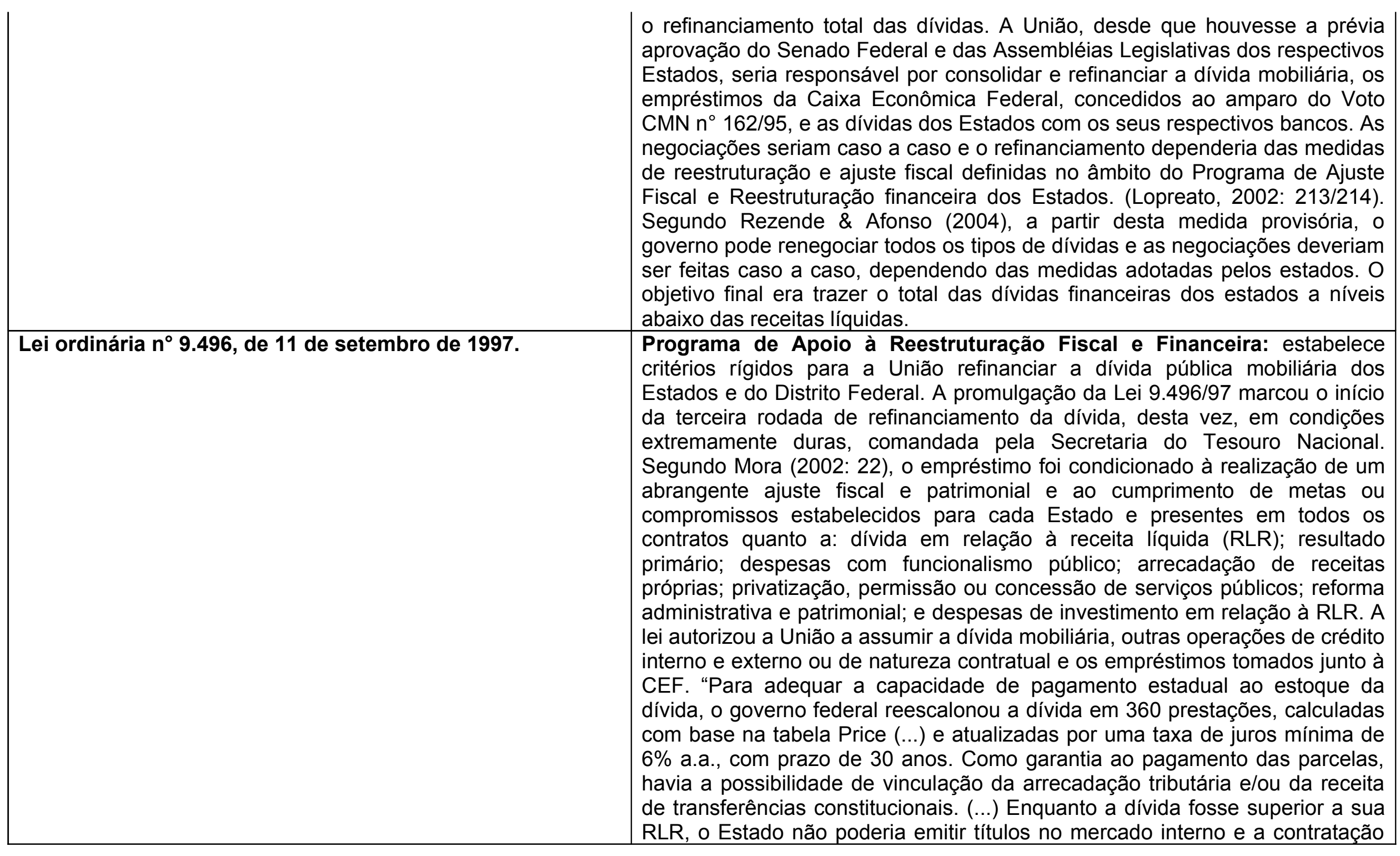




\begin{tabular}{|c|c|}
\hline & $\begin{array}{l}\text { de novos empréstimos no exterior estava condicionada ao cumprimento das } \\
\text { metas de trajetória da dívida. (...) O equivalente a } 20 \% \text { do montante total } \\
\text { refinanciado deveria ser entregue, sob a forma de bens e direitos, à União } \\
\text { para amortização da dívida" (Mora 2002: } 23 \text { ). Ademais, no caso de não } \\
\text { pagamento das parcelas do refinanciamento, os recursos do Fundo de } \\
\text { Participação Estadual (FPE) seriam retidos. (idem: 26). Segundo Tavares } \\
\text { (2005), "nas experiências anteriores, o Tesouro contava somente com as } \\
\text { garantias relativas às parcelas dos fundos de participação dos Estados ou } \\
\text { Municípios, o que na maioria dos casos era insuficientes quantitativamente } \\
\text { falando e muito mais difíceis de serem executadas do ponto de vista político" } \\
\text { (idem: } 87 \text { ). }\end{array}$ \\
\hline Medida Provisória n 1.590, de 24 de setembro de 1997 & $\begin{array}{l}\text { Assegurava aos Estados financiamento em condições similares àquelas } \\
\text { propostas na Lei } 9.496 / 97 \text { para sanear os respectivos bancos estaduais e, } \\
\text { depois, encaminhá-los para a liquidação, privatização ou transformação em } \\
\text { agência de fomento. }\end{array}$ \\
\hline Resolução do Banco Central n 2.443 de novembro de 1997 & $\begin{array}{l}\text { Limita as operações de Antecipação de Receita Orçamentária (ARO) aos } \\
\text { saldos que especifica. }\end{array}$ \\
\hline $\begin{array}{l}\text { Emenda Constitucional no 19, de } 04 \text { de junho de } 1998 \\
\text { (Reforma Administrativa). } \\
\text { Autoria: Presidência da República (MSG 00886, 18/08/1995) }\end{array}$ & $\begin{array}{l}\text { Modifica o regime e dispõe sobre o princípio e normas da administração } \\
\text { pública, servidores e agentes políticos, controle de despesas e finanças } \\
\text { públicas e custeio de atividades a cargo do Distrito Federal e dá outras } \\
\text { providências. } \\
\text { Art. } 20 \text {. O caput do art. } 167 \text { da Constituição Federal passa a vigorar acrescido } \\
\text { de inciso X, com a seguinte redação: } \\
\text { "Art. 167. São vedados: X - a transferência voluntária de recursos e a } \\
\text { concessão de empréstimos, inclusive por antecipação de receita, pelos } \\
\text { Governos Federal e Estaduais e suas instituições financeiras, para pagamento } \\
\text { de despesas com pessoal ativo, inativo e pensionista, dos Estados, do Distrito } \\
\text { Federal e dos Municípios" }\end{array}$ \\
\hline $\begin{array}{l}\text { Resolução do Senado Federal } n^{\circ} 78 \text {, de } 08 \text { de julho de } \\
\text { 1998. } \\
\text { Autoria: Sen. Esperidião Amin (PPB/SC) }\end{array}$ & $\begin{array}{l}\text { Esta resolução reforça o controle do endividamento, ao "proibir novos } \\
\text { empréstimos de qualquer tipo aos Estados que apresentassem um déficit } \\
\text { primário no período de doze meses anterior à aplicação, reduziu as margens } \\
\text { de endividamento e aplicou uma redução gradual na proporção dívida/receita. } \\
\text { Os contratos assinados com os Estados também proibiam a emissão de nova } \\
\text { dívida em caso de não cumprimento da trajetória estabelecida para reduzir a }\end{array}$ \\
\hline
\end{tabular}




\begin{tabular}{|c|c|}
\hline & $\begin{array}{l}\text { proporção dívida/receita, ou contrair nova dívida que pudesse alterar essa } \\
\text { trajetória" (Rezende \& Afonso, 2004). A partir da Resolução } n^{\circ} 78 \text {, houve uma } \\
\text { mudança importante: o Senado reitera o seu comprometimento com o ajuste } \\
\text { fiscal, ao transferir para o Banco Central porção considerável de seu poder } \\
\text { decisório em matéria de endividamento. O artigo VII da Resolução } 78 / 98 \\
\text { assim estabelece: "O Banco Central do Brasil não encaminhará ao Senado } \\
\text { Federal pedido de autorização para a contratação de qualquer operação de } \\
\text { crédito de tomador que apresente resultado primário negativo no período de } \\
\text { apuração da Receita Líquida Real ou que esteja inadimplente junto a } \\
\text { instituições integrantes do Sistema Financeiro Nacional"(Loureiro 2001: } 57 \text { ). O } \\
\text { Art. } 13^{\circ} \text { também se refere a questão. }\end{array}$ \\
\hline Medida Provisória nº 1.716, de 08/09/1998 & $\begin{array}{l}\text { Definiu a meta de superávit primário para aquele ano e o prazo de até } \\
15 / 11 / 1998 \text { para a formulação do Programa de Estabilização Fiscal (PEF). }\end{array}$ \\
\hline $\begin{array}{l}\text { Lei complementar } \mathbf{n}^{\circ} \text { 96, de } 01 \text { de junho de } 1999 \text { (Lei } \\
\text { Camata II). } \\
\text { Autoria: Presidência da República (MSG 01310, 28/10/1998) }\end{array}$ & $\begin{array}{l}\text { Disciplina os limites das despesas com funcionalismo público, na forma do art } \\
169 \text { da Constituição. Comparada à Lei Camata I, esta lei reduziu o limite de } \\
\text { gasto da União para } 50 \% \text { e manteve dos estados e municípios em } 60 \% \text {. Esta } \\
\text { lei detalha as vedações que podem sofrer os entes federativos, caso não } \\
\text { cumpram os limites, dentre elas o recebimento dos repasses de verbas } \\
\text { federais ou estaduais (Art. 5). No Art. } 6 \text {, a lei estabelece que para atender aos } \\
\text { limites, é permitida a exoneração dos servidores estáveis e não estáveis, } \\
\text { inclusive no âmbito dos poderes executivo, legislativo e judiciário (Art. 9). }\end{array}$ \\
\hline Resolução do Senado Federal n 43 de dezembro de 2001 & $\begin{array}{l}\text { Mantém as condições da resolução } 78 \text {, mas transfere do BC para a STN o } \\
\text { poder de decidir sobre os pedidos de endividamento dos governos } \\
\text { subnacionais (Loureiro \& Abrucio 2002). }\end{array}$ \\
\hline
\end{tabular}


Quadro 3: Atos normativos sobre o controle do gasto e do endividamento dos entes federativos, em ordem cronológica.

\begin{tabular}{|c|c|c|c|c|c|c|}
\hline \multirow[t]{2}{*}{ Períodos } & \multirow{2}{*}{$\begin{array}{c}\text { Sobre controle } \\
\text { dos gastos }\end{array}$} & \multicolumn{2}{|c|}{ Sobre controle da dívida } & \multirow{2}{*}{$\begin{array}{c}\text { Renegociação } \\
\text { das Dívidas }\end{array}$} & \multirow{2}{*}{$\begin{array}{l}\text { Programas de } \\
\text { Reforma Fiscal }\end{array}$} & \multirow{2}{*}{$\begin{array}{c}\text { Sobre Antecipação } \\
\text { de Restrição } \\
\text { Orçamentária } \\
\text { (ARO) }\end{array}$} \\
\hline & & $\begin{array}{c}\text { Consolidada ou } \\
\text { fundada }\end{array}$ & Mobiliária & & & \\
\hline $1988-1994$ & & 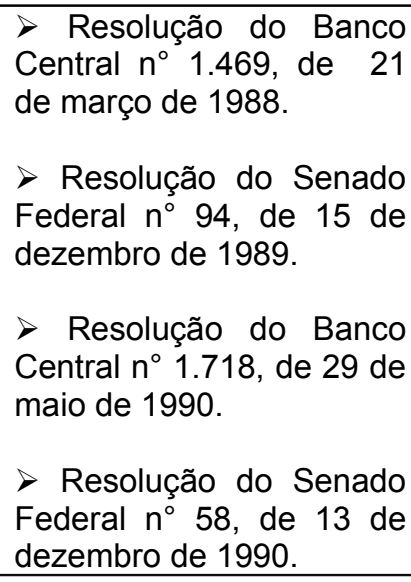 & $\begin{array}{l}\text { Resolução do Senado } \\
\text { Federal } n^{\circ} 1.813 \text {, de } 05 \text { de } \\
\text { abril de } 1991 . \\
>\text { Lei Ordinária } n^{\circ} 8.388 \text {, } \\
\text { de } 30 \text { de dezembro de } \\
1991 . \\
>\text { Emenda constitucional } \\
n^{\circ} 3 \text {, de } 17 \text { de março de } \\
1993 \text {. } \\
>\text { Resolução do Senado } \\
\text { Federal } n^{\circ} 11 \text {, de } 31 \text { de } \\
\text { janeiro de } 1994 \text {. }\end{array}$ & $\begin{array}{l}\text { Lei Ordinária } \mathrm{n}^{\circ} \\
8727 \text {, de } 05 \text { de } \\
\text { novembro } \\
1993 .\end{array}$ & $\begin{array}{l}\text { Programa de Ação } \\
\text { Imediata (PAI), de } 14 \\
\text { de junho de } 1993 .\end{array}$ & $\begin{array}{l}\text { Resolução do } \\
\text { Senado Federal } \mathrm{n}^{\circ} \\
\text { 1997, de } 30 \text { de junho } \\
\text { de } 1993 . \\
\text { Resolução do } \\
\text { Senado Federal } n^{\circ} \\
\begin{array}{l}\text { 2008, de } 28 \text { de julho } \\
\text { de } 1993 .\end{array}\end{array}$ \\
\hline $1995-1998$ & $\begin{array}{l}\text { Dei } \\
\text { Complementar } \mathrm{n}^{\circ} \\
82 \text { de } 27 \text { de } \\
\text { março de } 1995 \\
\text { (Lei Camata I). } \\
\text { Emenda } \\
\text { Constitucional } \mathrm{n}^{\circ} \\
19, \text { de } 04 \text { de } \\
\text { junho de } 1998 \\
\text { (Reforma } \\
\text { Administrativa). }\end{array}$ & $\begin{array}{l}\text { Resolução do Senado } \\
\text { Federal } n^{\circ} 78 \text {, de } 08 \text { de } \\
\text { julho de } 1998 \text {. } \\
\text { Matérias correlatas a RSF } \\
\text { 78/98: } \\
\text { >RSF- } 93 \text { 09/12/1998 }\end{array}$ & $\begin{array}{l}\text { Resolução do Senado } \\
\text { Federal } n^{\circ} 69 \text {, de } 14 \text { de } \\
\text { dezembro de } 1995 .\end{array}$ & 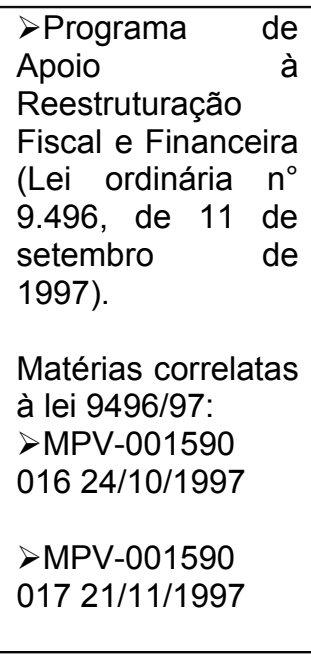 & $\begin{array}{l}\text { Programa de } \\
\text { Ajuste Fiscal e } \\
\text { Reestruturação } \\
\text { Financeira } \\
\text { Estados. (Voto CMN } \\
\mathrm{n}^{\circ} 162 \text {, de } 05 \text { de } \\
\text { dezembro de } 1995 . \\
\text { "FMl do Malan"). } \\
\text { PROES (Medida } \\
\text { Provisória } \mathrm{n}^{\circ} 1514, \\
\text { de 07 de agosto de } \\
\text { 1996). } \\
>\text { Medida Provisória } \\
\mathrm{n}^{\circ} \text { 1560, de } 19 \text { de } \\
\text { dezembro de } 1996 .\end{array}$ & $\begin{array}{l}\text { Resolução do } \\
\text { Banco Central } n^{\circ} \\
2.443 \text { de novembro } \\
\text { de } 1997\end{array}$ \\
\hline
\end{tabular}


$>$ MPV-001612

018 12/12/1997

$>$ MPV-001612

019 09/01/1998

$>$ MPV-001612

020 06/02/1998

$>$ MPV-001612

021 06/03/1998

$>$ MPV-001612

022 03/04/1998

$>$ MPV-001654

023 16/04/1998

$>$ MPV-001654

024 15/05/1998

$>$ MPV-001654

025 12/06/1998

$>$ MPV-001702

026 01/07/1998

$>$ MPV-001702

027 31/07/1998

$>$ MPV-001702

028 30/08/1998

$>$ MPV-001702

029 29/09/1998

$>$ MPV-001702

030 29/10/1998

$>$ MPV-001702 


\begin{tabular}{|c|c|c|c|c|c|c|}
\hline & & & & $\begin{array}{l}031 \text { 28/11/1998 } \\
\text { > MPV-001773 } \\
032 \text { 15/12/1998 } \\
\\
\text { > MPV-001711 } \\
005 \text { 31/12/1998. }\end{array}$ & & \\
\hline $1999-2005$ & $\begin{array}{l}>\text { Lei } \\
\text { complementar } \mathrm{n}^{\circ} \\
96, \text { de } 01 \text { de } \\
\text { junho de } 1999 \\
\text { (Lei Camata II). } \\
\text { 'Lei } \\
\text { Complementar } \\
\mathbf{n}^{\circ} \text { 101, de } \mathbf{0 5} \text { de } \\
\text { maio de 2000 } \\
\text { (Lei de de } \\
\text { Responsabilidad } \\
\text { e Fiscal). }\end{array}$ & 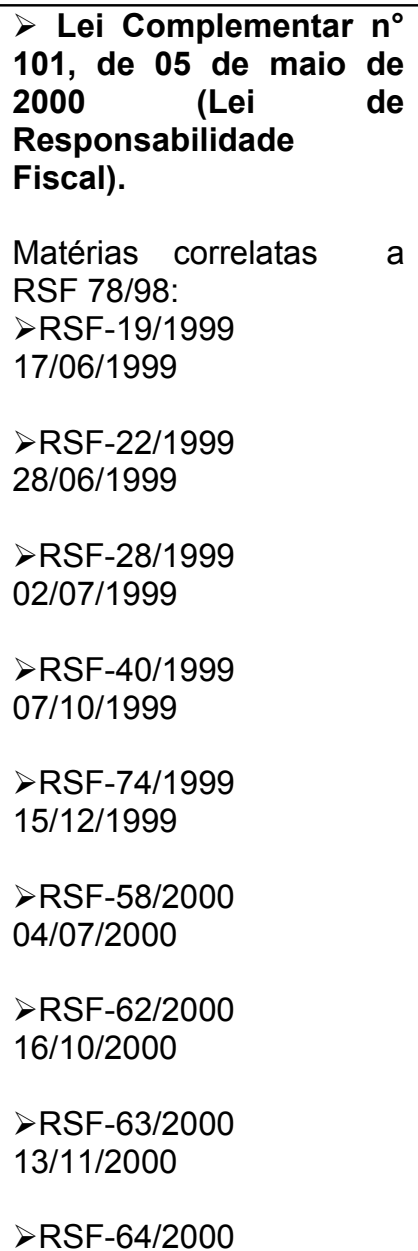 & $\begin{array}{l}7 \text { Lei Complementar } \mathrm{n}^{\circ} \\
101 \text {, de } 05 \text { de maio de } \\
2000 \text { (Lei de de } \\
\text { Responsabilidade } \\
\text { Fiscal). }\end{array}$ & & 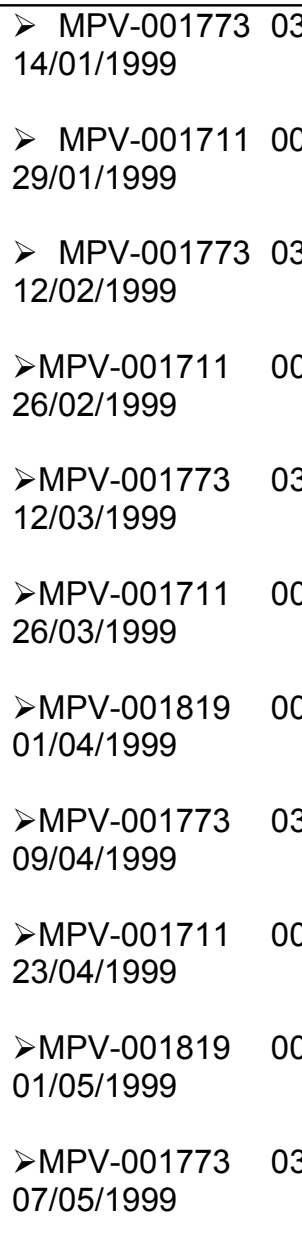 & $\begin{array}{l}\text { DLei } \\
\text { Complementar } \mathrm{n}^{\circ} \\
101, \text { de } 05 \text { de maio } \\
\text { de } 2000 \text { (Lei de } \\
\text { Responsabilidade } \\
\text { Fiscal). }\end{array}$ \\
\hline
\end{tabular}




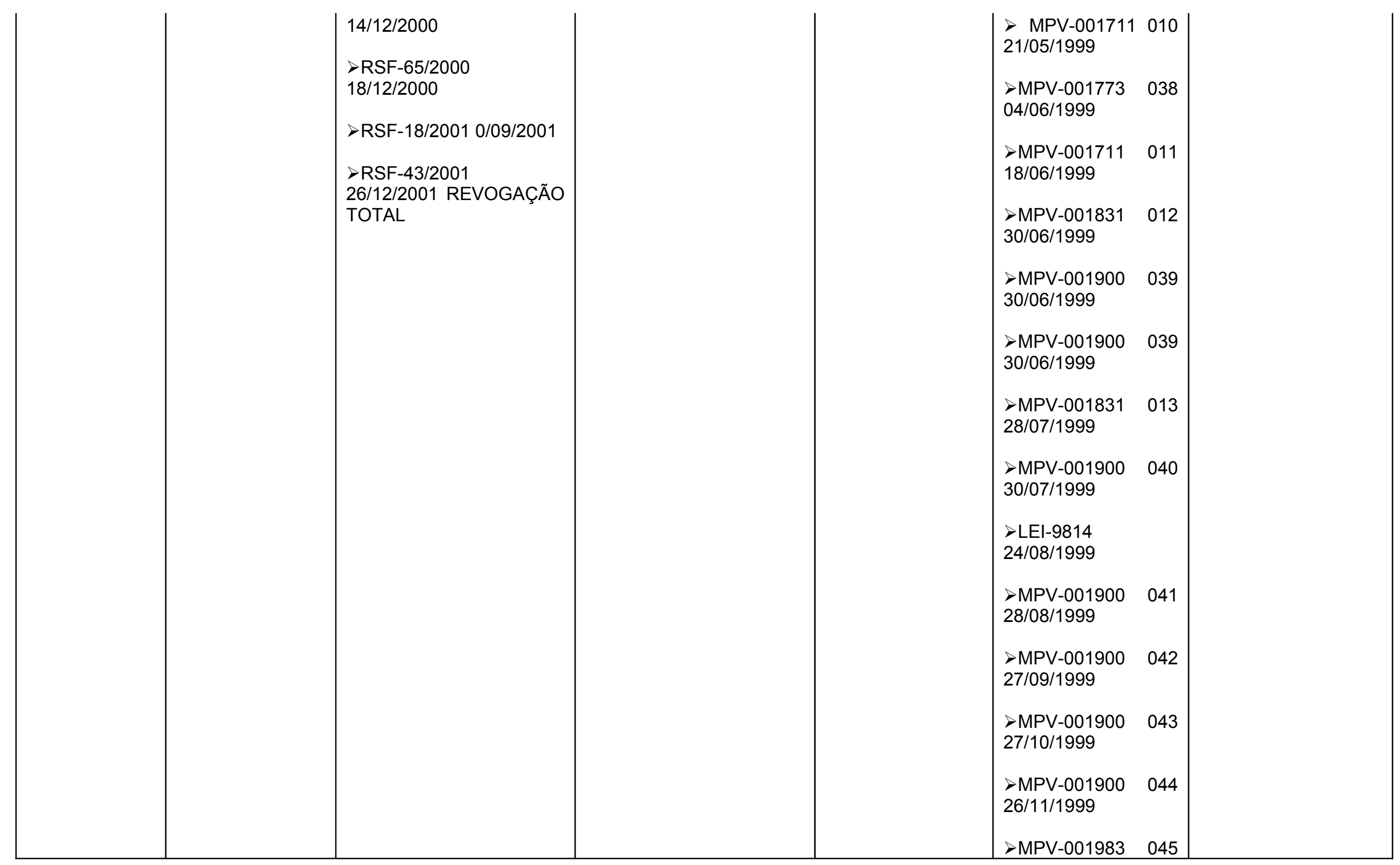




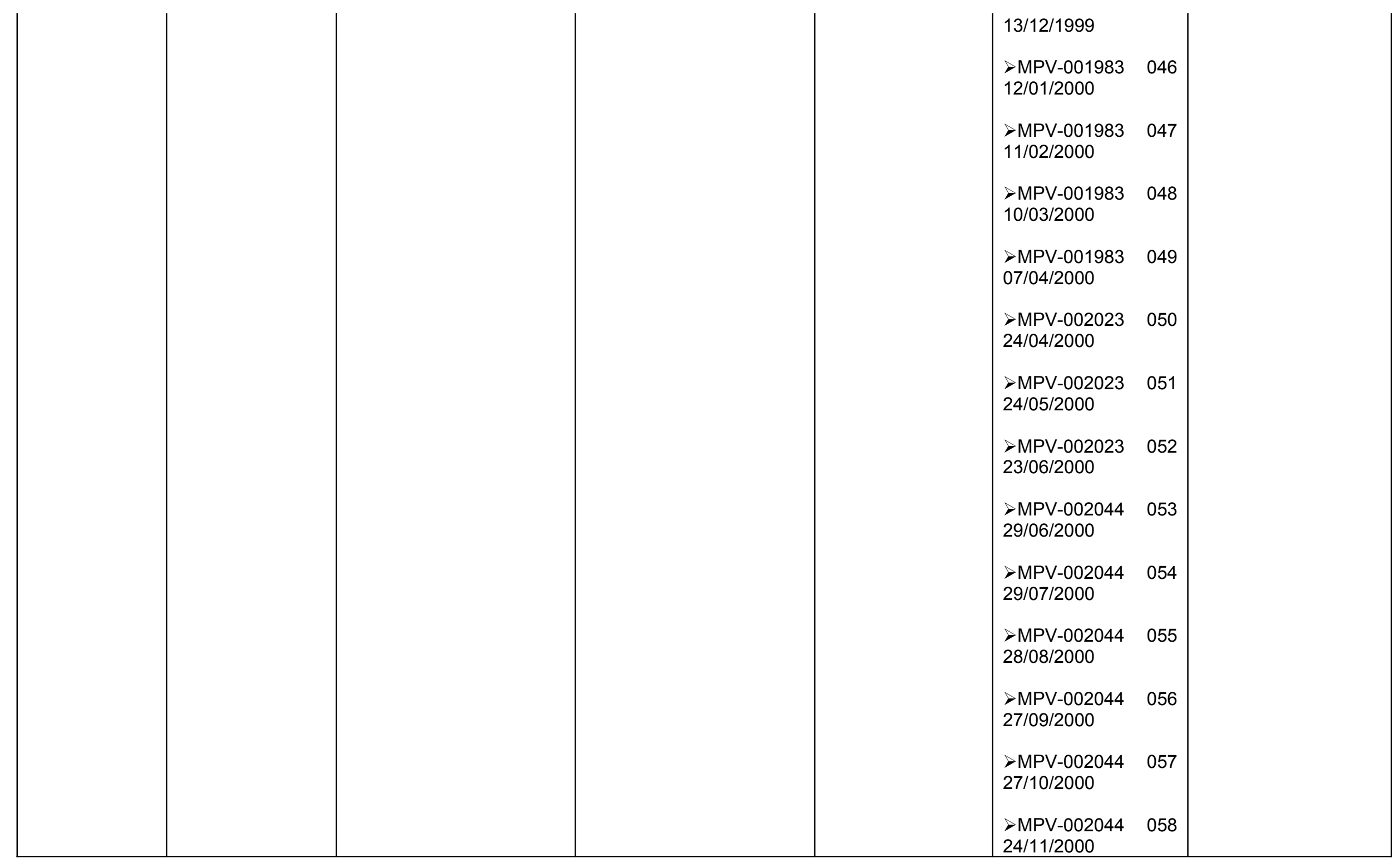




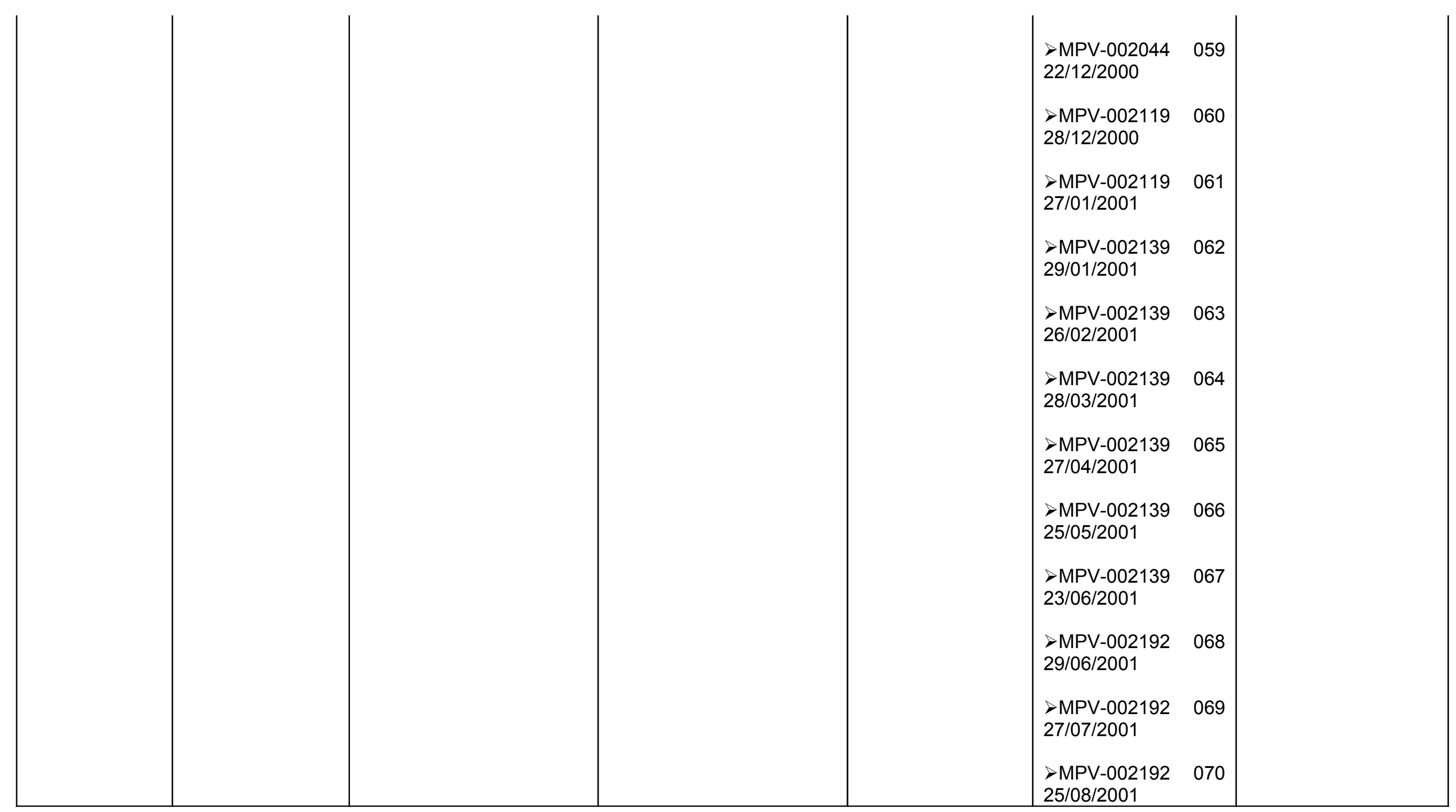


Anexo 2:

Modelo básico das questões feitas nas entrevistas (houve algumas variações dependendo do entrevistado)

1)Em que momento a questão do ordenamento fiscal (a implementação gradual de um conjunto de medidas como planejamento, transparência, limitação à contratação de dívidas e gastos dos entes federativos) entrou efetivamente na agenda política do Governo Federal, (seja na forma de discussão entre técnicos do governo, seja na forma de projetos de lei para regulamentação dos artigos da Constituição de 1988 que tratam das finanças públicas)? Qual foi o primeiro impacto político das primeiras iniciativas governamentais na direção da construção do arcabouço normativo do ordenamento fiscal?

2)No texto "A Constituição e o Gasto Público", de 1989, o então deputado federal José Serra alertava para o fato da Constituição ter dado pouca atenção aos dispositivos relacionados ao controle, à transparência e ao planejamento das decisões sobre os gastos públicos. O Sr. concorda com esta análise? Se sim, por que isso ocorreu? Por que foi deixado para regulamentação posterior, na forma de legislação infraconstitucional, a matéria do controle do gasto e do endividamento dos entes federativos?

3)Desde a implementação do Plano Real, em 1994, já se falava na necessidade de um ajuste fiscal dos entes federativos, especialmente dos Estados, como condição sine qua non para a manutenção da estabilidade monetária. Na sua opinião, por que o projeto de lei complementar que regulamentaria o artigo 163, o projeto da LRF, entrou na agenda política do governo só em 1998, no processo de elaboração da primeira versão do projeto de autoria do Executivo Federal?

4)Se antes da LRF já havia uma série de atos normativos (Lei Camata II, a própria lei 9496, a resolução 78/98, e leis para punição de maus governantes - Lei do Colarinho Branco...) para ordenar as finanças públicas, limitando o gasto e o endividamento, e punindo os administrativos com sanções penais, porque se optou em fazer um projeto tão abrangente, abarcando todos esses pontos, além do orçamento?

5)Há várias experiências pelo mundo de leis que controlam o nível de endividamento e de gastos dos entes federativos. Tecnicamente, como foi a concepção dos mecanismos de controle do gasto e do endividamento que está na LRF? (perguntar Martus e Afonso)

6)Em fevereiro de 1995, o Dep. Mendonça Filho apresenta o projeto de emenda constitucional da reeleição. Em junho de 1997, a emenda constitucional $n^{\circ} 16$ foi sancionada. Em setembro de 1997, sai a Lei 9496 que regulamentava a renegociação das dívidas. O Sr. vê alguma relação entre a reeleição e o processo de renegociação? $\mathrm{E}$ com relação a aprovação da LRF?

7)Como foi o processo de renegociação da dívida do Estado de (SP), no âmbito da Lei 9496? O Sr. vê alguma relação entre o encaminhamento desta negociação e a aprovação rápida da LRF no Congresso, entre 99 e 2000?

8)Em artigo na FSP do dia 06 de maio de 2005, o Sr. Luiz Carlos Mendonça de Barros afirma que entre 1996 e 1998 aconteceram fatos que quase inviabilizaram a aprovação do projeto de lei da LRF como conhecemos hoje, envolvendo o Ministério da Fazenda, o presidente e os governadores.

a) O Sr. conhece esses fatos? Quais foram esses fatos? (Ele falou que o Ministério da Fazenda e o próprio presidente da República iniciaram uma verdadeira luta corpo a corpo com os governadores. Articulados politicamente por FHC, começaram a discutir 
com o Ministério da Fazenda os ajustes para equilibrar seus Orçamentos. Paralelamente, a Fazenda e o Banco Central iniciaram negociações com o Senado visando o estabelecimento de regras mais racionais e duras para o endividamento dos Estados. Naquele momento, quase ocorreu o colapso da Lei de Responsabilidade Fiscal de hoje. As regras que o Ministério da Fazenda pretendia implantar nos Estados levaram a uma quase revolta dos governadores).

b) Como eles foram contornados? (Ele citou o papel chave do ministro Sérgio Motta que propôs a saída de negociar vantagens agora para que eles aprovem, em seus Estados, medidas que passem a valer somente a partir do próximo mandato (não existia a reeleição naquele momento). Em linguagem militar, retirar-se para poder avançar).

9)Como foi a elaboração do projeto original, do Executivo Federal, de abril de 1998?

-Além do Ministério do Orçamento e Gestão, do Ministério da Fazenda e do Ministério da Previdência e da Assistência Social, técnicos de outros ministérios ou autarquias também participaram da elaboração?

-Houve algum tipo de conflito entre os técnicos neste processo? Entre os técnicos da Fazenda e do Planejamento?

-Houve interferência política?

-Quais pontos são os mais importantes deste projeto original?

-Este projeto, assim como o projeto de lei apresentado ao Congresso, tem 110 artigos. O texto aprovado tem 75 artigos. Neste enxugamento que o texto sofreu houve mudanças significativas?

10) Em junho de 1998, foi promulgada a Emenda Constitucional $n^{\circ} 20$, da Reforma Administrativa do Governo FHC. O art. 30 desta emenda prevê: "O projeto de lei complementar a que se refere o art. 163 da Constituição Federal será apresentado pelo Poder Executivo ao Congresso Nacional no prazo máximo de cento e oitenta dias da promulgação desta Emenda". Por que (e como) foi incluído no texto da emenda a regulamentação do art. 163 da Constituição?

11)Em outubro de 1998 foi criado o Programa de Estabilidade Fiscal e em dezembro de 1998, foi divulgado o anteprojeto de lei, pelo governo federal, para consulta pública.

- Na sua opinião, a assinatura do acordo com o FMI e a crise russa tiveram alguma relação com a elaboração deste programa e deste anteprojeto? De que forma? Foi pressão do FMl a inclusão da LRF enquanto compromisso do governo?

-Como foi a escolha do formato da apresentação do anteprojeto, com a especificação, em cada artigo, da fundamentação e de comentários reforçando a relevância do artigo? Previam-se reações contrárias dos atores políticos? De qual(ais)?

12) Na fase de audiência pública, foram realizadas 5 reuniões entre dezembro de 1998 e março de 1999 com secretários de estado e representantes do mercado. (Aqui eles abrem espaço para sugestões dos prefeitos e governadores)

a) Segundo uma apresentação do Secretário de Executivo de Orçamento e Gestão, de maio de 1999, o grau de transparência e a abertura pública ao debate no processo de preparação da proposta foi uma experiência inovadora. Como foi resolvido que o processo seria desta forma?

b) Segundo essa mesma apresentação, foram incorporadas várias sugestões à versão final do projeto de lei complementar. Quais foram essas sugestões e quem as formulou?

c) Comparando os artigos do projeto, do anteprojeto e do projeto de lei complementar $n^{\circ} 18$ apresentado à Câmara, não houve muitas modificações importantes no texto. Por que essas reuniões não provocaram mudanças mais significativas no texto? 
13) $A 1^{\text {a }}$ reunião sobre o anteprojeto, com os representantes do mercado financeiro, realizada em dezembro de 1998;

a $2^{\mathrm{a}}$ foi realizada com secretários municipais da Fazenda;

a $3^{\mathrm{a}} \mathrm{com}$ assessores dos Estados;

a $4^{\mathrm{a}}$ com secretários de Estado da Administração

e a $5^{a}$ com secretários de Estado da Fazenda e do Planejamento.

Como o anteprojeto foi recebido nessas reuniões? Houve alguma reunião mais polêmica? Quais foram as sugestões e a reação das autoridades estaduais e municipais ao texto do anteprojeto?

14) Lendo as memórias das reuniões, chama a atenção as observações críticas feitas pelo Secretário da Fazenda de SP na época, Yoshiaki Nakano, na reunião com os secretários da fazenda. Ele aponta problemas da lei com relação ao rompimento do princípio da autonomia, excessivo detalhamento e engessamento das administrações das unidades federativas em virtude da centralização burocrática. Como essas críticas foram digeridas pela equipe do Governo Federal que elaborava o projeto?

15) O projeto de lei complementar foi apresentado à Câmara em março de 1999. Havia a expectativa por parte dos técnicos do governo de que a tramitação parlamentar se encerrasse no mesmo ano? Com base em que? (texto Martus Tavares indica isso...)

16) Na sua visão, em que medida a crise Russa, o Acordo assinado com o FMI, em 1998, a crise da desvalorização do Real, em janeiro de 1999, afetaram o processo de tramitação da LRF? Estas "variáveis exógenas", o contexto da crise, gerou mais impacto na negociação extra-plenário ou no plenário da casas legislativas?

17) Como os governadores reagiram diante da apresentação do Projeto de Lei Complementar $n^{\circ} 18$ de 1999? Eles atuaram no processo político de aprovação da LRF?

18) Houve alguma estratégia do Governo Federal para negociar com os atores políticos federativos? $E$ as lideranças parlamentares? Se houve negociação, quais foram as moedas de troca? Qual foi o papel dos Governadores de oposição? (queriam o sublimite)

Sobre o período da tramitação na Câmara e no Senado:

19) A equipe que elaborou a lei acompanhou a tramitação na Câmara e no Senado? De um modo geral, qual a opinião de vocês sobre o processo de discussão legislativa sobre o projeto?

20)O projeto de lei complementar $n^{0} 18$ deu entrada na Câmara em abril de 1999. Na opinião do sr., qual era o "clima" político com relação à matéria entre os prefeitos e os governadores? E entre os parlamentares? Era um clima favorável à aprovação, ou não?

21) O Sr. acompanhou a montagem da CESP que discutiu a matéria? A Comissão Especial na Câmara foi presidida pelo Dep. Joaquim Francisco (PFL-PE) e a relatoria ficou com o Dep. Pedro Novais (PMDB-MA). Como a Comissão foi formada? Como foi a escolha do relator, o Dep. Pedro Novais (PMDB-MA)? Houve muitas mudanças importantes no texto do projeto durante as discussões na CESP?

22) Que pontos foram cedidos no âmbito da CESP? (foram inseridas regras sobre o BC de proibição de emissão de papéis). O projeto entrou na Comissão Especial com 110 artigos e saiu com 76. Além da quantidade de artigos, quais foram as principais mudanças no texto que ocorreram no período da tramitação na CESP?

23) Como foi a negociação com a assessoria parlamentar e com os membros do CESP? 
24) Sobre emissão de papel do BC: como este ponto foi negociado?

25) Na Comissão Especial, ficou definido, com base no art. $34^{188}$ do Regimento, que haveria 40 sessões, como no exame de emendas constitucionais, pelo fato desta matéria ter deixado de passar por 5 comissões. Pode-se afirmar que a instalação da CESP foi parte da estratégia do governo em correr com a tramitação da LRF?

26) Na mesma época em que se iniciaram os trabalhos da CESP, estava havendo manifestações dos Prefeitos em Brasília. Por que eles protestaram e qual foi o impacto dos protestos nos trabalhos da CESP?

27) Qual foi a reação do Governo diante das mudanças propostas pelos deputados da CESP?

\section{8) Como foi a negociação com os parlamentares na Câmara?}

29) Em janeiro de 2000, logo que o projeto retorna ao Plenário da Câmara, foi aprovado um requerimento solicitando urgência para o projeto. Por que a urgência foi solicitada? Havia uma estratégia regimental por parte do governo para eliminar um dos turnos de votação e agilizar a aprovação da lei?

30) No discurso do dep. Walfrido Mares Guia, ele argumenta que o projeto deveria ser votado até o dia 15 de fevereiro, porque fazia parte dos 19 itens da convocação extraordinária do Congresso Nacional. Como o projeto entrou nesses 19 itens?

31) Das 124 emendas apresentadas em plenário, 93 foram rejeitadas e, dentre elas, somente 9 de autoria de deputados da base do governo e 84 de autoria da oposição. É possível afirmar, na opinião do Sr., que o governo não tinha interesse que os deputados fizessem modificações importantes no projeto, na fase de votação em turno único?

32) Em 25 de janeiro, o dep. João Fassarella, em discurso em plenário, relata que estava havendo pressão sobre os deputados para a votação do projeto. Havia mesma essa pressão e do que ela se tratava, concretamente?

33) O Sr., enquanto líder do Governo, no mesmo dia, solicitou a votação em globo dos destaques simples. Por que foi tomada essa decisão?

34) O governo estabeleceu alguma negociação com a oposição sobre a retirada de algum ponto polêmico da lei? Em discurso do dep. José Genoino, ele afirma que a bancada do PT tentou um acordo para mudar os artigos 4, 9 e 31 sobre os juros das dívidas, mas o governo não quis negociar os destaques apresentados pelo partido.

35) O Sr. acompanhou a votação no Senado? Segundo o Senador Sebastião Rocha (PDT-SP), era lamentável o fato do Senado não poder emenda o projeto, em virtude do

\footnotetext{
${ }^{188}$ Art. 34. As Comissões Especiais serão constituídas para dar parecer sobre:

I - proposta de emenda à Constituição e projeto de código, casos em que sua organização e funcionamento obedecerão às normas fixadas nos Capítulos I e III, respectivamente, do Título VI;

II - proposições que versarem matéria de competência de mais de três Comissões que devam pronunciar-se quanto ao mérito, por iniciativa do Presidente da Câmara, ou a requerimento de Líder ou de Presidente de Comissão interessada.

$\S 1^{\circ}$ Pelo menos metade dos membros titulares da Comissão Especial constituída para os fins do disposto no inciso II será composta por membros titulares das Comissões Permanentes que deveriam ser chamadas a opinar sobre a proposição em causa.

$\S 2^{\circ}$ Caberá à Comissão Especial o exame de admissibilidade e do mérito da proposição principal e das emendas que lhe forem apresentadas, observado o disposto no art. 49 e no $\S 1^{\circ}$ do art. 24.
} 
acordo da Bancada Governista com o Palácio do Planalto, que fazia com que o senado aprovasse o que vinha da Câmara. Este acordo existiu de fato?

36) Na mesma época em que o projeto tramitava no Senado, o contrato de refinanciamento da dívida da cidade de SP ainda não tinha sido autorizado pelo Senado. Se a LRF fosse aprovada antes, inviabilizaria o contrato, em virtude do art. 35 da lei. Como foi equacionado este problema?

37) Houve um veto parcial à lei sancionada pelo presidente. Sobre o que foi este veto? (o relator queria renegociação de dívida com empreiteiro e escreveu regra de restos a pagar ruim; tiraram regra ano a ano de despesa para antecessor, importante para prefeitura).

38) Como foi o fecho do processo de tramitação da lei? (questão das prefeituras, promessa de financiamento do BNDES para capacitação das prefeituras para implementação).

39) É possível dizer que a tramitação foi influenciada pela tramitação de outras matérias, como a Reforma Tributária?

40) Questão das adins (reação dos técnicos dos tribunais de contas).

41) Desde que foi elaborado no governo até sair no Senado, o projeto teve algumas versões: 1) a original, elaborada pelo Executivo Federal;

2) o anteprojeto;

3) a versão que deu entrada na Câmara;

4) a versão com modificações sugeridas a partir do trabalho da Comissão Especial;

5) a versão que deu entrada no Senado e

6) a versão que saiu do Senado. Na sua opinião, em qual(is) etapa(s) houve maiores modificações no texto? Por que? Essas modificações foram negociadas com o governo?

42) O Projeto de Lei Complementar $n^{\circ} 18$ de 1999 passou pela Câmara dos Deputados e pelo Senado Federal, segundo a literatura, com rápida tramitação e obteve elevado índice de votos favoráveis: 385 votos a favor, 86 contra e quatro abstenções. Com base nessas características, é possível dizer que o processo político de aprovação da LRF caracterizou-se como um processo de pouco conflito político entre os atores?

(Hipóteses: descrença de que ia passar e foi passando; desconhecimento sobre a lei)

43) Alguns pontos do texto da Lei de Responsabilidade Fiscal merecem destaque:

a) a limitação de gastos com pessoal, estabelecendo não somente o quanto pode ser gasto por cada nível de governo em relação à receita líquida, mas também o percentual equivalente a cada um dos Poderes;

b) a reafirmação dos limites mais rígidos para o endividamento público estabelecidos pelo Senado Federal, indicando que o não cumprimento será punido com mais rigor (judicialmente; com retenção de transferências constitucionais e com a proibição de obtenção de empréstimos e de convênios com o Governo Federal);

c) a definição de metas fiscais anuais, a exigência de apresentação de relatórios trimestrais de acompanhamento e outros mecanismos de transparência, como o Conselho de Gestão Fiscal;

d) o estabelecimento de mecanismos de controle das finanças públicas em anos eleitorais;

e) a proibição de socorro financeiro entre os níveis de governo, reduzindo o risco moral entre agentes públicos e destes com os privados.

Dentre esses pontos, qual(is) gerou(aram) mais conflito entre os atores políticos envolvidos no processo? Qual é o mais relevante? 
Anexo 2:

LEI COMPLEMENTAR Nº 101, DE 4 DE MAIO DE 2000.

Estabelece normas de finanças públicas voltadas para a responsabilidade na gestão fiscal e dá outras providências.

O PRESIDENTE DA REPÚBLICA

Faço saber que o Congresso Nacional decreta e eu sanciono a seguinte Lei Complementar:

\section{CAPÍTULO I \\ DISPOSIÇÕES PRELIMINARES}

Art. 1o Esta Lei Complementar estabelece normas de finanças públicas voltadas para a responsabilidade na gestão fiscal, com amparo no Capítulo II do Título VI da Constituição. $\S 10 \mathrm{~A}$ responsabilidade na gestão fiscal pressupõe a ação planejada e transparente, em que se previnem riscos e corrigem desvios capazes de afetar o equilíbrio das contas públicas, mediante o cumprimento de metas de resultados entre receitas e despesas e a obediência a limites e condições no que tange a renúncia de receita, geração de despesas com pessoal, da seguridade social e outras, dívidas consolidada e mobiliária, operações de crédito, inclusive por antecipação de receita, concessão de garantia e inscrição em Restos a Pagar.

§ 20 As disposições desta Lei Complementar obrigam a União, os Estados, o Distrito Federal e os Municípios.

$\S 30$ Nas referências:

I - à União, aos Estados, ao Distrito Federal e aos Municípios, estão compreendidos:

a) o Poder Executivo, o Poder Legislativo, neste abrangidos os Tribunais de Contas, o Poder Judiciário e o Ministério Público;

b) as respectivas administrações diretas, fundos, autarquias, fundações e empresas estatais dependentes;

II - a Estados entende-se considerado o Distrito Federal;

III - a Tribunais de Contas estão incluídos: Tribunal de Contas da União, Tribunal de Contas do Estado e, quando houver, Tribunal de Contas dos Municípios e Tribunal de Contas do Município.

Art. 2o Para os efeitos desta Lei Complementar, entende-se como:

I - ente da Federação: a União, cada Estado, o Distrito Federal e cada Município;

II - empresa controlada: sociedade cuja maioria do capital social com direito a voto pertença, direta ou indiretamente, a ente da Federação;

III - empresa estatal dependente: empresa controlada que receba do ente controlador recursos financeiros para pagamento de despesas com pessoal ou de custeio em geral ou de capital, excluídos, no último caso, aqueles provenientes de aumento de participação acionária;

IV - receita corrente líquida: somatório das receitas tributárias, de contribuições, patrimoniais, industriais, agropecuárias, de serviços, transferências correntes e outras receitas também correntes, deduzidos:

a) na União, os valores transferidos aos Estados e Municípios por determinação constitucional ou legal, e as contribuições mencionadas na alínea a do inciso I e no inciso Il do art. 195, e no art. 239 da Constituição;

b) nos Estados, as parcelas entregues aos Municípios por determinação constitucional;

c) na União, nos Estados e nos Municípios, a contribuição dos servidores para o custeio do seu sistema de previdência e assistência social e as receitas provenientes da compensação financeira citada no § 9o do art. 201 da Constituição. 
$\S 10$ Serão computados no cálculo da receita corrente líquida os valores pagos e recebidos em decorrência da Lei Complementar no 87, de 13 de setembro de 1996, e do fundo previsto pelo art. 60 do Ato das Disposições Constitucionais Transitórias.

§ 20 Não serão considerados na receita corrente líquida do Distrito Federal e dos Estados do Amapá e de Roraima os recursos recebidos da União para atendimento das despesas de que trata o inciso $V$ do $\S 10$ do art. 19.

$\S 30$ A receita corrente líquida será apurada somando-se as receitas arrecadadas no mês em referência e nos onze anteriores, excluídas as duplicidades.

\author{
CAPÍTULO II \\ DO PLANEJAMENTO \\ Seção I \\ Do Plano Plurianual
}

Art. 3o (VETADO)

Seção II

Da Lei de Diretrizes Orçamentárias

Art. 4o A lei de diretrizes orçamentárias atenderá o disposto no $\S 20$ do art. 165 da Constituição e:

I - disporá também sobre:

a) equilíbrio entre receitas e despesas;

b) critérios e forma de limitação de empenho, a ser efetivada nas hipóteses previstas na alínea $b$ do inciso II deste artigo, no art. 90 e no inciso II do § 10 do art. 31;

c) (VETADO)

d) (VETADO)

e) normas relativas ao controle de custos e à avaliação dos resultados dos programas financiados com recursos dos orçamentos;

f) demais condições e exigências para transferências de recursos a entidades públicas e privadas;

II - (VETADO)

III - (VETADO)

$\S 10$ Integrará o projeto de lei de diretrizes orçamentárias Anexo de Metas Fiscais, em que serão estabelecidas metas anuais, em valores correntes e constantes, relativas a receitas, despesas, resultados nominal e primário e montante da dívida pública, para o exercício a que se referirem e para os dois seguintes.

$\S 20$ O Anexo conterá, ainda:

I - avaliação do cumprimento das metas relativas ao ano anterior;

II - demonstrativo das metas anuais, instruído com memória e metodologia de cálculo que justifiquem os resultados pretendidos, comparando-as com as fixadas nos três exercícios anteriores, e evidenciando a consistência delas com as premissas e os objetivos da política econômica nacional;

III - evolução do patrimônio líquido, também nos últimos três exercícios, destacando a origem e a aplicação dos recursos obtidos com a alienação de ativos;

IV - avaliação da situação financeira e atuarial:

a) dos regimes geral de previdência social e próprio dos servidores públicos e do Fundo de Amparo ao Trabalhador;

b) dos demais fundos públicos e programas estatais de natureza atuarial;

$\mathrm{V}$ - demonstrativo da estimativa e compensação da renúncia de receita e da margem de expansão das despesas obrigatórias de caráter continuado.

§ 30 A lei de diretrizes orçamentárias conterá Anexo de Riscos Fiscais, onde serão avaliados os passivos contingentes e outros riscos capazes de afetar as contas públicas, informando as providências a serem tomadas, caso se concretizem. 
$\S 40$ A mensagem que encaminhar o projeto da União apresentará, em anexo específico, os objetivos das políticas monetária, creditícia e cambial, bem como os parâmetros e as projeções para seus principais agregados e variáveis, e ainda as metas de inflação, para o exercício subseqüente.

\author{
Seção III \\ Da Lei Orçamentária Anual
}

Art. 5o 0 projeto de lei orçamentária anual, elaborado de forma compatível com o plano plurianual, com a lei de diretrizes orçamentárias e com as normas desta Lei Complementar:

I - conterá, em anexo, demonstrativo da compatibilidade da programação dos orçamentos com os objetivos e metas constantes do documento de que trata o $\S 10$ do art. 40;

II - será acompanhado do documento a que se refere o $\S 60$ do art. 165 da Constituição, bem como das medidas de compensação a renúncias de receita e ao aumento de despesas obrigatórias de caráter continuado;

III - conterá reserva de contingência, cuja forma de utilização e montante, definido com base na receita corrente líquida, serão estabelecidos na lei de diretrizes orçamentárias, destinada ao:

a) (VETADO)

b) atendimento de passivos contingentes e outros riscos e eventos fiscais imprevistos.

$\S 10$ Todas as despesas relativas à dívida pública, mobiliária ou contratual, e as receitas que as atenderão, constarão da lei orçamentária anual.

$\S 20$ O refinanciamento da dívida pública constará separadamente na lei orçamentária e nas de crédito adicional.

§ 30 A atualização monetária do principal da dívida mobiliária refinanciada não poderá superar a variação do índice de preços previsto na lei de diretrizes orçamentárias, ou em legislação específica.

$\S 40$ É vedado consignar na lei orçamentária crédito com finalidade imprecisa ou com dotação ilimitada.

§ 50 A lei orçamentária não consignará dotação para investimento com duração superior a um exercício financeiro que não esteja previsto no plano plurianual ou em lei que autorize a sua inclusão, conforme disposto no $\S 10$ do art. 167 da Constituição.

§ 60 Integrarão as despesas da União, e serão incluídas na lei orçamentária, as do Banco Central do Brasil relativas a pessoal e encargos sociais, custeio administrativo, inclusive os destinados a benefícios e assistência aos servidores, e a investimentos.

$\S 70($ VETADO)

\title{
Art. 60 (VETADO)
}

Art. 7o O resultado do Banco Central do Brasil, apurado após a constituição ou reversão de reservas, constitui receita do Tesouro Nacional, e será transferido até o décimo dia útil subseqüente à aprovação dos balanços semestrais.

$\S 10$ O resultado negativo constituirá obrigação do Tesouro para com o Banco Central do Brasil e será consignado em dotação específica no orçamento.

§ 20 O impacto e o custo fiscal das operações realizadas pelo Banco Central do Brasil serão demonstrados trimestralmente, nos termos em que dispuser a lei de diretrizes orçamentárias da União.

§ 3o Os balanços trimestrais do Banco Central do Brasil conterão notas explicativas sobre os custos da remuneração das disponibilidades do Tesouro Nacional e da manutenção das reservas cambiais e a rentabilidade de sua carteira de títulos, destacando os de emissão da União.

Seção IV

Da Execução Orçamentária e do Cumprimento das Metas 
Art. 8o Até trinta dias após a publicação dos orçamentos, nos termos em que dispuser a lei de diretrizes orçamentárias e observado o disposto na alínea c do inciso I do art. 40, o Poder Executivo estabelecerá a programação financeira e o cronograma de execução mensal de desembolso.

Parágrafo único. Os recursos legalmente vinculados a finalidade específica serão utilizados exclusivamente para atender ao objeto de sua vinculação, ainda que em exercício diverso daquele em que ocorrer o ingresso.

Art. 9o Se verificado, ao final de um bimestre, que a realização da receita poderá não comportar o cumprimento das metas de resultado primário ou nominal estabelecidas no Anexo de Metas Fiscais, os Poderes e o Ministério Público promoverão, por ato próprio e nos montantes necessários, nos trinta dias subseqüentes, limitação de empenho e movimentação financeira, segundo os critérios fixados pela lei de diretrizes orçamentárias. $\S 10$ No caso de restabelecimento da receita prevista, ainda que parcial, a recomposição das dotações cujos empenhos foram limitados dar-se-á de forma proporcional às reduções efetivadas.

$\S 20$ Não serão objeto de limitação as despesas que constituam obrigações constitucionais e legais do ente, inclusive aquelas destinadas ao pagamento do serviço da dívida, e as ressalvadas pela lei de diretrizes orçamentárias.

$\S 30$ No caso de os Poderes Legislativo e Judiciário e o Ministério Público não promoverem a limitação no prazo estabelecido no caput, é o Poder Executivo autorizado a limitar os valores financeiros segundo os critérios fixados pela lei de diretrizes orçamentárias.

$\S 40$ Até o final dos meses de maio, setembro e fevereiro, o Poder Executivo demonstrará e avaliará o cumprimento das metas fiscais de cada quadrimestre, em audiência pública na comissão referida no $\S 10$ do art. 166 da Constituição ou equivalente nas Casas Legislativas estaduais e municipais.

$\S 50$ No prazo de noventa dias após o encerramento de cada semestre, o Banco Central do Brasil apresentará, em reunião conjunta das comissões temáticas pertinentes do Congresso Nacional, avaliação do cumprimento dos objetivos e metas das políticas monetária, creditícia e cambial, evidenciando o impacto e o custo fiscal de suas operações e os resultados demonstrados nos balanços.

Art. 10. A execução orçamentária e financeira identificará os beneficiários de pagamento de sentenças judiciais, por meio de sistema de contabilidade e administração financeira, para fins de observância da ordem cronológica determinada no art. 100 da Constituição.

\section{CAPÍTULO III \\ DA RECEITA PÚBLICA \\ Seção I \\ Da Previsão e da Arrecadação}

Art. 11. Constituem requisitos essenciais da responsabilidade na gestão fiscal a instituição, previsão e efetiva arrecadação de todos os tributos da competência constitucional do ente da Federação.

Parágrafo único. É vedada a realização de transferências voluntárias para o ente que não observe o disposto no caput, no que se refere aos impostos.

Art. 12. As previsões de receita observarão as normas técnicas e legais, considerarão os efeitos das alterações na legislação, da variação do índice de preços, do crescimento econômico ou de qualquer outro fator relevante e serão acompanhadas de demonstrativo de sua evolução nos últimos três anos, da projeção para os dois seguintes àquele a que se referirem, e da metodologia de cálculo e premissas utilizadas. 
$\S 10$ Reestimativa de receita por parte do Poder Legislativo só será admitida se comprovado erro ou omissão de ordem técnica ou legal.

§ 20 O montante previsto para as receitas de operações de crédito não poderá ser superior ao das despesas de capital constantes do projeto de lei orçamentária.

§ 30 O Poder Executivo de cada ente colocará à disposição dos demais Poderes e do Ministério Público, no mínimo trinta dias antes do prazo final para encaminhamento de suas propostas orçamentárias, os estudos e as estimativas das receitas para o exercício subseqüente, inclusive da corrente líquida, e as respectivas memórias de cálculo.

Art. 13. No prazo previsto no art. 8o, as receitas previstas serão desdobradas, pelo Poder Executivo, em metas bimestrais de arrecadação, com a especificação, em separado, quando cabível, das medidas de combate à evasão e à sonegação, da quantidade e valores de ações ajuizadas para cobrança da dívida ativa, bem como da evolução do montante dos créditos tributários passíveis de cobrança administrativa.

\title{
Seção II
}

\section{Da Renúncia de Receita}

Art. 14. A concessão ou ampliação de incentivo ou benefício de natureza tributária da qual decorra renúncia de receita deverá estar acompanhada de estimativa do impacto orçamentário-financeiro no exercício em que deva iniciar sua vigência e nos dois seguintes, atender ao disposto na lei de diretrizes orçamentárias e a pelo menos uma das seguintes condições:

I - demonstração pelo proponente de que a renúncia foi considerada na estimativa de receita da lei orçamentária, na forma do art. 12, e de que não afetará as metas de resultados fiscais previstas no anexo próprio da lei de diretrizes orçamentárias;

II - estar acompanhada de medidas de compensação, no período mencionado no caput, por meio do aumento de receita, proveniente da elevação de alíquotas, ampliação da base de cálculo, majoração ou criação de tributo ou contribuição.

$\S 10$ A renúncia compreende anistia, remissão, subsídio, crédito presumido, concessão de isenção em caráter não geral, alteração de alíquota ou modificação de base de cálculo que implique redução discriminada de tributos ou contribuições, e outros benefícios que correspondam a tratamento diferenciado.

$\S 20$ Se o ato de concessão ou ampliação do incentivo ou benefício de que trata o caput deste artigo decorrer da condição contida no inciso II, o benefício só entrará em vigor quando implementadas as medidas referidas no mencionado inciso.

$\S 30$ O disposto neste artigo não se aplica:

I - às alterações das alíquotas dos impostos previstos nos incisos I, II, IV e V do art. 153 da Constituição, na forma do seu § 10;

II - ao cancelamento de débito cujo montante seja inferior ao dos respectivos custos de cobrança.

\author{
CAPÍTULO IV \\ DA DESPESA PÚBLICA \\ Seção 1 \\ Da Geração da Despesa
}

Art. 15. Serão consideradas não autorizadas, irregulares e lesivas ao patrimônio público a geração de despesa ou assunção de obrigação que não atendam o disposto nos arts. 16 e 17.

Art. 16. A criação, expansão ou aperfeiçoamento de ação governamental que acarrete aumento da despesa será acompanhado de:

I - estimativa do impacto orçamentário-financeiro no exercício em que deva entrar em vigor e nos dois subseqüentes; 
II - declaração do ordenador da despesa de que o aumento tem adequação orçamentária e financeira com a lei orçamentária anual e compatibilidade com o plano plurianual e com a lei de diretrizes orçamentárias.

$\S 10$ Para os fins desta Lei Complementar, considera-se:

I - adequada com a lei orçamentária anual, a despesa objeto de dotação específica e suficiente, ou que esteja abrangida por crédito genérico, de forma que somadas todas as despesas da mesma espécie, realizadas e a realizar, previstas no programa de trabalho, não sejam ultrapassados os limites estabelecidos para o exercício;

II - compatível com o plano plurianual e a lei de diretrizes orçamentárias, a despesa que se conforme com as diretrizes, objetivos, prioridades e metas previstos nesses instrumentos e não infrinja qualquer de suas disposições.

$\S 20$ A estimativa de que trata o inciso I do caput será acompanhada das premissas e metodologia de cálculo utilizadas.

§ 30 Ressalva-se do disposto neste artigo a despesa considerada irrelevante, nos termos em que dispuser a lei de diretrizes orçamentárias.

§ 4o As normas do caput constituem condição prévia para:

I - empenho e licitação de serviços, fornecimento de bens ou execução de obras;

II - desapropriação de imóveis urbanos a que se refere o § 30 do art. 182 da Constituição.

Subseção I

Da Despesa Obrigatória de Caráter Continuado

Art. 17. Considera-se obrigatória de caráter continuado a despesa corrente derivada de lei, medida provisória ou ato administrativo normativo que fixem para o ente a obrigação legal de sua execução por um período superior a dois exercícios.

$\S 10$ Os atos que criarem ou aumentarem despesa de que trata o caput deverão ser instruídos com a estimativa prevista no inciso I do art. 16 e demonstrar a origem dos recursos para seu custeio.

§ 2o Para efeito do atendimento do § 10, o ato será acompanhado de comprovação de que a despesa criada ou aumentada não afetará as metas de resultados fiscais previstas no anexo referido no $\S 10$ do art. 4o, devendo seus efeitos financeiros, nos períodos seguintes, ser compensados pelo aumento permanente de receita ou pela redução permanente de despesa.

$\S 30$ Para efeito do § 2o, considera-se aumento permanente de receita o proveniente da elevação de alíquotas, ampliação da base de cálculo, majoração ou criação de tributo ou contribuição.

$\S 40$ A comprovação referida no $\S 20$, apresentada pelo proponente, conterá as premissas e metodologia de cálculo utilizadas, sem prejuízo do exame de compatibilidade da despesa com as demais normas do plano plurianual e da lei de diretrizes orçamentárias.

$\S 50$ A despesa de que trata este artigo não será executada antes da implementação das medidas referidas no $\S 20$, as quais integrarão o instrumento que a criar ou aumentar.

$\S 600$ disposto no $\S 10$ não se aplica às despesas destinadas ao serviço da dívida nem ao reajustamento de remuneração de pessoal de que trata o inciso $X$ do art. 37 da Constituição.

§ 70 Considera-se aumento de despesa a prorrogação daquela criada por prazo determinado.

\author{
Seção II \\ Das Despesas com Pessoal \\ Subseção I \\ Definições e Limites
}

Art. 18. Para os efeitos desta Lei Complementar, entende-se como despesa total com pessoal: o somatório dos gastos do ente da Federação com os ativos, os inativos e os pensionistas, relativos a mandatos eletivos, cargos, funções ou empregos, civis, militares e de membros de Poder, com quaisquer espécies remuneratórias, tais como vencimentos 
e vantagens, fixas e variáveis, subsídios, proventos da aposentadoria, reformas e pensões, inclusive adicionais, gratificações, horas extras e vantagens pessoais de qualquer natureza, bem como encargos sociais e contribuições recolhidas pelo ente às entidades de previdência.

$\S 10$ Os valores dos contratos de terceirização de mão-de-obra que se referem à substituição de servidores e empregados públicos serão contabilizados como "Outras Despesas de Pessoal".

§ 20 A despesa total com pessoal será apurada somando-se a realizada no mês em referência com as dos onze imediatamente anteriores, adotando-se o regime de competência.

Art. 19. Para os fins do disposto no caput do art. 169 da Constituição, a despesa total com pessoal, em cada período de apuração e em cada ente da Federação, não poderá exceder os percentuais da receita corrente líquida, a seguir discriminados:

I - União: $50 \%$ (cinqüenta por cento);

II - Estados: $60 \%$ (sessenta por cento);

III - Municípios: $60 \%$ (sessenta por cento).

$\S 10 \mathrm{Na}$ verificação do atendimento dos limites definidos neste artigo, não serão computadas as despesas:

I - de indenização por demissão de servidores ou empregados;

II - relativas a incentivos à demissão voluntária;

III - derivadas da aplicação do disposto no inciso II do § 60 do art. 57 da Constituição;

IV - decorrentes de decisão judicial e da competência de período anterior ao da apuração a que se refere o $\S 20$ do art. 18;

V - com pessoal, do Distrito Federal e dos Estados do Amapá e Roraima, custeadas com recursos transferidos pela União na forma dos incisos XIII e XIV do art. 21 da Constituição e do art. 31 da Emenda Constitucional no 19;

$\mathrm{VI}$ - com inativos, ainda que por intermédio de fundo específico, custeadas por recursos provenientes:

a) da arrecadação de contribuições dos segurados;

b) da compensação financeira de que trata o § 9o do art. 201 da Constituição;

c) das demais receitas diretamente arrecadadas por fundo vinculado a tal finalidade, inclusive o produto da alienação de bens, direitos e ativos, bem como seu superávit financeiro.

$\S 20$ Observado o disposto no inciso IV do $\S 10$, as despesas com pessoal decorrentes de sentenças judiciais serão incluídas no limite do respectivo Poder ou órgão referido no art. 20.

Art. 20. A repartição dos limites globais do art. 19 não poderá exceder os seguintes percentuais:

I - na esfera federal:

a) 2,5\% (dois inteiros e cinco décimos por cento) para o Legislativo, incluído o Tribunal de Contas da União;

b) $6 \%$ (seis por cento) para o Judiciário;

c) $40,9 \%$ (quarenta inteiros e nove décimos por cento) para o Executivo, destacando-se $3 \%$ (três por cento) para as despesas com pessoal decorrentes do que dispõem os incisos XIII e XIV do art. 21 da Constituição e o art. 31 da Emenda Constitucional no 19, repartidos de forma proporcional à média das despesas relativas a cada um destes dispositivos, em percentual da receita corrente líquida, verificadas nos três exercícios financeiros imediatamente anteriores ao da publicação desta Lei Complementar;

d) $0,6 \%$ (seis décimos por cento) para o Ministério Público da União;

II - na esfera estadual:

a) 3\% (três por cento) para o Legislativo, incluído o Tribunal de Contas do Estado;

b) $6 \%$ (seis por cento) para o Judiciário;

c) $49 \%$ (quarenta e nove por cento) para o Executivo; 
d) $2 \%$ (dois por cento) para o Ministério Público dos Estados;

III - na esfera municipal:

a) 6\% (seis por cento) para o Legislativo, incluído o Tribunal de Contas do Município, quando houver;

b) $54 \%$ (cinqüenta e quatro por cento) para o Executivo.

$\S 10$ Nos Poderes Legislativo e Judiciário de cada esfera, os limites serão repartidos entre seus órgãos de forma proporcional à média das despesas com pessoal, em percentual da receita corrente líquida, verificadas nos três exercícios financeiros imediatamente anteriores ao da publicação desta Lei Complementar.

$\S 20$ Para efeito deste artigo entende-se como órgão:

I - o Ministério Público;

II- no Poder Legislativo:

a) Federal, as respectivas Casas e o Tribunal de Contas da União;

b) Estadual, a Assembléia Legislativa e os Tribunais de Contas;

c) do Distrito Federal, a Câmara Legislativa e o Tribunal de Contas do Distrito Federal;

d) Municipal, a Câmara de Vereadores e o Tribunal de Contas do Município, quando houver;

III - no Poder Judiciário:

a) Federal, os tribunais referidos no art. 92 da Constituição;

b) Estadual, o Tribunal de Justiça e outros, quando houver.

$\S 30$ Os limites para as despesas com pessoal do Poder Judiciário, a cargo da União por força do inciso XIII do art. 21 da Constituição, serão estabelecidos mediante aplicação da regra do $\S 10$.

$\S 40$ Nos Estados em que houver Tribunal de Contas dos Municípios, os percentuais definidos nas alíneas a e c do inciso II do caput serão, respectivamente, acrescidos e reduzidos em $0,4 \%$ (quatro décimos por cento).

$\S 50$ Para os fins previstos no art. 168 da Constituição, a entrega dos recursos financeiros correspondentes à despesa total com pessoal por Poder e órgão será a resultante da aplicação dos percentuais definidos neste artigo, ou aqueles fixados na lei de diretrizes orçamentárias.

$\S 60($ VETADO)

\section{Subseção II}

Do Controle da Despesa Total com Pessoal

Art. 21. É nulo de pleno direito o ato que provoque aumento da despesa com pessoal e não atenda:

I - as exigências dos arts. 16 e 17 desta Lei Complementar, e o disposto no inciso XIII do art. 37 e no $\S 10$ do art. 169 da Constituição;

II - o limite legal de comprometimento aplicado às despesas com pessoal inativo.

Parágrafo único. Também é nulo de pleno direito o ato de que resulte aumento da despesa com pessoal expedido nos cento e oitenta dias anteriores ao final do mandato do titular do respectivo Poder ou órgão referido no art. 20.

Art. 22. A verificação do cumprimento dos limites estabelecidos nos arts. 19 e 20 será realizada ao final de cada quadrimestre.

Parágrafo único. Se a despesa total com pessoal exceder a $95 \%$ (noventa e cinco por cento) do limite, são vedados ao Poder ou órgão referido no art. 20 que houver incorrido no excesso:

I - concessão de vantagem, aumento, reajuste ou adequação de remuneração a qualquer título, salvo os derivados de sentença judicial ou de determinação legal ou contratual, ressalvada a revisão prevista no inciso $X$ do art. 37 da Constituição;

II - criação de cargo, emprego ou função;

III - alteração de estrutura de carreira que implique aumento de despesa; 
IV - provimento de cargo público, admissão ou contratação de pessoal a qualquer título, ressalvada a reposição decorrente de aposentadoria ou falecimento de servidores das áreas de educação, saúde e segurança;

V - contratação de hora extra, salvo no caso do disposto no inciso II do § 60 do art. 57 da Constituição e as situações previstas na lei de diretrizes orçamentárias.

Art. 23. Se a despesa total com pessoal, do Poder ou órgão referido no art. 20, ultrapassar os limites definidos no mesmo artigo, sem prejuízo das medidas previstas no art. 22, o percentual excedente terá de ser eliminado nos dois quadrimestres seguintes, sendo pelo menos um terço no primeiro, adotando-se, entre outras, as providências previstas nos $\S \S$ 30 e 40 do art. 169 da Constituição.

$\S 10$ No caso do inciso I do $\S 30$ do art. 169 da Constituição, o objetivo poderá ser alcançado tanto pela extinção de cargos e funções quanto pela redução dos valores a eles atribuídos.

§ 20 É facultada a redução temporária da jornada de trabalho com adequação dos vencimentos à nova carga horária.

§ 30 Não alcançada a redução no prazo estabelecido, e enquanto perdurar o excesso, o ente não poderá:

I - receber transferências voluntárias;

II - obter garantia, direta ou indireta, de outro ente;

III - contratar operações de crédito, ressalvadas as destinadas ao refinanciamento da dívida mobiliária e as que visem à redução das despesas com pessoal.

$\S 40$ As restrições do $\S 30$ aplicam-se imediatamente se a despesa total com pessoal exceder o limite no primeiro quadrimestre do último ano do mandato dos titulares de Poder ou órgão referidos no art. 20.

\section{Seção III \\ Das Despesas com a Seguridade Social}

Art. 24. Nenhum benefício ou serviço relativo à seguridade social poderá ser criado, majorado ou estendido sem a indicação da fonte de custeio total, nos termos do $\S 50$ do art. 195 da Constituição, atendidas ainda as exigências do art. 17.

$\S 10$ É dispensada da compensação referida no art. 17 o aumento de despesa decorrente de:

I - concessão de benefício a quem satisfaça as condições de habilitação prevista na legislação pertinente;

II - expansão quantitativa do atendimento e dos serviços prestados;

III - reajustamento de valor do benefício ou serviço, a fim de preservar o seu valor real.

$\S 20$ O disposto neste artigo aplica-se a benefício ou serviço de saúde, previdência e assistência social, inclusive os destinados aos servidores públicos e militares, ativos e inativos, e aos pensionistas.

\section{CAPÍTULO V \\ DAS TRANSFERÊNCIAS VOLUNTÁRIAS}

Art. 25. Para efeito desta Lei Complementar, entende-se por transferência voluntária a entrega de recursos correntes ou de capital a outro ente da Federação, a título de cooperação, auxílio ou assistência financeira, que não decorra de determinação constitucional, legal ou os destinados ao Sistema Único de Saúde.

§ 10 São exigências para a realização de transferência voluntária, além das estabelecidas na lei de diretrizes orçamentárias:

I - existência de dotação específica;

II - (VETADO)

III - observância do disposto no inciso X do art. 167 da Constituição;

IV - comprovação, por parte do beneficiário, de: 
a) que se acha em dia quanto ao pagamento de tributos, empréstimos e financiamentos devidos ao ente transferidor, bem como quanto à prestação de contas de recursos anteriormente dele recebidos;

b) cumprimento dos limites constitucionais relativos à educação e à saúde;

c) observância dos limites das dívidas consolidada e mobiliária, de operações de crédito, inclusive por antecipação de receita, de inscrição em Restos a Pagar e de despesa total com pessoal;

d) previsão orçamentária de contrapartida.

$\S 20$ É vedada a utilização de recursos transferidos em finalidade diversa da pactuada.

§ 30 Para fins da aplicação das sanções de suspensão de transferências voluntárias constantes desta Lei Complementar, excetuam-se aquelas relativas a ações de educação, saúde e assistência social.

\section{CAPÍTULO VI \\ DA DESTINAÇÃO DE RECURSOS PÚBLICOS PARA O SETOR PRIVADO}

Art. 26. A destinação de recursos para, direta ou indiretamente, cobrir necessidades de pessoas físicas ou déficits de pessoas jurídicas deverá ser autorizada por lei específica, atender às condições estabelecidas na lei de diretrizes orçamentárias e estar prevista no orçamento ou em seus créditos adicionais.

$\S 100$ disposto no caput aplica-se a toda a administração indireta, inclusive fundações públicas e empresas estatais, exceto, no exercício de suas atribuições precípuas, as instituições financeiras e o Banco Central do Brasil.

$\S 20$ Compreende-se incluída a concessão de empréstimos, financiamentos e refinanciamentos, inclusive as respectivas prorrogações e a composição de dívidas, a concessão de subvenções e a participação em constituição ou aumento de capital.

Art. 27. Na concessão de crédito por ente da Federação a pessoa física, ou jurídica que não esteja sob seu controle direto ou indireto, os encargos financeiros, comissões e despesas congêneres não serão inferiores aos definidos em lei ou ao custo de captação.

Parágrafo único. Dependem de autorização em lei específica as prorrogações e composições de dívidas decorrentes de operações de crédito, bem como a concessão de empréstimos ou financiamentos em desacordo com o caput, sendo o subsídio correspondente consignado na lei orçamentária.

Art. 28. Salvo mediante lei específica, não poderão ser utilizados recursos públicos, inclusive de operações de crédito, para socorrer instituições do Sistema Financeiro Nacional, ainda que mediante a concessão de empréstimos de recuperação ou financiamentos para mudança de controle acionário.

$\S 10$ A prevenção de insolvência e outros riscos ficará a cargo de fundos, e outros mecanismos, constituídos pelas instituições do Sistema Financeiro Nacional, na forma da lei.

$\S 200$ disposto no caput não proíbe o Banco Central do Brasil de conceder às instituições financeiras operações de redesconto e de empréstimos de prazo inferior a trezentos e sessenta dias.

\section{CAPÍTULO VII \\ DA DÍVIDA E DO ENDIVIDAMENTO Seção I \\ Definições Básicas}

Art. 29. Para os efeitos desta Lei Complementar, são adotadas as seguintes definições:

I - dívida pública consolidada ou fundada: montante total, apurado sem duplicidade, das obrigações financeiras do ente da Federação, assumidas em virtude de leis, contratos, 
convênios ou tratados e da realização de operações de crédito, para amortização em prazo superior a doze meses;

II - dívida pública mobiliária: dívida pública representada por títulos emitidos pela União, inclusive os do Banco Central do Brasil, Estados e Municípios;

III - operação de crédito: compromisso financeiro assumido em razão de mútuo, abertura de crédito, emissão e aceite de título, aquisição financiada de bens, recebimento antecipado de valores provenientes da venda a termo de bens e serviços, arrendamento mercantil e outras operações assemelhadas, inclusive com o uso de derivativos financeiros;

IV - concessão de garantia: compromisso de adimplência de obrigação financeira ou contratual assumida por ente da Federação ou entidade a ele vinculada;

V - refinanciamento da dívida mobiliária: emissão de títulos para pagamento do principal acrescido da atualização monetária.

§ 10 Equipara-se a operação de crédito a assunção, o reconhecimento ou a confissão de dívidas pelo ente da Federação, sem prejuízo do cumprimento das exigências dos arts. 15 e 16.

§ 20 Será incluída na dívida pública consolidada da União a relativa à emissão de títulos de responsabilidade do Banco Central do Brasil.

$\S 30$ Também integram a dívida pública consolidada as operações de crédito de prazo inferior a doze meses cujas receitas tenham constado do orçamento.

$\S 40$ O refinanciamento do principal da dívida mobiliária não excederá, ao término de cada exercício financeiro, o montante do final do exercício anterior, somado ao das operações de crédito autorizadas no orçamento para este efeito e efetivamente realizadas, acrescido de atualização monetária.

\section{Seção II}

Dos Limites da Dívida Pública e das Operações de Crédito

Art. 30. No prazo de noventa dias após a publicação desta Lei Complementar, o Presidente da República submeterá ao:

I - Senado Federal: proposta de limites globais para o montante da dívida consolidada da União, Estados e Municípios, cumprindo o que estabelece o inciso VI do art. 52 da Constituição, bem como de limites e condições relativos aos incisos VII, VIII e IX do mesmo artigo;

II - Congresso Nacional: projeto de lei que estabeleça limites para o montante da dívida mobiliária federal a que se refere o inciso XIV do art. 48 da Constituição, acompanhado da demonstração de sua adequação aos limites fixados para a dívida consolidada da União, atendido o disposto no inciso I do $\S 10$ deste artigo.

$\S 10$ As propostas referidas nos incisos I e II do caput e suas alterações conterão:

I - demonstração de que os limites e condições guardam coerência com as normas estabelecidas nesta Lei Complementar e com os objetivos da política fiscal;

II - estimativas do impacto da aplicação dos limites a cada uma das três esferas de governo;

III - razões de eventual proposição de limites diferenciados por esfera de governo;

IV - metodologia de apuração dos resultados primário e nominal.

$\S 20$ As propostas mencionadas nos incisos I e II do caput também poderão ser apresentadas em termos de dívida líquida, evidenciando a forma e a metodologia de sua apuração.

$\S 30$ Os limites de que tratam os incisos I e II do caput serão fixados em percentual da receita corrente líquida para cada esfera de governo e aplicados igualmente a todos os entes da Federação que a integrem, constituindo, para cada um deles, limites máximos.

$\S 40$ Para fins de verificação do atendimento do limite, a apuração do montante da dívida consolidada será efetuada ao final de cada quadrimestre. 
$\S 50$ No prazo previsto no art. 5o, o Presidente da República enviará ao Senado Federal ou ao Congresso Nacional, conforme o caso, proposta de manutenção ou alteração dos limites e condições previstos nos incisos I e II do caput.

$\S 60$ Sempre que alterados os fundamentos das propostas de que trata este artigo, em razão de instabilidade econômica ou alterações nas políticas monetária ou cambial, o Presidente da República poderá encaminhar ao Senado Federal ou ao Congresso Nacional solicitação de revisão dos limites.

$\S 70$ Os precatórios judiciais não pagos durante a execução do orçamento em que houverem sido incluídos integram a dívida consolidada, para fins de aplicação dos limites.

\section{Seção III \\ Da Recondução da Dívida aos Limites}

Art. 31. Se a dívida consolidada de um ente da Federação ultrapassar o respectivo limite ao final de um quadrimestre, deverá ser a ele reconduzida até o término dos três subseqüentes, reduzindo o excedente em pelo menos $25 \%$ (vinte e cinco por cento) no primeiro.

$\S 10$ Enquanto perdurar o excesso, o ente que nele houver incorrido:

I - estará proibido de realizar operação de crédito interna ou externa, inclusive por antecipação de receita, ressalvado o refinanciamento do principal atualizado da dívida mobiliária;

II - obterá resultado primário necessário à recondução da dívida ao limite, promovendo, entre outras medidas, limitação de empenho, na forma do art. 9o.

$\S 20$ Vencido o prazo para retorno da dívida ao limite, e enquanto perdurar o excesso, o ente ficará também impedido de receber transferências voluntárias da União ou do Estado.

$\S 30$ As restrições do $\S 10$ aplicam-se imediatamente se o montante da dívida exceder o limite no primeiro quadrimestre do último ano do mandato do Chefe do Poder Executivo.

§ 40 O Ministério da Fazenda divulgará, mensalmente, a relação dos entes que tenham ultrapassado os limites das dívidas consolidada e mobiliária.

$\S 50$ As normas deste artigo serão observadas nos casos de descumprimento dos limites da dívida mobiliária e das operações de crédito internas e externas.

\section{Seção IV \\ Das Operações de Crédito \\ Subseção I \\ Da Contratação}

Art. 32. O Ministério da Fazenda verificará o cumprimento dos limites e condições relativos à realização de operações de crédito de cada ente da Federação, inclusive das empresas por eles controladas, direta ou indiretamente.

$\S 10 \mathrm{O}$ ente interessado formalizará seu pleito fundamentando-o em parecer de seus órgãos técnicos e jurídicos, demonstrando a relação custo-benefício, o interesse econômico e social da operação e o atendimento das seguintes condições:

I - existência de prévia e expressa autorização para a contratação, no texto da lei orçamentária, em créditos adicionais ou lei específica;

II - inclusão no orçamento ou em créditos adicionais dos recursos provenientes da operação, exceto no caso de operações por antecipação de receita;

III - observância dos limites e condições fixados pelo Senado Federal;

IV - autorização específica do Senado Federal, quando se tratar de operação de crédito externo;

V - atendimento do disposto no inciso III do art. 167 da Constituição;

VI - observância das demais restrições estabelecidas nesta Lei Complementar. 
§ 20 As operações relativas à dívida mobiliária federal autorizadas, no texto da lei orçamentária ou de créditos adicionais, serão objeto de processo simplificado que atenda às suas especificidades.

$\S 30$ Para fins do disposto no inciso $V$ do $\S 10$, considerar-se-á, em cada exercício financeiro, o total dos recursos de operações de crédito nele ingressados e o das despesas de capital executadas, observado o seguinte:

I - não serão computadas nas despesas de capital as realizadas sob a forma de empréstimo ou financiamento a contribuinte, com o intuito de promover incentivo fiscal, tendo por base tributo de competência do ente da Federação, se resultar a diminuição, direta ou indireta, do ônus deste;

II - se o empréstimo ou financiamento a que se refere o inciso I for concedido por instituição financeira controlada pelo ente da Federação, o valor da operação será deduzido das despesas de capital;

III - (VETADO)

§ 40 Sem prejuízo das atribuições próprias do Senado Federal e do Banco Central do Brasil, o Ministério da Fazenda efetuará o registro eletrônico centralizado e atualizado das dívidas públicas interna e externa, garantido o acesso público às informações, que incluirão:

I - encargos e condições de contratação;

II - saldos atualizados e limites relativos às dívidas consolidada e mobiliária, operações de crédito e concessão de garantias.

$\S 50$ Os contratos de operação de crédito externo não conterão cláusula que importe na compensação automática de débitos e créditos.

Art. 33. A instituição financeira que contratar operação de crédito com ente da Federação, exceto quando relativa à dívida mobiliária ou à externa, deverá exigir comprovação de que a operação atende às condições e limites estabelecidos.

$\S 10$ A operação realizada com infração do disposto nesta Lei Complementar será considerada nula, procedendo-se ao seu cancelamento, mediante a devolução do principal, vedados o pagamento de juros e demais encargos financeiros.

§ 20 Se a devolução não for efetuada no exercício de ingresso dos recursos, será consignada reserva específica na lei orçamentária para o exercício seguinte.

§ 30 Enquanto não efetuado o cancelamento, a amortização, ou constituída a reserva, aplicam-se as sanções previstas nos incisos do § 3o do art. 23.

$\S 40$ Também se constituirá reserva, no montante equivalente ao excesso, se não atendido o disposto no inciso III do art. 167 da Constituição, consideradas as disposições do $\S 30$ do art. 32 .

\section{Subseção II \\ Das Vedações}

Art. 34. O Banco Central do Brasil não emitirá títulos da dívida pública a partir de dois anos após a publicação desta Lei Complementar.

Art. 35. É vedada a realização de operação de crédito entre um ente da Federação, diretamente ou por intermédio de fundo, autarquia, fundação ou empresa estatal dependente, e outro, inclusive suas entidades da administração indireta, ainda que sob a forma de novação, refinanciamento ou postergação de dívida contraída anteriormente.

$\S 10$ Excetuam-se da vedação a que se refere o caput as operações entre instituição financeira estatal e outro ente da Federação, inclusive suas entidades da administração indireta, que não se destinem a:

I - financiar, direta ou indiretamente, despesas correntes;

II - refinanciar dívidas não contraídas junto à própria instituição concedente.

$\S 20$ O disposto no caput não impede Estados e Municípios de comprar títulos da dívida da União como aplicação de suas disponibilidades. 
Art. 36. É proibida a operação de crédito entre uma instituição financeira estatal e o ente da Federação que a controle, na qualidade de beneficiário do empréstimo.

Parágrafo único. O disposto no caput não proíbe instituição financeira controlada de adquirir, no mercado, títulos da dívida pública para atender investimento de seus clientes, ou títulos da dívida de emissão da União para aplicação de recursos próprios.

Art. 37. Equiparam-se a operações de crédito e estão vedados:

I - captação de recursos a título de antecipação de receita de tributo ou contribuição cujo fato gerador ainda não tenha ocorrido, sem prejuízo do disposto no § 7o do art. 150 da Constituição;

II - recebimento antecipado de valores de empresa em que o Poder Público detenha, direta ou indiretamente, a maioria do capital social com direito a voto, salvo lucros e dividendos, na forma da legislação;

III - assunção direta de compromisso, confissão de dívida ou operação assemelhada, com fornecedor de bens, mercadorias ou serviços, mediante emissão, aceite ou aval de título de crédito, não se aplicando esta vedação a empresas estatais dependentes;

IV - assunção de obrigação, sem autorização orçamentária, com fornecedores para pagamento a posteriori de bens e serviços.

Subseção III

Das Operações de Crédito por Antecipação de Receita Orçamentária

Art. 38. A operação de crédito por antecipação de receita destina-se a atender insuficiência de caixa durante o exercício financeiro e cumprirá as exigências mencionadas no art. 32 e mais as seguintes:

I - realizar-se-á somente a partir do décimo dia do início do exercício;

II - deverá ser liquidada, com juros e outros encargos incidentes, até o dia dez de dezembro de cada ano;

III - não será autorizada se forem cobrados outros encargos que não a taxa de juros da operação, obrigatoriamente prefixada ou indexada à taxa básica financeira, ou à que vier a esta substituir;

IV - estará proibida:

a) enquanto existir operação anterior da mesma natureza não integralmente resgatada;

b) no último ano de mandato do Presidente, Governador ou Prefeito Municipal.

$\S 10$ As operações de que trata este artigo não serão computadas para efeito do que dispõe o inciso III do art. 167 da Constituição, desde que liquidadas no prazo definido no inciso II do caput.

$\S 20$ As operações de crédito por antecipação de receita realizadas por Estados ou Municípios serão efetuadas mediante abertura de crédito junto à instituição financeira vencedora em processo competitivo eletrônico promovido pelo Banco Central do Brasil.

§ 30 O Banco Central do Brasil manterá sistema de acompanhamento e controle do saldo do crédito aberto e, no caso de inobservância dos limites, aplicará as sanções cabíveis à instituição credora.

\section{Subseção IV \\ Das Operações com o Banco Central do Brasil}

Art. 39. Nas suas relações com ente da Federação, o Banco Central do Brasil está sujeito às vedações constantes do art. 35 e mais às seguintes:

I - compra de título da dívida, na data de sua colocação no mercado, ressalvado o disposto no § 20 deste artigo;

II - permuta, ainda que temporária, por intermédio de instituição financeira ou não, de título da dívida de ente da Federação por título da dívida pública federal, bem como a operação de compra e venda, a termo, daquele título, cujo efeito final seja semelhante à permuta; 
III - concessão de garantia.

$\S 10 \mathrm{O}$ disposto no inciso II, in fine, não se aplica ao estoque de Letras do Banco Central do Brasil, Série Especial, existente na carteira das instituições financeiras, que pode ser refinanciado mediante novas operações de venda a termo.

$\S 20$ O Banco Central do Brasil só poderá comprar diretamente títulos emitidos pela União para refinanciar a dívida mobiliária federal que estiver vencendo na sua carteira.

$\S 30 \mathrm{~A}$ operação mencionada no $\S 20$ deverá ser realizada à taxa média e condições alcançadas no dia, em leilão público.

$\S 40$ É vedado ao Tesouro Nacional adquirir títulos da dívida pública federal existentes na carteira do Banco Central do Brasil, ainda que com cláusula de reversão, salvo para reduzir a dívida mobiliária.

\section{Seção V \\ Da Garantia e da Contragarantia}

Art. 40. Os entes poderão conceder garantia em operações de crédito internas ou externas, observados o disposto neste artigo, as normas do art. 32 e, no caso da União, também os limites e as condições estabelecidos pelo Senado Federal.

$\S 10 \mathrm{~A}$ garantia estará condicionada ao oferecimento de contragarantia, em valor igual ou superior ao da garantia a ser concedida, e à adimplência da entidade que a pleitear relativamente a suas obrigações junto ao garantidor e às entidades por este controladas, observado o seguinte:

I - não será exigida contragarantia de órgãos e entidades do próprio ente;

II - a contragarantia exigida pela União a Estado ou Município, ou pelos Estados aos Municípios, poderá consistir na vinculação de receitas tributárias diretamente arrecadadas e provenientes de transferências constitucionais, com outorga de poderes ao garantidor para retê-las e empregar o respectivo valor na liquidação da dívida vencida.

$\S 20$ No caso de operação de crédito junto a organismo financeiro internacional, ou a instituição federal de crédito e fomento para o repasse de recursos externos, a União só prestará garantia a ente que atenda, além do disposto no $\S 10$, as exigências legais para o recebimento de transferências voluntárias.

$\S 30(V E T A D O)$

$\S 40$ (VETADO)

$\S 5$ o É nula a garantia concedida acima dos limites fixados pelo Senado Federal.

$\S 60$ É vedado às entidades da administração indireta, inclusive suas empresas controladas e subsidiárias, conceder garantia, ainda que com recursos de fundos.

$\S 700$ disposto no § 60 não se aplica à concessão de garantia por:

I - empresa controlada a subsidiária ou controlada sua, nem à prestação de contragarantia nas mesmas condições;

II - instituição financeira a empresa nacional, nos termos da lei.

$\S 80$ Excetua-se do disposto neste artigo a garantia prestada:

I - por instituições financeiras estatais, que se submeterão às normas aplicáveis às instituições financeiras privadas, de acordo com a legislação pertinente;

II - pela União, na forma de lei federal, a empresas de natureza financeira por ela controladas, direta e indiretamente, quanto às operações de seguro de crédito à exportação.

§ 9o Quando honrarem dívida de outro ente, em razão de garantia prestada, a União e os Estados poderão condicionar as transferências constitucionais ao ressarcimento daquele pagamento.

$\S 10$. O ente da Federação cuja dívida tiver sido honrada pela União ou por Estado, em decorrência de garantia prestada em operação de crédito, terá suspenso o acesso a novos créditos ou financiamentos até a total liquidação da mencionada dívida.

Seção VI

Dos Restos a Pagar 


\section{Art. 41. (VETADO)}

Art. 42. É vedado ao titular de Poder ou órgão referido no art. 20 , nos últimos dois quadrimestres do seu mandato, contrair obrigação de despesa que não possa ser cumprida integralmente dentro dele, ou que tenha parcelas a serem pagas no exercício seguinte sem que haja suficiente disponibilidade de caixa para este efeito.

Parágrafo único. Na determinação da disponibilidade de caixa serão considerados os encargos e despesas compromissadas a pagar até o final do exercício.

\section{CAPITULO VIII \\ DA GESTÃO PATRIMONIAL Seção I \\ Das Disponibilidades de Caixa}

Art. 43. As disponibilidades de caixa dos entes da Federação serão depositadas conforme estabelece o § 30 do art. 164 da Constituição.

$\S 10$ As disponibilidades de caixa dos regimes de previdência social, geral e próprio dos servidores públicos, ainda que vinculadas a fundos específicos a que se referem os arts. 249 e 250 da Constituição, ficarão depositadas em conta separada das demais disponibilidades de cada ente e aplicadas nas condições de mercado, com observância dos limites e condições de proteção e prudência financeira.

$\S 20$ É vedada a aplicação das disponibilidades de que trata o § $10 \mathrm{em}$ :

I - títulos da dívida pública estadual e municipal, bem como em ações e outros papéis relativos às empresas controladas pelo respectivo ente da Federação;

II - empréstimos, de qualquer natureza, aos segurados e ao Poder Público, inclusive a suas empresas controladas.

\section{Seção II}

Da Preservação do Patrimônio Público

Art. 44. É vedada a aplicação da receita de capital derivada da alienação de bens e direitos que integram o patrimônio público para o financiamento de despesa corrente, salvo se destinada por lei aos regimes de previdência social, geral e próprio dos servidores públicos.

Art. 45. Observado o disposto no $\S 50$ do art. 5o, a lei orçamentária e as de créditos adicionais só incluirão novos projetos após adequadamente atendidos os em andamento e contempladas as despesas de conservação do patrimônio público, nos termos em que dispuser a lei de diretrizes orçamentárias.

Parágrafo único. O Poder Executivo de cada ente encaminhará ao Legislativo, até a data do envio do projeto de lei de diretrizes orçamentárias, relatório com as informações necessárias ao cumprimento do disposto neste artigo, ao qual será dada ampla divulgação.

Art. 46. É nulo de pleno direito ato de desapropriação de imóvel urbano expedido sem o atendimento do disposto no $\S 30$ do art. 182 da Constituição, ou prévio depósito judicial do valor da indenização.

\section{Seção III \\ Das Empresas Controladas pelo Setor Público}

Art. 47. A empresa controlada que firmar contrato de gestão em que se estabeleçam objetivos e metas de desempenho, na forma da lei, disporá de autonomia gerencial, 
orçamentária e financeira, sem prejuízo do disposto no inciso II do $\S 50$ do art. 165 da Constituição.

Parágrafo único. A empresa controlada incluirá em seus balanços trimestrais nota explicativa em que informará:

I - fornecimento de bens e serviços ao controlador, com respectivos preços e condições, comparando-os com os praticados no mercado;

II - recursos recebidos do controlador, a qualquer título, especificando valor, fonte e destinação;

III - venda de bens, prestação de serviços ou concessão de empréstimos e financiamentos com preços, taxas, prazos ou condições diferentes dos vigentes no mercado.

\section{CAPITTULO IX \\ DA TRANSPARÊNCIA, CONTROLE E FISCALIZAÇÃO Seção I \\ Da Transparência da Gestão Fiscal}

Art. 48. São instrumentos de transparência da gestão fiscal, aos quais será dada ampla divulgação, inclusive em meios eletrônicos de acesso público: os planos, orçamentos e leis de diretrizes orçamentárias; as prestações de contas e o respectivo parecer prévio; o Relatório Resumido da Execução Orçamentária e o Relatório de Gestão Fiscal; e as versões simplificadas desses documentos.

Parágrafo único. A transparência será assegurada também mediante incentivo à participação popular e realização de audiências públicas, durante os processos de elaboração e de discussão dos planos, lei de diretrizes orçamentárias e orçamentos.

Art. 49. As contas apresentadas pelo Chefe do Poder Executivo ficarão disponíveis, durante todo o exercício, no respectivo Poder Legislativo e no órgão técnico responsável pela sua elaboração, para consulta e apreciação pelos cidadãos e instituições da sociedade.

Parágrafo único. A prestação de contas da União conterá demonstrativos do Tesouro Nacional e das agências financeiras oficiais de fomento, incluído o Banco Nacional de Desenvolvimento Econômico e Social, especificando os empréstimos e financiamentos concedidos com recursos oriundos dos orçamentos fiscal e da seguridade social e, no caso das agências financeiras, avaliação circunstanciada do impacto fiscal de suas atividades no exercício.

\section{Seção II}

\section{Da Escrituração e Consolidação das Contas}

Art. 50. Além de obedecer às demais normas de contabilidade pública, a escrituração das contas públicas observará as seguintes:

I - a disponibilidade de caixa constará de registro próprio, de modo que os recursos vinculados a órgão, fundo ou despesa obrigatória fiquem identificados e escriturados de forma individualizada;

II - a despesa e a assunção de compromisso serão registradas segundo o regime de competência, apurando-se, em caráter complementar, o resultado dos fluxos financeiros pelo regime de caixa;

III - as demonstrações contábeis compreenderão, isolada e conjuntamente, as transações e operações de cada órgão, fundo ou entidade da administração direta, autárquica e fundacional, inclusive empresa estatal dependente;

IV - as receitas e despesas previdenciárias serão apresentadas em demonstrativos financeiros e orçamentários específicos;

V - as operações de crédito, as inscrições em Restos a Pagar e as demais formas de financiamento ou assunção de compromissos junto a terceiros, deverão ser escrituradas 
de modo a evidenciar o montante e a variação da dívida pública no período, detalhando, pelo menos, a natureza e o tipo de credor;

VI - a demonstração das variações patrimoniais dará destaque à origem e ao destino dos recursos provenientes da alienação de ativos.

$\S 10$ No caso das demonstrações conjuntas, excluir-se-ão as operações intragovernamentais.

§ 20 A edição de normas gerais para consolidação das contas públicas caberá ao órgão central de contabilidade da União, enquanto não implantado o conselho de que trata o art. 67.

§ 3o A Administração Pública manterá sistema de custos que permita a avaliação e o acompanhamento da gestão orçamentária, financeira e patrimonial.

Art. 51. O Poder Executivo da União promoverá, até o dia trinta de junho, a consolidação, nacional e por esfera de governo, das contas dos entes da Federação relativas ao exercício anterior, e a sua divulgação, inclusive por meio eletrônico de acesso público.

$\S 10$ Os Estados e os Municípios encaminharão suas contas ao Poder Executivo da União nos seguintes prazos:

I - Municípios, com cópia para o Poder Executivo do respectivo Estado, até trinta de abril;

II - Estados, até trinta e um de maio.

$\S 200$ descumprimento dos prazos previstos neste artigo impedirá, até que a situação seja regularizada, que o ente da Federação receba transferências voluntárias e contrate operações de crédito, exceto as destinadas ao refinanciamento do principal atualizado da dívida mobiliária.

\section{Seção III \\ Do Relatório Resumido da Execução Orçamentária}

Art. 52. O relatório a que se refere o $\S 30$ do art. 165 da Constituição abrangerá todos os Poderes e o Ministério Público, será publicado até trinta dias após o encerramento de cada bimestre e composto de:

I - balanço orçamentário, que especificará, por categoria econômica, as:

a) receitas por fonte, informando as realizadas e a realizar, bem como a previsão atualizada;

b) despesas por grupo de natureza, discriminando a dotação para o exercício, a despesa liquidada e o saldo;

II - demonstrativos da execução das:

a) receitas, por categoria econômica e fonte, especificando a previsão inicial, a previsão atualizada para o exercício, a receita realizada no bimestre, a realizada no exercício e a previsão a realizar;

b) despesas, por categoria econômica e grupo de natureza da despesa, discriminando dotação inicial, dotação para o exercício, despesas empenhada e liquidada, no bimestre e no exercício;

c) despesas, por função e subfunção.

$\S 10$ Os valores referentes ao refinanciamento da dívida mobiliária constarão destacadamente nas receitas de operações de crédito e nas despesas com amortização da dívida.

$\S 20$ O descumprimento do prazo previsto neste artigo sujeita o ente às sanções previstas no $\S 20$ do art. 51.

Art. 53. Acompanharão o Relatório Resumido demonstrativos relativos a:

I - apuração da receita corrente líquida, na forma definida no inciso IV do art. 2o, sua evolução, assim como a previsão de seu desempenho até o final do exercício;

II - receitas e despesas previdenciárias a que se refere o inciso IV do art. 50;

III - resultados nominal e primário;

IV - despesas com juros, na forma do inciso II do art. 40; 
V - Restos a Pagar, detalhando, por Poder e órgão referido no art. 20, os valores inscritos, os pagamentos realizados e o montante a pagar.

$\S 10$ O relatório referente ao último bimestre do exercício será acompanhado também de demonstrativos:

I - do atendimento do disposto no inciso III do art. 167 da Constituição, conforme o § 30 do art. 32;

II - das projeções atuariais dos regimes de previdência social, geral e próprio dos servidores públicos;

III - da variação patrimonial, evidenciando a alienação de ativos e a aplicação dos recursos dela decorrentes.

§ 20 Quando for o caso, serão apresentadas justificativas:

I - da limitação de empenho;

II - da frustração de receitas, especificando as medidas de combate à sonegação e à evasão fiscal, adotadas e a adotar, e as ações de fiscalização e cobrança.

\section{Seção IV \\ Do Relatório de Gestão Fiscal}

Art. 54. Ao final de cada quadrimestre será emitido pelos titulares dos Poderes e órgãos referidos no art. 20 Relatório de Gestão Fiscal, assinado pelo:

I - Chefe do Poder Executivo;

II - Presidente e demais membros da Mesa Diretora ou órgão decisório equivalente, conforme regimentos internos dos órgãos do Poder Legislativo;

III - Presidente de Tribunal e demais membros de Conselho de Administração ou órgão decisório equivalente, conforme regimentos internos dos órgãos do Poder Judiciário;

IV - Chefe do Ministério Público, da União e dos Estados.

Parágrafo único. O relatório também será assinado pelas autoridades responsáveis pela administração financeira e pelo controle interno, bem como por outras definidas por ato próprio de cada Poder ou órgão referido no art. 20.

Art. 55. O relatório conterá:

I - comparativo com os limites de que trata esta Lei Complementar, dos seguintes montantes:

a) despesa total com pessoal, distinguindo a com inativos e pensionistas;

b) dívidas consolidada e mobiliária;

c) concessão de garantias;

d) operações de crédito, inclusive por antecipação de receita;

e) despesas de que trata o inciso II do art. 40;

II - indicação das medidas corretivas adotadas ou a adotar, se ultrapassado qualquer dos limites;

III - demonstrativos, no último quadrimestre:

a) do montante das disponibilidades de caixa em trinta e um de dezembro;

b) da inscrição em Restos a Pagar, das despesas:

1) liquidadas;

2) empenhadas e não liquidadas, inscritas por atenderem a uma das condições do inciso II do art. 41;

3) empenhadas e não liquidadas, inscritas até o limite do saldo da disponibilidade de caixa;

4) não inscritas por falta de disponibilidade de caixa e cujos empenhos foram cancelados;

c) do cumprimento do disposto no inciso II e na alínea b do inciso IV do art. 38.

$\S 10$ O relatório dos titulares dos órgãos mencionados nos incisos II, III e IV do art. 54 conterá apenas as informações relativas à alínea a do inciso I, e os documentos referidos nos incisos II e III.

$\S 20$ O relatório será publicado até trinta dias após o encerramento do período a que corresponder, com amplo acesso ao público, inclusive por meio eletrônico. 
$\S 30 \mathrm{O}$ descumprimento do prazo a que se refere o $\S 20$ sujeita o ente à sanção prevista no $\S 20$ do art. 51.

$\S 40$ Os relatórios referidos nos arts. 52 e 54 deverão ser elaborados de forma padronizada, segundo modelos que poderão ser atualizados pelo conselho de que trata o art. 67.

\section{Seção V \\ Das Prestações de Contas}

Art. 56. As contas prestadas pelos Chefes do Poder Executivo incluirão, além das suas próprias, as dos Presidentes dos órgãos dos Poderes Legislativo e Judiciário e do Chefe do Ministério Público, referidos no art. 20, as quais receberão parecer prévio, separadamente, do respectivo Tribunal de Contas.

$\S 10$ As contas do Poder Judiciário serão apresentadas no âmbito:

I - da União, pelos Presidentes do Supremo Tribunal Federal e dos Tribunais Superiores, consolidando as dos respectivos tribunais;

II - dos Estados, pelos Presidentes dos Tribunais de Justiça, consolidando as dos demais tribunais.

§ 20 O parecer sobre as contas dos Tribunais de Contas será proferido no prazo previsto no art. 57 pela comissão mista permanente referida no $\S 10$ do art. 166 da Constituição ou equivalente das Casas Legislativas estaduais e municipais.

§ 30 Será dada ampla divulgação dos resultados da apreciação das contas, julgadas ou tomadas.

Art. 57. Os Tribunais de Contas emitirão parecer prévio conclusivo sobre as contas no prazo de sessenta dias do recebimento, se outro não estiver estabelecido nas constituições estaduais ou nas leis orgânicas municipais.

$\S 10$ No caso de Municípios que não sejam capitais e que tenham menos de duzentos mil habitantes o prazo será de cento e oitenta dias.

$\S 20$ Os Tribunais de Contas não entrarão em recesso enquanto existirem contas de Poder, ou órgão referido no art. 20, pendentes de parecer prévio.

Art. 58. A prestação de contas evidenciará o desempenho da arrecadação em relação à previsão, destacando as providências adotadas no âmbito da fiscalização das receitas e combate à sonegação, as ações de recuperação de créditos nas instâncias administrativa e judicial, bem como as demais medidas para incremento das receitas tributárias e de contribuições.

\section{Seção VI \\ Da Fiscalização da Gestão Fiscal}

Art. 59. O Poder Legislativo, diretamente ou com o auxílio dos Tribunais de Contas, e o sistema de controle interno de cada Poder e do Ministério Público, fiscalizarão o cumprimento das normas desta Lei Complementar, com ênfase no que se refere a:

I - atingimento das metas estabelecidas na lei de diretrizes orçamentárias;

II - limites e condições para realização de operações de crédito e inscrição em Restos a Pagar;

III - medidas adotadas para o retorno da despesa total com pessoal ao respectivo limite, nos termos dos arts. 22 e 23;

IV - providências tomadas, conforme o disposto no art. 31, para recondução dos montantes das dívidas consolidada e mobiliária aos respectivos limites;

$\mathrm{V}$ - destinação de recursos obtidos com a alienação de ativos, tendo em vista as restrições constitucionais e as desta Lei Complementar;

$\mathrm{VI}$ - cumprimento do limite de gastos totais dos legislativos municipais, quando houver. 
$\S 10$ Os Tribunais de Contas alertarão os Poderes ou órgãos referidos no art. 20 quando constatarem:

I - a possibilidade de ocorrência das situações previstas no inciso II do art. 40 e no art. 9o;

II - que o montante da despesa total com pessoal ultrapassou 90\% (noventa por cento) do limite;

III - que os montantes das dívidas consolidada e mobiliária, das operações de crédito e da concessão de garantia se encontram acima de $90 \%$ (noventa por cento) dos respectivos limites;

IV - que os gastos com inativos e pensionistas se encontram acima do limite definido em lei;

$\mathrm{V}$ - fatos que comprometam os custos ou os resultados dos programas ou indícios de irregularidades na gestão orçamentária.

§ 20 Compete ainda aos Tribunais de Contas verificar os cálculos dos limites da despesa total com pessoal de cada Poder e órgão referido no art. 20.

$\S 30$ O Tribunal de Contas da União acompanhará o cumprimento do disposto nos $\S \S 20$, 30 e 40 do art. 39.

\section{CAPÍTULO X \\ DISPOSIÇÕES FINAIS E TRANSITÓRIAS}

Art. 60. Lei estadual ou municipal poderá fixar limites inferiores àqueles previstos nesta Lei Complementar para as dívidas consolidada e mobiliária, operações de crédito e concessão de garantias.

Art. 61. Os títulos da dívida pública, desde que devidamente escriturados em sistema centralizado de liquidação e custódia, poderão ser oferecidos em caução para garantia de empréstimos, ou em outras transações previstas em lei, pelo seu valor econômico, conforme definido pelo Ministério da Fazenda.

Art. 62. Os Municípios só contribuirão para o custeio de despesas de competência de outros entes da Federação se houver:

I - autorização na lei de diretrizes orçamentárias e na lei orçamentária anual;

II - convênio, acordo, ajuste ou congênere, conforme sua legislação.

Art. 63. É facultado aos Municípios com população inferior a cinqüenta mil habitantes optar por:

I - aplicar o disposto no art. 22 e no $\S 40$ do art. 30 ao final do semestre;

II - divulgar semestralmente:

a) (VETADO)

b) o Relatório de Gestão Fiscal;

c) os demonstrativos de que trata o art. 53;

III - elaborar o Anexo de Política Fiscal do plano plurianual, o Anexo de Metas Fiscais e o Anexo de Riscos Fiscais da lei de diretrizes orçamentárias e o anexo de que trata o inciso I do art. 50 a partir do quinto exercício seguinte ao da publicação desta Lei Complementar. $\S 10$ A divulgação dos relatórios e demonstrativos deverá ser realizada em até trinta dias após o encerramento do semestre.

$\S 20$ Se ultrapassados os limites relativos à despesa total com pessoal ou à dívida consolidada, enquanto perdurar esta situação, o Município ficará sujeito aos mesmos prazos de verificação e de retorno ao limite definidos para os demais entes.

Art. 64. A União prestará assistência técnica e cooperação financeira aos Municípios para a modernização das respectivas administrações tributária, financeira, patrimonial e previdenciária, com vistas ao cumprimento das normas desta Lei Complementar. 
§ 10 A assistência técnica consistirá no treinamento e desenvolvimento de recursos humanos e na transferência de tecnologia, bem como no apoio à divulgação dos instrumentos de que trata o art. 48 em meio eletrônico de amplo acesso público.

$\S 20$ A cooperação financeira compreenderá a doação de bens e valores, o financiamento por intermédio das instituições financeiras federais e o repasse de recursos oriundos de operações externas.

Art. 65. Na ocorrência de calamidade pública reconhecida pelo Congresso Nacional, no caso da União, ou pelas Assembléias Legislativas, na hipótese dos Estados e Municípios, enquanto perdurar a situação:

I - serão suspensas a contagem dos prazos e as disposições estabelecidas nos arts. 23 , 31 e 70 ;

II - serão dispensados o atingimento dos resultados fiscais e a limitação de empenho prevista no art. 9o.

Parágrafo único. Aplica-se o disposto no caput no caso de estado de defesa ou de sítio, decretado na forma da Constituição.

Art. 66. Os prazos estabelecidos nos arts. 23, 31 e 70 serão duplicados no caso de crescimento real baixo ou negativo do Produto Interno Bruto (PIB) nacional, regional ou estadual por período igual ou superior a quatro trimestres.

$\S 10$ Entende-se por baixo crescimento a taxa de variação real acumulada do Produto Interno Bruto inferior a 1\% (um por cento), no período correspondente aos quatro últimos trimestres.

§ 20 A taxa de variação será aquela apurada pela Fundação Instituto Brasileiro de Geografia e Estatística ou outro órgão que vier a substituí-la, adotada a mesma metodologia para apuração dos PIB nacional, estadual e regional.

$\S 30 \mathrm{Na}$ hipótese do caput, continuarão a ser adotadas as medidas previstas no art. 22.

$\S 40 \mathrm{Na}$ hipótese de se verificarem mudanças drásticas na condução das políticas monetária e cambial, reconhecidas pelo Senado Federal, o prazo referido no caput do art. 31 poderá ser ampliado em até quatro quadrimestres.

Art. 67. O acompanhamento e a avaliação, de forma permanente, da política e da operacionalidade da gestão fiscal serão realizados por conselho de gestão fiscal, constituído por representantes de todos os Poderes e esferas de Governo, do Ministério Público e de entidades técnicas representativas da sociedade, visando a:

I - harmonização e coordenação entre os entes da Federação;

II - disseminação de práticas que resultem em maior eficiência na alocação e execução do gasto público, na arrecadação de receitas, no controle do endividamento e na transparência da gestão fiscal;

III - adoção de normas de consolidação das contas públicas, padronização das prestações de contas e dos relatórios e demonstrativos de gestão fiscal de que trata esta Lei Complementar, normas e padrões mais simples para os pequenos Municípios, bem como outros, necessários ao controle social;

IV - divulgação de análises, estudos e diagnósticos.

$\S 100$ conselho a que se refere o caput instituirá formas de premiação e reconhecimento público aos titulares de Poder que alcançarem resultados meritórios em suas políticas de desenvolvimento social, conjugados com a prática de uma gestão fiscal pautada pelas normas desta Lei Complementar.

$\S 20$ Lei disporá sobre a composição e a forma de funcionamento do conselho.

Art. 68. Na forma do art. 250 da Constituição, é criado o Fundo do Regime Geral de Previdência Social, vinculado ao Ministério da Previdência e Assistência Social, com a finalidade de prover recursos para o pagamento dos benefícios do regime geral da previdência social.

$\S 10$ O Fundo será constituído de: 
I - bens móveis e imóveis, valores e rendas do Instituto Nacional do Seguro Social não utilizados na operacionalização deste;

II - bens e direitos que, a qualquer título, Ihe sejam adjudicados ou que the vierem a ser vinculados por força de lei;

III - receita das contribuições sociais para a seguridade social, previstas na alínea a do inciso I e no inciso II do art. 195 da Constituição;

IV - produto da liquidação de bens e ativos de pessoa física ou jurídica em débito com a Previdência Social;

$\mathrm{V}$ - resultado da aplicação financeira de seus ativos;

VI - recursos provenientes do orçamento da União.

$\S 20$ O Fundo será gerido pelo Instituto Nacional do Seguro Social, na forma da lei.

Art. 69. O ente da Federação que mantiver ou vier a instituir regime próprio de previdência social para seus servidores conferir-lhe-á caráter contributivo e o organizará com base em normas de contabilidade e atuária que preservem seu equilíbrio financeiro e atuarial.

Art. 70. O Poder ou órgão referido no art. 20 cuja despesa total com pessoal no exercício anterior ao da publicação desta Lei Complementar estiver acima dos limites estabelecidos nos arts. 19 e 20 deverá enquadrar-se no respectivo limite em até dois exercícios, eliminando o excesso, gradualmente, à razão de, pelo menos, $50 \%$ a.a. (cinqüenta por cento ao ano), mediante a adoção, entre outras, das medidas previstas nos arts. 22 e 23.

Parágrafo único. A inobservância do disposto no caput, no prazo fixado, sujeita o ente às sanções previstas no § 30 do art. 23.

Art. 71. Ressalvada a hipótese do inciso $X$ do art. 37 da Constituição, até o término do terceiro exercício financeiro seguinte à entrada em vigor desta Lei Complementar, a despesa total com pessoal dos Poderes e órgãos referidos no art. 20 não ultrapassará, em percentual da receita corrente líquida, a despesa verificada no exercício imediatamente anterior, acrescida de até $10 \%$ (dez por cento), se esta for inferior ao limite definido na forma do art. 20.

Art. 72. A despesa com serviços de terceiros dos Poderes e órgãos referidos no art. 20 não poderá exceder, em percentual da receita corrente líquida, a do exercício anterior à entrada em vigor desta Lei Complementar, até o término do terceiro exercício seguinte.

Art. 73. As infrações dos dispositivos desta Lei Complementar serão punidas segundo o Decreto-Lei no 2.848, de 7 de dezembro de 1940 (Código Penal); a Lei no 1.079, de 10 de abril de 1950; o Decreto-Lei no 201, de 27 de fevereiro de 1967; a Lei no 8.429, de 2 de junho de 1992; e demais normas da legislação pertinente.

Art. 74. Esta Lei Complementar entra em vigor na data da sua publicação.

Art. 75. Revoga-se a Lei Complementar no 96, de 31 de maio de 1999.

Brasília, 4 de maio de 2000; 179 o da Independência e 1120 da República.

FERNANDO HENRIQUE CARDOSO

Pedro Malan

Martus Tavares

Publicada no D.O. de 5.5.2000 
Anexo 2:

MENSAGEM Nº 627, DE 4 DE MAIO DE 2000.

Senhor Presidente do Senado Federal,

Comunico a Vossa Excelência que, nos termos do parágrafo 10 do artigo 66 da Constituição Federal, decidi vetar parcialmente o Projeto de Lei no 4, de 2000 Complementar (no 18/99 - Complementar na Câmara dos Deputados), que "Estabelece normas de finanças públicas voltadas para a responsabilidade na gestão fiscal e dá outras providências". Ouvidos, os Ministérios do Planejamento, Orçamento e Gestão e da Fazenda manifestaram-se pelo veto aos dispositivos a seguir transcritos:

Art. 30

"Art. 3o O projeto de lei do plano plurianual de cada ente abrangerá os respectivos Poderes e será devolvido para sanção até o encerramento do primeiro período da sessão legislativa.

$\S 10$ Integrará o projeto Anexo de Política Fiscal, em que serão estabelecidos os objetivos e metas plurianuais de política fiscal a serem alcançados durante o período de vigência do plano, demonstrando a compatibilidade deles com as premissas e objetivos das políticas econômica nacional e de desenvolvimento social.

$\S 20$ O projeto de que trata o caput será encaminhado ao Poder Legislativo até o dia trinta de abril do primeiro ano do mandato do Chefe do Poder Executivo."

\section{Razões do veto}

"O caput deste artigo estabelece que o projeto de lei do plano plurianual deverá ser devolvido para sanção até o encerramento do primeiro período da sessão legislativa, enquanto o $\S 2^{\circ}$ obriga o seu envio, ao Poder Legislativo, até o dia 30 de abril do primeiro ano do mandato do Chefe do Poder Executivo. Isso representará não só um reduzido período para a elaboração dessa peça, por parte do Poder Executivo, como também para a sua apreciação pelo Poder Legislativo, inviabilizando o aperfeiçoamento metodológico e a seleção criteriosa de programas e ações prioritárias de governo.

Ressalte-se que a elaboração do plano plurianual é uma tarefa que se estende muito além dos limites do órgão de planejamento do governo, visto que mobiliza todos os órgãos e unidades do Executivo, do Legislativo e do Judiciário. Além disso, o novo modelo de planejamento e gestão das ações, pelo qual se busca a melhoria de qualidade dos serviços públicos, exige uma estreita integração do plano plurianual com o Orçamento da União e os planos das unidades da Federação.

Acrescente-se, ainda, que todo esse trabalho deve ser executado justamente no primeiro ano de mandato do Presidente da República, quando a Administração Pública sofre as naturais dificuldades decorrentes da mudança de governo e a necessidade de formação de equipes com pessoal nem sempre familiarizado com os serviços e sistemas que devem fornecer os elementos essenciais para a elaboração do plano.

Ademais, a fixação de mesma data para que a União, os Estados e os Municípios encaminhem, ao Poder Legislativo, o referido projeto de lei complementar não leva em consideração a complexidade, as peculiaridades e as necessidades de cada ente da Federação, inclusive os pequenos municípios.

Por outro lado, o veto dos prazos constantes do dispositivo traz consigo a supressão do Anexo de Política Fiscal, a qual não ocasiona prejuízo aos objetivos da Lei Complementar, considerando-se que a lei de diretrizes orçamentárias já prevê a apresentação de Anexo de Metas Fiscais, contendo, de forma mais precisa, metas para cinco variáveis - receitas, despesas, resultados nominal e primário e dívida pública -, para três anos, especificadas em valores correntes e constantes.

Diante do exposto, propõe-se veto ao art. 3o, e respectivos parágrafos, por contrariar o interesse público." 
"Art. 40

1 -

c) parâmetros para os Poderes e órgãos referidos no art. 20 , com vistas à fixação, no projeto de lei orçamentária, dos montantes relativos a despesas com pessoal e a outras despesas correntes, inclusive serviços de terceiros, com base na receita corrente líquida;"

Razões do veto

"A estrutura orçamentária está concebida de maneira a propiciar a integração entre o plano plurianual e a lei orçamentária anual, sendo o programa o elo de ligação entre os instrumentos de planejamento e de alocação de recursos públicos.

Nesse sentido, deve-se dar ênfase à realização das ações, representadas pelos projetos, atividades e operações especiais, com vistas ao alcance dos objetivos estabelecidos nos programas.

Dessa forma, estabelecer a priori parâmetros para a fixação de despesas, segundo a sua natureza de gasto, sem levar em consideração as prioridades da programação a ser atendida, contraria o interesse público, por inflexibilizar a alocação dos recursos, dificultando o atendimento das demandas da sociedade.

Por essa razão, propõe-se veto ao dispositivo em questão."

\section{Alínea "d" do inciso I do art. 40}

"Art. 40

1 -

d) destinação de recursos provenientes das operações de crédito, inclusive por antecipação de receita;"

\section{Razões do veto}

"As operações de crédito por antecipação de receita têm como objetivo legal a recomposição momentânea do fluxo de caixa global do órgão ou da entidade. Assim, não existe a possibilidade de indicar, com antecedência, a destinação dos recursos provenientes dessas operações.

Nessa mesma linha de raciocínio, o dispositivo mostra-se dúbio, com relação às demais operações de crédito, uma vez que ao se referir à "destinação dos recursos" não especificou qual a classificação da despesa orçamentária que deveria ser considerada, se por funções ou por categorias econômicas, dentre outras.

Assim, por contrariar o interesse público, os Ministérios do Planejamento, Orçamento e Gestão e da Fazenda propõem veto à referida alínea."

\section{Inciso II do art. 40}

"Art. 40

II - estabelecerá, para efeito de adoção das medidas especificadas nas alíneas deste inciso, limite referencial para o montante das despesas com juros, com base em percentual da receita corrente líquida, apurado na forma do $\S 30$ do art. 20 , que, se excedido, implicará:

a) vedação da realização de novas operações de crédito, ressalvadas as realizadas com a finalidade de pagamento de juros, as operações por antecipação de receita e as relativas ao refinanciamento da dívida;

b) obtenção de resultado primário necessário à redução do montante da dívida e das despesas com juros, dentre outras medidas;"

Razões do veto 
"O projeto de lei complementar prevê a fixação de limites para a dívida consolidada de cada esfera de governo bem como a definição no âmbito da lei de diretrizes orçamentárias de metas de superávit primário a cada exercício.

Saliente-se que há, ainda, disciplina dos limites da dívida pública e sanções decorrentes de sua inobservância, até com expressa determinação de se considerar na dívida consolidada os valores dos precatórios judiciais doravante incluídos nos orçamentos e não pagos.

Dessa forma, afigura-se redundante a fixação de limites adicionais para a despesa com juros nominais.

Adicionalmente, o princípio que norteia o estabelecimento, no projeto de lei complementar, de limites para a dívida é a manutenção do nível de endividamento público em patamar razoável. As dívidas antigas e os juros devem continuar sendo pagos, pois, caso contrário, haveria quebra de contratos, atitude inadmissível em regime de direito democrático. Contudo, a introdução de limite para despesas com juros, ainda que com caráter referencial, suscitaria a interpretação de que o objetivo seria o não pagamento de juros, o que apresenta caráter bastante distinto, senão oposto, à tônica do projeto de lei complementar.

Por esses motivos, sugere-se oposição de veto ao referido inciso, e respectivas alíneas, por contrariar o interesse público."

\section{Inciso III do art. 40}

"Art. 40

III - definirá limites e condições para a expansão das despesas obrigatórias de caráter continuado referidas no art. $17 . "$

Razões do veto

"O art. 17 do projeto de lei complementar já estabelece as regras para a expansão das despesas obrigatórias de caráter continuado. Por outro lado, se as despesas já foram legalmente definidas como sendo "obrigatórias", não há que se estabelecer limites e condições para a sua expansão. Portanto, em face da contradição que apresenta a redação do dispositivo em questão, sugere-se oposição de veto a ele, por contrariar o interesse público."

\section{Alínea "a" do inciso III do art. 50}

"Art. 50

III -

a) pagamento de restos a pagar que excederem as disponibilidades de caixa ao final do exercício, nos termos do art. 41;"

Razões do veto

"O dispositivo não respeita o princípio que deve nortear a introdução de reserva de contingência na proposta orçamentária: a prudência. A reserva de contingência deve representar proteção contra riscos e passivos contingentes capazes de ameaçar o equilíbrio orçamentário e, como tal, destinar-se a gastos novos, imprevistos.

Ao prever a cobertura de despesas que não foram contempladas no período anterior por insuficiência de disponibilidade financeira, o dispositivo fere o princípio em que se assenta a reserva de contingência, que nenhuma relação possui com o conceito de saldo financeiro. Além disso, o dispositivo apresenta-se flagrantemente contrário à responsabilidade fiscal, na medida em que pressupõe a execução de despesas acima das disponibilidades financeiras do exercício.

Ademais, sendo a proposta orçamentária encaminhada ao Poder Legislativo quatro meses antes de encerrado o exercício financeiro, tornar-se-ia impossível prever o 
montante das despesas que seriam executadas sem a correspondente cobertura financeira.

Além das razões acima, o aludido dispositivo contraria outras disposições do presente projeto de lei complementar, que determinam a obtenção de superávits primário e nominal e dispõem sobre a compatibilização entre receita e despesa.

Por esses motivos, sugere-se oposição de veto à referida alínea por ser contrária ao interesse público."

\section{§7o do art. 5o}

"Art. 50

§ 7o O projeto de lei orçamentária anual será encaminhado ao Poder Legislativo até o dia quinze de agosto de cada ano."

Razões do veto

"A Constituição Federal, no $\S 2^{\circ}$ do art. 35 do Ato das Disposições Constitucionais Transitórias, determina que, até a entrada em vigor da lei complementar a que se refere o art. $165, \S 9^{\circ}$, I e II, o projeto de lei orçamentária da União seja encaminhado até quatro meses antes do encerramento do exercício financeiro. Estados e Municípios possuem prazos de encaminhamento que são determinados, respectivamente, pelas Constituições Estaduais e pelas Leis Orgânicas Municipais.

A fixação de uma mesma data para que a União, os Estados e os Municípios encaminhem, ao Poder Legislativo, o projeto de lei orçamentária anual contraria o interesse público, na medida em que não leva em consideração a complexidade, as particularidades e as necessidades de cada ente da Federação, inclusive os pequenos municípios.

Além disso, a fixação de uma mesma data não considera a dependência de informações entre esses entes, principalmente quanto à estimativa de receita, que historicamente tem sido responsável pela precedência da União na elaboração do projeto de lei orçamentária. Por esse motivo, sugere-se oposição de veto ao referido parágrafo."

\section{Art. 60}

"Art. 6o Se o orçamento não for sancionado até o final do exercício de seu encaminhamento ao Poder Legislativo, sua programação poderá ser executada, até o limite de dois doze avos do total de cada dotação, observadas as condições constantes da lei de diretrizes orçamentárias."

\section{Razões do veto}

"Parcela significativa da despesa orçamentária não tem sua execução sob a forma de duodécimos ao longo do exercício financeiro. Assim, a autorização para a execução, sem exceção, de apenas dois doze avos do total de cada dotação, constante do projeto de lei orçamentária, caso não seja ele sancionado até o final do exercício de seu encaminhamento ao Poder Legislativo, poderá trazer sérios transtornos à Administração Pública, principalmente no que tange ao pagamento de salários, aposentadorias, ao serviço da dívida e as transferências constitucionais a Estados e Municípios.

Por outro lado, tal comando tem sido regulamentado pela lei de diretrizes orçamentárias, que proporciona maior dinamismo e flexibilidade em suas disposições.

$\mathrm{Na}$ ausência de excepcionalidade, o dispositivo é contrário ao interesse público, razão pela qual sugere-se oposição de veto, no propósito de que o assunto possa ser tratado de forma adequada na lei de diretrizes orçamentárias."

\section{$\S 60$ do art. 20}

"Art. 20 
$\S 60$ Somente será aplicada a repartição dos limites estabelecidos no caput, caso a lei de diretrizes orçamentárias não disponha de forma diferente."

\section{Razões do veto}

"A possibilidade de que os limites de despesas de pessoal dos Poderes e órgãos possam ser alterados na lei de diretrizes orçamentárias poderá resultar em demandas ou incentivo, especialmente no âmbito dos Estados e Municípios, para que os gastos com pessoal e encargos sociais de determinado Poder ou órgão sejam ampliados em detrimento de outros, visto que o limite global do ente da Federação é fixado na Lei Complementar.

Desse modo, afigura-se prejudicado o objetivo da lei complementar em estabelecer limites efetivos de gastos de pessoal aos três Poderes.

$\mathrm{Na}$ linha desse entendimento, o dispositivo contraria o interesse público, motivo pelo qual sugere-se a oposição de veto."

\section{Inciso III do § 30 do art. 32}

"Art. 32

\section{$\S 30$}

III - equiparam-se a despesa de capital as de custeio dela decorrentes, bem como as destinadas à capacitação de servidores nas atividades-fim das áreas de educação, saúde, assistência social e segurança."

\section{Razões do veto}

"Não é possível precisar o que seja "despesas de custeio decorrentes de despesas de capital". Dependendo da interpretação, poder-se-ia chegar ao extremo de considerar que todas as despesas de manutenção e funcionamento são decorrentes da existência anterior de despesas de capital, como, por exemplo, a construção de uma escola, de uma estrada ou de um hospital.

Por outro lado, ao caracterizar como despesas de capital as de custeio delas decorrentes, entende-se que o projeto de lei complementar extrapola as disposições do art. 167, inciso III, da Constituição Federal, que não dá margem a interpretação extensiva.

Por essas razões, sugere-se oposição de veto a este dispositivo, por inconstitucionalidade."

\section{§ 30 do art. 40}

"Art. 40

§ 3o Será cobrada comissão pela garantia prestada, na forma de percentual sobre o valor garantido, e exigido o ressarcimento das despesas efetuadas pelo garantidor à conta da operação."

\section{Razões do veto}

"Tradicionalmente, por força de norma estatutária as agências multilaterais de crédito exigem aval da União em operações com Estados e Municípios destinadas a financiamento de projetos sociais e de infra-estrutura.

Portanto, a exigência de cobrança de comissão pela garantia prestada elevaria o custo das operações para os Estados e Municípios que as contratassem. Assim, ainda que seja procedimento usual no mercado financeiro, entende-se que o dispositivo contraria o interesse público da Federação, cujo princípio é a solidariedade e o equilíbrio federativo, uma vez que o interesse da União está resguardado pela exigência de contragarantia.

Por esta razão, sugere-se oposição de veto ao dispositivo." 
"Art. 40

$\S 40 \mathrm{~A}$ falta de ressarcimento dos valores honrados, por mais de sessenta dias a partir da data de pagamento, importará na execução da contragarantia, com os valores atualizados."

\section{Razões do veto}

"O Tesouro Nacional tem garantido, por contrato, a imediata liberdade de ação para promover o bloqueio das transferências e a liquidação de pendências em caso de falta de pagamento à União, agindo com a tempestividade necessária.

A alteração do prazo para execução da contragarantia para sessenta dias, além de modificar os contratos a serem firmados, cria dificuldades para manter os entes avalizados em posição corrente, o que contraria o interesse público.

Por esse motivo, sugere-se oposição de veto ao referido parágrafo."

\section{Art. 41}

"Art. 41. Observados os limites globais de empenho e movimentação financeira, serão inscritas em Restos a Pagar:

I - as despesas legalmente empenhadas e liquidadas, mas não pagas no exercício;

II - as despesas empenhadas e não liquidadas que correspondam a compromissos efetivamente assumidos em virtude de:

a) normas legais e contratos administrativos;

b) convênio, ajuste, acordo ou congênere, com outro ente da Federação, já assinado, publicado e em andamento.

§ 10 Considera-se em andamento o convênio, ajuste, acordo ou congênere cujo objeto esteja sendo alcançado no todo ou em parte.

§ 20 Após deduzido de suas disponibilidades de caixa o montante das inscrições realizadas na forma dos incisos I e II do caput, o Poder ou órgão referidos no art. 20 poderá inscrever as demais despesas empenhadas, até o limite do saldo remanescente. $\S 30$ Os empenhos não liquidados e não inscritos serão cancelados."

\section{Razões do veto}

"A exemplo de vários outros limites e restrições contidos no projeto de lei complementar, o sentido original da introdução de uma regra para Restos a Pagar era promover o equilíbrio entre as aspirações da sociedade e os recursos que esta coloca à disposição do governo, evitando déficits imoderados e reiterados. Neste intuito, os Restos a Pagar deveriam ficar limitados às disponibilidades de caixa como forma de não transferir despesa de um exercício para outro sem a correspondente fonte de despesa.

A redação final do dispositivo, no entanto, não manteve esse sentido original que se assentava na restrição básica de contrapartida entre a disponibilidade financeira e a autorização orçamentária. O dispositivo permite, primeiro, inscrever em Restos a Pagar várias despesas para, apenas depois, condicionar a inscrição das demais à existência de recursos em caixa. Tal prática fere o princípio do equilíbrio fiscal, pois faz com que sejam assumidos compromissos sem a disponibilidade financeira necessária para saldá-los, cria transtornos para a execução do orçamento e, finalmente, ocasiona o crescimento de Restos a Pagar que equivale, em termos financeiros, a crescimento de dívida pública.

Assim, sugere-se oposição de veto a este dispositivo por ser contrário ao interesse público."

\section{Alínea "a" do inciso II do art. 63}

"Art. 63

II -

a) o Relatório Resumido da Execução Orçamentária;" 
Razões do veto

"O § 30 do art. 165 da Constituição Federal estabelece que o "relatório resumido da execução orçamentária" será publicado "até trinta dias após o encerramento de cada bimestre".

Assim, não obstante o mérito da proposta, no sentido de criar condições mais flexíveis para pequenos municípios, a faculdade concedida aos municípios com população inferior a cinqüenta mil habitantes, para a publicação semestral do referido relatório, vai de encontro à norma constitucional, razão pela qual propõe-se veto ao dispositivo."

Ademais, o Ministério da Educação manifestou-se pelo veto ao dispositivo a seguir transcrito:

Inciso II do § 10 do art. 25

Art. 25.

$\S 10$

II - formalização por meio de convênio;"

Razões do veto

"O estabelecimento desta exigência em lei complementar compromete importantes programas de responsabilidade deste Ministério, onde a eliminação da figura do convênio proporcionou notável avanço quantitativo e qualitativo.

O Programa Nacional de Alimentação Escolar e o Programa Dinheiro Direto na Escola atingiram grau de descentralização sem precedentes na história, a partir da edição da Medida Provisória hoje vigente sob o no 1.979-17, de 6 de abril de 2000.

Com base naquela medida provisória, os recursos destinados aos dois programas constituem assistência financeira de caráter suplementar, calculada com base nos parâmetros fixados pelo Fundo Nacional de Desenvolvimento da Educação - FNDE, e são transferidos automaticamente pela Secretaria Executiva desse órgão aos Estados, Municípios e unidades executoras de escolas públicas, sem a necessidade de convênio, ajuste ou contrato.

Tal sistemática é fundamental para que o primeiro programa atinja mais de cinco mil municípios e o segundo mais de sessenta mil unidades executoras, ambos com excelentes indicadores de retorno social dos recursos aplicados.

Da mesma forma, a complementação da União aos Fundos de Manutenção e Desenvolvimento do Ensino Fundamental e Valorização do Magistério é transferida automaticamente para as unidades da Federação, onde o valor por aluno é inferior ao mínimo nacional fixado em ato do Presidente da República.

Além dos casos concretos acima relatados, a exigência de convênio em lei complementar inviabiliza futuras experiências de simplificação de procedimentos no âmbito da Administração Pública, em programas onde aquele instrumento mostra-se progressivamente dispensável ou substituível por outros mais modernos e eficazes.

Considerando a possibilidade de restabelecimento da exigência de convênio para as transferências voluntárias anualmente e com as devidas exceções, na lei de diretrizes orçamentárias, é de todo recomendável a supressão do dispositivo em tela, por tratar-se de norma que contraria o interesse público."

Estas, Senhor Presidente, as razões que me levaram a vetar em parte o projeto em causa, as quais ora submeto à elevada apreciação dos Senhores Membros do Congresso Nacional.

Brasília, 4 de maio de 2000. 
Anexo 2:

LEI N 1.079 - DE 10 DE ABRIL DE 1950 - DOU DE 12/4/50

Define os crimes de responsabilidade e regula o respectivo processo de julgamento.

O PRESIDENTE DA REPÚBLICA , faço saber que o CONGRESSO NACIONAL decreta e eu sanciono a seguinte Lei:

PARTE PRIMEIRA -

DO PRESIDENTE DA REPÚBLICA E MINISTROS DE ESTADO

Art $1^{\circ}$ São crimes de responsabilidade os que esta lei especifica.

Art $2^{\circ}$ Os crimes definidos nesta lei, ainda quando simplesmente tentados, são passíveis da pena de perda do cargo, com inabilitação, até cinco anos, para o exercício de qualquer função pública, imposta pelo Senado Federal nos processos contra o Presidente da República ou Ministros de Estado, contra os Ministros do Supremo Tribunal Federal ou contra o Procurador Geral da República.

Art $3^{\circ} \mathrm{A}$ imposição da pena referida no artigo anterior não exclui o processo e julgamento do acusado por crime comum, na justiça ordinária, nos têrmos das leis de processo penal.

Art $4^{\circ}$ São crimes de responsabilidade os atos do Presidente da República que atentarem contra a Constituição Federal, e, especialmente, contra:

I - A existência da União;

II - O livre exercício do Poder Legislativo, do Poder Judiciário e dos poderes constitucionais dos Estados;

III - O exercício dos direitos políticos, individuais e sociais;

IV - A segurança interna do país;

$V$ - A probidade na administração;

VI - A lei orçamentária;

VII - A guarda e o legal emprêgo dos dinheiros públicos;

VIII - O cumprimento das decisões judiciárias (Constituição, artigo 89).

TÍTULO I

CAPITULO I -

DOS CRIMES CONTRA A EXISTÊNCIA DA UNIÃO

Art $5^{\circ}$ São crimes de responsabilidade contra a existência política da União:

1 - entreter, direta ou indiretamente, inteligência com govêrno estrangeiro, provocando-o a fazer guerra ou cometer hostilidade contra a República, prometer-lhe assistência ou favor, ou dar-lhe qualquer auxílio nos preparativos ou planos de guerra contra a República;

2 - tentar, diretamente e por fatos, submeter a União ou algum dos Estados ou Territórios a domínio estrangeiro, dela separar qualquer Estado ou porção do territorio nacional;

3 - cometer ato de hostilidade contra nação estrangeira, expondo a República ao perigo da guerra, ou comprometendo-lhe a neutralidade;

4 - revelar negócios políticos ou militares, que devam ser mantidos secretos a bem da defesa da segurança externa ou dos interesses da Nação;

5 - auxiliar, por qualquer modo, nação inimiga a fazer a guerra ou a cometer hostilidade contra a República; 
6 - celebrar tratados, convenções ou ajustes que comprometam a dignidade da Nação;

7 - violar a imunidade dos embaixadores ou ministros estrangeiros acreditados no país;

8 - declarar a guerra, salvo os casos de invasão ou agressão estrangeira, ou fazer a paz, sem autorização do Congresso Nacional;

9 - não empregar contra o inimigo os meios de defesa de que poderia dispor;

10 - permitir o Presidente da República, durante as sessões legislativas e sem autorização do Congresso Nacional, que forças estrangeiras transitem pelo território do país, ou, por motivo de guerra, nele permaneçam temporariamente;

11 - violar tratados legitimamente feitos com nações estrangeiras.

CAPÍTULO II -

DOS CRIMES CONTRA O LIVRE EXERCIICIO DOS PODERES CONSTITUCIONAIS

Art $6^{\circ}$ São crimes de responsabilidade contra o livre exercício dos poderes legislativo e judiciário e dos poderes constitucionais dos Estados:

1 - tentar dissolver o Congresso Nacional, impedir a reunião ou tentar impedir por qualquer modo o funcionamento de qualquer de suas Câmaras;

2 - usar de violência ou ameaça contra algum representante da Nação para afastá-lo da Câmara a que pertença ou para coagí-lo no modo de exercer o seu mandato bem como conseguir ou tentar conseguir o mesmo objetivo mediante suborno ou outras formas de corrupção;

3 - violar as imunidades asseguradas aos membros do Congresso Nacional, das Assembléias Legislativas dos Estados, da Câmara dos Vereadores do Distrito Federal e das Câmaras Municipais;

4 - permitir que força estrangeira transite pelo território, do país ou nele permaneça quando a isso se oponha o Congresso Nacional;

5 - opor-se diretamente e por fatos ao livre exercício do Poder Judiciário, ou obstar, por meios violentos, ao efeito dos seus atos, mandados ou sentenças;

6 - usar de violência ou ameaça, para constranger juiz, ou jurado, a proferir ou deixar de proferir despacho, sentença ou voto, ou a fazer ou deixar de fazer ato do seu ofício;

7 - praticar contra os poderes estaduais ou municipais ato definido como crime neste artigo;

8 - intervir em negócios peculiares aos Estados ou aos Municípios com desobediência às normas constitucionais.

CAPÍTULO III -

DOS CRIMES CONTRA O EXERCÍCIO DOS DIREITOS POLÍTICOS, INDIVIDUAIS E SOCIAIS

Art $7^{\circ}$ São crimes de responsabilidade contra o livre exercício dos direitos políticos, individuais e sociais:

1 - impedir por violência, ameaça ou corrupção, o livre exercício do voto;

2 - obstar ao livre exercício das funções dos mesários eleitorais;

3 - violar o escrutínio de seção eleitoral ou inquinar de nulidade o seu resultado pela subtração, desvio ou inutilização do respectivo material;

4 - utilizar o poder federal para impedir a livre execução da lei eleitoral;

5 - servir-se das autoridades sob sua subordinação imediata para praticar abuso do poder,

ou tolerar que essas autoridades o pratiquem sem repressão sua;

6 - subverter ou tentar subverter por meios violentos a ordem política e social;

7 - incitar militares à desobediência à lei ou infração à disciplina;

8 - provocar animosidade entre as classes armadas ou contra elas, ou delas contra as instituições civis;

9 - violar patentemente qualquer direito ou garantia individual constante do art. 141 e bem assim os direitos sociais assegurados no artigo 157 da Constituição; 
10 - tomar ou autorizar durante o estado de sítio, medidas de repressão que excedam os limites estabelecidos na Constituição.

CAPITULO IV -

DOS CRIMES CONTRA A SEGURANÇA INTERNA DO PAÍS

Art $8^{\circ}$ São crimes contra a segurança interna do país:

1 - tentar mudar por violência a forma de govêrno da República;

2 - tentar mudar por violência a Constituição Federal ou de algum dos Estados, ou lei da União, de Estado ou Município;

3 - decretar o estado de sítio, estando reunido o Congresso Nacional, ou no recesso dêste, não havendo comoção interna grave nem fatos que evidenciem estar a mesma a irromper ou não ocorrendo guerra externa;

4 - praticar ou concorrer para que se perpetre qualquer dos crimes contra a segurança interna, definidos na legislação penal;

5 - não dar as providências de sua competência para impedir ou frustrar a execução dêsses crimes;

6 - ausentar-se do país sem autorizacão do Congresso Nacional;

7 - permitir, de forma expressa ou tácita, a infração de lei federal de ordem pública;

8 - deixar de tomar, nos prazos fixados, as providências determinadas por lei ou tratado federal e necessárias à sua execução e cumprimento.

CAPÍTULO V -

DOS CRIMES CONTRA A PROBIDADE NA ADMINISTRAÇÃO

Art $9^{\circ}$ São crimes de responsabilidade contra a probidade na administração:

1 - omitir ou retardar dolosamente a publicação das leis e resoluções do Poder Legislativo ou dos atos do Poder Executivo;

2 - não prestar ao Congresso Nacional dentro de sessenta dias após a abertura da sessão legislativa, as contas relativas ao exercício anterior;

3 - não tornar efetiva a responsabilidade dos seus subordinados, quando manifesta em delitos funcionais ou na prática de atos contrários à Constituição;

4 - expedir ordens ou fazer requisição de forma contrária às disposições expressas da Constituição;

5 - infringir no provimento dos cargos públicos, as normas legais;

6 - usar de violência ou ameaça contra funcionário público para coagí-lo a proceder ilegalmente, bem como utilizar-se de subôrno ou de qualquer outra forma de corrupção para o mesmo fim;

7 - proceder de modo incompatível com a dignidade, a honra e o decôro do cargo.

CAPITULO VI -

DOS CRIMES CONTRA A LEI ORÇAMENTÁRIA

Art 10. São crimes de responsabilidade contra a lei orçamentária:

1 - Não apresentar ao Congresso Nacional a proposta do orçamento da República dentro dos primeiros dois meses de cada sessão legislativa;

2 - Exceder ou transportar, sem autorização legal, as verbas do orçamento;

3 - Realizar o estorno de verbas;

4 - Infringir, patentemente, e de qualquer modo, dispositivo da lei orçamentária.

CAPITULO VII -

DOS CRIMES CONTRA A GUARDA E LEGAL EMPRÊGO DOS DINHEIROS PÚBLICOS

Art 11. São crimes de responsabilidade contra a guarda e o legal emprêgo dos dinheiros públicos: 
1 - ordenar despesas não autorizadas por lei ou sem observância das prescrições legais relativas às mesmas;

2 - Abrir crédito sem fundamento em lei ou sem as formalidades legais;

3 - Contrair empréstimo, emitir moeda corrente ou apólices, ou efetuar operação de crédito sem autorização legal;

4 - alienar imóveis nacionais ou empenhar rendas públicas sem autorização em lei;

5 - negligenciar a arrecadação das rendas, impostos e taxas, bem como a conservação do patrimônio nacional.

CAPITULO VIII -

DOS CRIMES CONTRA O CUMPRIMENTO DAS DECISÕES JUDICIÁRIAS

Art 12. São crimes de responsabilidade contra as decisões judiciárias:

1 - impedir, por qualquer meio, o efeito dos atos, mandados ou decisões do Poder Judiciário;

2 - Recusar o cumprimento das decisões do Poder Judiciário no que depender do exercício das funções no Poder Executivo;

3 - deixar de atender a requisição de intervenção federal do Supremo Tribunal Federal ou do Tribunal Superior Eleitoral;

4 - Impedir ou frustrar pagamento determinado por sentença judiciária.

TÍTULO II -

DOS MINISTROS DE ESTADO

Art 13. São crimes de responsabilidade dos Ministros de Estado:

1 - os atos definidos nesta lei, quando por êles praticados ou ordenados;

2 - os atos previstos nesta lei que os Ministros assinarem com o Presidente da República ou por ordem dêste praticarem;

3 - A falta de comparecimento sem justificação, perante a Câmara dos Deputados ou o Senado Federal, ou qualquer das suas comissões, quando uma ou outra casa do Congresso os convocar para pessoalmente, prestarem informações acêrca de assunto prèviamente determinado;

4 - Não prestarem dentro em trinta dias e sem motivo justo, a qualquer das Câmaras do Congresso Nacional, as informações que ela Ihes solicitar por escrito ou prestarem-nas com falsidade.

PARTE SEGUNDA -

PROCESSO E JULGAMENTO

TÍTULO ÚNICO -

DO PRESIDENTE DA REPÚBLICA E EMINISTROS DE ESTADO

CAPÍTULO I -

DA DENÚNCIA

Art 14. É permitido a qualquer cidadão denunciar o Presidente da República ou Ministro de Estado por crime de responsabilidade, perante a Câmara dos Deputados.

Art 15. A denúncia só poderá ser recebida enquanto o denunciado não tiver, por qualquer motivo, deixado definitivamente o cargo.

Art 16. A denúncia assinada pelo denunciante e com a firma reconhecida, deve ser acompanhada dos documentos que a comprovem, ou da declaração de impossibilidade de apresentá-los, com a indicação do local onde possam ser encontrados, nos crimes de que haja prova testemunhal, a denúncia deverá conter rol das testemunhas, em número de cinco no mínimo. 
Art 17. No processo de crime de responsabilidade, servirá de escrivão um funcionário da Secretaria da Câmara dos Deputados, ou do Senado, conforme se achar o mesmo em uma ou outra casa do Congresso Nacional.

Art 18. As testemunhas arroladas no processo deverão comparecer para prestar o seu depoimento, e a Mesa da Câmara dos Deputados ou do Senado por ordem de quem serão notificadas, tomará as providências legais que se tornarem necessárias para compelí-las a obediência.

CAPÍTULO II -

DA ACUSAÇÃO

Art 19. Recebida a denúncia, será lida no expediente da sessão seguinte e despachada a uma comissão especial eleita, da qual participem, observada a respectiva proporção, representantes de todos os partidos para opinar sôbre a mesma.

Art 20. A comissão a que alude o artigo anterior se reunirá dentro de 48 horas e, depois de eleger seu Presidente e relator, emitirá parecer, dentro do prazo de dez dias, sôbre se a denúncia deve ser ou não julgada objeto de deliberação. Dentro dêsse período poderá a comissão proceder às diligências que julgar necessárias ao esclarecimento da denúncia. $\S 1^{\circ} \mathrm{O}$ parecer da comissão especial será lido no expediente da sessão da Câmara dos Deputados e publicado integralmente no Diário do Congresso Nacional e em avulsos, juntamente com a denúncia, devendo as publicações ser distribuídas a todos os deputados.

$\S 2^{\circ}$ Quarenta e oito horas após a publicação oficial do parecer da Comissão especial, será o mesmo incluído, em primeiro lugar, na ordem do dia da Câmara dos Deputados, para uma discussão única.

Art 21. Cinco representantes de cada partido poderão falar, durante uma hora, sôbre o parecer, ressalvado ao relator da comissão especial o direito de responder a cada um.

Art 22. Encerrada a discussão do parecer, e submetido o mesmo a votação nominal, será a denúncia, com os documentos que a instruam, arquivada, se não fôr considerada objeto de deliberação. No caso contrário, será remetida por cópia autêntica ao denunciado, que terá o prazo de vinte dias para contestá-la e indicar os meios de prova com que pretenda demonstrar a verdade do alegado.

$\S 1^{\circ}$ Findo esse prazo e com ou sem a contestação, a comissão especial determinará as diligências requeridas, ou que julgar convenientes, e realizará as sessões necessárias para a tomada do depoimento das testemunhas de ambas as partes, podendo ouvir o denunciante e o denunciado, que poderá assistir pessoalmente, ou por seu procurador, a tôdas as audiências e diligências realizadas pela comissão, interrogando e contestando as testemunhas e requerendo a reinquirição ou acareação das mesmas.

$\S 2^{\circ}$ Findas essas diligências, a comissão especial proferirá, no prazo de dez dias, parecer sôbre a procedência ou improcedência da denúncia.

$\S 3^{\circ}$ Publicado e distribuído esse parecer na forma do $\S 1^{\circ}$ do art. 20 , será o mesmo, incluído na ordem do dia da sessão imediata para ser submetido a duas discussões, com o interregno de 48 horas entre uma e outra.

$\S 4^{\circ}$ Nas discussões do parecer sôbre a procedência ou improcedência da denúncia, cada representante de partido poderá falar uma só vez e durante uma hora, ficando as questões de ordem subordinadas ao disposto no $\S 2^{\circ}$ do art. 20.

Art 23. Encerrada a discussão do parecer, será o mesmo submetido a votação nominal, não sendo permitidas, então, questões de ordem, nem encaminhamento de votação.

$\S 1^{\circ}$ Se da aprovação do parecer resultar a procedência da denúncia, considerar-se-á decretada a acusação pela Câmara dos Deputados. 
$\S 2^{\circ}$ Decretada a acusação, será o denunciado intimado imediatamente pela Mesa da Câmara dos Deputados, por intermédio do $1^{\circ}$ Secretário.

$\S 3^{\circ}$ Se o denunciado estiver ausente do Distrito Federal, a sua intimação será solicitada pela Mesa da Câmara dos Deputados, ao Presidente do Tribunal de Justiça do Estado em que êle se encontrar.

$\S 4^{\circ} \mathrm{A}$ Câmara dos Deputados elegerá uma comissão de três membros para acompanhar o julgamento do acusado.

$\S 5^{\circ}$ São efeitos imediatos ao decreto da acusação do Presidente da República, ou de Ministro de Estado, a suspensão do exercício das funções do acusado e da metade do subsídio ou do vencimento, até sentença final.

$\S 6^{\circ}$ Conforme se trate da acusação de crime comum ou de responsabilidade, o processo será enviado ao Supremo Tribunal Federal ou ao Senado Federal.

CAPÍTULO III -

DO JULGAMENTO

Art 24. Recebido no Senado o decreto de acusação com o processo enviado pela Câmara dos Deputados e apresentado o libelo pela comissão acusadora, remeterá o Presidente cópia de tudo ao acusado, que, na mesma ocasião e nos têrmos dos parágrafos $2^{\circ}$ e $3^{\circ}$ do art. 23, será notificado para comparecer em dia prefixado perante o Senado.

Parágrafo único. Ao Presidente do Supremo Tribunal Federal enviar-se-á o processo em original, com a comunicação do dia designado para o julgamento.

Art 25. O acusado comparecerá, por si ou pelos seus advogados, podendo, ainda, oferecer novos meios de prova.

Art 26. No caso de revelia, marcará o Presidente novo dia para o julgamento e nomeará para a defesa do acusado um advogado, a quem se facultará o exame de tôdas as peças de acusação.

Art 27. No dia aprazado para o julgamento, presentes o acusado, seus advogados, ou o defensor nomeado a sua revelia, e a comissão acusadora, o Presidente do Supremo Tribunal Federal, abrindo a sessão, mandará ler o processo preparatório o libelo e os artigos de defesa; em seguida inquirirá as testemunhas, que deverão depor públicamente e fora da presença umas das outras.

Art 28. Qualquer membro da Comissão acusadora ou do Senado e bem assim o acusado ou seus advogados, poderão requerer que se façam às testemunhas perguntas que julgarem necessárias.

Parágrafo único. A Comissão acusadora, ou o acusado ou seus advogados, poderão contestar ou arguir as testemunhas sem contudo interrompê-las e requerer a acareação.

Art 29. Realizar-se-á a seguir o debate verbal entre a comissão acusadora e o acusado ou os seus advogados pelo prazo que o Presidente fixar e que não poderá exceder de duas horas.

Art 30. Findos os debates orais e retiradas as partes, abrir-se-á discussão sôbre o objeto da acusação.

Art 31. Encerrada a discussão o Presidente do Supremo Tribunal Federal fará relatório resumido da denúncia e das provas da acusação e da defesa e submeterá a votação nominal dos senadores o julgamento. 
Art 32. Se o julgamento fôr absolutório produzirá desde logo, todos os efeitos a favor do acusado.

Art 33. No caso de condenação, o Senado por iniciativa do Presidente fixará o prazo de inabilitação do condenado para o exercício de qualquer função pública; e no caso de haver crime comum deliberará ainda sôbre se o Presidente o deverá submeter à justiça ordinária independentemente da ação de qualquer interessado.

Art 34. Proferida a sentença condenatória o acusado estará, ipso facto, destituído do cargo.

Art 35. A resolução do Senado constará de sentença que será lavrada, nos autos do processo, pelo Presidente do Supremo Tribunal Federal, assinada pelos senadores que funcionarem como juízes, transcrita na ata da sessão e, dentro desta, publicada no Diário Oficial e no Diário do Congresso Nacional .

Art 36. Não pode interferir, em nenhuma fase do processo de responsabilidade do Presidente da República ou dos Ministros de Estado, o deputado ou senador:

a) que tiver parentesco consanguíneo ou afim, com o acusado, em linha reta; em linha colateral, os irmãos cunhados, enquanto durar o cunhadio, e os primos co-irmãos;

b) que, como testemunha do processo, tiver deposto de ciência própria.

Art 37. O Congresso Nacional deverá ser convocado, extraordinàriamente, pelo têrço de uma de suas câmaras, caso a sessão legislativa se encerre sem que se tenha ultimado o julgamento do Presidente da República ou de Ministro de Estado, bem como no caso de ser necessário o início imediato do processo.

Art 38. No processo e julgamento do Presidente da República e dos Ministros de Estado, serão subsidiários desta lei, naquilo em que Ihes forem aplicáveis, assim os regimentos internos da Câmara dos Deputados e do Senado Federal, como o Código de Processo Penal.

PARTE TERCEIRA

TÍTULO I -

CAPÍTULO I -

DOS MINISTROS DO SUPREMO TRIBUNAL FEDERAL

Art 39. São crimes de responsabilidade dos Ministros do Supremo Tribunal Federal:

1 - alterar, por qualquer forma, exceto por via de recurso, a decisão ou voto já proferido em sessão do Tribunal;

2 - proferir julgamento, quando, por lei, seja suspeito na causa;

3 - exercer atividade político-partidária;

4 - ser patentemente desidioso no cumprimento dos deveres do cargo;

5 - proceder de modo incompatível com a honra, dignidade e decôro de suas funções.

CAPÍTULO II -

DO PROCUPADOR GERAL DA REPÚBLICA

Art 40. São crimes de responsabilidade do Procurador Geral da República:

1 - emitir parecer, quando, por lei, seja suspeito na causa;

2 - recusar-se à prática de ato que lhe incumba;

3 - ser patentemente desidioso no cumprimento de suas atribuições;

4 - proceder de modo incompatível com a dignidade e o decôro do cargo.

TÍTULO II - 


\section{DO PROCESSO E JULGAMENTO \\ CAPÍTULO I - \\ DA DENÚNCIA}

Art 41. É permitido a todo cidadão denunciar perante o Senado Federal, os Ministros do Supremo Tribunal Federal e o Procurador Geral da República, pelos crimes de responsabilidade que cometerem (artigos 39 e 40).

Art 42. A denúncia só poderá ser recebida se o denunciado não tiver, por qualquer motivo, deixado definitivamente o cargo.

Art 43. A denúncia, assinada pelo denunciante com a firma reconhecida deve ser acompanhada dos documentos que a comprovem ou da declaração de impossibilidade de apresentá-los, com a indicação do local onde possam ser encontrados. Nos crimes de que haja prova testemunhal, a denúncia deverá conter o rol das testemunhas, em número de cinco, no mínimo.

Art 44. Recebida a denúncia pela Mesa do Senado, será lida no expediente da sessão seguinte e despachada a uma comissão especial, eleita para opinar sôbre a mesma.

Art 45. A comissão a que alude o artigo anterior, reunir-se-á dentro de 48 horas e, depois de eleger o seu presidente e relator, emitirá parecer no prazo de 10 dias sôbre se a denúncia deve ser, ou não julgada objeto de deliberação. Dentro dêsse período poderá a comissão proceder às diligências que julgar necessárias.

Art 46. O parecer da comissão, com a denúncia e os documentos que a instruírem, será lido no expediente de sessão do Senado, publicado no Diário do Congresso Nacional e em avulsos, que deverão ser distribuídos entre os senadores, e dado para ordem do dia da sessão seguinte.

Art 47. O parecer será submetido a uma só discussão, e a votação nominal considerando-se aprovado se reunir a maioria simples de votos.

Art 48. Se o Senado resolver que a denúncia não deve constituir objeto de deliberação, serão os papéis arquivados.

Art 49. Se a denúncia fôr considerada objeto de deliberação, a Mesa remeterá cópia de tudo ao denunciado, para responder à acusação no prazo de 10 dias.

Art 50. Se o denunciado estiver fora do Distrito Federal, a cópia Ihe será entregue pelo Presidente do Tribunal de Justiça do Estado em que se achar. Caso se ache fora do país ou em lugar incerto e não sabido, o que será verificado pelo $1^{\circ}$ Secretário do Senado, a intimação far-se-á por edital, publicado na Diário do Congresso Nacional, com a antecedência de 60 dias, aos quais se acrescerá, em comparecendo o denunciado, o prazo do art. 49.

Art 51. Findo o prazo para a resposta do denunciado, seja esta recebida, ou não, a comissão dará parecer, dentro de dez dias, sôbre a procedência ou improcedência da acusação.

Art 52. Perante a comissão, o denunciante e o denunciado poderão comparecer pessoalmente ou por procurador, assistir a todos os atos e diligências por ela praticados, inquirir, reinquirir, contestar testemunhas e requerer a sua acareação. Para êsse efeito, a comissão dará aos interessados conhecimento das suas reuniões e das diligências a que deva proceder, com a indicação de lugar, dia e hora. 
Art 53. Findas as diligências, a comissão emitirá sôbre elas, o seu parecer, que será publicado e distribuído, com tôdas as peças que o instruírem, e dado para ordem do dia 48 horas, no mínimo, depois da distribuição.

Art 54. Êsse parecer terá uma só discussão e considerar-se-á aprovado se, em votação nominal, reunir a maioria simples dos votos.

Art 55. Se o Senado entender que não procede a acusação, serão os papéis arquivados. Caso decida o contrário, a Mesa dará, imediato conhecimento dessa decisão ao Supremo Tribunal Federal, ao Presidente da República, ao denunciante e ao ser-lhe-á comunicada a requisição que será verificado pelo $1^{\circ}$ Secretário do Senado denunciado.

Art 56. Se o denunciado não estiver no Distrito Federal, a decisão da Mesa, pelo Presidente do Tribunal de Justiça do Estado onde se achar. Se estiver fora do país ou em lugar incerto e não sabido, far-se-á a intimação mediante edital pelo Diário do Congresso Nacional, com a antecedência de 60 dias.

Art 57. A decisão produzirá desde a data da sua intimação os seguintes efeitos contra o denunciado:

a) ficar suspenso do exercício das suas funções até sentença final;

b) ficar sujeito a acusação criminal;

c) perder, até sentença final, um têrço dos vencimentos, que the será pago no caso de absolvição.

CAPÍTULO II -

DA ACUSAÇÃO E DA DEFESA

Art 58. Intimado o denunciante ou o seu procurador da decisão a que aludem os três últimos artigos, ser-lhe-á dada vista do processo, na Secretaria do Senado, para, dentro de 48 horas, oferecer o libelo acusatório e o rol das testemunhas. Em seguida abrir-se-á vista ao denunciado ou ao seu defensor, pelo mesmo prazo para oferecer a contrariedade e o rol das testemunhas.

Art 59. Decorridos êsses prazos, com o libelo e a contrariedade ou sem êles, serão os autos remetidos, em original, ao Presidente do Supremo Tribunal Federal, ou ao seu substituto legal, quando seja êle o denunciado, comunicando-se-Ihe o dia designado para o julgamento e convidando-o para presidir a sessão.

Art 60. O denunciante e o acusado serão notificados pela forma estabelecida no art. 56, para assistirem ao julgamento, devendo as testemunhas ser, por um magistrado, intimadas a comparecer a requisição da Mesa.

Parágrafo único. Entre a notificação e o julgamento deverá mediar o prazo mínimo de 10 dias.

Art 61. No dia e hora marcados para o julgamento, o Senado reunir-se-á, sob a presidência do Presidente do Supremo Tribunal Federal ou do seu substituto legal. Verificada presença de número legal de Senadores, será aberta a sessão e feita a chamada das partes, acusador e acusado, que poderão comparecer pessoalmente ou pelos seus procuradores.

Art 62. A revelia do acusador não importará transferência do julgamento, nem perempção da acusação. 
$\S 1^{\circ} \mathrm{A}$ revelia do acusado determinará o adiamento de julgamento, para o qual o Presidente designará novo dia, nomeando um advogado para defender o revel.

$\S 2^{\circ}$ Ao defensor nomeado será, facultado o exame de tôdas as peças do processo.

Art 63. No dia definitivamente aprazado para o julgamento, verificado o número legal de senadores será aberta a sessão e facultado o ingresso às partes ou aos seus procuradores. Serão juízes todos os senadores presentes, com exceção dos impedidos nos têrmos do art. 36 .

Parágrafo único. O impedimento poderá ser oposto pelo acusador ou pelo acusado e invocado por qualquer senador.

Art 64. Constituído o Senado em Tribunal de julgamento, o Presidente mandará ler o processo e, em seguida, inquirirá publicamente as testemunhas, fora da presença uma das outras.

Art 65. O acusador e o acusado, ou os seus procuradores, poderão reinquirir as testemunhas, contestá-las sem interrompê-las e requerer a sua acareação. Qualquer senador poderá requerer sejam feitas as perguntas que julgar necessárias.

Art 66. Finda a inquirição haverá debate oral, facultadas a réplica e a tréplica entre o acusador e o acusado, pelo prazo que o Presidente determinar.

Parágrafo único. Ultimado o debate, retirar-se-ão as partes do recinto da sessão e abrirse-á uma discussão única entre os senadores sôbre o objeto da acusação.

Art 67. Encerrada a discussão, fará o Presidente um relatório resumido dos fundamentos da acusação e da defesa, bem como das respectivas provas, submetendo em seguida o caso a julgamento.

CAPÍTULO III -

DA SENTENÇA

Art 68. O julgamento será feito, em votação nominal pelos senadores desimpedidos que responderão "sim" ou "não" à seguinte pergunta enunciada pelo Presidente: "Cometeu o acusado $\mathrm{F}$ o crime que lhe é imputado e deve ser condenado à perda do seu cargo?"

Parágrafo único. Se a resposta afirmativa obtiver, pelo menos, dois terços dos votos dos senadores presentes, o Presidente fará nova consulta ao plenário sôbre o tempo não excedente de cinco anos, durante o qual o condenado deverá ficar inabilitado para o exercício de qualquer função, pública.

Art 69. De acôrdo com a decisão do Senado, o Presidente lavrará nos autos, a sentença que será assinada por êle e pelos senadores, que tiverem tomado parte no julgamento, e transcrita na ata.

Art 70. No caso de condenação, fica o acusado desde logo destituído do seu cargo. Se a sentença fôr absolutória, produzirá a imediata reabilitação do acusado, que voltará ao exercício do cargo, com direito à parte dos vencimentos de que tenha sido privado.

Art 71. Da sentença, dar-se-á imediato conhecimento ao Presidente da República, ao Supremo Tribunal Federal e ao acusado.

Art 72. Se no dia do encerramento do Congresso Nacional não estiver concluído o processo ou julgamento de Ministro do Supremo Tribunal Federal ou do Procurador Geral 
da República, deverá êle ser convocado extraordináriamente pelo têrço do Senado Federal.

Art 73. No processo e julgamento de Ministro do Supremo Tribunal, ou do Procurador Geral da República, serão subsidiários desta lei, naquilo em que Ihes forem aplicáveis, o Regimento Interno do Senado Federal e o Código de Processo Penal.

PARTE QUARTA

TÍTULO ÚNICO

CAPÍTULO I -

DOS GOVERNADORES E SECRETÁRIOS DOS ESTADOS

Art 74. Constituem crimes de responsabilidade dos governadores dos Estados ou dos seus Secretários, quando por êles praticados, os atos definidos como crimes nesta lei.

CAPÍTULO II -

DA DENÚNCIA, ACUSAÇÃO E JULGAMENTO

Art 75. É permitido a todo cidadão denunciar o Governador perante a Assembléia Legislativa, por crime de responsabilidade.

Art 76. A denúncia, assinada pelo denunciante e com a firma reconhecida, deve ser acompanhada dos documentos que a comprovem, ou da declaração de impossibilidade de apresentá-los com a indicação do local em que possam ser encontrados. Nos crimes de que houver prova testemunhal, conterá o ról das testemunhas, em número de cinco pelo menos.

Parágrafo único. Não será recebida a denúncia depois que o Governador por qualquer motivo, houver deixado definitivamente o cargo.

Art 77. Apresentada a denúncia e julgada objeto de deliberação, se a Assembléia por maioria absoluta, decretar a procedência na acusação, será o Governador imediatamente suspenso de suas funções.

Art 78. O Governador será julgado nos crimes de responsabilidade, pela forma que determinar a Constituição do Estado e não poderá ser condenado, senão à perda do cargo, com inabilitação até cinco anos, para o exercício de qualquer função pública, sem prejuízo da ação da justiça comum.

$\S 1^{\circ}$ Quando o tribunal de julgamento fôr de jurisdição mista, serão iguais, pelo número, os representantes dos órgãos que o integrarem, excluído o Presidente, que será o Presidente do Tribunal de Justiça.

$\S 2^{\circ} \mathrm{Em}$ qualquer hipótese, só poderá ser decretada a condenação pelo voto de dois têrços dos membros de que se compuser o tribunal de julgamento.

$\S 3^{\circ}$ Nos Estados, onde as Constituições não determinarem o processo nos crimes de responsabilidade dos Governadores, aplicar-se-á o disposto nesta lei, devendo, porém, o julgamento ser proferido por um tribunal composto de cinco membros do Legislativo e de cinco desembargadores, sob a presidência do Presidente do Tribunal de Justiça local, que terá direito de voto no caso de empate. A escolha desse Tribunal será feita - a dos membros do legislativo, mediante eleição pela Assembléia: a dos desembargadores, mediante sorteio.

$\S 4^{\circ}$ Êsses atos deverão ser executados dentro em cinco dias contados da data em que a Assembléia enviar ao Presidente do Tribunal de Justiça os autos do processo, depois de decretada a procedência da acusação.

Art 79. No processo e julgamento do Governador serão subsidiários desta lei naquilo em que Ihe forem aplicáveis, assim o regimento interno da Assembléia Legislativa e do Tribunal de Justiça, como o Código de Processo Penal. 
Parágrafo único. Os Secretários de Estado, nos crimes conexos com os dos governadores, serão sujeitos ao mesmo processo e julgamento.

\section{DISPOSIÇÕES GERAIS}

Art 80. Nos crimes de responsabilidade do Presidente da República e dos Ministros de Estado, a Câmara dos Deputados é tribunal de pronúncia e o Senado Federal, tribunal de julgamento: nos crimes de responsabilidade dos Ministros do Supremo Tribunal Federal e do Procurador Geral da República, o Senado Federal é, simultâneamente, tribunal de pronúncia e julgamento.

Parágrafo único. O Senado Federal, na apuração e julgamento dos crimes de responsabilidade funciona sob a presidência do Presidente do Supremo Tribunal, e só proferirá sentença condenatória pelo voto de dois têrços dos seus membros.

Art 81. A declaração de procedência da acusação nos crimes de responsabilidade só poderá ser decreta pela maioria absoluta da Câmara que proferir.

Art 82. Não poderá exceder de cento e vinte dias, contados da data da declaração da procedência da acusação, o prazo para o processo e julgamento dos crimes definidos nesta lei.

Art 83. Esta lei entrará em vigor na data de sua publicação, revogadas as disposições em contrário.

Rio de Janeiro, 10 de abril de 1950; $129^{\circ}$ da Independência e $62^{\circ}$ da República.

\section{EURICO G. DUTRA}

Honório Monteiro

Sylvio de Noronha

Canrobert P. da Costa

Raul Fernandes

Guilherme da Silveira

João Valdetaro de Amorim e Mello

Daniel de Carvalho

Clemente Mariani

Armando Trompowsky 
Anexo 2:

DECRETO-LEI N 201 - DE 27 DE FEVEREIRO DE 1967 - DOU DE 27/02/67

Dispõe sobre a responsabilidade dos Prefeitos e Vereadores, e dá outras providências.

O PRESIDENTE DA REPÚBLICA, usando da atribuição que the confere o parágrafo $2^{\circ}$, do artigo $9^{\circ}$, do Ato Institucional $n^{\circ} 4$, de 7 de dezembro de 1966 ,

\section{DECRETA:}

Art. $1^{\circ}$ São crimes de responsabilidade dos Prefeitos Municipal, sujeitos ao julgamento do Poder Judiciário, independentemente do pronunciamento da Câmara dos Vereadores:

I - apropriar-se de bens ou rendas públicas, ou desviá-los em proveito próprio ou alheio;

II - utilizar-se, indevidamente, em proveito próprio ou alheio, de bens, rendas ou serviços públicos;

III - desviar, ou aplicar indevidamente, rendas ou verbas públicas;

IV - empregar subvenções, auxílios, empréstimos ou recursos de qualquer natureza, em desacordo com os planos ou programas a que se destinam;

$\mathrm{V}$ - ordenar ou efetuar despesas não autorizadas por lei, ou realizá-las em desacordo com as normas financeiras pertinentes;

VI - deixar de prestar contas anuais da administração financeira do Município a Câmara de Vereadores, ou ao órgão que a Constituição do Estado indicar, nos prazos e condições estabelecidos;

VII - Deixar de prestar contas, no devido tempo, ao órgão competente, da aplicação de recursos, empréstimos subvenções ou auxílios internos ou externos, recebidos a qualquer tíitulo;

VIII - Contrair empréstimo, emitir apólices, ou obrigar o Município por títulos de crédito, sem autorização da Câmara, ou em desacordo com a lei;

IX - Conceder empréstimo, auxílios ou subvenções sem autorização da Câmara, ou em desacordo com a lei;

X - Alienar ou onerar bens imóveis, ou rendas municipais, sem autorização da Câmara, ou em desacordo com a lei;

XI - Adquirir bens, ou realizar serviços e obras, sem concorrência ou coleta de preços, nos casos exigidos em lei;

XII - Antecipar ou inverter a ordem de pagamento a credores do Município, sem vantagem para o erário;

XIII - Nomear, admitir ou designar servidor, contra expressa disposição de lei;

XIV - Negar execução a lei federal, estadual ou municipal, ou deixar de cumprir ordem judicial, sem dar o motivo da recusa ou da impossibilidade, por escrito, à autoridade competente;

$\mathrm{XV}$ - Deixar de fornecer certidões de atos ou contratos municipais, dentro do prazo estabelecido em lei.

XVI - deixar de ordenar a redução do montante da dívida consolidada, nos prazos estabelecidos em lei, quando o montante ultrapassar o valor resultante da aplicação do limite máximo fixado pelo Senado Federal; (Inciso acrescido pela Lei 10.028, de 19/10/2000)

XVII - ordenar ou autorizar a abertura de crédito em desacordo com os limites estabelecidos pelo Senado Federal, sem fundamento na lei orçamentária ou na de crédito adicional ou com inobservância de prescrição legal; (Inciso acrescido pela Lei 10.028, de 19/10/2000)

XVIII - deixar de promover ou de ordenar, na forma da lei, o cancelamento, a amortização ou a constituição de reserva para anular os efeitos de operação de crédito realizada com inobservância de limite, condição ou montante estabelecido em lei; (Inciso acrescido pela Lei 10.028, de 19/10/2000) 
XIX - deixar de promover ou de ordenar a liquidação integral de operação de crédito por antecipação de receita orçamentária, inclusive os respectivos juros e demais encargos, até o encerramento do exercício financeiro; (Inciso acrescido pela Lei 10.028, de 19/10/2000)

XX - ordenar ou autorizar, em desacordo com a lei, a realização de operação de crédito com qualquer um dos demais entes da Federação, inclusive suas entidades da administração indireta, ainda que na forma de novação, refinanciamento ou postergação de dívida contraída anteriormente; (Inciso acrescido pela Lei 10.028, de 19/10/2000)

XXI - captar recursos a título de antecipação de receita de tributo ou contribuição cujo fato gerador ainda não tenha ocorrido; (Inciso acrescido pela Lei 10.028, de 19/10/2000)

XXII - ordenar ou autorizar a destinação de recursos provenientes da emissão de títulos para finalidade diversa da prevista na lei que a autorizou; (Inciso acrescido pela Lei 10.028, de 19/10/2000)

XXIII - realizar ou receber transferência voluntária em desacordo com limite ou condição estabelecida em lei. (Inciso acrescido pela Lei 10.028, de 19/10/2000)

$\S 1^{\circ}$ Os crimes definidos neste artigo são de ação pública, punidos os dos itens I e II, com a pena de reclusão, de dois a doze anos, e os demais, com a pena de detenção, de três meses a três anos.

$\S 2^{\circ} \mathrm{A}$ condenação definitiva em qualquer dos crimes definidos neste artigo, acarreta a perda de cargo e a inabilitação, pelo prazo de cinco anos, para o exercício de cargo ou função pública, eletivo ou de nomeação, sem prejuízo da reparação civil do dano causado ao patrimônio público ou particular.

Art. $2^{\circ} \mathrm{O}$ processo dos crimes definidos no artigo anterior é o comum do juízo singular, estabelecido pelo Código de Processo Penal, com as seguintes modificações:

I - Antes de receber a denúncia, o Juiz ordenará a notificação do acusado para apresentar defesa prévia, no prazo de cinco dias. Se o acusado não for encontrado para a notificação, ser-lhe-á nomeado defensor, a quem caberá apresentar a defesa, dentro no mesmo prazo.

II - Ao receber a denúncia, o Juiz manifestar-se-á, obrigatória e motivadamente, sobre a prisão preventiva do acusado, nos casos dos itens I e II do artigo anterior, e sobre o seu afastamento do exercício do cargo durante a instrução criminal, em todos os casos.

III - Do despacho, concessivo ou denegatório, de prisão preventiva, ou de afastamento do cargo do acusado, caberá recurso, em sentido estrito, para o Tribunal competente, no prazo de cinco dias, em autos apartados. O recurso do despacho que decreta a prisão preventiva ou o afastamento do cargo terá efeito suspensivo.

$\S 1^{\circ}$ Os órgãos federais, estaduais ou municipais, interessados na apuração da responsabilidade do Prefeito, podem requerer a abertura do inquérito policial ou a instauração da ação penal pelo Ministério Público, bem como intervir, em qualquer fase do processo, como assistente da acusação.

$\S 2^{\circ}$ Se as previdências para a abertura do inquérito policial ou instauração da ação penal não forem atendidas pela autoridade policial ou pelo Ministério Público estadual, poderão ser requeridas ao Procurador-Geral da República.

Art. $3^{\circ}$ O Vice-Prefeito, ou quem vier a substituir o Prefeito, fica sujeito ao mesmo processo do substituído, ainda que tenha cessado a substituição.

Art. $4^{\circ}$ São infrações político-administrativas dos Prefeitos Municipais sujeitas ao julgamento pela Câmara dos Vereadores e sancionadas com a cassação do mandato: 
I - Impedir o funcionamento regular da Câmara;

II - Impedir o exame de livros, folhas de pagamento e demais documentos que devam constar dos arquivos da Prefeitura, bem como a verificação de obras e serviços municipais, por comissão de investigação da Câmara ou auditoria, regularmente instituída; III - Desatender, sem motivo justo, as convocações ou os pedidos de informações da Câmara, quando feitos a tempo e em forma regular;

IV - Retardar a publicação ou deixar de publicar as leis e atos sujeitos a essa formalidade; V - Deixar de apresentar à Câmara, no devido tempo, e em forma regular, a proposta orçamentária;

VI - Descumprir o orçamento aprovado para o exercício financeiro,

VII - Praticar, contra expressa disposição de lei, ato de sua competência ou emitir-se na sua prática;

VIII - Omitir-se ou negligenciar na defesa de bens, rendas, direitos ou interesses do Município sujeito à administração da Prefeitura;

IX - Ausentar-se do Município, por tempo superior ao permitido em lei, ou afastar-se da Prefeitura, sem autorização da Câmara dos Vereadores;

$\mathrm{X}$ - Proceder de modo incompatível com a dignidade e o decoro do cargo.

Art. $5^{\circ} \mathrm{O}$ processo de cassação do mandato do Prefeito pela Câmara, por infrações definidas no artigo anterior, obedecerá ao seguinte rito, se outro não for estabelecido pela legislação do Estado respectivo:

I - A denúncia escrita da infração poderá ser feita por qualquer eleitor, com a exposição dos fatos e a indicação das provas. Se o denunciante for Vereador, ficará impedido de voltar sobre a denúncia e de integrar a Comissão processante, podendo, todavia, praticar todos os atos de acusação. Se o denunciante for o Presidente da Câmara, passará a Presidência ao substituto legal, para os atos do processo, e só votará se necessário para completar o quorum de julgamento. Será convocado o suplente do Vereador impedido de votar, o qual não poderá integrar a Comissão processante.

II - De posse da denúncia, o Presidente da Câmara, na primeira sessão, determinará sua leitura e consultará a Câmara sobre o seu recebimento. Decidido o recebimento, pelo voto da maioria dos presentes, na mesma sessão será constituída a Comissão processante, com três Vereadores sorteados entre os desimpedidos, os quais elegerão, desde logo, o Presidente e o Relator.

III - Recebendo o processo, o Presidente da Comissão iniciará os trabalhos, dentro em cinco dias, notificando o denunciado, com a remessa de cópia da denúncia e documentos que a instruírem, para que, no prazo de dez dias, apresente defesa prévia, por escrito, indique as provas que pretender produzir e arrole testemunhas, até o máximo de dez. Se estiver ausente do Município, a notificação far-se-á por edital, publicado duas vezes, no órgão oficial, com intervalo de três dias, pelo menos, contado o prazo da primeira publicação. Decorrido o prazo de defesa, a Comissão processante emitirá parecer dentro em cinco dias, opinando pelo prosseguimento ou arquivamento da denúncia, o qual, neste caso, será submetido ao Plenário. Se a Comissão opinar pelo prosseguimento, o Presidente designará desde logo, o início da instrução, e determinará os atos, diligências e audiências que se fizerem necessários, para o depoimento do denunciado e inquirição das testemunhas.

IV - O denunciado deverá ser intimado de todos os atos do processo, pessoalmente, ou na pessoa de seu procurador, com a antecedência, pelo menos, de vinte e quatro horas, sendo lhe permitido assistir as diligências e audiências, bem como formular perguntas e reperguntas às testemunhas e requerer o que for de interesse da defesa.

V - Concluída a instrução, será aberta vista do processo ao denunciado, para razões escritas, no prazo de cinco dias, e após, a Comissão processante emitirá parecer final, pela procedência ou improcedência da acusação, e solicitará ao Presidente da Câmara, a convocação de sessão para julgamento. Na sessão de julgamento, o processo será lido, integralmente, e, a seguir, os Vereadores que o desejarem poderão manifestar-se 
verbalmente, pelo tempo máximo de quinze minutos cada um, e, ao final, o denunciado, ou seu procurador, terá o prazo máximo de duas horas, para produzir sua defesa oral.

VI - Concluída a defesa, proceder-se-á a tantas votações nominais, quantas forem as infrações articuladas na denúncia. Considerar-se-á afastado, definitivamente, do cargo, o denunciado que for declarado pelo voto de dois terços, pelo menos, dos membros da Câmara, em curso de qualquer das infrações especificadas na denúncia. Concluído o julgamento, o Presidente da Câmara proclamará imediatamente o resultado e fará lavrar ata que consigne a votação nominal sobre cada infração, e, se houver condenação, expedirá o competente decreto legislativo de cassação do mandato de Prefeito. Se o resultado da votação for absolutório, o Presidente determinará o arquivamento do processo. Em qualquer dos casos, o Presidente da Câmara comunicará à Justiça Eleitoral o resultado.

VII - O processo, a que se refere este artigo, deverá estar concluído dentro em noventa dias, contados da data em que se efetivar a notificação do acusado. Transcorrido o prazo sem o julgamento, o processo será arquivado, sem prejuízo de nova denúncia ainda que sobre os mesmos fatos.

Art. $6^{\circ}$ Extingue-se o mandato de Prefeito, e, assim, deve ser declarado pelo Presidente da Câmara de Vereadores, quando:

I - Ocorrer falecimento, renúncia por escrito, cassação dos direitos políticos, ou condenação por crime funcional ou eleitoral.

II - Deixar de tomar posse, sem motivo justo aceito pela Câmara, dentro do prazo estabelecido em lei.

III - Incidir nos impedimentos para o exercício do cargo, estabelecidos em lei, e não se desincompatibilizar até a posse, e, nos casos supervenientes, no prazo que a lei ou a Câmara fixar.

Parágrafo único. A extinção do mandato independe de deliberação do plenário e se tornará efetiva desde a declaração do fato ou ato extintivo pelo Presidente e sua inserção em ata.

Art. $7^{\circ} \mathrm{A}$ Câmara poderá cassar o mandato de Vereador, quando:

I - Utilizar-se do mandato para a prática de atos de corrupção ou de improbidade administrativa;

II - Fixar residência fora do Município;

III - Proceder de modo incompatível com a dignidade, da Câmara ou faltar com o decoro na sua conduta pública.

$\S 1^{\circ} \mathrm{O}$ processo de cassação de mandato de Vereador é, no que couber, o estabelecido no art. $5^{\circ}$ deste decreto-lei.

$\S 2^{\circ} \mathrm{O}$ Presidente da Câmara poderá afastar de suas funções o Vereador acusado, desde que a denúncia seja recebida pela maioria absoluta dos membros da Câmara, convocando o respectivo suplente, até o julgamento final. O suplente convocado não intervirá nem votará nos atos do processo do substituído. (Parágrafo revogado pela Lei $\mathrm{n}^{\circ}$ 9.504, de 30/09/97)

Art. $8^{\circ}$ Extingue-se o mandato do Vereador e assim será declarado pelo Presidente da Câmara, quando:

I - Ocorrer falecimento, renúncia por escrito, cassação dos direitos políticos ou condenação por crime funcional ou eleitoral;

II - Deixar de tomar posse, sem motivo justo aceito pela Câmara, dentro do prazo estabelecido em lei;

III - Deixar de comparecer, sem que esteja licenciado, a cinco sessões ordinárias consecutivas, ou a três sessões extraordinárias convocadas pelo Prefeito para a apreciação de matéria urgente; 
III - deixar de comparecer, em cada sessão legislativa anual, à terça parte das sessões ordinárias da Câmara Municipal, salvo por motivo de doença comprovada, licença ou missão autorizada pela edilidade; ou, ainda, deixar de comparecer a cinco sessões extraordinárias convocadas pelo prefeito, por escrito e mediante recibo de recebimento, para apreciação de matéria urgente, assegurada ampla defesa, em ambos os casos. (Redação dada pela Lei ${ }^{\circ} 6.793$, de 13/06/80)

IV - Incidir nos impedimentos para o exercício do mandato, estabelecidos em lei e não se desincompatibilizar até a posse, e, nos casos supervenientes, no prazo fixado em lei ou pela Câmara.

$\S 1^{\circ}$ Ocorrido e comprovado o ato ou fato extintivo, o Presidente da Câmara, na primeira sessão, comunicará ao plenário e fará constar da ata a declaração da extinção do mandato e convocará imediatamente o respectivo suplente.

$\S 2^{\circ}$ Se o Presidente da Câmara omitir-se nas providências no parágrafo anterior, o suplente do Vereador ou o Prefeito Municipal poderá requerer a declaração de extinção do mandato, por via judicial, e se procedente, o juiz condenará o Presidente omisso nas custas do processo e honorários de advogado que fixará de plano, importando a decisão judicial na destituição automática do cargo da Mesa e no impedimento para nova investidura durante toda a legislatura.

$\S 3^{\circ} \mathrm{O}$ disposto no item III não se aplicará às sessões extraordinárias que forem convocadas pelo Prefeito, durante os períodos de recesso das Câmaras Municipais. (Parágrafo incluído pela Lei $n^{\circ} 5.659$, de 8/06/71)

Art. $9^{\circ} \mathrm{O}$ presente decreto-lei entrará em vigor na data de sua publicação, revogadas as Leis números 211, de 7 de janeiro de 1948, e 3.528, de 3 de janeiro de 1959, e demais disposições em contrário.

Brasília, 24 de fevereiro de $1967 ; 146^{\circ}$ da Independência e $79^{\circ}$ da República. H. CASTELLO BRANCO 
Anexo 2:

LEI No 10.028, DE 19 DE OUTUBRO DE 2000.

Altera o Decreto-Lei no 2.848, de 7 de dezembro de 1940 - Código Penal, a Lei no 1.079, de 10 de abril de 1950, e o Decreto-Lei no 201, de 27 de fevereiro de 1967.

O PRESIDENTE DA REPÚBLICA Faço saber que o Congresso Nacional decreta e eu sanciono a seguinte Lei:

Art. $10 \mathrm{O}$ art. 339 do Decreto-Lei no 2.848, de 7 de dezembro de 1940, passa a vigorar com a seguinte redação:

"Art. 339. Dar causa à instauração de investigação policial, de processo judicial, instauração de investigação administrativa, inquérito civil ou ação de improbidade administrativa contra alguém, imputando-lhe crime de que o sabe inocente:" (NR)

"Pena

"§ 10

"§ 20

Art. 20 O Título XI do Decreto-Lei no 2.848, de 1940, passa a vigorar acrescido do seguinte capítulo e artigos:

"CAPÍTULO IV

DOS CRIMES CONTRA AS FINANÇAS PÚBLICAS" (AC)*

"Contratação de operação de crédito" (AC)

"Art. 359-A. Ordenar, autorizar ou realizar operação de crédito, interno ou externo, sem prévia autorização legislativa:" (AC)

"Pena - reclusão, de 1 (um) a 2 (dois) anos." (AC)

"Parágrafo único. Incide na mesma pena quem ordena, autoriza ou realiza operação de crédito, interno ou externo:" (AC)

"I - com inobservância de limite, condição ou montante estabelecido em lei ou em resolução do Senado Federal;" (AC)

"II - quando o montante da dívida consolidada ultrapassa o limite máximo autorizado por lei." (AC)

"Inscrição de despesas não empenhadas em restos a pagar" (AC)

"Art. 359-B. Ordenar ou autorizar a inscrição em restos a pagar, de despesa que não tenha sido previamente empenhada ou que exceda limite estabelecido em lei:" (AC)

"Pena - detenção, de 6 (seis) meses a 2 (dois) anos." (AC)

"Assunção de obrigação no último ano do mandato ou legislatura" (AC)

"Art. 359-C. Ordenar ou autorizar a assunção de obrigação, nos dois últimos quadrimestres do último ano do mandato ou legislatura, cuja despesa não possa ser paga no mesmo exercício financeiro ou, caso reste parcela a ser paga no exercício seguinte, que não tenha contrapartida suficiente de disponibilidade de caixa:" (AC)

"Pena - reclusão, de 1 (um) a 4 (quatro) anos." (AC)

"Ordenação de despesa não autorizada" (AC)

"Art. 359-D. Ordenar despesa não autorizada por lei:" (AC)

"Pena - reclusão, de 1 (um) a 4 (quatro) anos." (AC)

"Prestação de garantia graciosa" (AC) 
"Art. 359-E. Prestar garantia em operação de crédito sem que tenha sido constituída contragarantia em valor igual ou superior ao valor da garantia prestada, na forma da lei:" $(\mathrm{AC})$

"Pena - detenção, de 3 (três) meses a 1 (um) ano." (AC)

"Não cancelamento de restos a pagar" (AC)

"Art. 359-F. Deixar de ordenar, de autorizar ou de promover o cancelamento do montante de restos a pagar inscrito em valor superior ao permitido em lei:" (AC)

"Pena - detenção, de 6 (seis) meses a 2 (dois) anos." (AC)

"Aumento de despesa total com pessoal no último ano do mandato ou legislatura" (AC)

"Art. 359-G. Ordenar, autorizar ou executar ato que acarrete aumento de despesa total com pessoal, nos cento e oitenta dias anteriores ao final do mandato ou da legislatura:"

$(\mathrm{AC})$

"Pena - reclusão, de 1 (um) a 4 (quatro) anos." (AC)

"Oferta pública ou colocação de títulos no mercado" (AC)

"Art. 359-H. Ordenar, autorizar ou promover a oferta pública ou a colocação no mercado financeiro de títulos da dívida pública sem que tenham sido criados por lei ou sem que estejam registrados em sistema centralizado de liquidação e de custódia:" (AC)

"Pena - reclusão, de 1 (um) a 4 (quatro) anos." (AC) alterações:

Art. 3o A Lei no 1.079, de 10 de abril de 1950, passa a vigorar com as seguintes "Art. 10.

"5) deixar de ordenar a redução do montante da dívida consolidada, nos prazos estabelecidos em lei, quando o montante ultrapassar o valor resultante da aplicação do limite máximo fixado pelo Senado Federal;" (AC)

"6) ordenar ou autorizar a abertura de crédito em desacordo com os limites estabelecidos pelo Senado Federal, sem fundamento na lei orçamentária ou na de crédito adicional ou com inobservância de prescrição legal;" (AC)

"7) deixar de promover ou de ordenar na forma da lei, o cancelamento, a amortização ou a constituição de reserva para anular os efeitos de operação de crédito realizada com inobservância de limite, condição ou montante estabelecido em lei;" (AC)

"8) deixar de promover ou de ordenar a liquidação integral de operação de crédito por antecipação de receita orçamentária, inclusive os respectivos juros e demais encargos, até o encerramento do exercício financeiro;" (AC)

"9) ordenar ou autorizar, em desacordo com a lei, a realização de operação de crédito com qualquer um dos demais entes da Federação, inclusive suas entidades da administração indireta, ainda que na forma de novação, refinanciamento ou postergação de dívida contraída anteriormente;" (AC)

"10) captar recursos a título de antecipação de receita de tributo ou contribuição cujo fato gerador ainda não tenha ocorrido;" (AC)

"11) ordenar ou autorizar a destinação de recursos provenientes da emissão de títulos para finalidade diversa da prevista na lei que a autorizou;" (AC)

"12) realizar ou receber transferência voluntária em desacordo com limite ou condição estabelecida em lei." (AC)

"Art. 39-A. Constituem, também, crimes de responsabilidade do Presidente do Supremo Tribunal Federal ou de seu substituto quando no exercício da Presidência, as condutas previstas no art. 10 desta Lei, quando por eles ordenadas ou praticadas." (AC) 
"Parágrafo único. O disposto neste artigo aplica-se aos Presidentes, e respectivos substitutos quando no exercício da Presidência, dos Tribunais Superiores, dos Tribunais de Contas, dos Tribunais Regionais Federais, do Trabalho e Eleitorais, dos Tribunais de Justiça e de Alçada dos Estados e do Distrito Federal, e aos Juízes Diretores de Foro ou função equivalente no primeiro grau de jurisdição." (AC)

"Art. 40-A. Constituem, também, crimes de responsabilidade do Procurador-Geral da República, ou de seu substituto quando no exercício da chefia do Ministério Público da União, as condutas previstas no art. 10 desta Lei, quando por eles ordenadas ou praticadas." (AC)

"Parágrafo único. O disposto neste artigo aplica-se:" (AC)

"I - ao Advogado-Geral da União;" (AC)

"Il - aos Procuradores-Gerais do Trabalho, Eleitoral e Militar, aos Procuradores-Gerais de Justiça dos Estados e do Distrito Federal, aos Procuradores-Gerais dos Estados e do Distrito Federal, e aos membros do Ministério Público da União e dos Estados, da Advocacia-Geral da União, das Procuradorias dos Estados e do Distrito Federal, quando no exercício de função de chefia das unidades regionais ou locais das respectivas instituições." (AC)

"Art. 41-A. Respeitada a prerrogativa de foro que assiste às autoridades a que se referem o parágrafo único do art. 39-A e o inciso II do parágrafo único do art. 40-A, as ações penais contra elas ajuizadas pela prática dos crimes de responsabilidade previstos no art. 10 desta Lei serão processadas e julgadas de acordo com o rito instituído pela Lei no 8.038, de 28 de maio de 1990, permitido, a todo cidadão, o oferecimento da denúncia." $(\mathrm{AC})$

Art. 40 O art. 1o do Decreto-Lei no 201, de 27 de fevereiro de 1967, passa a vigorar com a seguinte redação:

"Art. 10

"XVI - deixar de ordenar a redução do montante da dívida consolidada, nos prazos estabelecidos em lei, quando o montante ultrapassar o valor resultante da aplicação do limite máximo fixado pelo Senado Federal;" (AC)

"XVII - ordenar ou autorizar a abertura de crédito em desacordo com os limites estabelecidos pelo Senado Federal, sem fundamento na lei orçamentária ou na de crédito adicional ou com inobservância de prescrição legal;" (AC)

"XVIII - deixar de promover ou de ordenar, na forma da lei, o cancelamento, a amortização ou a constituição de reserva para anular os efeitos de operação de crédito realizada com inobservância de limite, condição ou montante estabelecido em lei;" (AC)

"XIX - deixar de promover ou de ordenar a liquidação integral de operação de crédito por antecipação de receita orçamentária, inclusive os respectivos juros e demais encargos, até o encerramento do exercício financeiro;" (AC)

"XX - ordenar ou autorizar, em desacordo com a lei, a realização de operação de crédito com qualquer um dos demais entes da Federação, inclusive suas entidades da administração indireta, ainda que na forma de novação, refinanciamento ou postergação de dívida contraída anteriormente;" (AC)

"XXI - captar recursos a título de antecipação de receita de tributo ou contribuição cujo fato gerador ainda não tenha ocorrido;" (AC)

"XXII - ordenar ou autorizar a destinação de recursos provenientes da emissão de títulos para finalidade diversa da prevista na lei que a autorizou;" (AC) 
"XXIII - realizar ou receber transferência voluntária em desacordo com limite ou condição estabelecida em lei." (AC)

"

Art. 5o Constitui infração administrativa contra as leis de finanças públicas:

I - deixar de divulgar ou de enviar ao Poder Legislativo e ao Tribunal de Contas o relatório de gestão fiscal, nos prazos e condições estabelecidos em lei;

II - propor lei de diretrizes orçamentárias anual que não contenha as metas fiscais na forma da lei;

III - deixar de expedir ato determinando limitação de empenho e movimentação financeira, nos casos e condições estabelecidos em lei;

IV - deixar de ordenar ou de promover, na forma e nos prazos da lei, a execução de medida para a redução do montante da despesa total com pessoal que houver excedido a repartição por Poder do limite máximo.

§ 10 A infração prevista neste artigo é punida com multa de trinta por cento dos vencimentos anuais do agente que lhe der causa, sendo o pagamento da multa de sua responsabilidade pessoal.

§ 20 A infração a que se refere este artigo será processada e julgada pelo Tribunal de Contas a que competir a fiscalização contábil, financeira e orçamentária da pessoa jurídica de direito público envolvida.

Art. 6o Esta Lei entra em vigor na data de sua publicação.

Brasília, 19 de outubro de 2000; 179o da Independência e 112o da República.

FERNANDO HENRIQUE CARDOSO

José Gregori 


\section{Anexo 3}

Quadro 1:

Deputados e técnicos que tomaram a palavra em casa reunião da CESP (composição: 31 deputados e igual número de suplentes).

\begin{tabular}{|c|c|c|c|c|c|c|c|c|c|c|c|c|c|c|c|c|c|c|c|c|c|c|c|c|c|c|c|c|}
\hline \multirow[t]{2}{*}{ Deputados } & \multicolumn{28}{|c|}{ Reuniões } \\
\hline & 1 & 2 & 3 & 4 & 5 & 6 & 7 & 8 & 9 & 10 & 11 & 12 & 13 & 14 & 15 & 16 & 17 & 18 & 19 & 20 & 21 & 22 & 23 & 24 & 25 & 26 & 27 & Total \\
\hline $\begin{array}{l}\text { Adolfo Marinho } \\
\text { (PSDB-CE) }\end{array}$ & & & & & & & & & & & $\mathrm{X}$ & & & & & & & & & & & & & & & & & 1 \\
\hline $\begin{array}{l}\text { Aloizio Santos } \\
\text { (PSDB-ES) }\end{array}$ & $\mathrm{X}$ & & & & & & & & & $X$ & & & & & & & $X$ & & & & & & & & & & & 3 \\
\hline $\begin{array}{l}\text { Andre Benassi } \\
\text { (PSDB-SP) }\end{array}$ & & & & $X$ & & & & & & & & & & & & & & & & & & & $X$ & & $X$ & & & 3 \\
\hline $\begin{array}{l}\text { Antonio Cambraia } \\
\text { (PMDB-CE) }\end{array}$ & & & & $\mathrm{X}$ & & $\mathrm{X}$ & & & & & $\mathrm{X}$ & & & $\mathrm{X}$ & & & & & & & & & & $\mathrm{X}$ & $X$ & & & 6 \\
\hline $\begin{array}{l}\text { Armando Monteiro } \\
\text { (PMDB-PE) }\end{array}$ & $X$ & & & & & & & $X$ & & & & & & & & & & & & & & & & & & & & 2 \\
\hline $\begin{array}{l}\text { Carlito Merss } \\
\text { (PT-SC) }\end{array}$ & $X$ & $X$ & & $X$ & $X$ & & & & $X$ & & & $X$ & $X$ & $X$ & $X$ & $X$ & $X$ & & & & $X$ & $X$ & & & & $X$ & $X$ & 15 \\
\hline $\begin{array}{l}\text { Carlos Dunga } \\
\text { (PMDB-PB) }\end{array}$ & & & & & $X$ & & & & & & & & & & & & & & & & & & $X$ & & & & & 2 \\
\hline $\begin{array}{l}\text { Cezar Schirmer } \\
\text { (PMDB-RS) }\end{array}$ & & & $X$ & & $X$ & $X$ & & & & & & & $X$ & & & & & & & & & $X$ & & & & & & 5 \\
\hline $\begin{array}{l}\text { Custódio Mattos } \\
\text { (PSDB-MG) }\end{array}$ & $\mathrm{X}$ & $X$ & & $X$ & $X$ & & $X$ & & & & & & $X$ & & $X$ & & & & & & & & & $X$ & & & & 8 \\
\hline $\begin{array}{l}\text { Eduardo Paes } \\
\text { (PFL-RJ) }\end{array}$ & & & & & & & $X$ & & & & & & $X$ & & & & & & & & & & & & & & $X$ & 3 \\
\hline $\begin{array}{l}\text { Evandro Milhomen } \\
\text { (PSB-AP) }\end{array}$ & & & & & & & & & & & & & & & & $\mathrm{X}$ & & & & & & & & & & & & 1 \\
\hline $\begin{array}{l}\text { Félix Mendonça } \\
\text { (PTB-BA) }\end{array}$ & & & & & & & & & & & $X$ & & & & & & & & & & & & & & & & & 1 \\
\hline $\begin{array}{l}\text { Fernando Marroni } \\
\text { (PT-RS) }\end{array}$ & $\mathrm{X}$ & & & & & & & & & $X$ & & & & & & & & & & & & & & & & & & 2 \\
\hline $\begin{array}{l}\text { Gastão Vieira } \\
\text { (PMDB-MA) }\end{array}$ & & $X$ & & & $X$ & & $\mathrm{X}$ & & & $X$ & & & & $X$ & & & & & & & & $\mathrm{X}$ & $X$ & & & & & 7 \\
\hline $\begin{array}{l}\text { Geraldo Magela } \\
\text { (PT-DF) }\end{array}$ & & $\mathrm{X}$ & & & & & & & & & & & & & & & & & & & $\mathrm{X}$ & & & & & & & 2 \\
\hline
\end{tabular}




\begin{tabular}{|c|c|c|c|c|c|c|c|c|c|c|c|c|c|c|c|c|c|c|c|c|c|c|c|c|c|c|c|c|}
\hline $\begin{array}{l}\text { Helenildo Ribeiro } \\
\text { (PSDB-AL) }\end{array}$ & & & & & & & & & & & & & & $X$ & & & & & & & & & & & & & & 1 \\
\hline $\begin{array}{l}\text { lara Bernardi (PT- } \\
\text { SP) }\end{array}$ & & & & & & & & & & & & & & & & & & & & & & & $X$ & & & & & 1 \\
\hline $\begin{array}{l}\text { Iberê Ferreira } \\
\text { (PPB-RN) }\end{array}$ & $\mathrm{X}$ & $\mathrm{X}$ & & & & & & & & & & & & & & & & & & & & & & & & & & 2 \\
\hline $\begin{array}{l}\text { João Almeida } \\
\text { (PSDB-BA) }\end{array}$ & & & & & & & & & & & & & & & & & & & & & & & & & & & $\mathrm{X}$ & 1 \\
\hline $\begin{array}{l}\text { João Caldas (PL- } \\
\text { AL) }\end{array}$ & & & & & & & & & & & & & & $X$ & & & & & & & & & & & & & & 1 \\
\hline $\begin{array}{l}\text { João Coser (PT- } \\
\text { ES) }\end{array}$ & & $\mathrm{X}$ & & $X$ & & & & & & & & & & & & & & & & & & & & & & & & 2 \\
\hline $\begin{array}{l}\text { João Fassarella } \\
\text { (PT-MG) }\end{array}$ & $\mathbf{X}$ & & & & & $\mathbf{X}$ & $\mathbf{X}$ & & & $\mathbf{X}$ & $\mathbf{X}$ & $\mathbf{X}$ & & $\mathbf{X}$ & & & & $\mathbf{X}$ & & $\mathbf{X}$ & $\mathbf{X}$ & $\mathbf{X}$ & $\mathbf{X}$ & $\mathbf{X}$ & & $\mathbf{X}$ & $\mathbf{X}$ & 15 \\
\hline $\begin{array}{l}\text { Joaquim } \\
\text { Francisco } \\
\text { (pres.) (PFL-PE) }\end{array}$ & $\mathbf{X}$ & $\mathbf{X}$ & $\mathbf{X}$ & $\mathbf{X}$ & $\mathbf{X}$ & $\mathbf{X}$ & $\mathbf{X}$ & $\mathbf{X}$ & $\mathbf{X}$ & $\mathbf{X}$ & $\mathbf{X}$ & $\mathbf{X}$ & $\mathbf{X}$ & $\mathbf{X}$ & $\mathbf{X}$ & $\mathbf{X}$ & $\mathbf{X}$ & $\mathbf{X}$ & $\mathbf{X}$ & $\mathbf{X}$ & $\mathbf{X}$ & $\mathbf{X}$ & $\mathbf{X}$ & $\mathbf{X}$ & $\mathbf{X}$ & $\mathbf{X}$ & $\mathbf{X}$ & 27 \\
\hline $\begin{array}{l}\text { José Ronaldo } \\
\text { (PFL-BA) }\end{array}$ & & & & & & & & & & & & & & & & & $X$ & & & & & & & $X$ & & & & 2 \\
\hline Juquinha (PL-GO) & & & & & & & & & & $\mathrm{X}$ & & & & & & & & & & $\mathrm{X}$ & & & & & & & & 2 \\
\hline $\begin{array}{l}\text { Luiza Erundina } \\
\text { (PSB-SP) }\end{array}$ & & & & & & & & & & & & & & & & $\mathrm{X}$ & & & & & & & & & & & & 1 \\
\hline $\begin{array}{l}\text { Luiz Carlos Hauly } \\
\text { (PSDB-PR) }\end{array}$ & $\bar{X}$ & & & & $\mathbf{X}$ & & & & & $\bar{X}$ & $\mathbf{X}$ & & $\mathbf{X}$ & & $\mathbf{X}$ & & & & $\mathbf{X}$ & & & $\mathbf{X}$ & & $\mathbf{X}$ & $\mathbf{X}$ & $\mathbf{X}$ & $\mathbf{X}$ & 12 \\
\hline $\begin{array}{l}\text { Luiz Salomão } \\
\text { (PDT-RJ) }\end{array}$ & & $\mathbf{X}$ & $\mathbf{X}$ & $\mathbf{X}$ & $\mathbf{X}$ & $\mathbf{X}$ & & & $\mathbf{X}$ & & & & $\mathbf{X}$ & $\mathbf{X}$ & $\mathbf{X}$ & & $\mathbf{X}$ & & & & & $\mathbf{X}$ & $\mathbf{X}$ & & $\mathbf{X}$ & $\mathbf{X}$ & $\mathbf{X}$ & 15 \\
\hline $\begin{array}{l}\text { Márcio Matos } \\
\text { (PTB-PR) }\end{array}$ & & & & & & & & & & & & & & & & $\mathrm{X}$ & & & & & & & & & & & & 1 \\
\hline $\begin{array}{l}\text { Moreira Ferreira } \\
\text { (PFL-SP) }\end{array}$ & $X$ & & & & & & & & & $X$ & & & & & & & & & & & & & & & & & & 2 \\
\hline $\begin{array}{l}\text { Pedro Novais } \\
\text { (rel.) (PMDB-MA) }\end{array}$ & $X$ & $\mathbf{X}$ & $\mathbf{X}$ & $\mathbf{X}$ & $\mathbf{X}$ & $X$ & $X$ & $X$ & $\mathbf{X}$ & $X$ & $X$ & $X$ & $\mathbf{X}$ & $X$ & $X$ & $X$ & $X$ & $\mathbf{X}$ & $X$ & $X$ & $\mathbf{X}$ & $\mathbf{X}$ & $\mathbf{X}$ & $X$ & $\mathbf{X}$ & $\mathbf{X}$ & $X$ & 27 \\
\hline $\begin{array}{l}\text { Raimundo Gomes } \\
\text { de Matos (PSDB- } \\
\text { CE) }\end{array}$ & $X$ & & & & & & & & & & & & & & & & & & & & & & & & & & & 1 \\
\hline $\begin{array}{l}\text { Roberto Brant } \\
\text { (PFL-MG) }\end{array}$ & & & & & & & & & & & & & $X$ & & & & & & & & & & & $X$ & & & $X$ & 3 \\
\hline
\end{tabular}




\begin{tabular}{|c|c|c|c|c|c|c|c|c|c|c|c|c|c|c|c|c|c|c|c|c|c|c|}
\hline $\begin{array}{l}\text { Roberto Rocha } \\
\text { (PSDB-MA) }\end{array}$ & & & & & & & $X$ & & & & & & & & & & & & & & & 1 \\
\hline $\begin{array}{l}\text { Rodrigo Maia } \\
\text { (PFL-RJ) }\end{array}$ & & & & & & & & & & & & $X$ & & & & & $X$ & $X$ & & & $X$ & 4 \\
\hline $\begin{array}{l}\text { Rubem Medina } \\
\text { (PFL-RJ) }\end{array}$ & & & & & & & & & & & & & & & & & & & & & & 1 \\
\hline $\begin{array}{l}\text { Sérgio Miranda } \\
\text { (PCdoB-MG) }\end{array}$ & $X$ & $X$ & $\bar{X}$ & & & $X$ & & & $X$ & $X$ & $X$ & $X$ & $X$ & $X$ & $X$ & $X$ & $X$ & & $X$ & $\mathbf{X}$ & $X$ & 16 \\
\hline $\begin{array}{l}\text { Silas Brasileiro } \\
\text { (PMDB-MG) }\end{array}$ & & & & & & & & & & & & & & & & & $X$ & & & & & 1 \\
\hline $\begin{array}{l}\text { Yeda Crusius } \\
\text { (PSDB-RS) }\end{array}$ & & & & & & & & $X$ & & & $X$ & & & & & & & & & & & 2 \\
\hline $\begin{array}{l}\text { José Roberto } \\
\text { Afonso (Chefe } \\
\text { Sec. p/ Ass. } \\
\text { Fiscais BNDES) }\end{array}$ & & & & & & $X$ & & & & & & & & & & & & & & & & 1 \\
\hline $\begin{array}{l}\text { Martus Tavares } \\
\text { (Sec. Exec. do } \\
\text { Min. de Orçam. e } \\
\text { Gestão) }\end{array}$ & $X$ & $X$ & & $X$ & $X$ & & & & & & & & & & & & & & & & & 4 \\
\hline $\begin{array}{l}\text { Domingos Poubel } \\
\text { de Castro (Sec. } \\
\text { Federal de } \\
\text { Controle do MF) }\end{array}$ & & & & & & & $X$ & & & & & & & & & & & & & & & 1 \\
\hline $\begin{array}{l}\text { Prof. Adilson de } \\
\text { Abreu Dallari - } \\
\text { PUC/SP }\end{array}$ & & & & & & & & $X$ & & & & & & & & & & & & & & 1 \\
\hline $\begin{array}{l}\text { Claudia Costin } \\
\text { (Sec. de Estado } \\
\text { da Adm. e do } \\
\text { Patrimônio) } \\
\end{array}$ & & & & & & & & & $X$ & & & & & & & & & & & & & 1 \\
\hline $\begin{array}{l}\text { Sebastião Jorge } \\
\text { Jatobá Bezerra } \\
\text { dos Santos, } \\
\text { Albérico } \\
\text { Mascarenhas e } \\
\text { Ednilton Gomes }\end{array}$ & & & & & & & & & & $X$ & & & & & & & & & & & & 1 \\
\hline
\end{tabular}




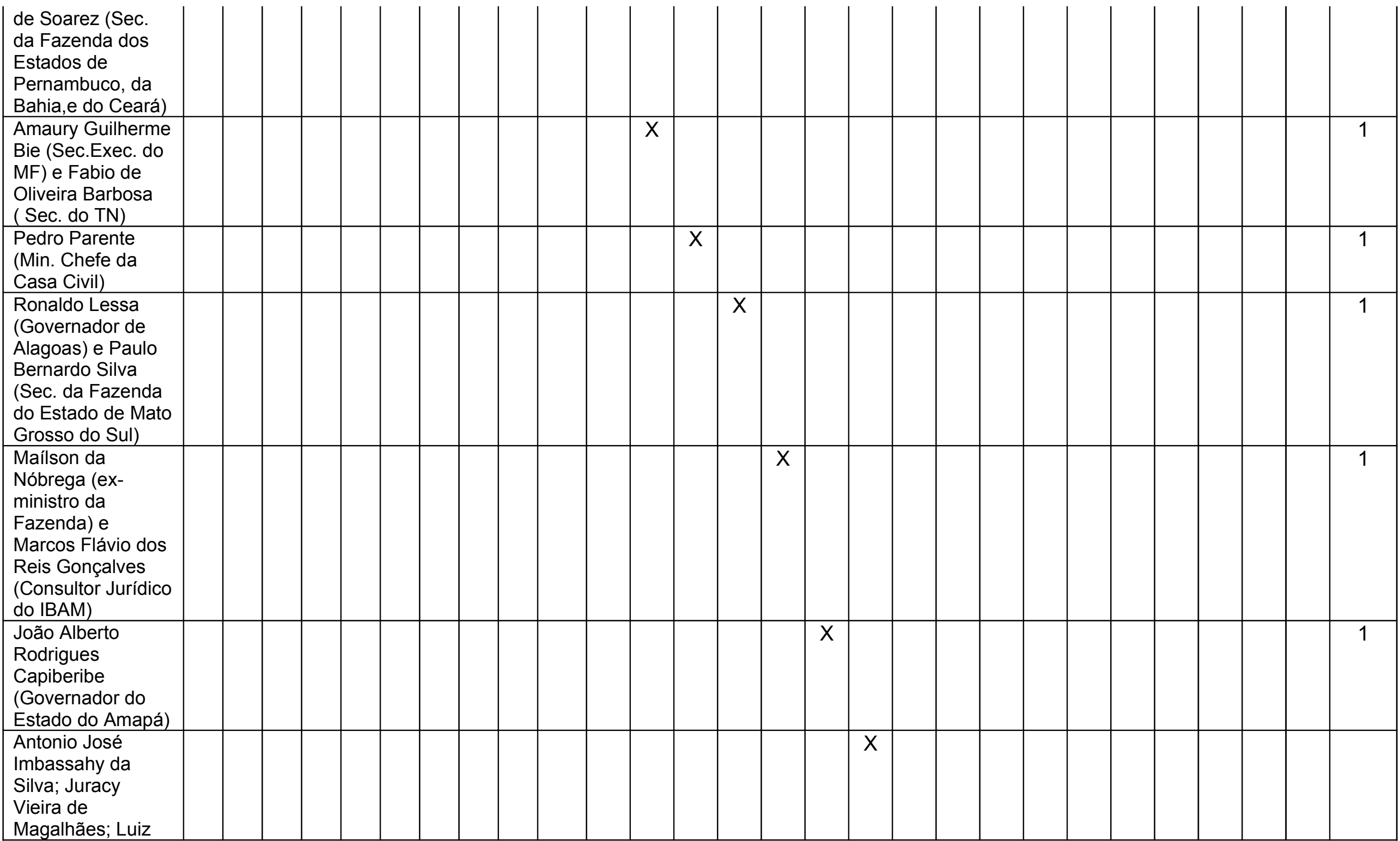




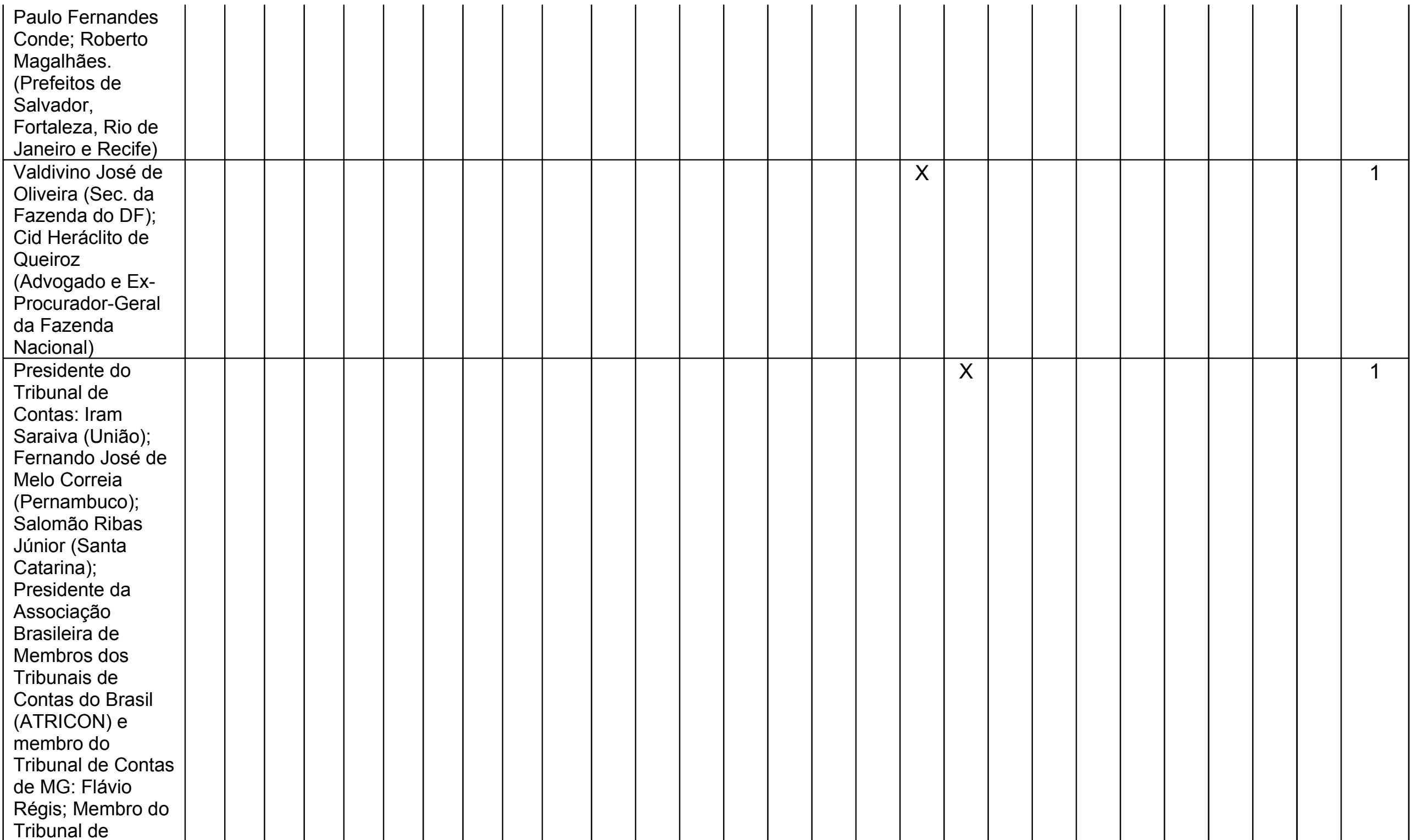




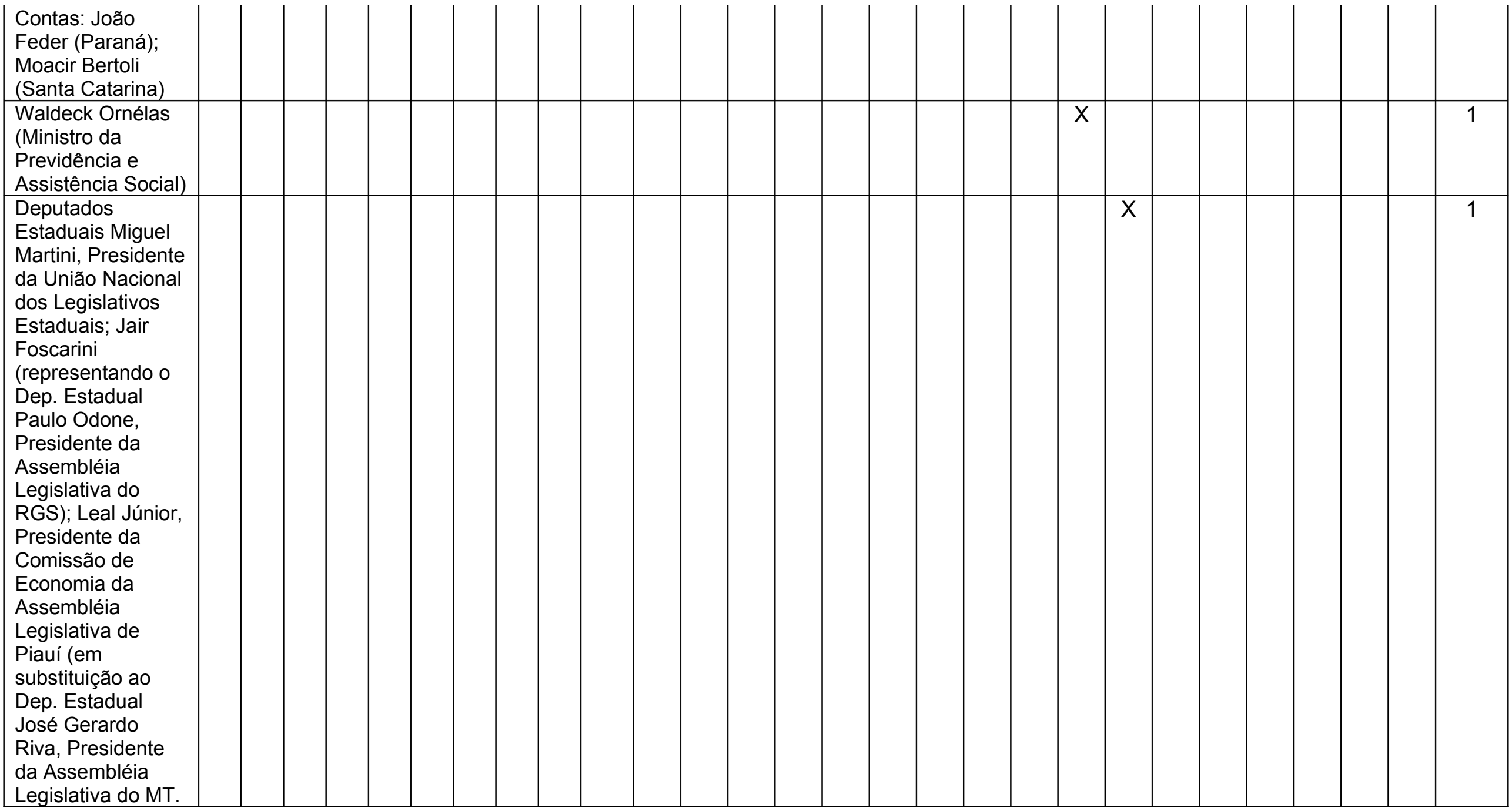


Quadro 2:

Destaques Simples votados na Câmara

\begin{tabular}{|c|c|}
\hline $\begin{array}{l}\text { Destaques } \\
\text { Simples }\end{array}$ & Autoria e objeto \\
\hline$n^{0} 1$ & $\begin{array}{l}\text { Bancada do Dep. Dr. Hélio, Vice-Líder do PDT; destaque para votação em separado } \\
\text { da Emenda de Plenário } n^{\circ} 30 \text {, de autoria do Deputado Miro Teixeira (PDT-RJ). }\end{array}$ \\
\hline $\mathrm{n}^{\circ} 2$ & $\begin{array}{l}\text { Bancada do Dep. Dr. Hélio, Vice-Líder do PDT; destaque para votação em separado } \\
\text { da Emenda de Plenário } n^{\circ} 31 \text {, de autoria do Deputado Luiz Alfredo Salomão (PT-RJ). }\end{array}$ \\
\hline$n^{\circ} 3$ & $\begin{array}{l}\text { Bancada do Dep. Dr. Hélio, Vice-Líder do PDT; destaque para votação em separado } \\
\text { da Emenda de Plenário } n^{\circ} 32 \text {, de autoria do Deputado Luiz Alfredo Salomão (PT-RJ). }\end{array}$ \\
\hline$n^{\circ} 4$ & $\begin{array}{l}\text { Bancada do Dep. Dr. Hélio, Vice-Líder do PDT; destaque para votação em separado } \\
\text { da Emenda de Plenário n } 33 \text {, de autoria do Deputado Luiz Alfredo Salomão (PT-RJ). }\end{array}$ \\
\hline$n^{\circ} 5$ & $\begin{array}{l}\text { Bancada do Dep. Dr. Hélio, Vice-Líder do PDT; destaque para votação em separado } \\
\text { da Emenda de Plenário }{ }^{\circ} 34 \text {, de autoria do Deputado Luiz Alfredo Salomão (PT-RJ). }\end{array}$ \\
\hline$n^{\circ} 6$ & $\begin{array}{l}\text { Bancada do Dep. Dr. Hélio, Vice-Líder do PDT; destaque para votação em separado } \\
\text { da Emenda de Plenário n } 35 \text {, de autoria do Deputado Luiz Alfredo Salomão (PT-RJ). }\end{array}$ \\
\hline $\mathrm{n}^{0} 7$ & $\begin{array}{l}\text { Bancada do Dep. Dr. Hélio, Vice-Líder do PDT; destaque para votação em separado } \\
\text { da Emenda de Plenário } n^{\circ} 36 \text {, de autoria do Deputado Luiz Alfredo Salomão (PT-RJ). }\end{array}$ \\
\hline$n^{0} 8$ & $\begin{array}{l}\text { Bancada do Dep. Dr. Hélio, Vice-Líder do PDT; destaque para votação em separado } \\
\text { da Emenda de Plenário }{ }^{\circ} 37 \text {, de autoria do Deputado Luiz Alfredo Salomão (PT-RJ). }\end{array}$ \\
\hline$n^{\circ} 9$ & $\begin{array}{l}\text { Bancada do Dep. Dr. Hélio, Vice-Líder do PDT; destaque para votação em separado } \\
\text { da Emenda de Plenário n }{ }^{\circ} 38 \text {, de autoria do Deputado Luiz Alfredo Salomão (PT-RJ). }\end{array}$ \\
\hline$n^{0} 10$ & $\begin{array}{l}\text { Bancada do Dep. Dr. Hélio, Vice-Líder do PDT; destaque para votação em separado } \\
\text { da Emenda de Plenário n }{ }^{\circ} 39 \text {, de autoria do Deputado Luiz Alfredo Salomão (PT-RJ). }\end{array}$ \\
\hline$n^{0} 11$ & $\begin{array}{l}\text { Bancada do Dep. Dr. Hélio, Vice-Líder do PDT; destaque para votação em separado } \\
\text { da Emenda de Plenário } n^{\circ} 40 \text {, de autoria do Deputado Luiz Alfredo Salomão (PT-RJ). }\end{array}$ \\
\hline$n^{0} 12$ & $\begin{array}{l}\text { Bancada do Dep. Dr. Hélio, Vice-Líder do PDT; destaque para votação em separado } \\
\text { da Emenda de Plenário }{ }^{\circ} 41 \text {, de autoria do Deputado Luiz Alfredo Salomão (PT-RJ). }\end{array}$ \\
\hline$n^{0} 13$ & $\begin{array}{l}\text { Bancada do Dep. Dr. Hélio, Vice-Líder do PDT; destaque para votação em separado } \\
\text { da Emenda de Plenário n }{ }^{\circ} 42 \text {, de autoria do Deputado Luiz Alfredo Salomão (PT-RJ). }\end{array}$ \\
\hline $\mathrm{n}^{0} 14$ & $\begin{array}{l}\text { Bancada do Dep. Dr. Hélio, Vice-Líder do PDT; destaque para votação em separado } \\
\text { da Emenda de Plenário } n^{\circ} 43 \text {, de autoria do Deputado Luiz Alfredo Salomão (PT-RJ). }\end{array}$ \\
\hline$n^{0} 15$ & $\begin{array}{l}\text { Bancada do Dep. Dr. Hélio, Vice-Líder do PDT; destaque para votação em separado } \\
\text { da Emenda de Plenário } n^{\circ} 44 \text {, de autoria do Deputado Luiz Alfredo Salomão (PT-RJ). }\end{array}$ \\
\hline$n^{0} 16$ & $\begin{array}{l}\text { Bancada do Dep. Dr. Hélio, Vice-Líder do PDT; destaque para votação em separado } \\
\text { da Emenda de Plenário }{ }^{\circ} 45 \text {, de autoria do Deputado Luiz Alfredo Salomão (PT-RJ). }\end{array}$ \\
\hline $\mathrm{n}^{\circ} 17$ & $\begin{array}{l}\text { Bancada do Dep. Dr. Hélio, Vice-Líder do PDT; destaque para votação em separado } \\
\text { da Emenda de Plenário n }{ }^{\circ} 46 \text {, de autoria do Deputado Luiz Alfredo Salomão (PT-RJ). }\end{array}$ \\
\hline$n^{0} 18$ & $\begin{array}{l}\text { Bancada do Dep. Dr. Hélio, Vice-Líder do PDT; destaque para votação em separado } \\
\text { da Emenda de Plenário } n^{\circ} 47 \text {, de autoria do Deputado Luiz Alfredo Salomão (PT-RJ). }\end{array}$ \\
\hline $\mathrm{n}^{0} 19$ & $\begin{array}{l}\text { Bancada do Dep. Dr. Hélio, Vice-Líder do PDT; destaque para votação em separado } \\
\text { da Emenda de Plenário } n^{\circ} 48 \text {, de autoria do Deputado Luiz Alfredo Salomão (PT-RJ). }\end{array}$ \\
\hline $\mathrm{n}^{\circ} 20$ & $\begin{array}{l}\text { Bancada do Dep. Dr. Hélio, Vice-Líder do PDT; destaque para votação em separado } \\
\text { da Emenda de Plenário }{ }^{\circ} 49 \text {, de autoria do Deputado Luiz Alfredo Salomão (PT-RJ). }\end{array}$ \\
\hline $\mathrm{n}^{\circ} 21$ & $\begin{array}{l}\text { Bancada do Dep. Dr. Hélio, Vice-Líder do PDT; destaque para votação em separado } \\
\text { da Emenda de Plenário } n^{\circ} 50 \text {, de autoria do Deputado Luiz Alfredo Salomão (PT-RJ). }\end{array}$ \\
\hline $\mathrm{n}^{\circ} 22$ & $\begin{array}{l}\text { Bancada do Dep. Dr. Hélio, Vice-Líder do PDT; destaque para votação em separado } \\
\text { da Emenda de Plenário } n^{\circ} 51 \text {, de autoria do Deputado Luiz Alfredo Salomão (PT-RJ). }\end{array}$ \\
\hline$n^{\circ} 23$ & $\begin{array}{l}\text { Bancada do Dep. Dr. Hélio, Vice-Líder do PDT; destaque para votação em separado } \\
\text { da Emenda de Plenário } n^{\circ} 70 \text {, de autoria do Deputado Dr. Hélio, Vice-Líder do PDT. }\end{array}$ \\
\hline $\mathrm{n}^{0} 24$ & $\begin{array}{l}\text { Bancada do Dep. Dr. Hélio, Vice-Líder do PDT; destaque para votação em separado } \\
\text { da Emenda de Plenário } n^{\circ} 71 \text {, de autoria do Deputado Luiz Alfredo Salomão (PT-RJ). }\end{array}$ \\
\hline $\mathrm{n}^{\circ} 25$ & $\begin{array}{l}\text { Bancada do Dep. Dr. Hélio, Vice-Líder do PDT; destaque para votação em separado } \\
\text { da Emenda de Plenário } n^{\circ} 72 \text {, de autoria do Deputado Luiz Alfredo Salomão (PT-RJ). }\end{array}$ \\
\hline
\end{tabular}




\section{Quadro 3:}

Destaques para Votação em Separado (DVS) votados nominalmente na Câmara

\begin{tabular}{|c|c|}
\hline DVS & Autoria, objeto e destino \\
\hline$n^{0} 1$ & $\begin{array}{l}\text { Bancada do PDT; destaque para votação em separado das expressões "as realizadas com } \\
\text { a finalidade de pagamento de juros" e "as relativas ao refinanciamento da dívida", } \\
\text { constante da alínea a do inciso II do art. } 4^{\circ} \text { do presente substitutivo; foram mantidas as } \\
\text { expressões destacadas. }\end{array}$ \\
\hline $\mathrm{n}^{\circ} 2$ & $\begin{array}{l}\text { Bancada do PT; destaque para votação em separado da expressão "inclusive aquelas } \\
\text { destinadas ao pagamento do serviço da dívida" constante do } \S 2^{\circ} \text { do artigo } 9^{\circ} \text { do } \\
\text { substitutivo; foi mantida a expressão destacada. }\end{array}$ \\
\hline$n^{\circ} 4$ & $\begin{array}{l}\text { Bancada do Bloco Parlamentar PSB/PCdoB; destaque para votação em separado do } \S 3^{\circ} \\
\text { do artigo } 17^{\circ} \text {, constante no Substitutivo; é mantido o dispositivo destacado. }\end{array}$ \\
\hline $\mathrm{n}^{\circ} 5$ & $\begin{array}{l}\text { Bancada do PPS; destaque para votação em separado da Emenda de Plenário } n^{\circ} 75 \\
\text { oferecida pelo PPS ao PLC no } 18-A \text { de 1999; foi rejeitada a emenda de plenário destacada. }\end{array}$ \\
\hline$n^{\circ} 6$ & $\begin{array}{l}\text { Bancada do PT; destaque para votação em separado da expressão "ao serviço da dívida } \\
\text { nem" constante do } \S 6^{\circ} \text { do artigo } 17 \text { do substitutivo; foi mantida a expressão destacada. }\end{array}$ \\
\hline $\mathrm{n}^{\circ} 8$ & $\begin{array}{l}\text { Bancada do PTB; destaque para a emenda de plenário de autoria do Dep. Rodrigo Maia } \\
\text { sobre contabiliza terceirizações como outras despesas com pessoal; foi aprovada a } \\
\text { emenda de plenário } \mathrm{n}^{\circ} 56 \text {, destacada. }\end{array}$ \\
\hline$n^{\circ} 9$ & $\begin{array}{l}\text { Bancada do PT; destaque para a votação para a expressão "novação, refinanciamento ou" } \\
\text { constante do caput do art. } 35 \text { do substitutivo; foi mantida a expressão destacada. }\end{array}$ \\
\hline $\mathrm{n}^{\circ} 10$ & Bancada do PSDB; destaque para votação em separado do art. 58 do substitutivo; foi \\
\hline
\end{tabular}


Quadro 4:

Emendas de Plenário (Câmara)

\begin{tabular}{|c|c|c|c|}
\hline $\mathrm{n}^{0}$ & assunto & autoria & destino \\
\hline $\mathrm{n}^{0} 1$ & Emenda de Redação & $\begin{array}{l}\text { Dep. Inocêncio Oliveira } \\
\text { (PFL-PE) }\end{array}$ & $\begin{array}{l}\text { Aprovada } \\
\text { integralmente }\end{array}$ \\
\hline$n^{\circ} 2$ & $\begin{array}{l}\text { Suprime alínea c, inciso I, art. 20, } \\
\text { expressão que exclui o Ministério Público } \\
\text { do DF do limite aplicado neste caso. }\end{array}$ & $\begin{array}{l}\text { Dep. Inocêncio Oliveira } \\
\text { (PFL-PE) }\end{array}$ & $\begin{array}{l}\text { Aprovada } \\
\text { integralmente }\end{array}$ \\
\hline$n^{\circ} 3$ & Emenda de Redação & $\begin{array}{l}\text { Dep. Antonio Carlos } \\
\text { Konder Reis (PFL-SC) }\end{array}$ & Rejeitada \\
\hline$n^{\circ} 4$ & $\begin{array}{l}\text { Suprime inciso III do } \S 1^{\circ} \text { do art. } 19 \text {, que } \\
\text { exclui do limite de despesa com pessoal } \\
\text { gastos com convocação extraordinária do } \\
\text { Congresso Nacional. }\end{array}$ & $\begin{array}{l}\text { Dep. João Fassarella } \\
\text { (PT-MG) }\end{array}$ & Rejeitada \\
\hline$n^{0} 5$ & $\begin{array}{l}\text { Muda redação do inciso I do art. 19: pela } \\
\text { volta dos } 60 \% \text { de receita corrente líquida } \\
\text { como limite para a despesa com pessoal, } \\
\text { como na Lei Camata. }\end{array}$ & $\begin{array}{l}\text { Dep. João Fassarella } \\
\text { (PT-MG) }\end{array}$ & Rejeitada \\
\hline$n^{\circ} 6$ & $\begin{array}{l}\text { Suprime o } § 2^{\circ} \text { do art. } 3^{\circ} \text {, sobre o } \\
\text { tratamento do PPA que é ato interna } \\
\text { corporis do Poder Legislativo. }\end{array}$ & $\begin{array}{l}\text { Dep. João Fassarella } \\
\text { (PT-MG) }\end{array}$ & $\begin{array}{l}\text { Aprovada } \\
\text { integralmente }\end{array}$ \\
\hline$n^{0} 7$ & $\begin{array}{l}\text { Suprime } 0 \S 6^{\circ} \text { do art. 17: supressão de } \\
\text { parágrafo de artigo que não aplica limite às } \\
\text { despesas destinadas ao serviço da dívida. }\end{array}$ & $\begin{array}{l}\text { Dep. João Fassarella } \\
\text { (PT-MG) }\end{array}$ & Rejeitada \\
\hline$n^{0} 8$ & $\begin{array}{l}\text { Suprime o inciso II do art. 21, sobre a pena } \\
\text { de nulidade aos atos que provoquem } \\
\text { aumento de despesa com pessoal e não } \\
\text { atendam ao limite aplicado à despesa com } \\
\text { pessoal inativo. }\end{array}$ & $\begin{array}{l}\text { Dep. João Fassarella } \\
\text { (PT-MG) }\end{array}$ & Rejeitada \\
\hline$n^{0} 9$ & $\begin{array}{l}\text { Propõe a supressão da expressão } \\
\text { refinanciamento do caput do art. 35, pois, } \\
\text { do ponto de vista dos deputados, não é } \\
\text { aceitável que a União não possa refinanciar } \\
\text { dívida de outros entes, extinguindo a } \\
\text { solidariedade entre eles. }\end{array}$ & $\begin{array}{l}\text { Dep. João Fassarella } \\
\text { (PT-MG) }\end{array}$ & Rejeitada \\
\hline$n^{\circ} 10$ & Emenda de Redação & $\begin{array}{l}\text { Dep. João Fassarella } \\
\text { (PT-MG) }\end{array}$ & Rejeitada \\
\hline$n^{0} 11$ & $\begin{array}{l}\text { Acrescenta alínea ao inciso I do art. 55, } \\
\text { incluindo no Relatório de Gestão Fiscal a } \\
\text { mesma condição pedida no Relatório } \\
\text { Resumido que trata o art. } 53 \text {. }\end{array}$ & $\begin{array}{l}\text { Dep. João Fassarella } \\
\text { (PT-MG) }\end{array}$ & $\begin{array}{l}\text { Aprovada } \\
\text { integralmente }\end{array}$ \\
\hline$n^{\circ} 12$ & $\begin{array}{l}\text { Muda redação do art. 31, para que haja } \\
\text { punição para descumprimento da lei, } \\
\text { excetuando o cumprimento de despesas } \\
\text { programadas na área social. }\end{array}$ & $\begin{array}{l}\text { Dep. João Fassarella } \\
\text { (PT-MG) }\end{array}$ & Rejeitada \\
\hline$n^{0} 13$ & $\begin{array}{l}\text { Muda redação do } \S 2^{\circ} \text { do Art. } 28 \text {, limitando } \\
\text { prazo para assistência de liquidez do Banco } \\
\text { Central às instituições financeiras. }\end{array}$ & $\begin{array}{l}\text { Dep. João Fassarella } \\
\text { (PT-MG) }\end{array}$ & Rejeitada \\
\hline$n^{\circ} 14$ & $\begin{array}{l}\text { Acrescenta ao art. } 16 \circ \S 5^{\circ} \text {, para evitar } \\
\text { burlas às normas orçamentárias. }\end{array}$ & $\begin{array}{l}\text { Dep. João Fassarella } \\
\text { (PT-MG) }\end{array}$ & Rejeitada \\
\hline$n^{0} 15$ & semelhante a emenda 12 & $\begin{array}{l}\text { Dep. João Fassarella } \\
\text { (PT-MG) }\end{array}$ & Rejeitada \\
\hline$n^{0} 16$ & $\begin{array}{l}\text { Acrescenta ao art. } 14 \text { o } \S 4^{\circ} \text {, que veda a } \\
\text { captação de recursos a título de } \\
\text { antecipação ou pagamento de tributo cujo } \\
\text { fato gerador não tenha ocorrido. }\end{array}$ & $\begin{array}{l}\text { Dep. João Fassarella } \\
\text { (PT-MG) }\end{array}$ & $\begin{array}{l}\text { Aprovada } \\
\text { integralmente }\end{array}$ \\
\hline $\mathrm{n}^{0} 17$ & $\begin{array}{l}\text { Muda redação da alínea e, inciso I do art. } 4^{\circ} \\
\text { (sobre LDO). }\end{array}$ & $\begin{array}{l}\text { Dep. João Fassarella } \\
\text { (PT-MG) }\end{array}$ & Rejeitada \\
\hline $\mathrm{n}^{0} 18$ & Acrescenta $\S 3^{\circ}$ ao art. $3^{\circ}$ (sobre PPA). & Dep. João Fassarella & Rejeitada \\
\hline
\end{tabular}




\begin{tabular}{|c|c|c|c|}
\hline & & (PT-MG) & \\
\hline$n^{\circ} 19$ & $\begin{array}{l}\text { Muda redação do } \S 1^{\circ} \text { ao art. } 3^{\circ} \text { (sobre } \\
\text { PPA) }\end{array}$ & $\begin{array}{l}\text { Dep. João Fassarella } \\
\text { (PT-MG) }\end{array}$ & Rejeitada \\
\hline $\mathrm{n}^{\circ} 20$ & $\begin{array}{l}\text { Acrescenta ao art. } 4^{\circ} \circ \S 1^{\circ} \text {, sobre limite de } \\
\text { despesa com juros dos entes federativos. }\end{array}$ & $\begin{array}{l}\text { Dep. João Fassarella } \\
\text { (PT-MG) }\end{array}$ & Rejeitada \\
\hline $\mathrm{n}^{\circ} 21$ & $\begin{array}{l}\text { Muda redação do inciso II do art } 4^{\circ} \text {, sobre } \\
\text { controle de despesa com juros. }\end{array}$ & $\begin{array}{l}\text { Dep. João Fassarella } \\
\text { (PT-MG) }\end{array}$ & Rejeitada \\
\hline $\mathrm{n}^{\circ} 22$ & $\begin{array}{l}\text { Acrescenta ao art. } 4^{\circ} \circ \S 5^{\circ} \text {, sobre LDO e } \\
\text { PPA. }\end{array}$ & $\begin{array}{l}\text { Dep. João } \\
\text { (PT-MG) }\end{array}$ & Rejeitada \\
\hline$n^{\circ} 23$ & Emenda de Redação & $\begin{array}{l}\text { Dep. João Fassarella } \\
\text { (PT-MG) }\end{array}$ & Rejeitada \\
\hline $\mathrm{n}^{\circ} 24$ & $\begin{array}{l}\text { Acrescenta-se ao art. } 55 \text { o inciso IV, sobre } \\
\text { inclusão de avaliação qualitativa no } \\
\text { Relatório de Gestão Fiscal. }\end{array}$ & $\begin{array}{l}\text { Dep. João Fassarella } \\
\text { (PT-MG) }\end{array}$ & Rejeitada \\
\hline $\mathrm{n}^{\circ} 25$ & Emenda de Redação & $\begin{array}{l}\text { Dep. João Fassarella } \\
\text { (PT-MG) }\end{array}$ & Rejeitada \\
\hline $\mathrm{n}^{\circ} 26$ & $\begin{array}{l}\text { Muda redação do art. } 17, \S 2^{\circ} \text {, que prevê } \\
\text { que mesmo se houver aumento da } \\
\text { arrecadação por efeito de crescimento } \\
\text { econômico, não poderá haver aumento de } \\
\text { salários de servidores ou de gastos com } \\
\text { previdência. }\end{array}$ & $\begin{array}{l}\text { Dep. João Fassarella } \\
\text { (PT-MG) }\end{array}$ & Rejeitada \\
\hline $\mathrm{n}^{\circ} 27$ & $\begin{array}{l}\text { Propõe supressão do art. } 20, \text { que } \\
\text { estabelece a fixação de limites de gasto por } \\
\text { poder. }\end{array}$ & $\begin{array}{l}\text { Dep. João Fassarella } \\
\text { (PT-MG) }\end{array}$ & Rejeitada \\
\hline $\mathrm{n}^{0} 28$ & $\begin{array}{l}\text { Suprime a expressão "as exigências dos } \\
\text { arts. } 16 \text { e } 17 \text { " do inciso I do art. } 21 \text {. }\end{array}$ & $\begin{array}{l}\text { Dep. João Fassarella } \\
\text { (PT-MG) }\end{array}$ & Rejeitada \\
\hline$n^{0} 29$ & $\begin{array}{l}\text { Muda redação do inciso VIII do } \S 1^{\circ} \text { do art. } \\
19 .\end{array}$ & $\begin{array}{l}\text { Dep. João Fassarella } \\
\text { (PT-MG) }\end{array}$ & Rejeitada \\
\hline $\mathrm{n}^{\circ} 30$ & $\begin{array}{l}\text { Muda redação da alínea a, inciso II, do art. } \\
20 \text {, que junta os limites de gasto com } \\
\text { pessoal do Legislativo e do Tribunal de } \\
\text { Contas num único orçamento. }\end{array}$ & $\begin{array}{l}\text { Dep. Miro Teixeira (PDT- } \\
\text { RJ) }\end{array}$ & Rejeitada \\
\hline$n^{0} 31$ & $\begin{array}{l}\text { Veda a adoção de taxa de juros flutuantes } \\
\text { em operações de crédito pelos entes da } \\
\text { federação. }\end{array}$ & $\begin{array}{l}\text { Dep. Luiz Salomão (PT- } \\
\text { RJ) e outros. }\end{array}$ & Rejeitada \\
\hline$n^{0} 32$ & Emenda de Redação & $\begin{array}{l}\text { Dep. Luiz Salomão (PT- } \\
\text { RJ) e outros. }\end{array}$ & Rejeitada \\
\hline $\mathrm{n}^{0} 33$ & $\begin{array}{l}\text { Emenda de Redação (substitui a expressão } \\
\text { "sessenta" contida no } \S 5^{\circ} \text { do art. } 9^{\circ} \text { por } \\
\text { "noventa"). }\end{array}$ & $\begin{array}{l}\text { Dep. Luiz Salomão (PT- } \\
\text { RJ) e outros. }\end{array}$ & $\begin{array}{l}\text { Aprovada } \\
\text { integralmente }\end{array}$ \\
\hline$n^{0} 34$ & $\begin{array}{l}\text { Emenda de Redação (muda redação } \S 2^{\circ} \\
\text { do art. 14). }\end{array}$ & $\begin{array}{l}\text { Dep. Luiz Salomão (PT- } \\
\text { RJ) e outros. }\end{array}$ & $\begin{array}{l}\text { Aprovada } \\
\text { integralmente }\end{array}$ \\
\hline $\mathrm{n}^{0} 35$ & Emenda de Redação & $\begin{array}{l}\text { Dep. Luiz Salomão (PT- } \\
\text { RJ) e outros. }\end{array}$ & Rejeitada \\
\hline$n^{0} 36$ & Emenda de Redação & $\begin{array}{l}\text { Dep. Luiz Salomão (PT- } \\
\text { RJ) e outros. }\end{array}$ & Rejeitada \\
\hline$n^{\circ} 37$ & Emenda de Redação & $\begin{array}{l}\text { Dep. Luiz Salomão (PT- } \\
\text { RJ) e outros. }\end{array}$ & Rejeitada \\
\hline $\mathrm{n}^{0} 38$ & $\begin{array}{l}\text { Estende a transparência à prestação de } \\
\text { contas. }\end{array}$ & $\begin{array}{l}\text { Dep. Luiz Salomão (PT- } \\
\text { RJ) e outros. }\end{array}$ & Rejeitada \\
\hline $\mathrm{n}^{\circ} 39$ & Sobre transparência das contas públicas. & $\begin{array}{l}\text { Dep. Luiz Salomão (PT- } \\
\text { RJ) e outros. }\end{array}$ & Rejeitada \\
\hline$n^{\circ} 40$ & Sobre transparência das contas públicas. & $\begin{array}{l}\text { Dep. Luiz Salomão (PT- } \\
\text { RJ) e outros. }\end{array}$ & Rejeitada \\
\hline$n^{\circ} 41$ & Emenda de Redação & $\begin{array}{l}\text { Dep. Luiz Salomão (PT- } \\
\text { RJ) e outros. }\end{array}$ & Rejeitada \\
\hline$n^{\circ} 42$ & Emenda de Redação & $\begin{array}{l}\text { Dep. Luiz Salomão (PT- } \\
\text { RJ) e outros. }\end{array}$ & Rejeitada \\
\hline
\end{tabular}




\begin{tabular}{|c|c|c|c|}
\hline$n^{\circ} 43$ & Emenda de Redação & $\begin{array}{l}\text { Dep. Luiz Salomão (PT- } \\
\text { RJ) e outros. }\end{array}$ & Rejeitada \\
\hline$n^{\circ} 44$ & Emenda de Redação & $\begin{array}{l}\text { Dep. Luiz Salomão (PT- } \\
\text { RJ) e outros. }\end{array}$ & Rejeitada \\
\hline$n^{\circ} 45$ & $\begin{array}{l}\text { Prevê sanção ao Chefe do Executivo que } \\
\text { atrasar o encaminhamento da prestação de } \\
\text { contas ao Legislativo ( }\left(3^{\circ} \text { do art. } 58\right) \text {. }\end{array}$ & $\begin{array}{l}\text { Dep. Luiz Salomão (PT- } \\
\text { RJ) e outros. }\end{array}$ & Rejeitada \\
\hline$n^{\circ} 46$ & Amplia abrangência à prestação de contas. & $\begin{array}{l}\text { Dep. Luiz Salomão (PT- } \\
\text { RJ) e outros. }\end{array}$ & Rejeitada \\
\hline$n^{\circ} 47$ & Emenda de Redação & $\begin{array}{l}\text { Dep. Luiz Salomão (PT- } \\
\text { RJ) e outros. }\end{array}$ & Rejeitada \\
\hline$n^{\circ} 48$ & $\begin{array}{l}\text { Dá tratamento diferenciado aos pequenos } \\
\text { municípios. }\end{array}$ & $\begin{array}{l}\text { Dep. Luiz Salomão (PT- } \\
\text { RJ) e outros. }\end{array}$ & $\begin{array}{l}\text { Aprovada } \\
\text { Parcialmente }\end{array}$ \\
\hline$n^{\circ} 49$ & (Art. $4^{\circ}$ ) Dá limite para pagamento de juros. & $\begin{array}{l}\text { Dep. Luiz Salomão (PT- } \\
\text { RJ) e outros. }\end{array}$ & Rejeitada \\
\hline$n^{0} 50$ & $\begin{array}{l}\text { Retira a exceção do pagamento do serviço } \\
\text { da dívida das limitações de despesa. }\end{array}$ & $\begin{array}{l}\text { Dep. Luiz Salomão (PT- } \\
\text { RJ) e outros. }\end{array}$ & Rejeitada \\
\hline$n^{0} 51$ & $\begin{array}{l}\text { Suprime o parágrafo do art. } 9 \text { que prevê } \\
\text { que o Executivo enquadre o Legislativo e o } \\
\text { Judiciário nos limites de despesa, o que é } \\
\text { inconstitucional. }\end{array}$ & $\begin{array}{l}\text { Dep. Luiz Salomão (PT- } \\
\text { RJ) e outros. }\end{array}$ & Rejeitada \\
\hline $\mathrm{n}^{0} 52$ & Emenda modificativa (de Redação) & $\begin{array}{l}\text { Dep. José Genoino (PT- } \\
\text { SP) }\end{array}$ & Rejeitada \\
\hline$n^{0} 53$ & Emenda modificativa (de Redação) & $\begin{array}{l}\text { Dep. José Genoino (PT- } \\
\text { SP) }\end{array}$ & $\begin{array}{l}\text { Aprovada } \\
\text { Parcialmente }\end{array}$ \\
\hline $\mathrm{n}^{0} 54$ & Emenda modificativa (de Redação) & $\begin{array}{l}\text { Dep. José Genoino (PT- } \\
\text { SP) }\end{array}$ & $\begin{array}{l}\text { Aprovada } \\
\text { Parcialmente }\end{array}$ \\
\hline $\mathrm{n}^{\circ} 55$ & Emenda modificativa (de Redação) & $\begin{array}{l}\text { Dep. José Genoino (PT- } \\
\text { SP) }\end{array}$ & $\begin{array}{l}\text { Aprovada } \\
\text { Parcialmente }\end{array}$ \\
\hline$n^{0} 56$ & $\begin{array}{l}\text { Inclui a terceirização no controle de } \\
\text { despesa com pessoal, aspecto que faltava } \\
\text { a Lei Camata. }\end{array}$ & $\begin{array}{l}\text { Dep. Rodrigo Maia } \\
\text { (PFL/RJ) e Inocência } \\
\text { Oliveira (PFL-PE) }\end{array}$ & Rejeitada \\
\hline $\mathrm{n}^{0} 57$ & $\begin{array}{l}\text { Regula o uso de dinheiro público para } \\
\text { publicidade governamental }\end{array}$ & $\begin{array}{l}\text { Dep. Rodrigo Maia } \\
\text { (PFL/RJ) e Inocência } \\
\text { Oliveira (PFL-PE) }\end{array}$ & Rejeitada \\
\hline $\mathrm{n}^{0} 58$ & $\begin{array}{l}\text { Muda a redação da alínea c, inciso IV, dort. } \\
2^{\circ} \text {, sobre contribuição previdenciária e } \\
\text { cálculo da receita corrente líquida. }\end{array}$ & $\begin{array}{l}\text { Dep. Yeda Crusius } \\
\text { (PSDB-RS) e outros. }\end{array}$ & $\begin{array}{l}\text { Aprovada } \\
\text { integralmente }\end{array}$ \\
\hline $\mathrm{n}^{\circ} 59$ & $\begin{array}{l}\text { Muda redação do art. } 17, \S 2^{\circ} \text { e } \S 6^{\circ} \text {, } \\
\text { evitando que reajustes nas despesas de } \\
\text { pessoal necessitem de mecanismos de } \\
\text { compensação. A remuneração de pessoal } \\
\text { ativo deve ter o mesmo tratamento das } \\
\text { despesas com a seguridade social. }\end{array}$ & $\begin{array}{l}\text { Dep. Yeda } \quad \text { Crusius } \\
\text { (PSDB-RS) e outros. }\end{array}$ & $\begin{array}{l}\text { Aprovada } \\
\text { parcialmente }\end{array}$ \\
\hline$n^{\circ} 60$ & $\begin{array}{l}\text { Suprime o inciso VI, do } \S 1^{\circ} \text {, do art. } 19 \text { do } \\
\text { Substitutivo adotado pela CESP. Trata da } \\
\text { exclusão das contribuições dos entes aos } \\
\text { regimes próprios da previdência social da } \\
\text { base de cálculo das despesas de pessoal. }\end{array}$ & $\begin{array}{l}\text { Dep. Yeda } \quad \text { Crusius } \\
\text { (PSDB-RS) e outros. }\end{array}$ & $\begin{array}{l}\text { Aprovada } \\
\text { integralmente }\end{array}$ \\
\hline $\mathrm{n}^{\circ} 61$ & $\begin{array}{l}\text { Suprime o inciso VIII, do } \S 1^{\circ} \text {, do art. } 19 \text { do } \\
\text { Substitutivo adotado pela CESP. Trata de } \\
\text { contribuição de previdência privada e } \\
\text { cálculo de despesa com pessoal. }\end{array}$ & $\begin{array}{l}\text { Dep. Yeda } \quad \text { Crusius } \\
\text { (PSDB-RS) e outros. }\end{array}$ & $\begin{array}{l}\text { Aprovada } \\
\text { integralmente }\end{array}$ \\
\hline$n^{0} 62$ & $\begin{array}{l}\text { Muda redação do inciso } \mathrm{II} \text {, art. } 37 \text {, do } \\
\text { Substitutivo. }\end{array}$ & $\begin{array}{l}\text { Dep. Yeda Crusius } \\
\text { (PSDB-RS) e outros. }\end{array}$ & $\begin{array}{l}\text { Aprovada } \\
\text { integralmente }\end{array}$ \\
\hline$n^{0} 63$ & $\begin{array}{l}\text { Suprime o inciso IV, do caput, do art. } 4^{\circ} \text { do } \\
\text { Substitutivo adotado pela CESP. Sobre } \\
\text { repartição dos recursos do FAT e dos } \\
\text { fundos constitucionais. }\end{array}$ & $\begin{array}{l}\text { Dep. Yeda Crusius } \\
\text { (PSDB-RS) e outros. }\end{array}$ & $\begin{array}{l}\text { Aprovada } \\
\text { integralmente }\end{array}$ \\
\hline
\end{tabular}




\begin{tabular}{|c|c|c|c|}
\hline$n^{\circ} 64$ & $\begin{array}{l}\text { Mudança de redação do art. } 4^{\circ} \text {, trata da não } \\
\text { inclusão em anexo da avaliação financeira } \\
\text { a atuarial. }\end{array}$ & $\begin{array}{l}\text { Dep. Yeda Crusius } \\
\text { (PSDB-RS) e outros. }\end{array}$ & $\begin{array}{l}\text { Aprovada } \\
\text { integralmente }\end{array}$ \\
\hline$n^{\circ} 65$ & $\begin{array}{l}\text { Mudança de redação do art. } 28 \text {, deixando } \\
\text { claro que não se proíbe o BC conceder às } \\
\text { instituições financeiras operações de } \\
\text { redesconto e empréstimos de prazo inferior } \\
\text { a } 360 \text { dias. }\end{array}$ & $\begin{array}{l}\text { Dep. Yeda } \quad \text { Crusius } \\
\text { (PSDB-RS) e outros. }\end{array}$ & $\begin{array}{l}\text { Aprovada } \\
\text { integralmente }\end{array}$ \\
\hline$n^{\circ} 66$ & $\begin{array}{llll}\begin{array}{l}\text { Emenda } \\
\text { remissão) }\end{array} & \text { Redação } & \text { (correção } & \text { de } \\
\end{array}$ & $\begin{array}{l}\text { Dep. Yeda Crusius } \\
\text { (PSDB-RS) e outros. }\end{array}$ & $\begin{array}{l}\text { Aprovada } \\
\text { integralmente }\end{array}$ \\
\hline $\mathrm{n}^{\circ} 67$ & $\begin{array}{llll}\begin{array}{l}\text { Emenda de } \\
\text { remissão) }\end{array} & \text { Redação } & \text { (correção de } \\
\end{array}$ & $\begin{array}{l}\text { Dep. Yeda Crusius } \\
\text { (PSDB-RS) e outros. }\end{array}$ & $\begin{array}{l}\text { Aprovada } \\
\text { integralmente }\end{array}$ \\
\hline $\mathrm{n}^{\circ} 68$ & Emenda de Redação & $\begin{array}{l}\text { Dep. Yeda Crusius } \\
\text { (PSDB-RS) e outros. }\end{array}$ & $\begin{array}{l}\text { Aprovada } \\
\text { integralmente }\end{array}$ \\
\hline $\mathrm{n}^{0} 69$ & Correção de erro técnico do $\S 1^{\circ}$ do art. 39. & $\begin{array}{l}\text { Dep. Yeda Crusius } \\
\text { (PSDB-RS) e outros. }\end{array}$ & $\begin{array}{l}\text { Aprovada } \\
\text { integralmente }\end{array}$ \\
\hline $\mathrm{n}^{0} 70$ & $\begin{array}{l}\text { Inclui art. no Capítulo IX, sobre a inclusão } \\
\text { dos consórcios e convênios de cooperação } \\
\text { no âmbito da LRF. }\end{array}$ & $\begin{array}{l}\text { Dep. Dr. Helio ( PDT-SP) } \\
\text { e outros }\end{array}$ & Rejeitada \\
\hline $\mathrm{n}^{0} 71$ & $\begin{array}{l}\text { Suprime o } \S 6^{\circ} \text { do art. } 17 \text {, que excetua as } \\
\text { despesas destinadas ao serviço da dívida } \\
\text { dos limites das outras despesas. }\end{array}$ & $\begin{array}{l}\text { Dep. Luiz Salomão (PT- } \\
\text { RJ) e outros. }\end{array}$ & Rejeitada \\
\hline $\mathrm{n}^{0} 72$ & $\begin{array}{l}\text { Muda redação do inciso III do art. 38; trata } \\
\text { da vedação da flutuação dos juros para } \\
\text { financiamento dos entes da federação. }\end{array}$ & $\begin{array}{l}\text { Dep. Luiz Salomão (PT- } \\
\text { RJ) e outros. }\end{array}$ & Rejeitada \\
\hline $\mathrm{n}^{0} 73$ & $\begin{array}{l}\text { Acrescenta parágrafo ao art. 49, sobre a } \\
\text { exigência de demonstrativo dos valores de } \\
\text { execução orçamentária, no âmbito de } \\
\text { Estados e Municípios, perante os } \\
\text { respectivos poderes legislativos, durante o } \\
\text { exercício fiscal. }\end{array}$ & $\begin{array}{l}\text { Dep. João Almeida } \\
\text { (PSDB-BA) e outros. }\end{array}$ & Rejeitada \\
\hline $\mathrm{n}^{0} 74$ & $\begin{array}{l}\text { Inclui nas Disposições Finais e Transitórias } \\
\text { emenda que estabelece prazo de dois anos } \\
\text { fiscais para enquadramento no art. 49, } \\
\text { sujeito às sanções previstas no art. } 23 \text {. }\end{array}$ & $\begin{array}{l}\text { Dep. João Almeida } \\
\text { (PSDB-BA) e outros. }\end{array}$ & Rejeitada \\
\hline $\mathrm{n}^{\circ} 75$ & Muda redação do $\S 3^{\circ}$ do art. 17. & $\begin{array}{l}\text { Dep. Pedro Eugenio (PT- } \\
\text { PE) e outros }\end{array}$ & Rejeitada \\
\hline $\mathrm{n}^{0} 76$ & $\begin{array}{l}\text { Suprime expressão da alínea c, inciso I do } \\
\text { art. } 4^{\circ} \text { sobre a inclusão das despesas } \\
\text { correntes, inclusive serviços de terceiros, } \\
\text { nos limites de despesas. }\end{array}$ & $\begin{array}{l}\text { Dep. Sérgio Miranda } \\
\text { (Bloco/PCdoB }-\mathrm{MG} \text { ) }\end{array}$ & Rejeitada \\
\hline $\mathrm{n}^{\circ} 77$ & $\begin{array}{l}\text { Suprime expressão do inciso II, do } \S 2^{\circ} \text { do } \\
\text { art. } 4^{\circ} \text { de conteúdo normativo, sobre } \\
\text { objetivos de políticas econômica nacional. }\end{array}$ & $\begin{array}{l}\text { Dep. Sérgio Miranda } \\
\text { (Bloco/PCdoB - MG) }\end{array}$ & Rejeitada \\
\hline $\mathrm{n}^{0} 78$ & Nova redação para $\S 3^{\circ}$ do art. $4^{\circ}$ & $\begin{array}{l}\text { Dep. Sérgio Miranda } \\
\text { (Bloco/PCdoB }-\mathrm{MG} \text { ) }\end{array}$ & Rejeitada \\
\hline $\mathrm{n}^{0} 79$ & $\begin{array}{l}\text { Suprime expressão do } \S 2^{\circ} \text { do art. } 5^{\circ} \text {, sobre } \\
\text { atualização do principal da dívida. }\end{array}$ & $\begin{array}{l}\text { Dep. Sérgio Miranda } \\
\text { (Bloco/PCdoB }-\mathrm{MG} \text { ) }\end{array}$ & Rejeitada \\
\hline $\mathrm{n}^{\circ} 80$ & $\begin{array}{l}\text { Suprime } 0 \text { } \S 1^{\circ} \text { do art. } 7^{\circ} \text { sobre } \\
\text { financiamento do déficit do } \mathrm{BC} \text { pelo } \\
\text { Tesouro e supressão da prerrogativa do CN } \\
\text { de discutir esses déficits. }\end{array}$ & $\begin{array}{l}\text { Dep. Sérgio Miranda } \\
\text { (Bloco/PCdoB - MG) }\end{array}$ & Rejeitada \\
\hline$n^{0} 81$ & $\begin{array}{l}\text { Nova redação para } \S 3^{\circ} \text { do art. } 7^{\circ} \text {, sobre } \\
\text { abrangência dos balancetes do BC. }\end{array}$ & $\begin{array}{l}\text { Dep. Sérgio Miranda } \\
\text { (Bloco/PCdoB }-\mathrm{MG} \text { ) }\end{array}$ & Rejeitada \\
\hline $\mathrm{n}^{\circ} 82$ & $\begin{array}{l}\text { Nova redação art. } 9^{\circ} \text {, sobre } 0 \text { anexo de } \\
\text { metas fiscais. }\end{array}$ & $\begin{array}{l}\text { Dep. Sérgio Miranda } \\
\text { (Bloco/PCdoB - MG) }\end{array}$ & Rejeitada \\
\hline $\mathrm{n}^{0} 83$ & Nova redação para $\S 2^{\circ}$ do art. $9^{\circ}$. & $\begin{array}{l}\text { Dep. Sérgio Miranda } \\
\text { (Bloco/PCdoB }-\mathrm{MG} \text { ) }\end{array}$ & Rejeitada \\
\hline$n^{\circ} 84$ & Nova redação para $\S 2^{\circ}$ do art. 12. & Dep. Sérgio Miranda & Rejeitada \\
\hline
\end{tabular}




\begin{tabular}{|c|c|c|c|}
\hline & & (Bloco/PCdoB - MG) & \\
\hline $\mathrm{n}^{\circ} 85$ & $\begin{array}{l}\text { Suprime o inciso II do } \S 4^{\circ} \text { do art. } 16 \text {, sobre } \\
\text { reforma urbana. }\end{array}$ & $\begin{array}{l}\text { Dep. Sérgio Miranda } \\
\text { (Bloco/PCdoB - MG) }\end{array}$ & Rejeitada \\
\hline$n^{0} 86$ & $\begin{array}{l}\text { Suprime o } \S 3^{\circ} \text { do art. } 17 \text {, que trata do } \\
\text { aumento da receita apenas proveniente de } \\
\text { elevação de alíquotas, ampliação da base } \\
\text { de cálculo, majoração ou criação de tributo } \\
\text { ou contribuição. }\end{array}$ & $\begin{array}{l}\text { Dep. Sérgio Miranda } \\
\text { (Bloco/PCdoB - MG) }\end{array}$ & Rejeitada \\
\hline $\mathrm{n}^{\circ} 87$ & $\begin{array}{l}\text { Suprime o } \S 6^{\circ} \text { do art. } 17 \text {, sobre a retirada } \\
\text { dos serviços da dívida das limitações } \\
\text { adotadas pela lei. }\end{array}$ & $\begin{array}{l}\text { Dep. Sérgio Miranda } \\
\text { (Bloco/PCdoB - MG) }\end{array}$ & Rejeitada \\
\hline $\mathrm{n}^{0} 88$ & $\begin{array}{l}\text { Suprime o art. } 20 \text {, sobre a repartição de } \\
\text { limites globais por poder. }\end{array}$ & $\begin{array}{l}\text { Dep. Sérgio Miranda } \\
\text { (Bloco/PCdoB - MG) }\end{array}$ & Rejeitada \\
\hline $\mathrm{n}^{\circ} 89$ & $\begin{array}{l}\text { Suprime o } \S 1^{0} \text { do art. } 23 \text {, que é } \\
\text { inconstitucional porque proíbe a redução de } \\
\text { vencimentos dos servidores públicos, com } \\
\text { a exceção para os funcionários colocados } \\
\text { em disponibilidade. }\end{array}$ & $\begin{array}{l}\text { Dep. Sérgio Miranda } \\
\text { (Bloco/PCdoB - MG) }\end{array}$ & Rejeitada \\
\hline $\mathrm{n}^{\circ} 90$ & $\begin{array}{l}\text { Suprime o } \S 2^{\circ} \text { do art. } 23 \text {, com a mesma } \\
\text { justificativa da emenda } n^{\circ} 89 \text {. }\end{array}$ & $\begin{array}{l}\text { Dep. Sérgio Miranda } \\
\text { (Bloco/PCdoB }-\mathrm{MG} \text { ) }\end{array}$ & Rejeitada \\
\hline $\mathrm{n}^{\circ} 91$ & $\begin{array}{l}\text { Acrescenta o inciso IV ao } \S 1^{\circ} \text { do art. } 24 \\
\text { redação sobre despesas extraordinárias e } \\
\text { emergenciais. }\end{array}$ & $\begin{array}{l}\text { Dep. Sérgio Miranda } \\
\text { (Bloco/PCdoB - MG) }\end{array}$ & Rejeitada \\
\hline$n^{0} 92$ & Modifica redação do art. 25. & $\begin{array}{l}\text { Dep. Sérgio Miranda } \\
\text { (Bloco/PCdoB - MG) }\end{array}$ & $\begin{array}{l}\text { Aprovada } \\
\text { integralmente }\end{array}$ \\
\hline$n^{0} 93$ & Modifica redação do $\S 3^{\circ}$ do art. 25. & $\begin{array}{l}\text { Dep. Sérgio Miranda } \\
\text { (Bloco/PCdoB - MG) }\end{array}$ & Rejeitada \\
\hline $\mathrm{n}^{\circ} 94$ & $\begin{array}{l}\text { Suprime o inciso II do } \S 1^{\circ} \text { do art. } 31 \text {, que } \\
\text { trata da dívida consolidada de um ente da } \\
\text { Federação que ultrapasse o respectivo } \\
\text { limite, deverá obter resultado primário } \\
\text { necessário a recondução da dívida ao } \\
\text { limite. }\end{array}$ & $\begin{array}{l}\text { Dep. Sérgio Miranda } \\
\text { (Bloco/PCdoB - MG) }\end{array}$ & Rejeitada \\
\hline $\mathrm{n}^{\circ} 95$ & $\begin{array}{l}\text { Suprime a expressão do caput do art. } 33 \\
\text { que excetua do limite das contratações de } \\
\text { operação de crédito a dívida mobiliária ou à } \\
\text { externa. }\end{array}$ & $\begin{array}{l}\text { Dep. Sérgio Miranda } \\
\text { (Bloco/PCdoB - MG) }\end{array}$ & Rejeitada \\
\hline $\mathrm{n}^{\circ} 96$ & $\begin{array}{l}\text { Suprime o inciso I do art. } 37 \text {, que veda as } \\
\text { operações de antecipação de receita cujo } \\
\text { fato gerador ainda não tenha ocorrido. }\end{array}$ & $\begin{array}{l}\text { Dep. Sérgio Miranda } \\
\text { (Bloco/PCdoB - MG) }\end{array}$ & Rejeitada \\
\hline$n^{\circ} 97$ & $\begin{array}{l}\text { Suprime o art. 44, que veda que as receitas } \\
\text { de capital derivadas da alienação de bens e } \\
\text { direitos do patrimônio público sejam } \\
\text { utilizadas para despesas correntes. }\end{array}$ & $\begin{array}{l}\text { Dep. Sérgio Miranda } \\
\text { (Bloco/PCdoB - MG) }\end{array}$ & Rejeitada \\
\hline $\mathrm{n}^{\circ} 98$ & $\begin{array}{l}\text { Suprime o inciso IV, do } \S 1^{\circ} \text {, do art. } 60 \text {, cuja } \\
\text { premissa é a existência de um limite para } \\
\text { as despesas com inativos e pensionistas. }\end{array}$ & $\begin{array}{l}\text { Dep. Sérgio Miranda } \\
\text { (Bloco/PCdoB }-\mathrm{MG} \text { ) }\end{array}$ & Rejeitada \\
\hline$n^{\circ} 99$ & $\begin{array}{l}\text { Altera o art. } 64 \text {, mudando o limite de } \mathrm{n}^{\circ} \text { de } \\
\text { habitantes por municípios de } 20 \text { mil para } \\
200 \text { mil que devem elaborar relatórios de } \\
\text { prestação de contas. }\end{array}$ & $\begin{array}{l}\text { Dep. Sérgio Miranda } \\
\text { (Bloco/PCdoB - MG) }\end{array}$ & $\begin{array}{l}\text { Aprovada } \\
\text { Parcialmente }\end{array}$ \\
\hline$n^{\circ} 100$ & $\begin{array}{l}\text { Inclui no Capítulo IX o artigo que considera } \\
\text { que a receita da DRU deve integrar a } \\
\text { receita corrente líquida. }\end{array}$ & $\begin{array}{l}\text { Dep. } \\
\text { Sérgio Miranda } \\
\text { (Bloco/PCdoB - MG) }\end{array}$ & Rejeitada \\
\hline$n^{0} 101$ & $\begin{array}{l}\text { Substitui o inciso I do art. } 29 \text { pelos incisos I } \\
\text { e II, que incluem a dívida pública federal } \\
\text { constituída de títulos de curto prazo no } \\
\text { controle do endividamento (a dívida } \\
\text { mobiliária federal). }\end{array}$ & $\begin{array}{l}\text { Dep. Sérgio Miranda } \\
\text { (Bloco/PCdoB - MG) }\end{array}$ & Rejeitada \\
\hline$n^{0} 102$ & Suprime os $\S \S 2^{\circ}, 3^{\circ}$ e $4^{\circ}$ do art. 30 & Miranda & Rejeitada \\
\hline
\end{tabular}




\begin{tabular}{|c|c|c|c|}
\hline & & (Bloco/PCdoB - MG) & \\
\hline$n^{0} 103$ & $\begin{array}{l}\text { Nova redação do art. } 66 \text {, que diz que a } \\
\text { decretação da calamidade pública deve } \\
\text { antes ser reconhecida pelo Poder } \\
\text { Legislativo. }\end{array}$ & $\begin{array}{l}\text { Dep. Sérgio Miranda } \\
\text { (Bloco/PCdoB }-\mathrm{MG} \text { ) }\end{array}$ & Rejeitada \\
\hline $\mathrm{n}^{0} 104$ & Nova redação do $\S 1^{\circ}$ do art. 67. & $\begin{array}{l}\text { Dep. Sérgio Miranda } \\
\text { (Bloco/PCdoB - MG) }\end{array}$ & Rejeitada \\
\hline$n^{0} 105$ & $\begin{array}{l}\text { Suprime o termo "drásticas" do } \S 4^{\circ} \text { do art. } \\
67 \text {. }\end{array}$ & $\begin{array}{l}\text { Dep. Sérgio Miranda } \\
\text { (Bloco/PCdoB - MG) }\end{array}$ & Rejeitada \\
\hline $\mathrm{n}^{0} 106$ & $\begin{array}{l}\text { Suprime expressão do inciso } \mathrm{VI} \text { do } \S 1^{\circ} \text { do } \\
\text { art. } 69 \text {. }\end{array}$ & $\begin{array}{l}\text { Dep. Sérgio Miranda } \\
\text { (Bloco/PCdoB - MG) }\end{array}$ & $\begin{array}{l}\text { Aprovada } \\
\text { integralmente }\end{array}$ \\
\hline $\mathrm{n}^{0} 107$ & $\begin{array}{l}\text { Suprime o parágrafo } 2^{\circ} \text { do art. } 3^{\circ} \text { sobre um } \\
\text { requisito que disciplina o funcionamento do } \\
\text { Legislativo. }\end{array}$ & $\begin{array}{l}\text { Dep. Sérgio Miranda } \\
\text { (Bloco/PCdoB }-\mathrm{MG} \text { ) }\end{array}$ & $\begin{array}{l}\text { Aprovada } \\
\text { integralmente }\end{array}$ \\
\hline $\mathrm{n}^{\circ} 108$ & Muda redação do inciso II do art. $4^{\circ}$. & $\begin{array}{l}\text { Dep. Sérgio Miranda } \\
\text { (Bloco/PCdoB - MG) }\end{array}$ & Rejeitada \\
\hline$n^{0} 109$ & $\begin{array}{l}\text { Suprime no parágrafo } 1^{\circ} \text { do art, } 4^{\circ} \text { a } \\
\text { expressão "resultados nominal e primário". }\end{array}$ & $\begin{array}{l}\text { Dep. Sérgio Miranda } \\
\text { (Bloco/PCdoB - MG) }\end{array}$ & Rejeitada \\
\hline $\mathrm{n}^{0} 110$ & $\begin{array}{l}\text { Suprime as alíneas a e b do inciso III do art. } \\
5^{\circ} \text {. }\end{array}$ & $\begin{array}{l}\text { Dep. Sérgio Miranda } \\
\text { (Bloco/PCdoB - MG) }\end{array}$ & Rejeitada \\
\hline $\mathrm{n}^{0} 111$ & 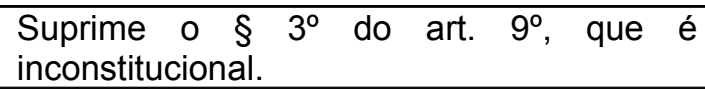 & $\begin{array}{l}\text { Dep. Sérgio Miranda } \\
\text { (Bloco/PCdoB - MG) }\end{array}$ & Rejeitada \\
\hline$n^{\circ} 112$ & Suprime no $\S 2^{\circ}$ do art. 14 & $\begin{array}{l}\text { Dep. Sérgio Miranda } \\
\text { (Bloco/PCdoB - MG) }\end{array}$ & Rejeitada \\
\hline$n^{0} 113$ & Muda redação do art. 21. & $\begin{array}{l}\text { Dep. Sérgio Miranda } \\
\text { (Bloco/PCdoB - MG) }\end{array}$ & Rejeitada \\
\hline $\mathrm{n}^{\circ} 114$ & Suprime parágrafo único do art. 22. & $\begin{array}{l}\text { Dep. Sérgio Miranda } \\
\text { (Bloco/PCdoB }-\mathrm{MG} \text { ) }\end{array}$ & Rejeitada \\
\hline $\mathrm{n}^{0} 115$ & $\begin{array}{l}\text { Suprime no caput do art. } 24 \text { a expressão: } \\
\text { "atendidas ainda as exigências do art. 17". }\end{array}$ & $\begin{array}{l}\text { Dep. Sérgio Miranda } \\
\text { (Bloco/PCdoB - MG) }\end{array}$ & Rejeitada \\
\hline $\mathrm{n}^{0} 116$ & $\begin{array}{l}\text { Suprime no inciso II do } \S 1^{\circ} \text { do art. } 24 \text { a } \\
\text { expressão: "na forma da legislação" (sobre } \\
\text { despesa com seguridade social). }\end{array}$ & $\begin{array}{l}\text { Dep. Sérgio Miranda } \\
\text { (Bloco/PCdoB }-\mathrm{MG} \text { ) }\end{array}$ & $\begin{array}{l}\text { Aprovada } \\
\text { integralmente }\end{array}$ \\
\hline $\mathrm{n}^{\circ} 117$ & $\begin{array}{l}\text { Fala sobre sanar um vício de } \\
\text { constitucionalidade do substitutivo } \\
\text { (competência concorrente entre União, } \\
\text { Estados e Municípios). }\end{array}$ & $\begin{array}{l}\text { Dep. Sérgio Miranda } \\
\text { (Bloco/PCdoB - MG) }\end{array}$ & Rejeitada \\
\hline $\mathrm{n}^{0} 118$ & Nova redação ao caput do art. 31. & $\begin{array}{l}\text { Dep. Manoel Castro } \\
\text { (PFL-BA) e Inocêncio } \\
\text { Oliveira (PFL-PE) }\end{array}$ & $\begin{array}{l}\text { Aprovada } \\
\text { Parcialmente }\end{array}$ \\
\hline$n^{\circ} 119$ & $\begin{array}{l}\text { Dá novos textos para os arts. } 75 \text { e } 76, \\
\text { prevendo a revogação da Lei Camata II a } \\
\text { partir da entrada em vigor da LRF e que a } \\
\text { LRF entra em vigor em } 1^{\circ} \text { de janeiro do } \\
\text { exercício seguinte ao da sua publicação. }\end{array}$ & $\begin{array}{l}\text { Dep. Manoel Castro } \\
\text { (PFL-BA) e Inocêncio } \\
\text { Oliveira (PFL-PE) }\end{array}$ & Rejeitada \\
\hline $\mathrm{n}^{\circ} 120$ & Suprime o $\S 4^{\circ}$ do art. 23 & $\begin{array}{l}\text { Dep. Manoel Castro } \\
\text { (PFL-BA) e Inocêncio } \\
\text { Oliveira (PFL-PE) }\end{array}$ & Rejeitada \\
\hline $\mathrm{n}^{\circ} 121$ & $\begin{array}{l}\text { Suprime o } \S 3^{\circ} \text { do art. } 17 \text {, sobre a elevação } \\
\text { da despesa de caráter continuado só poder } \\
\text { acontecer mediante aumento permanente } \\
\text { de receita por elevação de alíquota, } \\
\text { ampliação da base de cálculo ou majoração } \\
\text { ou criação de tributo ou contribuição. }\end{array}$ & $\begin{array}{l}\text { Dep. Manoel Castro } \\
\text { (PFL-BA) e Inocêncio } \\
\text { Oliveira (PFL-PE) }\end{array}$ & Rejeitada \\
\hline$n^{0} 122$ & $\begin{array}{l}\text { Nova redação para os art. } 75 \text { e } 76 \text {, falando } \\
\text { da necessidade de medidas preparatórias à } \\
\text { sua entrada em vigor e da não revogação } \\
\text { imediata da Lei Camata II, para não se cair } \\
\text { em um vazio no que tange ao limite de }\end{array}$ & $\begin{array}{l}\text { Dep. Manoel Castro } \\
\text { (PFL-BA) e Inocêncio } \\
\text { Oliveira (PFL-PE) }\end{array}$ & Rejeitada \\
\hline
\end{tabular}




\begin{tabular}{|l|l|l|l|} 
& despesa com pessoal. & & \\
\hline$n^{0} 123$ & Acrescentar expressão ao caput do art. 58. & $\begin{array}{l}\text { Dep. Cezar Schirmer } \\
\text { (PMDB-RS) e outros. }\end{array}$ & $\begin{array}{l}\text { Aprovada } \\
\text { integralmente }\end{array}$ \\
\hline$n^{0} 124$ & Nova redação ao § $2^{\circ}$ do art. 38. & $\begin{array}{l}\text { Dep. Milton Monti (PL- } \\
\text { SP) e outros. }\end{array}$ & $\begin{array}{l}\text { Aprovada } \\
\text { integralmente }\end{array}$ \\
\hline
\end{tabular}




\section{Quadro 5:}

Argumentos da oposição contra o projeto de LRF, apresentados recorrentemente nas discussões no plenário da Câmara.

\begin{tabular}{|c|c|}
\hline Questões & Autoria \\
\hline $\begin{array}{l}\text { Todas as limitações para as despesas de } \\
\text { investimento, custeio e pessoal são rígidas, mas } \\
\text { em vários artigos ela livra de qualquer limitação } \\
\text { o pagamento de juros (idem). Lei feita para dar } \\
\text { garantia absoluta ao credor financeiro e a limitar } \\
\text { gastos de duração continuada, especialmente os } \\
\text { sociais }\end{array}$ & $\begin{array}{l}\text { Dep. Sérgio Miranda (Bloco/PCdoB - MG) (DCD, } \\
\text { 19/01/2000, 2393); } \\
\text { Dep. Luiz Salomão (PDT/RJ) (DCD, 20/01/00, } \\
\text { 2674); } \\
\text { Dep. Sérgio Miranda (Bloco/PCdoB - MG) (DCD, } \\
\text { 26/01/2000, 3662/3663); } \\
\text { Dep. Carlito Merss (PT-SC) (DCD, 26/01/2000, } \\
\text { 3692/3693) } \\
\text { Dep. José Genoino (PT-SP) (DCD, 26/01/2000, } \\
\text { 3709). }\end{array}$ \\
\hline $\begin{array}{l}\text { Crítica ao art. 17, sobre aumento de salário de } \\
\text { servidor somente mediante aumento de alíquota } \\
\text { ou criando novo imposto (idem). }\end{array}$ & $\begin{array}{l}\text { Dep. Sérgio Miranda (Bloco/PCdoB - MG) (DCD, } \\
\text { 19/01/2000, 2393); } \\
\text { Dep. Agnelo Queiroz (Bloco PCdoB - DF) (DCD, } \\
\text { 20/01/00, 2675) }\end{array}$ \\
\hline $\begin{array}{l}\text { O art. } 17 \text { (e 24), colocado por pressão do } \\
\text { Ministério do Planejamento, impede qualquer } \\
\text { aumento de gasto de duração continuada, por } \\
\text { dois anos. Congela-se o gasto social do país a } \\
\text { partir de 1999. }\end{array}$ & $\begin{array}{l}\text { Dep. Sérgio Miranda (Bloco/PCdoB - MG) . } \\
\text { (DCD, 20/01/00, 2673); } \\
\text { Dep. José Genoíno (PT/SP) (DCD, 20/01/00, } \\
2660)\end{array}$ \\
\hline $\begin{array}{l}\text { Transforma em lei complementar a política } \\
\text { econômica e financeira do governo. É a política } \\
\text { do FMI, uma política recessiva. }\end{array}$ & 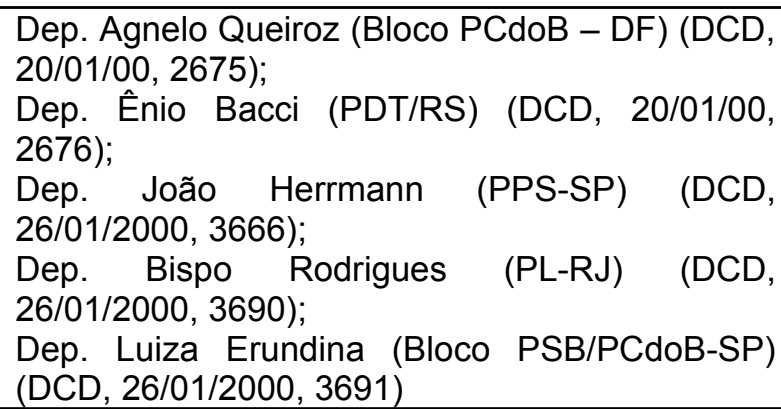 \\
\hline $\begin{array}{l}\text { Deveria ser chamada de "Lei da } \\
\text { Irresponsabilidade Monetária", pois proíbe a } \\
\text { renegociação da dívida dos Estados. }\end{array}$ & $\begin{array}{l}\text { Dep. Agnelo Queiroz (Bloco PCdoB - DF) (DCD, } \\
20 / 01 / 00,2675)\end{array}$ \\
\hline 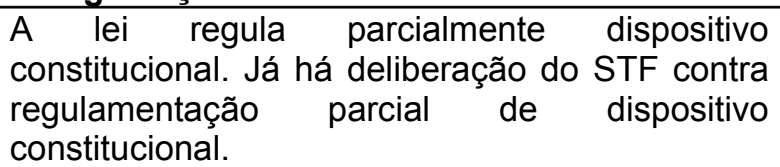 & $\begin{array}{l}\text { Dep. Agnelo Queiroz (Bloco PCdoB - DF) (DCD, } \\
\text { 20/01/00, 2675) }\end{array}$ \\
\hline $\begin{array}{l}\text { O governo federal regulamenta princípios e } \\
\text { normas gerais em desacordo com a } \\
\text { Constituição. Matéria financeira é de } \\
\text { competência concorrente entre Estado, } \\
\text { Município e União. }\end{array}$ & $\begin{array}{l}\text { Dep. Agnelo Queiroz (Bloco PCdoB - DF) (DCD, } \\
\text { 20/01/00, 2675) }\end{array}$ \\
\hline $\begin{array}{l}\text { A lei não é limitadora de gastos com pessoal, } \\
\text { porque isso já foi feito na } L C n^{\circ} 69 ;\end{array}$ & $\begin{array}{l}\text { Dep. Sérgio Miranda (Bloco/PCdoB - MG) (DCD, } \\
\text { 26/01/2000, 3662/3663); }\end{array}$ \\
\hline $\begin{array}{l}\text { A lei não trata de diminuir as ARO, porque a } \\
\text { proibição do Executivo de deixar ARO para o } \\
\text { seu sucessor já está definido na Resolução } n^{\circ} \\
\text { 78. As restrições para o endividamento já estão } \\
\text { nesta resolução; }\end{array}$ & $\begin{array}{l}\text { Dep. Sérgio Miranda (Bloco/PCdoB - MG) (DCD, } \\
\text { 26/01/2000, 3662/3663); }\end{array}$ \\
\hline $\begin{array}{l}\text { Fixa em lei complementar uma política } \\
\text { econômica. }\end{array}$ & $\begin{array}{l}\text { Dep. Sérgio Miranda (Bloco/PCdoB - MG) (DCD, } \\
\text { 26/01/2000, 3662/3663); }\end{array}$ \\
\hline $\begin{array}{l}\text { É o fim do pacto federativo, ela enquadra de } \\
\text { forma autoritária e rígida governadores e } \\
\text { prefeitos e impede a renegociação das dívidas }\end{array}$ & $\begin{array}{l}\text { Dep. Sérgio Miranda (Bloco/PCdoB - MG) (DCD, } \\
\text { 26/01/2000, 3662/3663); } \\
\text { Dep. Luiza Erundina (Bloco PSB/PCdoB-SP) }\end{array}$ \\
\hline
\end{tabular}


em LC.

(DCD, 26/01/2000, 3691)

Essa lei criminaliza o gestor fiscal, não o Dep. Sérgio Miranda (Bloco/PCdoB - MG) (DCD, corrupto. Vai preso o prefeito que não quiser 26/01/2000, 3662/3663);

demitir, que não quiser fechar um posto de saúde, que não pagar a dívida.

Promoverá a maior onda de demissões da $\quad$ Dep. Sérgio Miranda (Bloco/PCdoB - MG) (DCD, história.

26/01/2000, 3662/3663);

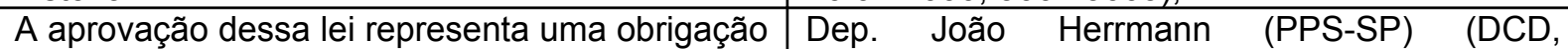
primária do administrador público: não poder $26 / 01 / 2000,3666)$

gastar mais do que arrecadar, não poder ter

mais despesas do que verba que tem para

gastar. A lei engessa, gruda despesa com

receita. 
Quadro 6:

Emendas de Plenário (Senado)

\begin{tabular}{|c|c|c|c|}
\hline $\mathrm{n}^{0}$ & assunto & autoria & destino \\
\hline$n^{0} 5$ & $\begin{array}{l}\text { Corrige um erro de redação do art. } 7^{\circ}, \S 3^{\circ} \text { (tira } \\
\text { o termo balanço e coloca balancete); }\end{array}$ & $\begin{array}{l}\text { Senador Edison Lobão } \\
\text { (PFL-MA) }\end{array}$ & Rejeitada \\
\hline$n^{\circ} 6$ & $\begin{array}{l}\text { Define o que são obrigações constitucionais, } \\
\text { inserindo o } \S 3^{\circ} \text { no art. } 9^{\circ} \text {. }\end{array}$ & $\begin{array}{l}\text { Senador José Eduardo } \\
\text { Dutra (PT-SE) }\end{array}$ & Rejeitada \\
\hline$n^{\circ} 7$ & $\begin{array}{l}\text { Mudança na redação do } \S 3^{\circ} \text { do art. } 17 \text {, } \\
\text { redefinindo o que é aumento permanente de } \\
\text { receita. No texto, este aumento advem de } \\
\text { elevação de alíquotas, ampliação da base de } \\
\text { cálculo e majoração ou criação de tributos e } \\
\text { contribuições. O senador Dutra propõe aumento } \\
\text { de arrecadação verificado em pelo menos } 3 \\
\text { exercícios consecutivos, devido ao } \\
\text { aperfeiçoamento dos procedimentos de } \\
\text { fiscalização tributária ou melhorias nas variáveis } \\
\text { econômicas. }\end{array}$ & $\begin{array}{l}\text { Senador José } \text { Eduardo } \\
\text { Dutra (PT-SE) }\end{array}$ & Rejeitada \\
\hline $\mathrm{n}^{\circ} 8$ & Muda a redação do caput do art. 20. & $\begin{array}{l}\text { Senador Ney Suassuna } \\
\text { (PMDB-PB) }\end{array}$ & Rejeitada \\
\hline$n^{\circ} 9$ & Muda redação do art. 20, inciso II. & $\begin{array}{l}\text { Senador Luiz Otávio } \\
\text { (PMDB-PA) }\end{array}$ & Rejeitada \\
\hline $\mathrm{n}^{\circ} 10$ & $\begin{array}{l}\text { Modifica alínea a, do inciso II, do art. } 20 \\
\text { (mesma justificativa da emenda 9, que é } \\
\text { separar os percentuais dos Legislativos } \\
\text { estaduais e Tribunais de Contas dos Estados). }\end{array}$ & $\begin{array}{l}\text { Senador Nabor Júnior } \\
\text { (PMDB-AC) }\end{array}$ & Rejeitada \\
\hline $\mathrm{n}^{0} 11$ & $\begin{array}{l}\text { Suprime do art. 30, I, expressão que transfere } \\
\text { competência de dispor sobre limites globais e } \\
\text { condições de endividamento e operações de } \\
\text { crédito do Senado para a Presidência da } \\
\text { República. }\end{array}$ & $\begin{array}{l}\text { Senador José } \text { Eduardo } \\
\text { Dutra (PT-SE) }\end{array}$ & Rejeitada \\
\hline$n^{0} 12$ & & & Rejeitada \\
\hline$n^{0} 13$ & $\begin{array}{l}\text { Propõe nova redação ao art. } 32, \S 1^{\circ} \text {, que } \\
\text { invade as prerrogativas do Senado nos pleitos } \\
\text { relativos à contratação de operações de crédito } \\
\text { interno e externo. Na lei o Ministério da } \\
\text { Fazenda verifica o cumprimento dos limites e } \\
\text { condições relativos à realização de operações } \\
\text { de crédito. }\end{array}$ & $\begin{array}{l}\text { Senador José } \text { Eduardo } \\
\text { Dutra (PT-SE) }\end{array}$ & Rejeitada \\
\hline $\mathrm{n}^{0} 14$ & $\begin{array}{l}\text { Toca no art. 35. Propõe a alteração do } \S 1^{\circ} \text { do } \\
\text { art. } 35 \text { para preservar as prerrogativas do } \\
\text { Senado previstas no art. 52, inciso VII. A lei } \\
\text { veda a realização de operações de crédito entre } \\
\text { entes federativos sob a forma de novação, } \\
\text { refinanciamento ou postergação de dívida } \\
\text { contraída anteriormente. A emenda do senador } \\
\text { propõe que se incluam entre as exceções as } \\
\text { operações entre a União e os municípios } \\
\text { destinados ao refinanciamento de suas dívidas } \\
\text { mobiliária e contratual. }\end{array}$ & $\begin{array}{l}\text { Senador Eduardo Suplicy } \\
\text { (PT-SP) }\end{array}$ & Rejeitada \\
\hline$n^{0} 15$ & Corrige erro de remissão do art. 39, inciso I. & $\begin{array}{l}\text { Senador Edison Lobão } \\
\text { (PFL-MA) }\end{array}$ & Rejeitada \\
\hline$n^{0} 16$ & $\begin{array}{l}\text { Suprime o art. } 40 \text {, que segundo ele, invade as } \\
\text { prerrogativas exclusivas do Senado. }\end{array}$ & $\begin{array}{l}\text { Senador José } \text { Eduardo } \\
\text { Dutra (PT-SE) }\end{array}$ & Rejeitada \\
\hline $\mathrm{n}^{0} 17$ & $\begin{array}{l}\text { Suprime art. } 50, \S 2^{\circ} \text {, que incumbi a União o } \\
\text { papel do Conselho de Gestão Fiscal, enquanto } \\
\text { ele não é aprovado. }\end{array}$ & $\begin{array}{l}\text { Senador José } \text { Eduardo } \\
\text { Dutra (PT-SE) }\end{array}$ & Rejeitada \\
\hline
\end{tabular}




\begin{tabular}{|c|c|c|c|}
\hline$n^{0} 18$ & $\begin{array}{l}\text { Propõe artigo que inclui na renegociação das } \\
\text { dívidas (lei 9496/97) os passivos com } \\
\text { executores de obras públicas. }\end{array}$ & $\begin{array}{l}\text { Senador Edison Lobão } \\
\text { (PFL-MA) }\end{array}$ & Rejeitada \\
\hline $\mathrm{n}^{0} 19$ & Suprime o $\S 3^{\circ}$ do art. 40. & $\begin{array}{lc}\text { Senador } & \text { Morazildo } \\
\text { Cavalcanti } & \text { (PTB-RR) } \\
\end{array}$ & Rejeitada \\
\hline$n^{\circ} 20$ & $\begin{array}{l}\text { Suprime o } \S 7^{\circ} \text { do art. } 30 \text {, pois a PEC } 90 / 99 \text { já } \\
\text { trata do pagamento de precatórios, parcelado } \\
\text { em } 10 \text { anos. } 0 \S 7^{\circ} \text { inclui os precatórios não } \\
\text { pagos nos limites de endividamento. }\end{array}$ & $\begin{array}{ll}\text { Senador } & \text { Morazildo } \\
\text { Cavalcanti (PTB-RR) }\end{array}$ & Rejeitada \\
\hline$n^{0} 21$ & $\begin{array}{l}\text { Suprime do caput do art. } 20 \text { a expressão "caso } \\
\text { não seja fixada na LDO". }\end{array}$ & $\begin{array}{lc}\text { Senador } & \text { Morazildo } \\
\text { Cavalcanti (PTB-RR) }\end{array}$ & Rejeitada \\
\hline$n^{0} 22$ & $\begin{array}{l}\text { Suprime no parágrafo único do art. } 48 \text { o termo } \\
\text { "incentivo", substituindo-se a crase a, que se lhe } \\
\text { segue, pelo artigo a. }\end{array}$ & $\begin{array}{l}\text { Senador Pedro Simon } \\
\text { (PMDB-RS) }\end{array}$ & Aprovada \\
\hline
\end{tabular}


Quadro 7:

Votação Nominal do Projeto

\begin{tabular}{|c|c|c|c|c|}
\hline Parlamentar Partido UF & SIM & NÃO & ABSTENÇÃO & AUSENTE \\
\hline Ademir Andrade PSB PA & & 1 & & \\
\hline Agnelo Alves PMDB RN & 1 & & & \\
\hline Alberto Silva PMDB PI & & & & 1 \\
\hline Alvaro Dias PSDB PR & 1 & & & \\
\hline Amir Lando PMDB RO & 1 & & & \\
\hline Antero Paes de Barros PSDB MT & 1 & & & \\
\hline Antonio Carlos Magalhães PFL BA (presidente) & & & & \\
\hline Antônio Carlos Valadares PSB SE & & & & 1 \\
\hline Arlindo Porto PTB MG & 1 & & & \\
\hline Artur da Tavola PSDB RJ & 1 & & & \\
\hline Bello Parga PFL MA & 1 & & & \\
\hline Bernardo Cabral PFL AM & 1 & & & \\
\hline Carlos Bezerra PMDB MT & 1 & & & \\
\hline Carlos Patrocínio PTB TO & 1 & & & \\
\hline Carlos Wilson PTB PE & 1 & & & \\
\hline Casildo Maldaner PMDB SC & 1 & & & \\
\hline Djalma Bessa PFL BA & 1 & & & \\
\hline Edison Lobão PFL MA & 1 & & & \\
\hline Eduardo Suplicy PT SP & & 1 & & \\
\hline Emília Fernandes $\mathrm{PT}$ RS & & 1 & & \\
\hline Ernandes Amorim PPB RO & 1 & & & \\
\hline Francelino Pereira PFL MG & 1 & & & \\
\hline Freitas Neto PSDB PI & 1 & & & \\
\hline Geraldo Althoff PFL SC & 1 & & & \\
\hline Geraldo Candido PT RJ & & 1 & & \\
\hline Geraldo Lessa PSDB AL & & & & 1 \\
\hline Geraldo Melo PSDB RN & 1 & & & \\
\hline Gerson Camata PMDB ES & 1 & & & \\
\hline Gilberto Mestrinho PMDB AM & 1 & & & \\
\hline Gilvam Borges $\mathrm{PMDB}$ AP & 1 & & & \\
\hline Heloísa Helena PSOL AL & & 1 & & \\
\hline Hugo Napoleão PFL PI & & & & 1 \\
\hline Iris Rezende PMDB GO & 1 & & & \\
\hline Jader Barbalho PMDB PA & 1 & & & \\
\hline $\begin{array}{ll}\text { Jefferson Peres } & \text { PDT AM } \\
\end{array}$ & 1 & & & \\
\hline João Alberto Souza PMDB MA & 1 & & & \\
\hline $\begin{array}{ll}\text { Jonas Pinheiro } & \text { PFL MT } \\
\end{array}$ & 1 & & & \\
\hline Jorge Bornhausen PFL SC & 1 & & & \\
\hline José Agripino $\quad$ PFL RN & 1 & & & \\
\hline José Alencar $\mathrm{PL} \mathrm{MG}$ & 1 & & & \\
\hline José Eduardo Dutra PT SE & & 1 & & \\
\hline José Fogaça PPS RS & & & & 1 \\
\hline José Jorge PFL PE & 1 & & & \\
\hline José Roberto Arruda PSDB DF & 1 & & & \\
\hline José Sarney PMDB AP & 1 & & & \\
\hline Juvêncio da Fonseca PDT MS & 1 & & & \\
\hline $\begin{array}{ll}\text { Lauro Campos } & \text { PDT DF }\end{array}$ & & & & 1 \\
\hline Leomar Quintanilha PFL TO & 1 & & & \\
\hline Lúcio Alcântara PSDB CE & 1 & & & \\
\hline Lúdio Coelho PSDB MS & 1 & & & \\
\hline Luiz Estevão PMDB DF & 1 & & & \\
\hline Luiz Otavio PMDB PA & 1 & & & \\
\hline Luiz Pontes PSDB CE & 1 & & & \\
\hline Luzia Toledo PSDB ES & 1 & & & \\
\hline
\end{tabular}




\begin{tabular}{|c|c|c|c|c|}
\hline Maguito Vilela PMDB GO & & & 1 & \\
\hline Maria do Carmo Alves PFL SE & & & & 1 \\
\hline Marina Silva $\mathrm{PT}$ AC & & 1 & & \\
\hline Marluce Pinto PMDB RR & 1 & & & \\
\hline Mauro Miranda PMDB GO & 1 & & & \\
\hline Moreira Mendes PFL RO & 1 & & & \\
\hline Mozarildo Cavalcanti PTB RR & & & 1 & \\
\hline Nabor Júnior $\quad$ PMDB $A C$ & 1 & & & \\
\hline Ney Suassuna PMDB PB & 1 & & & \\
\hline Osmar Dias PDT PR & 1 & & & \\
\hline Paulo Hartung PSB ES & 1 & & & \\
\hline Paulo Souto PFL BA & 1 & & & \\
\hline Pedro Piva PSDB SP & 1 & & & \\
\hline Pedro Simon PMDB RS & 1 & & & \\
\hline Ramez Tebet PMDB MS & 1 & & & \\
\hline Renan Calheiros PMDB AL & 1 & & & \\
\hline Roberto Freire PPS PE & 1 & & & \\
\hline Roberto Requião PMDB PR & & 1 & & \\
\hline Roberto Saturnino PT RJ & & 1 & & \\
\hline Romero Jucá PSDB RR & 1 & & & \\
\hline Romeu Tuma PFL SP & 1 & & & \\
\hline Ronaldo Cunha Lima PSDB PB & 1 & & & \\
\hline Sebastião Rocha PDT AP & & & 1 & \\
\hline Sérgio Machado PMDB CE & 1 & & & \\
\hline Thelma Siqueira Campos PPB TO & 1 & & & \\
\hline Tião Viana PT AC & & 1 & & \\
\hline Wellington Roberto PTB PB & 1 & & & \\
\hline Total & 60 & 10 & 3 & 7 \\
\hline
\end{tabular}


Quadro 8:

Votação Nominal da Emenda $\mathrm{n}^{\circ} 7$

\begin{tabular}{|c|c|c|c|c|}
\hline Parlamentar Partido UF & SIM & NÃO & ABSTENÇÃO & AUSENTE \\
\hline Ademir Andrade PSB PA & & & & 1 \\
\hline Agnelo Alves PMDB RN & & 1 & & \\
\hline Alberto Silva PMDB PI & & & & 1 \\
\hline Alvaro Dias PSDB PR & & 1 & & \\
\hline Amir Lando PMDB RO & & 1 & & \\
\hline Antero Paes de Barros PSDB MT & & 1 & & \\
\hline Antonio Carlos Magalhães PFL BA (presidente) & & & & \\
\hline Antônio Carlos Valadares PSB SE & & & & 1 \\
\hline Arlindo Porto PTB MG & & 1 & & \\
\hline Artur da Tavola PSDB RJ & 1 & & & \\
\hline Bello Parga PFL MA & & 1 & & \\
\hline Bernardo Cabral PFL AM & & 1 & & \\
\hline Carlos Bezerra PMDB MT & & 1 & & \\
\hline Carlos Patrocínio PTB TO & & 1 & & \\
\hline Carlos Wilson PTB PE & 1 & & & \\
\hline Casildo Maldaner PMDB SC & & 1 & & \\
\hline Djalma Bessa PFL BA & & 1 & & \\
\hline Edison Lobão PFL MA & & 1 & & \\
\hline Eduardo Suplicy PT SP & 1 & & & \\
\hline Emília Fernandes $\mathrm{PT}$ RS & 1 & & & \\
\hline Ernandes Amorim PPB RO & & & & 1 \\
\hline Francelino Pereira PFL MG & & & & 1 \\
\hline Freitas Neto PSDB PI & & 1 & & \\
\hline Geraldo Althoff PFL SC & & 1 & & \\
\hline Geraldo Candido PT RJ & 1 & & & \\
\hline Geraldo Lessa PSDB AL & & & & 1 \\
\hline Geraldo Melo PSDB RN & & 1 & & \\
\hline Gerson Camata PMDB ES & & & & 1 \\
\hline Gilberto Mestrinho PMDB AM & & 1 & & \\
\hline Gilvam Borges PMDB AP & & 1 & & \\
\hline Heloísa Helena PSOL AL & 1 & & & \\
\hline Hugo Napoleão PFL PI & & & & 1 \\
\hline Iris Rezende PMDB GO & & 1 & & \\
\hline Jader Barbalho PMDB PA & & & & 1 \\
\hline Jefferson Peres PDT AM & & 1 & & \\
\hline João Alberto Souza PMDB MA & & 1 & & \\
\hline Jonas Pinheiro PFL MT & & 1 & & \\
\hline Jorge Bornhausen PFL SC & & & & 1 \\
\hline José Agripino PFL RN & & 1 & & \\
\hline José Alencar PL MG & & 1 & & \\
\hline José Eduardo Dutra PT SE & 1 & & & \\
\hline José Fogaça PPS RS & & & & 1 \\
\hline José Jorge PFL PE & & & & 1 \\
\hline José Roberto Arruda PSDB DF & & 1 & & \\
\hline José Sarney PMDB AP & & 1 & & \\
\hline Juvêncio da Fonseca PDT MS & & 1 & & \\
\hline Lauro Campos PDT DF & & & & 1 \\
\hline Leomar Quintanilha PFL TO & & 1 & & \\
\hline Lúcio Alcântara PSDB CE & & 1 & & \\
\hline Lúdio Coelho PSDB MS & & 1 & & \\
\hline Luiz Estevão PMDB DF & & 1 & & \\
\hline Luiz Otavio PMDB PA & & & & 1 \\
\hline Luiz Pontes PSDB CE & & 1 & & \\
\hline Luzia Toledo PSDB ES & & 1 & & \\
\hline
\end{tabular}




\begin{tabular}{|l|c|c|c|c|} 
Maguito Vilela PMDB GO & \multicolumn{1}{l|}{} & 1 \\
\hline Maria do Carmo Alves PFL SE & & & & 1 \\
\hline Marina Silva PT AC & 1 & & & \\
\hline Marluce Pinto PMDB RR & & 1 & & \\
\hline Mauro Miranda PMDB GO & & 1 & & \\
\hline Moreira Mendes PFL RO & & 1 & & \\
\hline Mozarildo Cavalcanti PTB RR & & 1 & & 1 \\
\hline Nabor Júnior PMDB AC & & & & 1 \\
\hline Ney Suassuna PMDB PB & & & & \\
\hline Osmar Dias PDT PR & 1 & & & 1 \\
\hline Paulo Hartung PSB ES & & & & \\
\hline Paulo Souto PFL BA & & 1 & & \\
\hline Pedro Piva PSDB SP & 1 & & & \\
\hline Pedro Simon PMDB RS & & 1 & & \\
\hline Ramez Tebet PMDB MS & & 1 & & \\
\hline Renan Calheiros PMDB AL & 1 & & & \\
\hline Roberto Freire PPS PE PR & 1 & & & \\
\hline Roberto Requião PMDB PR & 1 & & & \\
\hline Roberto Saturnino PT RJ & & 1 & & \\
\hline Romero Jucá PSDB RR & & 1 & & \\
\hline Romeu Tuma PFL SP & & & & \\
\hline Ronaldo Cunha Lima PSDB PB & 1 & & & \\
\hline Sebastião Rocha PDT AP & & 1 & & \\
\hline Sérgio Machado PMDB CE & & 1 & & \\
\hline Thelma Siqueira CampoS PPB TO & 1 & & & \\
\hline Tião Viana PT AC & 16 & 43 & & \\
\hline Wellington Roberto PTB PB & & & \\
\hline Total & & & \\
\hline
\end{tabular}




\section{Quadro 9:}

\section{Votação Nominal da Emenda $n^{\circ} 22$}

\begin{tabular}{|c|c|c|c|c|}
\hline Parlamentar Partido UF & SIM & NÃO & ABSTENÇÃO & AUSENTE \\
\hline Ademir Andrade PSB PA & & & & 1 \\
\hline Agnelo Alves PMDB RN & & 1 & & \\
\hline Alberto Silva PMDB PI & & & & 1 \\
\hline Alvaro Dias PSDB PR & 1 & & & \\
\hline Amir Lando PMDB RO & 1 & & & \\
\hline Antero Paes de Barros PSDB MT & & 1 & & \\
\hline Antonio Carlos Magalhães PFL BA (presidente) & & & & \\
\hline Antônio Carlos Valadares PSB SE & & & & 1 \\
\hline Arlindo Porto PTB MG & & 1 & & \\
\hline Artur da Tavola PSDB RJ & & 1 & & \\
\hline Bello Parga PFL MA & & 1 & & \\
\hline Bernardo Cabral PFL AM & 1 & & & \\
\hline Carlos Bezerra PMDB MT & & 1 & & \\
\hline Carlos Patrocínio PTB TO & & 1 & & \\
\hline Carlos Wilson PTB PE & 1 & & & \\
\hline Casildo Maldaner PMDB SC & & 1 & & \\
\hline Djalma Bessa PFL BA & & 1 & & \\
\hline Edison Lobão PFL MA & & 1 & & \\
\hline Eduardo Suplicy PT SP & 1 & & & \\
\hline Emília Fernandes $\mathrm{PT}$ RS & 1 & & & \\
\hline Ernandes Amorim PPB RO & & & & 1 \\
\hline Francelino Pereira PFL MG & & & & 1 \\
\hline Freitas Neto PSDB PI & & 1 & & \\
\hline Geraldo Althoff PFL SC & & 1 & & \\
\hline Geraldo Candido PT RJ & 1 & & & \\
\hline Geraldo Lessa PSDB AL & & & & 1 \\
\hline Geraldo Melo PSDB RN & & 1 & & \\
\hline Gerson Camata PMDB ES & & & & 1 \\
\hline Gilberto Mestrinho PMDB AM & & 1 & & \\
\hline Gilvam Borges PMDB AP & & & & 1 \\
\hline Heloísa Helena PSOL AL & 1 & & & \\
\hline Hugo Napoleão PFL PI & & & & 1 \\
\hline Iris Rezende $\mathrm{PMDB}$ GO & & 1 & & \\
\hline Jader Barbalho PMDB PA & & & & 1 \\
\hline $\begin{array}{ll}\text { Jefferson Peres } & \text { PDT AM } \\
\end{array}$ & 1 & & & \\
\hline João Alberto Souza PMDB MA & & 1 & & \\
\hline $\begin{array}{ll}\text { Jonas Pinheiro } & \text { PFL MT } \\
\end{array}$ & & & & 1 \\
\hline Jorge Bornhausen PFL SC & & & & 1 \\
\hline $\begin{array}{ll}\text { José Agripino } & \text { PFL RN } \\
\end{array}$ & & 1 & & \\
\hline José Alencar PL MG & & 1 & & \\
\hline José Eduardo Dutra PT SE & 1 & & & \\
\hline José Fogaça PPS RS & & & & 1 \\
\hline José Jorge PFL PE & & 1 & & \\
\hline José Roberto Arruda PSDB DF & & 1 & & \\
\hline José Sarney PMDB AP & & 1 & & \\
\hline $\begin{array}{ll}\text { Juvêncio da Fonseca } & \text { PDT MS }\end{array}$ & & 1 & & \\
\hline $\begin{array}{ll}\text { Lauro Campos } & \text { PDT DF } \\
\end{array}$ & & & & 1 \\
\hline Leomar Quintanilha PFL TO & & 1 & & \\
\hline Lúcio Alcântara $\quad$ PSDB CE & & 1 & & \\
\hline Lúdio Coelho PSDB MS & 1 & & & \\
\hline Luiz Estevão PMDB DF & 1 & & & \\
\hline Luiz Otavio PMDB PA & & & & 1 \\
\hline Luiz Pontes PSDB CE & & 1 & & \\
\hline
\end{tabular}


Luzia Toledo PSDB ES

Maguito Vilela PMDB GO

Maria do Carmo Alves PFL SE

Marina Silva PT AC

Marluce Pinto PMDB RR

Mauro Miranda PMDB GO

Moreira Mendes PFL RO

Mozarildo Cavalcanti PTB RR

Nabor Júnior PMDB AC

Ney Suassuna PMDB PB

Osmar Dias PDT PR

Paulo Hartung PSB ES

Paulo Souto PFL BA

Pedro Piva PSDB SP

Pedro Simon PMDB RS

Ramez Tebet PMDB MS

Renan Calheiros PMDB AL

Roberto Freire PPS PE

Roberto Requião PMDB PR

Roberto Saturnino PT RJ

Romero Jucá PSDB RR

Romeu Tuma PFL SP

Ronaldo Cunha Lima PSDB PB

Sebastião Rocha PDT AP

Sérgio Machado PMDB CE

Thelma Siqueira Campos PPB TO

Tião Viana PT AC

Wellington Roberto PTB PB

Total

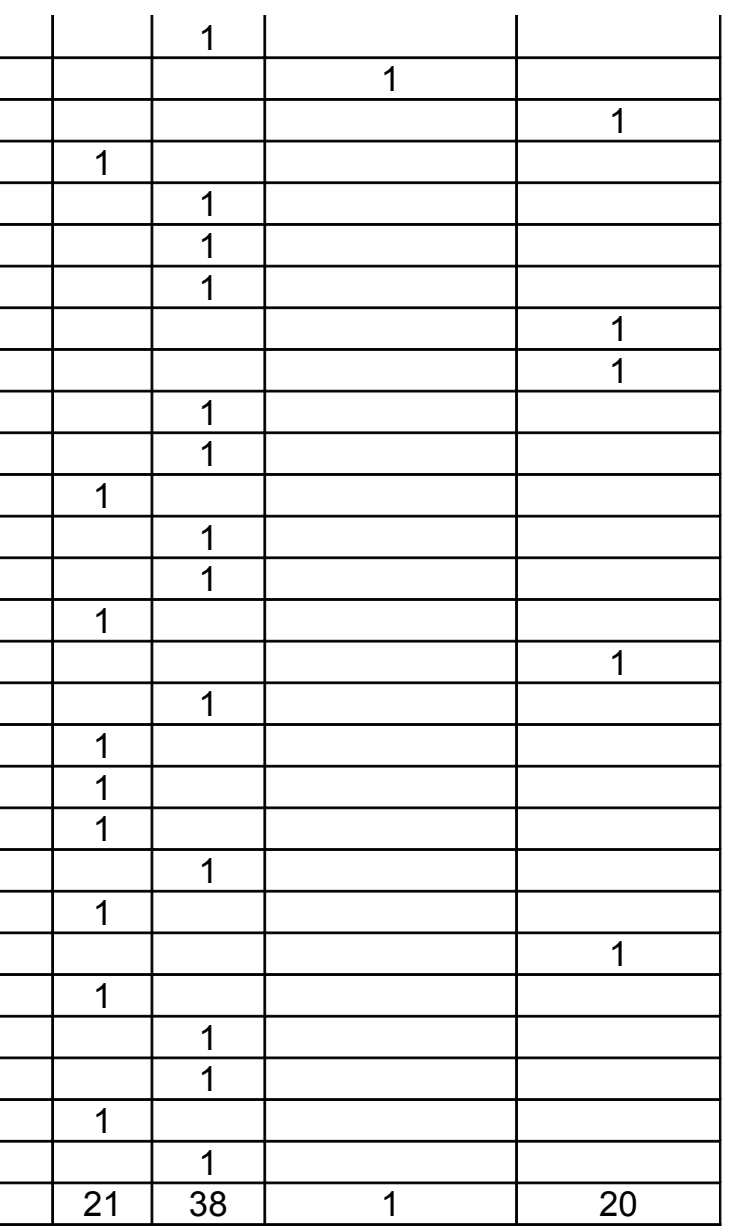


Quadro 10:

Votação Nominal, em globo, das emendas nº 1-CCJ e 2 a 4-CAE.

\begin{tabular}{|c|c|c|c|c|}
\hline Parlamentar Partido UF & SIM & NÃO & ABSTENÇÃO & AUSENTE \\
\hline Ademir Andrade PSB PA & & & & 1 \\
\hline Agnelo Alves PMDB RN & 1 & & & \\
\hline Alberto Silva PMDB PI & & & & 1 \\
\hline Alvaro Dias PSDB PR & 1 & & & \\
\hline Amir Lando PMDB RO & 1 & & & \\
\hline Antero Paes de Barros PSDB MT & 1 & & & \\
\hline Antonio Carlos Magalhães PFL BA (presidente) & & & & \\
\hline Antônio Carlos Valadares PSB SE & & & & 1 \\
\hline Arlindo Porto PTB MG & 1 & & & \\
\hline Artur da Tavola PSDB RJ & 1 & & & \\
\hline Bello Parga PFL MA & 1 & & & \\
\hline Bernardo Cabral PFL AM & 1 & & & \\
\hline Carlos Bezerra PMDB MT & & 1 & & \\
\hline Carlos Patrocínio PTB TO & 1 & & & \\
\hline Carlos Wilson PTB PE & 1 & & & \\
\hline Casildo Maldaner PMDB SC & 1 & & & \\
\hline Djalma Bessa PFL BA & 1 & & & \\
\hline Edison Lobão PFL MA & 1 & & & \\
\hline Eduardo Suplicy PT SP & & & 1 & \\
\hline Emília Fernandes $\mathrm{PT}$ RS & & & 1 & \\
\hline Ernandes Amorim PPB RO & & & & 1 \\
\hline Francelino Pereira PFL MG & & & & 1 \\
\hline Freitas Neto PSDB PI & 1 & & & \\
\hline Geraldo Althoff PFL SC & 1 & & & \\
\hline Geraldo Candido PT RJ & & 1 & & \\
\hline Geraldo Lessa PSDB AL & & & & 1 \\
\hline Geraldo Melo PSDB RN & & & & 1 \\
\hline Gerson Camata PMDB ES & & & & 1 \\
\hline Gilberto Mestrinho PMDB AM & 1 & & & \\
\hline Gilvam Borges PMDB AP & 1 & & & \\
\hline Heloísa Helena PSOL AL & & & 1 & \\
\hline Hugo Napoleão PFL PI & & & & 1 \\
\hline Iris Rezende $\mathrm{PMDB}$ GO & 1 & & & \\
\hline Jader Barbalho PMDB PA & & & & 1 \\
\hline $\begin{array}{l}\text { Jefferson Peres } \\
\text { PDT AM } \\
\end{array}$ & 1 & & & \\
\hline João Alberto Souza PMDB MA & 1 & & & \\
\hline $\begin{array}{ll}\text { Jonas Pinheiro } & \text { PFL MT } \\
\end{array}$ & 1 & & & \\
\hline Jorge Bornhausen PFL SC & & & & 1 \\
\hline $\begin{array}{ll}\text { José Agripino } & \text { PFL RN } \\
\end{array}$ & 1 & & & \\
\hline José Alencar PL MG & 1 & & & \\
\hline José Eduardo Dutra PT SE & & & 1 & \\
\hline José Fogaça PPS RS & & & & 1 \\
\hline José Jorge PFL PE & 1 & & & \\
\hline José Roberto Arruda PSDB DF & 1 & & & \\
\hline José Sarney PMDB AP & 1 & & & \\
\hline $\begin{array}{ll}\text { Juvêncio da Fonseca } & \text { PDT MS }\end{array}$ & 1 & & & \\
\hline $\begin{array}{ll}\text { Lauro Campos } & \text { PDT DF } \\
\end{array}$ & & & & 1 \\
\hline Leomar Quintanilha PFL TO & 1 & & & \\
\hline Lúcio Alcântara $\quad$ PSDB CE & 1 & & & \\
\hline Lúdio Coelho PSDB MS & & & & 1 \\
\hline Luiz Estevão PMDB DF & 1 & & & \\
\hline Luiz Otavio PMDB PA & & & & 1 \\
\hline Luiz Pontes PSDB CE & 1 & & & \\
\hline
\end{tabular}


Luzia Toledo PSDB ES

Maguito Vilela PMDB GO

Maria do Carmo Alves PFL SE

Marina Silva PT AC

Marluce Pinto PMDB RR

Mauro Miranda PMDB GO

Moreira Mendes PFL RO

Mozarildo Cavalcanti PTB RR

Nabor Júnior PMDB AC

Ney Suassuna PMDB PB

Osmar Dias PDT PR

Paulo Hartung PSB ES

Paulo Souto PFL BA

Pedro Piva PSDB SP

Pedro Simon PMDB RS

Ramez Tebet PMDB MS

Renan Calheiros PMDB AL

Roberto Freire PPS PE

Roberto Requião PMDB PR

Roberto Saturnino PT RJ

Romero Jucá PSDB RR

Romeu Tuma PFL SP

Ronaldo Cunha Lima PSDB PB

Sebastião Rocha PDT AP

Sérgio Machado PMDB CE

Thelma Siqueira Campos PPB TO

Tião Viana PT AC

Wellington Roberto PTB PB

Total

\begin{tabular}{|c|c|c|c|c|} 
& 1 & & & \\
\hline & 1 & & & 1 \\
\hline & & & & \\
\hline & 1 & & & \\
\hline & 1 & & & 1 \\
\hline & 1 & & & \\
\hline & & & & \\
\hline & 1 & & & \\
\hline & 1 & & & \\
\hline & 1 & & & \\
\hline & 1 & & & \\
\hline & 1 & & & \\
\hline & & & & \\
\hline & 1 & & & \\
\hline & 1 & & & \\
\hline & 1 & & & \\
\hline & 1 & & & \\
\hline & 1 & & & \\
\hline & 1 & & & \\
\hline & 1 & & & \\
\hline & 1 & & & \\
\hline & 50 & 2 & 7 & \\
\hline
\end{tabular}


Quadro 11:

Votação Nominal, em globo, das emendas ns 8 a 14, 16, 17, 19 a 21.

\begin{tabular}{|c|c|c|c|c|}
\hline Parlamentar Partido UF & SIM & NÃO & ABSTENÇÃO & AUSENTE \\
\hline Ademir Andrade PSB PA & & & & 1 \\
\hline Agnelo Alves PMDB RN & & 1 & & \\
\hline Alberto Silva PMDB PI & & & & 1 \\
\hline Alvaro Dias PSDB PR & & 1 & & \\
\hline Amir Lando PMDB RO & & & 1 & \\
\hline Antero Paes de Barros PSDB MT & & 1 & & \\
\hline Antonio Carlos Magalhães PFL BA (presidente) & & & & \\
\hline Antônio Carlos Valadares PSB SE & & & & 1 \\
\hline Arlindo Porto PTB MG & & 1 & & \\
\hline Artur da Tavola PSDB RJ & & 1 & & \\
\hline Bello Parga PFL MA & & 1 & & \\
\hline Bernardo Cabral PFL AM & & 1 & & \\
\hline Carlos Bezerra PMDB MT & & & & 1 \\
\hline Carlos Patrocínio PTB TO & & 1 & & \\
\hline Carlos Wilson PTB PE & & 1 & & \\
\hline Casildo Maldaner PMDB SC & & 1 & & \\
\hline Djalma Bessa PFL BA & & 1 & & \\
\hline Edison Lobão PFL MA & & 1 & & \\
\hline Eduardo Suplicy PT SP & 1 & & & \\
\hline Emília Fernandes $\mathrm{PT}$ RS & 1 & & & \\
\hline Ernandes Amorim PPB RO & & & & 1 \\
\hline Francelino Pereira PFL MG & & & & 1 \\
\hline Freitas Neto PSDB PI & & 1 & & \\
\hline Geraldo Althoff PFL SC & & 1 & & \\
\hline Geraldo Candido PT RJ & 1 & & & \\
\hline Geraldo Lessa PSDB AL & & & & 1 \\
\hline Geraldo Melo PSDB RN & & & & 1 \\
\hline Gerson Camata PMDB ES & & & & 1 \\
\hline Gilberto Mestrinho PMDB AM & & 1 & & \\
\hline Gilvam Borges PMDB AP & & 1 & & \\
\hline Heloísa Helena PSOL AL & 1 & & & \\
\hline Hugo Napoleão PFL PI & & & & 1 \\
\hline Iris Rezende PMDB GO & & 1 & & \\
\hline Jader Barbalho PMDB PA & & & & 1 \\
\hline Jefferson Peres PDT AM & & 1 & & \\
\hline João Alberto Souza PMDB MA & & 1 & & \\
\hline $\begin{array}{ll}\text { Jonas Pinheiro } & \text { PFL MT } \\
\end{array}$ & & 1 & & \\
\hline Jorge Bornhausen PFL SC & & & & 1 \\
\hline José Agripino PFL RN & & 1 & & \\
\hline José Alencar PL MG & & 1 & & \\
\hline José Eduardo Dutra PT SE & 1 & & & \\
\hline José Fogaça PPS RS & & & & 1 \\
\hline 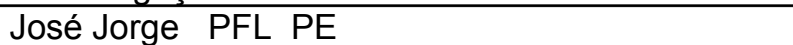 & & 1 & & \\
\hline José Roberto Arruda PSDB DF & & 1 & & \\
\hline José Sarney PMDB AP & & 1 & & \\
\hline Juvêncio da Fonseca PDT MS & & 1 & & \\
\hline Lauro Campos PDT DF & & & & 1 \\
\hline Leomar Quintanilha PFL TO & & 1 & & \\
\hline Lúcio Alcântara $\quad$ PSDB CE & & & & 1 \\
\hline Lúdio Coelho PSDB MS & & & & 1 \\
\hline Luiz Estevão PMDB DF & & 1 & & \\
\hline Luiz Otavio PMDB PA & & & & 1 \\
\hline Luiz Pontes PSDB CE & & 1 & & \\
\hline
\end{tabular}




\begin{tabular}{|c|c|c|c|c|}
\hline Luzia Toledo PSDB ES & & 1 & & \\
\hline Maguito Vilela PMDB GO & 1 & & & \\
\hline Maria do Carmo Alves PFL SE & & & & 1 \\
\hline Marina Silva PT AC & 1 & & & \\
\hline Marluce Pinto PMDB RR & & 1 & & \\
\hline Mauro Miranda PMDB GO & & 1 & & \\
\hline Moreira Mendes PFL RO & & & & 1 \\
\hline Mozarildo Cavalcanti PTB RR & & & & 1 \\
\hline Nabor Júnior $\quad$ PMDB $\quad A C$ & & & & 1 \\
\hline Ney Suassuna PMDB PB & & 1 & & \\
\hline Osmar Dias PDT PR & 1 & & & \\
\hline Paulo Hartung PSB ES & & 1 & & \\
\hline Paulo Souto PFL BA & & 1 & & \\
\hline Pedro Piva PSDB SP & & 1 & & \\
\hline Pedro Simon PMDB RS & 1 & & & \\
\hline Ramez Tebet PMDB MS & & & & 1 \\
\hline Renan Calheiros PMDB AL & & & & 1 \\
\hline Roberto Freire PPS PE & & 1 & & \\
\hline Roberto Requião PMDB PR & & & 1 & \\
\hline Roberto Saturnino $\mathrm{PT}$ RJ & 1 & & & \\
\hline Romero Jucá PSDB RR & & 1 & & \\
\hline Romeu Tuma PFL SP & & 1 & & \\
\hline Ronaldo Cunha Lima PSDB PB & & & & 1 \\
\hline Sebastião Rocha PDT AP & & & & 1 \\
\hline Sérgio Machado PMDB CE & & 1 & & \\
\hline Thelma Siqueira Campos PPB TO & & 1 & & \\
\hline $\begin{array}{ll}\text { Tião Viana } & \text { PT AC } \\
\end{array}$ & 1 & & & \\
\hline Wellington Roberto PTB PB & & 1 & & \\
\hline Total & 11 & 42 & 2 & 25 \\
\hline
\end{tabular}

